\title{
ZESZYTY HISTORYCZNE
}

XVIII 



\section{Prace NaUkowe \\ UNIWERSYTETU HUMANISTYCZNO-PRZYRODNICZEGO \\ IM. JANA DŁUGOSZA W CZĘSTOCHOWIE}

\section{ZESZYTY HISTORYCZNE tom XVIII}

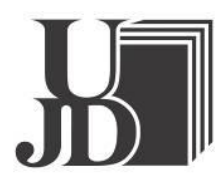

Częstochowa 2019 


\author{
Redakcja \\ Maciej TRĄBSKI (redaktor naczelny) \\ Norbert MORAWIEC (sekretarz redakcji)
}

Rada Naukowa

Marceli ANTONIEwicz (UJD), Werner BENECKE (Frankfurt am Oder), Marek CETwiŃSKi (UJD), Jurij EsKIN (Moskwa), Zigmantas KiauPA (Wilno), Kirył Koczegarov (Moskwa), Walery ŁASTOWSKi (Kijów), Robert MAJZnER (Częstochowa), Varfołomij SawCZuK

(Dniepropietrowsk), Evgen Sinkevich (Mikołajew), Tadeusz Srogosz (UJD), Andrzej STROYNOWSKI (UJD), Vratislav VANÍČEK (Praga), Aleš ZÁŘıICKÝ (Ostrawa), Dariusz ZŁOTKOWSKI (UJD)

Recenzenci zewnętrzni

Bogumiła Burda (UZ), Wiesław CABAN (UJK), Tomasz Ciesielski (UO), Bogusław DybaŚ (UMK), Maciej Franz (UAM), Tomasz GaJowniK (UWM), Tadeusz GrabarcZYK (UŁ), Jarosław Kita (UŁ), Norbert KASPAREK (UWM), Igor KRIVOsZEJA (Humań), Mirosław J. LeszKa (UŁ), Kazimierz Miroszewski (UŚ), Olga Morozowa (Mikołajew), Mirosław NAGIELSKi (UW), Dariusz Nawrot (UŚ), Andrzej NiEwIŃSKi (KUL), Tomasz NodZYŃSKi (UZ), Vova Padalinski (Mińsk), Dariusz Rolnik (UŚ), Mariusz SAwicki (UO), Juliusz SĘTOWSKi (Muzeum Częstochowskie), Marek Sioma (UMCS), Aleksander SMOLIŃSKi (UMK), Ramunė STUKIENĖ-ŠMigelSkyté (Wilno), Agnieszka TeteryCZ-PuZio (AP)

\title{
Redaktor naczelna wydawnictwa
}

Paulina PIASECKA

\author{
Korekta \\ Andrzej MisZCZAK \\ Redaktor techniczny \\ Piotr GOSPODAREK \\ Projekt okładki \\ Sławomir SADOWSKI \\ PISMO RECENZOWANE
}

Podstawową wersją periodyku jest publikacja książkowa

Adres Redakcji:

42-200 Częstochowa, al. Armii Krajowej 36a

www.ih.ujd.edu.pl/ZeszytyHistoryczne.htm

(C) Copyright by Uniwersytet Humanistyczno-Przyrodniczy im. Jana Długosza w Częstochowie Częstochowa 2019

\section{ISSN 2545-3580}

Wydawnictwo Naukowe

Uniwersytetu Humanistyczno-Przyrodniczego im. Jana Długosza w Częstochowie

42-200 Częstochowa, ul. Waszyngtona 4/8

tel. (34) 378-43-29, faks (34) 378-43-19

www.ujd.edu.pl

e-mail: wydawnictwo@ujd.edu.pl 


\section{Spis treści}

\section{ARTYKULY}

\section{Łukasz RÓŻYCKI}

The campaign of 586 and the relief of Adrianople in the context

of roman military craft

Kampania roku 586 oraz odsiecz Adrianopola w świetle rzymskiej sztuki wojennej

(Streszczenie)

Jacek SZPAK

Zapisy finansowe na rzecz Klasztoru OO. Paulinów na Jasnej Górze

w Częstochowie do 1795 roku

Financial donations for the Pauline monastery at Jasna Góra in Częstochowa in 1795

(Summary)

Marzena GONERA

Aktywność parlamentarna i oratorska Adama Kazimierza

Czartoryskiego na sejmie 1782 roku

Adam Kazimierz Czartoryski's parlamentary activity and elocution during the Seym of 1782 (Summary)

Katarzyna MILIK

Wpływ Kościoła katolickiego na rozwój szpitalnictwa polskiego w XVI-XIX wieku

The influence of the Catholic Church on the development of Polish hospital service in the $16^{\text {th }}-19^{\text {th }}$ centuries (Summary)

\section{Piotr DERENGOWSKI}

Polityczne aspekty organizacji, szkolenia i wykorzystania

U.S. Colored Troops w czasie wojny secesyjnej

Political aspects of organization, training and usage of U.S. Colored Troops during the Civil War (Summary)

Jerzy Witold KARYŚ

Maksym Tarejwo - kapłan zaangażowany w powstanie styczniowe ..... 103

MaksymTarejwo - the priest advanced in polish January insurrection (Summary) ......... 117

Tomasz SUMARA

Wybory parlamentarne w Rzeszowie i powiecie rzeszowskim

w 1928 roku

Parliamentary elections in Rzeszów and the Rzeszów poviat in 1928 (Summary) 


\section{Ryszard KRAWCZYK}

Czy Polakom potrzebne są zabytki? Kilka słów o niszczeniu zabytków nieruchomych w Polsce

Do Polish people need monuments? Some comments on the destruction of historical monuments in Poland (Summary)

\section{ŹRÓDLA}

\section{Przemysław GORZAŁKA}

Stan twierdzy częstochowskiej w sierpniu 1807 r. w świetle raportu ppłk. Antoniego Górskiego

Condition of the Jasna Góra fortress in August 1807 in the light of the lieutenant colonel Antoni Górski's report (Summary)

Anna CZERNIECKA-HABERKO, Karolina STUDNICKA-MARIAŃCZYK

Trzy odsłony Statutu Ochotniczej Straży Pożarnej w Mostach przy Jabłonkowie

Three versions of the articles of associations of the Voluntary Fire Brigade in Mosty u Jablunkova (Summary)

\section{ARTYKULY RECENZYJNE I RECENZJE}

\section{Marek STAWSKI}

Magiczne „ósemki” czyli nowa propozycja refleksji

nad dziejami Czech

Magical "eighths" as the new proposition for a reflection on the Czech history (Summary)

Mariusz ŻYMIERSKI

Współczesne nośniki kultury historycznej na przykładzie dwóch wydawnictw z powiatu lublinieckiego

Contemporary mediums of historical culture on the basis of two publishing houses from Lubliniec district (Summary)

\section{SPRAWOZDANIA}

Anna CZERNIECKA-HABERKO, Karolina STUDNICKA-MARIAŃCZYK Sprawozdanie ze stażu naukowego w Centrum Historii Gospodarczej i Społecznej (Wydział Filozoficzny Uniwersytet w Ostrawie)

Report on academic internship in the Centre for Economic and Social History

(The Faculty of Philosophy, University of Ostrava) (Summary) 
ARTYKULY 

http://dx.doi.org/10.16926/zh.2019.18.01

Łukasz RÓŻYCKI

https://orcid.org/0000-0002-1536-3387

Uniwersytet im. Adama Mickiewicza w Poznaniu

\section{The campaign of 586 and the relief of Adrianople in the context of roman military craft ${ }^{*}$}

\section{Summary}

The purpose of the piece entitled The campaign of 586 and the relief of Adrianople in the context of roman military craft is an attempt to analyze Roman tactics during the campaign against the Avars in 586 and to compare it with military treatises, mainly Strategikon. Apart from analyzing the campaign against the nomads in 586 the author also presents the figure of Drokton, a Roman commander who normally operated in Italia against the Longobards, but in this campaign headed the wing of the army sent to relieve the besieged Adrianople.

Keywords: Strategicon, Roman art of war, Theophylact Simocatta, Balkans, Avars.

In the year 586 the Roman army started gaining advantage on the eastern front in the fight against its ancient adversary - Persia $^{1}$. At the Battle of Solachon the forces of the persian warlord Mebodes were routed and strategos Philippicus and his second-in-command - Heraclius (the father of the future emperor of the same name) later concluded a series of raids on enemy territory. Although Philippicus was forced to retreat and did not manage to seize control over major fortresses, fate clearly seemed to favor the Romans in this conflict. Successes in the war against Persia were partially due to Romans focusing their military efforts in the

* My first attempt at analyzing the campaign of 586 is available in Polish in a piece entitled: Łukasz RóżYCKI, Kampania z 586 roku i odsiecz Adrianopola w świetle rzymskiej sztuki wojennej, [in:] Człowiek $i$ wojna. Z dziejów wojskowości polskiej i powszechnej, ed. Andrzej NIEWIŃSKI, Oświęcim 2013, p. 7-17.

1 An overview of this period has been provided in: Franziska E. SHLOSSER, The Reign of the Emperor Maurikios (582-602) A Reassessment, Athens 1994, p. 40-70. 
East at the cost of the European territories, especially the Balkans ${ }^{2}$. This was possible thanks to a truce concluded by Emperor Maurice and the Avar khagan ${ }^{3}-$ Bayan $\mathrm{II}^{4}$ in $584^{5}$. Both sides agreed to cease all hostilities and the Avar ruler was also presented with a significant tribute in gold. The temporary armistice, because this is how it must have been treated by the nomads, was to give the Avars time to cement their rule over any captured territories and pacify the Slav population, which had not been completely subjugated yet ${ }^{6}$. The Romans likely intended to deal with Persia and then concentrate their military might on the European limes ${ }^{7}$. Both sides saw the truce as a transitory state and made preparations for a renewal of hostilities. The Romans in particular were fully aware of this fact, actually expecting the Avars to breach the armistice. This is best exemplified in a fragment of Strategikon, where the author describes the nomads as treacherous people, ready to break any concluded agreement ${ }^{8}$. Two years after the truce, in 586, a powerful nomad army crossed the Roman limes, exploiting the weakened con-

2 Stanisław TuRLeJ, Upadek granicy cesarstwa na Dunaju, [in:] Barbarzyńcy u bram Imperium, ed. S. TURLEJ, Kraków 2007, p. 185-246.

3 In this context the title of khagan (recently Jarosław DudEK, Chazarowie Polityka kultura religia VII-XI wiek, Warszawa 2016, p. 252-282, provided an extensive comparative analysis of possible meanings of this title in the social systems of Turkish peoples from antiquity to late middle ages) should be understood as a ruler of "many dynasties/peoples and many parts of the world" (i.e. four corners of the world), see: Ivan DujČEv, Le sept tribus slaves de la Mésie, "Slavia Antiqua" 6 (1957-1959), p. 100-108.

4 Thérèse OlAJOs, La chronologie de la dynastie avare de Bä̈an, "Revue des études byzantines" 34 (1976), p. 151-158.

5 Peace was concluded in 584 by the khagan and a Roman envoy Elpidius (Sym. 1. 6.4-6). Despite the peace with the Avars, imperial armies had to carry out military operations against the Slavs, although without the additional threat of the nomads the Roman army effectively neutralized any Slavic activity. This was proven by the victory at the Erginia river in 584 or the failed invasion of Ardagast. Simocatta suggested that the Slav raids were inspired by the khagan (Sym. 1. 6. 5).

6 A good introduction into the issue of Slav-Avar relations is available in: Lech A. TYszKIEWICZ, Stowianie i Awarowie. Organizacja plemienna Stowian, Wrocław 2009, especially p. 19-34.

7 Although we do not know the exact plan of Emperor Maurice, the fact of dismissing Philippicus, who failed to capitalize on the victory at Solachon, supports the presented theory.

8 See: Strategikon 11. 2. The following authors wrote extensively about the Avars: Alexander Avenarius, Die Awaren in Europa, Bratislava 1974; Walter PoHL, Die Awaren. Ein Steppenvolk in Mitteleuropa 567-822 n. Chr., München 1988; Wolfgang H. FRITZE, Zur Bedeutung der Awaren für die Slawische Ausdehnungsbewegung im frühen Mittelalter, "Zeitschrift f. Ostforschung" 28 (1979), p. 498-545. Roman-Avar relations were presented in: Bohumila ZÁstěrová, Les Avares et les Slaves dans la Tactique de Maurice, Praha 1971,

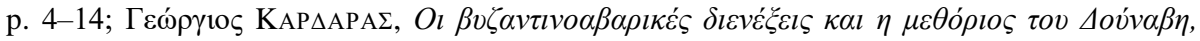

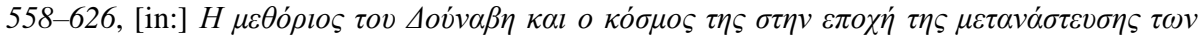

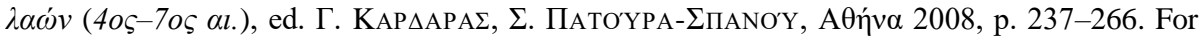
sources in Polish, see: L.A. TYSZKIEWICZ, Stowianie i ludy tureckie przed pojawieniem się Protobutgarów na Pótwyspie Bałkańskim, [in:] Barbarzyńcy w Europie. Studia z późnego antyku I wczesnego średniowiecza, Wrocław 2007, p. 19-30; idem, Stowianie i Awarowie, (collections of previously written pieces). 
dition of border defense troops. This came as no surprise and the European provinces of the Empire were not left defenseless - there were still soldiers there, who clashed on a daily basis with small parties of Slavs crossing the Danube ${ }^{9}$. The Avars' initial strike was targeted towards key positions of the border defensive system, weakened by previous raids. According to Theophanes the Confessor, the khagan managed to take Ratiarna, Bononia, Akys, Dorostolon, Zadrapa ${ }^{10}$ and Marcianopolis ${ }^{11}$.

Romans did not remain passive in the face of this attack. The commander of the armies of the West at that time was Comentiolus, who did not have sufficient manpower to stop the Avars at the border. The limes was too difficult to hold in the event of a full-scale invasion; instead, Comentiolus decided to harass the invaders within Roman lands, being better familiarized with the terrain and having the additional advantage of fortified cities. Strategos divided his forces into 3 contingents - two consisting of cavalry and the main one that also included infantry units - possibly expecting the nomads to split their forces as well, since their main goal was looting. The leader of one detachment was Castonus, the other one - Martinos, and the main force was led by the strategos himself. Theophylact Simocatta gives information about the size of the whole army. It included 6 thousand $^{12}$ able-bodied soldiers and 4 thousand troops unfit for combat $^{13}$, who were left with the wagon train ${ }^{14}$. It is worth emphasizing that leaving troops that were not field-ready out of action is consistent with the instructions given by the author of Strategikon. We should assume that Comentiolus wanted to be able to cover a wider area and that the detachments were supposed to operate in tight coordination, although Theophylact does not mention the strategic objectives of the campaign, focusing rather on the marching route and combat engagements ${ }^{15}$. From the fast marching pace of the above Roman contingents we can conclude that Castonus and Martinos were given command over cavalry units. The two mounted forces were to protect the main strength of the army, scout ahead and ensure that the Avars would stay in close formation. In the event that the invaders dispersed, it would also allow the Romans to engage the enemy cav-

9 On the subject of everyday life in militarized border communities, see more in: Andrzej B. BIERNACKI, Łukasz RóżYCKI, Early Byzantine Arms and Weapons from the Episcopal Complex in Novae, [in:] Proceedings of the First International Roman and Late Antique Thrace Conference, National Archaeological Institute XLIV, Sofia 2018, p. 453-466.

10 This is clearly an error made by Theophanes; the captured city he was referring to must have been Zaldapa.

11 Theoph. Conf., AM 6079.

12 Sym. 2. 10. 8-9.

13 According to Theophanes the number of men unfit for combat was not 4000 but 40000 ! This is completely improbable and should be considered a misspelling (Theoph. Conf., AM 6079).

14 Sym. 2. 10. 8-10.

15 Any other option would assume that the strategos intended to challenge 10000 Avars with a force of only 2000 Romans. So it stands to reason that success could only be achieved by planning on close cooperation between detachments. 
alry. Comentiolus most likely commanded a mixed force with a majority of infantry units, which meant they moved at a slower pace. Initially, the situation seemed to favor the Romans. Castonus, leading a third of the whole army, ambushed the nomads at Zaldapa and destroyed them, taking rich spoils ${ }^{16}$. This may indicate that despite the Roman threat the khagan decided to divide his forces into smaller detachments, which could operate and plunder in a larger area. At the same time Martinos was nearing the heavily fortified city of Tomis, where he encountered a second Avar camp. In a surprise attack, the Romans were able to force the numerically superior barbarians to flee and according to Simocatta, the life of the khagan himself was threatened as a result ${ }^{17}$.

After a couple of days both victorious officers met in a place appointed by Comentiolus and joined forces ${ }^{18}$. The army strategos ordered them to advance before the main force and pursue the retreating Avars. This part of Simocatta's account is unclear. The chronicler accuses the strategos of remaining passive in the face of the enemy ${ }^{19}$. In reality, the army commander was faced with a difficult choice, as the officers in charge of cavalry detachments refused to follow orders and began retreating, afraid of the combined Avar strength. During that time Bayan must have already finished gathering all nomad raiding parties from around the province and so moved to clash with the main opposing army. The Romans joined their forces at Marcianopolis, clearly afraid of letting the nomads destroy their smaller cavalry detachments in separate engagements ${ }^{20}$.

Strategos, judging by the course of events, intended to choose the most suitable location for a battle and either rout the weakened nomad force or at least halt their advance. The location he chose was the Valley of Roses (Sabulente Kanalion $)^{21}$. Romans set up camp on the path of the enemy's marching route, on the side of a river, which separated them from the Avars. The fact that Romans made use of this natural obstacle and had more infantry units was supposed to give them tactical advantage and possibly make the Avars retreat without a fight. Comentiolus once again divided his army, ordering the victorious cavalry commanders to reconnoiter and operate on the other side of the river. These mounted detachments were to gather intelligence on the strength of the Avars and find out where the nomads intended to cross the current. This seemed like

16 Sym. 2. 10. 10.

17 Sym. 2. 10. 13.

18 Sym. 2. 10. 13.

19 Sym. 2.11. 1-3.

20 Theophanes's account is even less favorably disposed towards the commander. The chronicler accuses him of cowardice in the face of the enemy. According to Theophanes, Roman detachments apparently regrouped only after reaching the Haimos Pass, which Comentiolus blocked with his main force (Theoph. Conf., AM 6079). This was not an act of cowardice, but prudence. The strategos closed off the most convenient passage, forcing the Avar khagan to confront the Roman force.

21 Sym. 2. 11. 4. 
a good solution. Scouting and skirmishing by the cavalry could buy time for the infantry to secure the crossing point. Comentiolus obviously wanted to stop the invaders from reaching the far side of the river and establish a blockade to drive them back. Although the plan was sound, it all hinged on how well the mounted units could fulfill their objectives on the far shore. The first tragedy befell Castonus and his force. Having defeated the enemy's advance guard, he was cut off from the point of crossing, which was a wooden bridge. The next morning the main strength of the Avars descended on the isolated detachment and forced it to flee in panic; and during the flight Castonus was captured ${ }^{22}$. Following this rout the strategos discarded his previous strategy of blocking the crossing and ordered a retreat ${ }^{23}$. When the khagan realized this, he dispatched raiding parties all over Thracia. A portion of his force apparently continued pursuing the Romans, because the historical account also mentions a chaotic clash in the night, won by the Romans $^{24}$. Despite this success ${ }^{25}$, the main Roman force did not manage to break the Avar army. Instead, it continued retreating towards the capital, allowing the invaders to besiege more cities and pillage the province unopposed ${ }^{26}$.

News of the defeat, the capture of Castonus and the retreat of the army caused general dissent in Constantinople ${ }^{27}$. Theophanes claims that the Avars advanced all the way to the Long Walls of Thrace, i.e. the capital's first line of defense ${ }^{28}$. The city residents went as far in their discontent as to publicly insult Emperor Maurice $^{29}$. To quell these disturbances, the ruler paid a hefty ransom for the captured commander and began preparations for a counter-offensive. The Roman army was to relieve Adrianople besieged by the khagan's main forces ${ }^{30}$. Choosing

22 Sym. 2. 11. 11-12. 4.

23 Theophanes claims that the Roman forces retreated into fortresses guarding the mountain passes (Theoph. Conf., AM 6079).

24 Sym. 2. 15. 1-13.

25 Once the khagan, along with a portion of his men, had crossed the mountains, the main Roman forces attacked the nomad rear, causing serious casualties. The night engagement ended in widespread panic on both sides and both armies retreating (Theoph. Conf., AM 6079).

26 It should be mentioned that Avars were not particularly skilled in siege warfare. Most cities blocked by the nomads managed to defend themselves. As an aside, Theophylact mentions a story about a Roman renegade, who supposedly taught the barbarians to construct siege engines. Failure to take any of the less significant cities or forts must have irritated the khagan, who was well aware that the best spoils were hidden behind city walls. See: Georgios Kardaras, The Episode of Bousas (586/7) and the Use of Siege Engines by the Avars, "Byzantinoslavica" 63 (2005), p. 53-67.

27 See: Małgorzata LeSzKA, Mirosław LeSZKA, Ewolucja statusu Miasta. Idea Konstantynopola - Nowego Rzymu, [in:] Konstantynopol Nowy Rzym miasto $i$ ludzie $w$ okresie wczesnobizantyńskim, ed. M.J. LESZKA, T. WOLIŃSKA, Warszawa 2011, p. 38-42.

28 Theoph. Conf., AM 6079.

29 Sym. 2. 16. 5-6.

30 Theophanes the Confessor makes no mention of this fact. His account of the events of 586 ends with Castonus being taken prisoner. The Roman relief of Adrianople is not mentioned either, 
such an objective gives clear indication that the emperor wanted to fight a pitched battle and scatter the enemy found within Roman borders.

This new army underwent significant personnel changes. Comentiolus was dismissed $^{31}$ and command was given to John Mystacon ${ }^{32}$ and a Suebi in service to the Empire named Droktulf ${ }^{33}$. The situation had to be serious indeed, since Droktulf had been dispatched quickly from around Ravenna, probably with a portion of his own soldiers. This was possible because at that time a short armistice was in effect in Italia between the Empire and the Longobards ${ }^{34}$. An army was gathered in haste, most likely strengthened with units that fought in the first stage of the campaign ${ }^{35}$, and moved towards Adrianople ${ }^{36}$. Apparently the goal

although Theophanes does notice that barbarians learned how to besiege cities, which caused a lot of problems for the Romans (Theoph. Conf., AM 6079). This reference to a new skill being possessed by the Avars must have been influenced by the work of Simocatta and his story of the Roman renegade. Theophanes based his account of the events from the end of the 6th century primarily on the work of Theophylact. It is worth noting the significance of the city itself. Adrianople was an important location within the whole Roman defensive system, blocking the access to Constantinople from the north. The importance of cities and military encampments in the Balkans for the Roman system of defense was excellently explained by Серге́й Арка́дьевич Иванов, Оборона балканских провинций Византии и проникновение “варваров" на Балканах в первой половине VI века, "Византийский временник”, vol. 45: 1984, p. 35-53.

31 It is possible that this was a consequence of the strategos being too passive on the offensive. The two successful engagements from the beginning of the campaign were not sufficiently capitalized upon.

32 The moniker "Mystacon" was due to his mustache. In the years 582-583 he was the main officer in charge of Roman armies in the East, being replaced by Philippicus in 583. This replacement was due to lack of results in the fight against Persia. In 587 Mystacon assumed command over Roman forces in Thrace, replacing Castonus, who had been captured by the Avars. After 589, he once again served as magister militum in Armenia (PLRE, p. 680). John was not one of the most prominent Roman commanders. His greatest success was the victory at Adrianople, although in that engagement we also need to remember about Drokton's contribution.

33 The sources provide two forms for his name. Paulus Diaconus calls him "Droktulf", whereas Simocatta uses the form "Drokton". The variation used by Paul the Deacon seems to be the correct one. Droktulf was a Suebe, but probably spent his childhood among the Longobards as an honorary hostage. For his achievements he was awarded the title of $d u x$, but as soon as an opportunity presented itself, he defected to the Romans and devoted his life to fighting the Longobards, who took away his childhood and forced him to serve in their ranks (Paul. Diac., 3. 18). His presence in Thracia was the result of a temporary armistice between the Romans and Longobards (PLRE, p. 425-426). When quoting the epitaph found on Droktulf's tombstone, Paul the Deacon left the Greek version of the name ("Clauditur hoc tumulo, tantum sed corpore, Drocton" - Paul. Diac. 3. 19) and emphasized his significant contribution to the victory against the Avars.

34 PLRE, p. 425-426.

35 We do not know the exact size of John's army. We also have no information on the losses suffered by strategos Comentiolus. We can safely assume around two thousand dead, since that was roughly how many soldiers were in Castonus's unit.

36 A short description of the battle can be found in: Ilkka SYVÄNnE, The Age of Hippotoxotai: Art of War in Roman Military Revival and Disaster (491-636), Tampere 2004, p. 448. 
was to force the Avars to abandon the siege and to give battle if the conditions were favorable. Simocatta did not report on any of the events preceding the battle before the city walls. We don't know the route taken by John's troops, nor do we have any info on smaller skirmishes with raiding parties that surely took place. It is also difficult to determine if Droktulf joined the army later on - and if so, when - or if his force was present from the moment of raising this second army ${ }^{37}$. Obviously, lack of any information does not mean that the road to Adrianople was uneventful. Simocatta limits his account to the clash between the main Roman force with the khagan's army. But the Roman chronicler focused his attention on the maneuvering of troops under Droktulf, failing to present even a basic plan of the battle or the deployment of individual units. Still, Simocatta's account is quite interesting:

\begin{abstract}
Romans proved victorious in the clash with the barbarians, turning the tide of battle in their favor thanks to a maneuver by hypostrategos Drokton. The army wing under his command showed their backs to the enemy in mock-retreat, making it seem as though the Romans feared their opponents. He then turned around, dispatched the pursuing force and, making his way to the rear of the barbarian formation, slew anyone in his path. At noon, the Avars souded their retreat and scattered in all directions. The strategos did not give chase, since he was a firm believer in moderation in success. Because fate is fickle and unreliable, and "victory goes back and forth between men", if I may quote Homer's words in my narrative 38 .
\end{abstract}

Although the Roman chronicler did not describe the road to Adrianople, his account of these events suggests that the Avars were prepared for the coming army. The nomads did not let themselves be surprised before the walls of the city. This would have been ideal for the Romans and the khagan's army - caught between Adrianople's defenses and a hostile force - would have been annihilated. The barbarians were well aware of this fact, so on the first day they outmaneuvered the Romans and took position allowing for an easy retreat. This was possible thanks to the great mobility of the Avar army, whose main strength was its cavalry. Despite avoiding being pressed against the city walls, the Avars were still blocking Adrianople. The fact that they maintained the siege is rather surprising. Why did the khagan continue to block the city if he knew about the approaching relief force, and did he actually believe that despite previous failures

37 The second option seems highly improbable, unless Droktulf was there alone, without his soldiers from Italia.

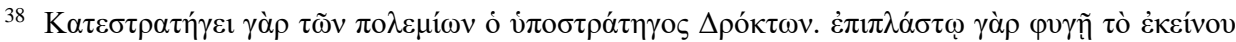

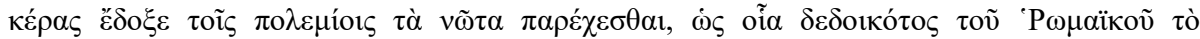

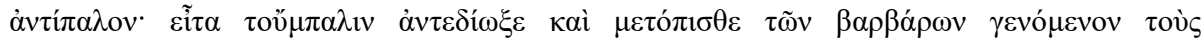

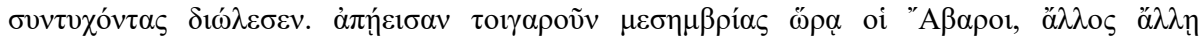

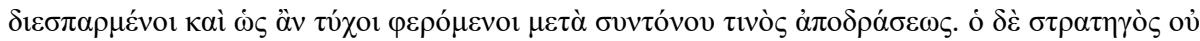

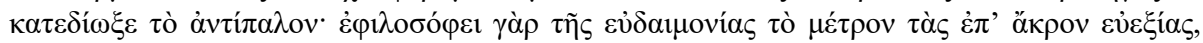

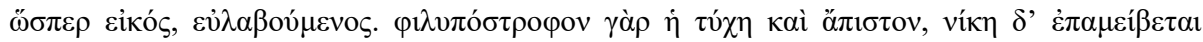

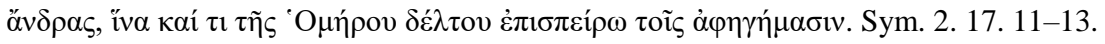


in siege warfare his army would this time successfully overcome the Roman fortifications?

In Theophylact's short account it is worth focusing on the maneuvers of the Roman army and compare them to Strategikon, a military treatise written at the end of the 6th century. Strategikon is a work comprising two overlapping spheres - an erudite layer, modelled on the works of ancient tacticians and an observatory layer, containing personal deliberations of the author, who was likely an experienced military leader, familiar with the European front and deeply knowledgeable about the nomads and Slavs ${ }^{39}$. The section of the treatise devoted to tactics (mainly for cavalry) demonstrates the reality of how war was waged in the 6th century. It grants insight into certain standards of behavior of field commanders. Proving that the maneuvers undertaken by strategos John and his subordinates are consistent with those described in Strategikon can serve as a valuable argument in the discussion regarding the applicability of the treatise.

The first maneuver from Simocatta's work employed by the Romans was a variation of a tactic used by the nomads, who rarely chose direct confrontation. Rather, they would normally stage a controlled retreat and when the opponent broke formation during pursuit, the barbarians would turn around and scatter the pursuing force ${ }^{40}$. The Romans were familiar with this stratagem and although they did not often use it in combat, they trained in its execution ${ }^{41}$. Simulating a retreat during an engagement was a rare solution, which required soldiers to be tactically disciplined. While executing the maneuver there was a high risk that actual panic would occur and that pretend flight from the battlefield would turn into a real one. Adopting this nomad trick demanded that the Romans be highly disciplined, tactical, experienced and mentally resilient. In this particular case, the person assigned to carry out the task was Droktulf, who probably based his actions on past experiences. It is very likely that the units Droktulf led in this campaign were the same ones he commanded every day in Italia. It is difficult to imagine such a risky maneuver, which could lead to the men panicking, being executed by a recently formed detachment, which did not have any experience in joint operations. All this seems to indicate that Droktulf would have had under his command units that were transferred from Italia, i.e. units he could rely on and knew their worth. The Romans, according to their tactical principles, would position the infantry in the

39 Aussaresses believed that the author of Strategikon was Emperor Maurice, claiming that although it is impossible to unequivocally identify the author, most clues point to it being the emperor. Despite the passage of years, the ideas of this French scholar remain relevant: François AusSARESSES, L'auteur du Stratégicon, "Revue des études anciennes", vol. 8: 1906, p. 23-40.

40 Strat. 11.2.

41 The same exercises were conducted by the Roman army: Strat. 6. 2. On the subject of the nomads, see: Strat. 11. 2. More in: B. ZÁstĚrovÁ, Les Avares et les Slaves dans la Tactique de Maurice, Praha 1971. John WiITA, The Ethnika in Byzantine Military Treatises, University of

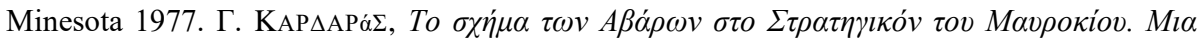

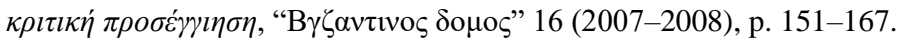


center, and the cavalry, which normally would have two ranks of spearmen followed by ranks of bowmen ${ }^{42}$, was probably left on the flanks, waiting for an opportunity of rolling the enemy's flank.

The army of Bayan II must have been mostly mounted units, as evidenced by its previous progress during the campaign and its ability to swiftly disperse and reform if a threat presented itself ${ }^{43}$. Such a force was challenging to fight against; despite suffering a number of defeats previously in the campaign, the Avars were still able to engage in another pitched battle. This was due to the nomads' mobility; even after losing a clash they knew how to disengage from the enemy and avoid pursuit, which was when most casualties would be suffered. The Romans were in a hurry to reach the besieged Adrianople, but we should not assume that their forces were all cavalry, especially since this was an army raised in haste, most likely partially from city garrisons. The fact that Droktulf along with his soldiers were recalled from Italia speaks volumes about how serios the situation seemed to the Romans.

Droktulf $^{44}$ employed a modified nomad tactic combined with a flanking maneuver that the Roman army was well-known for. The author of Strategikon suggested deploying special flanking units, which had very particular tasks during a battle:

Initially hyperkerastes should be positioned on the right flank, obscured by the first line of our troops, or be deployed among the horsemen of the first line. Whatever the case may be, once the time comes for their flanking maneuver, they should move right and advance as far as necessary. Next, maintaining a tight formation, they should roll up the enemy's flank, moving as though they were trying to get back to their own lines through the enemy's units ${ }^{45}$.

The cavalry flank led by Droktulf executed the Avar-style mock retreat. This tactic has either met with no reaction from the enemy, or possibly only a portion of the opposing army was lured into pursuit ${ }^{46}$. Regardless, the nomad

42 Strat. 1.2. 12-13. This type of a mounted warrior was nothing new in the army of Justinian the Great. Michael O'Rour Ke, Arrow-Storms and Cavalry Pikes Warfare In the Age of Justinian I, AD 527-565 The Armies of Belisarius and Narses, Canberra 2007, p. 6. and Pat Southern, Karen Ramsey Dixon, The Late Roman Army, New York 2009, p. 116-117.

43 See more in: Florin CURTA, Avar Blitzkrieg, Slavic and Bulgar raiders, and Roman special ops: mobile warriors in the 6th-century Balkans, [in:] Central Eurasia in the Middle Ages Studies in Honour of Peter B. Golden, ed. I. ZimOnYI, O. Karatay, Wiesbaden 2016, p. 69-89.

44 Droktulf's role in the battle was also noted by Paul the Deacon in an epitaph in his name: He was the one who, in eastern lands, crushed the savage Avars, bringing a great victory to his masters. Paulus Diaconus, 3. 19. "Eastern lands" obviously refers to the Balkans, where Droktulf fought under Roman banners.

45 Strat. 6. 5.

46 If the whole wing of the Avar cavalry had given chase after Droktulf's unit simulating its retreat, the Romans would not have been able to carry out the second part of their plan. 
army as a whole did not break formation and concentrated on the remaining Roman forces, including the center, where most of the infantry units were positioned. Roman plans for the battle likely only assumed employing the basic tactic for the right and left wing, which was to make the enemy soldiers scatter in pursuit and dispatch them with a counter-charge ${ }^{47}$. The barbarians may have seen through the Roman ruse, recognizing a trap that they themselves have success-

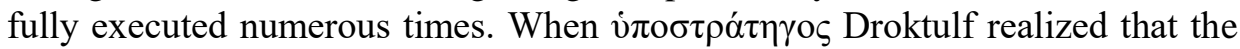
Avars are not following him, he was forced to improvise. The cavalry under his command $^{48}$ encircled the enemy force and attacked it from behind ${ }^{49}$. Lack of reaction from the Avars means that they were not expecting these Roman units to return to the battlefield. It may indicate that the leader of the nomad flank assumed that Droktulf's troops were actually retreating and decided to engage the infantry in the center rather than execute a difficult pursuit of the fleeing cavalry. This turn of events must have taken the barbarians completely by surprise, causing a panic which led to the disintegration of the Avar army.

We also shouldn't exclude the possibility that Droktulf made a more complicated tactical move. Perhaps the simulated retreat of the Roman flank was in fact merely a "smoke screen" for the ambushing drungos ${ }^{50}$ - a cavalry formation operating as an extension of the flank, whose task was precisely to move around the opposing force in a wide arc, and to strike at the rear of the enemy formation. If that was the case, it would be consistent with the diagrams ${ }^{51}$ from Strategikon shown below ${ }^{52}$ :

47 A counter-charge was one of the few cavalry maneuvers that was executed at full speed. Strat. 3.5. 26-36. It is impossible to accurately determine the speed. Intermediate trot $(250 \mathrm{~m} / \mathrm{min}$. $)$ is faster than collected gallop $(225 \mathrm{~m} / \mathrm{min}$.), but slower than intermediate gallop $(300 \mathrm{~m} / \mathrm{min}$.). Vide: Ewa HoRdý́SKA, O koniu i jeździe konnej, Zbrosławice 1995, p. 42-47. The author of Strategikon provides too little information to decide on how fast the charging soldiers moved. According to Gyftopoulou most of the maneuver was executed at a rather slow pace, with the horse accelerating to gallop immediately before the charge: Sophia GYFTOPOULOU, Riding and reserving equii in the late antique/middle Byzantine army, " $\beta \gamma \zeta \alpha v \tau \mathrm{tvo} \varsigma \delta \rho \mu \mu \mathrm{s} " 16$ (20072008), p. 389-410.

48 In the second half of the 6th century there were at least two other engagements, apart from the Battle of Adrianople, which were decided by cavalry operating on the flanks: the Battle of Solachon: Sym. 2. 4.1-8. and the Battle of Colchida: Sym. 3.7.10-12.

49 We cannot exclude the possibility that this was the Roman plan all along, although it does seem less likely.

50 The author of Strategikon reiterates a number of times the importance of choosing the correct moment for the ambushing drungos to strike. See: Strat. 1. 5. and Book IV: Strat. 4.

51 For more on the subject of diagrams, see: Carlo Maria MAZzUCCHI, Le "katagraphai" dello "Strategicon" di Maurizio e lo schieramento di battaglia dell'esercito romano nel VI/VII secolo, “Aevum", vol. 55/1: 1981, p. 111-138.

52 Strat. 3.X. 50-52. 


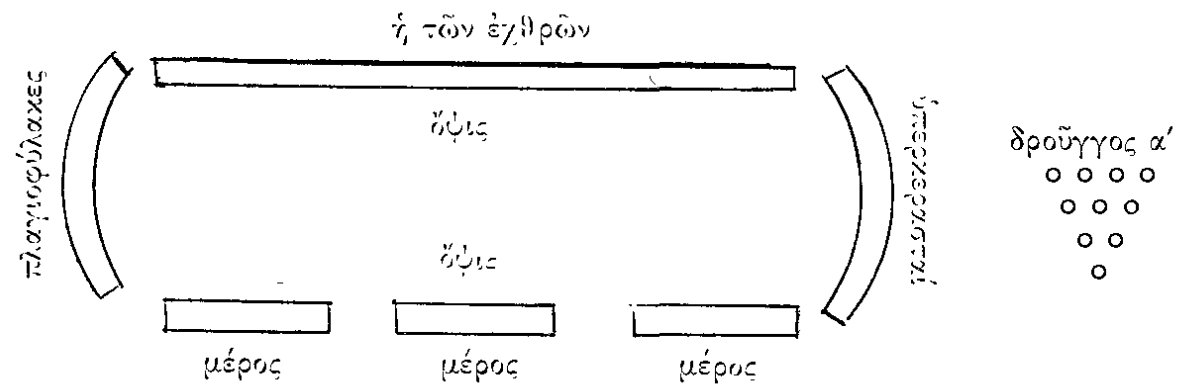

Consequently, in the final stages of the battle the situation would perfectly mirror another diagram included in Strategikon:

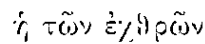

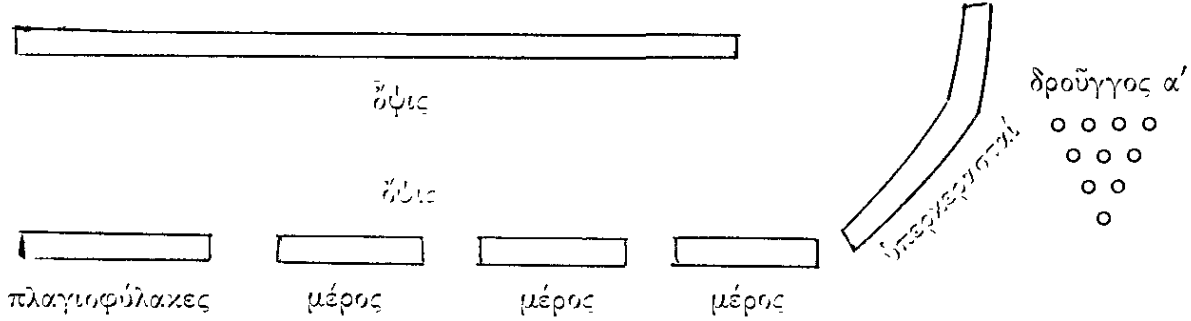

The Avar forces converged on the Roman center, where infantry units (meroi) were stationed. Droktulf's horsemen returned and assaulted the Avar's exposed flank, while the ambushing drungos executed its assigned maneuver and charged from behind, completely surrounding the flank and compounding the chaos among the nomads $/{ }^{53}$. The author of Strategikon instructs to execute an encircling cavalry maneuver and strike at the enemy's flank or rear whenever possible ${ }^{54}$. It was the most effective and least costly method of winning - the appearance of enemy cavalry on the flanks or behind own lines usually resulted in panic. This,

53 It is not certain if the ambushing drungos engaged the enemy together with hyperkerastes. Possibly, the archon leading the ambush waited for other Roman forces to roll the flanks and only then decided to attack the Avar center from the rear. Such an action would have been crushing for the enemy's morale, but it required deep trust in one's own forces and a commander who could correctly assess the situation. It is very likely that during the Battle for Adrianople exactly such a situation occurred.

54 Compare: Strat. 3. 10. 31-38; Strat. 3. 10. 50-52; and Strat. 3. 10. 39-43. In each of these instances, even if the enemy line was longer than the Roman one, the author of Strategikon instructed the readers to have detachments operating on the flanks in order to force the enemy to flee the battlefield. 
in turn, would normally cause the surrounded force to retreat, thus ensuring victory for the Romans.

In the case of Droktulf's maneuver it is inaccurate to say that he simply copied nomad tactics. Roman military doctrine assumes that in a pitched battle the commander will always appoint a detachment to work its way around the enemy formation and attack from the flank or from behind ${ }^{55}$. According to the manuals, this flanking attack should be carried out by several bandons ${ }^{56}$ of hyperkerastes ${ }^{57}$. In the Battle of Adrianople the maneuver was executed by the whole Roman flank ${ }^{58}$, most likely supported by the ambushing drungos. Theophylact, who wrote the account of the battle studied here, was not overly familiar with Roman military doctrine, so he fails to provide crucial details, which can be deduced from analyzing Strategikon. By cross-referencing the two sources we can reconstruct quite a sophisticated tactical plan for the battle with the Avars.

Simocatta notes with some surprise that Romans stopped fighting and began retreating. This behavior was necessary to lure the enemy into a trap and must have been planned ${ }^{59}$. We could say that Roman troops acted in a textbook fashion, with their tactics being slightly modified by a competent commander due to the actions of the enemy or an opportunity that presented itself. And if the ambushing drungos had been prepared beforehand, then this was a perfectly "by-the-book" tactic, which yielded excellent results. Once again Simocatta goes beyond the established literary topos of how a battle should be described ${ }^{60}$ and includes certain details in his narrative that - in his opinion - were crucial to Roman success.

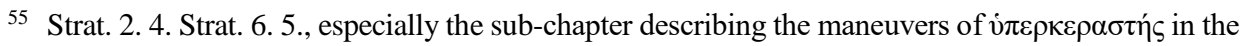
case when the enemy battle line is either longer or shorter than the Roman one (Strat. 3. 14).

56 Usually 1 or 2 bandons (Strat. 3. 8), which would be 500-600 horsemen.

57 This disposition of forces on the flanks seem to have been an innovative approach in the 6th century. Hyperkerastes were a new unit type altogether, whereas plagiofilakses, stationed on the other wing, have been mentioned in the work of Asclepiodotus as the archons tasked with maintaining discipline on the sides of cavalry formations. Asclepiodotus, 7. 2. See also: Ł. RÓŻYCKI, Hyperkerastes oraz plagiofilakses a działania na skrzydłach rzymskiej formacji bitewnej, [in:] "Mieczem i Szczytem" broń na polu walki $Z$ dziejów wojskowości polskiej $i$ powszechnej, ed. A. Niewiński, Lublin 2016, p. 23-43. Similar tasks were assigned to plagiofilakses and hyperkerastes in the times of Nicephorus Phocas. See: Praecepta militaria, 61. 12. Although at the beginning of the engagement their tasks were consistent with those described in Strategikon. Praecepta militaria, 61. 8.

58 Unless Droktulf was not the leader of the Roman flank but rather the ambushing drungos. Simocatta might not necessarily have known the difference between these two formations, and could have mistaken one for the other.

59 In this particular maneuver it was the sudden turn before engaging the enemy that was adapted from barbarian tactics. It is difficult to determine if the Romans expected to trick the enemy wing into pursuit and destroy it with a counter-charge or if they assumed that the enemy would attack the main body of the army, ignoring the fleeing troops and giving them the opportunity to turn back and strike at the enemy's rear.

60 See: Anna KотŁowsкA, Łukasz RóżYCKi, The Battle of Solachon of 586 in light of the works of Theophylact Simocatta and Theophanes Confessor (Homologetes), "Travaux et Mémoires", vol. 19: 2015, p. 315-327. 
The maneuver executed by Roman cavalry at the Battle of Adrianople was a tactic taken straight out of a military manual. Although the officer in command utilized a nomad stratagem, it was well known to the Romans. Evident similarities with modified versions of this maneuver practiced by Roman flanking units suggest that Droktulf was well versed in the tactics of the imperial army. Through clever adoption of enemy tricks, the Romans were able to defeat the main army of the Avar khagan and have it retreat. Yet, despite this victory, the enemy army had not been destroyed. The Avars were forced to flee the battlefield, but they did not suffer heavy losses. Assuming that there was a strong infantry force in the center of the Roman formation, then the army could not effectively pursue the fleeing nomads. The barbarians had already disengaged from the main body of the opposing army and giving chase with just the cavalry would disrupt the Roman's tight tactical formation ${ }^{61}$ and expose them to an Avar counter-charge, which could still turn the tide of the battle. The risk was too high to take, since the major strategic objectives of the campaign had already been achieved: the siege of Adrianople was lifted and the army of Bayan II forced to retreat. Heavy Avar activity in the following years only goes to show that even after the defeat at Adrianople the barbarian army remained an effective fighting force.

Looking at the events of 586 from a broader perspective, we arrive at several conclusions. The Roman army basically did not lose a single battle - the defeat of Castonus's detachment was caused by bad planning and an overenthusiastic commander $^{62}$. No major city was taken by the enemy ${ }^{63}$. Several times, Avar parties were scattered by smaller Roman forces. And it should be pointed out that these were not elite Roman soldiers from mobile armies - the best imperial troops were still assigned to the war with Persia. Undoubtedly, the invasion was disastrous for the countryside population. It is difficult to determine how far the barbarian raiding parties reached and, consequently, what area of the province was plundered. It is possible that only those farms located directly along the marching route of the khagan's army were targeted. The Romans managed to repel the enemy without having to redeploy any of the units engaged in fighting on the eastern

61 Strategikon has a passage that emphasizes this fact: Sive pugnas sive seques inimicum sive aequalis facies, nom forte minaret ut ne sparges tu suum ordinem. During combat and pursuit after the enemy, or if you are in the first line of troops, do not charge ahead too swiftly so as not to break formation. Strat. 3.V. 3-9. This Latin text was written in Greek alphabet and was probably part of Roman army regulations or of another treatise. Rance suggests that the author of Strategikon translated whole passages from Latin and compiled them in his own treatise. Vide: Philip RANCE, Simulacra Pugnae: The Literary and Historical tradition of Mock Battles in the Roman and Early Byzantine Army, "Greek, Roman and Byzantine Studies", vol. 41/3: 2000, p. 233.

62 However, the Romans stopped retreating and everything points to the fact that they were readying themselves for a pitched battle against khagan's forces.

63 The following cities did not surrender, despite being besieged: Beroe, Diocletianopolis, Philippopolis and Adrianople. 
front, although they likely used some of the forces from Italia, which after this operation returned to their staging grounds around Ravenna ${ }^{64}$. The end result of the campaign might have cemented Emperor Maurice's conviction that the European front was secondary in importance and did not require the involvement of a significant military force and that the Avars, despite being a constant nuisance, were inferior to Romans in warfare. For the next couple of years the majority of imperial armies were fighting over control of the Arzanene province, leaving the Balkans under the protection of local commanders, who were unable to handle things as well as in 586. The fact that victory in the campaign, which concluded with the Battle of Adrianople, was achieved at a relatively low cost and that the Avars were willing to receive gifts in exchange for peace ${ }^{65}$ may have led Emperor Maurice to neglect matters in European provinces. This would bear bitter fruits in the future. During successive Avar raids the Empire's rulers would adopt the same strategy as in the campaign of 586, intervening directly only in the event of a major crisis. European armies were slowly bleeding out in numerous small skirmishes with the Slavs and during Avar raids, gradually losing their combat effectiveness ${ }^{66}$.

Studying the similarities in the handling of a number of topics between Strategikon and the History of Theophylact Simocatta leads to two observations. The first is that the tactics described by the author of Strategikon were actually in use during the reign of Emperor Maurice. Although we cannot draw too far-reaching conclusions based on a single example, we are still dealing with a representative sample here. A similar study was carried out by I. Syvänne ${ }^{67}$, who shortly analyzed a bigger number of clashes and battles, and reached similar conclusions.

The second benefit from analyzing the engagement at Adrianople ${ }^{68}$ is determining how schematic the descriptions of battles were in the work of Theophylact Simocatta. Some of the historians of antiquity avoided describing combat, or included descriptions that were nothing more than literary topoi, based on ancient traditions ${ }^{69}$,

${ }^{64}$ Although before setting off to Adrianople Roman forces were probably reinforced with the imperial guard and freshly drafted troops (Sym. 2. 16. 8).

65 The author of Strategikon considered Avars to be untrustworthy and treacherous (Strat. 11.2).

${ }^{66}$ It was only once Persia had been defeated that the Empire focused its military efforts on the West. This has resulted in spectacular successes. In the final two years of Maurice's reign the barbarians were pushed back completely beyond the Danube limes and the army was to continue the offensive in enemy territory. The murder of Maurice in 602 put a halt to that and under the rule of Phocas the Danube limes disintegrated completely, leading the Roman Balkans to ruin.

67 I. SYVÄNNE, op. cit., p. 435-484.

68 A similar plan was followed in the Battle of Solachon. Although Theophylact talks about three formations in the Roman army, he lists four commander, not mentioning Philippicus who probably held command over the second line. This would mean that one of the listed archons (Elifredas or Apsich the Hun) was in charge of the flanking units and the ambushing drungos. Sym. 2. 3.1-3.

69 On the subject of literary topoi in Early Byzantine geographical descriptions, see: Anthony KALDELLIS, Ethnography after Empire. Foreign Lands and Peoples in Byzantine Literature, Pennsylvania 2013. 
having little to do with the realities of the battlefield. Theophylact wrote differently, but we do not have any comparative sources ${ }^{70}$ that would allow us to verify his descriptions. However, it is very likely that the author had access to imperial archives and to people who participated in the described events, which makes his work unique $^{71}$. By confronting Theophylact's work with Strategikon, we can at least partially answer if Simocatta's descriptions were stylized passages mirroring ancient sources, or if he actually collected accounts from eyewitnesses and participants of events and included these in his opus magnum. Although, once again, it should be emphasized that the research methodology is not perfect and the studied material is selective, the results of the analysis indicate that despite his deficiencies in military and geographical knowledge ${ }^{72}$, Theophylact managed to give a competent account of the Battle of Adrianople.

\section{Bibliography}

\section{Mauricii Strategicon}

Mauricius, Arta militară, ed., transl. H. MihǍEscu, Bucureşti 1970.

Das Strategikon des Maurikios, ed. G.T. Dennis, transl. E. GAMILLSChEG, Wien 1981.

Maurice's Strategikon Handbook of Byzantine Military Strategy, transl. G.T. DENNIS, Philadelphia 1984. Стратегикон Маврикия, transl. В.В. КучмА, Санкт-Петербург 2004.

\section{Paulus Diaconus}

Pauli Historia Langobardorum in usum scholarum ex Monumentis Germaniae Historicis recusa, ed. L. Bethmann, G. Waitz, Hannoverae 1878.

Paweł Diakon, Historia rzymska. Historia Longobardów, transl. I. LeWANDOwsKi, Warszawa 1995.

\section{Publius Flavius Vegetius Renatus}

Flavii Vegeti Renati, Epitoma Rei Militaris, ed. C. Lang, Lipsae 1869.

Flawiusz Wegecjusz, Zarys wojskowości, transl. A. KomornickA, Meander vol. 28: 1973, vol. 29: 1974.

70 Descriptions of military clashes in the work of Evagrius Scholasticus are very schematic, and the author did not focus his attention on the struggles of the Empire, but rather continued his narrative about the history of the Church. For a military historian, the situation is slightly better in the work of Theophanes Confessor. Unfortunately, the latter author used the work of Theophylact Simocatta as a source, so similarities between the two are extensive.

71 T. Olajos, Les sources de Théophylacte Simocatta historien, Leiden 1988.

72 The author of Historia often digressed and when writing about the Avar front would suddenly switch his narrative to the Persian one. Detailing the chronology and geography of this work is extremely difficult. See: Gerard LABUdA, La Chronologie des guerres de Byzance contre les Avares et les Slaves à la fin du VI e siècle, "Byzantinoslavica" 11 (1954), p. 167-173; Michael Whiтвy, The Emperor Maurice and his Historian Theophylact Simocatta on Persian and Balkan Warfare, Oxford 1988. 


\section{Theophylactus Simocatta}

Theophylacti Simocattae Historiarum, ed. I. BEKKERUs, Bonnae 1834.

Theophylacti Simocattae Historiae, ed. C. de Boor, Lipsiae 1887.

The History of Theophylact Simocatta an English Translation with Introduction and Notes, transl. Michael i Mary Whiтвy, Oxford 1986.

Teofilakt Simokatta, Historia powszechna, transl. A. KoTŁOwSKA, Ł. RóżYCKI, Poznań 2016.

\section{Works}

Aussaresses François, L'auteur du Stratégicon, "Revue des études anciennes" 8 (1906), p. 23-40.

Avenarius Alexander, Die Awaren in Europa, Bratislava: A.M. Hakkert, 1974.

BIERNACKI B. Andrzej, RÓŻYCKi Łukasz, Early Byzantine Arms and Weapons from the Episcopal Complex in Novae, [in:] Proceedings of the First International Roman and Late Antique Thrace Conference, National Archaeological Institute XLIV, Sofia: National Archaeological Institute, 2018, p. 453-466.

CURTA Florin, Avar Blitzkrieg, Slavic and Bulgar raiders, and Roman special ops: mobile warriors in the 6th-century Balkans, [in:] Central Eurasia in the Middle Ages Studies in Honour of Peter B. Golden, ed. István Zimonyi, Osman KaRATAY, Wiesbaden: Otto Harrassowitz, 2016, p. 69-89.

DuDEK Jarosław, Chazarowie Polityka kultura religia VII-XI wiek, Warszawa: PWN, 2016.

DujČEv Ivan, Le sept tribus slaves de la Mésie, "Slavia Antiqua" 6 (1957-1959), p. 100-108.

FrITZE H. Wolfgang, Zur Bedeutung der Awaren für die Slawische Ausdehnungsbewegung im frühen Mittelalter, "Zeitschrift f. Ostforschung" 28 (1979), p. 498-545.

Gyftopoulou Sophia, Riding and reserving equii in the late antique/middle Byzantine army,

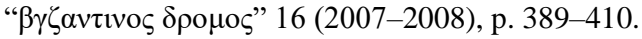

HordYŃSKA Ewa, $O$ koniu $i$ jeździe konnej, Zbrosławice: Zakład Treningowy Koni w Zbrosławicach, 1995.

KALDELlis Anthony, Ethnography after Empire. Foreign Lands and Peoples in Byzantine Literature, Pennsylvania: University of Pennsylvania Press, 2013.

KARDARAS Georgios, The Episode of Bousas (586/7) and the Use of Siege Engines by the Avars, "Byzantinoslavica" 63 (2005), p. 53-67.

KotŁowska Anna, Różycki Łukasz, The Battle of Solachon of 586 in light of the works of Theophylact Simocatta and Theophanes Confessor (Homologetes), "Travaux et Mémoires" 19 (2015), p. 315-327.

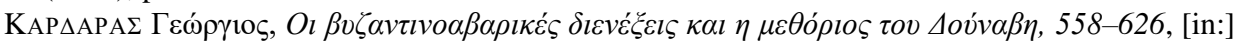

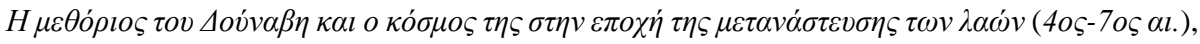

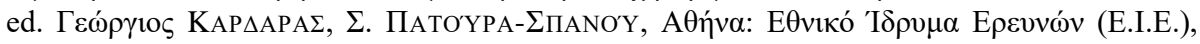

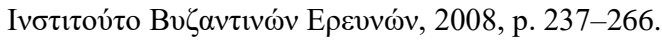

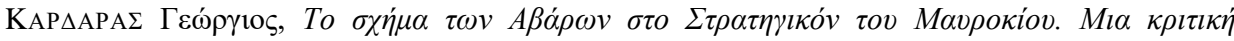

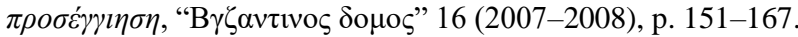

LABUda Gerard, La Chronologie des guerres de Byzance contre les Avares et les Slaves à la fin du $V I^{e}$ siècle, "Byzantinoslavica" 11 (1954), p. 167-173.

LeSZKA Mirosław, LeszKa Małgorzata, Ewolucja statusu Miasta. Idea Konstantynopola - Nowego Rzymu, [in:] Konstantynopol Nowy Rzym miasto i ludzie w okresie wczesnobizantyńskim, ed. Mirosław LESZKA, Teresa WolińsKA, Warszawa: PWN, 2011, p. 38-42.

MAZzUCCHI Carlo Maria, Le "katagraphai" dello "Strategicon" di Maurizio e lo schieramento di battaglia dell'esercito romano nel VI/VII secolo, “Aevum” 55/1 (1981), p. 111-138.

O'ROURKE Michael, Arrow-Storms and Cavalry Pikes Warfare In the Age of Justinian I, AD 527565 The Armies of Belisarius and Narses, Canberra 2007. 
Olajos Thérèse, La chronologie de la dynastie avare de Baïan, "Revue des études byzantines" 34 (1976), p. 151-158.

Olajos Thérèse, Les sources de Théophylacte Simocatta historien, Leiden: Brill, 1988.

PoHL Walter, Die Awaren. Ein Steppenvolk in Mitteleuropa 567-822 n. Chr., München: C.H. Beck, 1988.

Rance Philip, Simulacra Pugnae: The Literary and Historical tradition of Mock Battles in the Roman and Early Byzantine Army, "Greek, Roman and Byzantine Studies" 41/3 (2000), p. 223-275.

RóżYCKi Łukasz, Kampania z 586 roku i odsiecz Adrianopola w świetle rzymskiej sztuki wojennej, [in:] Człowiek $i$ wojna $Z$ dziejów wojskowości polskiej i powszechnej, ed. Andrzej NIEWIŃSKI, Oświęcim: Napoleon V, 2013, p. 7-17.

RÓŻYCKI Łukasz, Hyperkerastes oraz plagiofilakses a działania na skrzydtach rzymskiej formacji bitewnej, [in:] "Mieczem i Szczytem" broń na polu walki Z dziejów wojskowości polskiej i powszechnej, ed. Andrzej NIEWIŃSKI, Lublin: Napoleon V, 2016, p. 23-43.

SHLOSSER E. Franziska, The Reign of the Emperor Maurikios (582-602) A Reassessment, Athens: Basilopoulos Historical Publications, 1994.

Southern Pat, Dixon Karen Ramsey, The Late Roman Army, New York: Yale University Press, 2009.

Syvänne Ilkka, The Age of Hippotoxotai: Art of War in Roman Military Revival and Disaster (491-636), Tampere: Tampere University Press, 2004.

TuRLEJ Stanisław, Upadek granicy cesarstwa na Dunaju, [in:] Barbarzyńcy u bram Imperium, ed. Stanisław TuRLEJ, Kraków: Historia Iagellonica, 2007, p. 185-246.

TyszKIEwicz A. Lech, Stowianie i Awarowie. Organizacja plemienna Stowian, Wrocław: Ossolineum, 2009.

TySZKIEwICZ A. Lech, Stowianie i ludy tureckie przed pojawieniem się Protobutgarów na Pótwyspie Bałkańskim, [in:] Barbarzyńcy w Europie. Studia z późnego antyku I wczesnego średniowiecza, Wrocław: Ossolineum, 2007.

Whiтвy Michael, The Emperor Maurice and his Historian Theophylact Simocatta on Persian and Balkan Warfare, Oxford: Clarendon Press, 1988.

WiITA John, The Ethnika in Byzantine Military Treatises, University of Minesota 1977.

ZÁstĚrová Bohumila, Les Avares et les Slaves dans la Tactique de Maurice, Praha: Academia, 1971.

АРКА́ДьЕВич Иванов Серге́й, Оборона балканских провиниий Византии и проникновение ,варваров” на Балканах в первой половине VI века, „Византийский временник”, vol. 45: 1984, p. 35-53.

\section{Kampania roku 586 oraz odsiecz Adrianopola w świetle rzymskiej sztuki wojennej}

\section{Streszczenie}

Celem tekstu zatytułowanego The campaign of 586 and the relief of Adrianople in the context of roman military craft jest próba analizy rzymskiej taktyki w czasie walk z Awarami w $586 \mathrm{r}$. i zestawienie jej z traktatami wojskowymi, głównie ze Strategikonem. Poza analizą kampanii przeciwko koczownikom w 586 r. autor przedstawił również sylwetkę Droktona, rzymskiego dowódcy na co dzień operującego w Italii przeciwko Longobardom, tym razem dowodzącego skrzydłem armii idącej z odsieczą oblężonemu Adrianopolowi.

Slowa kluczowe: Strategikon, rzymska sztuka wojenna, Teofilakt Symokatta, Bałkany, Awarowie. 

Prace Naukowe Uniwersytetu Humanistyczno-Przyrodniczego im. Jana Długosza w Częstochowie

Jacek SZPAK

https://orcid.org/0000-0003-3464-9214

Uniwersytet Śląski w Katowicach

\section{Zapisy finansowe na rzecz Klasztoru OO. Paulinów na Jasnej Górze w Częstochowie do 1795 roku}

\section{Streszczenie}

Klasztor paulinów na Jasnej Górze został ufundowany przez ks. Władysława Opolczyka w 1382 r. Podstawą utrzymania klasztoru i sanktuarium jasnogórskich były dobra ziemskie oraz różnego rodzaju darowizny finansowe. Zapisów dokonywali władcy polscy, przedstawiciele rodzin królewskich, magnaci i szlachta, sejm Rzeczypospolitej oraz przeorowie klasztorów paulińskich jako przedstawiciele wspólnoty danego konwentu.

Na podstawie zachowanych źródeł zidentyfikowano 56 zapisów na kwotę 1131121,29 złp. Od tej kwoty klasztor powinien otrzymywać odsetki od 3,5 do 7\%. Jednak według zachowanych źródeł rocznie zbierano 8215,10 złp, zatem odsetki wynosiły zaledwie $0,73 \%$ zapisanych kwot. Część zapisów była martwa, tzn. klasztor nie otrzymywał żadnych odsetek. Ponadto traktat petersburski z 26 stycznia 1797 r. stwierdzał, że kwoty należące do Kościoła pozostawały „pod opieką” państw zaborczych i znajdowały się w gestii skarbu tych państw.

Zapisy finansowe klasztoru jasnogórskiego były najwyższe spośród klasztorów polskiej prowincji. Wynikało to z pozycji jaką Jasna Góra odgrywała w życiu religijnym Rzeczpospolitej. Odsetek przychodów z tytułu zapisów finansowych w ogólnej kwocie przychodów wahał się od 16,10\% do 4,76\%. Wysokość uzyskiwanych kwot spadała w ciągu XVIII w. Umożliwiały one paulinom działalność, która była prowadzona dzięki ofiarności i przychylności elit Rzeczpospolitej.

Słowa kluczowe: zakon paulinów, Jasna Góra, Częstochowa, finanse.

\section{Wstęp}

Klasztor OO. Paulinów na Jasnej Górze jest jednym z najważniejszych miejsc kultu religijnego na świecie. Co roku przybywają tutaj miliony wiernych i turystów, którzy chcą dotknąć tajemnicy religijnej lub poznać zabytki sztuki i kultury 
katolickiej. Stąd też wielu badaczy z różnych dziedzin podejmowało prace nad dziejami tego sanktuarium ${ }^{1}$. Jednak brak jest jak dotąd szerszego zainteresowania dziejami gospodarczymi klasztoru. To ważne zagadnienie, aczkolwiek wymagające długich i żmudnych badań w oparciu o źródła rękopiśmienne, gdyż klasztor i sanktuarium nie mogłyby istnieć bez podstaw ekonomicznych, ponieważ wszelka działalność człowieka wymaga odpowiednich środków materialnych. Stąd też moje zainteresowania dotyczą zagadnień dziejów gospodarczych klasztoru jasnogórskiego ${ }^{2}$.

Niniejszy tekst oparty jest przede wszystkim na źródłach znajdujących się w Archiwum Zakonu Paulinów na Jasnej Górze w Częstochowie, gdzie zachowały się księgi finansowe prowadzone przez administratorów dóbr klasztornych.

1 Można wymienić m.in.: Kazimierz SZAFrANIEC, Konwent paulinów jasnogórskich 1382-1864, Rzym 1966; Henryk Czerwień, Sprawa obrazu Matki Boskiej Częstochowskiej na sejmie grodzieńskim w 1793 roku, „Nasza Przeszłość”, t. 31: 1969; Bolesław KumoR, Austriackie władze zaborcze wobec kultu Królowej Polski i pielgrzymek na Jasna Górę (1772-1809), „Studia Claromontana”, t. 1: 1981; Stefan Jan RożEJ, Bractwo Najświętszej Marii Panny Jasnogórskiej i Znalezienia Krzyża Świętego na Jasnej Górze w XVIII i XIX wiek, „Studia Claromontana", t. 1: 1981; Kazimierz STOPNIAK, Z dziejów kultu Matki Boskiej Częstochowskiej na Lubelszczyźnie i Podlasiu w latach 1815-1914, „Studia Claromontana”, t. 2: 1981; Władysław SzCZEPAŃSKI, Apteka jasnogórska, „Studia Claromontana”, t. 2: 1981; Bronisław MATYSZCZYK, Bractwa religijne na Jasnej Górze w okresie Polski przed-rozbiorowej, Warszawa 1982; Stanisław Zachariasz JABŁOŃSKI, Jasna Góra. Ośrodek kultu maryjnego (1864-1914), Lublin 1984; Leszek WoJCIECHOWsKi, Przekazy Dlugosza o pierwszej fundacji Jasnej Góry, „Studia Claromontana”, t. 5: 1984; Jacek WIESIOŁOWSKI, Fundacje paulińskie XIV i XV wieku na tle ruchu fundacyjnego klasztorów w Polsce, „Studia Claromontana”, t. 6: 1985; L. WojcIECHOwsKi, Najstarsze klasztory paulinów w Polsce. Fundacja - uposażenie - rozwój do około 1430 roku, „Studia Claromontana”, t. 11: 1991; Janusz ZBUDNIEweK, Klasztor jasnogórski $i$ jego rola pielgrzymkowa, [in:] Częstochowa. Dzieje miasta $i$ klasztoru jasnogórskiego, t. 1: Okres staropolski, Częstochowa 2002; idem, Paulini wczoraj i dzisiaj, „Studia Claromontana”, t. 25: 2007; Jerzy SPERKA, Otoczenie Władystawa Opolczyka w latach 1370-1401, Katowice 2006; Brunon KuBICA, Pierwsza koronacja cudownego obrazu Matki Bożej Częstochowskiej, „Studia Claromontana”, t. 25: 2007; Jan KoPIEC, Udziat pogranicznego Śląska Opolskiego w ksztattowaniu duchowości maryjnej paulinów od 1740 roku do I wojny światowej, „Studia Claromontana”, t. 27: 2009; Michał WARDZYŃSKI, Rzeźba nowożytna w kręgu jasnej Góry $i$ polskiej prowincji zakonu paulinów, t. 1: Ośrodek rzeźbiarski w Częstochówce pod Jasną Góra 1620-1705, Warszawa 2009.

2 Do tej pory ukazało się zaledwie kilka prac, które poruszały kwestie ekonomiczne, m.in.: Z. ZABORSKI, Rezydencja paulinów w Wiewcu, „Studia Claromontana”, t. 6: 1985; Wojciech KĘDER, Jasna Góra wobec przemian politycznych w Rzeczypospolitej w latach 1661-1813, „Studia Claromontana”, t. 13: 1993; Dariusz Zıоткоwsкi, Udziat zakonu ojców paulinów w życiu społeczno-politycznym Rzeczypospolitej w XVIII w., Częstochowa 1994; Zygmunt ZABORSKI, Parafia Wiewiec. Zarys dziejów, Częstochowa 1999; Ewa Maria ZıóŁeK, Między tronem a oltarzem. Kościót i państwo w Księstwie Warszawskim, Lublin 2012; JACEK SZPAK, Finanse starostwa klobuckiego 1659-1789, „Magazyn Numizmatyczny”, nr 40: 2014; idem, Ciężary wojskowe z dóbr starostwa brzeźnickiego w latach 1651-1793, [in:] Pecunia nervus belli. $Z$ dziejów dyplomacji i stosunków międzynarodowych w XVI-XVIII wieku, red. Mariusz MARKIEWICZ, Ryszard SKOwRON, Filip WOLAŃSKI, Katowice 2016. 
Poza tym każdy klasztor pauliński był zobowiązany do składania sprawozdań, również ekonomicznych, w czasie obrad kapituł, które zbierały się co 1,5 roku.

Andrzej Jerzy Zakrzewski stwierdził w jednym ze swoich tekstów, że: „Większość historyków i badaczy dziejów Jasnej Góry i Częstochowy przyznaje, że głównym źródłem utrzymania i rozwoju dwu organizmów w XVII-XVIII wieku był ruch pątniczy”. Jednak do takiej opinii podchodzono ostrożnie, ponieważ opierała się ona na przypuszczeniach ${ }^{3}$. Stąd też jednym z najważniejszym celów badań nad dziejami Jasnej Góry jest odpowiedź na pytanie, jakie były ekonomiczne podstawy funkcjonowania klasztoru i sanktuarium na Jasnej Górze w okresie nowożytnym?

\section{Zarys dziejów klasztoru jasnogórskiego do 1795 r.}

Klasztor paulinów na Jasnej Górze w Częstochowie został ufundowany przez księcia opolskiego Władysława 9 sierpnia 1382 r. ${ }^{4} \mathrm{Z}$ jego inicjatywy do Polski przybyło kilku zakonników z Węgier, którzy prawdopodobnie przejęli z rąk plebana częstochowskiego Henryka Biela z Błeszna herbu Ostoja, kościół parafialny istniejący na wzgórzu jasnogórskim. Natomiast dotychczasową parafię przeniesiono do kościoła św. Zygmunta w Starej Częstochowie 5 . W dniu 31 sierpnia 1384 r. paulini jasnogórscy otrzymali od ks. Władysława obraz Matki Boskiej, który wg legendy przywiózł z zamku bełskiego ${ }^{6}$. Fundacja otrzymała także zatwierdzenie biskupa krakowskiego Jana Radlicy ${ }^{7}$.

W latach 1391-1396 doszło do wojny ks. Władysława z królem Polski Władysławem Jagiełłą, który odebrał mu tzw. księstwo wieluńskie, otrzymane jako lenno od Ludwika Węgierskiego ${ }^{8}$. W tej sytuacji klasztor jasnogórski stracił podstawy prawne swojego istnienia, Władysław Jagiełło bowiem nie uznawał nadań poprzednika. Jednak w 1393 r. król ponownie dokonał fundacji klasztorów na Jasnej Górze i w Wieluniu?.

3 Cit. a: W. KęDER, Jasna Góra wobec, s. 71.

4 J. SPERKA, op. cit., s. 136, 233, 253, 287, 290, 301, 344.

5 AJG 540, APP t. 11b, s. 200-203; J. ZBUDNIEWEK, Katalog domów i rezydencji polskiej prowincji paulinów, „Nasza Przeszłość”, 31: 1969, s. 199-200; J. SPERKA, op. cit., s. 70-71, 179, 258 259, 301, 346; Jacek LABERSCHEK, Częstochowa i jej okolice jej okolice w średniowieczu, Kraków 2006, s. 98-99.

6 J. SPERKa, Otoczenie Wtadystawa Opolczyka, s. 249, 253, 297.

7 Bożena CZwoJdraK, J. SPERKA, Biskupi polscy wobec paulinów w Polsce średniowiecznej, „Studia Claromontana", t. 27: 2009, s. 58; J. SPERKA, op. cit., s. 249, 253, 297; Anna PorĘBA, Aleksandra SKRZYPIETZ, J. SZPAK, Źródła Leśniowa, cz. 2, Leśniów-Kraków 2016, s. 15-22.

8 Szerzej na ten temat: J. SPERKA, Wojny króla Władysława Jagietly z księciem opolskim Władystawem (1391-1396), Wodzisław Śląski 2011.

9 L. WojcIechowski, Najstarsze klasztory paulinów, s. 115-119; Karol NaBiateK, Starostwo olsztyńskie od XIV do polowy XVII wieku, Kraków 2012, s. 88-92; Michał BaLIŃsKI, Piel- 
Po wybuchu wojny trzydziestoletniej w rejonie Częstochowy dochodziło prawdopodobnie do napadów wojsk obu stron. Przynosiło to spore straty, np. w 1620 r. liczba kmieci we wsi Kusięta, należącej do starostwa olsztyńskiego, spadła z 13 do $3^{10}$. Dlatego w 1620 r. podjęto decyzję o przekształceniu Jasnej Góry w twierdzę. Projekt autorstwa Andrzeja del'Aqua powstał na przełomie 1623 i 1624 r., a prace zakończono ok. 1648 r. Twierdza znajdowała się pod nadzorem paulinów, a funkcję komendanta pełnił prowincjał. Przejęła ona funkcję nadgranicznego punktu oporu, który bronił granicy Rzeczypospolitej od strony Śląska ${ }^{11}$. Twierdza jasnogórska odgrywała ważną rolę na zachodniej granicy Małopolski. Stąd też w 1652 r. sejm uchwalił konstytucję, na mocy, której paulini zostali zwolnieni z ciężarów podatkowych. W zamian zakon miał utrzymywać własnym sumptem załogę twierdzy ${ }^{12}$.

Jednym z najważniejszych wydarzeń nie tylko w dziejach klasztoru jasnogórskiego, ale również całej polskiej prowincji zakonu było oblężenie w czasie „,potopu szwedzkiego". W dniu 18 listopada 1655 r. oddziały gen. Burharda Müllera stanęły pod Jasną Górą z zamiarem zajęcia twierdzy, jednak po miesiącu zostały zmuszone do odwrotu ${ }^{13}$. Wojska szwedzkie próby jej zdobycia podejmowały również w latach 1702-1709, ale i tym razem bezskutecznie ${ }^{14}$. Postawa paulinów w dobie „potopu” i III wojny północnej przyniosła im ogromną popularność w społeczeństwie szlacheckim ${ }^{15}$. Na dworze królewskim, wśród magnatów

grzymka do Jasnej Góry w Częstochowie odbytej przez pątnika XIX wieku i wydana z rękopisu przez Michała Balińskiego, Warszawa 1846, s. 222-226.

10 K. NABIAŁEK, op. cit., s. 341-342, 349.

11 W. KęDER, Jasna Góra wobec, s. 43-45, 83-84, 148-151; Ryszard Henryk BocheneK, Rola twierdzy jasnogórskiej u jej genezy $i$ w rzeczywistości połowy XVII wieku, „Studia Claromontana", t. 23: 2005, s. 159-160; J. ZBudNIEweK, Paulini wczoraj i dzisiaj, s. 88, 201-202.

12 AJG 1155, s. 55, 237-243; VL, t. IV. Petersburg 1859, s. 259; W. KĘDER, Jasna Góra wobec, s. 64.

13 K. SZAFRANIEC, Konwent paulinów jasnogórskich, s. 70, 82-103; K. SZAFRANIEC, Ojciec Augustyn Kordecki w świetle duchowości paulinów polskich XVII w., Warszawa 1980, s. 67-68; Zbigniew WósCIK, Tło historyczne obrony klasztoru jasnogórskiego w roku 1655, [in:] Częstochowa. Dzieje miasta i klasztoru, s. 318-335.

14 ANK, Acta Castriensia Cracoviensia 761, s. 31; Księga 2 obejmująca lata od 1663 do 1727. Autor: o. Mikołaj Benger OSPE, [in:] Roczniki zakonu św. Pawła Pierwszego Pustelnika, t. I, oprac. Leon ChalupKa, Częstochowa-Jasna Góra 2008, s. 720-721, 735-739, 744-745; J. ZBudnieweK, Człowiek wielkiej wiary i pracowitości. O. Innocenty Pokorski (1656-1734), „Studia Claromontana”, t. 2: 1981, s. 127-136; W. KĘDER, Zygmunt ŁAKOCIŃSKI, Klasztor na Jasnej Górze wobec zagrożenia szwedzkiego w czasie trzeciej wojny pótnocnej w latach 1702 1705, „Studia Claromontana”, t. 4: 1983, s. 270-273, 276-277, 283-284; D. ZŁOTKOwSKI, Udział zakonu ojców, s. 30; W. KęDER, Jasna Góra wobec, s. 110-119, 123, 780-781; Łukasz PABICH, Twierdza Jasna Góra w okresie Wielkiej Wojny Pótnocnej (w latach 1702-1710), [in:] Twierdze osiemnastowiecznej Europy. Studia z dziejów nowożytnej sztuki wojskowej, red. Maciej TrąBSKI, Oświęcim 2016, s. 84-96.

15 ANK, Acta Castriensia Cracoviensia 761, s. 31, 144; Ksiega 2. Autor: o. Mikotaj Benger, s. 720-721, 735-739, 787-788; AJG 1155, s. 67-68, 237-240; W. KĘDER, Jasna Góra wobec, s. $66-67,138-139$. 
świeckich oraz biskupów szczególnie ceniony był wielokrotny prowincjał, o. Konstanty Moszyński ${ }^{16}$. O pozycji sanktuarium jasnogórskiego w Rzeczpospolitej świadczyła pierwsza na ziemiach polskich koronacja wizerunku Matki Boskiej koronami papieskimi, która odbyła się 8 września 1717 r. ${ }^{17}$

Za panowania Stanisława Augusta Poniatowskiego (1764-1795) nastroje antyklerykalne, a zwłaszcza antyzakonne narastały wśród części społeczeństwa szlacheckiego. Król popierał zakony w jego pojęciu przydatne, czyli takie, które prowadziły szkoły publiczne i roztaczały opiekę nad chorymi ${ }^{18}$. Nieprzyjaznym wobec paulinów pociągnięciem władcy było odebranie w 1765 r. dowództwa nad twierdzą przeorowi jasnogórskiemu. Odtąd miał nią zarządzać komendant podległy Komisji Wojskowej ${ }^{19}$.

W dobie konfederacji barskiej (1768-1772) twierdza była trzykrotnie opanowywana przez konfederatów (w 1769 i 1770). Szczególnie aktywne działania militarne pod Częstochową miały miejsce na przełomie 1770 i 1771 r., kiedy pod Jasną Górą stanęły wojska rosyjskie pod dowództwem mjr. Iwana Drewicza, jednakże tak jak poprzednio szwedzkie musiały od niej odstąpić nie osiągnąwszy sukcesu $^{20}$. Ostatecznie twierdza skapitulowała 18 sierpnia 1772 r. i na pięć miesięcy została zajęta przez wojska rosyjskie ${ }^{21}$.

Dwadzieścia jeden lat później (1793) w wyniku II rozbioru Jasna Góra znalazła się pod panowaniem pruskim ${ }^{22}$. Na sejmie grodzieńskim biskupi: wileński

16 J. ZbUdnIEweK, Paulini wczoraj i dzisiaj, s. 122-123; W. KĘDER, Jasna Góra wobec, s. 87, 108110, 121-122, 128-133; Ł. Pabich, op. cit., s. 93.

17 J. Zbudniewer, Paulini wczoraj i dzisiaj, s. 123; Alfons JęDRZeJewski, Jasna Góra. Historia klasztoru i cudownego obrazu Matki Boskiej Częstochowskiej, Częstochowa 1946, s. 168-173; B. KubiCA, Pierwsza koronacja cudownego obrazu Matki Bożej Częstochowskiej, „Studia Claromontana", t. 25: 2007, s. 429-458.

18 Stanisław ChodyŃSki, Paulini w Polsce, [in:] Encyklopedia kościelna, t. 18, wyd. Michał NoWODWORSKI. Warszawa 1892, s. 454; Stanisław LITAK, Od reformacji do oświecenia. Kościót katolicki w Polsce nowożytnej, Lublin 1994, s. 188.

19 W. KęDer, Jasna Góra wobec, s. 149-150; idem, Nuncjusz Angelo Maria Durini a paulini. Przyczynek do wzajemnych relacji Stolicy Apostolskiej z Rzeczpospolita w dobie panowania Stanisława Augusta Poniatowskiego, „Studia Claromontana”, t. 27: 2009, s. 408-412.

20 Diariusz ataku fortecy częstochowskiej woyskiem konfederackim osadzonej, przez woysko moskiewskie uczynionego, Biblioteka Polska w Paryżu, s. 216-243; Kopia listu do JKM dnia 1 listopada 1770 roku pisanego względem odstąpienia imprezy ataku Częstochowy, ibidem, s. 601-604; Maciej TrąBSKI, Diariusz oblężenia twierdzy jasnogórskiej w 1771 roku, [in:] Częstochowskie teki historyczne, t. 4, red. Norbert MORAWIEC, M. TRĄBSKI, Częstochowa 2013/2014, s. 183-207; D. ZŁOTKOWsKi, Udziat zakonu ojców, s. 90-91; W. KĘDER, Nuncjusz Angelo Maria Durini, s. 412-418.

${ }^{21}$ Księga 3. Z uzupełnieniami obejmujące lata od 1727 do 1786. Ks. 3. Autor: o. Marcin Streska OSPEE, [in:] Roczniki zakonu św. Pawła, t. 1, s. 459-463; M. TRĄBSKI, Diariusz oblężenia twierdzy, s. 192-193; idem, Artyleria twierdzy jasnogórskiej w epoce saskiej i stanistawowskiej (1702-1793), [in:] Twierdze, s. 109, 112.

22 Przez trzynaście lat (1793-1806) twierdzą komenderowali kolejni pruscy oficerowie: de Zeltzer (†1796 r.), Gliński, gen. mjr Karl Philipp Politz (†1805) i mjr Hundt. Vide: D. ZıOTKOwsKI, 
Ignacy Massalski, inflancki Jan Kossakowski i chełmski Wojciech Skarszewski wysunęli propozycję, aby obraz Matki Boskiej Częstochowskiej został przeniesiony z Jasnej Góry do Krakowa. Zażądano także oddania skarbca jasnogórskiego. Poseł pruski Ludwig Heinrich Buchholtz, stwierdził jednak, że obraz powinien pozostać w Częstochowie. Na kolejnych sesjach ponawiano żądanie oddania obrazu Rzeczpospolitej, które popierał poseł rosyjski Jakov Sievers. Władze pruskie zrazu były przeciwne przekazaniu obrazu. Jednak w instrukcji dla L.H. Buchholtza z 13 września 1793 r., pozostawiły decyzję co do obrazu w jego rękach. Paulini zaczęli starać się o poparcie dla pozostawienia obrazu na Jasnej Górze wśród elit pruskich (Ferdynand Jerzy von Oppeln Bronikowski prezes kamery piotrkowskiej) oraz polskich, m.in. Izabeli Czartoryskiej. Dwór pruski ostatecznie odrzucił polskie żądania. Na sesji sejmowej z 23 września 1793 r. zatwierdzono traktat cesyjny na rzecz Prus, a obraz jasnogórski pozostał w Częstochowie ${ }^{23}$.

Wybuch powstania kościuszkowskiego zaniepokoił władze pruskie, obawiano się bowiem rozruchów. Dlatego szybko w rejon Częstochowy ściągnięto większe oddziały wojska. Na Jasnej Górze znalazł się też Fryderyk Wilhelm II, który zdążał do korpusu mającego thumić powstanie ${ }^{24}$. Operacje z kwietniaczerwca 1794 r., które toczyły się w rejonie Częstochowy przyniosły znaczne straty materialne okolicznej ludności oraz w dobrach klasztoru jasnogórskiego ${ }^{25}$.

Po likwidacji Rzeczpospolitej w 1795 r., Prusacy zaostrzyli swoją politykę wobec Polaków, a przede wszystkim wobec Kościoła katolickiego. Niechęć władz pruskich do zakonów zaowocowała przejęciem wszystkich dóbr klasztoru jasnogórskiego (m.in.: starostw kłobuckiego i brzeźnickiego), co nastąpiło w latach $1796-1798^{26}$.

\section{Zapisy finansowe dla klasztoru jasnogórskiego do 1795 r.}

Podstawą utrzymania klasztoru jasnogórskiego były dobra ziemskie oraz różnego rodzaju zapisy i darowizny finansowe przekazywane przez wiernych róż-

Pod pruskim zaborem 1793-1806, [in:] Częstochowa. Dzieje miasta i klasztoru jasnogórskiego,

t. 2: W okresie niewoli 1793-1918, Częstochowa 2002, s. 15-18.

23 H. CZerwié, Sprawa obrazu Matki Boskiej, s. 107-123.

24 D. Zıotкowski, Pod pruskim zaborem, s. 19.

25 Tadeusz Rawski, Przeciwdziałania rosyjskie i pruskie, [in:] Powstanie kościuszkowskie 1794. Dzieje militarne, t. 1, Warszawa 1994, s. 169; idem, Decyzje stron, [in:] ibidem, s. 173; Stanisław Herbst, Próba Kościuszki marszu na Warszawę, [in:] ibidem, s. 191-192; S. Herbst, T. RAWski, Działania wstępne, [in:] ibidem, s. 243-244; Zygmunt WALTER-JANKE, Uderzenie od zachodu - Szczekociny, [in:] ibidem, s. 254-255; D. ZŁotкowski, Powstanie kościuszkowskie widziane z Jasnej Góry (w świetle Kroniki Konwentu), „Zeszyty Historyczne WSP w Częstochowie", z. 4: 1997, s. 161-173.

26 AJG 1135, s. 7, 23, 33-36, 53. 
nych stanów. Były to wyderkafy, darowizny z obowiązkami religijnymi lub innego typu darowizny finansowe, a także zwrot pożyczek oraz odsetki bankowe. Tabela nr 1 ilustruje udokumentowane zapisy na rzecz Jasnej Góry zapisane do III rozbioru Rzeczpospolitej w 1795 r., wówczas bowiem, klasztor znalazł się pod władzą Prus.

Tabela 1. Zapisy kapitałowe na rzecz klasztoru paulinów na Jasnej Górze w Częstochowie

\begin{tabular}{|c|c|c|c|c|c|c|}
\hline data zapisu & ofiarodawca & $\begin{array}{c}\text { dobra na } \\
\text { których } \\
\text { zabezpieczono } \\
\text { zapis }\end{array}$ & rodzaj zapisu & $\begin{array}{c}\text { kwota zapisu } \\
\text { [zlp, gr] }\end{array}$ & $\begin{array}{c}\text { odsetki } \\
\text { rocznie } \\
{[\%-} \\
\text { kwota] }\end{array}$ & $\begin{array}{c}\text { do kiedy } \\
\text { wyplacan } \\
\text { o odsetki }\end{array}$ \\
\hline XV w. & $\begin{array}{l}\text { Wtadystaw } \\
\text { Jagietto }\end{array}$ & Kalej & $\begin{array}{l}\text { nabożeństwa } \\
\text { i msze za króla } \\
\text { i jego rodzinę }\end{array}$ & . & 703,26 & 1794 \\
\hline $1622 \mathrm{r}$. & $\begin{array}{l}\text { Sebastian } \\
\text { i Barbara } \\
\text { Żeromscy }\end{array}$ & $\begin{array}{c}\text { na wsiach } \\
\text { Dziewki i Nowa } \\
\text { Wieś }\end{array}$ & wyderkaf & 1000,00 & $6 \%-60,00$ & 1794 \\
\hline $1626 \mathrm{r}$. & $\begin{array}{c}\text { Stanistaw } \\
\text { Dobrzylewski }\end{array}$ & $\begin{array}{l}\text { na Wiewcu, } \\
\text { Woli } \\
\text { Wiewieckiej } \\
\text { i Łochińsku }\end{array}$ & wyderkaf & 30000,00 & $100,00^{\mathrm{a})}$ & . \\
\hline 1633 r. & $\begin{array}{c}\text { Dorota } \\
\text { Kotficzowa żona } \\
\text { Jana Kotficza }\end{array}$ & na wsi Wiewiec & msze żałobne & 1000,00 & $5 \%-50,00$ & . \\
\hline $1633 \mathrm{r}$. & $\begin{array}{c}\text { Tomasz Zamoyski } \\
\text { podkanclerzy } \\
\text { koronny }\end{array}$ & $\begin{array}{l}\text { na dobrach } \\
\text { rodowych }\end{array}$ & $\begin{array}{c}\text { msze żałobne za } \\
\text { zmarłych } \\
\text { przodków }\end{array}$ & 3000,00 & . & . \\
\hline 1642 r. & $\begin{array}{c}\text { Jan Sapieha } \\
\text { marszatek WKL }\end{array}$ & - & $\begin{array}{c}15 \text { mszy za } \\
\text { ofiarodawcę i jego } \\
\text { przodków }\end{array}$ & 300,00 & bez odsetek & . \\
\hline 17 IV 1643 r. & $\begin{array}{c}\text { klasztor } w \\
\text { Wielgomtynach }\end{array}$ & 一 & darowizna & 300,00 & bez odsetek & . \\
\hline $1647-1648$ & $\begin{array}{c}\text { Jerzy Ossolinski } \\
\text { kanclerz wielki } \\
\text { koronny }\end{array}$ & \begin{tabular}{|c|} 
Zakrzów \\
i Goźlice w ziemi \\
sandomierskiej
\end{tabular} & wyderkaf & 6266,00 & $7 \%-439,00 \mid$ & . \\
\hline $3 \times 1651$ r. & $\begin{array}{c}\text { Stanistaw } \\
\text { Chodakowski }\end{array}$ & 一 & $\begin{array}{c}\text { w zamian za mszę } \\
\text { za zmarłą żonę } \\
\text { Annę z Bobolic }\end{array}$ & 1000,00 & . & . \\
\hline ok. 1658 r. & $\begin{array}{c}\text { król Jan } \\
\text { Kazimierz }\end{array}$ & $\begin{array}{c}\text { na starostwie } \\
\text { kłobuckim }\end{array}$ & wyderkaf & . & . & 1794 \\
\hline $20 \mathrm{~V} 1671 \mathrm{r}$. & $\begin{array}{l}\text { ks. Aleksander } \\
\text { Denhoff }\end{array}$ & $\begin{array}{c}\text { kamienice nr } 23 \\
\text { i } 49 \text { na rynku } \\
\text { krakowskim }\end{array}$ & $\begin{array}{c}\text { nabożeństw za } \\
\text { ofiarodawcę } \\
\text { w kaplicy } \\
\text { „Denhoffowskiej” } \\
\text { na Jasnej Górze }\end{array}$ & 10000,00 & $5 \%-500,00$ & $\mid \begin{array}{c}1815-1827 \\
1845\end{array}$ \\
\hline
\end{tabular}


Tabela 1. Zapisy kapitałowe na rzecz klasztoru paulinów... (cd.)

\begin{tabular}{|c|c|c|c|c|c|c|}
\hline data zapisu & ofiarodawca & \begin{tabular}{|c|} 
dobra na \\
których \\
zabezpieczono \\
zapis
\end{tabular} & rodzaj zapisu & $\begin{array}{c}\text { kwota zapisu } \\
\text { [zlp, gr] }\end{array}$ & $\begin{array}{c}\text { odsetki } \\
\text { rocznie } \\
{[\%-} \\
\text { kwota] }\end{array}$ & $\begin{array}{l}\text { do kiedy } \\
\text { wyplacan } \\
\text { o odsetki }\end{array}$ \\
\hline XVII w. & $\begin{array}{c}\text { królowa Maria } \\
\text { Kazimiera } \\
\text { Sobieska }\end{array}$ & $\begin{array}{c}\text { na wsi } \\
\text { Skrzydłów }\end{array}$ & wyderkaf & 12000,00 & $\begin{array}{c}3,50 \%- \\
420,00\end{array}$ & 1794 r. \\
\hline $1686 \mathrm{r}$. & $\begin{array}{l}\text { klasztor w } \\
\text { Warszawie }\end{array}$ & . & wyderkaf & 1000,00 & . & . \\
\hline . & . & $\begin{array}{c}\text { na dobrach } \\
\text { Oleśnica woj. } \\
\text { sandomierskie }\end{array}$ & wyderkaf & 9000,00 & $\begin{array}{l}3,5 \%- \\
315,00\end{array}$ & $\begin{array}{c}\text { nie } \\
\text { wypłacano }\end{array}$ \\
\hline 1710 r. & $\begin{array}{l}\text { Rada Walna } \\
\text { Warszawska }\end{array}$ & - & darowizna & 30000,00 & bez odsetek & $\begin{array}{c}\text { nie } \\
\text { wypłacono }\end{array}$ \\
\hline XVIII w. & $\begin{array}{c}\text { prowincjat K. } \\
\text { Moszyński }\end{array}$ & $\begin{array}{c}\text { na wsi } \\
\text { Konopiska }\end{array}$ & wyderkaf & . & 734,14 & 1794 \\
\hline XVIII w. & $\begin{array}{c}\text { paulin Primus } \\
\text { Michat } \\
\text { Krasowski }\end{array}$ & na wsi Brudzice & wyderkaf & . & 1000,00 & 1794 \\
\hline 8 XI 1712 r. & ks. Jan Męciński & $\begin{array}{c}\text { Skrzydłów woj. } \\
\text { sieradzkie }\end{array}$ & $\begin{array}{c}\text { modlitwy za } \\
\text { zmarłych z rodu } \\
\text { Męcińskich }\end{array}$ & 100,00 & . & . \\
\hline 1717 r. & \begin{tabular}{|c|} 
Samuel \\
Ruszkowski \\
potwierdzil zapis \\
Franciszka $i$ \\
Elenory z \\
Radlickich \\
Zapolskich
\end{tabular} & . & . & 1000,00 & . & . \\
\hline 1720 r. & $\begin{array}{l}\text { Jerzy Dominik } \\
\text { Lubomirski }\end{array}$ & $\begin{array}{c}\text { kwota w } 1741 \mathrm{r} . \\
\text { zapisana na } \\
\text { dobrach } \\
\text { rodowych } \\
\text { Grodzisk }\end{array}$ & $\begin{array}{l}40 \text { mszy św. } \\
\text { rocznie }\end{array}$ & 50000,00 & $7 \%-3500$ & $\begin{array}{c}\text { nie } \\
\text { wypłacano }\end{array}$ \\
\hline 1717-1720 & $\begin{array}{c}\text { Jerzy Dominik } \\
\text { Lubomirski } \\
\text { starosta olsztyński }\end{array}$ & 一 & $\begin{array}{l}\text { darowizna na } \\
\text { remont twierdzy } \\
\text { jasnogórskiej }\end{array}$ & 110000,00 & bez odsetek & . \\
\hline $1717-1720^{b)}$ & $\begin{array}{c}\text { Jerzy Dominik } \\
\text { Ossolinski } \\
\text { podkomorzy wielki } \\
\text { koronny }\end{array}$ & 一 & $\begin{array}{c}\text { darowizna } \\
\text { na remont twierdzy } \\
\text { jasnogórskiej }\end{array}$ & 50000,00 & bez odsetek & . \\
\hline
\end{tabular}


Tabela 1. Zapisy kapitałowe na rzecz klasztoru paulinów... (cd.)

\begin{tabular}{|c|c|c|c|c|c|c|}
\hline data zapisu & ofiarodawca & \begin{tabular}{|c|} 
dobra na \\
których \\
zabezpieczono \\
zapis \\
\end{tabular} & rodzaj zapisu & $\begin{array}{c}\text { kwota zapisu } \\
\text { [zlp, gr] }\end{array}$ & $\begin{array}{c}\text { odsetki } \\
\text { rocznie } \\
{[\%-} \\
\text { kwota] }\end{array}$ & $\begin{array}{c}\text { do kiedy } \\
\text { wyplacan } \\
\text { o odsetki }\end{array}$ \\
\hline 22 II 1721 r. & $\begin{array}{c}\text { królewicz Jakub } \\
\text { Sobieski }\end{array}$ & - & \begin{tabular}{|c} 
pożyczka, którą \\
paulini musieli \\
odebrać od \\
hetmana wielkiego \\
litewskiego \\
Kazimierz Jan \\
Sapiehy
\end{tabular} & 80000,00 & bez odsetek & $\begin{array}{c}\text { nie } \\
\text { uzyskano }\end{array}$ \\
\hline $1722 \mathrm{r}$. & $\begin{array}{c}\text { Stanistaw } \\
\text { Chomentowski }\end{array}$ & - & $\begin{array}{c}\text { darowizna na prace } \\
\text { artystyczne } \\
\text { w bazylice } \\
\text { jasnogórskiej }\end{array}$ & 50000,00 & bez odsetek & $\begin{array}{c}\text { wypłacano } \\
\text { przez kilka } \\
\text { lat }\end{array}$ \\
\hline \multirow[b]{2}{*}{7 IV 1725 r. } & \multirow[b]{2}{*}{$\begin{array}{c}\text { Saтиеl } \\
\text { Ruszkowski }\end{array}$} & - & dług do odebrania & 5200,05 & . & . \\
\hline & & - & $\begin{array}{c}\text { odsetki } \\
\text { wyderkafowe }\end{array}$ & 70,00 & - & . \\
\hline 1742 r. & $\begin{array}{c}\text { hetman wielki } \\
\text { koronny Józef } \\
\text { Potocki }\end{array}$ & - & $\begin{array}{l}\text { darowizna na } \\
\text { remont twierdzy }\end{array}$ & 19000,00 & bez odsetek & wypłacono \\
\hline 1742 r. & $\begin{array}{c}\text { Marianna z } \\
\text { Pociejów } \\
\text { Borzęcka }\end{array}$ & - & $\begin{array}{c}\text { darowizna na } \\
\text { wieczna lampę } \\
\text { przed obrazem } \\
\text { Matki Bożej }\end{array}$ & 75000,00 & . & $\begin{array}{c}\text { wypłacano } \\
\text { ratami } \\
\text { prze } \\
\text { kilkanaście } \\
\text { lat }\end{array}$ \\
\hline ok. 1742 r. & $\begin{array}{c}\text { Józef Potocki } \\
\text { wojewoda } \\
\text { krakowski } i \\
\text { hetman wielki } \\
\text { koronny }\end{array}$ & $\begin{array}{c}\text { dobra } \\
\text { Kotaczków } \\
\text { w województwie } \\
\text { sandomierskim }\end{array}$ & wyderkaf & 71429,00 & . & . \\
\hline $1747 \mathrm{r}$. & $\begin{array}{c}\text { chorażyna halicka } \\
\text { Anna z Brzezia } \\
\text { Kalinowska }\end{array}$ & . & wyderkaf & 9000,00 & . & $\begin{array}{c}\text { nie } \\
\text { wypłacano }\end{array}$ \\
\hline $15 \times 1760 \mathrm{r}$. & $\begin{array}{c}\text { starosta kaniowski } \\
\text { Mikołaj Potocki }\end{array}$ & $\begin{array}{c}\text { na dobrach } \\
\text { rodowych }\end{array}$ & $\begin{array}{l}\text { Msze św. i modły } \\
\text { za zmarłego } \\
\text { fundatora }\end{array}$ & 200000,00 & . & $\begin{array}{c}\text { nie } \\
\text { wiadomo } \\
\text { czy } \\
\text { wypłacano }\end{array}$ \\
\hline $10 \times 1766$ r. & $\begin{array}{c}\text { ks. Stanistaw } \\
\text { Lubomirski } \\
\text { wojewoda } \\
\text { bracławski }\end{array}$ & $\begin{array}{c}\text { na dobrach } \\
\text { Dąbrowa }\end{array}$ & $\begin{array}{c}\text { Msze odprawiane } \\
\text { za dusze księcia, } \\
\text { jego małżonki oraz } \\
\text { przodków }\end{array}$ & 7500,00 & . & $\begin{array}{c}\text { nie } \\
\text { wypłacano, } \\
\text { zapis } \\
\text { utracony } \\
\text { w } 1785 \mathrm{r} \text {. }\end{array}$ \\
\hline
\end{tabular}


Tabela 1. Zapisy kapitałowe na rzecz klasztoru paulinów... (cd.)

\begin{tabular}{|c|c|c|c|c|c|c|}
\hline data zapisu & ofiarodawca & \begin{tabular}{|c|} 
dobra na \\
których \\
zabezpieczono \\
zapis \\
\end{tabular} & rodzaj zapisu & $\begin{array}{c}\text { kwota zapisu } \\
\text { [zlp, gr] }\end{array}$ & $\begin{array}{c}\text { odsetki } \\
\text { rocznie } \\
{[\%-} \\
\text { kwota] }\end{array}$ & $\begin{array}{l}\text { do kiedy } \\
\text { wyplacan } \\
\text { o odsetki }\end{array}$ \\
\hline XVIII w. & \begin{tabular}{|c|} 
Jadwiga \\
Lanckorońska \\
żona Jana \\
Lanckorońskiego $^{\text {kasztelana }}$ \\
radomskiego $^{\mathrm{c})}$
\end{tabular} & $\begin{array}{c}\text { na wsi } \\
\text { Czekarzowice }\end{array}$ & wyderkaf & 9000,00 & . & \\
\hline XVIII w. & . & na wsi Lgota & . & 979,24 & e & $1790 \mathrm{r}$. \\
\hline $1790 \mathrm{r}$. & $\begin{array}{c}\text { dowódca } \\
\text { garnizonu } \\
\text { jasnogórskiego }\end{array}$ & - & $\begin{array}{l}\text { darowizna na } \\
\text { remont twierdzy }\end{array}$ & 1077,00 & bez odsetek & 1790 \\
\hline XVIII w. & . & $\begin{array}{c}\text { na kahale } \\
\text { w Koniecpolu }\end{array}$ & wyderkaf & 9000,00 & . & 1792 \\
\hline XVIII w. & $\begin{array}{c}\text { Agnieszka } \\
\text { Mieroszewska }\end{array}$ & . & . & 2300,00 & . & 1794 \\
\hline XVIII w. & $\begin{array}{l}\text { Franciszek } \\
\text { Leśniewicz }\end{array}$ & . & . & 7000,00 & . & 1794 \\
\hline XVIII w. & $\begin{array}{c}\text { Marcin } \\
\text { i Katarzyna } \\
\text { Dolewscy }\end{array}$ & . & . & 1000,00 & . & 1794 \\
\hline XVIII w. & $\begin{array}{c}\text { Rafat i Katarzyna } \\
\text { Leszczyńscy }\end{array}$ & . & . & 10000 & . & 1794 \\
\hline XVIII w. & $\begin{array}{c}\text { Jadwiga } \\
\text { Szypowska }\end{array}$ & na wsi Rząsa & wyderkaf & 1000,00 & $\begin{array}{c}3,50 \%- \\
35,00\end{array}$ & \\
\hline XVIII w. & Adam Korczyński & . & . & 3000,00 & . & 1794 \\
\hline XVIII w. & $\begin{array}{c}\text { Katarzyna } \\
\text { Męcińska }\end{array}$ & . & . & 7000,00 & $2 \%-140,00$ & 1794 \\
\hline XVIII w. & $\begin{array}{c}\text { Stanistaw } \\
\text { i Eufemia } \\
\text { Denhoffowie }\end{array}$ & $\begin{array}{c}\text { na dobrach } \\
\text { Kruszyna }\end{array}$ & wyderkaf & 4000,00 & $4 \%-175,00$ & $\begin{array}{l}1794, \\
1864^{\mathrm{d})}\end{array}$ \\
\hline XVIII w. & $\begin{array}{c}\text { Władystaw } \\
\text { Zawadzki }\end{array}$ & . & wyderkaf & 3000,00 & $\begin{array}{c}1,50 \%- \\
43,00\end{array}$ & 1794 \\
\hline $\begin{array}{c}\text { XVII/XVIII } \\
\text { w. }\end{array}$ & $\begin{array}{c}\text { Stanistaw i Helena } \\
\text { Warszyccy }\end{array}$ & . & wyderkaf & 100,00 & . & 1794 \\
\hline XVIII w. & $\begin{array}{c}\text { Andrzej i Zofia } \\
\text { Wolscy }\end{array}$ & . & . & 2000,00 & . & 1794 \\
\hline XVIII w. & Stefan Leszczyński & . & . & 37000,00 & . & 1794 \\
\hline XVIII w. & $\begin{array}{c}\text { Jadwiga } \\
\text { Wylezińska }\end{array}$ & . & . & . & 3600,00 & 1794 \\
\hline
\end{tabular}


Tabela 1. Zapisy kapitałowe na rzecz klasztoru paulinów... (cd.)

\begin{tabular}{|c|c|c|c|c|c|c|}
\hline data zapisu & ofiarodawca & $\begin{array}{c}\text { dobra na } \\
\text { których } \\
\text { zabezpieczono } \\
\text { zapis }\end{array}$ & rodzaj zapisu & $\begin{array}{c}\text { kwota zapisu } \\
\text { [zlp, gr] }\end{array}$ & $\begin{array}{c}\text { odsetki } \\
\text { rocznie } \\
{[\%-} \\
\text { kwota] }\end{array}$ & $\begin{array}{l}\text { do kiedy } \\
\text { wyplacan } \\
\text { o odsetki }\end{array}$ \\
\hline XVIII w. & $\begin{array}{c}\text { Stanistaw } \\
\text { Chodakowski }\end{array}$ & - & . & 1000,00 & . & 1794 \\
\hline XVIII w. & $\begin{array}{c}\text { ród } \\
\text { Myślakowskich }\end{array}$ & . & . & 1000,00 & . & 1794 \\
\hline XVIII w. & Korytkiewicz & . & . & 1000,00 & . & 1794 \\
\hline XVIII w. & $\begin{array}{c}\text { Franciszek } \\
\text { Zawacki }\end{array}$ & na wsi Jurkowo & . & 34000,00 & . & 1794 \\
\hline XVIII w. & Maciej Dmowski & . & . & . & 7142,00 & 1794 \\
\hline XVIII w. & Feliks Trepka & na wsi Biała & . & . & . & 1794 \\
\hline XVIII w. & Józef Poleski & . & . & . & . & 1794 \\
\hline XVIII w. & Mikołaj Patecki & . & . & . & . & 1794 \\
\hline 56 zapisów & - & - & - & 1131121,29 & $\begin{array}{l}\mathbf{0 , 7 3 \%}- \\
8215,10\end{array}$ & - \\
\hline
\end{tabular}

a) Kwota 100 złp była wypłacana dopóki żyła wdowa po śmierci testatora, a po jej śmierci cała kwota miała przejść w posiadanie klasztoru.

b) Nieokreślone kwoty na remont twierdzy przekazali: kasztelan sądecki Michał Morsztyn. Dzięki temu w latach 1724-1746 zmodernizowano bastiony św. Barbary i św. Jakuba.

c) W 1836 r. konwent jasnogórski rozpoczął starania o odzyskanie zapisu w wysokości $9000 \mathrm{złp}$, którego dokonała Jadwiga Lanckorońska żona Jana Lanckorońskiego kasztelana radomskiego. Zapis został zabezpieczony na wsi Czekarzowice leżącej na obszarze guberni sandomierskiej. Starania zakonu poparła Prokuratoria Królestwa Polskiego. Jednak mimo zaangażowania całego aparatu administracyjnego, łącznie z policmajstrem, do 1854 r. nie udało się odzyskać zapisu. Nie znaleziono bowiem żadnych spadkobierców zapisodawczyni. Vide: APR, Rząd Gubernialny Radomski [1808] 1815-1866 [1898] 5799, s. 11-13, 16-51, 58, 64-67; Jan Kazimierz z Brzezia Lanckoroński kasztelan radomski w latach 1693-1698. Vide: Urzędnicy województwa sandomierskiego XVI-XVIII wieku. Spisy, oprac. Krzysztof CHŁAPOWSKI, Alicja FALNIOWSKA-GradowSKA, red. Antoni GąSIOROWSKI, Kórnik 1993, s. 72, 190.

d) 18 II 1827 r. konwent jasnogórski odzyskał kapitał 4000 złp na Kruszynie. Kwoty zapisów zostały przekazane przez dziedziców dóbr listami zastawnymi TKZ. Vide: AJG 547, APP, T. 18, s. 182-183.

Źródło: AJG 27, s. 1-42; AJG 30, s. 3-45; AJG 269, s. 15, 17, 21-23; AJG 484-485, b. pag.; AJG 461, s. 19-36, 83-99; AJG 536. APP. T. 6, s. 443-444; AJG 537. APP. T. 7, s. 478; AJG 540. APP. T. 11b, s. 64-65, 83-84, 227-228; 339-340; AJG 544. APP. T. 15, s. 142-145, 443-445; AJG 547. APP. T. 18, s. 21, 182-183, 326-328; AJG 548. APP. T. 20, s. 198, 205-207, 291, 298-300; AJG 741. APP. T. 1, s. 333-335; AJG 742. APP. T. 2, s. 90-91, 201-202; AJG 743. APP. T. 3, s. $268-$ 269; AJG 758. APP. T. 10, s. 478-481; AJG 812, s. 5; AJG 938, s. 1-3, 12-13, 41-63; AJG 939, s. 1, 3-114; AJG 950, s. 19-21, 51-55; AJG 1010, s. 16-17, AJG 1036, s. 1, 7-13; AJG 1124, s. 37-38; AJG 1128, s. 82-83; AJG 1142, s. 31-32; AJG 1155, s. 67-68, 237-243; AJG 1178, s. 83; AJG 1402, s. 5; AJG 1682, s. 101-103; AJG 1693, s. 27-29; AJG 2226, s. 15, 17, 19, 21, 33, 65-67; APCz, AmCz 200, s. 205-242, 251-254, 379-380 (część kart nie paginowana); ANK, Acta 
Castriensia Cracoviensia 761, s. 31, 179; R.H. BochENEK, op. cit., s. 134-138; D. ZŁOTKOWSKI, Udziat zakonu ojców, s. 40; W. KĘDER, Jasna Góra wobec, s. 50, 66-70, 138-143; Aleksander SKRZYPIETZ, Kontakty królewiczów Sobieskich z klasztorem jasnogórskim, „Studia Claromontana”, t. 30: 2012, s. 542; Ksiegga 2 obejmujaca lata od 1676 do 1727. Autor: o. Mikołaj Benger OSPEE, [in:] Roczniki zakonu św. Pawta, t. I, s. 720-721, 735-739, 897; Księga 3. Z uzupetnieniami obejmujace lata od 1727 do 1786. Autor: o. Marcin Streska OSPEE, [in:] Roczniki zakonu św. Pawła, t. 2, s. 144, 242; K. SZAFRANIEC, Konwent paulinów jasnogórskich, s. 15; Z. ZABORSKI, Rezydencja paulinów w Wiewcu, s. 161-168; Z. ZABORSKI, Parafia Wiewiec, s. 156-157; Stanisław ToMoń, Fundacja paulińskiego klasztoru i kościoła pw. śś. Barbary i Andrzeja Ap. w Częstochowie w pierwszej połowie wieku XVII, „Studia Claromontana”, t. 23: 2005, s. 240-245.

Na podstawie zachowanych źródeł zidentyfikowano 56 zapisów na kwotę 1131121 złp i 29 gr. Od tej kwoty klasztor powinien otrzymywać odsetki, ale nie wiadomo w jakiej wysokości. Według zachowanych źródeł rocznie zbierano 8215 złp i 10 gr. Zatem odsetki wynosiły zaledwie $0,73 \%$ zapisanych kwot. Jednak luki w materiale archiwalnym uniemożliwiają dokładne ustalenie wysokości pobieranych odsetek. Wiadomo, że odsetki od wyderkafów wahały się od 3,5 do 7\%. Jak więc widać paulini jasnogórscy nie otrzymywali wszystkich odsetek, a część z nich napływała z opóźnieniem. Trzeba również wspomnieć, że w 1794 r. klasztor jasnogórski, w wyniku przejęcia zapisów przez zaborców, utracił co najmniej $159042 \mathrm{złp}^{27}$.

Część zapisów była martwa, tzn. klasztor nie otrzymywał żadnych odsetek. Co prawda przeorowie jasnogórscy starali się odzyskać zapisy na drodze sądowej, ale nie zawsze się to udawało. Przykładem może być zapis dokonany przez księdza Aleksandra Denhoffa, który w dniu 20 maja 1671 r. zapisał 10000 złp. Kwota została zabezpieczona na kamienicach nr 23 i 49 stojących na rynku w Krakowie. W zamian paulini jasnogórscy byli zobowiązani do odprawiania nabożeństw za ofiarodawcę w kaplicy „Denhoffowskiej”. Po 1795 r. paulini jasnogórscy utracili ten zapis. Starano się go odzyskać po 1815 r., ale bez powodzenia ${ }^{28}$.

Odsetki jakie miał pobierać klasztor jasnogórski od zapisów i wyderkafów wynosiły od 7\% do 3,5\%. Warto jednak zauważyć, że sejm z 1775 r. ustalił odsetki od pożyczonych kwot jakie mogły pobierać instytucje kościelne. Odtąd nie mogły one przekraczać $3,5 \%$, podczas gdy świeccy mogli pobierać odsetki w wysokości 5\%. Ponadto traktat petersburski z 26 stycznia 1797 r. stwierdzał, że kwoty należące do Kościoła pozostawały „pod opieką” państw zaborczych i znajdowały się w gestii skarbu tych państw ${ }^{29}$.

Zapisy ze zobowiązaniami religijnymi wyniosły 265400 złp, zapisy wyderkafowe $165695 \mathrm{złp}$, darowizny celowe 335077 złp, zapisy pożyczek, które trzeba było odebrać wyniosły 85 200,05 złp. Warto zauważyć, że część zapisów

27 AJG 544, APP t. 15, s. 142-145.

28 AJG 547, APP t. 18, s. 326-328; AJG 807, APP t. 21, s. 150, 561-569; APCz, AmCz 200, b. pag.

29 Tadeusz WALACHOwICZ, Kościól katolicki w prawodawstwie Księstwa Warszawskiego, Lublin 1984, s. 153-155, 173-178, 202. 
nie została zidentyfikowana jeżeli chodzi o ich rodzaj (33,93\% zapisów). Poza tym część darowizn celowych nie została w ogóle wypłacona, np. 30000 złp, które obiecywała przekazać Rada Walna Warszawska w 1710 r. Spośród darowizn celowych 180077 złp przeznaczono na prace przy infrastrukturze obronnej twierdzy, 50000 złp przeznaczono na prace artystyczne w bazylice jasnogórskiej, 75000 złp na zabezpieczenie wiecznej lampy w kaplicy Matki Bożej ${ }^{30}$.

Zapisów dokonywali władcy polscy, przedstawiciele rodzin królewskich, magnaci i szlachta, a w XIX w. również mieszczanie. Ponadto kwoty zapisywali: sejm Rzeczpospolitej, przeorowie klasztorów paulińskich jako przedstawiciele wspólnoty danego konwentu, prowincjał paulinów, zakonnicy otrzymujący zapisy po rodzicach oraz dowódca garnizonu jasnogórskiego. Jeden zapis przeniesiono ze skasowanego w 1819 r. klasztoru brdowskiego.

Klasztor jasnogórski uzyskał największe zapisy spośród klasztorów polskiej prowincji, co ilustruje tabela nr 2. Trzeba jednak zaznaczyć, że dalsze badania nad sytuacją ekonomiczną w polskiej prowincji paulinów są kontynuowane i dotychczasowe ustalenia mogą ulec zmianie.

Tabela 2. Zapisy kapitałowe i darowizny w klasztorach polskiej prowincji paulinów

\begin{tabular}{|c|c|}
\hline klasztor & kwota zapisów [zlp, gr] \\
\hline Wlodawa & 857496,00 \\
\hline Stara Wieś & 319692,00 \\
\hline Leśna Podlaska & 311262,00 \\
\hline Leśniów & 181000,00 \\
\hline Wieluń & 82250,00 \\
\hline Konopnica & 56929,00 \\
\hline $\begin{array}{c}\text { Klasztor na Ląkach Panny Maryi pod } \\
\text { Glogówkiem na Śląsku }\end{array}$ & 36536,00 \\
\hline ogólem & $\mathbf{1 ~ 8 4 5 ~ 1 6 5 , 0 0}$ \\
\hline
\end{tabular}

Źródło: AJG 596, s. 1-3, 6-8, 27-47, 143-162; AJG 1529, s. 1-2, 4-5, 7-13, 18-20; AJG 1530, s. 7-8, 15-17, 19-20, 51; AJG 1539, s. 129-131, 145-149, 162-163, 188-189; AJG 1547, s. 177182; AJG 1548, s. 1-7, 9; AJG 1549, s. 70; AJG 1567, s. 199; AJG 1579, s. 127, 133-134, 144 151; AJG 1585, s. 9, 11; AJG 1586, s. 55-59, 75-77; AJG 1607, s. 45; AJG 1609, s. 245-246; AJG 1614, s. 217-218, 313; AJG 1615, s. 207-233, 237-245, 253, 261-262, 267, 269, 275, 281, 309, 335; AJG 1623, s. 17, 48-53; AJG 1624, s. 91; AJG 1625, s. 1-3, 5-6, 280, 289, 327-329; AJG 1652, s. 344, 376, 397; AJG 1658, s. 33-44; AJG 1661, s. 9-11; ANK, Teki Schneidra 1514, s. $57-$ 58, 79-80; Ksiega 3. Autor: o. Marcin Streska, s. 209; J. ZBUDNIEweK, Fundacja konwentu paulinów w Leśniowie-Żarkach, [in:] Źródła Leśniowa, red. J. SZPAK, Leśniów 2009, s. 66; J. ZBUDNIEWEK, Wkład paulinów starowiejskich w kulture ziemi przemyskiej, „Studia Claromontana”, t. 16: 1996, s. 345-347; Dariusz Cichor, Dzieje kościoła i klasztoru paulinów we Włodawie 1698-1864, „Studia Claromontana”, t. 13: 1993, s. 378-380, 401-403; Remigiusz ZMudA, Kasata klasztorów paulińskich na terenie Królestwa Polskiego w 1819 roku, „Studia Claromontana”, t. 25: 2007,

30 Na podstawie źródeł znajdujących się pod tabelą nr 107. 
s. 420-422; J. SzPAK, Dzieje konwentu i parafii paulinów w Leśniowie-Żarkach 1706-1864. Cz. 1 , „Studia Claromontana”, t. 20: 2002, s. 570, 582-591; idem, Dzieje konwentu i parafii paulinów w Leśniowie-Żarkach 1706-1864. Cz. 2, „Studia Claromontana”, t. 22: 2004, s. 532, 567.

Jak widać największe zapisy obok klasztoru jasnogórskiego, otrzymał klasztor we Włodawie, Starej Wsi, Leśnej Podlaskiej i Leśniowie. Jednak kwota zapisów dla Jasnej Góry stanowiła 86,82\% kwot zapisanych dla pozostałych klasztorów.

Wysokość zapisów i darowizn finansowych jakie uzyskał klasztor jasnogórski świadczy o znaczeniu klasztoru i sanktuarium zarówno w polskiej prowincji paulinów, jak i w Rzeczpospolitej. Inne klasztory paulińskie nie mogły się równać randze Jasnej Góry. Były to co najwyżej ośrodki znane w lokalnym środowisku lub w regionie, stąd też zapisy były zdecydowanie mniejsze.

Podobnie rzecz się miała $\mathrm{z}$ wysokością zapisów w innych klasztorach funkcjonujących na ziemiach polskich. Klasztor i kościół kanoników regularnych w Mstowie pod Częstochową w 1774 r. posiadał zapisy na 23350 złp, ale w aktach wizytacji biskupich nie zostały wymienione wszystkie zapisy. Odsetki od tej kwoty wynosiły $432 \mathrm{złp}$, a zaległości w ich wypłacie wynosiły ponad 4000 $\mathrm{zlp}^{31}$. Z kolei klasztor bernardynów w Kalwarii Zebrzydowskiej w latach 16711772 otrzymał zapisy wyderkafowe na kwotę 66700 złp, z których miał otrzymywać rocznie co najmniej $3220 \mathrm{złp}^{32}$. Natomiast klasztor franciszkanów w Międzyrzeczu Ostrogskim otrzymał łącznie z zapisów testamentowych 6928 złp, a z wyderkafów 36400 złp. Z tej ostatniej kwoty, franciszkanie międzyrzeccy otrzymywali odsetki w wysokości co najmniej 1770 złp rocznie ${ }^{33}$.

Widać więc, że klasztor i sanktuarium jasnogórskie odgrywało zdecydowanie ważniejszą rolę religijną, co też przekładało się na zaopatrzenie finansowe, które w znacznej mierze związane było z posługami religijnymi (nabożeństwa i Msze za ofiarodawców).

Część pieniędzy otrzymywano jako odsetki od sum zdeponowanych w bankach, np. w 1769 r. klasztor jasnogórski złożył w Banku Wiedeńskim 239200 złp. Odsetki były wypłacane do 20 września 1798 r., ponieważ na podstawie konwencji petersburskiej ze stycznia 1797 r., całą kwotę przejęło państwo austriackie. W 1812 r. paulini starali się odzyskać utracone kapitały, ale bez powodzenia ${ }^{34}$.

$\mathrm{W}$ archiwum jasnogórskim zachowały się sprawozdania finansowe dotyczące przychodów rocznych otrzymywanych z tytułu odsetek od wyderkafów i darowizn oraz zwrotów długów z lat 1719-1794. Problem ten ilustruje tabela nr 3.

31 ADWł. Akta Wizytacji Arcybiskupów Gnieźnieńskich 0374, s. 90-95.

32 Hieronim Eugeniusz WyCZAwsKI, Kalwaria Zebrzydowska. Historia klasztoru bernardynów i kalwaryjskich dróżek, Kalwaria Zebrzydowska 2006, s. 231-233, 244.

33 Tomasz CIESIELSKI, Aktywność gospodarcza klasztoru franciszkanów w Międzyrzeczu Ostrogskim w XVI w., [in:] Klasztor w gospodarce średniowiecznej i nowożytnej, red. Marek DERWICH, Wrocław 2013, s. 439-441, 445.

34 AJG 548. APP t. 20, s. 198, 205-207, 240-246. 
Według Wdj. i Wdł. po 1719/1720 r. uzyskiwano mniejsze kwoty, a średnie roczne przychody w latach 1719-1794 wynosiły 21479 złp.

Tabela 3. Roczne przychody z wyderkafów, darowizn, zwrotu pożyczek i odsetek bankowych w latach $1717-1794^{35}$

\begin{tabular}{|c|c|c|}
\hline kwota przychodów [zlp, gr] & Wdj. & Wdt. \\
\hline \multicolumn{3}{|c|}{ 1719-1720 } \\
\hline $53500,00^{36}$ & 100,00 & - \\
\hline \multicolumn{3}{|c|}{ 1742-1743 } \\
\hline 29984,06 & 56,04 & 56,04 \\
\hline \multicolumn{3}{|c|}{ IX 1759-IX 1760} \\
\hline 27191,13 & 50,82 & 90,68 \\
\hline \multicolumn{3}{|c|}{ 1767-1768 } \\
\hline 10694,04 & 19,99 & 39,33 \\
\hline \multicolumn{3}{|c|}{30 IX 1788-31 X 1789} \\
\hline 3112,00 & 5,82 & 29,10 \\
\hline \multicolumn{3}{|c|}{1794} \\
\hline 2391,10 & 4,47 & 76,83 \\
\hline średnia za lata 1719-1794 & \multicolumn{2}{|c|}{21479,00 zlp } \\
\hline
\end{tabular}

Obliczenia własne na podstawie: AJG 27, s. 1-42; AJG 30, s. 20-23, 35, 38, 40-43;AJG 269, s. 15, 17 , 21-23; AJG 422, s. 3-13; AJG 461, s. 83-99; AJG 537. APP t. 7, s. 478; AJG 540. APP, t. 11b, s. 8384, 227-228, 339-340; AJG 546. APP, t. 17, s. 55, 58; AJG 548. APP, t. 20, s. 291, 298-300; AJG 758. APP t. 10, s. 478-481; AJG 807. APP, t. 21, s. 150, 561-569, 573-574; AJG 812, s. 5; AJG 1124, s. $37-$ 38; AJG 1128, s. 82-83; AJG 1155, s. 67-68, 237-243; AJG 1178, s. 83; AJG 1402, s. 5; AJG 544. APP t. 15, s. 142-145; AJG 1682, s. 101-103; AJG 1693, s. 27-29; AJG 2226, s. 15, 17, 19, 21, 33, 65-67; APCz, AmCz 200, s. 205-242, 251-254, 379-380; ANK, Acta Castriensia Cracoviensia 761, s. 31, 179; Ks. 3. Autor: o. Mikołaj Benger, s. 720-721, 735-739; R.H. BocHENEK, op. cit., s. 134-137; D. ZŁOTKOwSKI, Udziat zakonu ojców, s. 40; W. KęDER, Jasna Góra wobec, s. 50, 66-70, 138, 140-142.

Pojawia się pytanie jaki odsetek w ogólnych dochodach uzyskiwanych przez klasztor stanowiły dochody z zapisów finansowych? Można ustalić ten odsetek, ale tylko w przybliżeniu, ponieważ nie zachowały się wszystkie materiały archiwalne. W latach 1742/1743 z tytułu zapisów finansowych klasztor uzyskał 29 984,06 złp, co stanowiło $16,10 \%$ wszystkich przychodów, w 1759/1760 r. uzyskano 27 191,13 złp, co stanowiło 9,13\% wszystkich dochodów, a w 1767/1768 r. uzyskano 10 694,04 złp, czyli 4,76\% wszystkich dochodów. Widać zatem duży i stały spadek odsetka środków z zapisów finansowych ${ }^{37}$.

35 W tabeli umieszczono tylko sumy, które z pewnością wpłynęły do kasy klasztornej.

3616000 złp było przeznaczonych na remont twierdzy, a 500 złp to odsetki o wyderkafu zapisanego na kamienicach krakowskich przez księdza Aleksandra Denhoffa.

37 AJG 27, s. 1-372; AJG 30, s. 3-45, 68-216; AJG 260, s. 2-8; AJG 269, s. 15, 17, 21-23; AJG 303, s. 279-280, 291, 323-341, 353-355, 369-371, 395-396; AJG 323, s. 91-93; AJG 324, 


\section{Zakończenie}

Klasztor jasnogórski uzyskał największe zapisy spośród klasztorów polskiej prowincji w XVII i XVIII w. Było to naturalne, ponieważ Jasna Góra była największym i najważniejszym z punktu widzenia religijnego i organizacyjnego klasztorem prowincji. Wśród ofiarodawców na rzecz sanktuarium i klasztoru byli władcy (Władysław Jagiełło, Jan Kazimierz i Maria Kazimiera), 19 przedstawicieli magnaterii, 23 przedstawicieli szlachty, 2 paulinów, 2 konwenty paulińskie, po 1 zapisie przekazali: stany Rzeczpospolitej oraz komendant twierdzy jasnogórskiej. Natomiast w 2 przypadkach nie udało się ustalić osoby ofiarodawcy.

$\mathrm{Na}$ dobrach ziemskich zabezpieczono 22 zapisy, na kamienicach miejskich i na kahale żydowskim zabezpieczono 1 zapis. W 18 przypadkach nie udało się ustalić, czy zapis był zabezpieczony na dobrach ziemskich. W przypadku 18 zapisów mamy do czynienia $\mathrm{z}$ wyderkafami, 10 zapisów otrzymano w zamian za odprawianie mszy i nabożeństw w intencji zmarłych lub żywych ofiarodawców, w 8 przypadkach przekazano ofiary na konkretne cele, w 2 przypadkach paulini otrzymali długi, które należało dopiero odzyskać, a w 18 przypadkach nie udało się ustalić charakteru zapisów.

Wysokość zapisów wyderkafowych wyniosła 165795 złp, a odsetki wg. zachowanych źródeł wynosiły 3321,14 złp, co stanowiło zaledwie 2\% zapisanej kwoty. Trzeba jednak pamiętać, że nie zachowały się wszystkie materiały archiwalne i rzeczywistość mogła wyglądać inaczej. W przypadku ofiar z obowiązkami religijnymi klasztor otrzymał 272900 złp, a odsetki od tej sumy wynosiły 4753,26 złp, co stanowiło 1,74\% zapisanych kwot. Darowizny na remont twierdzy jasnogórskiej wynosiły 180077 złp, darowizny na cele kultu religijnego 75 $000 \mathrm{złp}$, a na prace artystyczne w sanktuarium $50000 \mathrm{złp}$. Inne darowizny wynosiły 30300 złp, w tym Rada Walna Warszawska przekazała 30000 złp, których

s. 6-22, 26-27, 29-34, 36-38; AJG 391, s. 1-6, 35, 43, 59, 71, 73-75, 89, 97, 105, 113-115, 131, 149, 189, 171, 185-186, 247, 253-259, 263-264, 295-296, 301; AJG 422, s. 3-13; AJG 461, s. 83-99, 107-112, 115-117, 127-129; AJG 537. APP t. 7, s. 478; AJG 540. APP t. 11b, s. 83-84, 194, 227-228, 339-340; AJG 544. APP t. 15, s. 142-145; AJG 545. APP t. 16, s. 149, 227-228, 242; AJG 546. APP t. 17, s. 55,. 58, 172-174, 367; AJG 547. APP t. 18, s. 242; AJG 548. APP t. 20, s. 291, 298-300, 452, 455-457; AJG 758. APP t. 10, s. 478-481; AJG 759. APP t. 14, s. 43, 341; AJG 806. APP t. 19, s. 361, 366-367; AJG 812, s. 5; AJG 1124, s. 37-38; AJG 1128, s. 82-83; AJG 1155, s. 67-68, 237-243; AJG 1682, s. 101-103; AJG 1178, s. 83; AJG 1724, s. 141; AJG 1402, s. 5; AJG 1682, s. 101-103; AJG 1693, s. 27-29; AJG 1727, s. 77-87; AJG 2226, s. 5, 15, 17, 19, 21, 33, 65-67, 81, 85; APCz, AmCz 200, s. 205-242, 245-246, 251254, 276-277, 255-271, 301, 379-380; ADWłocł. Dokumenty Samoistne i Kopiariusze 3248, s. 1-3; ANK, Acta Castriensia Cracovienisa 761, s. 31, 179; Diariusz Jasnogórski p. Stanisława Kapiczyńskiego z lat 1839-1881, oprac. J. ZBudniEweK, „Studia Claromontana” 7: 1987, s. 346; W. SZCZEPAŃSKI, Apteka jasnogórska, s. 343; B. MATYSZCZYK, Bractwa religijne na Jasnej Górze, s. 66-67; Ks. 3. Autor: o. Mikotaj Benger, s. 720-721, 735-739; R. H. BocHENEK, op. cit., s. 134-137; D. ZŁotKowski, Udział zakonu ojców, s. 40; W. KęDER, Jasna Góra wobec, s. $50,66-70,138,140-142$. 
jednak paulini jasnogórscy nigdy nie otrzymali. Wreszcie długi do odebrania wynosiły 85 200,05 złp. W pozostałych przypadkach nie udało się ustalić charakteru zapisów.

Odsetek przychodów z tytułu zapisów finansowych w ogólnej kwocie przychodów wahał się od $16,10 \%$ do $4,76 \%$, ale dzięki zapisom finansowym klasztor jasnogórski osiągnął znaczne dochody. Umożliwiały one paulinom działalność, która była prowadzona dzięki ofiarności i przychylności elit Rzeczpospolitej.

Zapisy finansowe odgrywały ważną rolę w ekonomice klasztoru jasnogórskiego, jednak jak znacząca była to rola, należy dopiero dokładnie przebadać. Na razie bowiem nie mamy rozpoznanych innych źródeł dochodów klasztoru. Jednak kwoty uzyskiwane z różnego rodzaju darowizn były znaczne, chociaż wysokość przychodów z tych źródeł w XVIII w. spadała. Poza tym jak już wspomniano niektóre zapisy miały charakter tylko teoretyczny. Części pożyczek bowiem nigdy nie odzyskano, a część odsetek nie było w ogóle wypłacanych. Trzeba również pamiętać, że w latach 1794-1797 klasztor jasnogórski utracił znaczną liczbę zapisów, które skonfiskowały państwa zaborcze.

\section{Bibliografia}

\section{Źródła archiwalne}

Archiwum Diecezjalne we Włocławku: Dokumenty Samoistne i Kopiariusze 3248, Akta Wizytacji Arcybiskupów Gnieźnieńskich 0374.

Archiwum Narodowe w Krakowie: Acta Castriensia Cracovienisa 761, Teki Schneidra 1514;

Archiwum Państwowe w Częstochowie: Akta Miasta Częstochowy: 200;

Archiwum Państwowe w Radomiu: Rząd Gubernialny Radomski [1808] 1815-1866 [1898]: 5799.

Archiwum Zakonu Paulinów na Jasnej Górze w Częstochowie, sygn.: 27; 30; 260; 269; 303; 323; $324 ; 391 ; 422 ; 461 ; 484-485 ; 536$. APP t. $6 ; 537$. APP t. 7; 540. APP t. 11b; 544. APP t. 15; 545. APP t. 16; 546. APP t. 17; 547. APP t. 18; 548. APP t. 20; 596; AJG 741. APP t. $1 ; 742$. APP t. $2 ; 743$. APP t. $3 ; 758$. APP t. $10 ; 759$. APP t. $14 ; 806$. APP t. $19 ; 807$, APP t. $21 ; 812 ; 938$; 939; 950; 1010; 1036; 1124; 1128; 1135; 1142; 1155; 1682; 1178; 1724; 1402; 1529; 1530; $1539 ; 1547 ; 1548 ; 1549 ; 1567 ; 1579 ; 1585 ; 1586 ; 1607 ; 1609 ; 1614 ; 1615 ; 1623 ; 1624 ; 1625$; $1652 ; 1658 ; 1661,1682 ; 1693 ; 1727 ; 2226$.

Biblioteka Polska w Paryżu: sygn. 47, Diariusz ataku fortecy częstochowskiej woyskiem konfederackim osadzonej, przez woysko moskiewskie uczynionego, s. 216-243; sygn. 111, Kopia listu do JKM dnia 1 listopada 1770 roku pisanego względem odstąpienia imprezy ataku Częstochowy, s. 601-604.

\section{Źródla drukowane}

BALIŃSKI Michał, Pielgrzymka do Jasnej Góry w Częstochowie odbytej przez pątnika XIX wieku i wydana z rękopisu przez Michała Balińskiego, Warszawa 1846.

Diariusz Jasnogórski p. Stanisława Kapiczyńskiego z lat 1839-1881, oprac. J. ZBUDNIEWEK, „Studia Claromontana" t. 7: 1987, s. 321-406. 
Księga 2 obejmująca lata od 1663 do 1727. Autor: o. Mikołaj Benger OSPE, [in:] Roczniki zakonu św. Pawta Pierwszego Pustelnika, t. 1, oprac. Leon ChaŁupKA, Częstochowa-Jasna Góra 2008, s. 395-928.

Ksiega 3 z uzupetnieniami obejmujace lata od 1727 do 1786. Ks. 3. Autor: o. Marcin Streska OSPE, [in:] Roczniki zakonu św. Pawła Pawła Pierwszego Pustelnika, t. 1, oprac. Leon ChaŁupKA, Częstochowa-Jasna Góra 2008, s. 3-674.

Volumina Legum, t. 4, Petersburg 1859.

\section{Opracowania}

BocHENEK Ryszard Henryk, Rola twierdzy jasnogórskiej u jej genezy $i$ w rzeczywistości połowy XVII wieku, „Studia Claromontana”, t. 23: 2005, s. 159-164.

Chodyński Stanisław, Paulini w Polsce, [in:] Encyklopedia kościelna, t. 18, wyd. Michał NowoDWORSKI, Warszawa 1892, s. 427-519.

CichOR Dariusz, Dzieje kościoła i klasztoru paulinów we Włodawie 1698-1864, „Studia Claromontana", t. 13: 1993, s. 365-447.

CIESIELSKI Tomasz, Aktywność gospodarcza klasztoru franciszkanów w Międzyrzeczu Ostrogskim w XVI w., [in:] Klasztor w gospodarce średniowiecznej i nowożytnej, red. Marek DERwICH, Wrocław: Wrocławskie Towarzystwo Miłośników Historii, 2013, s. 433-446.

CzERWIEŃ Henryk, Sprawa obrazu Matki Boskiej Częstochowskiej na sejmie grodzieńskim w 1793 roku, „Nasza Przeszłość”, t. 31: 1969, s. 101-158.

CzwoJdRAK Bożena, SPERKA Jerzy, Biskupi polscy wobec paulinów w Polsce średniowiecznej, „Studia Claromontana”, t. 27: 2009, s. 57-70.

Herbst Stanisław, Próba Kościuszki marszu na Warszawę, [in:] Powstanie kościuszkowskie 1794. Dzieje militarne, t. 1, red. T. RAwsKI, Warszawa: Agencja Wydawnicza „Egros”, 1994, s. 191-192.

Herbst Stanisław, Rawski Tadeusz, Dziatania wstepne, [in:] Powstanie kościuszkowskie 1794. Powstanie kościuszkowskie 1794. Dzieje militarne, t. 1, Warszawa: Agencja Wydawnicza „Egros”, 1994, s. 241-253.

JĘDRZEJEwSKi Alfons, Jasna Góra. Historia klasztoru i cudownego obrazu Matki Boskiej Częstochowskiej, Częstochowa: nakład autora, 1946.

KĘDER Wojciech, Jasna Góra wobec przemian politycznych w Rzeczypospolitej w latach 16611813, „Studia Claromontana”, t. 13: 1993, s. 5-206.

KĘDER Wojciech, Nuncjusz Angelo Maria Durini a paulini. Przyczynek do wzajemnych relacji Stolicy Apostolskiej z Rzeczpospolita $w$ dobie panowania Stanisława Augusta Poniatowskiego, „Studia Claromontana”, t. 27: 2009, s. 397-432.

KĘDER Wojciech, ŁAKOCIŃSKI Zygmunt, Klasztor na Jasnej Górze wobec zagrożenia szwedzkiego w czasie trzeciej wojny pótnocnej w latach 1702-1705, „Studia Claromontana”, t. 4: 1983, s. $268-288$.

Kubica Brunon, Pierwsza koronacja cudownego obrazu Matki Bożej Częstochowskiej, „Studia Claromontana", t. 25: 2007, s. 429-458.

LABERSCHEK Jacek, Częstochowa i jej okolice jej okolice w średniowieczu, Kraków: Wydawnictwo Towarzystwa Naukowego Młodych Historyków „Societas Vistulana”, 2006.

Litak Stanisław, Od reformacji do oświecenia. Kościót katolicki w Polsce nowożytnej, Lublin: Towarzystwo Naukowe KUL, 1994.

NABIAŁEK Karol, Starostwo olsztyńskie od XIV do połowy XVII wieku, Kraków: Wydawnictwo Towarzystwa Naukowego Młodych Historyków „Societas Vistulana”, 2012.

PABICH Łukasz, Twierdza Jasna Góra w okresie Wielkiej Wojny Pótnocnej (w latach 1702-1710), [in:] Twierdze osiemnastowiecznej Europy. Studia z dziejów nowożytnej sztuki wojskowej, red. M. Trąbski, Oświęcim: Napoleon V, 2016, s. 84-96.

PORĘBA Anna, SKRZYPIETZ Aleksandra, SZPAK Jacek, Źródła Leśniowa, cz. 2, Leśniów-Kraków 2016. 
Rawski Tadeusz, Decyzje stron, [in:] Powstanie kościuszkowskie 1794. Powstanie kościuszkowskie 1794. Dzieje militarne, t. 1, red. T. RAwsKI, Warszawa: Agencja Wydawnicza „Egros”, 1994, s. $172-175$.

Rawski Tadeusz, Przeciwdziałania rosyjskie i pruskie, [in:] Powstanie kościuszkowskie 1794. Dzieje militarne, t. 1, red. T. RAwSKI, Warszawa: Agencja Wydawnicza „Egros”, 1994, s. 168-171.

SKRZYPIETZ Aleksander, Kontakty królewiczów Sobieskich z klasztorem jasnogórskim, „Studia Claromontana", t. 30: 2012, s. 527-548.

SPERKA Jerzy, Otoczenie Wtadystawa Opolczyka w latach 1370-1401, Katowice: Wydawnictwo UŚ, 2006.

SZAFRANIEC Kazimierz, Konwent paulinów jasnogórskich 1382-1864, Rzym: Instytut Studiów Kościelnych, 1966.

SZAFRANIEC Kazimierz, Ojciec Augustyn Kordecki w świetle duchowości paulinów polskich XVII w., Warszawa: Akademia Teologii Katolickiej, 1980.

SZPAK Jacek, Dzieje konwentu i parafii paulinów w Leśniowie-Żarkach 1706-1864. Cz. 1, „Studia Claromontana", t. 20: 2002, s. 487-598.

SzPAK Jacek, Dzieje konwentu i parafii paulinów w Leśniowie-Żarkach 1706-1864. Cz. 2, „Studia Claromontana", t. 22: 2004, s. 405-636.

Tomoń Stanisław, Fundacja paulińskiego klasztoru i kościoła pw. śś. Barbary i Andrzeja Ap. w Częstochowie w pierwszej polowie wieku XVII, „Studia Claromontana”, t. 23: 2005, s. 183-272.

TRĄBSKI Maciej, Artyleria twierdzy jasnogórskiej w epoce saskiej i stanisławowskiej (1702-1793), [in:] Twierdze osiemnastowiecznej Europy. Studia z dziejów nowożytnej sztuki wojskowej, red. M. Trąbski, Oświęcim: Napoleon V, 2016, s. 97-132.

TRĄBSKI Maciej, Diariusz oblężenia twierdzy jasnogórskiej w 1771 roku, [in:] Częstochowskie teki historyczne, t. 4, red. Norbert MoRAwIEC, M. TRĄBSKI, Częstochowa: Wydawnictwo PTH Oddział w Częstochowie, 2013/2014, s. 183-207.

Urzędnicy województwa sandomierskiego XVI-XVIII wieku. Spisy, oprac. Krzysztof CHŁAPOWSKI, Alicja FalniowsKa-GradowsKa, red. Antoni GąSIOROwSKI, Kórnik: Biblioteka Kórnicka, 1993.

WalaChowicz Tadeusz, Kościót katolicki w prawodawstwie Księstwa Warszawskiego, Lublin: Wydawnictwo KUL, 1984.

Walter-Janke Zygmunt, Uderzenie od zachodu-Szczekociny, [in:] Powstanie kościuszkowskie 1794. Dzieje militarne, t. 1, red. T. RAwsKi, Warszawa: Agencja Wydawnicza „Egros”, 1994, s. $254-278$.

WIESIOŁOWSKI Jacek, Fundacje paulińskie XIV i XV wieku na tle ruchu fundacyjnego klasztorów w Polsce, „Studia Claromontana”, t. 6: 1985, s. 145-159.

WOJCIECHOWSKI Leszek, Najstarsze klasztory paulinów w Polsce. Fundacja-uposażenie - rozwój do około 1430 roku, ,Studia Claromontana”, t. 11: 1991, s. 5-215.

WóscIK Zbigniew, Tło historyczne obrony klasztoru jasnogórskiego w roku 1655, [in:] Częstochowa. Dzieje miasta i klasztoru jasnogórskiego, t. 1: Okres staropolski, Częstochowa: Urząd Miasta, 2002, s. 303-335.

WyCZAWSKI Hieronim Eugeniusz, Kalwaria Zebrzydowska. Historia klasztoru bernardynów i kalwaryjskich dróżek, Kalwaria Zebrzydowska: Wydawnictwo OO. Bernardynów „Calvarianum”, 2006.

ZbudNIEweK Janusz, Człowiek wielkiej wiary i pracowitości. O. Innocenty Pokorski (1656-1734), „Studia Claromontana”, t. 2: 1981, s. 116-171.

ZBUDNIEWEK Janusz, Fundacja konwentu paulinów w Leśniowie-Żarkach, [in:] Źródta Leśniowa, red. J. SZPAK, Leśniów 2009, s. 59-86.

ZBUDNIEWEK Janusz, Katalog domów i rezydencji polskiej prowincji paulinów, „Nasza Przeszłość”, t. 31: 1969, s. 181-228. 
ZBUDNIEweK Janusz, Klasztor jasnogórski i jego rola pielgrzymkowa, [in:] Częstochowa. Dzieje miasta i klasztoru jasnogórskiego, t. 1: Okres staropolski, Częstochowa: Urząd Miasta, 2002, s. 385-426.

ZbudnIEweK Janusz, Paulini wczoraj i dzisiaj, „Studia Claromontana”, t. 25: 2007, s. 5-288.

ZBUDNIEWEK Janusz, Wkład paulinów starowiejskich w kulturę ziemi przemyskiej, „Studia Claromontana", t. 16: 1996, s. 345-352.

ZŁotкоwski Dariusz, Powstanie kościuszkowskie widziane z Jasnej Góry (w świetle Kroniki Konwentu), „Zeszyty Historyczne WSP w Częstochowie”, z. 4: 1997, s. 161-173.

ZŁotкоwski Dariusz, Pod pruskim zaborem 1793-1806, [in:] Częstochowa. Dzieje miasta i klasztoru jasnogórskiego, t. 2: W okresie niewoli 1793-1918, Częstochowa: Urząd Miasta, 2002, s. $13-22$.

ZŁOTKOwSKi Dariusz, Udział zakonu ojców paulinów w życiu społeczno-politycznym Rzeczypospolitej w XVIII w., Częstochowa: Wydawnictwo WSP w Częstochowie, 1994.

ZMUdA Remigiusz, Kasata klasztorów paulińskich na terenie Królestwa Polskiego w 1819 roku, „Studia Claromontana”, t. 25: 2007, s. 353-428.

\section{Financial donations for the Pauline monastery at Jasna Góra in Częstochowa in 1795}

\section{Summary}

The Pauline monastery at Jasna Góra was founded by Prince Władysław Opolczyk in 1382. Landed demesne and different financial donations provided livelihood for the monastery and Jasna Góra sanctuary. That financial support was made by Polish rulers, the royal family members, nobility, Parliament and priors of the Paulinian monasteries as representatives of convents' communities.

On the basis of preserved sources 56 donations for PLN 1131121.29 were identified. The monastery should get the interest rate from 3.5 to $7 \%$ from this amount but according to the sources it got only PLN 8215.10 annually so the interest rate was merely $0.73 \%$. A certain amount of funds was defunct, it means that the monastery did not receive any money. And furthermore, the treaty of Petersburg from January 26, 1797, stated that amount which belonged to the Church was "under protection" of the partitioning powers and it remained the responsibility of the State Treasury of these three countries.

The Monastery of Jasna Góra's financial records were the highest of all monasteries in the Polish Province. This resulted from the high position of Jasna Góra in the Polish religious life. The interest rate of the donations in the overall income fluctuated between $16.10 \%$ and $4.76 \%$. The height of amount received was on the decline throughout the 18th century. Donations were vital for the monastery and the monks benefited from the generosity and favour of the Polish elites.

Keywords: the Pauline monastery, Jasna Góra, Częstochowa, finance. 
Prace Naukowe Uniwersytetu Humanistyczno-Przyrodniczego im. Jana Długosza w Częstochowie

Marzena GONERA

https://orcid.org/0000-0003-0657-3910

Uniwersytet Humanistyczno-Przyrodniczy im. Jana Długosza w Częstochowie

\section{Aktywność parlamentarna i oratorska Adama Kazimierza Czartoryskiego na sejmie 1782 roku}

\section{Streszczenie}

Celem artykułu była prezentacja działalności parlamentarnej ks. Adama Kazimierza Czartoryskiego podczas sejmu $1782 \mathrm{r}$. Rozważania były skupione na udzieleniu odpowiedzi na następujące pytania: Czy ks. Czartoryski był skutecznym politykiem?, Jakie poglądy generał ziem podolskich wyznawał w najważniejszych sprawach poruszanych w czasie sesji sejmowych? Jak na jego mowy reagowało audytorium? Różnie istotną kwestią był sposób argumentacji, dlatego autorka wskazała najważniejsze cechy książęcego oratorstwa.

Głównymi źródłami są: diariusz sejmu 1782, zbiory mów, prasa i pamiętniki. Co więcej autorka zastosowała metodę analizy historycznej.

Słowa kluczowe: działalność polityczna, opozycja magnacka, biskup Kajetan Sołtyk, Rada Nieustająca, oratorstwo.

Działalność parlamentarna posłów i senatorów Rzeczypospolitej po I rozbiorze odbywała się w specyficznych warunkach. Realizację rodzącej się powoli i opornie myśli reformatorskiej (np. w postaci Kodeksu Zamoyskiego odrzuconego na sejmie 1780 r. ${ }^{1}$ ) ograniczało skrępowanie sejmu przez ambasadora rosyjskiego Ottona Magnusa Stackelberga oraz przez Radę Nieustającą (utworzoną w latach 1773-1775), a także konieczność uzyskania nad Newą zgody na przeprowadzenie nawet drobnych zmian ustrojowych. W związku z tym plany stron-

1 Łukasz Kurdy васна, Dzieje Kodeksu Andrzeja Zamoyskiego, [b.m.w.] 1951, s. 136; Andrzej Stroynowski, Przyczyny odrzucenia Kodeksu Zamoyskiego, „Czasopismo Prawno-Historyczne", t. 36/1-2: 1984, s. 187-198. 
nictwa regalistycznego w stosunku do kolejnego „wolnego"2 i pracującego bez asysty wojsk rosyjskich zgromadzenia parlamentarnego 1782 r. były skromne. Dotyczyły bieżących spraw gospodarczych, tj. wynagrodzeń dla deputatów trybunału oraz zdobycia dostawców soli i funduszy na jej przywóz (Rzeczpospolita utraciła do niej dostęp po I rozbiorze, gdyż Wieliczka znalazła się w zaborze austriackim). Zamierzano zająć się także uregulowaniem kwestii granicznych ${ }^{3}$ i rozwiązaniem spraw monetarnych, tzn. przekazaniem zwierzchnictwa nad mennicą Komisji Skarbowej. Liczono na zwiększenie liczby senatorów z Wielkiego Księstwa Litewskiego ${ }^{4}$. Zadaniem sejmujących była również weryfikacja działalności Rady Nieustającej i jej departamentów oraz udzielenie im absolutorium ${ }^{5}$. Do tego zaś nie chciała dopuścić wewnętrznie zróżnicowana ${ }^{6}$ opozycja magnacka, (mimo, iż jej przedstawiciele - Celestyn Czaplic, Adam Kazimierz Czartoryski, Stanisław Lubomirski, Józef Mierzejewski, Ignacy Potocki, Kazimierz Nestor Sapieha - weszli w 1778 r. w skład magistratury) ${ }^{7}$, zręcznie wykorzystu-

2 Z powodu sprzeciwu Rosji nie ziściły się królewskie plany zwołania sejmu skonfederowanego, co miało osłabić działanie opozycji. Dlatego też regaliści zaniechali działań reformatorskich. Vide: A. STRoynowski, Opozycja sejmowa w dobie rządów Rady Nieustającej: studium z dziejów kultury politycznej, Łódź 2005, s. 158.

3 Vide: Marzena Gonera, Działalność parlamentarna Adama Kazimierza Czartoryskiego, Praca doktorska napisana pod kierunkiem naukowym prof. dr hab. Andrzeja STROYNOwSKIEGO, Maszynopis znajduje się w Bibliotece Głównej Uniwersytetu Humanistyczno-Przyrodniczego im. Jana Długosza w Częstochowie, s. 98.

4 O składzie senatu: Stanisław KutrzeBA, Skład sejmu polskiego 1493-1793, „PH”, t. 2: 1906, z. 1, s. 72-73; Tomasz Schramm, Senat I Rzeczypospolitej-geneza, skład i kompetencje, [in:] Senat w tradycji i praktyce ustrojowej I Rzeczypospolitej, Warszawa 2013.

5 Sesja XI - 12 X 1782 r., [in:] Dyariusz seymu ordynaryjnego warszawskiego sześcioniedzialnego roku pańskiego MDCCLXXXII w Warszawie w Drukarni Jego Królewskiej Mości, Warszawa 1782 [dalej: Diariusz sejmu]; Witold FILIPCZAK, Uwagi o funkcjonowaniu ,wolnych” sejmów okresu Rady Nieustającej 1778-1786, [in:] Parlamentaryzm w Polsce we wspótczesnej historiografii, red. Jerzy BARDACH, przy współudziale Wandy STUDNIK, Warszawa 1995, s. 17-26.

6 A. Stroynowski, Pierwszy wolny sejm stanisławowski 1778 (główne problemy obrad), „AUL.FH”, t. 37: 1990, s. 46-47. Opozycja magnacka dzieliła się na dwa odłamy: tj. Nowa Familia czyli przedstawiciele rodziny Czartoryskich i skoligaconych z nimi przez małżeństwa córek przewodniczącego ugrupowania S. Lubomirskiego z braćmi Potockimi: Ignacym i Stanisławem Kostką oraz Sewerynem Rzewuskim. Drugie skrzydło opozycyjnego stronnictwa to grupa hetmańska pod wodzą Franciszka Ksawerego Branickiego. Vide: Władysław KonOPCZYŃSKI, Branicki Franciszek Ksawery, [in:] PSB, t. 2, Kraków 1936, s. 398-401; Jerzy MiCHaLSKI, Lubomirski Stanistaw, [in:] PSB, t. 18, Wrocław 1973, s. 53-56; idem, Poczatki opozycyjnej działalności Franciszka Ksawerego Branickiego, „KH”, R. 113/2: 2006, s. 75-131; Zofia ZIELIŃSKA, Potocki Roman Ignacy, [in:] PSB, t. 28, Wrocław 1984-1985, s. 1-17; eadem, Rzewuski Seweryn, [in:] PSB, t. 34, Wrocław 1992-1993, s. 138-152; Barbara GrochULSKA, Potocki Stanisław Kostka, [in:] PSB, t. 28, Wrocław 1984-1985, s. 158-170; W. FILIPCZAK, Sejm 1778 roku, Warszawa 2000, s. 38; A. STROYNOWSKI, Hetmani koronni na sejmach stanisławowskich, [in:] idem, Wieczory sejmowe. Studia nad dziejami parlamentaryzmu w epoce stanisławowskiej, Częstochowa 2013, s. 172-173.

7 Stanisław August Poniatowski, Pamiętniki Stanisława Augusta Poniatowskiego. Antologia, oprac. Anna GrzeŚKOWIAK-KrwawiCZ, Warszawa 2013, s. 510; W. KonOPCZYŃsKi, Geneza 
jąc w tym celu sprawę uwięzionego przez kapitułę krakowską niezrównoważonego psychicznie biskupa krakowskiego Kajetana Sołtyka i brak interwencji w obronie hierarchy Departamentu Wojskowego i króla. Podkreślano, iż postępowanie dworu jest działaniem celowym, korzystnym dla monarchy, gdyż funkcję koadiutora byłego więźnia Kaługi pełnił brat Stanisława Augusta - biskup płocki Michał Poniatowski ${ }^{8}$.

Mimo znacznego postępu badań naukowych dotyczących parlamentaryzmu okresu Rady Nieustającej, sejm 1782 r. nie doczekał się (podobnie jak większość zgromadzeń $^{9}$ z tego okresu) odrębnej monografii. Nie omówiono również dzia-

i ustanowienie Rady Nieustającej, Kraków 1917; idem, Pierwszy rozbiór Polski, Kraków 2010; Ryszard ŁasZewski, Sejm polski w latach 1764-1793. Studium historyczno-prawne, Poznań 1973; Emanuel RostworowsKi, Mierzejewski Józef Wojciech, [in:] PSB, t. 21, Wrocław 1976, s. 12-15; Zdzisław JANECZEK, Ignacy Potocki. Marszatek wielki litewski (1750-1809), Katowice 1992, s. 41; Łukasz KąDZIEla, Sapieha Kazimierz Nestor, [in:] PSB, t. 35, Warszawa 1994, s. 52-65; Katarzyna Bucholc-Srogosz, Departament Wojskowy Rady Nieustajacej w latach 1775-1789 i 1793-1794, Poznań 2007, s. 19-20; eadem, Poszerzenie kompetencji Rady Nieustajacej na sejmie 1776, „Teki Sejmowe”, nr 2: 2011, s. 71-85; eadem, Polityczne aspekty sejmowej kontroli Rady Nieustającej - wybrane zagadnienia, „Przegląd Nauk Historycznych”, t. 11/2: 2012, s. 86-87; A. STROYNOWSKI, Patriotyczne wystapienia opozycji na sejmie 1778 roku, „AUL.FH”, t. 19: 1984, s. 173; idem, Rola elity w życiu parlamentarnym epoki stanistawowskiej, „AUL.FH”, t. 22: 1985, s. 50; idem, Ignacy Potocki - marszałek Rady Nieustajacej (1778-1780), [in:] idem, Wieczory sejmowe, s. 191.

8 Papiery dotyczące sprawy uwięzienia przez kapitułę krakowską biskupa K. Sołtyka w 1782 r., Archiwum Morstinów, rkps. 25533 196; Jędrzej Kitowicz, Pamiętniki, czyli Historia polska, oprac. i wstępem poprzedziła Przemysława MATUSZEwSKA, komentarz Zofii LewinównY, Warszawa 2009, s. 360-363; Michał ZALESKI, Pamiętniki Michała Zaleskiego, senatora, wojewody Wielkiego Księstwa Litewskiego i posła na Sejm Czteroletni, Poznań 1849, s. 150; Kazimierz Rudnicki, Biskup Kajetan Sottyk (1715-1788), Kraków 1906, s. 238; Michał Marian GrZYBowski, Pochodzenie, młodość i poczatki kariery Michała Jerzego Poniatowskiego, „Studia Płockie", t. 2: 1974, s. 233-240; A. Stroynowski, Sejmowa opozycja antykrólewska w czasach rząów Rady Nieustajacej (Kryteria klasyfikacji), „AUL.FH”, t. 18: 1984, s. 25; Maria CzEPPE Soltyk Kajetan, [in:] PSB, t. 40, Warszawa-Kraków 2001, s. 401; eadem, Józef ŚmiAŁowsKi, Soltyk Maciej Kajetan, [in:] PSB, t. 40, s. 404-406; M. CzEPPE, Kanonik putkownikiem czyli ksiadz rotmistrz. Ksiadz Maciej Kajetan Soltyk, „Napis”, z. 8: 2002, s. 80-81; Ewa ZiEliŃsKA, Otto Magnus Stackelberg wobec planów skonfederowania sejmu. Przyczynek do polityki rosyjskiej przed Sejmem Wielkim, „KH”, t. 106/3: 2004, s. 89; Ewa M. ZıóŁEK, Biskupi senatorowie wobec reform Sejmu Czteroletniego, Lublin 2008, s. 60-61; Richard BUTTERWICK, Polska rewolucja a Kościół Katolicki (1788-1792), thum. Marek UGNIEwsKi, Warszawa 2010, s. 220-221; Paweł ZAJĄC, Giovanni Andrea Archetti i Stanisław August Poniatowski. Obraz króla i relacji w depeszach nuncjusza do sekretariatu stanu stolicy apostolskiej, „KH”, t. 118/2: 2016, s. 300-303; Barbara WolsKA, O mentekaptacji księcia biskupa Sottyka, www.wilanow_palac.pl [data dostępu: 14.02.2019]. Jak pisała Zofia Zielińska „biskupstwo krakowskie było ważne dla Poniatowskiego ze względów politycznych. Administrację kościelną powierzył natomiast swoim współpracownikom" - vide: Z. ZIELIŃsKA, Poniatowski Michał Jerzy, [in:] $P S B$, t. 27, Wrocław 1982-1983, s. 468.

9 Dysponujemy dwiema monografiami sejmów okresu Rady Nieustającej - W. FILIPCZAK, Sejm, oraz Adam DANiLcZy K, W kręgu afery Dogrumowej. Sejm 1786 roku, Warszawa 2010. Na ten 
łalności ks. A.K. Czartoryskiego podczas tego zjazdu parlamentarnego. Niewielkie wzmianki na ten temat możemy znaleźć w pracach i artykułach naukowych autorstwa: Henryka Schmitta ${ }^{10}$, Kajetana Rudnickiego ${ }^{11}$, Adama Michała. Skałkowskiego $^{12}$, Bronisława Dembińskiego ${ }^{13}$, Andrzeja Stroynowskiego ${ }^{14}$, Witolda Filipczaka $^{15}$, Richarda Butterwicka ${ }^{16}$, Marii Czeppe ${ }^{17}$ oraz Ewy Zielińskiej ${ }^{18}$, toteż celem mojego artykułu było uzupełnienie tej wyraźnej luki badawczej, dzięki czemu jeszcze pełniej zostaną ukazane działania opozycji magnackiej. Dodatkowo rozważania poszerzono o książęce oratorstwo i erystykę.

Głównymi źródłami, na podstawie których opracowałam temat były: diariusz zgromadzenia parlamentarnego $1782 \mathrm{r}{ }^{19}$, mowy sejmowe wydane drukiem ${ }^{20}$, protokoły głosowań ${ }^{1}$, relacje z obrad sejmowych opublikowane na łamach „Gazety Warszawskiej" "22, gazetki pisane ${ }^{23}$ oraz pamiętniki ${ }^{24}$ obrazujące zakulisowe rozgrywki i przedsejmowe przygotowania.

problem wskazywali również K. BuCHOLC-SROGOSz, Stan badań nad parlamentaryzmem polskim doby rzadów Rady Nieustajacej. Potrzeba podjęcia szerszych badań nad funkcjonowaniem stronnictwa królewskiego, „Teki Sejmowe”, t. 1: 2010, s. 93-106; eadem, Senat stanisławowski w historiografii polskiej, Częstochowa 2015, s. 97-98 oraz Michał GŁUSZAK, Rada Nieustajaca - badawcze osiagnięcia i perspektywy, „Studia z Dziejów Państwa i Prawa Polskiego”, t. 19: 2016, s. 131; R. BUTTERWICK, Jak pisać o dziejach sejmów Rady Nieustającej? W związu z ksiązka Adama Danilczyka o sejmie 1786 roku, „KH”, t. 119/3: 2012, s. 567-569.

10 Henryk Schmitt, Dzieje Polski XVIII i XIX wieku osnowane na przeważanie nie wydanych dotąd źródtach, t. II, Kraków 1867.

11 K. RUDNICKI, op. cit.

12 Adam M. SkaŁKowski, O cześć polskiego imienia, Lwów 1908.

13 Bronisław Dembiński, Ksiązę Adam Czartoryski, generat ziem podolskich i jego działalność polityczna w latach 1780-1782, „Sprawozdania z Czynności i Posiedzeń Polskiej Akademii Umiejętności”, t. 37/6: 1932, s. 33-39.

14 A. Stroynowski, op. cit., idem, Znaczenie alternaty sejmów dla Wielkiego Księstwa Litewskiego, „Przegląd Nauk Historycznych”, t. 17/1: 2018, s. 121-142.

15 W. FILIPCZAK, Stanisław August i Elżbieta Sapieżyna. Spór wokót losów sejmu 1782, [in:] Władza i polityka w czasach nowożytnych, red. Zbigniew ANUSIK, Łódź 2011, s. 53-72; idem, Życie sejmikowe prowincji wielkopolskiej w latach 1780-1786, Łódź 2012.

16 R. Butterwick, Polska Rewolucja, s. 220-221.

17 Maria Czeppe, Soltyk Kajetan, s. 386-406.

18 E. ZielińsKA, op. cit., s. 73-87.

19 Diariusz sejmu.

20 Zbiór mów różnych $w$ czasie sześcioniedzielnego sejmu roku 1782 mianych [dalej: Zbiór mów], Wilno 1782.

21 Tabele głosowań w izbie poselskiej 1782, AGAD, Zbiór Popielów, rkps 108, k. 29-88.

22 „GW”, nr 76 z 25 IX 1782 r. - nr 90 z 9 XI 1782 r.

23 Gazetka pisana z Warszawy 7 X 1782, BK PAN, rkps 01577; Teodor Ostrowski, Poufne wieści z oświeconej Warszawy. Gazetki pisane z 1782, wyd. Roman KALETA, Wrocław 1972.

24 Johann Bernouliı, Podróż po Polsce (1778), [in:] Polska stanistawowska w oczach cudzoziemców, oprac. i wstępem poprzedził Wacław ZAWADZKI, t. I, Łódź 1965; Franciszek KARPIŃSKI, Historia mojego wieku i ludzi z którymi żylem, oprac. Roman SoBoL, Warszawa 1987; J. KiтоwICZ, op. cit.; Julian Ursyn NiEMCEwICZ, Pamiętniki czasów moich, oprac. i wstępem poprzedził Jan DinM, Warszawa 1957; S.A. PONIATOWSKI, op. cit.; M. ZALESKI, op. cit. 


\section{Przebieg obrad sejmowych}

Sejm 1782 r. należał do istotnych momentów w karierze politycznej ks. A.K. Czartoryskiego. Nie przyniósł wprawdzie znacznego przełomu politycznego, ale był wielkim powrotem generała ziem podolskich na salę sejmową po dwunastoletniej absencji spowodowanej pobytem za granicą oraz sprawami rodzinnymi, bądź nieuzyskaniem mandatu. Książę był już wówczas doświadczonym parlamentarzystą, miał bowiem za sobą posłowanie podczas czterech zgromadzeń parlamentarnych okresu saskiego $(1758,1760,1761$ i 1762), marszałkowstwo sejmu konwokacyjnego 1764 r., udział w zjeździe elekcyjnym w roli marszałka starej laski i poselstwo na sejmie koronacyjnym tego roku. Brał także udział w „sejmie Czaplica” (1766 r.), dwa lata później i niemal milcząco (zabrał głos tylko jeden raz, prosząc o pozwolenie na wyjazd ze stolicy z powodu ważnych spraw rodzinnych, powodowany interesami rodowymi, a przynaglany przez ojca ks. Augusta Czartoryskiego i stryja Fryderyka Michała ${ }^{25}$ ) oraz uczestniczył w pracach delegacji 1767-1768. Interesował się przebiegiem sejmików przedsejmowych przed sejmem $1776 \mathrm{r}$. w województwie małopolskim. Sam nie wszedł na salę sejmową, gdyż nie podpisał aktu konfederacji przedsejmowej. Zasiadał również w latach 1778-1780 w Departamencie Wojskowym Rady Nieustającej. W 1781 r. pełnił funkcję marszałka trybunału litewskiego ${ }^{26}$. Spełniał się wówczas jako pedagog, komendant Korpusu Kadetów, redaktor „Monitora” i współpracownik „Zabaw Przyjemnych i Pożytecznych”, teatrolog i thumacz francuskich sztuk oraz poeta i dramatopisarz (niezbyt udanych warsztatowo utworów). Działał także w Komisji Edukacji Narodowej i Towarzystwie Ksiąg Elementarnych ${ }^{27}$.

25 W. KONOPCZYŃSKI, Czartoryski Michat Fryderyk, [in:] Czartoryscy: trzydzieści sześć życiorysów, Kraków 1938, s. 72; Helena WaniczKówna, Czartoryski Adam Kazimierz, [in:] PSB, t. 4, Kraków 1938, s. 251; Tadeusz FrĄCZYK, Adam Kazimierz Czartoryski. Biografia literacka na tle przemian ideowych polskiego Oświecenia, Kraków 2012, s. 266; M. GONERA, op. cit., s. 92.

26 Diariusz sądowy Tryb. Główny W.X.Lit, KAD. VII, t. II, AGAD, Zbiór Branickich w Suchej, rkps 58/74; Ludwik DĘBICKI, Puławy (1762-1830): monografia z życia towarzyskiego, politycznego i literackiego, t. I: Czasy przedrozbiorowe, Lublin 1887 s. 46-51; J. MiCHALSKI, Sarmatyzm i europeizacja Polski w XVIII wieku, [in:] idem, Studia Historyczne w XVIII i XIX wieku, t. II: Ideologia, nauka, historiografia, Warszawa 2007, s. 25; T. FRĄCZYK, op. cit., s. 336.

27 S.A. Poniatowski, op. cit., s. 459; H. Waniczkówna, op. cit., s. 250-251; Kamila MrozowSKA, Szkoła Rycerska Stanisława Augusta Poniatowskiego (1765-1794), Wrocław 1961; eadem, Komisja Edukacji Narodowej (1773-1794), Warszawa-Kraków 1973; Julian PLATT, Zabawy Przyjemne i Pożyteczne (1770-1777). Zarys monografii pierwszego polskiego czasopisma literackiego, Gdańsk 1986; Elżbieta ALEKSANDrowsKA, W kręgu poezji zabawowej pałacu Błękitnego. Nieznane wiersze Adama Kazimierza Czartoryskiego, Kaspra Rogalińskiego i Józefa Bielawskiego, „Pamiętnik Literacki”, t. 77/1: 1986, s. 218-226; eadem, Na tropie autorstwa króla w „Monitorze”, „Pamiętnik Literacki”, t. 82/2: 1991, s. 184; Z. JANECZEK, op. cit., s. 35; Zofia WoŁoszyńska, Adam Kazimierz Czartoryski, [in:] Pisarze polskiego Oświecenia, t. I, red. Teresa KostKiewiczowa i Zbigniew Goliński, Warszawa 1992, s. 399-411; Wojciech STANEK, Konfederacja sejmowa z roku 1776 jako narzędzie zamachu stanu, „Acta Universitatis 
W 1782 r. starania generała ziem podolskich o mandat poselski zostały uwieńczone sukcesem i wszedł on do sali sejmowej jako reprezentant województwa wileńskiego ${ }^{28}$.

Obrady sejmowe zainaugurowano mszą świętą w katedrze Św. Jana 30 września 1782 r. Po zakończonym nabożeństwie senatorowie udali się do senatu, zaś posłowie zasiedli w izbie poselskiej, gdzie prace rozpoczął uroczystą mową marszałek starej laski Antoni Małachowski. W swoim wystąpieniu podziękował sejmującym za okazane mu dwa lata temu zaufanie i powierzenie laski marszałkowskiej. Powołując się na autorytet przodków, nawoływał do zgody, jedności, poszanowania wolności szlacheckiej i przestrzegania porządku sejmowania. Kurtuazyjnie zwrócił się również do króla, życząc mu szczęśliwego panowania. Na zakończenie przemowy zainaugurował rugi poselskie. W tym dniu dokonano również elekcji marszałka. Kierownictwo pracami izby poselskiej jednogłośnie powierzono umiarkowanemu politykowi, a zarazem regaliście - posłowi drohickiemu Kazimierzowi Krasińskiem ${ }^{29}$. Następnego dnia wyznaczył on członków deputacji konstytucyjnej. Doceniono wiedzę prawniczą ks. Czartoryskiego, gdyż znalazł się w jej składzie ${ }^{30}$.

Przestrzeganie porządku sejmowego było także tematem pierwszej mowy Adama Kazimierza wygłoszonej tego dnia w trakcie weryfikacji legalności mandatów poselskich. Książę zwrócił się do Antoniego Światopełka Czetwertyńskiego z prośbą o spokój i rezygnację z domagania się o kolejne (trzecie) zabranie głosu. Swoją opinię argumentował tym, iż czas na merytoryczne dyskusje przy-

Lodziensis. Nicolai Copernici. Nauki Humanistyczno-Społeczne”, t. 259: 1993, s, 128; W. FIlipCZAK, Sejm, s. 159, 164; A. Stroynowski, Opozycja, s. 161; K. Bucholc-Srogosz, Departament Wojskowy, s. 19; Robert SAwICKI, Dzieje Szkoly Rycerskiej - Korpusu Kadetów w latach 1765-1794, Warszawa 2015, s. 5; Waldemar BEDNARUK, Narodziny Szkoły Rycerskiej, [in:] Szkoła Rycerska Kadetów Jego Królewskiej Mości i Rzeczpospolitej, red. idem, K. JASZCZUK, Lublin 2016, s. 32; M. GONERA, op. cit., s. 73-74.

28 Diariusz sejmu, s. 3; „GW” nr 68 z 24 VIII 1782; F. KARPIŃSKI, op. cit., 115; W. FILIPCZAK, Stanisław August i Elżbieta Sapieżyna, s. 61; M. GonERA, op. cit., s. 98. W „GW” podano, iż ks. A.K. Czartoryski przybył do stolicy na obrady sejmowe pod koniec września - vide: „GW”, nr 77 z 25 IX 1782. W jednej z gazetek pisanych zanotowano, iż Czartoryscy przed sejmem prowadzili „dom otwarty”. W ten sposób zdobywano zwolenników. Była to częsta praktyka w ferworze walki przedsejmowej oraz w trakcie obrad sejmowych. Vide: Gazetka pisana z Warszawy 7 X 1782, BK PAN, rkps 01577, nlb; M. GONERA Życie codzienne posła w epoce stanisławowskiej, [in:] Między prawdą a zwątpieniem. W poszukiwaniu obrazu przeszłości, red. Robert MAJZNer i Łukasz CHOLEwiŃsKi, Częstochowa 2014, s. 125-138.

29 Sesja I 30 IX 1782 w izbie poselskiej, [in:] Diariusz sejmu, s. 4-5; Mowa Jaśnie Wielmożnego Antoniego Małachowskiego, sekretarza Wielkiego Koronnego przy podniesieniu laski marszatkowskiej miana 30 września 1782, [in:] Zbiór mów, nlb; „GW”, nr 79 z 2 X 1782; Hanna DYMNICKA-WoŁosZyńsKa, Małachowski Antoni, [in:] PSB, t. 19, Wrocław 1974, s. 388-389; Piotr OLSZEWSKI, Kanclerz Jacek Nałęcz Małachowski (1737-1821), Warszawa 2013, s. 34.

30 Sesja II 2 X 1782, [in:] Diariusz sejmu, s. 17. Pełny skład deputacji konstytucyjnej - vide: M. Gonera, Działalnośćc, s. 89. Postępowanie A. Czetwertyńskiego było legalne w tym sensie, iż poseł pragnący zabrać głos każdorazowo musiał poprosić marszałka sejmowego o pozwolenie. 
padał w czasie procesu legislacyjnego, tj. po pierwszym rozłączeniu się izb. Tego samego zdania byli: poseł inflancki Stanisław Rembieliński oraz poseł podolski Antoni Polikarp Złotnicki. Apel odniósł zamierzony skutek, gdyż posłowie bez przeszkód (po sprawdzeniu legalności mandatów poselskich) przeszli do senatu ${ }^{31}$.

Kolejne sesje sejmowe zostały zdominowane przez wypełnianie formalności związanych ze zgłaszaniem kandydatów do Rady Nieustającej, weryfikacją ich uprawnień oraz głosowaniami. Pojawiła się wówczas okazja do kolejnego zakłócenia prac parlamentarnych. Podczas posiedzenia 3 października starania się posła dobrzyńskiego Jana Ośmiałowskiego o urząd konsyliarza magistratury, zakwestionował poseł starodubowski Jan Horain, podnosząc, iż kandydat nie posiadał dóbr ziemskich na terenie Wielkiego Księstwa Litewskiego (co było warunkiem możności ubiegania się o niego ${ }^{32}$ ), z którego aplikował o członkostwo w Radzie Nieustającej. Nie podjęto wówczas dyskusji na ten temat. gdyż kanclerz wielki koronny, biskup poznański Antoni Okęcki oraz kanclerz wielki litewski Aleksander Michał Sapieha, wyznaczyli senatorski skład deputacji do badania działalności magistratur tzn. Rady Nieustającej, Departamentu Wojskowego, Komisji Edukacji Narodowej oraz Komisji Skarbowych (Koronnej i Litewskiej). Problem powrócił na sesji następnego dnia. W tej sprawie pojednawcze stanowisko zajął ks. A.K. Czartoryski. Podziękował zainteresowanemu za dobrowolną rezygnację z ubiegania się o funkcję urzędniczą, jednocześnie zapraszając go do współpracy dla dobra prowincji Litewskiej i Rzeczpospolitej. Tematu nie kontynuowano ${ }^{33}$.

Następne posiedzenia parlamentu upłynęły na egzaminowaniu wspomnianych wyżej ciał kolegialnych. Była to świetna sposobność do wygłaszania mów. Generał ziem podolskich nie brał w nich czynnego udziału. W dniu 12 października złożył przysięgę jako nowy sędzia sejmowy ${ }^{34}$.

Czartoryski jako komendant Korpusu Kadetów reprezentował w sali sejmowej interesy kierowanej przez siebie placówki. Okazja ku temu nadarzyła się na sesji 17 października, podczas weryfikacji działalności Komisji Edukacji Narodowej ${ }^{35}$. Zwrócił wówczas uwagę na konieczność monitorowania kariery jej absolwentów i umożliwienie im rozwoju poprzez służbę w kawalerii narodowej. Apelował o obsadzenie trzeciej części miejsc w formacji przez młodzieńców

31 Sesja II 1 X 1782, [in:] Diariusz sejmu, s. 13-14.

32 Johann Bernoulli, op. cit., s. 270; Aleksander CZAJA, Między tronem, buława, a dworem petersburskim. Z dziejów Rady Nieustającej 1786-1789, Warszawa 1988, s. 53-54.

33 Sesja III 3 X 1782 w senacie, Diariusz sejmu, s. 20; „GW” nr 80 z 5 X 1782; M. Zaleski, op. cit., s. 150; W. SZCZYGIELSKI, Ośniałowski Jan, [in:] PSB, t. 24, Wrocław-Warszawa 1979, s. 618; Z. ZIELIŃSKA, Sapieha Michat Aleksander, [in:] PSB, t. 34, Wrocław 1992-1993, s. 565569; M. Gonera, Działalność, s. 99-100.

34 Sesja IX 12 X 1782, Diariusz sejmu, s. 39. O obowiązkach sędziów sejmowych - vide: M. GoNERA, op. cit., s. 100. Tam też podstawowa literatura.

35 Działalność KEN była oceniana przez parlamentarzystów na ogół pozytywnie. Vide: Sesja XVI, [in:] Diariusz sejmu, s. 117. 
opuszczających mury szkoły. Podobną koncepcję przedstawił także poseł słonimski Michał Szweykowski. Ich perswazje nie odniosły zamierzonego skutku podczas omawianego zjazdu parlamentarnego. Poseł wileński musiał czekać na odpowiednie regulacje do Sejmu Wielkiego ${ }^{36}$.

Następne wystąpienie generała ziem podolskich sekretarz sejmowy Pius Kiciński odnotował dwa dni później. Tematem jego wypowiedzi było miejsce obrad następnego sejmu. Kwestię tę podjęli posłowie: słonimski M. Szweykowski oraz brzeskolitewski Stanisław Ursyn Niemcewicz. Książę Czartoryski reprezentując interesy województwa wileńskiego, podobnie jak jego przedmówcy proponował, by kolejny sejm odbywał się w Grodnie. Na dowód słuszności swoich słów powoływał się na zapisy konstytucji Unii Lubelskiej, według której zgodnie z zasadą alternaty miejsca i laski, co trzeci sejm winien pracować na Litwie pod przewodnictwem marszałka z Wielkiego Księstwa Litewskiego (częściowo kwestię tę rozwiązano na sejmie 1778 r., kiedy to marszałkiem sejmowym został poseł wileński Ludwik Tyszkiewicz). Książę postulował także powołanie do życia Szkoły Rycerskiej na Litwie. Nie omówiono jednak tych zagadnień, gdyż naglącą sprawą była kontrola działalności Komisji Skarbowej ${ }^{37}$.

Istotnym problemem podczas omawianego sejmu okazało się zakwitowanie działalności Rady Nieustającej i Departamentu Wojskowego. Papierkiem lakmusowym przeciwko magistraturom była, jak napisano wyżej, sprawa pogwałcenia prawa kardynalnego neminem captivabimus nisi iure victum względem bp K. Sołtyka przez Departament Wojskowy na zlecenie kapituły krakowskiej. W gorących, długotrwałych debatach na ten temat najbardziej aktywnymi byli opozycjoniści. W dniu 23 października włączył się w nie także ks. Czartoryski. Poseł wileński przedstawiał siebie jako strażnika porządku sejmowego i prawa do wypowiadania się na forum publicznym. Odniósł się do prośby reprezentanta województwa lubelskiego Wojciecha Suchodolskiego i podobnie jak przedmówca domagał się prezentacji Zaświadczenia Rady zgłoszonego przez posła czernihowskiego Kajetana Kurdwanowskiego (klienta hetmana wielkiego koronnego Franciszka Ksawerego Branickiego). Procedurę tę próbował uniemożliwić biskup smoleński Gabriel Wodziński. Działanie generała ziem podolskich było postępowaniem celowym, konsekwentnym, obliczonym na zablokowanie udzielenia ab-

36 Ibidem, s. 119; A. STroynowski, Walory Szkoty Rycerskiej w opinii sejmowej, „Prace Naukowe Akademii im. Jana Długosza w Częstochowie. Rocznik Polsko-Ukraiński”, t. 17: 2015, s. 19; M. GONERA, op. cit., s. 100-101.

37 Sesja XVIII 19 X 1782, [in:] Diariusz sejmu, s. 120; A. STroynowski, Problem odrębności litewskiej na sejmach 1778-1786, [in:] idem, Wieczory sejmowe, s. 34; idem, Znaczenie alternaty, s. 122, 126; M. GONERA, op. cit., s. 101. Jedną z przyczyn niechęci do obradowania na Litwie były wysokie koszty utrzymania, problemy komunikacyjne i lokalowe. Vide: Jerzy GoRDZIEJEw, Socjotopografia Grodna w XVIII wieku, Toruń 2002, 44-45; M. GonerA, Życie codzienne posta, s. 127; Adam PerŁaKowski, Z sejmem czy bez sejmu? Konflikt o prywatne żupy solne na sejmie 1718 roku, „Studia Historyczne”, t. 59/2: 2016, s. 216; Natalia Stıž, Zamki grodzieńskie w II połowie XVIII wieku, „Częstochowskie Teki Historyczne”, t. 6: 2016, s. 53-54. 
solutorium magistraturze. Jego apel spotkał się ze sporym oddźwiękiem ze strony audytorium. Solidaryzowali się z nim posłowie podolscy Franciszek Pius Boreyko i A.P. Złotnicki oraz reprezentant ziemi mielnickiej Antoni Bądzyński. Odmiennego zdania byli: poseł łomżyński A. Małachowski i poseł czerski Antoni Suffczyński, jednak ten ostatni dał się przekonać i projekt Kurdwanowskiego przeczytano ${ }^{38}$.

Podczas tego posiedzenia generał ziem podolskich ponownie zabrał głos. Nawiązując do swojego wcześniejszego wystąpienia, prosił o nieblokowanie czytania Zaświadczenia Rady podanego przez biskupa poznańskiego Antoniego Okęckiego. Dokument został zaprezentowany. Spotkał się z falą krytyki ze strony opozycji magnackiej, gdyż znosił odpowiedzialność Rady Nieustającej za uwięzienie biskupa krakowskiego. Przeciwko jej zakwitowaniu wystąpili: ks. Czartoryski, poseł łomżyński A. Małachowski, poseł słonimski M. Szwykowski i poseł czernihowski Kajetan Mączyński ${ }^{39}$. Poseł wileński w swoim kolejnym przymówieniu się nie akceptował także kształtu Zaświadczenia przedstawionego przez bp. G. Wodzińskiego. Prosił o jego korektę, poprzez dodanie informacji o przekroczeniu uprawnień przez Radę Nieustającą w kwestii biskupa krakowskiego. Rozprężeniu w sali sejmowej skutecznie zapobiegł marszałek sejmowy poprzez zarządzenie głosowania. W ten sposób Krasiński realizował także interesy stronnictwa regalistycznego. Generał ziem podolskich opowiedział się w czasie turnum za jego przyjęciem ${ }^{40}$. Ostatecznie miażdżącą większością głosów zdecydowano o odrzuceniu dopisku posła czernihowskiego.

Kolejna sesja sejmowa następnego dnia stanowiła ważny akord w krytyce Rady Nieustającej. Książę Czartoryski występował na tym posiedzeniu w roli strażnika porządku sejmowego. Prosił, aby napływające do laski marszałkow-

38 Sesja XXI, 23 X 1782, [in:] Diariusz sejmu, s. 228-229; Mowa Jaśnie Wielmożnego Antoniego Małachowskiego, sekretarza wielkiego koronnego 23 października 1782 miana, [in:] Zbiór mów, nlb; „GW”, nr 85 z 23 X 1782. Największe oburzenie wywołał czytany wcześniej projekt zaświadczenia Rady zaprezentowany przez biskupa smoleńskiego G. Wodzińskiego, według którego Rada nie ponosiła odpowiedzialności za postępowanie kapituły krakowskiej, toteż nie było żadnych przeszkód do zaakceptowania jej działalności. Projekt posła czernihowskiego powtarzał zarzuty wobec Rady wysuwane przez opozycjonistów, stąd niemożliwym było w ich opinii udzielenie jej zakwitowania. Vide: J.U. NIEMCEWICZ, op. cit., s. 362-363; K. RUDNICKI, op. cit., s. 239; H. SChMitT, op. cit., s. 78; A. StROYNOwSKI Opozycja sejmowa, s. 162-163; M. Gonera, Działalność, s. 102.

39 Sesja XXI 23 X 1782, [in:] Diariusz sejmu, s. 230. Bp Okęcki był członkiem komisji badającej stan zdrowia bp. Sołtyka, która orzekła jego poważne zaburzenia psychiczne. Vide: H. DYMNICKA-WoŁoszyńska, Okęcki Antoni Onufry, [in:] PSB, t. 23, Wrocław 1978, s. 568-561; K. BucholC-Srogosz, Postawa polityczna biskupa Antoniego Okęckiego na sejmach stanistawowskich, [in:] Wymiary tożsamości, t. V: Język-Religia-Tożsamość, red. Grzegorz CYGAN i Elżbieta SKORUPSKA-RACZYŃSKA, Gorzów Wielkopolski 2011, s. 23-24; A. STROYNOWSKI, Rola biskupów w obradach sejmów lat 1778-1786, [in:] idem, Wieczory sejmowe, s. 161.

40 Za odrzuceniem dodatku głosowało 30 senatorów, a za jego zamieszczeniem 6. Dopisek winien być uwzględniony zdaniem 36 posłów, a przeciwnego zdania było aż 136. Vide: Sesja XXII 24 X 1782, [in:] Diariusz sejmu, s. 270.

40 Ibidem, s. 263; H. SCHMitT, op. cit., s. 80; K. RUDNICKI, op. cit., s. 237. 
skiej zażalenia wobec magistratury były prezentowane płynnie, w porządku chronologicznym. Uspokoił również W. Suchodolskiego, iż takie rozwiązanie zapobiegnie nadmiernemu trawieniu czasu. Twierdził, że najlepszym rozwiązaniem będzie przedstawienie najważniejszych założeń Zażaleń. Jego propozycję poparli F.P. Boreyko i Antoni Mikołuski (poseł sandomierski). Ostatecznie jednak częściowo zmieniono temat i rozpoczęto dyskusję nad zakwitowaniem Departamentu Wojskowego ${ }^{41}$.

Asumpt do jego podjęcia dał Stanisław Kostka Potocki, wnosząc opracowany przez siebie projekt Zaświadczenia. Propozycja wywołała silne emocje i nową falę sprzeciwów wobec pracy magistratur. Merytoryczne stanowisko w tej sprawie zajął również ks. Czartoryski. Reprezentując program opozycji magnackiej, winą za postępowanie kapituły krakowskiej względem bp. K. Sołtyka konsekwentnie obarczał Radę Nieustającą i Departament Wojskowy. Ich autorytet w jego oczach podkopało pogwałcenie prawa kardynalnego: captivabimus nisi iure victum $\mathrm{w}$ stosunku do biskupa krakowskiego. Nie kontynuowano dyskusji na ten temat, gdyż marszałek sejmowy solwował sesję na 25 października ${ }^{42}$. Tego dnia generał ziem podolskich wypełnił także swoje obowiązki deputowanego do konstytucji, złożył bowiem w senacie opracowany w izbie poselskiej projekt granicy miedzy polską Ukrainą a Rosją ${ }^{43}$.

Rozpoczynając kolejne posiedzenie sejmowe, marszałek apelował o zgodne sejmowanie i rozpoczęcie dyskusji o kwestiach ekonomicznych, po czym P. Kiciński rozpoczął prezentację odroczonych ${ }^{44}$ projektów ekonomicznych i granicznych. Taki porządek sesji pochwalił ks. A.K. Czartoryski. W dodatku prosił o ich niezwłoczne przyjęcie. Z jego opinią zgodzili się: A. Suffczyński i poseł łęczycki Franciszek Jerzmonowski. Podobnie jak na poprzedniej sesji oponował W. Suchodolski - ostatecznie jednak wyraził zgodę i projekt jednogłośnie zatwierdzono ${ }^{45}$.

Jednym z uprawnień poselskich była inicjatywa ustawodawcza. $Z$ tego przywileju skorzystał również w tym dniu książę generał ziem podolskich. Oznajmił, iż w najbliższym czasie złoży projekt uregulowania podatku drogowego dla przewoźników, prosząc marszałka sejmowego o czas na jego prezentację - K. Krasiński wyraził zgodę (marszałek nie mógł odmówić posłowi głosu) ${ }^{46}$.

41 Sesja XXII 24 X 1782, [in:] Diariusz sejmu, s. 263.

42 Ibidem, s. 278.

43 Ibidem, s. 272.

44 Do deliberacji trafił przeczytany dzień wcześniej projekt uregulowania granicy polsko-pruskiej. Kolejny zaś dotyczył uregulowania interesów majątkowych kasztelana krakowskiego Antoniego Barnaby Jabłonowskiego. Przeciwko przyjęciu tych projektów występował W. Suchodolski. Ostatecznie marszałek solwował sesję na następny dzień. Vide: Sesja XXIII 25 X 1782, [in:] ibidem, s. 277; Helena WeresZycKA, Jabłonowski Antoni Barnaba, [in:] PSB, t. 10, Wrocław 1962-1764, s. 217.

45 Sesja XXIV 26 X 1782, [in:] Diariusz sejmu, s. 278.

46 Ibidem, s. 278; W. FıLIPCZAK, Stanisław August i Elżbieta Sapieżyna, s. 65. Głównym założeniem zapowiadanego projektu było uregulowanie stosunków handlowych między Galicją 
Kolejny raz w tym dniu chaosowi wkradającemu się w prace parlamentarne, z powodu licznych projektów, próbował zaradzić generał ziem podolskich. Tłumaczył sejmującym, iż niedopuszczalnym było przerywanie prezentacji wniesionych do laski propozycji ustaw, a swoją dezaprobatę do ich treści można było wyrazić w czasie głosowania. Prosił o spokojne wysłuchanie projektu ekonomicznego wniesionego przez posła wileńskiego Radziwiłła ${ }^{47}$. Perswazje ks. A.K. Czartoryskiego nie odniosły zamierzonego rezultatu, gdyż gro posłów, w tym: Felicjan Wierzchlejski (poseł poznański) i F.P. Boreyko, domagało się przedstawienia treści Zaświadczenia Rady autorstwa S.K. Potockiego. W tej sytuacji zainterweniował marszałek sejmowy zapowiadając, iż sejmujący będą mogli zapoznać się $\mathrm{z}$ treścią rzeczonego dokumentu na następnym posiedzeniu 28 października ${ }^{48}$.

Zagajając kolejną sesję dwa dni później, marszałek sejmowy ponownie zaapelował o zgodne, efektywne sejmowanie i właściwe wykorzystanie czasu. Podał również tematykę sesji sejmowej, zapraszając słuchaczy do wysłuchania projektów, które kilka dni temu trafiły do deliberacji. Marszałkowska prośba nie spotkała się ze zrozumieniem ze strony audytorium. W dyskusję włączył się także ks. A.K. Czartoryski, broniąc swojego prawa do przedstawienia zapowiedzianego dwa dni wcześniej projektu. Na pierwszeństwo książęcego wniesienia wskazywał także marszałek sejmowy. Czynność tę blokował poseł krakowski Piotr Ożarowski, dopominając się prezentacji Zaświadczenia Rady opracowanego przez S.K. Potockiego. Zapewnienia K. Krasińskiego, iż zostanie on przedstawiony po rozstrzygnięciu kwestii opłat transportowych odniosły skutek i zaprezentowano $\mathrm{w}$ tym dniu propozycję generała ziem podolskich. Zdecydowano jednak o wzięciu jej w deliberację. Projekt przyjęto jednogłośnie 2 listopada ${ }^{49}$.

Dalsza część sesji była zogniskowana na czytanie Uchylenia Rezolucji Rady. Obok S.K. Potockiego projekt ${ }^{50} \mathrm{w}$ tej sprawie przedstawił regalista, poseł nurski

a Rzeczpospolitą. Ks. A.K. Czartoryski realizował w ten sposób osobiste interesy, gdyż po I rozbiorze część jego dóbr znalazła się w zaborze austriackim. Vide: J. MichALSKI, Do dziejów stronnictwa austriackiego i polskiej polityki Austrii po I rozbiorze, [in:] Z dziejów wojny i polityki. Księga pamiątkowa ku uczczeniu siedemdziesiatej rocznicy urodzin prof. dra Janusza Wolińskiego, red. S. HABST i in. Warszawa 1964, s. 139-145; W. FilipCZAK, Sejm, s. 30.

47 Nie udało się zidentyfikować jego personaliów. W wykazie posłów na sejm, nie widnieje nazwisko „Radziwiłł” - vide: Diariusz sejmu, s. 3-5.

48 Sesja XXIV 26 X 1782, [in:] ibidem, s. 280, 281. To także realizacja prawa do wypowiadania się na forum publicznym. Vide: A. GRZEŚKOWIAK-KRWAWICZ, O formę rządu czy rząd dusz? Publicystyka polityczna Sejmu Czteroletniego, Gdańsk 2000, s. 15.

49 VL, t. IX, s. 5; Sesja XXV 28 X 1782, [in:] Diariusz sejmu, s. 286, 288; „GW”, nr 82 z 30 X 1782; T. OstrowsKI, op. cit., s. 288; W. FILIPCZAK, Stanistaw August i Elżbieta Sapieżyna, s. 64; M. Goner A, Działalność, s. 104; W ten sposób K. Krasiński nie tylko wypełniał marszałkowskie obowiązki, ale także reprezentował królewskie interesy.

50 W projekcie przedstawionym przez Szczepana Zambrzyckiego podkreślano, iż kapituła krakowska i Departament Wojskowy postąpiły niezgodnie z literą prawa i przekroczyły uprawnienia. W związku z tym należał biskupowi krakowskiemu zwrócić wolność. Brak odpowiedzi na powtórny list hetm. Seweryna Rzewuskiego w obronie hierarchy, z żądaniem pociągnięcia win- 
Szczepan Zambrzycki. W sali sejmowej zapanował chaos, gdyż posłowie spierali się o kolejność prezentacji dokumentów. Zainterweniował wówczas ks. A.K. Czartoryski, po raz kolejny apelując o ich czytanie w porządku chronologicznym. Realizował w ten sposób interesy opozycji magnackiej, gdyż kilka dni wcześniej do laski wpłynęło pismo autorstwa brata I. Potockiego. O pierwszeństwo zgłoszonego przez siebie projektu dopominał się, co zrozumiałe, S.K. Potocki. W podobnym duchu przemawiali F.P. Boreyko i P. Ożarowski. Pierwszeństwo projektowi Sz. Zambrzyckiego przydawał przedstawiciel ziemi nurskiej Adam Szydłowski. Ostatecznie przeczytano obie propozycje, począwszy od tej autorstwa Potockiego ${ }^{51}$.

Na następnym posiedzeniu znów pojawiły się problemy organizacyjne. Opozycjoniści magnaccy nie ustawali w staraniach zablokowania projektu Zambrzyckiego. Zwolennikami poddania pod głosowanie jedynie Uchylenia Rezolucji opracowanej przez Stanisława Kostkę byli posłowie: podolski F.P. Boreyko oraz lubelski W. Suchodolski. Do wypowiedzi przedmówców odniósł się A.K. Czartoryski, twierdząc, iż najpierw należy zdecydować o przyjęciu lub odrzuceniu projektu przedstawiciela województwa lubelskiego, gdyż on pierwszy został zgłoszony do laski. Perswazje Czartoryskiego nie odniosły rezultatu. O głosowanie nad swoimi propozycjami dopominali się projektodawcy ${ }^{52}$. Marszałek długo, bezskutecznie prosił o zgodę na głosowanie. Impas zakończył sam zainteresowany, poseł nurski, Sz. Zambrzycki, wycofując projekt z prośbą: „by po przyjęciu lub odrzuceniu projektu JW Lubelskiego już więcej nie mówić w materii krakowskiej”53. Nazajutrz zaplanowano turnum nad projektem Stanisława Kostki.

Kolejna sesja przebiegała zgodnie z marszałkowskim planem. Po krótkim zagajeniu rozpoczęto głosowanie nad pierwszym punktem projektu Potockiego. W czasie wotowania Adam Kazimierz Czartoryski ponownie konsekwentnie i konstruktywnie potępił postępowanie kapituły krakowskiej względem biskupa

nych do odpowiedzialności, był wyrazem troski o dobro publiczne i spokój w kraju, a nie zamierzonym sposobem znieważenia wojskowego. W projekcie S.K. Potockiego także uwypuklano konieczność uwolnienia biskupa. Dodatkowo zapisano iż brak responsu na hetmańską epistolę stanowiło pogwałcenie prawa wolnego głosu. Vide: Sesja XXV 28 X 1782, [in:] Diariusz sejmu, s. 288-289; K. RudnicKI, op. cit., 239; Krystyna MAKsimowiCZ, Seweryn Rzewuski w Nowej Familii (lata 1779-1788), „Pamiętnik Literacki”, t. 84/2: 1993, s. 142; A. STroyNOWsKi, Opozycja, s. 162-163; W. FILIPCZAK, Sejmiki ziemi nurskiej w latach 1780-1786, „Przegląd Nauk Historycznych”, t. 13/1: 2014, s. 35; M. GonERA, Działalność, s. 104.

51 Sesja XXV 28 X 1782, [in:] Diariusz sejmu, s. 283. Postawa posła Ożarowskiego (regalisty) była spowodowana rachubami politycznymi. Parlamentarzysta nie chciał konfliktu z opozycją - vide: Z. ZiELIŃSKA, Ożarowski Piotr, [in:] PSB, t. 24, Wrocław 1979, s. 673-678.

52 Sesja XXVI 29 X 1782, [in:] Diariusz sejmu, s. 305. Opozycjoniści odmawiali dokumentowi posła nurskiego statusu projektu, stosując w tym celu mało znaczące szczegóły, np. krój pisma czy sposób rozmieszczenia tekstu na karcie - vide: ibidem, s. 304. W rozprawie doktorskiej podałam błędną informację, jakoby ks. Czartoryski zajął na tej sesji merytoryczne stanowisko w kwestii prezentowanych projektów - vide: M. GonERA, Działalność, s. 104.

53 Sesja XXVI 29 X 1782, [in:] Diariusz sejmu, s. 312. 
Sołtyka, wnosząc o jego uwolnienie. W ten sam sposób głosowali posłowie sandomierscy: Jan Nepomucen Zboiński i Antoni Lanckoroński, podolscy: Józef Starzyński i F.P. Boreyko, lubelski W. Suchodolski i nowogródzki W. Rzewuski. Za utrzymaniem Rezolucji Rady w tej sprawie opowiedzieli się posłowie: czerski A. Suffczyński, lubelski Ignacy Karniewski, inflanccy S. Rembieliński i Andrzej Dobiecki oraz poznański A. Gorzeński. Ostatecznie zarówno w senackim, jak i poselskim głosowaniu punkt upad1 ${ }^{54}$.

Głosowanie nad następnym ustępem projektu kontynuowano na sesji następnego dnia. Fragment dotyczył braku odpowiedzi Rady Nieustającej na ponowny list hetmana Seweryna Rzewuskiego w obronie bp. K. Sołtyka. Procedura nie przebiegała. jednak płynnie. Sformułowanie propozycji do turnum blokował K. Kurdwanowski, stronnik hetmana F.K. Branickiego, domagając się przeczytania mowy I. Potockiego ${ }^{55}$ wygłoszonej na sesji Rady 12 marca 1782. Poparli go: poseł starodubowski J. Horain, nowogródzki W. Rzewuski i wołkowyski Aleksander Brzostowski. Porządek w dyskusji próbował razem z marszałkiem dwukrotnie zaprowadzić ks. A.K. Czartoryski. Apelował do K. Kurdwanowskiego i sekundującego mu W. Suchodolskiego o rezygnację ze swych żądań, z obawy o utratę czasu. W podobnym duchu przemawiał A. Małachowski. Prośba generała ziem podolskich nie przyniosła pożądanego skutku i sekretarz sejmowy zapoznał audytorium z treścią wystapienia I. Potockiego. Po zakończeniu lektury rozpoczęto głosowanie. W jego trakcie ks. Czartoryski opowiedział się za jego przyjęciem. Tak samo zagłosowali: I. Potocki i F.P. Boreyko. Rady Nieustającej bronili: A. Gorzeński, W. Rzewuski i S. Rembieliński. Ostatecznie ustęp odrzucono ${ }^{56}$.

54 Sesja XXVII 30 X 1782, [in:] ibidem, s. 315-319; W. FILIPCZAK, Sejmiki ziemi czerskiej 17801786, „Przegląd Nauk Historycznych”, R. IX/1: 2010, s. 155. Za uchyleniem rezolucji opowiedziało się w jawnym głosowaniu 38 posłów, za jej utrzymaniem zaś 131. Proporcje niewiele zmieniły się w czasie wotowania tajnego, gdyż wówczas projekt poparło 37 posłów, przeciwnych było 129 . W senacie w głosowaniu jawnym za przyjęciem projektu opowiedziało się 8 senatorów, opozycyjne stanowisko zaprezentowało 46 . W czasie głosowania tajnego za jego przyjęciem było 16, a przeciwko 38 senatorów. Vide: Sesja XXVII 30 X 1782, [in:] Diariusz sejmu 1782, s. 320; Sesja tego dnia w senacie, [in:] ibidem, s. 433; M. Gonera, Dzialalność, s. $105-106$.

55 W swoim wystąpieniu I. Potocki pomstował na kapitułę krakowską i Departament Wojskowy. Oskarżał magistratury o złamanie prawa kardynalnego neminem captivabimus nisi iure victim względem bp. K. Sołtyka. Vide: Sesja XXVIII 31 X 1782, [in:] Diariusz sejmu 1782, s. 404 406; Z. JANECZEK, op. cit., s. 45.

56 Sesja XXVIII 31 X 1782, [in:] Diariusz sejmu 1782, s. 353. Był to także kolejny polityczny policzek dla Departamentu Wojskowy, który odbierając władzę hetmanom, nie szanował prawa i doprowadził do sytuacji, w której praworządni Obywatele byli pozbawiani wolności. Vide: Z. ZielińsKa, Republikanizm spod znaku buławy. Publicystyka Seweryna Rzewuskiego z lat 1788-1790, Warszawa 1988, s. 16-20; eadem, Seweryn Rzewuski-pułapki republikanizmu, [in:] Bo insza jest rzecz zdradzać, insza dać się zdradzać, insza dać się zdradzie. Problem zdrady w Polsce przełomu XVIII i XIX wieku, red. A. GrZeŚKOWIAK-KrWawicz, Warszawa 1995, s. 31-47; K. Bucholc-Srogosz, Departament, s. 19; M. Gonera, Dziatalność, s. 98. W gło- 
Podczas kolejnego posiedzenia sejmowego rozpatrywano trzeci punkt Uchylenia Rezolucji Rady autorstwa S.K. Potockiego. Tematem wystąpienia ks. A.K. Czartoryskiego były sprawy organizacyjne. Poseł wileński wbrew obowiązującym przepisom Porzadku sejmowania z 1768 r., prosił marszałka sejmowego o umożliwienie wzięcia udziału w głosowaniu spóźnionym posłom. Poparł go W. Suchodolski. Na takie rozwiązanie nie godzili się: A. Bądzyński i A.P. Złotnicki. Perswazje generała ziem podolskich odniosły skutek i dodatkowe turnum przeprowadzono, ale nie udało się uratować projektu, na co liczyła opozycja ${ }^{57}$.

Zagajając następną sesje po południu, marszałek przywołując autorytet przodków apelował o zgodne sejmowanie. Następnie przeczytano czwarty punkt projektu S.K. Potockiego i rozpoczęto głosowanie, w czasie którego ks. A.K. Czartoryski opowiedział się za jego przyjęciem. Zwolennikami takiego rozwiązania byli także posłowie: F.P. Boreyko, W. Rzewuski, A. Bądzyński i Konstanty Janikowski (poseł łęczycki). Opozycyjne stanowisko prezentowali: A. Suffczyński, A. Gorzeński i Stanisław Paweł Jabłonowski, przedstawiciel ziemi łęczyckiej. Ostatecznie punkt został odrzucony ${ }^{58}$.

sowaniu jawnym za przyjęciem tegoż ustępu było 36 posłów. Oponowało 128 . W tajnym punkt spotkał się z aprobatą 35 głosujących. Odrzuciło go 125 . W senacie za projektem opowiedziało się w głosowaniu tajnym i jawnym 5 senatorów. Oponowało 48, Sesja XXVIII, 31 X 1782, [in:] Diariusz sejmu, s 353; Sesja dnia tegoż w senacie, [in:] ibidem, s. 363; K. RUDNICKI, op. cit., s. 240; M. Gonera, Działalność, s. 105. Regułą była wygrana w głosowaniach jawnych stronnictwa regalistycznego. Vide: W. FILIPCZAK, Stanisław August i Elżbieta Sapieżyna, s. 65.

57 Sesja XIX 2 XI 1782 ranna, [in:] Diariusz sejmu, s. 363. W pierwszym głosowaniu jawnym i tajnym za projektem głosowało 15 posłów, a opozycyjne stanowisko zajęło 78 . W drugim turnum za jego przyjęciem w glosowaniu jawnym opowiedziało się 15 posłów, a przeciwnego zdania było 77 . W glosowaniu tajnym za jego wprowadzeniem optowało 23 posłów, a odmiennego zdania było 70 . W senacie nie było dodatkowego głosowania. Za projektem w glosowaniu jawnym opowiedziało się 4 senatorów, a przeciwnego zdania było 44 . W glosowaniu tajnym projekt poparło 5, a oponowało 43. Vide: Sesja XXIX 2 XI 1782 ranna, [in:] Diariusz sejmu, s. 363; Sesja dnia tegoż w senacie, [in:] ibidem, s. 371; K. RudNICKI, op. cit., s. 240; M. GonERA, Działalność, s. 99. Rzeczony punkt Uchylenia Rezolucji Rady stanowił krytykę przekroczenia kompetencji magistratury i wkraczania w zakres obowiązków sądów. Vide: K. BUCHOLC-SROGosz, Departament, s. 19; eadem, Polityczne aspekty kontroli, s. 94; M. Goner A, Działalność, s. 107. Działanie ks. A.K. Czartoryskiego było wypełnieniem planów opozycji, dążącej do zmiany zasad głosowania, tzn. wprowadzenia dwóch jawnych głosowań i jednego tajnego zamiast dotychczasowych jednego jawnego i tajnego. Vide: A. Stroynowski, Opozycja, s. 163.

58 Sesja XXX 2 XI 1782 w izbie poselskiej po południu, [in:] Diariusz sejmu, s. 391; K. RUDNICKI, op. cit., s. 240; W. FILIPCZAK, Sejmiki ziemi czerskiej, s. 155; M. Gonera, Działalność, s. 107. Ostatni punkt Uchylenia Rezolucji Rady dotyczył konieczności pociągnięcia kapituły i Departamentu Wojskowego do odpowiedzialności karnej. Nie godzono się także na zakwitowanie działalności magistratur. Vide: Sesja XXX 2 XI 1782 w izbie poselskiej po południu, [in:] Diariusz sejmu, s. 376; M. Gonera, Działalność, s. 99. W czasie jawnego turnum za wprowadzeniem projektu w życie opowiedziało się 37 posłów. Opozycyjne stanowisko zajęło 129. Od głosu wstrzymał się poseł gnieźnieński Jan Nepomucen Dobrzycki. Podczas tajnego kreskowania wyniki nie uległy zmianom, gdyż projekt miał 35 zwolenników i 126 przeciwników. W senacie wyniki były tożsame w obu głosowaniach. Jego zwolennikami było 14 senatorów, a oponowało 
Ostatnią sesją, w której ks. Czartoryski wziął aktywny udział, było posiedzenie 4 listopada. Tematem pierwszego przymówienia się posła wileńskiego w tym dniu była alternata sejmowa. Podobnie jak w października, apelował o przygotowanie obrad kolejnego sejmu w Grodnie. Jego wystąpienie spotkało się z aplauzem posłów litewskich, ale nie spowodowało debaty. Książęca propozycja została wcielona w życie w 1784 r. ${ }^{59}$

Kolejne wystąpienie ks. A.K. Czartoryskiego dotyczyło interesów majątkowych Karola Stanisława Radziwiłła „Panie Kochanku”. Poseł wileński opowiedział się za zwrotem posiadłości magnata znajdujących się w zaborze rosyjskim. Żądanie książęce miało głęboki wydźwięk polityczny obliczony na zdobycie poparcia wojewody wileńskiego. Zwolennikami takiego rozwiązania byli: A. Małachowski, F.P. Boreyko i poseł bracławski Adam Moszczeński. Sprawa przeszła bez echa na tym sejmie ${ }^{60}$.

\section{Podsumowanie}

Książę Adam Kazimierz Czartoryski miał na sejmie 1782 r. 23 wystąpienia 1 mowę i 1 głos oraz 21 przymówieńn ${ }^{61}$, w czasie których zaprezentował swoje zdolności retoryczne. Niemal na każdej sesji celnie żonglował prawniczymi argumentami (Porzadek sejmowania 1768 roku oraz prawo kardynalne neminem captivabimus nisi iure victim ${ }^{62}$. Wywody retoryczne obfitowały $\mathrm{w}$ specjalistyczną leksykę parlamentarną - absolutorium, konsyliarz, projekt, rezolucja czy turnum $^{63}$. W zakresie erystyki stosował chwyty z autorytetu. Dogadzał próżności audytorium. Stylizował siebie na obrońcę bp. K. Sołtyka, używając chwytów z litości. Nie narzucał wprawdzie swojego sposobu rozumowania, lecz przywo-

44. Vide: Sesja XXX 2 XI 1782 w izbie poselskiej po południu, [in:] Diariusz sejmu, s. 391; Sesja tego dnia w senacie, [in:] ibidem, s. 395; M. Gonera, Działalność, s. 107.

59 Sesja XXXI 4 XI 1782, [in:] Diariusz sejmu, s. 294; M. Goner A, Działalnośćc, s. 100; A. STRoyNOWSKI, Znaczenie alternaty, s. 55.

60 Sesja XXXI 4 XI 1782, [in:] Diariusz sejmu, s 362, 366; J. Michalski, Od wrogości do przyjaźni. Czartoryscy wobec Karola Radziwiłła „Panie Kochanku”, „Miscellanea Historico-Archivistica", t. 11:2000, s. 145-158; idem, Wokót powrotu Karola Radziwilta z emigracji pobarskiej, „KH”, t. 106/4: 1999, s. 41; M. GonERA, Działalność, 100. Rekompensatę finansową Radziwiłłowie uzyskali na sejmie 1784 r. - 200000 złp przez kolejne dwa lata. Vide: J. MiCHALSKI, Radziwitt Karol Stanisław, [in:] PSB, t. 30, Wrocław 1987, s. 260.

61 M. Gonera, Działalność, s. 109.

62 Sesja II 2 X 1782, [in:] Diariusz sejmu, s. 17; Sesja XVIII 19 X 1782, [in:] ibidem, s. 120; Sesja XXVIII 31 X 1782, [in:] ibidem, s. 353.

63 Sesja XXVIII 31 X 1782, [in:] ibidem, s. 353; Sesja XIX 2 XI 1782 ranna, [in:] ibidem, s. 363. O słownictwie specjalistycznym wykorzystywanym w debacie parlamentarnej pisała Małgorzata DAWIDZIAK-KŁADOCZNA, Językowe aspekty kultury politycznej Sejmu Wielkiego, Częstochowa 2012, s. 178-180. 
ływał myślenie życzeniowe bądź pozorne naradzanie się ${ }^{64}$. Do swoich przedmówców odnosił się z należytym szacunkiem, używając tytulatury. Wskazywał także na ich zasługi dla dobra publicznego.

Jego wystąpienia zawierały także antyczny topos utraconego czasu w funkcji argumentu o intencji perswazyjnej. W związku z tym mowy generała ziem podolskich były krótkie: jedno bądź dwuzdaniowe. Cechował je brak makaronizmów.

Jak wynika z powyższych rozważań, poseł wileński był aktywnym parlamentarzystą na sejmie $1782 \mathrm{r}$. Tematem jego wystąpień była aktualna sytuacja polityczna oraz sposób prowadzenia obrad sejmowych. Książę wzywał do respektowania regulaminu sejmowego, sprzeciwiając się nadmiernemu gadulstwu:(z wyjątkiem sesji XXIX 2 listopada, kiedy to skutecznie walczył o przeprowadzenie dodatkowego głosowania w nadziei na zmianę wyników) i oszczędności czasu. Mówił też o konieczności wypełnienia przepisów dotyczących alternaty laski i miejsca prac sejmowych.

W sali sejmowej był członkiem i reprezentantem interesów opozycji magnackiej. Bezpardonowo, konsekwentnie i konstruktywnie, stosując argumenty z istniejącego prawa, krytykował Radę Nieustającą i Departament Wojskowy, do czego asumpt dało postępowanie magistratur względem bp. K. Sołtyka. Podnosił, podobnie jak inni jej członkowie (np. S.K. Potocki, I. Potocki F.P. Boreyko, K. Kurdwanowski), niemożność udzielenia im absolutorium. Swoją dezaprobatę w tej kwestii wyrażał również w głosowaniach, w czasie których opowiadał się za przyjęciem wszystkich czterech punktów Uchylenia Rezolucji Rady. Jego działania odniosły częściowy skutek, gdyż nie zakwitowano ${ }^{65}$ działalności Departamentu Wojskowego, a tylko całej Rady Nieustającej. Podejmował także działania mające na celu powiększenie szeregów stronnictwa opozycyjnego, dlatego bezskutecznie upominał się o zwrócenie ks. K.S. Radziwiłłowi „Panie Kochanku" zakordonowych dóbr.

Dbał również o interesy kierowanej przez siebie Szkoły Rycerskiej oraz jej absolwentów, bez rezultatu prosząc o zarezerwowanie im $1 / 3$ miejsc w kawalerii narodowej.

Sumiennie wypełniał też obowiązki deputowanego do konstytucji. Wykazał również inicjatywę ustawodawczą, zgłaszając przyjęty jednogłośnie projekt Drogowego dla furmanów.

Jego wystąpienia sejmowe spotykały się z dużym oddźwiękiem ze strony grona poselskiego. Popleczników miał w osobach opozycjonistów: F.P. Boreyki, W. Suchodolskiego, S.K. Potockiego, S. Rembielińskiego, W. Rzewuskiego, A. Suffczyńskiego, A. Mikołuskiego, S.U. Niemcewicza, K. Moszczeńskiego i K. Kurdwanowskiego. Przeciwne stanowisko zajmowali regaliści: K. Krasiński czy A. Małachowski.

${ }^{64}$ Sesja XVIII 19 X 1782, [in:] Diariusz sejmu, s. 120; Sesja XXVIII 31 X 1782, [in:] ibidem, s. 353; M. Gonera, Działalność, s. 248.

65 „GW” nr 86 z 26 X 1782; M. ZALESKI, op. cit., s. 151. 


\section{Bibliografia}

\section{Źródła archiwalne}

Archiwum Morstinów, rkps nr 25533196

Archiwum Główne Akt Dawnych, Zbiór Popielów, rkps nr 108.

Archiwum Główne Akt Dawnych, Zbiór Branickich z Suchej, rkps nr 5874.

Biblioteka Kórnicka Polskiej Akademii Nauk: rkps nr 01577.

\section{Źródła drukowane}

Bernouli Johann, Podróż po Polsce (1778), [in:] Polska stanisławowska w oczach cudzoziemców, oprac. i wstępem poprzedził W. ZAWADZKI, t. I, Łódź 1965, s. 227-476.

Dyariusz seymu ordynaryjnego warszawskiego sześcioniedzialnego roku pańskiego MDCCLXXXII w Warszawie w Drukarni Jego Królewskiej Mości, Warszawa 1782.

KARPIŃSKI Franciszek., Historia mojego wieku i ludzi z którymi żylem, oprac. Roman SOBOL, Warszawa 1987.

Kitowicz Jędrzej, Pamiętniki, czyli Historia polska, oprac. i wstępem poprzedziła Przemysława MATUSZEWSKA, komentarz Zofii LEWINÓwnY, Wrocław 2009.

NiEMCEWICZ Julian Ursyn, Pamiętniki czasów moich, oprac. i wstępem poprzedził J. DIHM, t. 1, Wrocław 1957.

Poniatowski Stanisław August, Pamiętniki Stanisława Augusta Poniatowskiego. Antologia, oprac. Anna GRZEŚKOWIAK-KRWAWICZ, Warszawa 2013.

Volumina Legum, Przedruk zbioru praw staraniem XX Pijarów w Warszawie od roku 1732 do roku 1782, t. IX, Petersburg 1860.

ZALESKI Michał Pamiętniki Michata Zaleskiego, senatora, wojewody Wielkiego Księstwa litewskiego i posta na Sejm Czteroletni, Poznań 1849.

Zbiór mów różnych w czasie sześcioniedzielnego sejmu roku 1782 mianych, Wilno 1782.

\section{Prasa}

„Gazeta Warszawska”, 25 IX 1782, nr 76; „Gazeta Warszawska”, 2 X 1782, nr 79; „Gazeta Warszawska”, 5 X 1782, nr 80; „Gazeta Warszawska”, 12 X 1782, nr 82; „Gazeta Warszawska”,16 X 1782, nr 83; „Gazeta Warszawska”, „Gazeta Warszawska”, 19 X 1782, nr 84; „Gazeta Warszawska”, 23 X 1782, nr 85; „Gazeta Warszawska”, 26 X 1782, nr 86; „Gazeta Warszawska”, 30 X 1782, nr 88; „Gazeta Warszawska”, 6 XI 1782, nr 89; „Gazeta Warszawska”, 9 XI 1782, nr 90.

Ostrowski Teodor, Poufne wieści z oświeconej Warszawy, wyd. Roman KalETA, Wrocław 1972.

\section{Opracowania}

AleKSANDROwSKa Elżbieta, Na tropie autorstwa króla w „Monitorze,” „Pamiętnik Literacki”, t. LXXXII, 1991, z. 2, s. 184-196.

AlEKSANDROwSKA Elżbieta, $W$ kręgu poezji zabawowej pałacu Btękitnego. Nieznane wiersze Adama Kazimierza Czartoryskiego, Kaspra Rogalińskiego i Józefa Bielawskiego, „Pamiętnik Literacki”, 1986, z. 1, s. 218-226.

AleKsandrowsKa Elżbieta, [rec.] J. Platt Zabawy Przyjemne i Pożyteczne (1770-1777). Zarys monografii pierwszego polskiego czasopisma literackiego, Gdańsk 1986, „Pamiętnik Literacki”, t. LXXVIII, 1987, z. 4, s. 330-348. 
BEDNARuK Waldemar, Narodziny Szkoty Rycerskiej, [in:] Szkoła Rycerska Kadetów Jego Królewskiej Mości i Rzeczpospolitej, red. W. BEDNARUK, K. JASZCZUK, Lublin, TN KUL, 2016, s. 23 35 .

Bucholc-Srogosz Katarzyna, Departament Wojskowy Rady Nieustajacej w latach 1775-1789 i 1793-1794, Poznań, Wydawnictwo Poznańskie, 2007.

Bucholc-Srogosz Katarzyna, Polityczne aspekty sejmowej kontroli Rady Nieustajacej - wybrane zagadnienia, „Przegląd Nauk Historycznych”, 2012, nr 2, s. 81-100.

Bucholc-Srogosz Katarzyna, Postawa polityczna biskupa Antoniego Okęckiego na sejmach stanisławowskich, [in:] Wymiary tożsamości, t. V: Język-Religia-Tożsamość, red. Grzegorz CYGAN i Elżbieta SKORUPSKA-RACZYŃSKA, Gorzów Wielkopolski, Wydawnictwo Naukowe Państwowej Wyższej Szkoły Zawodowej, 2011, s. 17-31.

Bucholc-Srogosz Katarzyna, Poszerzenie kompetencji Rady Nieustajacej na sejmie 1776, „Teki Sejmowe", 2011, nr 2, s. 71-85.

BuchOLC-Srogosz Katarzyna, Senat stanisławowski w historiografii polskiej, Częstochowa, AJD, 2015.

BuCHOLC-SRogosz Katarzyna, Stan badań nad parlamentaryzmem polskim doby rzadów Rady Nieustajacej. Potrzeba podjęcia szerszych badań nad funkcjonowaniem stronnictwa królewskiego, „Teki Sejmowe”, 2010, nr 1, s. 93-106.

ButTTERWICK Richard, Polska rewolucja a Kościół Katolicki 1788-1792, przekład z języka angielskiego Marek Ugniewski, Kraków, ARCANA, 2012.

BUTTERWICK-PAWLIKOWSKI Richard, Jak pisać o dziejach sejmów Rady Nieustającej? W zwiazku z ksiażka Adama Danilczyka o sejmie 1786 roku, „KH”, 2012, z. 3, s. 568-591.

CzAJA Aleksander, Między tronem, buława, a dworem petersburskim. Z dziejów Rady Nieustajacej, 1786-1789, Warszawa, Państwowe Wydawnictwo Naukowe, 1988.

CzEPPE Maria, Kanonik putkownikiem, czyli ksiądz rotmistrz Ksiadz Maciej Kajetan Sołtyk, „Napis", 2002, z. VIII, s. 79-89.

CzEPPE Maria, Sołtyk Kajetan, [in:] PSB, t. XL, Warszawa-Kraków 2001, s. 386-406.

CZEPPe Maria, ŚmiaŁowski Józef, Soltyk Maciej Kajetan, [in:] PSB, t. XL, Warszawa-Kraków 2001, s. 404-406.

DANILCZYK Adam, W kręgu afery Dogrumowej. Sejm 1786 roku, Warszawa, Wydawnictwo NERITON, 2010.

DAWIDZIAK-KŁADOCZNA Małgorzata, Językowe aspekty kultury politycznej Sejmu Wielkiego, Częstochowa, Wydawnictwo AJD, 2012.

DEMBIŃSKI Bronisław, Książę Adam Czartoryski, generat ziem podolskich i jego działalność polityczna w latach 1780-1782, „Sprawozdania z Czynności i Posiedzeń Polskiej Akademii Umiejętności”, t. 37, 1932, z. 6, s. 33-39.

DĘBICKI Ludwik, Puławy (1762-1830): monografia z życia towarzyskiego, politycznego i literackiego, t. I: Czasy przedrozbiorowe, Lwów, Nakład Księgarni Gubrynowicza i Schmidta, 1887.

DYMNICKA-WoŁOSZYŃSKA Hanna, Małachowski Antoni, [in:] PSB, t. XIX, Wrocław 1974, s. 388-389.

DYMnICKA-WoŁoszyŃsKa Hanna, Okęcki Antoni Onufry, [in:] PSB, t. XXIII, Wrocław 1978, s. $658-661$.

FILIPCZAK Witold, Sejm 1778, Warszawa, Wydawnictwo Naukowe „Semper”, 2000.

FILIPCZAK Witold, Sejmiki ziemi czerskiej 1780-1786, „Przegląd Nauk Historycznych”, 2010, nr 1, s. $139-180$.

FILIPCZAK Witold, Sejmiki ziemi liwskiej 1780-1786, „Przegląd Nauk Historycznych”, 2018, nr 2, s. $123-153$.

FILIPCZAK Witold, Sejmiki ziemi nurskiej 1780-1786, „Przegląd Nauk Historycznych”, 2014, nr 1, s. 23-62.

FILIPCZAK Witold, Stanisław August i Elżbieta Sapieżyna. Spór wokót losów sejmu 1782, [in:] Władza i polityka w czasach nowożytnych, red. Zbigniew Anusik, Łódź 2011, s. 53-72. 
FILIPCZAK Witold, Uwagi o funkcjonowaniu „,wolnych” sejmów okresu Rady Nieustającej 17781786, [in.] Parlamentaryzm w Polsce we wspótczesnej historiografii. Praca zbiorowa, red. Jerzy BARDACH, przy współudziale Wandy STUDNIK, Warszawa, Wydawnictwo Sejmowe 1995, s. 17-26.

FILIPCZAK Witold, Życie sejmikowe prowincji wielkopolskiej w latach 1780-1786, Łódź, Wydawnictwo Uniwersytetu Łódzkiego, 2012.

FRĄCZYK Tadeusz, Adam Kazimierz Czartoryski. Biografia literacka na tle przemian ideowych polskiego Oświecenia, Kraków, Księgarnia Akademicka, 2012

GıUSZAK Michał, Rada Nieustająca - badawcze osiagnięcia i perspektywy, „Studia z Dziejów Państwa i Prawa Polskiego", t. XIX, 2016, s. 127-134.

GolińSKi Zbigniew [rec.], Teatr polskiego Oświecenia. pod red. J. Kotta, Komedie Adam Kazimierz Czartoryski, oprac. Z. Zahrajówna, „Pamiętnik Literacki”, 1957, z. 1, s. 181-185.

GoNera Marzena Działalność parlamentarna Adama Kazimierza Czartoryskiego. Praca doktorska napisana pod kierunkiem naukowym prof. zw. A. Stroynowskiego, Częstochowa 2017.

GoNerA Marzena, Życie codzienne posła w epoce stanisławowskiej, [in:] Między prawda, a zwatpieniem. W poszukiwaniu obrazu przeszłości, red. Robert MAJZNER i Łukasz CHOLEWIŃSKI, Częstochowa, AJD, 2014, s. 125-138.

GoRDZIEJEW Jerzy, Socjotopografia Grodna w XVIII wieku, Torun, Wydawnictwo Adam Marszałek, 2002.

Grochulska Barbara, Potocki Stanisław Kostka, [in.] Polski Stownik Biograficzny, t. XXVIII, Wrocław 1984-1985, s. 158-170.

GrZeŚKowiak-Krwawicz Anna, O formę rządu czy rząd dusz? Publicystyka polityczna Sejmu Czteroletniego, Gdańsk, Wydawnictwo Instytutu Badań Literackich PAN, 2000.

GRZYBowski Michał Marian, Pochodzenie, młodość i poczatki kariery Michała Jerzego Poniatowskiego, „Studia Płockie”, 1974, z. 2, s. 233-240.

JANECZEK Zdzisław, Ignacy Potocki. Marszatek wielki litewski (1750-1809), Katowice, Wydawnictwo Uniwersytetu Śląskiego, 1992.

JURGAITIS Robertas, Gdzie odbywaty się obrady sejmiku wileńskiego w latach 1717-1795, „Przegląd Nauk Historycznych, 2017, nr 2, s. 245-260.

Monika Jusupović, Działalność Adama Kazimierza Czartoryskiego na początku Sejmu Czteroletniego, „KH”, 2009, z. 3, s. 35-70.

Prawa Kardynalne (1768-1791), wyd. Zdzisław KaCZMARZYK, Poznań, Księgarnia Akademicka w Poznaniu 1947.

KĄDZIELA Łukasz, Sapieha Kazimierz Nestor, [in:] PSB, t. XXXV, Warszawa 1994, s. 52-65.

KONOPCZYŃSKI Władysław, Branicki Franciszek Ksawery, [in:] PSB, t. II, Kraków 1936, s. 398-401.

KONOPCZYŃSKI Władysław, Czartoryski Michał Fryderyk, [in:] Czartoryscy: trzydzieśsi sześć życiorysów, Kraków, Drukarnia Uniwersytetu Jagiellońskiego, 1938, s. 42-64.

KonOPCZYŃSKI Władysław, Geneza i ustanowienie Rady Nieustającej, Kraków, Polska Akademia Umiejętności, 1917.

KoNOPCZYŃSKI Władysław, Pierwszy rozbiór Polski, Kraków, ARCANA, 2010.

KurdybaCha Łukasz, Dzieje Kodeksu Andrzeja Zamoyskiego, Kraków, „Czytelnik”, 1951.

KutRZEBA Stanisław, Sklad sejmu polskiego 1493-1793, „PH”, 1906, z. 1, s. 43-76.

LEŚNODORSKI Bogusław, Dzieło Sejmu Czteroletniego, Wrocław, Zakład Narodowy im. Ossolińskich, 1951.

MaKSIMOwicz Krystyna, Seweryn Rzewuski w Nowej Familii (lata 1779-1788), „Pamiętnik Literacki”, 1993, z. 2, s. 135-166.

MichALSKI Jerzy, Do dziejów stronnictwa austriackiego i polskiej polityki Austrii po I rozbiorze, [in:] Księga pamiątkowa ku uczczeniu siedemdziesiatej rocznicy urodzin prof. dra Janusza Wolińskiego, red. S. HABST i in. Warszawa 1964, s. 145-153. 
Michalski Jerzy, [rec.] Łukasz KYRDYBACHA, Dzieje Kodeksu Andrzeja Zamoyskiego, Kraków 1951, „PH”, t. 42, 1951, s. 444-451.

MichalSKI Jerzy, Lubomirski Stanistaw, [in:] PSB, t. XVIII, Wrocław 1978, s. 53-56.

Michalski Jerzy, Od wrogości do przyjaźni. Czartoryscy wobec Karola Radziwitła „Panie Kochanku”, „Miscellanea Historico-Archivistica”, t. XI, 2000, s. 145-158.

Michalski Jerzy, Poczatki opozycyjnej działalności Franciszka Ksawerego Branickiego, „KH”, 2006, nr 2, s. 75-131.

MichaLSKI Jerzy, Radziwitt Karol Stanistaw, [in:] PSB, t. XXX, Wrocław 1987, s. 248-262.

MichaLSKI Jerzy, Sarmatyzm a europeizacja Polski, [in:] J. MiCHALSKI, Studia Historyczne w XVIII i XIX wieku, t. II: Ideologia, nauka, historiografia, Warszawa, Wydawnictwo STENTOR, 2007, s. 7-37.

MichALSKI Jerzy, Wokót powrotu Karola Radziwitła z emigracji pobarskiej, „KH”, 1999, z. 4, s. 21-72.

Mrozowska Kamila, Komisja Edukacji Narodowej (1773-1794), Warszawa-Kraków 1973.

MrozowsKa Kamila, Szkoła Rycerska Stanisława Augusta Poniatowskiego (1765-1794), Wrocław 1961.

OLsZewsKi Piotr, Kanclerz Jacek Nałęcz Małachowski (1737-1821), Kielce, Agencja „JP” s.c, 2013.

PERŁAKOWSKI Adam, Z sejmem czy bez sejmu? Konflikt o prywatne żupy solne na sejmie 1718 roku, „Studia Historyczne”, 2016, z. 2, s. 215-231.

PiŁATowicz Józef, [rec.] Szkoła Rycerska Jego Królewskiej Mości i Rzeczpospolitej, red. Waldemar BEDNARUK i K. JASZCZUK, Lublin 2016, „Historia i Świat”, 2017, nr 6, s. 195-209.

Platt Julian, Zabawy Przyjemne i Pożyteczne (1770-1777). Zarys monografii pierwszego polskiego czasopisma literackiego, Gdańsk, Wydawnictwo Uniwersytetu Gdańskiego. 1986.

RADWAŃSKi Zbigniew, Prawa kardynalne w Polsce, Poznań, Poznańskie Towarzystwo Przyjaciół Nauk, 1952.

RostworowsKi Emanuel, Mierzejewski Józef Wojciech, [in:] PSB, t. XXI, Wrocław 1976, s. 12-15.

RuDNICKI Kazimierz Biskup Kajetan Sottyk (1715-1788), Kraków, Drukarnia W.L. Anczyca i Spółki, 1906.

SAwICKI Robert, Dzieje Szkoły Rycerskiej - Korpusu Kadetów w latach 1765-1794, Warszawa 2015.

SCHMITT Henryk, Dzieje Polski XVIII i XIX wieku osnowane na przeważanie nie wydanych dotąd źródłach, t. II-III, Kraków 1867.

SCHRAmm Tomasz, Senat I Rzeczypospolitej - geneza, sktad i kompetencje, [in:] Senat w tradycji i praktyce Rzeczypospolitej, Warszawa, Kancelaria Sejmu, 2013.

SKaŁKOWSKi Adam M., O cześć polskiego imienia, Lwów 1908.

SLIz Natalia, Zamki grodzieńskie w II połowie XVIII wieku, „Częstochowskie Teki Historyczne”, t. VI, 2016, s. 51-90.

STANEK Wojciech, Konfederacja sejmowa z roku 1776 jako narzędzie zamachu stanu, „Acta Universitatis Lodziensis. Nicolai Copernici. Nauki Humanistyczno-Społeczne”, 1993, z. 259, s. $125-148$.

STROYNOwSKI Andrzej, Opozycja sejmowa w dobie rządów Rady Nieustającej: studium z dziejów kultury politycznej, Łódź, Wydawnictwo Wyższej Szkoły Studiów Międzynarodowych 2005.

STROYNOwSKI Andrzej, O oratorstwie politycznym sejmów stanisławowskich, „Przegląd Nauk Historycznych", 2006, nr 1, s. 185-209.

STROYNOwsKi Andrzej, Patriotyczne wystapienia opozycji na sejmie 1778 roku, „Acta Universitatis Lodziensis. Folia Historica"', 1984, z. 19, s. 173-180.

STROYNOwski Andrzej, Pierwszy wolny sejm stanisławowski 1778 (główne problemy obrad), ,Acta Universitatis Lodziensis. Folia Historica" 1990, z. 37, s. 35-65. 
StroYNowski Andrzej, Problem oratorstwa sejmowego czasów stanistawowskich, „Częstochowskie Teki Historyczne", t. 1, 2010, s. 79-91.

Stroynowski Andrzej, Przyczyny odrzucenia kodeksu Zamoyskiego, „Czasopismo Prawno-Historyczne", 1984, z. 1-2, s. 187-198.

STROYNOWSKI Andrzej, Rola elity w życiu parlamentarnym epoki stanisławowskiej, „Acta Universitatis Lodziensis. Folia Historica, 1985, z. 22, s. 45-60.

STROYNOWSKI Andrzej, Sejmowa opozycja antykrólewska w czasie rząów Rady Nieustającej (Kryteria klasyfikacji), „Acta Universitatis Lodziensis. Folia Historica”, 1984, z. 18, s. 17-26.

STROYNOWSKI Andrzej, Walory Szkoły Rycerskiej w opinii sejmowej, „Prace Naukowe Akademii im. Jana Długosza w Częstochowie. Rocznik Polsko-Ukraiński, t. XVII, 2015, s. 11-28.

STROYNOWSKI Andrzej, Wieczory sejmowe. Studia nad dziejami parlamentaryzmu w epoce stanisławowskiej, Częstochowa, Wydawnictwo AJD 2013.

STROYNOWSKI Andrzej, Znaczenie alternaty sejmów dla Wielkiego Księstwa Litewskiego, „Przegląd Nauk Historycznych", 2018, nr 1, s. 121-142.

SzCZYGIELSKI Wacław, Krasiński Kazimierz, [in:] PSB, t. XV, Wrocław-Warszawa-Kraków 1970, s. $184-186$.

SzCZYGIELSKI Wacław Ośniałowski Jan, [in:] PSB, t. XXIV, Wrocław-Warszawa 1979, s. 618.

WanicZKównA Helena, Czartoryski Adam Kazimierz, [in:] PSB, t. IV, Kraków 1938, s. 249-257.

WeRESZYCKA, Jabłonowski Antoni Barnaba, [in:] PSB, t. X, Wrocław 1962-1764, s. 216-218.

WOLSKA Barbara, O mentekaptacji księcia biskupa Sołtyka, www.wilanow_palac.pl.

WoŁoszyŃska Zofia, Adam Kazimierz Czartoryski, [in:] Pisarze polskiego Oświecenia, t. I, red. Teresa KostKIEwiCZOwA i Zbigniew Goliśski, Warszawa 1992, s. 399-411.

Zając Paweł, Giovanni Andrea Archetti i Stanisław August Poniatowski. Obraz króla i relacji $w$ depeszach nuncjusza do sekretariatu stanu stolicy apostolskiej, „KH”, 2016, nr 2, s. 279-311.

ZielińsKa Ewa, Otto Magnus Stackelberg wobec planów skonfederowania sejmu. Przyczynek do polityki rosyjskiej przed Sejmem Wielkim, „KH”, 2004, z. 3, s. 73-87.

ZIELIŃSKA Zofia, Ożarowski Piotr, [in:] PSB, t. XXIV, Wrocław 1979, s. 673-678.

ZIELIŃSKA Zofia, Poniatowski Michat Jerzy, [in:] PSB, t. XXVII, Wrocław 1982-1983, s. 455-471.

ZIELIŃska Zofia, Potocki Roman Ignacy, [in:] PSB, t. XXVIII, Wrocław 1984-1985, s. 1-17.

ZielińsKa Zofia, Republikanizm spod znaku buławy. Publicystyka Seweryna Rzewuskiego z lat 1788-1790, Warszawa, Wydawnictwo Uniwersytetu Warszawskiego, 1988.

ZIELIŃSKa Zofia, Rzewuski Seweryn, [in:] PSB, t. XXXIV, Wrocław 1992-1993, s. 138-152.

ZIELIŃSKA Zofia, Sapieha Michat Aleksander, [in:] PSB, t. XXXIV, Wrocław 1992-1993, s. 565-569.

ZIELIŃSKA Zofia, Seweryn Rzewuski- pułapki republikanizmu, [in:] Bo insza jest rzecz zdradzać, insza dać się zdradzać, insza dać się zdradzie. Problem zdrady w Polsce przełomu XVIII i XIX wieku: praca zbiorowa, red. Anna GRZEŚKOWIAK-KRWAWICZ, Warszawa, Wydawnictwo Instytutu Badań Literackich PAN, 1995, s. 31-47.

ZıóŁeK Ewa M, Biskupi senatorowie wobec reform Sejmu Czteroletniego, Lublin, Towarzystwo Naukowe Katolickiego Uniwersytetu Lubelskiego, 2008. 


\title{
Adam Kazimierz Czartoryski sparlamentary activity and elocution during the Seym of $\mathbf{1 7 8 2}$
}

\begin{abstract}
Summary
The purpose of this article was the presentation of Adam Kazimierz Czartoryski's political activity during the Seym of 1782. These considerations were concentrated on the answer of the following questions: Was Czartoryski effective policies? What kind of views did General Earth Podolian have in the most important issues, which were discussed during parliamentary sessions? and how did listeners react to his speeches? Equally important issue was way of argumentation, therefore the author indicated the most important traits of Prince's elocution.

The main sources are session diary of the Seym 1782, speak parliamentary collection, newspapers such as "Gazeta Warszawska" and memories. What is more, the author took advantage of the method of historical analysis.
\end{abstract}

Keywords: political activity, magnate opposition, bishop Kajetan Sołtyk, Permanent council, elocution. 
Prace Naukowe Uniwersytetu Humanistyczno-Przyrodniczego im. Jana Długosza w Częstochowie ZESZYTY HISTORYCZNE 2019, t. XVIII, s. 69-83

http://dx.doi.org/10.16926/zh.2019.18.04

Katarzyna MILIK

https://orcid.org/0000-0001-8492-2800

Uniwersytet Humanistyczno-Przyrodniczy im. Jana Długosza w Częstochowie

\section{Wpływ Kościoła katolickiego na rozwój szpitalnictwa polskiego w XVI-XIX wieku}

\section{Streszczenie}

Wiek XVI przyniósł ze sobą idee humanizmu i reformacji, które zagroziły chrześcijańskiej wizji szpitala. Przez całe średniowiecze pielęgnowano uwielbienie dla ubóstwa i koncepcję szpitala-przytułku, podlegającego zwierzchnictwu Kościoła katolickiego. W epoce odrodzenia zaczęto jednak potępiać żebractwo, ponieważ stanowiło poważny problem społeczno-ekonomiczny. Pojawiły się głosy, że szpitale powinny służyć wyłącznie chorym i niezdolnym do pracy oraz podlegać nadzorowi władz miejskich. Aby zachować swoją dotychczasową pozycję Kościół musiał przygotować się do reformy.

Postanowienia Soboru Trydenckiego na nowo podporządkowały szpitale władzy kościelnej. Jednak zainicjowane w renesansie zmiany sprawiły, że stopniowo zmieniała się koncepcja szpitalnictwa. Wprawdzie jeszcze w końcu XVIII w. nazwą szpitali obejmowano wszystkie instytucje udzielające schronienia i opieki ubogim, ale dzięki działalności lekarzy oraz ogólnego postępu medycyny, zaczęto dzielić je nie tylko na przytułki i szpitale, ale również według specjalności.

Sytuacja Kościoła zmieniła się zasadniczo dopiero w pierwszej połowie XIX w., kiedy przeprowadzono sekularyzację szpitali i przekazano je władzy centralnej. Wówczas Kościół katolicki stracił miejsce w zarządzie szpitali, a jego rola została sprowadzona do posługi religijnej.

Słowa kluczowe: Kościół katolicki, szpitale, XVI-XIX wiek.

Wiek XVI przyniósł ze sobą idee humanizmu i reformacji, które zagroziły chrześcijańskiej wizji szpitala. Przez całe średniowiecze pielęgnowano uwielbienie dla ubóstwa i koncepcję szpitala-przytułku, w którym schronienie mógł znaleźć każdy biedny, nie tylko chory, ale również zdrowy. Tymczasem w epoce odrodzenia krytykowano nieróbstwo żebraków. Miało to związek z zanikającym kultem ubogiego i postrzeganiem żebractwa jako poważnego problemu społeczno-ekonomicznego. Pojawiły się też głosy, że szpitale powinny służyć wyłącznie chorym i niezdolnym do pracy. Ponadto reformatorzy postulowali odda- 
nie wszystkich szpitali pod nadzór władz miejskich. Postulaty te, zostały częściowo zrealizowane tam, gdzie przyjęto religię reformowaną. Niemniej nowe hasła przyczyniły się również do częściowej reorganizacji kościelnych instytucji charytatywnych ${ }^{1}$.

W Rzeczypospolitej okres reformacji wywołał temat reformy dobroczynności, w tym przekazania szpitali oraz ich funduszy pod nadzór państwa. Szpitale administrowane dotąd przez zarządy złożone z proboszcza oraz prowizorów świeckich, zamierzano przekształcić $\mathrm{w}$ instytucje państwowe. Uważano bowiem, że szpitale jako podstawowa forma zorganizowanej dobroczynności powinny podlegać nadzorowi publicznemu ${ }^{2}$. Andrzej Frycz Modrzewski domagał się utworzenia odrębnego świeckiego urzędu do spraw pomocy ubogim, który mógłby też zarządzać majątkiem przeznaczonym dla najbiedniejszych ${ }^{3}$.

Istotne znaczenie dla dalszego rozwoju polskiego szpitalnictwa kościelnego miały, podjęte w duchu kontrreformacji, uchwały Soboru Trydenckiego (15451563). Niestety spowodowały one powrót do dawnych praktyk. Wszystkie szpitale, nawet te które powstały z inicjatywy osób świeckich, miały znów całkowicie podlegać zwierzchnictwu Kościoła. Biskupi uzyskali najwyższe uprawnienia w zakresie zarządzania działalnością charytatywną ${ }^{4}$. Byli zobowiązani do regularnego wizytowania podległych im zakładów oraz przyjmowania corocznych sprawozdań zarządców tychże placówek ${ }^{5}$. Wśród uchwał soboru znalazło się zalecenie dla biskupów i księży, aby nie tylko obejmowali patronatem już istniejące szpitale, ale otwierali także nowe ośrodki. Na wszystkie nałożono obowiązek katechizacji, prowadzonej wśród podopiecznych oraz surowe wymagania dotyczące praktyk religijnych ${ }^{6}$.

W Rzeczypospolitej uchwały Soboru Trydenckiego przyjęto na synodzie piotrkowskim w 1577 r. ${ }^{7}$ Problematyka szpitalna była podejmowana też na wcześniejszych synodach. W 1530 r. pojawił się postulat prymasa Macieja Drzewiec-

1 Zofia Podgórska-Klawe, Początki i rozwój szpitalnictwa, [in:] Historia medycyny, red. Tadeusz BRZEZIŃSKI, Warszawa 1988, s. 84.

2 Ewa LEŚ, Zarys historii dobroczynności i filantropii w Polsce, Warszawa 2001, s. 23.

3 Zbigniew Góralski, Działalność charytatywna $w$ Polsce przedrozbiorowej, WarszawaKraków 1973, s. 28.

4 Dzieje szkolnictwa i pedagogiki specjalnej, red. Stanisław MaUERSBerg, Warszawa 1990, s. 8; Marian SuRdackI, Dzieci porzucone w Szpitalu Św. Ducha w Rzymie w XVIII wieku, Lublin 1998, s. 36; Ewa LEŚ, Od filantropii do pomocniczości. Studium porównawcze rozwoju i działalności organizacji społecznych, Warszawa 2000, s. 40.

5 Każdy zarządca szpitala mógł nim administrować nie dłużej niż trzy lata - vide: Józef PELCZAR, Zarys dziejów miłosierdzia $w$ Kościele katolickim, Kraków 1916, s. 98. O protokołach z wizytacji biskupów - vide: Leon WACHHOLZ, Szpitale krakowskie 1220-1920, t. I, Kraków 1921, s. 32-33.

6 Z. PodgóRSKA-KLAWE, op. cit., s. 84.

7 Ibidem. 
kiego, stałej opieki szpitalnej nad dziećmi ${ }^{8}$. Na ten cel miano uruchomić specjalne środki w formie alimentów, fundowanych przez parafian lub biskupów diecezjalnych $^{9}$. Statut z $1551 \mathrm{r}$. zwrócił uwagę biskupów na sprawę funduszy szpitalnych, które powinny być szczególnie nadzorowane, aby nie zostały wydatkowane: „na inne cele, jak tylko na te dla których są przeznaczone"10.

W związku z tym, że środków na szpitale zawsze brakowało, Sobór Trydencki nakazał biskupom, aby dokonywali zapisów na cele dobroczynne. Nakaz ten przypomniano na synodzie w Warszawie w $1561 \mathrm{r}$. i postanowiono, że biskupi mają przeznaczać na pomoc ubogim czwartą część swoich dochodów ${ }^{11}$. W parafiach pojawiły się też pierwsze rejestry biednych, a proboszczów zobowiązano do zapobiegania nędzy ${ }^{12}$. W celu usprawnienia organizacji szpitalnictwa, na wniosek kardynała Bernarda Maciejowskiego, przypisano też parafiom obowiązek utrzymywania swoich ubogich ${ }^{13}$.

Uchwały soborowe oraz wspomniane polskie akty synodalne przyczyniły się do powstania w Rzeczypospolitej nowego szpitala parafialnego, który był zarówno instytucją kościelno-dobroczynną, jak i częścią polskiego systemu społeczno-gospodarczego ${ }^{14}$. Szpitale tego typu rozwijały się początkowo głównie w miastach ${ }^{15}$ i były ,zjawiskiem typowym dla Rzeczypospolitej Obojga Narodów i stanowiły najważniejszy element opieki społecznej na naszych ziemiach w okresie przedrozbiorowym"16.

W pierwszej połowie XVI w. pojawiły się też na ziemiach polskich azyle dla chorych wenerycznie i dla upośledzonych, głównie „furiatów”. Z czasem przekształciły się one, zwłaszcza azyle dla wenerycznych, w pewien rodzaj „specjalistycznych szpitali" ${ }^{\prime 17}$. Podjęto również pierwsze próby leczenia dzieci przewlekle i zakaźne chorych w „domu dla ospowatych”, założonym w Gdańsku przy

8 Dzieci przed umieszczeniem w szpitalu miały zostać ochrzczone - vide: Historia Kościoła w Polsce, t. I, red. Bolesław Kumor, Zdzisław OBertyński, Poznań-Warszawa 1974, s. 440.

9 Bolesław KUMOR, Opieka społeczna $w$ świetle ustawodawstwa synodalnego $w$ Polsce (do 1795), [in:] Charitas. Miłosierdzie i opieka społeczna $w$ ideologii, normach postepowania i praktyce społeczności wyznaniowych w Rzeczypospolitej XVI-XVIII wieku, red. Urszula AUGUSTYNIAK, Andrzej KARPIŃSKI, Warszawa 1999, s. 18. W opiekę nad osieroconymi i porzuconymi dziećmi angażowały się szpitale duchaków - vide: Historia Kościoła, s. 439.

10 B. KuMOR, op. cit., s. 13.

11 Ibidem, s. 15.

12 Józef MaJKa, Rozwój działalności charytatywnej w Kościele, [in:] Miłość miłosierna, red. Jan KRUCINA, Wrocław 1985, s. 205.

13 B. KumOR, op. cit., s. 15.

14 Zdzisław BudZYŃSKI, Dzieje opieki społecznej w ziemi przemyskiej i sanockiej (XV-XVIII w.), Przemyśl-Kraków 1987, s. 48.

15 Ibidem, s. 91; Marian SURDACKI, Opieka spoleczna w Wielkopolsce Zachodniej w XVII i XVIII wieku, Lublin 1992, s. 249-250.

16 Edyta Bartkowiak, Z tradycji szpitalnictwa $w$ dawnej Polsce, „Colloquia Theologica Ottoniana", nr 1: 2009, s. 113.

17 Z. PODGÓRSKA-KLAwE, op. cit., s. 85-86. 
kościele św. Elżbiety. Zakład ten pełnił także funkcje instytucji edukacyjnej, ponieważ próbowano w nim nauczać chore dzieci ${ }^{18}$.

W XVI w. pojawiło się wiele dekretów wydawanych przez władzę państwową dotyczących organizacji szpitali. Już dekret Zygmunta Starego z 1539 r. dla szpitala św. Ducha w Warszawie stanowił, iż tylko osoby schorowane lub stare, które bez pomocy innych nie są w stanie żyć, mogą tutaj znaleźć schronienie. Natomiast chorzy w sile wieku, mieli być po wyleczeniu „oddaleni”. Dziesięć lat później (1549) mandat królewski polecił usunąć ze szpitali krakowskich wszystkich żebraków, którzy byli zdolni do pracy ${ }^{19}$.

W tym czasie niektóre z zakładanych szpitali zastrzegały już w swych aktach fundacyjnych, przyjmowanie wyłącznie chorych. W akcie fundacyjnym szpitala św. Łazarza, założonego w 1591 r. zapisano: ,aby zdrowy żaden i ten, który może żebrać, tam chowany nie był" ${ }^{20}$. Z XVI w. pochodzą również pierwsze wzmianki o zatrudnianiu w polskich szpitalach na stałe cyrulików, a nawet lekarzy. Przykładem może być szpital św. Ducha, w którym w 1571 r. zatrudniono Wojciecha Oczko, lekarza nadwornego Stefana Batorego ${ }^{21}$. Szpital powoli stawał się miejscem leczenia chorych ubogich ${ }^{22}$.

W następnym stuleciu, w okresie upowszechniania się reformy trydenckiej w Kościele katolickim na ziemiach polskich, można zaobserwować pewien wzrost liczby szpitali parafialnych. Wiele zakładów wymagało odbudowy po toczących się na ziemiach polskich wojnach, do czego zobowiązano przede wszystkim plebanów ${ }^{23}$. Pojawiały się też nowe fundacje szpitalne. Szpitale fundowało nie tylko duchowieństwo, ale również król, szlachta i mieszczanie. Znane są wielkie fundacje na przykład Mikołaja Spytka Ligęzy z Borku, właściciela ogromnej fortuny z ośrodkiem w Rzeszowie, który w 1631 r. ufundował 12 szpitali dla 128 swoich poddanych ${ }^{24}$.

Szczególny wzrost liczby szpitali parafialnych można odnotować w drugiej połowie XVII w. Dla przykładu w wielkopolskiej części diecezji poznańskiej w latach $1603-1630$ tylko w $21 \%$ parafii istniały szpitale, natomiast w latach

${ }^{18}$ Dzieje szkolnictwa, s. 14-15.

19 Z. POdGÓRSKA-KLAWE, op. cit., s. 84.

20 Franciszek GIEDROYĆ, Rys historyczny Szpitala św. Lazarza w Warszawie, Warszawa 1897, s. 47.

21 Jadwiga Karwasińska, Szpital św. Ducha w Warszawie. Dzieje fundacji Anny Bolestawowej księżny mazowieckiej początkowe (1444-1544), Warszawa 1938, s. 53; Józef PeSzKE, Oczko Wojciech, [in:] Wielka encyklopedia powszechna ilustrowana, seria II, t. III-IV, red. Jerzy ALEKSANDROWICZ, Warszawa 1904, s. 661-663.

22 Sprzyjała temu również kształtująca się powoli dydaktyczna forma szpitalnictwa, która obligowała szpitale do nauczania studentów medycyny - vide: Z. PODGÓRSKA-KLAWE, op. cit., s. 87.

23 Z. GórAlSKI, op. cit., s. 29; Z. BUdZYŃSKI, op. cit., s. 41-43, 56; M. SURDACKI, Opieka, s. 233-241.

${ }^{24}$ Franciszek BUjaK, Wielka fundacja szpitalna z pierwszej połowy XVII wieku, [in:] Z odległej i bliskiej przeszłości. Studia historyczno-gospodarcze, Lwów-Warszawa 1924, s. 59-69; Adam PrZYBoś, Fundacje szpitalne Mikołaja Spytka Ligęzy w XVII w., ,Rocznik Naukowo-Dydaktyczny WSP w Krakowie”, z. 14: 1962, s. 71-82; Z. BUDZYŃSKI, op. cit., s. 48-49. 
1660-1667 odnotowano wzrost do 47,2\% ${ }^{25}$. W końcu XVII w. w Wielkopolsce Zachodniej aż $87,9 \%$ parafii miejskich miało szpital ${ }^{26}$. W parafiach wiejskich było gorzej - na wspomnianych terenach tylko $30,9 \% \mathrm{z}$ nich posiadało szpital ${ }^{27}$.

Istotnym czynnikiem rozwoju szpitalnictwa była liczba ludności danej parafii. Im była ona ludniejsza, tym większe miała szanse na założenie szpitala ${ }^{28}$. Generalnie szpital w tym czasie to przede wszystkim instytucja kościelna oraz miejska. Najwięcej szpitali działało oczywiście w największych miastach Rzeczypospolitej: Krakowie, Poznaniu, Wilnie, Gdańsku, Lublinie, Lwowie i Elblągu. Według Stanisława Litaka można przyjąć, że w drugiej połowie XVIII w. od 40 do $45 \%$ parafii miało szpitale ${ }^{29}$. Gorzej było na słabiej zaludnionych ziemiach wschodnich, zasiedlonych głównie przez ludność ruską oraz częściowo litewską, mimo że odsetek parafii ze szpitalami, na przykład w diecezji wileńskiej, był wysoki $^{30}$. Gęstość sieci szpitalnej zależała bowiem, jak już wspomniano, od gęstości sieci parafialnej.

Charakterystyczny dla polskiego szpitalnictwa potrydenckiego był również rosnący udział zgromadzeń zakonnych w opiece nad chorymi. Wśród starych zgromadzeń, działających jeszcze w średniowieczu można wyróżnić bożogrobców. Około 1772 r. posiadali 33 domy, nie licząc placówek parafialnych, prowadzili liczne szpitale w Rzeczypospolitej i na Śląsku ${ }^{31}$. Działalność kontynuowali duchacy (6 domów w Rzeczypospolitej, licząc osobno konwent i parafię Św. Krzyża w Krakowie) oraz duchaczki (2 domy z największym ośrodkiem w Krakowie $^{32}$. Na Warmii powstało w $1571 \mathrm{r}$. zgromadzenie sióstr katarzynek, które pracowały głównie w szpitalach miejskich - w XVIII w. miały tam 6 domów, plus jeden w Krokach na Żmudzi ${ }^{33}$.

Wśród nowych zgromadzeń zakonnych szczególnie zasłużyli się bonifratrzy oraz szarytki (Zgromadzenie Sióstr Miłosierdzia). Pierwszy zakon został zało-

25 Stanisław Litak, Szpitale w Polsce przedrozbiorowej. Rozwój i problematyka, [in:] Szpitalnictwo w dawnej Polsce, red. Maria DĄBRowSKA, Jerzy KRUPPÉ, Warszawa 1998, s. 18.

26 Ibidem, s. 23.

27 Andrzej KARPIŃSKI, Pauperes. O mieszkańcach Warszawy XVI i XVII wieku, Warszawa 1983, s. 276; M. SURDACKI, Opieka, s. 47.

28 Ibidem, s. 93.

29 S. LiTAK, op. cit., s. 23.

30 Ibidem.

31 Tabele źródlowe, oprac. Ludomir BIEŃKOWSKI [in:] Zakony męskie w Polsce w 1772 roku, red. Ludomir BieŃKOwsKi, Jerzy KŁoczowSKI, Zygmunt SuŁowSKI, Lublin 1972, tabela 13, s. 201203. Conf. S. Litak, op. cit., s. 25. Na Śląsku własne szpitale posiadali również benedyktyni, cystersi i joannici - vide: L. WACHHOLZ, op. cit., s. 54-113; Klara ANTOSIEWICZ, Zakon Ducha świętego de Saxia w Polsce średniowiecznej, „Nasza Przeszłość”, t. 23: 1966, s. 167-198; S. LiTAK, Kościół taciński w Rzeczypospolitej około 1772 roku. Struktury administracyjne, Lublin 1996, s. 506, 534.

32 Kazimierz Dola, Opieka społeczna Kościoła, [in:] Historia Kościoła, s. 371.

33 Elżbieta Janicka-OlczaKowa, Zakony żeńskie w Polsce, [in:] Kościół w Polsce, red. Jerzy KŁoczowsKi, t. II, Kraków 1970, s. 756. 
żony przez Jana Bożego (Juan Ciudad) w 1540 r. Bonifratrzy prowadzili pierwszy w Europie specjalistyczny szpital dla obłąkanych ${ }^{34}$. Do Rzeczypospolitej przybyli w 1609 r. Przed rozbiorem posiadali 14 placówek szpitalnych, można ich uznać za prekursorów nowoczesnego szpitalnictwa ${ }^{35}$. W XVII i XVIII w. byli jedynym zgromadzeniem przygotowanym do pracy z chorymi, dysponowali własnymi obiektami szpitalnymi, wykwalifikowanym personelem pielęgniarskim, medycznym oraz farmaceutycznym ${ }^{36}$. Często przy szpitalach zakładali biblioteki medyczne, a niektórzy z bonifratrów zasłużyli się jako popularyzatorzy wiedzy medycznej (np. Ludwik Perzyna) ${ }^{37}$.

Zgromadzenie Sióstr Miłosierdzia powstało w 1633 r. Do Warszawy z Paryża sprowadziła je w 1652 r. królowa Ludwika Maria Gonzaga. Szarytki, których klasztorami miały być domy ubogich, a krużgankami ulice miast, wkrótce stały się bardzo popularne. Były najliczniejszym i najbardziej rozpowszechnionym zgromadzeniem zakonnym na ziemiach polskich ${ }^{38}$. Przed pierwszym rozbiorem Rzeczypospolitej prowadziły 20 domów, w tym 11 szpitali oraz 10 szkół dla dziewczą $t^{39}$. Ponadto pracowały w szpitalu Dzieciątka Jezus w Warszawie oraz innych zakładach prowadzonych przez misjonarzy ${ }^{40}$.

Misjonarze ze zgromadzenia założonego przez św. Wincentego á Paulo w 1625 r., dotarli na ziemie polskie w $1651 \mathrm{r}$. Osiedlali się przede wszystkim w dużych miastach jak: Warszawa, Kraków czy Wilno. Zajmowali się głównie kształceniem duchowieństwa świeckiego, prowadząc seminaria duchowne oraz pracę charytatywną. W czasach pierwszego rozbioru byli w posiadaniu 30 domów ${ }^{41}$.

Duże znaczenie dla rozwoju polskiego szpitalnictwa miała działalność Braci Miłosierdzia od św. Rocha, zakonu utworzonego w 1653 r. W 1713 r. Zgromadzenie przybyło do Wilna. Działało głównie na Litwie i Żmudzi. Głównym zadaniem rochitów była opieka nad zakaźnie chorymi. Z ich inicjatywy doszło do założenia w Warszawie pierwszego w kraju tego typu szpitala ${ }^{42}$.

Mniej rozpowszechnione były wizytki, osadzone w Warszawie w $1654 \mathrm{r}$. również przez królową Ludwikę Marię. Było to zgromadzenie ściśle klauzurowe,

34 Jerzy Duchniewski, Bonifratrzy, [in:] Encyklopedia Katolicka, red. Feliks GrygLewicz, Romuald ŁUKASZYK, Zygmunt SUŁOWSKI, t. II, Lublin 1985, kol. 799.

35 S. Litak, Szpitale, s. 26; L. WachHolz, op. cit., t. II, s. 7; Jerzy KŁoczowski, Zakony męskie w Polsce w XVI-XVIII w., [in:] Kościót w Polsce, s. 585-589; M. Surdacki, Dzieci, s. 39.

36 J. DuCHNIEWSKI, op. cit., s. 801. Conf. Dorota MAZEK, Bonifraterskie zasady opieki nad ubogimi i chorymi psychicznie w XVII-XVIII wieku, [in:] Charitas. Miłosierdzie, s. 189-191.

37 E. BARTKOWIAK, op. cit., s. 115.

38 Franciszek ŚmIDODA, Szpitalnictwo Polski przedrozbiorowej w opiece Kościoła, „Caritas” 4: 194, s. 97.

39 S. LiTAK, Szpitale, s. 26.

40 Alfons Schletz, Zarys historyczny Zgromadzenia Sióstr Miłosierdzia w Polsce (Karta z dziejów społecznych Kościoła), „Nasza Przeszłość”, t. 12: 1960, s. 59-172.

41 J. KŁOCZOWSKI, op. cit., s. 575-576; S. LiTAK, Szpitale, s. 26.

42 Alfons Schletz, Bracia św. Rocha w Warszawie, „Caritas” 7: 1945/1946, s. 11, 13. 
ale realizujące obok celów wychowawczych również te charytatywne. W Rzeczypospolitej miały jednak tylko 4 domy powstałe w latach $1654-1723^{43}$.

Generalnie, szpitale prowadzone przez zakony funkcjonowały lepiej. W większym stopniu łączyły też opiekę nad dziećmi, ubogimi i starcami z zadaniem leczenia Na wysokim poziomie prowadziły szpitale Siostry Miłosierdzia. Nawet przekazywane im stare ośrodki ożywiały swoją działalność. Szpitale zakonne przyjmowały też więcej podopiecznych. Dla przykładu u duchaków w Krakowie mogło przebywać nawet 350 ubogich, kobiet ciężarnych, chorych i dzieci, a faktycznie niekiedy znacznie więcej ${ }^{44}$.

Pobyt w szpitalu firmowanym przez Kościół katolicki zobowiązywał do pewnych praktyk religijnych, określonych najczęściej przez statuty synodalne oraz regulaminy szpitalne. $Z$ przepisów zwanych „konstytucjami szpitalnymi” wydanych w 1672 r. dla diecezji poznańskiej wynika, że nie interesowano się zbytnio opieką nad chorymi. Natomiast istotna była kwestia wychowania religijnego, a więc przestrzegania obowiązku regularnej spowiedzi, znajomości przykazań czy pobożnych pieśni ${ }^{45}$. Z reguły pensjonariusze byli też zobowiązani do pewnych prac na rzecz miejscowego kościoła, kleru, a czasem i samego szpitala. Pod koniec XVIII i na początku XIX w. niektórzy dorabiali sobie rzemiosłem ${ }^{46}$.

Niestety tylko część potrzebujących mogła znaleźć miejsce w szpitalach. Pozostałymi interesowały się zarówno władze świeckie jak i kościelne, które w miarę możliwości otaczały ich stosowną opieką. Zgodnie jednak potępiano włóczęgostwo. W parafiach usuwano obcych żebraków ${ }^{47}$, mimo tego problem ten narastał.

Podpowiedź rozwiązania problemu przyszła z Francji, gdzie w 1531 r. powstał pierwszy tzw. Szpital Generalny. Był to wielki wielofunkcyjny przytułek, w którym znajdowały się warsztaty rękodzielnicze, szkółka dla dzieci, stołówka dla ubogich oraz ogólnie dostępna apteka, organizowano także opiekę nad ubogimi poza szpitalem ${ }^{48}$. Wewnętrznie był podzielony na swego rodzaju oddziały. W takiej formie przetrwał do XVIII w. Podobny szpital powstał w Warszawie w 1758 r. Jego zalążkiem był utworzony z inicjatywy ks. Gabriela Baudouina dom dla podrzuconych dzieci. Nowy szpital próbowano podporządkować radzie

43 [Jan JastrzęBSKI], Polskie wizytki czyli historia pierwszego klasztoru zakonnic Nawiedzenia Najświętszej Maryi w Warszawie, Rzym 1849, s. 7-10; Łukasz JANCZAK, Wizytki w Polsce, [in:] Podręczna Encyklopedia Kościelna, t. XXXI, red. Stanisław GALL, Warszawa 1913, s. 538551; E. JanicKA-OlCZAKOWA, op. cit., s. 758-759; Franciszka IgNASZEWSKA, Historia fundacji klasztoru ss. Nawiedzenia NMP (wizytek) w Krakowie (1681-1699), „Nasza Przeszłość”, t. 58: 1982, s. 5-93.

44 Klara AnTosiewicz, Duchacy, [in:] Encyklopedia Katolicka, t. IV, red. Romuald ŁUKASZYK, Ludomir BIEŃKOWSKI, Feliks GRYGLEwICZ, Lublin 1983, kol. 301; eadem, Zakon, s. 195-197.

45 Z. PodgóRsKa-KLAwe, op. cit., s. 84.

46 Być może takie przypadki zdarzały się i wcześniej - vide: S. LiTAK, Szpitale, s. 28.

47 Idem, Od reformacji do Oświecenia. Kościół katolicki w Polsce nowożytnej, Lublin 1994, s. 200.

48 Z. PodgóRSKA-KLAwE, op. cit., s. 86. 
złożonej w większości z ludzi świeckich. Niestety plan się nie powiódł, ponieważ Kościół nadal trzymał pieczę nad szpitalnictwem ${ }^{49}$.

Temat szpitali generalnych powrócił w $1775 \mathrm{r}$. w związku z uchwaleniem przez sejm Komisji nad Szpitalami w Koronie i Wielkim Księstwie Litewskim. Planowano zakładanie szpitali generalnych w każdym województwie. Przyjmowani mieli być ubodzy oraz chorzy za opłatą, a lekarz miał pełnić dozór nad okolicznymi felczerami i aptekami. Przewidziano szczepienia na ospę. Postulowano kształcenie w salach szpitalnych akuszerek. Niestety projekt pozostał na papierze, a szpitale generalne stały się po prostu szpitalami ogólnymi ${ }^{50}$.

W XVIII w. pojawiły się też tzw. szpitale ospowe. Zakładano je już wcześniej jako izolatoria dla chorych na ospę, tym razem miały służyć głównie szczepieniom. W Warszawie na ospę szczepiono w szpitalu Dzieciątka Jezus (od 1760 r.) oraz w szpitalu założonym przez Otto de Ott przy ul. Mostowej. Ten ostatni powstał prawdopodobnie w latach siedemdziesiątych XVIII w. i był de facto domem dla zaszczepionych, a nie szpitalem zakaźnym ${ }^{51}$.

W tym czasie pojawiły się w Europie stałe szpitale wojskowe, przeznaczone dla rannych i chorych żołnierzy oraz marynarzy. Wkrótce stały się miejscem nauczania medycyny wojskowej i morskiej ${ }^{52}$.

Z końcem XVIII w. nastąpiły też zmiany w szpitalnictwie psychiatrycznym. Nowe koncepcje stanowiły o powstaniu leczniczych zakładów dla psychicznie chorych, gdzie już nie skuwano ciał łańcuchami, ale prowadzono obserwacje lekarskie i podejmowano próby leczenia. W Londynie taki specjalny szpital-lecznica działał od 1786 r. ${ }^{53}$ Tymczasem w Rzeczypospolitej wprawdzie uznano „wariację” za chorobę, ale nie było to równoznaczne z postępem organizacji jej leczenia. Tak jak i w wiekach wcześniejszych, główną funkcją polskiego szpitalnictwa psychiatrycznego było objęcie chorego kontrolą. Zachowały się przekazy świadczące o niechlubnych działaniach podejmowanych wobec ,psychicznych”. Na przykład w szpitalu Dzieciątka Jezus chore psychicznie kobiety trzymano w ciasnych komórkach, będących w opłakanym stanie. Z kolei u bonifratrów w Wielkanoc wpuszczano do szpitala gawiedź miejską, jak na widowisk $0^{54}$. Ostateczne zmiany przyniósł wiek XIX.

49 Ibidem, s. 87.

50 VL, t. VIII, Petersburg: wyd. Ohryzko, 1860, s. 173-178; Tadeusz SRoGosz, Skład, kompetencje i działalność Komisji nad szpitalami w latach 1775-1780, „Biuletyn Instytutu Filozoficzno-Historycznego Wyższej Szkoły Pedagogicznej w Częstochowie”, nr 26(7): 2000, s. 59-63.

51 Z. PodgóRSKA-KLAwe, Od hospicjum do wspótczesnego szpitala. Rozwój historyczny problematyki szpitalnej w Polsce do końca XIX wieku, Wrocław-Warszawa-Kraków 1981, s. 44. Szczepiono wówczas metodą wariolizacji, czyli wydzieliną z krosty chorego. Metoda ta wymagała wówczas hospitalizacji. Vide: ibidem.

52 Z. Podgórska-Klawe, Początki, s. 87; eadem, Od hospicjum, s. 123. O wojskowej służbie medycznej - vide: T. SRogosz, Żolnierz swawolny. Z dziejów obyczajów armii koronnej w XVII wieku, Warszawa 2010, s. 79-81.

53 Z. Podgórska-Klawe, Początki, s. 88; eadem, Od hospicjum, s. 45.

54 Ibidem. 
Stopniowo na ziemiach polskich zmieniała się również sama koncepcja szpitala. Wprawdzie jeszcze w końcu XVIII w. nazwą szpitali obejmowano wszystkie instytucje udzielające schronienia i opieki ubogim, ale dzięki działalności lekarzy oraz ogólnego postępu medycyny, zaczęto dzielić je już nie tylko na przytułki i szpitale, ale również według specjalności. Pojawiły się więc osobne dla nieuleczalnie chorych wenerycznie, położnic, chorych „,wewnętrznie i zewnętrznie" 55 . Kiedy funkcje lecznicze zaczęły dominować w szpitalach, kończył się też powoli czas wpływów Kościoła ${ }^{56}$. Przyczyniło się do tego powstanie kościuszkowskie, a jeszcze bardziej okres wojen napoleońskich. Wówczas formy organizacyjne oraz metody postępowania medycznego stosowane w lazaretach wojskowych zaczęły powoli przejmować szpitale cywilne. Wpływy prusko-francuskie oddziaływały bardzo mocno na organizację szpitalnictwa i opiekę społeczną̨ ${ }^{57}$. Decydujący wpływ na zmianę funkcji szpitala miał postęp medycyny, wzrost liczby lekarzy oraz zmieniający się status pacjenta.

W pierwszej połowie XIX w., do zmniejszonych już sal szpitalnych, zaczęto wprowadzać kolejne zmiany. Pojawiły się przede wszystkim surowe zakazy umieszczania dwóch chorych w jednym łóżku. Drewniane łóżka zaczęto zastępować żelaznymi, w niektórych szpitalach malowano olejno ściany. Na podłodze pojawił się asfalt lub kafle dla łatwiejszego utrzymania czystości. Nowością było urządzanie sal operacyjnych, bowiem dotąd operowano na salach chorych. Jednak prawdziwy postęp w higienie szpitalnej dokonał się dopiero po odkryciach Ludwika Pasteura i wprowadzeniu antyseptyki, a w ślad za nią aseptyki ${ }^{58}$.

Wielkim osiągnięciem pierwszych lat XIX w. było wydzielenie szpitali dla dzieci, które często umieszczano na wspólnych salach z dorosłymi, nierzadko na wspólnych łóżkach. W 1841 r. w warszawskim szpitalu Dzieciątka Jezus wydzielono 4 sale dla chorych dzieci, a cztery lata później oddano do użytku osobny szpitalik ${ }^{59}$. Według Elżbiety Mazur właściwe szpitalnictwo dziecięce zaczęło się jednak rozwijać dopiero od założenia w 1869 r. Zakładu Leczniczego dla Dzieci dr. Antoniego Sikorskiego ${ }^{60}$.

W tym czasie pojawiają się też pierwsze szpitale okulistyczne. Do ich powstania przyczyniła się panująca wśród społeczeństw jaglica ${ }^{61}$. Polacy na choroby oczu mogli się leczyć tylko w dwóch placówkach i to tylko w Warszawie:

55 F. Giedroyć, op. cit., s. 50-51.

56 Jeszcze w 1793 r. prowizorami - zarządcami warszawskich szpitali - z wyjątkiem miejskiego Szpitala św. Ducha i założonego przez bractwo miłosierdzia Szpitala św. Łazarza, byli przedstawiciele duchowieństwa. Vide: Z. PodgóRSKA-Klawe, Od hospicjum, przypis 19, s. 71.

57 Ibidem, s. 46.

58 Eadem, Poczatki, s. 94.

59 Ibidem.

60 Elżbieta MAzur, Zmiana funkcji szpitala w XIX wieku (na przykładzie szpitali warszawskich), [in:] Szpitalnictwo, s. 235; Andrzej WyBIERALSKI, Zarys historii warszawskiego szpitala dla dzieci 1869-1969, Warszawa 1969, s. 22-46.

61 Jaglica to przewlekłe lub nawracające zapalenie rogówki i spojówek. 
Instytucie Oftalmicznym ks. Lubomirskiego (od 1827) i Oddziale Okulistycznym przy szpitalu żydowskim (od 1902) ${ }^{62}$.

W ostatniej ćwierci XIX w. można zaobserwować nowe kryteria podziału szpitali, oparte przede wszystkim na postępie nauk medycznych. Postęp ten nakazywał dzielenie chorych według kryteriów chorobowych, wyznaczając jednocześnie coraz większą specjalizację lecznictwa zamkniętego ${ }^{63}$. Nowym zmianom i potrzebom miał sprostać też nowy zewnętrzny oraz wewnętrzny wizerunek szpitali.

Najtrudniej było przekonać do zmian samo społeczeństwo, w którego świadomości, jeszcze długo, szpital pełnił rolę instytucji charytatywnej. Przytułki, na przykład sierocińce, nie przyjmujące już chorych, nadal nazywano w pierwszej połowie XIX w. szpitalami ${ }^{64}$. W raporcie komisji lekarskiej dokonującej przeglądu warszawskich szpitali można przeczytać: „Szpital dostarcza lekarzy społeczeństwu i kieruje niejako całym leczeniem w kraju; szpital jest zakładem probierczym i wzorem dla wszystkich urządzeń leczniczych, higienicznych i sanitarnych. Społeczeństwo musi to pojąć i nie uważać szpitali, jak uważa dotychczas, jedynie za przytułki dla nędzarzy" ${ }^{\prime 65}$.

Nowe zadania szpitali ustaliła ostatecznie ich sekularyzacja i objęcie przez władzę centralną, co nastąpiło w latach $1817-1842^{66}$. Wszystkie szpitale nie wyłączając szpitali Sióstr Miłosierdzia, ostatecznie podporządkowanych władzom w 1841 r., stały się zasadniczo instytucjami państwowymi, mimo że nie zmienił się ich społeczny system finansowania. Warto podkreślić, że szczególne w okresie rządów Rady Głównej Opiekuńczej, tj. od 1832 do 1870 r., nastąpił największy rozkwit szpitali. W Królestwie Polskim powstało wówczas 47 nowych szpitali, starsze budynki szpitalne starano się remontować. Przygotowywano również plany kolejnych placówek leczniczych, w tym specjalistycznych (jak dla umysłowo chorych w Tworkach), których otwarcie nastąpiło po $1870 \mathrm{r}^{67}$

Dla rozwoju nowoczesnego szpitalnictwa istotne znaczenie miało również utworzenie w $1814 \mathrm{r}$. Warszawskiego Towarzystwa Dobroczynności oraz powołanego przy nim (w tym samym roku) Wydziału Lekarskiego, który skupił najbardziej znanych, poważanych w mieście lekarzy ${ }^{68}$. Pierwszą ich inicjatywą było uzyskanie zgody na inspekcję szpitali cywilnych - przeprowadzono ją u Dzie-

62 E. Mazur, Szpitale w Królestwie Polskim w XIX wieku, Warszawa 2008, s. 28, 34, 102.

63 Z. PodgórsKa-KLAwe, Poczatki, s. 94.

${ }^{64}$ Eadem, Od hospicjum, s. 47.

65 Referat komisji wyznaczonej przez prezesa Wydziału Hygieny szpitali, przytułków Towarzystwa Hygienicznego Warszawskiego dla skreślenia ogólnego programu zajęć tego wydziału, „Krytyka Lekarska", t. 4/nr 9: 1900, s. 238-239.

66 Z. Podgórska-Klawe, Od hospicjum, s. 57-63.

67 Bolesław JAKIMIAK, Rozwój, organizacja i stan obecny szpitalnictwa Warszawskiego, Warszawa 1928, s. 53; E. MAZuR, Szpitale, s. 18.

68 Z. PodgóRsKa-Klawe, Warszawskie Towarzystwo Dobroczynności i jego Wydziat Sierot i Ubogich Dzieci (1814-1914), [in:] Warszawa XIX wieku. Studia Warszawskie, t. VI, z. 1, Warszawa 1970, s. 145. 
ciątka Jezus i św. Łazarza. Inspekcja wykazała wiele haniebnych zaniedbań, na przykład chorzy tzw. wewnętrzni, zewnętrzni oraz kaleki leżeli razem na wspólnych salach ${ }^{69}$. Wobec tego, Towarzystwo Dobroczynności zdecydowało się na całościową kontrolę szpitali warszawskich, podjęto także kroki w kierunku przygotowania gruntownej reformy ${ }^{70}$.

Najtrudniej było zapewnić w szpitalach odpowiedni poziom higieny. W $1819 \mathrm{r}$. w szpitalu św. Ducha i św. Rocha leżało w jednym łóżku po dwóch chorych. Brakowało łazienek, nie izolowano chorych zakaźnie. Dieta szpitalna także nie była zbyt dobra. W 1819 r. w szpitalu św. Łazarza panował szkorbut, a w latach 1823 i 1824 tzw. gangrena szpitalna. Brakowało łóżek dla chorych ${ }^{71}$. Przyczyna była ciągle ta sama - brak pieniędzy. Niestety tylko część lepiej sytuowanych pacjentów mogła opłacać swoje leczenie, zdecydowana większość była na tzw. „funduszu”, czyli na utrzymaniu szpitala ${ }^{72}$.

Niemniej w 1837 r. otwarto w Warszawie tzw. Dom Zdrowia dla zamożniejszych chorych ${ }^{73}$. Jego naczelnym lekarzem został Aleksander Le Brun, który jednocześnie pełnił tę funkcję honorowo w szpitalu Dzieciątka Jezus (do 1839). To dzięki jego staraniom odebrano ten szpital Siostrom Miłosierdzia i przekazano Radzie Głównej Opiekuńczej, co było zresztą zgodne z prawem - art. 6 ukazu carskiego z 1838 r. wyraźnie stanowił: „Księża, misjonarze mają się trudnić tylko pełnieniem obowiązków religijnych i administracją sakramentów chorym, a siostry miłosierdzia usługą przy tychże chorych, bez udziału w zarządzie zakładu" ${ }^{\text {"4 }}$.

Ukaz nie pozostawiał wątpliwości - rolą Kościoła była wyłącznie posługa kapłańska, aby przebiegała sprawne, w każdym szpitalu znajdowała się kaplica, również w tych nowszych. W 1861 r. oddano do użytku w Warszawie budynek dla szpitala św. Ducha przy ul. Elektoralnej. W gmachu głównym mieściły się osobne pokoje dla opłacających pobyt chorych kobiet i mężczyzn, mieszkania naczelnego lekarza, felczera i sióstr miłosierdzia, a także izba przyjęć, kancelaria i kaplica ${ }^{75}$.

Po upadku powstania styczniowego, zmianom uległa również organizacja służby zdrowia. W Królestwie Polskim ustawa z 1870 r. szpitalnictwo całkowicie podporządkowała władzom carskim. Zarówno lekarze naczelni, jak i ordynatorzy oraz farmaceuci byli mianowani i zwalniani przez Ministra Spraw Wewnętrz-

69 Eadem, Szpitale warszawskie 1388-1945, Warszawa 1975, s. 147.

70 Julian Bartoszewicz, Opis Szpitala Dzieciatka Jezus w Warszawie, [in:] Rys historyczno-statystyczny szpitali i innych zakładów dobroczynnych w Królestwie Polskim, t. I, Warszawa 1872, s. 323. Conf. E. MAZur, Zmiana, s. 223-224.

71 F. Giedroyć, op. cit., s. 125-126.

72 E. Mazur, Zmiana, s. 225. Chorzy korzystający z tego funduszu szpitalnego, nierzadko byli wykorzystywani do różnych prac w szpitalu, podlegali też rozmaitym karom - vide: Z. PoDGÓRSKA-KLAWE, Poczatki, s. 92-93.

73 E. MAZUR, Zmiana, s. 226.

74 Z. PodgórsKa-Klawe, Szpitale warszawskie, s. 182.

75 Franciszek Groer, Opis Szpitala Św. Ducha w Warszawie, [in:] Rys historyczno-statystyczny, s. 548-551. 
nych. Ministerstwo decydowało również o uposażeniu wszystkich pracowników szpitali $^{76}$. Po odsunięciu Kościoła od udziału w zarządzie szpitali, teraz przyszedł czas na wyeliminowane wpływu społeczeństwa na sprawy szpitalne.

Konkludując, sytuacja Kościoła katolickiego na ziemiach polskich w XIX w. zmieniła się diametralnie, stracił ostatecznie wpływ na działalność szpitali. Jednak podporządkowanie szpitali władzom państwowym lub samorządowym nie zmieniło, właściwie aż do początków XX w., ich filantropijnego charakteru. Trudno się temu dziwić, skoro przez całe wieki szpital kojarzono przede wszystkim z działalnością charytatywną. Taki obraz budował zresztą sam Kościół. Trzeba przyznać, że zrobił wiele dobrego dla polskiego szpitalnictwa. W miarę swoich możliwości starał się zawsze pomagać potrzebującym i cierpiącym. Najlepszym miejscem do realizacji tego celu był oczywiście szpital, spełniający początkowo rolę przytułku dla ubogich. Pierwsze zmiany przyniosła dopiero epoka odrodzenia. Pojawiły się wówczas propozycje, aby szpitale były miejscem pobytu dla osób wyłącznie chorych oraz niezdolnych do pracy. Ponadto domagano się, aby nadzór nad szpitalami przejęły władze miejskie. Niestety w tym czasie realizacja tych postulatów nie była w pełni możliwa, ze względu na dość silną pozycję Kościoła. Do jej wzmocnienia przyczyniły się dodatkowo uchwały Soboru Trydenckiego, które generalne przywróciły Kościołowi zwierzchnictwo nad wszystkimi szpitalami. Sytuacja zmieniła się dopiero z początkiem XIX w.

\section{Bibliografia}

\section{Źródla drukowane}

Referat komisji wyznaczonej przez prezesa Wydziału Hygieny szpitali, przytułków Towarzystwa Hygienicznego Warszawskiego dla skreślenia ogólnego programu zajęć tego wydziału, „Krytyka Lekarska”, t. 4/nr 9: 1900, s. 237-243.

Tabele źródtowe, oprac. Ludomir BIEŃkOwski, [in:] Zakony męskie w Polsce w 1772 roku, red. Ludomir Bieńkowski, Jerzy KŁoczowski, Zygmunt SuŁowski, Lublin: Towarzystwo Naukowe KUL, 1972, s. 185-304.

Volumina Legum, t. VIII, Petersburg: wyd. Ohryzko, 1860.

\section{Opracowania}

AnTosiewicz Klara, Duchacy, [in:] Encyklopedia Katolicka, t. IV, red. Romuald ŁUKASZYK, Ludomir BIEŃKOwski, Feliks GryglewiCZ, Lublin: Towarzystwo Naukowe KUL, 1983, s. 299-301.

Antosiewicz Klara, Zakon Ducha Świętego de Saxia w Polsce średniowiecznej, „Nasza Przeszłość", t. 23: 1966, s. 167-198.

76 E. MAZUR, Szpitale, s. 26. Warto wspomnieć, że na ustawach warszawskich wzorowała się nawet organizacja szpitalnictwa w Wolnym Mieście Krakowie - vide: Z. PODGÓRSKA-KLAWE, Od hospicjum, s. 66. 
BARTKOWIAK Edyta, $Z$ tradycji szpitalnictwa w dawnej Polsce, „Colloquia Theologica Ottoniana”, nr 1: 2009, s. 103-121.

Bartoszewicz Julian, Opis Szpitala Dzieciatka Jezus w Warszawie, [in:] Rys historycznostatystyczny szpitali i innych zakładów dobroczynnych w Królestwie Polskim, t. I, Warszawa: Wyd. Józef Berger, 1872, s. 24-494.

BUdZYŃSKI Zdzisław, Dzieje opieki społecznej w ziemi przemyskiej i sanockiej (XV-XVIII w.), Przemyśl-Kraków: PTH Stacja Naukowa, 1987.

BUJAK Franciszek, Wielka fundacja szpitalna $z$ pierwszej połowy XVII wieku, [in:] Z odległej i bliskiej przeszłości. Studia historyczno-gospodarcze, Lwów-Warszawa: Ossolineum, 1924, s. 905-909.

Dola Kazimierz, Opieka społeczna Kościoła, [in:] Historia Kościoła, t. I, red. Bolesław Kumor, Zdzisław OBertyŃski, Poznań-Warszawa: Pallottinum, 1974, s. 433-442.

DuChNIEwski Jerzy, Bonifratrzy, [in:] Encyklopedia Katolicka, t. II, red. Feliks GrYGLEWICZ, Romuald ŁUKASZYK, Zygmunt SUŁOWSKI, Lublin: Towarzystwo Naukowe KUL, 1985, s. 799_ 801.

Dzieje szkolnictwa i pedagogiki specjalnej, red. Stanisław MAUERSBERG, Warszawa: PWN, 1990.

GIEDROYĆ Franciszek, Rys historyczny Szpitala św. Lazarza w Warszawie, Warszawa: Wyd. Kowalewski, 1897.

GÓRALSKI Zbigniew, Działalność charytatywna w Polsce przedrozbiorowej, Warszawa-Kraków: PWN, 1973.

Groer Franciszek, Opis Szpitala Św. Ducha w Warszawie, [in:] Rys historyczno-statystyczny szpitali i innych zakładów dobroczynnych w Królestwie Polskim, t. I, Warszawa: Wyd. Berger, 1872, s. 495-606.

Historia Kościoła $w$ Polsce, t. I, red. Bolesław Kumor, Zdzisław Obertyński, PoznańWarszawa: Pallottinum 1974.

IGNASZEWSKA Franciszka, Historia fundacji klasztoru ss. Nawiedzenia NMP (wizytek) w Krakowie (1681-1699), „Nasza Przeszłość”, t. 58: 1982, s. 5-93.

JАKIMIAK Bolesław, Rozwój, organizacja i stan obecny szpitalnictwa Warszawskiego, Warszawa: Zakł. Graf. „Medycyny”, 1928.

JanCZaK Łukasz, Wizytki w Polsce, [in:] Podręczna Encyklopedia Kościelna, t. XXXI, red. Stanisław GALL, Warszawa: Gebethner i S-ka, 1913, s. 538-551.

JanicKa-OlCZaKowa Elżbieta, Zakony żeńskie w Polsce, [in:] Kościół w Polsce, t. II, red. Jerzy KŁoczowsKi, Kraków: Znak, 1970, s. 761-771.

[JastrZĘBSKi Jan], Polskie wizytki czyli historia pierwszego klasztoru zakonnic Nawiedzenia Najświętszej Maryi w Warszawie, Rzym: Drukarnia Propagandy, 1849.

KARPIŃSKI Andrzej, Pauperes. O mieszkańcach Warszawy XVI i XVII wieku, Warszawa: PWN, 1983.

Karwasińska Jadwiga, Szpital św. Ducha w Warszawie. Dzieje fundacji Anny Bolestawowej księżny mazowieckiej początkowe (1444-1544), Warszawa: Wyd. Szpitala św. Ducha, 1938.

KŁoczowski Jerzy, Zakony męskie w Polsce w XVI-XVIII w., [in:] Kościót w Polsce, t. II, red. Jerzy KŁoczowsKi, Kraków: Znak, 1970, s. 483-730.

KUMOR Bolesław, Opieka społeczna w świetle ustawodawstwa synodalnego w Polsce (do 1795), [in:] Charitas. Miłosierdzie i opieka społeczna $w$ ideologii, normach postepowania i praktyce społeczności wyznaniowych w Rzeczypospolitej XVI-XVIII wieku, red. Urszula AUGUSTYNIAK, Andrzej KARPIŃSKI, Warszawa: Semper, 1999, s. 11-18.

LEŚ Ewa, Od filantropii do pomocniczości. Studium porównawcze rozwoju $i$ działalności organizacji społecznych, Warszawa: Dom Wydawniczy Elipsa, 2000.

LeŚ Ewa, Zarys historii dobroczynności i filantropii w Polsce, Warszawa: Prószyński i S-ka, 2001.

LiTAK Stanisław, Kościół łaciński w Rzeczypospolitej około 1772 roku. Struktury administracyjne, Lublin: Instytut Europy Środkowo-Wschodniej, 1996. 
Litak Stanisław, Od reformacji do Oświecenia. Kościół katolicki w Polsce nowożytnej, Lublin: Towarzystwo Naukowe KUL, 1994.

LitaK Stanisław, Szpitale w Polsce przedrozbiorowej. Rozwój i problematyka, [in:] Szpitalnictwo $w$ dawnej Polsce, red. Maria DĄBRowsKA, Jerzy KRUPpé, Warszawa: Instytut Archeologii i Etnologii PAN, 1998, s. 13-31.

MAJKA Józef, Rozwój działalności charytatywnej w Kościele, [in:] Miłość miłosierna, red. Jan KRUCiNA, Wrocław: Księgarnia Archidiecezjalna, 1985, s. 195-221.

MAZEK Dorota, Bonifraterskie zasady opieki nad ubogimi i chorymi psychicznie w XVII-XVIII wieku, [in:] Charitas. Miłosierdzie i opieka społeczna $w$ ideologii, normach postępowania $i$ praktyce społeczności wyznaniowych $w$ Rzeczypospolitej XVI-XVIII wieku, red. Urszula Augustyniak, Andrzej KARPiński, Warszawa: Semper, 1999, s. 187-194.

MAzur Elżbieta, Szpitale w Królestwie Polskim w XIX wieku, Warszawa: Instytut Archeologii i Etnologii PAN, 2008.

MAZUR Elżbieta, Zmiana funkcji szpitala w XIX wieku (na przyktadzie szpitali warszawskich), [in:] Szpitalnictwo $w$ dawnej Polsce, red. Maria DĄBRowsKA, Jerzy Kruppé, Warszawa: Instytut Archeologii i Etnologii PAN, 1998, s. 221-239.

PelCZAR Józef, Zarys dziejów miłosierdzia w Kościele katolickim, Kraków: nakładem autora druk UJ, 1916.

PESZKe Józef, Oczko Wojciech, [in:] Wielka encyklopedia powszechna ilustrowana, seria II, t. IIIIV, red. Jerzy ALEKSANDROwICZ, Warszawa: nakład Sikorskiego, 1904, s. 661-663.

PodgóRsKa-Klawe Zofia, Od hospicjum do wspótczesnego szpitala. Rozwój historyczny problematyki szpitalnej w Polsce do końca XIX wieku, Wrocław-Warszawa-Kraków: Zakład Narodowy im. Ossolińskich, 1981.

PodgórsKa-Klawe Zofia, Początki i rozwój szpitalnictwa, [in:] Historia medycyny, red. Tadeusz BRZEZIŃSKI, Warszawa: Wydawnictwo Lekarskie PZWL, 1988, s. 80-94.

PodgóRSKA-KLAWE Zofia, Szpitale warszawskie 1388-1945, Warszawa: PWN, 1975.

PodgóRsKa-Klawe Zofia, Warszawskie Towarzystwo Dobroczynności i jego Wydziat Sierot i Ubogich Dzieci (1814-1914), [in:] Warszawa XIX wieku. Studia Warszawskie, t. VI, z. 1, Warszawa: PWN, 1970, s. 142-184.

Przyboś Adam, Fundacje szpitalne Mikołaja Spytka Ligęzy w XVII w., „Rocznik NaukowoDydaktyczny WSP w Krakowie”, z. 14: 1962, s. 71-81.

SCHLETZ Alfons, Bracia św. Rocha w Warszawie, „Caritas”, t. 7: 1945/1946, s. 10-13.

SCHLETz Alfons, Zarys historyczny Zgromadzenia Sióstr Miłosierdzia w Polsce (Karta z dziejów społecznych Kościoła), „Nasza Przeszłość”, t. 12: 1960, s. 59-172.

SROGOSz Tadeusz, Skład, kompetencje i działalność Komisji nad szpitalami w latach 1775-1780, „Biuletyn Instytutu Filozoficzno-Historycznego WSP w Częstochowie”, nr 26(7): 2000, s. 59-64.

SRogosz Tadeusz, Żolnierz swawolny. Z dziejów obyczajów armii koronnej w XVII wieku, Warszawa: DIG, 2010.

SuRdacki Marian, Dzieci porzucone w Szpitalu Św. Ducha w Rzymie w XVIII wieku, Lublin: Towarzystwo Naukowe KUL, 1998.

SURDACKI Marian, Opieka spoteczna w Wielkopolsce Zachodniej w XVII i XVIII wieku, Lublin: Towarzystwo Naukowe KUL, 1992.

ŚMIDODA Franciszek, Szpitalnictwo Polski przedrozbiorowej w opiece Kościoła, „Caritas”, t. 4: 1948, s. 94-97.

Volumina Legum, t. VIII, Petersburg: Wyd. OHRYZKo, 1860.

W achHolz Leon, Szpitale krakowskie 1220-1920, t. I, Kraków: Anczyca i S-ki, 1921.

WyBIERALSKI Andrzej, Zarys historii warszawskiego szpitala dla dzieci 1869-1969, Warszawa: Wydawnictwo Lekarskie PZWL, 1969. 


\title{
The influence of the Catholic Church on the development of Polish hospital service in the $16^{\text {th }}-19^{\text {th }}$ centuries
}

\begin{abstract}
Summary
The $16^{\text {th }}$ century brought the concepts of humanism and reformation, which threatened the Christian vision of hospitals. Throughout the Middle Ages poverty had been cultivated together with the concept of a hospital-shelter subordinate to the Church. In the Renaissance period, begging started to be criticised as it constituted a serious social and economic issue. Some said that hospitals should serve the sick and those unable to work only, and be under the control of municipal authorities. In order to maintain its position, the Church had to prepare for the reform.

The resolutions of the Council of Trent once again submitted hospitals to the Church power. However, the changes initiated in the Renaissance made the concept of hospital service change gradually. Although at the end of the $18^{\text {th }}$ century the word 'hospital' still applied to all institutions providing shelter and care to the poor, due to doctors' activity and common access to medicine, they began to be divided not only into shelters and hospitals, but also according to their specialty.

The situation of the Church did not change substantially until the middle of the $19^{\text {th }}$ century, when hospitals were secularised and handed over to central power. Then, the Church did not manage hospitals any more and its role was reduced to religious service.
\end{abstract}

Keywords: Catholic Church, hospitals, XVI-XIX centuries. 

Prace Naukowe Uniwersytetu Humanistyczno-Przyrodniczego im. Jana Długosza w Częstochowie ZESZYTY HISTORYCZNE 2019, t. XVIII, s. 85-101

http://dx.doi.org/10.16926/zh.2019.18.05

Piotr DERENGOWSKI

http://orcid.org/0000-0002-4414-0545

Uniwersytet Gdański

\section{Polityczne aspekty organizacji, szkolenia i wykorzystania U.S. Colored Troops w czasie wojny secesyjnej}

\section{Streszczenie}

W powszechnej opinii wojna secesyjna uchodzi za konflikt, którego głównym celem było zniesienie niewolnictwa Murzynów w Stanach Zjednoczonych. Nic bardziej mylnego. Widoczne jest to nie tylko w deklarowanej polityce, ale także, a może przede wszystkim, w działaniach rządu federalnego w pierwszym etapie wojny, tj. przed wejściem w życie Proklamacji Emancypacji. Okres ten charakteryzuje swego rodzaju dychotomia w poczynaniach administracji Lincolna. Z jednej strony rząd za wszelką cenę starał się hamować wszystkie oddolne inicjatywy, które w jakikolwiek sposób dotyczyły kwestii niewolnictwa. $Z$ drugiej, kiedy cofnięcie tych decyzji okazywało się niemożliwe, wówczas za takimi działaniami szły kroki prawne. Nawet jednak po 1 stycznia 1863 r., mimo szczytnych haseł oraz obietnic równego traktowania wojska kolorowe często padały ofiarą dyskryminacji (w tym także ze strony rządu federalnego) oraz obelżywych ataków ze strony białych.

Slowa kluczowe: wojna secesyjna; Afroamerykanie; niewolnictwo; Proklamacja Emancypacji; wojska kolorowe; Abraham Lincoln; Benjamin F. Butler; Clement L. Vallandigham; Stany Zjednoczone.

W powszechnej opinii wojna secesyjna uchodzi za konflikt, którego głównym celem było zniesienie niewolnictwa Murzynów w Stanach Zjednoczonych ${ }^{1}$.

* Częściowo kwestie te były już przeze mnie poruszane w innych publikacjach. Vide: Piotr DERENGOWSKI, Polacy w wojnie secesyjnej 1861-1865, Oświęcim 2015, s. 339-344; idem, Kwalifikacje oficerów U.S. Colored Troops (USCT) w czasie wojny secesyjnej w świetle sprawozdań komisji egzaminacyjnej z St. Louis (Missouri), 1863-1865, [in:] O powinnościach żolnierskich, t. III: Na krętych drogach żolnierskich losów, red. Andrzej DRZEWIECKI, Oświęcim 2016, s. 445-460.

1 Pogląd ten podzielał m.in. Włodzimierz Krzyżanowski. Vide: Włodzimierz KRzYżANOwsKI, Wspomnienia z Pobytu w Ameryce Gen. Włodzimierza Krzyżanowskiego Podczas Wojny 18611864, Chicago 1963, s. 48-49; P. DerengowsKi, Polacy w wojnie secesyjnej, s. 189. 
Nic bardziej mylnego. Widoczne jest to nie tylko w deklarowanej polityce, ale także, a może przede wszystkim, w działaniach rządu federalnego w pierwszym etapie wojny, tj. przed wejściem w życie Proklamacji Emancypacji. Okres ten charakteryzuje swego rodzaju dychotomia w poczynaniach administracji Abrahama Lincolna. Z jednej strony rząd za wszelką cenę starał się hamować wszystkie oddolne inicjatywy, które w jakikolwiek sposób dotyczyły kwestii niewolnictwa. Dopiero kiedy cofnięcie tych decyzji okazywało się niemożliwe, wówczas za takimi działaniami szły kroki prawne, które utrzymywały je w mocy.

Stąd też nie powinien dziwić fakt, że kiedy wolni Murzyni z Północy już w $1861 \mathrm{r}$. zaproponowali swoje usługi rządowi Unii, inicjatywa ta nie spotkała się z pozytywnym odzewem administracji ${ }^{2}$. Warto pamiętać, że zgodnie z prawem federalnym z 1792 r. taki zaciąg do armii Stanów Zjednoczonych był formalnie zakazany. Zdarzały się jednak przypadki służby Afroamerykanów w jednostkach stanowych (ostatni taki oddział - New Orleans Free Men of Color został zorganizowany w 1834). Poza tym, Murzyni mogli praktycznie bez większych ograniczeń także służyć w marynarce (oczywiście z wyłączeniem stopni oficerskich) ${ }^{3}$.

Dodatkowo kwestia ewentualnego powołania pod broń Afroamerykanów była na samym początku konfliktu (w zasadzie do pierwszej bitwy pod Manassas - 21 VII 1861) mało popularna nawet wśród radykałów. Częściowo wynikało to z faktu, że administracja Lincolna, podobnie jak rząd Konfederacji (choć oczywiście z innych pobudek) nie chciała przyznać, że tocząca się wojna w jakikolwiek sposób dotyczyła niewolnictwa. Prezydent w swoim przemówieniu na specjalnej sesji Kongresu (4 VII 1861), potwierdzając niejako swoje słowa z mowy inauguracyjnej, stwierdził, że „nie ma zamiaru, bezpośrednio czy też pośrednio, ingerować $\mathrm{w}$ instytucję niewolnictwa, tam gdzie ona istnieje" ${ }^{\text {. Administracja }}$ w tym czasie zdecydowanie wysuwała na plan pierwszy niekonstytucyjność secesji oraz walkę o utrzymanie jedności Unii. Poza tym, Lincoln doskonale zdawał

2 Co ciekawe mniej więcej w tym samym czasie wolni Murzyni z Luizjany zorganizowali pułk piechoty Native Guards i oferowali swoje usługi rządowi Konfederacji. Wprawdzie podobnie, jak na północy ich oferta nie została zaakceptowana, jednakże jednostka ta formalnie została przyjęta na służbę stanową i pozostała na usługach Luizjany aż do czasu ofensywy federalnej na Nowy Orlean w 1862 r. Vide: Hondon B. HARgrove, Black Union Soldiers in the Civil War, Jefferson-London 2003, s. 5.

3 Ibidem, s. 2-3, 9-10; John D. SмIтH, Let Us All Be grateful That We Have Colored Troops That Will Fight, [in:] Black Soldiers in Blue. African American Troops in the Civil War Era, red. idem, Chapel Hill-London 2002, s. 9; P. Derengowski, Kwalifikacje oficerów U.S. Colored Troops, s. 446; idem, Polacy w wojnie secesyjnej, s. 339.

4 Obie izby wkrótce przegłosowały rezolucje, które poparły słowa Lincolna. Vide: Collected Works of Abraham Lincoln [dalej: CWL], red. Roy P. BASLER, t. IV, New Brunswick 1953, s. 263, 438-439 [https://quod.lib.umich.edu/l/lincoln/; dostęp: 3.04.2019]; The Congressional Globe, Thirty-Seventh Congress, $1^{\text {st }}$ Session, s. 222-223, 258-262 [https://memory.loc.gov/ammem/amlaw/lwcglink.html; dostęp: 3.04.2019]; James M. MCPHERson, Battle Cry of Freedom. The Civil War Era, New York-Oxford 1988, 312. 
sobie sprawę z faktu, że tak zaakcentowane cele wojny przemawiały znacznie bardziej do ochotników niż hasła powołania pod broń Murzynów i wyzwolenia niewolników ${ }^{5}$. Nie można przy tym zapomnieć o dwóch innych, dość istotnych kwestiach. Po pierwsze prezydent za wszelką cenę starał się utrzymać w Unii graniczne stany niewolnicze (Delaware, Maryland, Kentucky i Missouri). Stąd też, walcząc o poparcie wśród tamtejszych posiadaczy niewolników po prostu nie mógł otwarcie mówić o zniesieniu niewolnictwa. Po drugie, znaczna część, o ile nie większość mieszkańców Północy, włączając w to samego prezydenta, nie była wolna od uprzedzeń rasowych ${ }^{6}$. Czym innym było jednak postrzeganie własnej wyższości, a czym innym poparcie dla niewolnictwa. W tym przypadku potępienie „szczególnej instytucji” było w zasadzie równie uniwersalne (poza oczywiście obszarem stanów niewolniczych).

Było jednakże tylko kwestią czasu kiedy temat niewolnictwa powróci, tym bardziej, że większość działań wojennych toczyła się na terytorium Południa. Na pierwszy incydent nie trzeba było czekać. Już w maju $1861 \mathrm{r}$. trzech niewolników pracujących przy budowie konfederackich umocnień zbiegło w kierunku federalnych linii w okolicach Fortu Monroe (Wirginia). Następnego dnia ich właściciel - konfederacki pułkownik - pojawił się osobiście u dowódcy placówki, gen. mjr. Benjamina F. Butlera, i powołując się na ustawę o zbiegłych niewolnikach, żądał zwrotu swojej własności. W odpowiedzi usłyszał, że skoro Wirginia twierdzi, że opuściła Unię, powyższe prawo nie ma tu zastosowania. Ponadto zbiegli niewolnicy zostali uznani za „kontrabandę wojenną” i przeznaczeni do prac fizycznych wokół fortu

5 Szerzej na temat motywów, jakimi kierowali się ochotnicy vide: J.M. MCPHERson, What They Fought For, 1861-1865, New York-London-Toronto-Sydney-Auckland 1995.

6 Niechęć wobec Afroamerykanów na Północy przybrała formę „rasizmu awersyjnego” (ang. aversive racism), który, w dużym uproszczeniu, zakładał że idealna sytuacja to taka, w której Murzyni całkowicie zniknęliby z amerykańskiego życia. Takie podejście widoczne było zarówno w postulatach ruchu abolicjonistycznego w pierwszych dekadach XIX w., jak i w późniejszych działaniach polityków, zwłaszcza Partii Demokratycznej, podsycających strach białych mieszkańców przed napływem czarnych. Abraham Lincoln, w czasie słynnych debat z Stephenem Douglasem, broniąc się przed oskarżeniami o sprzyjanie ludności murzyńskiej, także potwierdził swoje przekonanie o wyższości białej rasy. Vide: The Lincoln-Douglas Debates (1858), [in:] Voices of Freedom. A Documentary History, red. idem, t. I, New York-London 2011, s. 261-265; Eric FonER, Give me Liberty! An American History!, t. I: To 1877, New York-London 2012, s. 439-440; idem, The Fiery Trial. Abraham Lincoln and American Slavery, New York-London 2010, s. 107-108; P. DeREnGowski, Polacy w wojnie secesyjnej, s. 184. Kwestie te były poruszane przeze mnie także w niepublikowanym dotąd wystąpieniu pt. „Przypadki znęcania się na jeńcami z U.S. Colored Troops (USCT) w okresie wojny secesyjnej - okrucieństwa wojny czy przejaw rasizmu?" wygłoszonym w ramach konferencji $W$ niewolidoświadczenia jenieckie, regulacje prawne, otoczenie spoleczne na przestrzeni wieków zorganizowanej przez Instytut Historii Uniwersytetu Jagiellońskiego, Wydział Historyczny Uniwersytetu Warszawskiego oraz Stowarzyszenie Miłośników Historii Wojskowości „Pola Chwały” w Niepołomicach (2017).

7 J.M. MCPHERSON, Battle Cry of Freedom, s. 355. 
Administracja, choć niechętnie, ostatecznie zaakceptowała działania gen. Butlera. Wkrótce za tą decyzją poszły także kroki legislacyjne. W sierpniu $1861 \mathrm{r}$. Kongres uchwalił pierwszą ustawę konfiskacyjną (ang. First Confiscation Act), która upoważniała rząd federalny do przejęcia wszelkiej własności, w tym niewolników, użytej przez Konfederację do pracy w fortach, stoczniach, arsenałach, okopach lub jakiejkolwiek innej służbie na rzecz wojska lub marynarki wojennej. Status prawny zbiegłych niewolników nadal jednak pozostawał niejednoznaczny, zwłaszcza w odniesieniu do zbiegłych kobiet i dzieci. O ile bowiem dość wyraźnie stwierdzono, że ci którzy pracowali bezpośrednio na rzecz sił zbrojnych Konfederacji nie są już niewolnikami, o tyle ustawa konfiskacyjna nie potwierdzała wprost, że są wolni ${ }^{8}$. Warto także zauważyć, że ustawa ta nie obejmowała niewolników zbiegłych z terenów stanów lojalnych wobec Unii. W tym wypadku nadal obowiązywały przepisy ustawy o zbiegłych niewolnikach, która nakazywała ich zwrot prawowitym właścicielom.

Mniej więcej w tym samym czasie kolejny z generałów Unii, John C. Frémont (dowódca Departamentu Zachodniego; ang. Western Department), postanowił odnieść się do kwestii niewolnictwa. Wydana przez niego proklamacja (30 VIII 1861) wprowadzała nie tylko stan wojenny na terenie stanu Missouri oraz karę śmierci dla partyzantów, ale przewidywała także konfiskatę mienia i wyzwolenie wszystkich niewolników należących do zwolenników Konfederacji ${ }^{9}$. Lincoln w prywatnej korespondencji przestrzegł Frémonta przed daleko idącymi konsekwencjami podjętych decyzji. Po pierwsze ewentualne egzekucje schwytanych partyzantów, musiały nieuchronnie doprowadzić do działań odwetowych ze strony konfederatów. Z kolei wyzwolenie niewolników mogło wywołać niepożądane reakcje wśród posiadaczy na terenie stanów granicznych, którzy wciąż pozostawali wierni Unii. Stąd też prezydent zasugerował aby generał przeredagował ten fragment proklamacji, tak aby był w zgodzie z uchwaloną 6 sierpnia ustawą konfiskacyjną. Frémont, odmówił zadośćuczynienia prośbie bez oficjalnego rozkazu, być może sądząc, że Lincoln nie odważy się otwarcie na taki krok. Prezydent nie zamierzał jednak ryzykować utraty poparcia właścicieli niewolników w Missouri i Kentucky i 11 września 1861 r. formalnie nakazał dostosowanie wydanej przez Frémonta proklamacji do treści ustawy konfiskacyjnej ${ }^{10}$.

W roku 1861 temat niewolników powrócił raz jeszcze, przy okazji rocznego raportu sekretarza wojny Simona Camerona, który został przekazany prasie bez

8 Przyjmuje się, że do końca wojny w szeregach Unii pracowało ok. 200 tys. niewolników, uznanych za „kontrabandę wojenną”. Vide: Private and Official Correspondence of Gen. Benjamin F. Butler during the Period of the Civil War, t. I: April 1860-June 1862, Norwood 1917, s. 185188; The Statutes at Large, Treaties, and Proclamations of the United States of America, t. XII, Boston 1863, s. 319; J.M. MCPHERson, Battle Cry of Freedom, s. 356.

9 Proclamation (30 VIII 1861), [in:] The War of the Rebellion: A Compilation of the Official Records of the Union and Confederate Armies [dalej: OR], ser. 1, t. III, Washington 1902, s. 466-467.

10 CWL, t. IV, s. 506, 517-518; J.M. MCPHERson, Battle Cry of Freedom, s. 352-353. 
autoryzacji prezydenta. Najwięcej kontrowersji budził fragment, w którym sekretarz stwierdzał, że rząd ma prawo uzbroić niewolników, gdy zajdzie taka potrzeba. Lincoln nakazał wycofanie raportu i jego przeredagowanie. Niektóre gazety postanowily jednak opublikować raport $\mathrm{w}$ jego pierwotnej wersji ${ }^{11}$. Zaistniała sytuacja nie pozostała bez wpływu na ocenę pracy sekretarza, który już na początku stycznia 1862 r. został zastąpiony przez Edwina M. Stantona ${ }^{12}$.

Ostra krytyka ze strony radykalnego skrzydła Republikanów w pewien sposób wymusiła jednak na prezydencie podjęcie kolejnych kroków legislacyjnych na rzecz niewolników. Najpierw w marcu przegłosowano dodatkowy artykuł wojny, który pod groźbą usunięcia ze służby zabraniał żołnierzom i marynarzom zwrotu zbiegłych niewolników ich właścicielom ${ }^{13}$. Następnie na początku kwietnia prezydent zażądał od Kongresu zobowiązania do udzielenia finansowej pomocy stanom, które podejmą kroki prawne w celu przeprowadzenia stopniowej emancypacji niewolników $\mathrm{z}$ odszkodowaniem dla ich właścicieli ${ }^{14}$. Jeszcze w tym samym miesiącu przegłosowano także zniesienie niewolnictwa w Dystrykcie Kolumbii z odszkodowaniem dla właścicieli oraz wsparciem finansowym dla kolonizacji wyzwoleńców na terenie Haiti, Liberii lub innego kraju ${ }^{15}$. Natomiast $\mathrm{w}$ czerwcu przegłosowano emancypację niewolników na obszarze terytoriów ${ }^{16}$. Wszystkie te działania miały jednak ograniczony charakter i jasno wskazywały, że prezydent nie miał zamiaru podejmować kwestii zniesienia niewolnictwa w całym kraju dopóki nie zaszłaby taka konieczność. W tym kontekście nie dziwi reakcja Lincolna na działania generała Davida Huntera, dowódcy Departamentu Południa (ang. Department of the South), który obejmował okupowane przez wojska Unii obszary Karoliny Południowej, Georgii i Florydy.

Generał Hunter - mimo braku oficjalnej zgody z Departamentu Wojny - już w kwietniu 1862 r. zaczął wyzwalać niewolników na kontrolowanych przez siebie terenach. Na początku maja posunął się jednak o krok dalej. W wydanym 9 maja Rozkazie Ogólnym nr 11 ogłosił wprowadzenie stanu wojennego na terenie stanów Karoliny Południowej, Georgii i Florydy oraz zniesienie niewolnictwa na tym obszarze ${ }^{17}$. Wkrótce wymusił także zaciąg do wojska wszystkich fizycznie zdolnych mężczyzn w wieku od 18 do 45 lat. Lincoln wprawdzie odpo-

11 Edward McPherson, The Political History of the United States during The Great Rebellion, Washington-New York 1864, s. 249; J.M. MCPHERson, Battle Cry of Freedom, s. 357-358.

12 Stanton został nominowany 13 I 1862 r. Dwa dni później jego nominacja została zatwierdzona dwa dni później. Zaprzysiężenie miało miejsce 20 I 1862 r. Vide: Frank A. Flower, Edwin McMasters Stanton. The Autocrat of Rebellion, Emancipation, and Reconstruction, Akron-New York-Chicago 1905, s. 117, 119.

13 The Statutes at Large, t. XII, s. 354.

14 Ibidem, 617.

15 District of Columbia Emancipation Act (16 IV 1862) [https://www.archives.gov/exhibits/featured-documents/dc-emancipation-act; dostęp: 5.04.2019].

16 The Statutes at Large, t. XII, s. 432.

17 General Orders, No. 11 (9 V 1862), [in:] OR, ser. 1, t. XIV, Washington 1885, s. 341. 
wiedział niemal natychmiast, anulując proklamację generała już 19 maja, jednak nie na wiele się to zdało ${ }^{18}$. Niezrażony Hunter kontynuował swój proceder, niekiedy porywając niewolników wprost z plantacji. Dopiero kiedy w sierpniu $1862 \mathrm{r}$. sekretarz wojny odmówił wypłaty żołdu dla oddziałów murzyńskich Huntera, ten został zmuszony do ich rozpuszczenia (pozostawiając sobie jedynie jedną kompanię). Cała sprawa odbiła się szerokim echem na Północy i przysporzyła administracji sporych problemów, wywołując dość burzliwą dyskusję w Izbie Reprezentantów. Kongresmen Charles A. Wickliffe z Kentucky potępił administrację Lincolna za zezwolenie na rekrutację czarnych bez zgody Kongresu, uznając że takie działania naznaczą wojnę piętnem hańby i wstydu. W sukurs przyszedł mu inny kongresmen z Kentucky, Robert Mallory, który nie tylko stwierdzil, że uzbrajanie czarnych stoi w sprzeczności z zasadami, którymi powinien kierować się cywilizowany naród, prowadząc wojnę, ale także podważył sens takich działań. Według niego Afroamerykanie byli z natury niezdolni do służby wojskowej, np. rzekomo bali się wystrzału artylerii. Przeciwnego zdania był Thaddeus Stevens z Pensylwanii, który twierdził że uzbrajanie niewolników w Karolinie Południowej było kluczowe przynajmniej z dwóch powodów. Po pierwsze pozbawiało to Konfederację jej siły roboczej, a po drugie umożliwiało zastąpienie na tym epidemicznym obszarze białych jednostek, czarnymi, które lepiej znosiły te ciężkie warunki klimatyczne ${ }^{19}$.

Praktycznie w tym samym czasie co gen. Hunter na wybrzeżu atlantyckim, w Luizjanie działania na rzecz utworzenia oddziałów murzyńskich podjął gen. John W. Phelps. W maju 1862 r. zwrócił się on z prośbą do swojego przełożonego, gen. Benjamina F. Butlera o zgodę na uzbrojenie niewolników znajdujących się w obozie dla uchodźców, niedaleko Nowego Orleanu - Camp Parapet. Butler odmówił, argumentując swoją decyzję brakiem upoważnienia do zaciągu Afroamerykanów. Mimo to Phelps nie zaniechał działań i w lipcu zorganizował 5 kompanii, licząc jednocześnie na otrzymanie dla nich broni. Butler jednak nakazał skierować te jednostki do wycinki drzew wokół obozu. Oburzony decyzją przełożonego Phelps odmówił wykonania rozkazu i złożył rezygnację ${ }^{20}$.

Innym oficerem, który podjął próbę zaciągu Afroamerykanów był James $\mathrm{H}$. Lane. Pełniąc jednocześnie obowiązki senatora z Kansas, wbrew woli sekretarza wojny autoryzował on w sierpniu 1862 r. na terenie swojego stanu zaciąg regi-

18 CWL, t. V, New Brunswick 1953, s. 222-224 [https://quod.lib.umich.edu/l/lincoln/; dostęp: 3.04.2019].

19 The Congressional Globe, Thirty-Seventh Congress, $2^{\text {nd }}$ Session, s. 3120-3127; Resolution adopted by the House of Representatives June 9, 1862, [in:] OR, ser. 2, t. I, Washington 1894, s. 820; J.D. SMith, op. cit., s. 10-11, 21-22; H. B. HARgrove, op. cit., s. 35-45; P. DerenGOWSKI, Polacy w wojnie secesyjnej, s. 341.

20 B.F. Butler do E.M. Stantona (2 VIII 1862) [wraz z załącznikami 1-4], [in:] OR, ser. 1, t. XV, Washington 1886, s. 534-537; B.F. Butler do J.W. Phelpsa (5 VIII 1862), [in:] ibidem, s. 542543; J.D. Smith, op. cit., s. 22; H.B. Hargrove, op. cit., s. 62-64; P. Derengowski, Polacy $w$ wojnie secesyjnej, s. 341 . 
mentu, który w znacznej mierze składał się ze zbiegłych z Missouri niewolników. Jednostka ta jeszcze fazie organizacji przeszła chrzest bojowy w potyczce na wyspie Island Mound (29 X 1862), będąc tym samym pierwszym czarnym oddziałem uczestniczącym w walce. Pierwsze sześć kompanii tworzących 1. pp z Kansas zostało wciągniętych na służbę 13 stycznia 1863 r. Kolejne cztery kompanie dołączyły w okresie od 13 stycznia do 2 maja $1863 \mathrm{r}^{21}$

Zdaje się, że coraz częstsze oddolne inicjatywy podejmowane przez kolejnych oficerów w różnych częściach kraju w końcu zaczęły uświadamiać zarówno prezydentowi, jak i jego otoczeniu, że nie da się już dłużej odkładać kwestii uzbrajania niewolników. W efekcie w lipcu 1862 r. przegłosowano dwie ustawy: 1) drugą ustawę konfiskacyjną (ang. Second Confiscation Act) oraz 2) ustawę o milicji (ang. Militia Act). Pierwsza z nich stanowiła znaczne rozszerzenie ustawy konfiskacyjnej z 1861 r., umożliwiając wyzwolenie nie tylko niewolników bezpośrednio wykorzystywanych do pracy przeciwko legalnemu rządowi, ale wszystkich należących do osób, które dopuściły się zdrady lub były aktywnie zaangażowane $\mathrm{w}$ rebelię. $\mathrm{Z}$ kolei ustawa o milicji upoważniała prezydenta do „przyjęcia na służbę Stanów Zjednoczonych w celach budowy umocnień, pełnienia służby obozowej lub innej pracy, lub też jakiejkolwiek służby wojskowej lub marynarskiej, do której mogą okazać się kompetentni, osób pochodzenia afrykańskiego", z płacą 10 dolarów miesięcznie (z czego 3 dolary miały być potrącane na ubranie $)^{22}$. Ustawa ta odegrała kluczową rolę w procesie rekrutacji Afroamerykanów. Warto jednak zwrócić uwagę na fakt, że choć istotnie zapisy w niej zawarte umożliwiały utworzenie oddziałów złożonych zarówno z wolnych Murzynów, jak i zbiegłych niewolników, to w istocie zamiarem rządu było powołanie jednostek, które pełniłyby służbę tyłową, a nie frontową.

Bez względu na intencje, w sierpniu 1862 r. po raz pierwszy przy aprobacie rządu zainicjowano proces tworzenia i przyjmowania na służbę oddziałów kolorowych. Praktycznie w tym samym czasie działania w tym kierunku podjęli generałowie Benjamin Butler w Luizjanie oraz Rufus Saxton w Karolinie Południowej. Pierwszy z nich przyjął na służbę pułk ochotników z luizjańskiej Native Gu$\operatorname{ard}^{23}$. Do listopada miał pod swoimi rozkazami już trzy takie regimenty, stając się jednocześnie pierwszym unijnym dowódcą, który oficjalnie wprowadził wolnych Murzynów do federalnej służby ${ }^{24}$. Natomiast gen. Saxton otrzymał od sekretarza Stantona upoważnienie do zaciągu 5000 Afroamerykanów. Dzięki temu,

21 H.B. Hargrove, op. cit., s. 51-58.

22 The Statutes at Large, t. XII, s. 589-592, 597-600; H.B. HARGROve, op. cit., s. 26-27; P. DERENGOWSKI, Polacy w wojnie secesyjnej, s. 340.

23 Był to regiment wolnych Murzynów, który w $1861 \mathrm{r}$. ofiarował swoją służbę Konfederacji.

${ }^{24}$ B.F. Butler do E.M. Stantona (14 VIII 1862), [in:] OR, ser. 1, t. XV, s. 548-549; B.F. Butler do H.W. Hallecka (27 VIII 1862) [wraz z załącznikami], [in:] ibidem, s. 555-557; B.F. Butler do E.M. Stantona ([?] IX 1862), [in:] ibidem, s. 559; H.B. HARGROVE, op. cit., s. 64-67; P. DERENGOWSKI, Polacy w wojnie secesyjnej, s. 341-342. 
wkrótce powstał pierwszy, utworzony pod auspicjami Departamentu Wojny regiment złożony z byłych niewolników - 1. (kolorowy) pułk ochotników z Karoliny Południowej, pod dowództwem Thomasa W. Higginsona ${ }^{25}$.

Nie zmienia to jednak faktu, iż Lincoln $\mathrm{w}$ dalszym ciągu pozostawał na stanowisku, że to utrzymanie Unii było dla niego najważniejsze, a wszystko inne stanowiło tylko środek prowadzący do tego celu. Dobitnie dał temu wyraz w liście do redaktora „New York Tribune” Horace Greelye'a z 22 sierpnia 1862 r.: „Jeśli mógłbym uratować Unię, nie uwalniając żadnego niewolnika, zrobiłbym to, i jeśli mógłbym ją uratować, uwalniając wszystkich, zrobiłbym to; i jeśli mógłbym ją uratować, uwalniając niektórych, a innych pozostawiając samym sobie, także bym to zrobił [...]”26. Wydaje się, że działania konfederatów na wschodnim teatrze, szczególnie zaś klęska Armii Wirginii w drugiej bitwie pod Manassas (28-30 VIII 1862) oraz ofensywa gen. Roberta E. Lee na Maryland, przełamały ostatecznie sceptycyzm prezydenta. Lincoln nie chciał jednak sięgać po ochotników afroamerykańskich w obliczu klęski, gdyż wówczas ruch ten miałby znamiona desperacji. Unii potrzebne było więc zwycięstwo. Upragniony sukces przyszedł 17 września. Wprawdzie wygrana w bitwie nad Antietam daleka była od ideału, to jednak na poziomie strategicznym bezsprzecznie był to znaczący sukces Unii. Pięć dni później prezydent wydał Wstępną Proklamację Emancypacji (ang. Preliminary Emancipation Proclamation) ${ }^{27}$, która nie tylko zapowiadała z dniem 1 stycznia $1863 \mathrm{r}$. zniesienie niewolnictwa na terenach objętych rebelią (chyba że zbuntowane stany do tego czasu zaprzestaną wrogich działań wobec rządu federalnego) ale także potwierdzała dotychczasowe kroki legislacyjne wobec zbiegłych z terenów Południa niewolników ${ }^{28}$.

Ogłoszenie proklamacji wywołało prawdziwą polityczną burzę w niektórych stanach Unii. Większość Demokratów była oburzona. Coraz częściej zaczęto wysuwać argument, że zniesienie niewolnictwa doprowadzi do masowej migracji ludności czarnoskórej na Północ. To z kolei miało doprowadzić do rywalizacji na rynku pracy, której biali nie byliby w stanie wygrać. Uznano bowiem za pewnik, że byli niewolnicy zgodzą się na znacznie niższe stawki. W konsekwencji więc doszłoby do ekonomicznego zniewolenia białych. $Z$ tej perspektywy Demokraci $\mathrm{i}$ ich zwolennicy nie tylko nie widzieli sensu w walce o zniesienie niewolnictwa, ale wręcz stanowiła ona dla nich zagrożenie. Anty-republikańskie nastroje znalazły swoje odzwierciedlenie w wyborach w roku 1862 . W ich wyniku Demokratom udało się zdobyć urząd gubernatora stanu Nowy Jork oraz New Jersey, jak również większość w legislaturach stanowych w New Jersey, Indianie i Illinois.

25 E.M. Stanton do R. Saxtona (26 VIII 1862) [wraz z załącznikiem], [in:] OR, ser. 1, t. XIV, s. 377-378; H.B. Hargrove, op. cit., s. 45-51; P. Derengowski, Polacy w wojnie secesyjnej, s. 341.

26 CWL, t. V, s. 388; P. Derengowski, Polacy w wojnie secesyjnej, s. 340-341.

$27 C W L$, t. V, s. 433-436.

28 Vide: Dodatkowy artykuł wojny oraz druga ustawa konfiskacyjna. 
Demokratom przybyło także 34 kongresmenów ${ }^{29}$. Zyski te oczywiście były istotne, ale nie możemy zapominać o fakcie, że Republikanie wciąż dominowali na scenie politycznej. Nadal w ich rękach pozostawało 17 z 19 urzędów gubernatora oraz 16 z 19 legislatur. Poza tym mimo utraty części miejsc w Kongresie, nadal dysponowali tam dość bezpieczną większością 25 głosów ${ }^{30}$.

Pozostawała jeszcze kwestia lojalności armii. Część generalicji, zwłaszcza ta z politycznego nadania, była zwolennikami Partii Demokratycznej. Stąd też obawy o lojalność tych oficerów były jak najbardziej zasadne. Krytyczne głosy wobec polityki administracji były szczególnie widoczne w Armii Potomaku. Jej dowódca, gen. George B. McClellan, choć prywatnie negatywnie oceniał działania Lincolna, oficjalnie (być może w obawie przed dezintegracją armii) wydał rozkaz przypominający oficerom o konieczności podporządkowania się armii władzom cywilnym ${ }^{31}$.

Prawdziwy przełom nadszedł wraz z wejściem w życie Proklamacji Emancypacji (1 I 1863), która choć nie uwolniła żadnego z niewolników znajdujących się na terenach okupowanych przez Unię, dała rządowi i armii federalnej zupełnie nowe możliwości działania. Raz jeszcze potwierdzono w niej prawo powołania Afroamerykanów pod broń. Warto jednak podkreślić, że po raz kolejny dość sugestywnie wskazywano, że powinna to być służba głównie garnizonowa ${ }^{32}$.

Już na początku stycznia Edwin Stanton upoważnił gubernatorów Massachusetts, Rhode Island i Connecticut do tworzenia regimentów złożonych z wolnych Murzynów. Jeszcze w tym samym miesiącu do Luizjany wysłano gen. Daniela Ullmanna z zadaniem wsparcia wysiłków generałów Benjamina Butlera i Nathaniela Banksa w powołaniu brygady wojsk kolorowych. Pod koniec marca do doliny Missisipi Stanton wysłał dotychczasowego adiutanta generalnego armii gen. Lorenzo Thomasa, który rozpoczął rekrutację Afroamerykanów na terenach położonych na północ od Vicksburga (Missisipi). Mniej więcej w tym samym czasie do Karoliny Północnej udał się gen. Edward A. Wild z upoważnieniem do powołania brygady złożonej z Murzynów ${ }^{33}$.

Wszystkie te działania nie tylko zintensyfikowały proces tworzenia wojsk kolorowych ale także znacząco zmieniły charakter wojny, która od tego momentu toczyć się miała także o zniesienie niewolnictwa. Właśnie ten czynnik w połączeniu z uchwaloną w marcu ustawą rekrutacyjną (ang. Enrollment Act), umożliwiającą powołanie pod broń wszystkich zdrowych obywateli płci męskiej do-

29 J.M. MCPherson, Battle Cry of Freedom, 560-561; Samuel S. Cox Condemns Emancipation, [in:] Voices of Freedom, t. I, s. 277-278.

30 J.M. MCPHERSON, Battle Cry of Freedom, s. 561-562.

31 General Orders, No. 163 (7 X 1862), [in:] OR, ser. 1, t. XIX, cz. 2, Washington 1887, s. 395396; J.M. MCPHERson, Battle Cry of Freedom, s. 559-560.

32 CWL, t. VI, New Brunswick 1953, s. 28-30 [https://quod.lib.umich.edu/l/lincoln/; dostęp: 3.04.2019].

33 J.D. Smith, op. cit., s. 24-25; H.B. HARgrove, op. cit., s. 103; P. Derengowski, Kwalifikacje oficerów U.S. Colored Troops, s. 446-447. 
prowadził jednak do poważnych rozruchów na Północy. Punktem zapalnym był zapis w ustawie, który umożliwiał uniknięcie powołania pod warunkiem uiszczenia opłaty w wysokości 300 dolarów lub znalezienie zamiennika (ang. substitute $^{34}$. Taka kwota była poza zasięgiem znacznej części społeczeństwa. Stąd też dość szybko upowszechnił się pogląd, że biedni mają walczyć i ginąć w wojnie bogatych.

Liderzy Partii Demokratycznej, wykorzystując swoje poparcie m.in. wśród licznej grupy imigrantów z Irlandii, wiosną i latem 1863 r. przystąpili do wzmożonego ataku na administrację, lansując się na obrońców praw obywatelskich i skutecznie podsycając antywojenne nastroje. Demokraci uznawali wojnę za niekonstytucyjną, a więc nielegalną. Pogląd ten zyskał na znaczeniu zwłaszcza po wejściu w życie Proklamacji Emancypacji, kiedy jej celem nie była już walka o Unię, a o zniesienie niewolnictwa. Raz jeszcze przywołano argumenty mówiące o tym, że emancypacja Afroamerykanów niechybnie doprowadzi do zniewolenia białych. Głośnym echem odbiła się zwłaszcza sprawa Clementa L. Vallandighama (byłego kongresmena z Ohio ${ }^{35}$, który w swoim przemówieniu w Mount Vernon w stanie Ohio (1 V 1863) nie tylko potępił administrację Lincolna za kontynuowanie „okrutnej i niepotrzebnej wojny”, ale także słynny Rozkaz Ogólny Nr 38 wydany przez gen. Ambrose'a Burnside'a, umożliwiający skazanie na śmierć lub banicję każdej osoby (w tym cywila), która dopuściła się zdrady ${ }^{36}$. Na efekty nie trzeba było długo czekać. Już 5 maja Vallandigham został aresztowany, a 11 dni później, po ekspresowym procesie, zapadł wyrok skazujący polityka na pobyt $w$ areszcie aż do zakończenia wojny. Prezydent Lincoln zmienił jednak ten wyrok (19 V 1863) na banicję ${ }^{37}$.

Demokraci oczywiście atakowali także samą ustawę rekrutacyjną. Efektem tych działań był narastający opór biedoty wobec przymusowego poboru oraz niechęć do walki za wolność Afroamerykanów. Kulminacja tych nastrojów miała miejsce na początku lipca. Najbardziej tragiczne w skutkach były zamieszki w Nowym Jorku (13-16 VII 1863), w wyniku których zginęło ponad 100 osób. Wprawdzie istotnie początkowo zniszczono kilka biur werbunkowych oraz zabito kilku oficerów rekrutacyjnych, ale znamienne jest że rozruchy te szybko

34 The Statutes at Large, t. XII, s. 731-737.

35 Jego mandat wygasł w styczniu 1863 r. Vide: J.M. MCPherson, Battle Cry of Freedom, s. 591.

36 Przy czym pojęcie zdrady nie zostało tu doprecyzowane, dając szerokie pole do interpretacji. Vide: Ibidem, s. 596; General Orders, No. 38 (13 IV 1863), [in:] OR, ser. 1, t. XXIII, cz. 2, Washington 1889, s. 237.

37 Vallandigham został przekazany w ręce konfederatów (25 V 1863). Lincoln nie przewidział jednak determinacji polityka z Ohio. Po zaledwie kilkutygodniowym pobycie na terenie Konfederacji, Vallandigham na pokładzie łamacza blokady przedostał się do Kanady, gdzie udał się do miejscowości Windsor na granicy z Ohio. Stamtąd prowadził swoją kampanię o urząd gubernatora. Vide: J.M. MCPHERSON, Battle Cry of Freedom, s. 596-598. Szerzej o sprawie Vallandighama vide: Michael K. CuRTIS, Lincoln, Vallandigham, and Anti-War Speech in the Civil War, „William \& Mary Bill of Rights Journal”, t. 7/nr 1: 1998, s. 105-191. 
zmieniły swój charakter z anty-wojennego na anty-murzyński. To właśnie ludność Afroamerykańska stała się głównym celem ataków motłochu. Dopiero interwencja armii przywróciła spokój na ulicach ${ }^{38}$.

Nie zmienia to jednak faktu, że pomimo oporów części społeczeństwa, rekrutacja wojsk kolorowych ruszyła w roku 1863 pełną parą. Już w maju do służby przyjęto pierwszy regiment: 1. pułk ochotników afrykańskiego pochodzenia z Arkansas. Do końca roku przyjęto ich $20^{39}$. Jednocześnie przed twórcami powoływanych oddziałów pojawiło się kolejne wyzwanie, a mianowicie - skąd wziąć odpowiednią kadrę oficerską dla nowych jednostek?

Naturalnymi kandydatami na dowódców oddziałów murzyńskich zdawali się być abolicjoniści. Wydaje się jednak, że rząd obawiał się, że mogliby oni wykorzystać swoje oddziały w celu przeprowadzenia niekontrolowanej emancypacji niewolników, czy wręcz jakiejś prywatnej vendetty na południowcach. Co nie oznacza, że nie znaleźli się oni wśród dowódców kolorowych regimentów (vide wspomniany już wcześniej Thomas W. Higginson). W szeregach wojsk murzyńskich znalazło się także wielu karierowiczów, którzy postanowili opuścić białe oddziały ochotnicze i dołączyć do czarnych skuszeni możliwością szybkiego awansu (nierzadko zdarzało się, że dotychczasowi szeregowcy czy sierżanci otrzymywali stopień porucznika, kapitana czy nawet majora, podczas gdy kapitanowie mogli liczyć nawet na szarżę pułkownika), związanym z tym wyższym żołdem i dodatkowymi świadczeniami ${ }^{40}$.

Od samego początku abolicjoniści, a także wolni Murzyni, liczyli, że stopnie oficerskie $\mathrm{w}$ tworzonych wojskach kolorowych zostaną zaoferowane również Afroamerykanom. Ich nadzieje okazały się jednak płonne. Zdecydowana większość polityków, jak i wojskowych nigdy nie rozważała innej możliwości jak obsadzenie wakatów białym oficerami. Takie rozwiązanie, choć w oczywisty sposób nie spełniające oczekiwań czarnej ludności miało jednak, przynajmniej teoretycznie, swoje logiczne uzasadnienie i pozostawało w zgodzie z ówczesnymi amerykańskimi uwarunkowaniami geopolitycznymi. Ponieważ zdecydowana większość kandydatów rekrutowała się z jednostek ochotniczych powstałych w latach 1861-1862 można było założyć, że gros z nich posiadała jakiekolwiek doświadczenie bojowe. Kolejnym istotnym elementem był czynnik polityczny. Odebranie gubernatorom stanów północnych rekrutujących oddziały wolnych Murzynów możliwości mianowania oficerów mogłoby mieć dla nich poważne konsekwencje polityczne. Trzecim, aczkolwiek równie ważkim powodem takiej,

38 Williston H. LofTon, Northern Labor and the Negro During the Civil War, „The Journal of Negro History", t. 34/nr 3: 1949, s. 262-273; Albon P. MAN jr., Labor Competition and the New York Draft Riots of 1863, „The Journal of Negro History”, t. 36/nr 4: 1951, s. 375-376, 388405; J.M. MCPHERSON, Battle Cry of Freedom, s. 609-611.

39 J.D. Smith, op. cit., s. 25; P. Derengowski, Polacy w wojnie secesyjnej, s. 343.

40 Ibidem, s. 37; H.B. Hargrove, op. cit., s. 111; P. DeREnGowski, Kwalifikacje oficerów U.S. Colored Troops, s. 447, 458. 
a nie innej decyzji były silne uprzedzenia rasowe. Nawet zakładając, że znaleźli by się wśród Afroamerykanów kandydaci z odpowiednimi kwalifikacjami do stopni oficerskich, nikt nie brał pod rozwagę możliwości, aby biały żołnierz, a tym bardziej oficer, mógł przyjąć rozkaz od czarnego przełożonego. W efekcie, nawet w jednostkach, w których Afroamerykanie znaleźli się wśród kadry oficerskiej (np. 1. pp z Kansas), w krótkim czasie zostali oni usunięci lub zdegradowani ${ }^{41}$.

Należy także pamiętać, że żołnierze decydujący się zostać oficerami w jednostkach afroamerykańskich musieli mieć świadomość tego, co mogło ich czekać w przypadku dostania się do konfederackiej niewoli. Już 21 sierpnia 1862 r., w odpowiedzi na pierwsze próby powołania oddziałów kolorowych, konfederacki adiutant i inspektor generalny Samuel Cooper wydał Rozkaz Ogólny nr 60, który wyjmował spod prawa generałów Davida Huntera i Johna Phelpsa. W przypadku schwytania obaj generałowie, podobnie jak inni oficerowie odpowiedzialni za musztrę, organizację lub szkolenie niewolników do służby wojskowej, mieli zostać pozbawieni statusu jeńców wojennych i jako zbrodniarze przetrzymywani w ścisłym odosobnieniu w oczekiwaniu na egzekucję, której czas i miejsce miał wskazać Jefferson Davis ${ }^{42}$. Dodatkowo, Kongres Konfederacji, w wydanej 1 maja 1863 r. rezolucji, upoważnił prezydenta do karania złapanych oficerów czarnych regimentów śmiercią za podburzanie niewolników do powstania. Spotkało się to z natychmiastową reakcją Lincolna, który zadeklarował, że w zamian za każdego zabitego lub źle potraktowanego unijnego żołnierza taki sam los spotka konfederackiego jeńca ${ }^{43}$. Wprawdzie przez większość wojny Południe oficjalnie nie dokonywało egzekucji ani białych oficerów, ani czarnych żołnierzy, jednak takie mordy się zdarzały ${ }^{44}$.

Inną kwestią był sposób powoływania oficerów w wojskach kolorowych. Początkowo zastosowano stare, ,sprawdzone" metody z armii ochotniczej, a mianowicie nominacje polityczne (przez gubernatorów) lub rekomendacje przełożonych (na szczeblu brygad i regimentów). $\mathrm{Z}$ czasem zaczęto w większym stopniu

41 J.D. Smith, op. cit., s. 36; William A. Doвак, Freedom by the Sword. The U.S. Colored Troops, 1862-1867, Washington 2011, s. 13; P. DERENGowsKi, Kwalifikacje oficerów U.S. Colored Troops, s. 447-448. Co ciekawe, uprzedzenia rasowe nie ominęły także białych oficerów wojsk kolorowych. Stali się oni celem swego rodzaju ostracyzmu i napiętnowania ze strony tak cywili, jak i oficerów wojsk ochotniczych. Vide: Frank Levstik, The Civil War Diary of Colonel Albert Rogall, „Polish American Studies”, t. 27/nr 1-2: 1970, s. 35-36, 40, 58, 73 [wpisy z 19, 26, 27 i 29 IV, 7 i 23 V oraz 5 X 1864, a także 17 II 1865]; P. DeRENGOWSKI, Granice dobrego smaku, czyli czego nie wypada pisać oficerowi w dzienniku - na przyktadzie dziennika ppłk. Alberta Rogalla, [in:] Wokót kresów, granic i pograniczy w historii wojskowej, red. Andrzej OleJKo, Paweł KorZENIOWSKI, Oświęcim 2015, s. 69.

42 General Orders, No. 60 (21 VIII 1862), [in:] OR, ser. 2, t. IV, Washington 1899, s. 857; P. DeRENGOWSKI, „Przypadki znęcania się na jeńcami”.

43 J.M. MCPherson, Marching Toward Freedom. Blacks in the Civil War 1861-1865, b.m.w. 1994, s. 81-82; P. DeRengowski, Kwalifikacje oficerów U.S. Colored Troops, s. 448.

44 Vide: Black Flag Over Dixie. Racial Atrocities and Reprisals in the Civil War, red. Gregory J.W. URwin, Carbondale 2004; P. Derengowski, „Przypadki znęcania się na jeńcami”. 
sprawdzać kandydatów na oficerów. Generał Thomas zainicjował m.in. system egzaminowania kandydatów przez komisje dywizyjne, które stały się bardzo powszechne na całym okupowanym przez wojska federalne Południu ${ }^{45}$. Wszystkie te działania miały jednak charakter doraźny i nie były w stanie sprostać rosnącemu zapotrzebowaniu na kadrę oficerską. Coraz wyraźniejsza stawała się potrzeba stworzenia jednego, scentralizowanego systemu rekrutacji tak samych oddziałów murzyńskich, jak i oficerów dla tych jednostek.

Wychodząc naprzeciw tym oczekiwaniom, Departament Wojny wydał Rozkaz Ogólny Nr 143 (22 V 1863), powołując do życia specjalne Biuro dla Oddziatów Kolorowych (ang. Bureau for Colored Troops) w biurze adiutanta generalnego. Kierownictwo tej instytucji powierzono mianowanemu zastępcą adiutanta generalnego mjr. Charlesowi W. Fosterowi ${ }^{46}$. Główne zadania biura nakreślone w rozkazie obejmowały przede wszystkim powołanie inspektorów nadzorujących organizację oddziałów kolorowych oraz komisji egzaminacyjnych dla kandydatów na oficerów w tychże jednostkach. Zaznaczono przy tym, że wszyscy aplikanci muszą wystąpić do biura adiutanta generalnego o wydanie stosownego upoważnienia do stawienia się przed komisją egzaminacyjną. Stwierdzono również, że rekrutację oddziałów kolorowych mogą prowadzić jedynie oficerowie posiadający upoważnienie z Departamentu Wojny oraz którzy uprzednio przeszli pomyślnie egzaminy. Zdarzały się jednak wyjątki od tej zasady. Chcąc wzmocnić pozycję polityczną późniejszego prezydenta USA Andrew Johnsona, pełniącego w tym czasie funkcję gubernatora wojennego Tennessee, Departament Wojny umożliwił mu kontrolę patentów w oddziałach kolorowych tworzonych na terenie stanu, wyłączając jednocześnie nominowanych przez gubernatora oficerów $\mathrm{z}$ konieczności stawienia się przed komisją egzaminacyjną ${ }^{47}$.

Jednocześnie wprowadzono ograniczenie liczby rekrutowanych na raz regimentów przez danego oficera do jednego. Na koniec potwierdzono, że wakaty na stanowiskach podoficerskich mogły zostać zapełnione w „Zwykły sposób”, tj. przez dowódcę regimentu ${ }^{48}$.

Jeszcze tego samego dnia wydano kolejny rozkaz, który w sposób szczegółowy regulował prace komisji egzaminacyjnych dla kandydatów na oficerów wojsk kolorowych, które zostały powołane w Waszyngtonie, Nowym Orleanie, St. Louis, Davenport, Nashville i Cincinnati, a pod koniec wojny także w Rich-

45 W.A. DobaK, op. cit., s. 14; P. DeRENGOwsKi, Kwalifikacje oficerów U.S. Colored Troops, s. 448.

46 General Orders, No. 143 (22 V 1863), [in:] General Orders Affecting the Volunteer Force, Adjutant General's Office, 1863, Washington 1864, s. 118-119; Dudley T. CoRnISH, The Sable Arm. Negro Troops in the Union Army, 1861-1865, New York 1966, s. 130; J.D. SMITH, op. cit., s. 26; H.B. Hargrove, op. cit., s. 104; P. DeRENGOwSKI, Kwalifikacje oficerów U.S. Colored Troops, s. 449.

47 P. Derengowski, Kwalifikacje oficerów U.S. Colored Troops, s. 449.

48 General Orders, No. 143 (22 V 1863), [in:] General Orders Affecting the Volunteer Force, 118; Revised United States Army Regulations of 1861, Washington 1863, s. 18-19; P. DERENGOWSKI, Kwalifikacje oficerów U.S. Colored Troops, s. 449. 
mond $^{49}$. Do końca 1863 r. komisje przeegzaminowały 1051, z czego jedynie 560 zostało zakwalifikowanych ${ }^{50}$. Była to liczba wystarczająca do zapełnienia wakatów w 16 regimentach, ale zdecydowanie zbyt mała wobec stale rosnącego zapotrzebowania. Departament Wojny był bardzo zaniepokojony wysokim procentem egzaminów zakończonych niepowodzeniem. Członkowie komisji egzaminacyjnej w Waszyngtonie analizując wyniki, stwierdzili, że wielu aplikantów zdołałoby pozytywnie zakończyć egzaminy, gdyby poświęcili kilka tygodni na naukę podstaw taktyki i regulacji armijnych pod okiem odpowiednich wykładowców. W związku z tym zdecydowano się powołać do życia w Filadelfii Darmową Szkołę Taktyki Wojskowej (ang. Free School for Military Tactics). Ze względu na brak funduszy szkoła działała niespełna rok (26 XII 1863-15 IX 1864). Mimo całkiem niezłych wyników absolwentów szkoły przed komisją egzaminacyjną $\mathrm{w}$ Waszyngtonie jej rola w procesie rekrutacji oficerów w wojskach kolorowych nie była decydująca ${ }^{51}$.

Efektem działań Biura dla Oddziałów Kolorowych było zebranie większości kolorowych regimentów w jednej organizacji - U.S. Colored Troops (USCT). Poza kilkoma jednostkami powstałymi w Connecticut, Luizjanie i Massachusetts wszystkie pozostałe oddziały Afroamerykanów weszły w skład sił rządowych i otrzymały swoją numerację w ramach USCT. Był to wyraźny sygnał, iż odtąd nie zaciągano już Murzynów do walki za poszczególne stany, ale za kraj, którego rząd obiecał im wolność ${ }^{52}$.

Niestety mimo tak szczytnych haseł oraz obietnic równego traktowania nowoutworzone wojska często padały ofiarą dyskryminacji i obelżywych ataków ze strony białych. Nierzadko otrzymywały także gorsze przydziały. Poza tym objęte były niewystarczającą i nieodpowiednią opieką medyczną ( 1 na 5 czarnych żołnierzy zmarł w wyniku chorób; w białych oddziałach wskaźnik ten wynosił 1 na 12; łącznie w trakcie wojny zmarło prawie 37 tys. żołnierzy afroamerykańskich, $\mathrm{z}$ czego niespełna 3 tys. $\mathrm{w}$ walce $)^{53}$, często nie przechodziły też odpowiedniego szkolenia (do pewnego stopnia wynikało to z przekonania części dowódców, że

49 General Orders, No. 144 (22 V 1863), [in:] General Orders Affecting the Volunteer Force; H.B. HARgROVE, op. cit., s. 104-105.

${ }^{50} \mathrm{~W}$ dwóch przebadanych przeze mnie dotychczas komisjach egzaminacyjnych (Cincinnati i St. Louis), wskaźnik zdawalności w całym okresie ich funkcjonowania wyniósł odpowiednio - $68 \%$ i 54\%. Pamiętać jednak należy, że zdanie egzaminu nie gwarantowało stopnia oficerskiego. Przyjmuje się, że jedynie ok. 25\% aplikantów otrzymało ostatecznie patenty. Vide: Proceedings of Examining Board, Cincinnati, Ohio, 1863-1864, RG 94, Records of Adjutant General's Office, 1780's-1917 (National Archives w Waszyngtonie); Proceedings of Examining Board, St. Louis, Mo., 1863-1865, t. I-II, RG 94, Records of Adjutant General's Office, 1780's-1917 (National Archives w Waszyngtonie); J.D. SMith, op. cit., s. 37-39; P. DerengowsKi, Kwalifikacje oficerów U.S. Colored Troops, s. 453, 457.

51 D.T. Cornish, op. cit., s. 217; H.B. HARgrove, op. cit., s. 109-113.

52 J.D. Smith, op. cit., s. 26-28; H.B. Hargrove, op. cit., s. 103-109; P. Derengowski, Polacy $w$ wojnie secesyjnej, s. 344.

53 H.B. HARGROVE, op. cit., s. 210-211. 
bardziej nadawali się do kopania rowów czy umocnień niż do żołnierki ${ }^{54}$ ) oraz posiadały gorsze uzbrojenie i praktycznie do końca wojny także niższy żołd. Dopiero czerwcu $1864 \mathrm{r}$. Kongres wprowadził równy żołd, ale z pewnym ważnym zastrzeżeniem. Żołnierze, którzy byli wolni przed wybuchem wojny mieli otrzymać wyrównanie za cały okres swojej służby, ci zaś którzy przed $1861 \mathrm{r}$. byli niewolnikami mieli otrzymać wyrównanie tylko od 1 stycznia 1864 r. Mimo powszechnego oburzenia byli niewolnicy musieli czekać na pozytywne rozwiązanie ich sprawy aż do 8 marca 1865 r.! Dopiero wówczas wprowadzono równy żołd dla wszystkich żołnierzy, bez względu na kolor skóry i ich przedwojenny status ${ }^{55}$.

Choć większość oddziałów kolorowych nie wzięła bezpośredniego udziału w walce, te które miały taką możliwość na ogół sprawdziły się w boju, co zapewne nie pozostało też bez wpływu na późniejszą decyzję umożliwiającą im po rozwiązaniu USCT (1866) na dalszą służbę ale już w armii regularnej. Ich postawa, zaangażowanie i poświęcenie choć zostały dostrzeżone, nie przełożyły się niestety, tak jak tego oczekiwali sami Afroamerykanie, na natychmiastową poprawę statusu ludności czarnoskórej w Stanach Zjednoczonych. Niemniej jednak jednostkowe działania poszczególnych żołnierzy zostały w pewien sposób nagrodzone, chociaż tu także zdarzały się przypadki przyznania wyróżnienia wiele lat po wojnie, a nawet pośmiertnie. Łącznie 25 afroamerykańskich uczestników wojny secesyjnej zostało odznaczonych Medalem Honoru ${ }^{56}$ (ostatni z nich - Andrew Jackson Smith dopiero w 2001 r.. ${ }^{17}$ ), większość (aż 13) za bitwę pod New Market Heights (29 IX 1864) ${ }^{58}$.

\section{Bibliografia}

\section{Źródła archiwalne}

National Archives w Waszyngtonie, Proceedings of Examining Board, Cincinnati, Ohio, 18631864, RG 94, Records of Adjutant General's Office, 1780's-1917.

National Archives w Waszyngtonie, Proceedings of Examining Board, St. Louis, Mo., 1863-1865, t. 1-2, RG 94, Records of Adjutant General's Office, 1780's-1917.

54 Wyjątek w tej kwestii wśród wyższych rangą oficerów federalnych stanowił Benjamin Butler, który odmawiał uznania czarnych żołnierzy za ,umundurowanych kopaczy rowów”. Pod koniec wojny do dowodzonej przez niego Armii James wszedł 25. Korpus, który był pierwszym i jedynym korpusem w armii amerykańskiej całkowicie złożonym z czarnych jednostek. Vide: P. DERENGOWSKI, Polacy w wojnie secesyjnej, s. 314-342.

55 J.D. SMITH, op. cit. s. 51-52.

56 Najwyższe odznaczenie wojskowe w USA, utworzone w czasie wojny secesyjnej. Łącznie 1523 uczestników tejże wojny zostało odznaczonych Medalem Honoru (w tym 33 pośmiertnie). Vide: Medal of Honor [https://en.wikipedia.org/wiki/Medal_of_Honor; dostęp 6 IV 2019]; List of Medal of Honor recipients [https://en.wikipedia.org/wiki/List_of_Medal_of_Honor_recipients; dostęp 6 IV 2019].

57 Nie był on ostatnim uczestnikiem wojny secesyjnej, który otrzymał to wyróżnienie. W 2014 r. prezydent Barack Obama pośmiertnie odznaczył Medalem Honoru por. Alonzo Cushinga. Vide: Ibidem.

58 H.B. HARGROVE, op. cit., s. 212-218. 


\section{Źródła drukowane}

Collected Works of Abraham Lincoln, red. Roy P. BASLER, t. IV-VI, New Brunswick: Rutgers University Press, 1953, [wyd. cyfrowe: Ann Arbor: University of Michigan Digital Library Production Services, 2001; https://quod.lib.umich.edu/l/lincoln/].

District of Columbia Emancipation Act (16 IV 1862), [https://www.archives.gov/exhibits/featureddocuments/dc-emancipation-act].

General Orders Affecting the Volunteer Force, Adjutant General's Office, 1863, Washington: Government Printing Office, 1864.

KRZYŻANOWSKI Włodzimierz, Wspomnienia $z$ Pobytu $w$ Ameryce Gen. Włodzimierza Krzyżanowskiego Podczas Wojny 1861-1864, Chicago: Polish Museum of America, 1963.

Levstik Frank, The Civil War Diary of Colonel Albert Rogall, „Polish American Studies”, t. 27, nr 1/2: 1970, s. 33-79.

Private and Official Correspondence of Gen. Benjamin F. Butler during the Period of the Civil War, t. 1: April 1860-June 1862, Norwood: The Plimpton Press, 1917.

Revised United States Army Regulations of 1861, Washington: Government Printing Office, 1863.

The Congressional Globe, Thirty-Seventh Congress, $1^{\text {st }}$ Session [https://memory.loc.gov/ ammem/amlaw/lwcglink.html].

The Congressional Globe, Thirty-Seventh Congress, $2^{\text {nd }}$ Session [https://memory.loc.gov/ ammem/amlaw/lwcglink.html].

The Statutes at Large, Treaties, and Proclamations of the United States of America, t. XII, Boston: Little, Brown and Company, 1863.

The War of the Rebellion: A Compilation of the Official Records of the Union and Confederate Armies, ser. 1, t. III, XIV-XV, XIX, XXIII, ser. 2, t. I, IV, Washington: Government Printing Office, 1885-1902.

\section{Opracowania}

Black Flag Over Dixie. Racial Atrocities and Reprisals in the Civil War, red. Gregory J.W. URWIN, Carbondale: Southern Illinois University Press, 2004.

Cornish, Dudley T., The Sable Arm. Negro Troops in the Union Army, 1861-1865, New York: W.W. Norton \& Company, 1966.

CuRTIS, Michael K., Lincoln, Vallandigham, and Anti-War Speech in the Civil War, „William \& Mary Bill of Rights Journal", t. 7, nr 1: 1998, s. 105-191.

DERENGOWSKI, Piotr, Granice dobrego smaku, czyli czego nie wypada pisać oficerowi w dzienniku - na przykładzie dziennika pptk. Alberta Rogalla, [in:] Wokól kresów, granic i pograniczy w historii wojskowej, red. Andrzej Olejko, Paweł Korzeniowski, Oświęcim: Napoleon V, 2015, s. 65-71.

DERENGOwsKi, P., Kwalifikacje oficerów U.S. Colored Troops (USCT) w czasie wojny secesyjnej w świetle sprawozdań komisji egzaminacyjnej z St. Louis (Missouri), 1863-1865, [in:] O powinnościach żotnierskich, t. 3: Na krętych drogach żotnierskich losów, red. Andrzej DRZEWIECKI, Oświęcim: Napoleon V, 2016, s. 445-460.

Derengowski, P., Polacy w wojnie secesyjnej 1861-1865, Oświęcim: Napoleon V, 2015

Dовак, William A., Freedom by the Sword. The U.S. Colored Troops, 1862-1867, Washington: Center of Military History United States Army, 2011.

Flower, Frank A., Edwin McMasters Stanton. The Autocrat of Rebellion, Emancipation, and Reconstruction, Akron-New York-Chicago: The Saalfield Publishing Company, 1905.

Foner Eric, Give me Liberty! An American History!, t. I: To 1877, New York-London: W.W. Norton \& Company, 2012. 
FONER, E., The Fiery Trial. Abraham Lincoln and American Slavery, New York-London: W.W. Norton \& Company, 2010.

Hargrove, Hondon B., Black Union Soldiers in the Civil War, Jefferson-London: McFarland \& Company, Inc. Publishers, 2003.

Lofton, Williston H., Northern Labor and the Negro During the Civil War, „The Journal of Negro History", t. 34, nr 3: 1949, s. 251-273.

Man jr., Albon P., Labor Competition and the New York Draft Riots of 1863, „The Journal of Negro History", t. 36, nr 4: 1951, s. 375-405.

McPherson, James M., Battle Cry of Freedom. The Civil War Era, New York-Oxford: Oxford University Press, 1988.

MCPherson, J. M., Marching Toward Freedom. Blacks in the Civil War 1861-1865, b.m.w.: Facts on File An Infobase Holdings Company, 1994.

MCPherson, J. M., What They Fought For, 1861-1865, New York-London-Toronto-SydneyAuckland: Anchor Books A Division of Random House, Inc., 1995.

Smith, John D., Let Us All Be grateful That We Have Colored Troops That Will Fight, [in:] Black Soldiers in Blue. African American Troops in the Civil War Era, red. idem, Chapel Hill-London: The University of North Carolina Press, 2002, s. 1-77.

Voices of Freedom. A Documentary History, red. E. FonER, t. 1, New York-London: W.W. Norton \& Company, 2011.

\title{
Netografia
}

Medal of Honor [https://en.wikipedia.org/wiki/Medal_of_Honor].

List of Medal of Honor recipients [https://en.wikipedia.org/wiki/List_of_Medal_of_ Honor_recipients].

\section{Political aspects of organization, training and usage of U.S. Colored Troops during the Civil War}

\begin{abstract}
Summary
In the general opinion the Civil War was a conflict to abolish slavery of African Americans in the USA. Nothing more erroneous. It is visible not only in a declared policy, but also, and maybe above all else, in the actions of federal government during the first stage of the war, i.e. before the enforcement of the Emancipation Proclamation. This period characterize itself with kind of dichotomy in Lincoln's actions. On one hand the government is doing everything to restrain all rank-infile initiatives, which were in any way related to slavery issue. On the other hand, when it was impossible to undo those actions, then they were followed by some legal steps. However, even after January $1^{\text {st }}, 1863$, despite all those noble watchwords and promises of equal treatment, the colored troops often were victims of discrimination (also by the federal government) and insults from whites.

Keywords: Civil War; African Americans; slavery; Emancipation Proclamation; U.S. Colored Troops; Abraham Lincoln; Benjamin F. Butler; Clement L. Vallandigham; United States of America.
\end{abstract}





\section{Maksym Tarejwo - kapłan zaangażowany w powstanie styczniowe}

\section{Streszczenie}

W pracy przedstawiono sylwetkę duchownego, zakonnika kapucyńskiego, uczestnika powstania styczniowego oraz środowisko zakonne i polityczne, w którym działał, zarówno w okresie przygotowującym go do działalności społecznej, jak i w okresie bezpośredniego udziału w walkach powstańczych, kiedy to pełnił funkcję kapelana oddziału. Pełnienie tej funkcji z pewnością umożliwiało zmniejszenie brutalności walk. Po okresie kapelańskim o. Maksym wykonywał prace kaznodziejskie, organizacyjne i zmierzające do zwiększenia udziału ludności w powstaniu. Przez dłuższy czas był poszukiwany przez wojsko rosyjskie, w końcu aresztowany w klasztorze kapucyńskim w Lądzie został powieszony w Koninie w lipcu 1864 r. Jego współbracia zakonni z Lądu także ponieśli karę i zostali zesłani na Syberię.

Slowa kluczowe: Powstanie styczniowe, Maksym Tarejwo, kapelan, działacz społeczny i polityczny.

Począwszy od insurekcji kościuszkowskiej, poprzez epokę napoleońską i powstanie listopadowe, każde pokolenie Polaków wchodzące w dorosłe życie dążyło do zmiany politycznego status quo i chciało wybijać się na niepodległość ${ }^{1}$. Do takiego pokolenia należał Józef Tarejwo lub Tarejwa urodzony 13 marca $1832 \mathrm{r}$. w Prenach, w powiecie mariampolskim, guberni augustowskiej. Był synem Antoniego Tarejwo i Elżbiety Markiewicz ${ }^{2}$. Pomimo, iż wywodzili się ze stanu szla-

1 Mikołaj W. BERG, Zapiski o powstaniu polskim 1863 i 1864 i poprzedzającej powstanie epoce demonstracji od 1856 roku, thum. Karol Radwan JASKŁOwsKI, Józef KRZEPELA, t. I, Kraków 1898, s. 1. Jest to powtórzona opinia hr. Fryderyka. Skarbka, który dodatkowo twierdził, że to nic nie uczy władze carskie. Conf. Bruliony listów, notatki, zapiski i regestr wydatków, BZNO, sygn. 5541-5543/I-II, 5545/I.

2 Wersję tę przyjęło wielu autorów piszących o o. Maksymie, jakkolwiek w herbarzach szlachty polskiej brak jest tego nazwiska. 
checkiego, rodzina utrzymywała się z pracy najemnej. Tak też przygotowała do życia następne pokolenie. Józef po ukończeniu trzeciej klasy szkoły w Suwałkach przez cztery lata pracował w handlu korzennym w Warszawie, a przez sześć kolejnych w urzędzie pocztowym. Zyskał więc w młodym wieku dość duże doświadczenie życiowe. Do zakonu kapucynów prowincji polskiej wstąpił 9 czerwca 1854 r. w Lubartowie. Po ukończeniu nowicjatu złożył zarówno śluby proste, jak i uroczyste ${ }^{3}$. Przyjął imię zakonne Maksym. W latach 1854-1855 r. uczył się gramatyki u uznanych autorytetów kościelnych oo. Fidelisa Paszkowskiego i Melitona Wernera. W $1856 \mathrm{r}$. udał się do Lublina na studium teologii. Święcenia kapłańskie otrzymał 1860 r. w Warszawie ${ }^{4}$, w okresie wzmożonej działalności patriotycznej polskiego społeczeństwa. Doświadczenia zdobyte podczas wcześniejszej dziesięcioletniej pracy zawodowej stały się pomocne o. Maksymowi, bowiem dzięki temu miał już skrystalizowane poglądy społeczne i polityczne, odpowiednie umiejętności organizacyjne, umiał ponadto nawiązywać szybko kontakty osobiste. Te cechy jego bogatej osobowości rozwinęły się jeszcze bardziej w czasie przedpowstaniowym, w którym był bardzo czynny, szczególnie od początku $1862 \mathrm{r}^{5}$

\section{Postawa społeczna i polityczna o. Maksyma przed wybuchem powstania styczniowego}

W latach przedpowstaniowych Kościół katolicki w Królestwie Polskim działał w niezwykle trudnym położeniu, ponieważ ograniczany był przez władze carskie w swojej działalności duszpasterskiej i w kontakcie ze Stolicą Apostolską. Wobec carskich szykan Kościół musiał uciekać się do działań nielegalnych z punktu widzenia prawodawstwa państwa rosyjskiego, prowadząc tajną korespondencję ze Stolicą Apostolską, stosując politykę pełną eufemizmów6. Taka polityka władz kościelnych sprzyjała również pojawianiu się oznak nieposłuszeństwa wśród duchowieństwa niższego względem władz rządowych, a poczucie doznawanej krzywdy występowało dość powszechnie wśród tej grupy duchownych. Dołączyło więc ono w dużej części do działań protestacyjnych społeczeństwa szczególnie w okresie manifestacji w latach 1860-1861 i w nieco mniejszym zakresie w 1862 r., kiedy tworzył się ruch podziemny.

3 Centralna Biblioteka Prowincji Warszawskiej w Zakroczymiu „Honoratianum” [dalej: CBPW], Kronika Prowincji Warszawskiej Kapucynów, Clarici et Laies Novitie Anno 1854, rok 1854, s. 225.

4 Jan Ludwik Gadacz, Stownik Polskich Kapucynów, t. II, Wrocław 1986, s. 357-363.

5 Eugeniusz NiEBELSKI, Wobec roku 1863. Księża w powstaniu styczniowym i ich losy, Lublin 2015, s. 103.

6 Adrien Boudou, Stolica Święta a Rosja. Stosunki dyplomatyczne między nimi w XIX wieku, thum. Zofia SKowrońsKA, t. I, Kraków 1928, s. 136; Paweł KUBICKI, Bojownicy kapłani za sprawę Kościoła i Ojczyzny w latach 1861-1915, cz. 3, t. I, Sandomierz 1939, passim. 
W tym okresie także kapucyni warszawscy prowadzili intensywną działalność, przede wszystkim o charakterze religijno-patriotycznym. Władze zgromadzenia próbowały odciągnąc zakonników od spraw politycznych, ograniczając dostęp do nich, przenosząc ich na inne piętra lub do innych klasztorów, aby w ten sposób przeciąć kontakty z osobami cywilnymi ${ }^{7}$. Wśród nich byli tacy, którzy kierowali się ku walce zbrojnej, chociaż kilku wybitnych przedstawicieli zgromadzenia kapucynów odmawiało jej wsparcia. Wśród zmierzających do walki zbrojnej w pierwszym rzędzie wymienić trzeba brata Szymona Grunwala (vel Grunwalda, Gründa lub Grzenwalca), kapucyna w Zakroczymiu, który ze względu na bliską odległość często przebywał w Warszawie. Poszukiwany był przez policję od 8 listopada 1860 r., głównie w Warszawie. Później poszukiwany był w całym Królestwie Polskim, ale bez rezultatu. Podobnie, jak ks. Aleksander Kwaśniewski, który w 1860 r. zbiegł z Nowego Miasta nad Pilicą, a władze wysłały za nim listy gończe ${ }^{8}$. Inny aktywny kapucyn ks. Eufrozy Lewczuk vel Eugeniusz Lenczuk ${ }^{9}$ był w latach 1861-1862 kaznodzieją, znanym i cenionym w Królestwie. Wyróżniał się również kapucyn ks. Tertulian Perkowski, który inspirował śpiewy „podburzające” i „rewolucyjne” w kościele kapucyńskim w Warszawie przy ul. Miodowej. Aresztowano go dopiero 11 maja 1862 r. wraz $\mathrm{z}$ bardzo aktywnym politycznie i religijnie ks. Oktawianem Bielawskim, ale po 16 dniach został on zwolniony z poleceniem wysłania go do jednego z klasztorów na prowincję ${ }^{10}$. Kara była niewielka - można przypuszczać, że był to sukces abp Zygmunta Szczęsnego Felińskiego, gdyż on z zasady wstawiał się za każdym aresztowanym kapłanem, a w tym czasie władze Królestwa Polskiego liczyły się $\mathrm{z}$ jego zdaniem. Podobne niebezpieczeństwo ściągnął na siebie kapucyn ks. Krescencjusz Gaszyc vel Krescenty Haszyc, który działał w kilku diecezjach. Według notatek policyjnych, przebywając u oo. kapucynów w Warszawie, ubliżył policji podczas jej pojawienia się w klasztorze ${ }^{11}$. Dnia 21 października 1861 r., po południu, podczas „Mszy za ojczyznę” wygłosił „podburzające” kazanie w Lądzie w guberni kaliskiej, a następnie ukrył się ${ }^{12}$. Ponieważ zasadą działania

7 CBPW, Kronika Prowincji Warszawskiej Kapucynów, wpis z 12 czerwca 1863 roku [dalej: KPWK - wpis 12 VI 1863], s. 258, 259.

8 Ewa JABŁoŃSKA-DEPTUŁA, Janina GAWRYSIAKOWA, Materiały do zaangażowania patriotycznego zakonów męskich $w$ Królestwie Polskim $w$ latach 1861-1864, [in:] Materiaty do historii zgromadzeń zakonnych na ziemiach polskich $w$ XIX i na poczatku XX wieku, oprac. Hanna DYLĄGOWA, Ewa JABŁoŃSKA-DePtUŁA i in., Lublin 1976, s. 135, 138.

9 P. Kubicki, Bojownicy kaptani, cz. 1, t. I, Sandomierz 1933, s. 691. Wielce był oddany działalności kaznodziejskiej i organizacyjnej. Niestety jego rola począwszy od $1867 \mathrm{r}$. była negatywna. Vide: E. JABŁoŃSKA-DEPTUŁA, J. GAWRYSIAKOWA, op. cit., s. 140-144.

10 E. JABŁońSKa-DeptuŁa, J. GAWRYSIAKOWA, op. cit., s. 144.

11 August R. KRĘCKI, Zbiór materiałów do historii powstania styczniowego 1863-1864-go roku, Warszawa 1916. Taka notatka istnieje w podpisie pod zdjęciem Krescentego Haszyca vel Krescencjusza Gaszyca.

12 Rano homilię wygłosił o. Oktawian Bielawski. Uroczystości skupiły kilkanaście tysięcy uczestników. Vide: Piotr GoŁdyn, Klasztor lądzki w okresie powstania styczniowego 1863-1864, „Poznańskie Zeszyty Humanistyczne”, t. 9: 2005, s. 34. 
policji carskiej była drobiazgowość, która miała pokazywać jej zaangażowanie, szukano go więc przez kilka lat.

Nieco wcześniej swoją tragiczną epopeję powstańczą rozpoczął o. Piotr Paweł (Agrypin) Konarski. W 1855 r. był w Warszawie, a w 1856 r. prowincjał kapucynów o. Beniamin Szymański, kazał go osadzić w domu księży demerytów (dom poprawczy dla kleru) na Łysej Górze na lat dziesięć. Jednak trzy lata później wyjechał do Rzymu, a potem udał się na misje do Konstantynopola i Bułgarii. W drodze powrotnej dwukrotnie został przyjęty przez Piusa IX (14 IX i 10 XI 1860) i uzyskał błogosławieństwo papieskie (dyplom) z odpustem zupełnym na godzinę śmierci dla siebie, rodziny i przyjació $1^{13}$.

Poważną rolę polityczną w Warszawie pełnili również ci kapucyni, którzy w prawdzie nie włączali się w działalność polityczną, ale poprzez swoją posługę kapłańską oraz wysokie walory moralne i intelektualne, byli uciążliwi dla władz carskich. Władze nie mogły zabraniać im działalności duszpasterskiej, ale przy wszelkich próbach wyróżniania tych osób mocno protestowały. Do tej grupy należeli: ks. Honorat Koźmiński, wybitny organizator ukrytego życia zakonnego, w tym czasie gwardian warszawski, organizator życia religijnego, służący posługą duszpasterską wśród więźniów politycznych. Do grupy tej należał także ks. Ksawery Kralczyński, płomienny mówca i wielki patriota, jakkolwiek przeciwnik walki zbrojnej był lubiany przez mieszkańców Warszawy. Według opinii władz niebezpieczny dla porządku publicznego był również ks. Prokop Leszczyński, uczestnik powstania listopadowego, jeden z kandydatów do funkcji arcybiskupa warszawskiego po śmierci abp Antoniego Melchiora Fijałkowskiego, człowiek zasłużony dla nauki Kościoła katolickiego. W końcu 1861 r. otrzymał on od władz polecenie opuszczenia klasztoru oo. kapucynów w Warszawie, a powodem było sprzyjanie manifestacjom. Aktywny w tym czasie w Warszawie, szczególnie podczas nabożeństw religijno-patriotycznych, był również ks. Grzybowski ${ }^{14}$. Zaangażowanymi społecznie i politycznie spośród współbraci w tym okresie byli także: brat Cyprian Michałowski, ks. Edward (Wacław) Nowakowski, brat Leon Przyłuski, ks. Józef Maria Rosset, brat-laik Roger Zawistowski. Widać z tego, że nieposłuszeństwo w odniesieniu do władz rządowych okazywało wielu kapłanów, zarówno w Warszawie, jak i na prowincji. Działo się tak pomimo pisma wydanego przez abp Fijałkowskiego 26 kwietnia 1861 r., a odnoszącego się do potrzeby bardzo ostrożnego traktowania przez duchownych w kazaniach kwestii politycznych, szczególnie po wypadkach warszawskich z 27 lutego i 8 kwietnia 1861 r. $^{15}$

13 Aktywny politycznie podczas powstania, schwytany, w czerwcu $1863 \mathrm{r}$. został powieszony na stokach cytadeli warszawskiej. Vide: Stefan KiEnIEwicz, Powstanie styczniowe, Warszawa 2009, s. 737.

14 P. Kubicki, op. cit., cz. 1, s. 682-705.

15 Archiwum Archidiecezji Warszawskiej, Pismo z konsystorza generalnego nr 917 w księdze parafialnej parafii Służew, sygn. DP/H. 3. 
Z tego przeglądu działalności współbraci wynika, że po uzyskaniu święceń kapłańskich o. Maksym Tarejwo żył w podniosłej atmosferze Warszawy, w środowisku zakonnym stanowiącym czynną i zaangażowaną w manifestacje i demonstracje grupę duchownych lub co najmniej sympatyzującą z nimi. O. Maksym szybko dołączył do tej grupy i okazał się człowiekiem bardzo pracowitym, sumiennym i wymagającym, a także osobą o pełnej postawie patriotycznej. Świadczą o tym liczne obowiązki, jakich podejmował się, ale także i sposób ich wykonywania. W latach 1861-1862 pełnił funkcję spowiednika i kapelana więziennego ${ }^{16}$. Mimo, że była to funkcja płatna, to gorliwość o. Maksyma wychodziła zdecydowanie ponad obowiązki kapelana ${ }^{17}$. O. Maksym znany był także z umiejętności kaznodziejskich i opieki nad uwięzionymi w Cytadeli, jak i w twierdzy modlińskiej. Dzięki temu imię jego stało się znane w Warszawie ${ }^{18}$. Za jego staraniem u władz kilku więźniów zwolniono, a innym złagodzono kary. Był też w wielu przypadkach łącznikiem uwięzionych z ich rodzinami, a rodziny widząc jego skuteczność w odniesieniu do losu uwięzionych chętnie uciekały się do jego umiejętności, prosząc o pomoc. Co ciekawe, interweniował nawet w interesie uwięzionych u namiestnika lub u innych władz rosyjskich ${ }^{19}$.W tym samym okresie brał udział w manifestacjach przedpowstaniowych. Wspierał organizację Czerwonych, ale nie stronił od Białych, wśród których miał szereg przyjaciół, szczególnie w późniejszym okresie ${ }^{20}$. Wspomagał rozszerzanie organizacji narodowych związanych z powstaniem styczniowym i ich idee. Przede wszystkim leżało mu na sercu uwłaszczenie włościan. W tym czasie wykryto również, że jednemu z więźniów dostarczył gazety zagraniczne w celu przygotowania obrony przed zarzutami komisji śledczej ${ }^{21}$.

To zaangażowanie spowodowało, że 12 lipca 1862 r. władze rządowe wymogły u władz kościelnych decyzję o przeniesieniu o. Maksyma w inne miejsce. Dnia 23 lipca 1862 r. został skierowany do Lądu. Władze rządowe miały nadzieję, że przeniosły kapłana na peryferie Królestwa Polskiego, gdzie jego działania będą wyciszone, stało się jednak zupełnie odwrotnie, o. Maksym trafił bo-

16 Spowiednikiem i kapelanem więziennym był również o. Józef Maria Rosset, a później ks. Ksawery Kralczyński.

17 Funkcja kapelana więziennego była w tym czasie niezwykle wymagająca, również z punktu widzenia fizycznego. Kapelan musiał zjawić się w więzieniu kilka godzin przed zmrokiem i po zmroku przygotować skazańca do spowiedzi, a po spowiedzi czuwał przy nim przez całą noc nie śpiąc. Rano udawał się po komunię, aby po jej udzieleniu być ze skazańcem przez cały dzień i całą noc, również nie śpiąc. Natomiast rano był obecny przy wykonaniu wyroku. Vide: CBPW, $K P W K$ - wpis 12 VI 1863, s. 258.

18 Ibidem, s. 258, 259.

19 Ibidem, s. 258, 259, 260.

20 Roland PREJs, Kapucyni prowincji polskiej po kasacie 1864 r. Losy - postawy, „Studia Franciszkańskie”, t. 8: 1997, s. 283-345; idem, Kapucyni prowincji polskiej w powstaniu styczniowym. Stan badań i kwestie dyskusyjne, „Teka Komisji Historycznej PAN, Oddział w Lublinie”, t. 10: 2013, s. 80-81.

21 Vide: P. KubICKI, op. cit., cz. 3, s. 489. 
wiem do środowiska patriotycznego. W klasztorze w Lądzie istniały już tradycje sprzyjające powstaniu, inicjowane i kultywowane tam począwszy od $1861 \mathrm{r}$. Jednocześnie żywy był tam kult Niepokalanego Poczęcia Matki Boskiej, mimo, stosunkowo niedawnego wprowadzenia tego dogmatu (od 8 XII 1854), kult bardzo niewygodny dla władz carskich ${ }^{22}$. Wzmiankowany wcześniej pobyt w Lądzie o. Krescencjusza Gaszyca vel Krescentego Haszyca, wraz z o. Oktawianem Bielawskim, którzy w obecności tłumów 21 października $1861 \mathrm{r}$., podczas dwóch „Mszy za ojczyznę” wygłosili „,podburzające” kazania, przyczynił się z pewnością do wzmocnienia postaw patriotycznych uczestników tych nabożeństw. Klasztor grupował w tym okresie wielu aktywnych politycznie współbraci. Od 1862 r. w klasztorze i kościele posługiwali: o. Ołtarzewski Józef Benedykt, imię zakonne - Emilian, o. Nienałtowski Wiktor, zakonne imię - Eugeniusz vel Eugeni, o. Słotwiński Aleksander, w zakonie nosił imię Cyriak, o. Lassota vel Lasota Ignacy Walenty, imię zakonne - Bazyli, o. Tarejwo Józef, w zakonie Maksym, o. Doliński Leon ${ }^{23}$, o. Wawrzyniec Liberkowski ${ }^{24}$, br. Ostrowski Wojciech, imię zakonne Andrzej. br. Fijałkowski Wit, w zakonie Aleksy, br. Chodkiewicz Karol, br. Ołtarek Wacław vel Otłamek ${ }^{25}$. Należy także dodać brata-laika Konrada Perzyńskiego, ale trzeba ująć, wspominanego w wielu publikacjach, o. Stanisława Dąbrowskiego. Tak więc konwent liczył 12 osób ${ }^{26}$.

Na nowym terenie o. Maksym nie zaprzestał działalności patriotycznej, a nawet zintensyfikował ją i pozyskał dla idei powstańczej późniejszego dowódcę jednego z oddziałów powstańczych na Żmudzi - ks. Antoniego Mackiewicza, którego poznał latem 1862 r. w klasztorze na Jasnej Górze, gdzie przybył w ramach pielgrzymki ${ }^{27}$. W Lądzie rozpoczął również działania wspierające powsta-

22 Janusz NowińsKi, Ottarz Matki Bożej Częstochowskiej i powstańcza mogiła - dwie pamiątki patriotyczne $w$ dawnym opactwie w Ladzie nad Warta, ,Seminare. Poszukiwania naukowe”, nr 26/2009, s. 332. Wieś Ląd liczyła w tym okresie jedynie 250, a folwark 55 mieszkańców. Vide: Lą, [in:] SGKP, t. V, Warszawa 1884, s. 107-108. Klasztor przejęli kapucyni reskryptem namiestnika Iwana Paskiewicza z 8/20 IV 1850 r. Vide: J.L. GADACZ, op. cit., t. I, Wrocław 1985, s. 175. Conf. P. Kubicki, op. cit., cz. 1, s. 701; E. JABŁońSKA-DePTUŁA, J. GAWrysiaKowa, op. cit., s. 130, 133, 138, 141, 142, 144, 146, 147-148.

23 Dnia 4 IV 1864 r. wydalony przez władze carskie do Krakowa. Vide: P. KuBICKI, op. cit., cz. 1, s. 682-705.

${ }^{24}$ Zmarły 9 IV 1864 r. Vide: Ibidem, s. 682-705.

25 Conf. P. GoŁdyn, op. cit., s. 33-35.

${ }^{26}$ P. Kubicki, op. cit., s. 701 (błędnie zapisano, że br. Konrad Perzyński był księdzem; podobnie jak br. Wojciech Ostrowski). Wspominany w wielu publikacjach o. Stanisław Dąbrowski 25 XI 1863 r. został skazany na osiedlenie w Rosji i wyruszył tam z Nowego Miasta nad Pilicą. Conf. E. JabŁońsKa-DeptuŁa, J. Gawrysiakowa, op. cit., s. 130, 133, 138, 141, 142, 144, 146, 147-148.

27 Obaj kapłani posiadali podobne cechy charakterologiczne - pochodzenie, duża aktywność, skromność, chęć niesienia oświaty pośród ludu, udział w walkach. W odniesieniu do ks. A. Mackiewicza jego monografię zawiera „Ojczyzna” nr 38-40 z 16, 17 i 18 VI 1864 r. Vide: J.L. GADACZ, op. cit., t. II, s. 357. 
nie, organizowanie ruchu podziemnego, szczególnie logistyczne, wobec bliskiej odległości do granicy z Wielkim Księstwem Poznańskim, gdzie idee powstańcze były bardzo żywe. Przygotował również klasztor lądzki do działań na rzecz przyszłego powstania. Klasztor stał się wówczas miejscem służącym do przerzutu broni z zaboru pruskiego, skrzynką kontaktową emisariuszy i miejscem spotkań kurierów. Ląd i okolice były także miejscem organizacji lub postoju oddziałów powstańczych ${ }^{28}$. W związku z tym w pobliżu dochodziło do potyczek z wojskami rosyjskimi, głównie oddziału płk. Edmunda Taczanowskiego, co niezwykle denerwowało niektórych, bardziej wrażliwych braci zakonnych. Już wcześniej o. Adrian Wrzosek powodowany strachem wyjechał do Warszawy, spodziewając się tam opieki współbraci ${ }^{29}$. Widocznienie sądził, że dom zakonny w Warszawie nie jest tak czynny w działaniach sprzyjających przygotowaniom do powstania.

\section{Udział o. Maksyma w walkach i w pracach na rzecz powstania w latach 1863-1864}

W Lądzie o. Maksym zyskał również szacunek wiernych za głoszenie patriotycznych kazań. Było ich wiele, a niektóre były nawet kolportowane w okolicach Lądu. Szczególnie zapamiętano kazania nawołujące do uwłaszczenia włościan, w tym wygłoszone w lasach Dziewicze Góry koło Grodźca Wlkp. na wiosnę 1863 r. oraz wygłoszone w czerwcu 1863 r., a więc w okresie intensywnych walk, Jak winnica Chrystusowa przez heretyckich schizmatyków od czasów rozbiorowych jest $w$ Polsce niszczona ${ }^{30}$.W tym okresie o. Maksym Tarejwo dość szybko włączył się w działania oddziałów powstańczych, a na początku jako kapelan. Brał udział w wielu zmaganiach, najdłużej w partii płk. Antoniego Rajmunda Garczyńskiego i mjr. Kazimierza Mielęckiego, a od 14 kwietnia do 8 maja 1863 r. był kapelanem w oddziale płk. Edmunda Taczanowskiego, naczelnika wojskowego województwa kaliskiego. Nosił w tym czasie pseudonimy: „ks. Maks”, „Dąb” i „Piorunek” lub „Piorun”31. W czasie bitwy pod Ignacewem (8 V 1863), gdzie zginęło 200 Polaków, a oddział płk. Taczanowskiego rozbity, o. Maksym został ranny odłamkiem granatu $\mathrm{w}$ głowę. Zatroskany płk Taczanowski ${ }^{32}$ wspo-

28 St. T. JAR KOWSKi, Józef Ignacy Kraszewski o „, Ojczyźnie”, „Przegląd Narodowy Warszawski”, nr 77: 1911, s. 214-235; Michał JARNECKI, Powstanie styczniowe w oczach Agatona Gillera, „Mazowieckie Studia Humanistyczne”, t. 10/1-2: 2004, s. 5-32.

29 Kronika klasztoru ladzkiego, Zapis z 25 II 1863 r. Conf. „Ojczyzna” nr 7 z 10 V 1864 r., s. 2; J.L. GADACZ, op. cit., t. II, s. 357-363; P. GoŁDYN, op. cit., s. 35.

30 P. GoŁDYN, op. cit., s. 39; J.L. GADACZ, op. cit., t. II, s. 357.

31 S. KienIEwICZ, op. cit., s. 485-487; E. NiEBELSKI, op. cit., s. 104.

32 Wkrótce generał wojsk powstańczych, gdyż w czerwcu 1863 r. został awansowany przez Rząd Narodowy. Vide: S. KIENIEwICZ, op. cit., s. 563; Janusz STASZEWSKI, Generat Edmund Taczanowski, Poznań 1936, s. 102, 103, 178; Kazimierz TACZANOwSKI, Generał Edmund Taczanowski (1822-1879), „Poznańskie Zeszyty Humanistyczne”, t. 14: 2010, s. 32. 
minał kapelana w liście do żony z 14 maja, używając jego pseudonimu „ks. Maks" ${ }^{\prime 3}$. Po bitwie o. Maksym schronił się w Śremie ${ }^{34}$, na terenie zaboru pruskiego. Obawiał się śmierci, ale okazało się, że dość szybko wygoił rany i już późnym latem powrócił do Lądu, tuż po bitwie stoczonej 12 lipca w pobliżu klasztoru przez gen. Taczanowskiego ${ }^{35}$.

Również latem tego roku gen. Taczanowski pragnął rozpocząć szkolenie chłopów do walki z oddziałami rosyjskimi, gdyż formacje kosynierów z nich złożone często go zawodziły. Planował stworzyć struktury wojskowe na wzór bractw religijnych, nad którymi władze sprawować mieliby ziemianie lub księża. Na okres szkolenia zmienił taktykę walki i postawił na kawalerię, a włościan pragnął włączyć do innych mniejszych oddziałów. $Z$ tego względu skierował o. Maksyma do mjr. Józefa Oxińskiego dowódcy oddziału walczącego na ziemi łęczyckiej i konińskiej - zajmował się przerzutem broni i przygotowaniem organizacyjnym włościan do powstania ${ }^{36}$. Widząc skuteczność i sukcesy o. Maksyma, Oxiński, pełniący wówczas jednocześnie funkcję naczelnika powiatu kaliskiego i konińskiego, mianował go naczelnikiem organizacji ludowej w powiecie konińskim $^{37}$. Organizacja przerzuciła w ciągu czterech tygodni osiemset karabinów belgijskich do oddziałów powstańczych - była to broń nowoczesna i wysokiej jakości ${ }^{38}$. Zadania, jakie o. Maksym Tarejwo miał do wypełniania, jako naczelnik organizacji ludowej, to przede wszystkim czuwanie nad współpracą ludności wiejskiej z powstańcami oraz karanie wszelkiego rodzaju nadużyć39.

Władze rosyjskie wiele wiedziały o dokonaniach o. Maksyma i szukały go intensywnie prawie od czasu wybuchu powstania. Był jednym z najbardziej poszukiwanych w tym czasie przez władze carskie powstańców na terenie Królestwa Polskiego. Widząc zagrożenie i zaciskającą się pętlę wywiadu ukrywał się w klasztorze w Lądzie prawie rok, jednocześnie intensywnie działając w najbliż-

33 J.L. GaDACZ, op. cit., t. II, s. 357-363; P. GoŁDYN, op. cit., s. 40. Obawy Taczanowskiego o tyle były słuszne, że pobyt w Wielkim Księstwie Poznańskim był niebezpieczny ze względu na politykę Prus i zaangażowanie wielu osób w niszczenie polskiego życia politycznego i spiskowego. Dla wyróżniających się Niemców przewidywano nagrodę w postaci Orderu Orła Czerwonego - drugiego w kolejności, co ważności odznaczeń pruskich. Vide: „Ojczyzna”, nr 7 z 10 V 1864 r., s. 3.

34 E. JabŁońSKa-DeptuŁa, J. Gawrysiakowa, op. cit., s. 148; E. Niebelski, op. cit., s. 105.

35 J. STASZEwSKI, op. cit., s. 103; Antoni CZUBIŃSKI, Powstanie styczniowe w woj. kaliskim, „Studia Materiały do Dziejów Wielkopolski i Pomorza", t. 8/2: 1963, s. 67-70.

36 Praca z włościanami należała do najtrudniejszych. Vide: „Ojczyzna”, nr 43 z 22 VI 1864 r.

37 Józefa Oxińskiego wspomnienia z powstania polskiego 1863/64 roku, Rocznik. Oddz. Łódzkiego. PTH, t. III, 1939, s. 353-357; E. NIEBELSKI, op. cit., s. 114.

38 O. Maksym zyskał duże uznanie wśród włościan, jednak trudno jest stwierdzić jak było ono szerokie. Vide: R. PREJs, Kapucyni prowincji polskiej po kasacie, s. 82; Michał DzIUBA, Kapucyni w Ladzie nad Warta (1850-1864), [in:] Zakony franciszkańskie w Polsce, t. 4: Polska Prowincja Kapucynów, cz. 1: Polska Prowincja Kapucynów w XIX w, Lublin 1987, s. 259; J.L. GADACZ, op. cit., t. II, s. 357-363.

39 Józefa Oxińskiego wspomnienia, s. 154-157. 
szej okolicy ${ }^{40}$. Tylko w okresie od 9 marca do 5 kwietnia 1864 r. przeprowadzono w klasztorze aż 24 rewizje, ale bezskutecznie, nasyłano również szpiegów, których udawało się neutralizować. W nocy z 15 (27) na 16 (28) czerwca 1864 r. oddział rosyjski, liczący przeszło 30 żołnierzy, otoczył klasztor. Znaleziono o. Maksyma w kryjówce, posiadającej precyzyjnie wykonane wejście od strony zakrystii. Aresztował go Wiskoski, rosyjski naczelnik wojenny ze Słupcy, o godz. 5 rano $^{41}$. Zakutego w kajdany, przy biciu w bębny, oprowadzano po mieście, a następnie wrzucono na wóz do wożenia kamieni i przewieziono do więzienia w Koninie ${ }^{42}$.

\section{Proces o. Maksyma i represje}

Kryjówkę o. Maksyma zdradził prawdopodobnie zakrystian Wawrzyniec Śmigielski - służący klasztorny, nie stroniący od alkoholu, przekupiony przez rosyjskiego szpiega Pinkusa ${ }^{43}$, który z kolei w nagrodę otrzymał od władz 1000 rubli srebrnych. Jak na ironię, wcześniej sam o. Maksym, w korespondencji do czasopisma „Ojczyzna” informował o przybyciu w maju 1864 r. do Konina Pinkusa vel Pinkoskiego, którego spotkał wcześniej i znał osobiście ${ }^{44}$. Szpieg ten zamierzał nawet wstąpić w szeregi powstańców, lecz go stamtąd usuwano. Po tych niepowodzeniach obrał inną taktykę i przyjechał z Warszawy ze swoim mocodawcą płk. Felkersamem oraz całą grupą szpiegów rosyjskich, która miała za zadanie śledzić oddziały powstańcze w okolicach Konina ${ }^{45}$.

W czasie śledztwa przeprowadzonego w Koninie o. Maksym zachował się z godnością ${ }^{46}$. Tymczasowa Komisja Wojenno-Śledcza skazała go na karę śmierci przez powieszenie. Wyrok umotywowano burzliwym i fanatycznym charakterem o. Maksyma, który jako jeden z pierwszych zalecał bunt przeciwko rządowi, korzystając przy tym z kazalnicy, wydawał rozkazy do wieszania sprzeci-

40 CBPW, KPWK - wpis 12 VI 1863, s. 258, 259.

41 Prawdopodobnie z pochodzenia był Polakiem. Vide: „Ojczyzna”, nr 57 z 8 VII 1864 r., s. 2; J.L. GADACZ, op. cit., t. II, s. 357-363.

42 Józef Stanisław PIETRZAK, Księża powstańcy 1863 roku, Kraków 1916; R. PrejS, Kapucyni prowincji polskiej w powstaniu, s. 78; J.L. GADACZ, op. cit., t. II, passim; P. GoŁDYN, op. cit., s. 39.

43 R. PREJS, Kapucyni prowincji polskiej w powstaniu, s. 80.

44 Korespondencja z Konińskiego - „Ojczyzna”, nr 28 z 4 VI 1864 r., s. 2-7. Szpieg ten rozpoczął działanie w czerwcu 1863 r. i zachowywał się niezwykle bezczelnie, nawet względem urzędników carskich, za co władze osadziły go na Pawiaku i wlepiły mu 50 kijów, co wykorzystywał podczas prób włączania się do oddziałów powstańczych. Był również świadkiem w głośnym procesie berlińskim prowadzonym przez władze pruskie względem Polaków z zaboru pruskiego. Vide: „Ojczyzna”, nr 85 z 19 IX 1864 r. s. 2.

45 Płk Felkersam był dwukrotnie degradowany do prostego żołnierza i dwukrotnie awansowany. Vide: „Ojczyzna”, nr 28 z 4 VI 1864 r., s. 2.

46 P. KuBICKI, op. cit., cz. 3, s. 45. 
wiających się jego postanowieniom, jak to podobno miało miejsce przed starciem pod Ignacewem względem niemieckich kolonistów. Przytaczając dosłownie fragment aktu oskarżenia: ,Jechał konno na czele bandy Taczanowskiego, z krzyżem w ręku, który świętokradzko zamieniał na godło powstania". Dla procarskiej prasy tak sformułowany akt oskarżenia stał się podstawą do postawienia o. Maksowi zarzutu, że należał do masonerii, gdyż nosił ponadto przy sobie godła tej organizacji ${ }^{47}$. Odpierało ten zarzut oświadczenie o. Leona Dolińskiego, który w tym czasie będąc już w Krakowie informował, że o. Maksym dostał dewizkę i zegarek w czasie bitwy pod Kołem od hr. Działyńskiego z Wielkiego Księstwa Poznańskiego i nosił je na pamiątkę ich spotkania ${ }^{48}$. Natomiast oskarżenie o mordowanie kolonistów niemieckich wynikało z tego, że brał udział w powstańczych sądach polowych. Sprawa zachowania kolonistów niemieckich w tym okresie miała szerszy kontekst, bowiem najczęściej poszczególne osoby narodowości niemieckiej, odosobnione w stosunku do swoich pobratymców, zachowywały się przyzwoicie ${ }^{49}$. Jednak koloniści niemieccy, żyjąc w morzu ludności polskiej, zamiast dla własnego bezpieczeństwa zachować neutralność, współpracowali czynnie z wojskami rosyjskimi przeciw powstańcom i dlatego zgodnie z przyjętymi wówczas zasadami walki ponosili niekiedy karę. Trzeba dodać, że koloniści byli w szczególny sposób faworyzowani przez władze carskie ${ }^{50}$.

Egzekucja odbyła się na błoniach konińskich nad Wartą 19 lipca 1864 r. o godzinie dziesiątej ${ }^{51}$. Podczas egzekucji o. Maksym trzymał w rękach różaniec. Przeszkodzono mu w próbie przemowy i próbowano zerwać z niego habit, jednak zaprzestano tego pod wpływem zachowania tłumu. Na śmierć przygotowywał skazanego o. Adrian Łopatkiewicz, reformat z Konina. Orkiestra grała Boże caria

47 Władze carskie z premedytacją poszukiwały wszelkich przejawów działania rewolucyjnego i masońskiego powstańców, aby zdyskredytować Polaków w oczach władców europejskich i Stolicy Apostolskiej.

48 Continuator Historia Conventus Cracoviensis Patrum Capucinorum in Anno 1836 [-1894], s. 182; J.L. GADACZ, op. cit., t. II, s. 357-363.

49 Andrzej Wocial, Powstanie styczniowe $1863 \mathrm{r}$. w powiecie stanistawowskim, „Rocznik Mińsko Mazowiecki”, z. 5: 2010, passim; R. MAZEK, Powstanie styczniowe na terenie gminy Parysów, „Zeszyty Historyczne Ziemi Garwolińskiej”, z. 19: 2013, s. 11; Piotr WoJdyGA, Grzegorz Wojdyga i jego oddziat powstańczy z lat 1863-1864, „Rocznik Mińsko Mazowiecki”, z. 18: 2010, s. 34 .

50 Przykładem może być sprawa posiadania broni. Broń odbierano Polakom już w 1861 r., nawet jeśli posiadali zezwolenie. Broń mogły jednak zatrzymać osoby wspierające władze carskie w walce z powstańcami, w tym koloniści niemeccy. Vide: Mateusz GAJZLER, Pabianice w okresie powstania w roku 1863, „Gazeta Pabianicka”, nr 21, 22, 23, 26, 27 z 1927 r.; Ludwik WASZKIEWICZ, Początek powstania 1863 roku w Lodzi i okolicy. Organizacja narodowa miasta Lodzi - wymarsz pierwszej partii powstańców, „Dziennik Łódzki”, 1963, passim.

51 P. Kubicki, op. cit., cz. 1, s. 705. W „Ojczyźnie”, w korespondencji z konińskiego z 22 Lipca, podano błędnie, że odbyło się to 18 lipca o godzinie dziewiątej. Oprawcę egzekucji Rosjanie aresztowali wcześniej na 24 godziny, aby nie uciekł. Vide: „Ojczyzna”, nr 74 z 28 VII 1864 r., s. $1-2$. 
chrani. O. Maksym oddał hołd brewiarzowi, wrzucił go do grobu i zawołał: „Niech żyje Polska!” oraz „In te Domine speravi, non confundar in aeternum”. Po wykonaniu wyroku, podobno na wpół żywy (widziano w nim jeszcze ślady życia) spadł do grobu. Po zasypaniu, miejsce egzekucji stratowano kopytami końskimi, z udziałem kolonistów niemieckich. Przy mogile przez cały tydzień stała warta wojskowa, aby ludność nie dokonała powtórnego pochówku. Sam klasztor praktycznie zawłaszczyło wojsko carskie ${ }^{52}$. Podczas egzekucji, na polecenie miejscowego proboszcza Boguckiego i wikariusza Eugeniusz Nowakowskiego i jak dość powszechnie sądzono, za przyzwoleniem gwardiana reformatów, rozdzwoniły się dzwony klasztorne w Koninie. Obydwaj duchowni zostali aresztowani, ale okazało się, że konsekwencje poniósł kto inny ${ }^{53}$. Następnego dnia odprawiono żałobną Mszę św. w intencji o. Maksyma. Mimo zupełnego braku zapisków o nim i o całym wydarzeniu w kronice klasztoru nie zapomniano o kapła$n_{i e}^{54}$. Mieszkańcy Konina pod osłoną nocy wykopali jego szczątki i złożyli je na cmentarzu parafialnym pod wielkim krzyżem z cierniową koroną. Istnieje jednak przypuszczenie, że pochowany został powtórnie przez mieszkańców Lądu, i że jego szczątki spoczywają przy ścianie północnego ramienia transeptu opactwa (na wysokości ołtarza św. Urszuli), w miejscu z czterema drzewkami i płytą wziętą z wejścia do grobowców klasztornych ${ }^{55}$.

Dyskusje o winowajcy pojmania o. Maksyma trwały przez dość długi okres. Zarzuty czyniono nie tylko zakrystianowi, ale i o. Emilianowi Ołtarzewskiemu, gwardianowi w Lądzie ${ }^{56}$. Co do o. Emiliana, oskarżenie to nie było prawdziwe, a wynikało to nie tylko z treści aktu oskarżenia, ale także i wysokości kary, jaka spotkała go ze strony władz carskich - kary najwyższej spośród zasądzonych. Również współbracia zostali ukarani - zesłaniem do Rosji, przeważnie w okolice Omska lub dalej na Syberię ${ }^{57}$. Restrykcje względem osób związanych ze sprawą

52 „Ojczyzna”, nr 74 z 28 VII 1864 r., s. 1-2; nr 77 z 31 VII 1864 r., s. 1; J.L. GADACZ, op. cit., t. II, s. 359.

53 J.L. GADACZ, op. cit., t. II, s. 359. Niestety w dostępnej literaturze nie ma śladu ukarania tych duchownych. Ukarany za to został ks. Emilian Perliński, reformat. Vide: P. KUBICKI, op. cit., cz. 1, s. 705.

54 P. GoŁdyn, op. cit., s. 35.

55 J. NowIŃSKI, op. cit., s. 333-334. W latach 50. XX w. odkryto tam resztki sosnowej trumny. Vide: J. Woś, Ląd. Materiaty źródtowe dotyczace klasztoru. Notatki robione w czasie mego ośmioletniego pobytu 1929-1937. Niektóre notatki z roku 1965, Zielone 1965 (maszynopis w zbiorach Biblioteki Wyższego Seminarium Duchownego Towarzystwa Salezjańskiego w Lądzie, sygn. 46).

56 Pojawiły się w $1863 \mathrm{r}$. opinie o złym traktowaniu rannych powstańców w odniesieniu do oo. Ołtarzewskiego, jak również Nienałtowskiego, być może z tego powodu pojawiła się również insynuacja o współpracy z wojskami carskimi, a dotycząca o. Ołtarzewskiego. Vide: „Ojczyzna", nr 37 z 15 VI 1864 r., s. 2. Jednak autor tego artykułu nie został określony. Conf. J.L. GADACZ, op. cit., t. II, s. 361.

57 M. Dziuba, op. cit., s. 251-252, 259. 
o. Maksyma Tarejwy dotyczyły prawie całego konwentu - w tym czasie 9 osób ${ }^{58}$. Braci zakonnych Karola Chodkiewicza ${ }^{59}$ oraz Aleksego Fijałkowskiego i Konrada Perzyńskiego, za współudział w ukrywaniu o. Maksyma, 18 września 1864 r. pozbawiono praw stanu i zesłano na osiedlenie na Syberię. Utrata praw stanu w sposób drastyczny pogarszała sytuację tych skazanych, gdyż drogę na Syberię musieli wówczas odbyć na piechotę, a pobyt na miejscu zesłania odbywał się w gorszych warunkach. Inni zesłani to: oo. Eugeniusz (Eugeni) Nienałtowski ${ }^{60}$, Bazyli Lassota vel Lasota, Cyriak Słotwiński ${ }^{61}$. Wyrokiem z 23 września lub 17 listopada 1864 r. zesłany został na 5 lat robót katorżniczych również o. Emilian Ołtarzewski, co ostatecznie wyjaśniło nie tylko brak współpracy gwardiana z rządem carskim, ale i spowodowało obciążenie go największą odpowiedzialnością za przechowywanie w klasztorze o. Maksyma ${ }^{62}$. Ponadto o. Emiliana Perlińskiego ${ }^{63}$, który w latach 1863-1864 był u oo. reformatów w Koninie i, jak się okazało, w czasie egzekucji kazał bić w dzwony, wysłano podczas kasaty klasztorów, dokładnie 1 stycznia 1865 r., za granicę, bez prawa do powrotu ${ }^{64}$. Natomiast dwóch, posiadających paszport austriacki i pruski, zostało wydalonych z Królestwa ${ }^{65}$. Poważne konsekwencje i restrykcje dotknęły więc wszystkich kapucynów lądzkich. Warto dodać, że skazanych kapucynów w czasie przejazdu przez Warszawę na drogę na Syberię zaopatrzyli ich współbracia ${ }^{66}$. Klasztor w Lądzie zamknięto 10 dni wcześniej przed wprowadzeniem ukazu z 8 listopada 1864 r. o etatowości i kasacie niektórych klasztorów w Królestwie Polskim ${ }^{67}$.

Historia o. Maksyma stanowi przykład losu wielu duchownych biorących udział w walkach podczas powstania styczniowego. Przykładów oddania życia podczas walk lub po ich zakończeniu było wiele. Kilku duchownych ukarano

58 O. Wawrzyniec Liberkowski zmarł 9 IV 1864 r., o. Leon Doliński nieco wcześniej (4 kwietnia) wyjechał do Krakowa bez prawa do powrotu, natomiast br. Ołtarka vel Otłamka (ogrodnika) zwolniono z podejrzeń i wysłano do Prus.

59 Ur. w 1836 r., zm. w 1911 r. W pracy P. Kubickiego jest księdzem. Vide: P. KUBICKI, op. cit., cz. 1 , s. 682-705.

60 Według innych autorów o. Eugeniusz (Eugeni) Nienałtowski, poniósł sroższą karę - zesłanie na czteroletnią katorgę. Wyrok zapadł 18 IX 1864 r. Vide: P. KUBICKI, op. cit., s. 682-705.

61 R. PREJS, Kapucyni prowincji polskiej po kasacie, s. 283. Wyroki zapadły kolejno: 18 i 23 IX, ale według innych tylko 18 IX 1864 r. Vide: P. KUBICKI, op. cit., s. 677-705; E. JABŁoŃSKADePTUŁA, J. GAWRYSIAKOWA, op. cit., s. 130, 133, 138, 141, 142,144, 146, 147-148.

62 P. Kubicki, op. cit., cz. 1, s. 682-705; E. JabŁońSKA-DePtula, J. GAWRYSiaKowa, op. cit., s. 142; P. GoŁDYN, op. cit., s. 37.

63 W 1862 r. sprawował obowiązki duszpasterskie w Brzezinach, a w latach 1863-1864 w Koninie.

64 P. KuBICKI, op. cit., cz. 1, s. 682-705.

65 R. Prejs, Kapucyni prowincji polskiej po kasacie, s. 80-81, 83. Dotyczyło to br. Wojciecha Ostrowskiego (był poddanym austriackim) i br. Wacława Ołtarka vel Otłamka (był poddanym pruskim). Vide: P. KuBICKI, op. cit., cz. 1, s. 682-705; E. JABŁoŃSKA-DEPTUŁA, J. GAWRYSIAKOWA, op. cit., s. 143.

66 Fakt ten opisano w bardzo pięknych i ciepłych słowach. Vide: CBPW, KPWK - wpis 12 VI 1863 , s. $258,259$.

67 M. DzIUBA, op. cit., s 259; P. GoŁdyn, op. cit., s. 36. 
śmiercią, a realizując wyrok, władze rządowe nie liczyły się z prawem kanonicznym, wielu zostało zmasakrowanych podczas walk, mimo, że odznaczali się od reszty powstańców - idąc z krzyżem i stułą, najczęściej nie posiadając żadnej broni ${ }^{68}$.

Analiza działalności o. Maksyma wskazuje, że jego postawa wynikała nie tylko z przekonań i predyspozycji osobistych, ale także z patriotycznie atmosfery panującej w środowisku zakonnym. W archidiecezji warszawskiej posługiwało w okresie powstania styczniowego 62 kapucynów, a zaangażowanych w działalność religijno-polityczną w różnym stopniu - było 34, podczas gdy w całym Królestwie Polskim w odniesieniu do kapucynów liczby te wynosiły odpowiednio 119 i 62 . Tak więc udział kapucynów w poparciu w różnym stopniu powstania $\mathrm{w}$ archidiecezji warszawskiej wynosił $(34 / 62) \times 100=55 \%$, a w Królestwie $(62 / 119) \times 100=52 \%$. W innych zgromadzeniach zakonnych udział duchownych w sprawach związanych z powstaniem nie przekraczał zazwyczaj $25 \%{ }^{69}$. Nie wartościując indywidualnych dokonań, kapucyni byli więc najbardziej aktywnymi zakonnikami w odniesieniu do różnorodnych potrzeb insurgentów.

\section{Podsumowanie}

Działalność i zaangażowanie o. Maksyma Tarejwo podczas powstania styczniowego wynikała z jego indywidualnego charakteru, drogi życiowej, ale z pewnością wzmocniona została oddziaływaniem środowiska kapucyńskiego, najbardziej czynnego ze wszystkich środowisk zakonnych w okresie przedpowstaniowym i podczas trwania powstania styczniowego. Miały one wybitnie charakter patriotyczno-religijny, z przewagą działań politycznych, dlatego historiografia zalicza go do działaczy organizacji Czerwonych, ale życzliwych również organizacji Białych. Symptomatyczne jest jego spotkanie na Jasnej Górze z ks. Antonim Mackiewiczem - później powstańczym bohaterem na Żmudzi. W okresie przedpowstaniowym działania religijne - „Msze za ojczyznę” i inne nabożeństwa religijno-patriotyczne, kazania, były trzonem jego poczynań, ale w okresie walki stanowiły mniejszą część jego zaangażowania w powstanie, a nawet można powiedzieć, że były wstępem do poczynań organizacyjnych i propagandowych. W okresie walki był człowiekiem czynu i przyczynił się w największym stopniu do wstępowania grup mieszczańskich i włościańskich do oddziałów powstańczych, dlatego był tak niebezpieczny dla władz carskich, które nie tylko zamierzały unieszkodliwić go fizycznie, ale i moralnie, przypisując mu działania wolnomularskie i rewolucyjne, co miało kwalifikować całe powstanie jako rewolucję, zniechęcającą do powstańców władze innych krajów i Stolicę Apostolską.

68 M. JARNECKI, op. cit., s. 5-32.

69 Wykazy duchownych - vide: P. KUBICKI, op. cit., cz. 1, s. 677-705; E. JABŁOŃSKA-DEPTUŁA, J. GAWRYSIAKOWA, op. cit., s. 93-193. 


\section{Bibliografia}

\section{Źródla rękopiśmienne}

Archiwum Archidiecezji Warszawskiej, Pismo z konsystorza generalnego nr 917 w księdze parafialnej parafii Służew, sygn. DP/H.3.

Centralna Biblioteka Prowincji Warszawskiej w Zakroczymiu „Honoratianum”:

- Kronika Prowincji Warszawskiej Kapucynów, wpis z 12 czerwca 1863 roku.

- Kronika Prowincji Warszawskiej Kapucynów, Clarici et Laies Novitie anno 1854, rok 1854

Continuator Historia Conventus Cracoviensis Patrum Capucinorum in Anno 1836 [-1894].

Kronika klasztoru lądzkiego, Zapis z 25 lutego 1863 r.

\section{Źródła drukowane}

BERG Mikołaj Wasiliewicz, Zapiski o powstaniu polskim 1863 i 1864 i poprzedzajacej powstanie epoce demonstracji od 1856 roku, tłum. Karol Radwan JASKŁOWSKI, Józef KrZEPELA, t. I, Kraków: Spółka Wydawnicza Polska, 1898.

KRĘCKI R. August, Zbiór materiatów do historii powstania styczniowego 1863-1864-go roku, Warszawa 1916, WAMP, sygn. Nr 27929/300/MW.

Woś J., Materiały źródłowe dotyczące klasztoru. Notatki robione w czasie mego ośmioletniego pobytu 1929-1937. Niektóre notatki z roku 1965, Zielone 1965 (maszynopis w zbiorach Biblioteki Wyższego Seminarium Duchownego Towarzystwa Salezjańskiego w Lądzie, sygn. 46).

\section{Czasopisma}

„Ojczyzna”, nr 7, 28, 38-40, 57, 74, 77, 85 z 1864 r.

\section{Pamiętniki}

Józefa Oxińskiego wspomnienia z powstania polskiego 1863/64 roku, Rocznik. Oddział Łódzki PTH, t. 3, 1939.

\section{Opracowania}

Boudou Adrien, Stolica Święta a Rosja. Stosunki dyplomatyczne między nimi w XIX wieku, thum. Zofia SKOwroŃSKA, t. I, Kraków: Wydawnictwo Księży Jezuitów, 1928.

CzubiŃski Antoni, Powstanie styczniowe w woj. kaliskim, „Studia Materiały do Dziejów Wielkopolski i Pomorza", t. 8/2: 1963, s. 65-78.

DzıUbA Michał, Kapucyni w Ladzie nad Warta (1850-1864), [in:] Zakony franciszkańskie w Polsce, t. 4: Polska Prowincja Kapucynów, cz. 1: Polska Prowincja Kapucynów w XIX w., Lublin: Prowincjałat OO. Ojców Franciszkanów Konwentualnych Prowincji św. Antoniego i bł. Jakuba Strepy, 1987, s. 211-270.

Gadacz Jan Ludwik, Stownik Polskich Kapucynów, t. I, Wrocław: Wydawnictwo OO. Kapucynów, 1985; t. II, Wrocław: Wydawnictwo OO. Kapucynów, 1986.

GAJZler Mateusz, Pabianice w okresie powstania w roku 1863, „Gazeta Pabianicka”, nr 21, 22, 23, 26, 27 z 1927 r.

GoŁDYN Piotr, Klasztor ladzki w okresie powstania styczniowego 1863-1864, „Poznańskie Zeszyty Humanistyczne", t. 9: 2005, s. 31-42.

JaBŁońSKa-Deptula Ewa, Gawrysiakowa Janina, Materiały do zaangażowania patriotycznego zakonów męskich $w$ Królestwie Polskim $w$ latach 1861-1864, [in:]Materiały do historii 
zgromadzeń zakonnych na ziemiach polskich $w$ XIX i na początku XX wieku, oprac. Hanna DYLĄGOWA, Ewa JABŁOŃSKA-DEPTUŁA i in., Lublin: Towarzystwo Naukowe KUL 1976, s. 93-198.

JARKOWski St. T., Józef Ignacy Kraszewski o „Ojczyźnie”, „Przegląd Narodowy Warszawski”, nr 77: 1911, s. 214-235.

JARNECKI Michał, Powstanie styczniowe w oczach Agatona Gillera, „Mazowieckie Studia Humanistyczne", t. 10/1-2: 2004, s. 5-32.

KIENIEwICZ Stefan, Powstanie styczniowe, Warszawa 2009.

Ląd, [in:] Stownik Geograficzny Królestwa Polskiego i innych krajów słowiańskich, t. V, Warszawa 1884.

KubICKI Paweł, Bojownicy kapłani za sprawę Kościoła i Ojczyzny w latach 1861-1915, cz. 1, t. 3, Sandomierz 1933, cz. 3, t. 1, Sandomierz 1939.

MAZEK Roman, Powstanie styczniowe na terenie gminy Parysów, „Zeszyty Historyczne Ziemi Garwolińskiej”, z. 19: 2013, s. 5-11.

NiEBELSKI Eugeniusz, Wobec roku 1863. Księża w powstaniu styczniowym i ich losy, Lublin: Towarzystwo Naukowe KUL, 2015.

NowIŃSKI Janusz, Ottarz Matki Bożej Częstochowskiej i powstańcza mogiła - dwie pamiatki patriotyczne $w$ dawnym opactwie $w$ Ladzie nad Warta, „Seminare. Poszukiwania naukowe”, nr 26/2009, s. 325-340.

PietrZaK Józef Stanisław, Księża powstańcy 1863 roku, Kraków: Gebethner i Spółka, 1916.

PREJS Roland, Kapucyni prowincji polskiej po kasacie 1864 r. Losy - postawy, „Studia Franciszkańskie", t. 8: 1997, s. 282-345.

PREJS Roland, Kapucyni prowincji polskiej w powstaniu styczniowym. Stan badań i kwestie dyskusyjne, „Teka komisji historycznej PAN, Oddział w Lublinie”, t. 10: 2013, s. 78-87.

Staszewski Janusz, Generat Edmund Taczanowski, Poznań: Drukarnia Poznańska, 1936.

TACZANOwski Kazimierz, Generat Edmund Taczanowski (1822-1879), „Poznańskie Zeszyty Humanistyczne", t. 14: 2010, s. 29-42.

WASZKIEWICZ Ludwik, Poczatek powstania 1863 roku w Lodzi i okolicy. Organizacja narodowa miasta Łodzi-wymarsz pierwszej partii powstańców, „Dziennik Łódzki”, 1963, s. 4-5.

Wocial Andrzej, Powstanie styczniowe 1863 r. w powiecie stanisławowskim, „Rocznik Mińsko Mazowiecki”, z. 5: 2010, s. 16-28.

WoJDYGa Piotr, Grzegorz Wojdyga i jego oddziat powstańczy z lat 1863-1864, „Rocznik Mińsko Mazowiecki”, z. 18: 2010, s. 34-39.

\section{Maksym Tarejwo - the priest advanced in polish January insurrection}

\section{Summary}

In paper the priest and Capuchin monk, participant of Polish January insurrection in 1863-1864 years, have been presented. For this priest, the period 1860-1862 years was preparatory to the insurrection - it was the time of preparatory works. And then, the battles with the Russian army in 1863 year, as the chaplain of the insurrection troops and famous preacher. Activity of priest Maksym have tolerated to limit the severing of battles. Later priest Maksym have stimulated Polish inhabitants to the battles and organized the auxiliary works. During many years, priest Maksym was wanted by the Russian troops. After the arrest in the Ląd monastery, he was executed in Konin in July 1864 year. The monks from Ląd cloister have also exiled to Siberia.

Keywords: Polish January insurrection, Maksym Tarejwo, chaplain, social and political worker. 

Prace Naukowe Uniwersytetu Humanistyczno-Przyrodniczego im. Jana Długosza w Częstochowie ZESZYTY HISTORYCZNE 2019 , t. XVIII, s. $119-152$

http://dx.doi.org/10.16926/zh.2019.18.07

Tomasz SUMARA

https://orcid.org/0000-0003-4343-6800

Uniwersytet Rzeszowski

\section{Wybory parlamentarne w Rzeszowie i powiecie rzeszowskim w 1928 roku}

\section{Streszczenie}

W 1926 r. w wyniku przewrotu majowego do władzy doszedł Józef Piłsudski. W tym okresie zachodzą w Drugiej Rzeczypospolitej zmiany polityczno-prawne. W 1928 r. odbyły się wybory parlamentarne, które zwłaszcza dla obozu sanacyjnego stanowiły test zaufania społecznego.

Z drugiej strony partie opozycyjne, które krytykowały rządy Piłsudskiego, akcentowały swój udział w wyborach. Warto poświęcić uwagę oraz przenalizować wybory parlamentarne w $1928 \mathrm{r}$. w Rzeszowie oraz powiecie rzeszowskim. Opracowanie artykułu oparto przede wszystkim na regionalnej prasie międzywojennej. Poszczególne tytuły prasowe dostarczają cennych informacji na temat kampanii wyborczej w regionie.

Słowa kluczowe: Rzeszów, powiat rzeszowski, wybory parlamentarne, sejm, senat.

\section{Sytuacja polityczna w Rzeszowie przed wyborami parlamentarnymi}

Rzeszów w okresie dwudziestolecia międzywojennego należał do kategorii mniejszych miast. Według pierwszego spisu powszechnego, przeprowadzonego 30 września 1921 r., liczył niemal 25 tys. mieszkańców. Miasto w przeważającej większości zamieszkiwane było przez ludność polską (17,7 tys.), po części żydowską ( 7 tys.) oraz niewielką liczbę ukraińskiej (ok. 100 osób) i niemieckiej (24 osoby $)^{1}$. W latach dwudziestych Rzeszów był mikroregionalnym ośrodkiem go-

1 Powyższe dane dotyczą zadeklarowanej narodowości. W 1921 r. odnotowano w Rzeszowie jeszcze 16 Rosjan, 10 Austriaków, 9 Anglików, 6 Czechów, 3 Węgrów, 1 Gruzina, 1 Fina, 1 Francuza, 1 Łotysza, 1 Morawianina i 1 Rumuna. Natomiast biorąc pod uwagę zadeklarowane wy- 
spodarczym, oddziałującym głównie na własny powiat ${ }^{2}$. Dominowały tam małe, niekiedy prymitywne zakłady przemysłowe, o niskiej jakości produkcji, zatrudniające od kilku do 200 pracowników ${ }^{3}$. Natomiast zdecydowana większość mieszkańców powiatu utrzymywała się z rolnictwa, które stanowiło zarówno podstawę handlu z miastem, jak i źródło egzystencji dla samego miasta. Dlatego też ważną rolę w powiecie odgrywał ruch ludowy. Doktor Tadeusz Spiss, pełniący w latach 1924-1926 urząd starosty rzeszowskiego, podkreślał jego bogatą tradycję: „Charakterystyczną cechą powiatu rzeszowskiego, była okoliczność, że powiat ten był uważany za kolebkę ruchu ludowego. Stąd wywodzili się za czasów austriackich pierwsi posłowie chłopi (Szajer, Bomba). Każdy odłam ruchu ludowego uznawał siebie za spadkobiercę owych pierwszych działaczy ludowych i każdy dążył do zamanifestowania tu swojej żywotności, swoich wpływów"4. $\mathrm{Z}$ drugiej jednak strony udział miasta $\mathrm{w}$ życiu politycznym regionu był znacznie większy, niż wskazywałby na to jego potencjał demograficzny i ekonomiczny.

Rzeszów niewątpliwie był ośrodkiem, w którym życie polityczne dynamicznie się rozwijało, a niekiedy obfitowało $\mathrm{w}$ wewnętrzne napięcia w szeregach różnych partii. W niniejszym artykule przedstawiona zostanie kampania wyborcza do sejmu i senatu w 1928 r. w Rzeszowie i powiecie rzeszowskim, które znajdowały się w okręg nr 47 (rzeszowsko-jarosławskim). Celem artykułu jest też przybliżenie sytuacji politycznej w mieście przed nadchodzącymi wówczas wyborami parlamentarnymi.

W maju 1926 r. w wyniku przewrotu dokonanego przez Józefa Piłsudskiego doszło do zmian na scenie politycznej. Władzę przejęła sanacja, szermująca hasłem „uzdrowienia państwa”. W latach 1926-1928 nastąpiły kluczowe przemiany ustrojowe. Pierwszą było uchwalenie noweli sierpniowej (2.08.1926) wzmacniającej kompetencje prezydenta kosztem sejmu ${ }^{5}$. Doprowadziło to do

znanie w Rzeszowie było 13345 rzymskich katolików, 11361 mojżeszowych, 193 grekokatolików, 20 prawosławnych i 19 ewangelików. Vide: Pierwszy Powszechny Spis Rzeczypospolitej Polskiej z dnia 30 września 1921 roku. Mieszkania, ludność, stosunki zawodowe, t. XXVII: Województwo lwowskie, Warszawa 1927, s. 9; Skorowidz miejscowości Rzeczypospolitej Polskiej. Opracowany na podstawie wyników pierwszego powszechnego spisu ludności z dn. 30 września 1921 r. i innych źródeł urzędowych, t. XIII: Województwo lwowskie, Warszawa 1924, s. 39.

2 Marek Piotr DeszczyńsKi, Rzeszów na mapie gospodarczej II Rzeczypospolitej, [in:] Rzeszów Dawny i Wspótczesny. Gospodarka, red. Krzysztof Kaszuba, Andrzej Szromnik, Rzeszów 2005, s. 106-107.

3 Jako przykładowe zakłady można wymienić: „Mars” zajmującą się produkcją sprzętu wojskowego, wytwórnię cukierków i marmolady „Alima”, wytwórnię guzików nicianych „IKA” czy gazownię. Vide: Juliusz Petrus, Stosunki Gospodarcze, [in:] Dzieje Rzeszowa, t. III: Rzeszów w okresie międzywojennym i okupacji (1918-1944), red. Feliks KIRYK, Rzeszów 2001, s. 62-64.

4 Tadeusz SPISs, Ze wspomnień c.k. urzędnika politycznego, Rzeszów 1936, s. 180.

5 Ustawa o zmianie o konstytucji, zwana nowelą sierpniowa wprowadzała następujące zmiany: prezydent miał prawo rozwiązać sejm i senat przy jednoczesnym pozbawieniu parlamentu możliwości rozwiązania się na podstawie własnej ustawy. Prezydent otrzymał również prawo wydawania rozporządzeń z mocą ustawy. Nowela sierpniowa stanowiła też, że wniosek sejmu o votum nieufności dla rządu nie mógł być głosowany na tym posiedzeniu, na którym go zgło- 
wyraźnej zmiany układu sił w stosunkach między parlamentem a rządem. Rząd otrzymał szeroki zakres uprawnień, a sejm, który w wyniku zamachu majowego stracił swoją pozycję, rezygnował ze znacznej części uprawnień ustawodawczych, zachowując jedynie funkcje kontrolne.

Parlament w nowej rzeczywistości politycznej miał mocno ograniczone możliwości działania. $Z$ jednej strony nowelą sierpniową, $w$ tym wyposażeniem prezydenta $\mathrm{w}$ prawo do wydawania dekretów $\mathrm{z}$ mocą ustaw ${ }^{6}, \mathrm{z}$ drugiej zaś precedensami konstytucyjnymi, chętnie wykorzystywanymi przez kształtujący się obóz sanacyjny. Nie ustawały również słowne ataki na parlamentarzystów, w czym prym wiódł sam Piłsudski. Mimo, że nie ukrywał on swej pogardy dla posłów, nie zdecydował się jednak na rozpisanie przedterminowych wyborów, co związane było ze słabością własnego zaplecza politycznego, ale także łatwość kontrolowania sejmu.

Obóz sanacyjny po objęciu władzy nie posiadał wyraźnego zaplecza politycznego oraz organizacyjnego. Co prawda po przewrocie majowym działał należący do tego obozu Związek Naprawy Rzeczypospolitej, ale nie miał on poparcia wśród większości społeczeństwa, opierając się głównie na inteligencji pracującej. W tej sytuacji pod koniec 1927 r. został powołany Bezpartyjny Blok Współpracy z Rządem Józefa Piłsudskiego (BBWR). Według koncepcji miała to być organizacja ponadpartyjna, zrzeszająca osoby popierające obóz rządzący oraz zapewniająca mu wpływy w administracji państwowej, władzach samorządowych i w przyszłym parlamencie ${ }^{7}$. Blok głosił hasła przebudowy ustroju państwa, zmiany konstytucji w kierunku wzmocnienia władzy wykonawczej. 19 stycznia 1928 r. BBWR ogłosił deklarację programową ${ }^{8}$, o bardzo ogólnikowym charakterze. Posługiwano się w nim sloganami takimi jak: „partyjniactwo” czy „odbudowa państwa”. W deklaracji głoszono potrzebę naprawy ustroju politycznego, rozszerzenie uprawnień prezydenta i rządu, zmniejszenie roli parlamentu oraz wzmocnienia produkcji krajowej. $Z$ drugiej strony ważne miejsce zajęła krytyka upartyjnienia i nadużyć popełnianych przez posłów ${ }^{9}$.

szono. Niewątpliwie dawało to możliwość wywierania nacisku na parlament. Dodatkowo budżet jeśli nie został uchwalony w ciągu określonego czasu, miał obowiązywać jako zgłoszony projekt lub w postaci , w jakiej uchwaliła go ta izba, która zakończyła w przewidzianym przez ustawę terminie tok prac legislacyjnych. Vide: „Dziennik Ustaw Rzeczypospolitej Polskiej” 1926, nr 78, poz. 442 .

6 Przykładowo już 6 VIII 1926 r. prezydent Ignacy Mościcki wydał dekret o ustanowieniu funkcji Generalnego Inspektora Sił Zbrojnych (GISZ), przewidzianego na stanowisko naczelnego wodza. Generalny Inspektor Sił Zbrojnych na mocy dekretu prezydenta miał zastępować ministra spraw wojskowych we wszystkich sprawach dotyczących przygotowania wojska i państwa do obrony na wypadek wybuchu konfliktu zbrojnego. Równocześnie uchwała przewidywała utworzenie Komitetu Obrony Państwa. Generalnym Inspektorem Sił Zbrojnych został Józef Piłsudski. Vide: „Dziennik Ustaw Rzeczypospolitej Polskiej” 1926, nr 79, poz. 445.

7 Andrzej Chojnowski, Pitsudczycy u władzy. Dzieje Bezpartyjnego Bloku Wspótpracy z Rzqdem, Wrocław 1986, s. 53-54.

8 Deklarację podpisało 373 osoby.

9 Deklaracja Bezpartyjnego Bloku Wspótpracy z Rządem, „Polska Zbrojna”, nr 20: 1928, s. 2. 
W BBWR znalazły się ugrupowania lewicowe popierające sanację: Partia Pracy i Związek Naprawy Rzeczypospolitej oraz organizacje konserwatywne: Polska Organizacja Zachowawczej Pracy Państwowej, Stronnictwo Prawicy Narodowej i Chrześcijańskie Stronnictwo Rolnicze. W skład bloku weszli również działacze związków zawodowych (np. Związek Zawodowy Nauczycieli Polskich Szkół Średnich), organizacji urzędniczych (np. Związek Urzędników Skarbowych) czy kombatanckich (Związek Legionistów, Związek Strzelecki, Polska Organizacja Wolności). Akces do BBWR zgłaszali także działacze wywodzący się z ruchu ludowego m.in.: PSL „Piast” czy PSL „Wyzwolenie”10. Jednocześnie na przełomie lat 1927/1928 nastąpiły zmiany organizacyjne i personalne w opozycyjnych do sanacji politycznej partiach.

Na kształt sceny politycznej przed 1928 r. zarówno w Rzeszowie, jak i w powiecie rzeszowskim istotny wpływ wywarły wybory parlamentarne w $1922 \mathrm{r}^{11}$ W samym Rzeszowie zwycięstwo odnieśli Żydzi. Wystawili oni jedną listę wyborczą - nr 28, pod nazwą Komitet Zjednoczonych Stronnictw Narodowo-Żydowskich, na którą oddano 3575 głosów. Natomiast w powiecie rzeszowskim na listę $\mathrm{nr} 28$ głosowało 5054 wyborców ${ }^{12}$. Ostatecznie z okręgu rzeszowsko-jarosławskiego z listy żydowskiej do sejmu dostał się Feiwel Stempel (przemysłowiec z Krakowa, właściciel kopalni węgla). Drugi wynik w Rzeszowie osiągnął Chrześcijański Związek Jedności Narodowej, który startował z listy nr 8. Endecja zdobyła w mieście 1792 głosów, a w powiecie - 5337. Uzyskany wynik przełożył się na zdobycie jednego mandatu poselskiego - z ramienia klubu Chrześcijańsko-Narodowego do parlamentu wszedł dr Kazimierz Chłapowski (radca prawny z Poznania, były starosta w Przeworsku) ${ }^{13}$.

Biorąc pod uwagę wyniki wszystkich partii w mieście najsłabiej wypadły ugrupowania ludowe - PSL „Piast”, PSL „Wyzwolenie”, PSL „Lewica”, Chłopskie Stronnictwo Radykalne ${ }^{14}$. Natomiast w powiecie zdecydowany sukces odniosło PSL „Piast”, uzyskując aż 27861 głosów, dzięki czemu partia Wincentego

10 Andrzej Ajnenkiel, Parlament II Rzeczypospolitej, Warszawa 1975, s. 262-263.

11 Na mocy dekretu Naczelnika Państwa, Józefa Piłsudskiego z dnia 18 sierpnia 1922 r. O zarzqdzeniu wyborów do Sejmu i Senatu Rzeczypospolitej Polskiej ustalono termin wyborów parlamentarnych. Wybory do sejmu miały odbyć się 5 listopada 1922 r., a do Senatu - 12 listopada 1922 r. Vide: „Dziennik Ustaw Rzeczypospolitej Polskiej” 1922, nr 66, poz. 593.

12 W całym okręgu wyborczym nr 47 (Rzeszów, Jarosław, Przeworsk, Łańcut, Nisko) Żydzi otrzymali 15409 głosów. Vide: Wynik wyborów sejmowych w okręgu rzeszowsko-jarosławskim, „Ziemia Rzeszowska i Jarosławska”, nr 45: 1922, s. 1; Statystyka wyborów do sejmu i senatu odbytych w dniu 5 i 12 listopada 1922 roku, [in:] Statystyka Polski, t. VIII, Warszawa 1926, s. 67.

13 Tadeusz RZEPECKI, Witold RZEPECKI, Sejm i Senat Rzeczypospolitej Polskiej 1922-1927, Poznań 1923, s. 297.

14 Na PSL „Piast” (lista nr 1) głosowały 23 osoby, na PSL „Wyzwolenie” (lista nr 3) - 14, a na PSL „Lewica” (lista nr 13 ) - 11. Natomiast Chłopskie Stronnictwo Radykalne (lista nr 15) otrzymało poparcie tylko 5 osób. Vide: Statystyka wyborów do sejmu i senatu odbytych $w$ dniu 5, s. 87. 
Witosa wprowadziła do sejmu 5 posłów z okręgu rzeszowsko-jarosławskiego: Andrzeja Plutę (rolnika ze Szklar - powiat rzeszowski), Jana Pieniążka (rolnika z Mokrej Strony - powiat przeworski), Jana Sobka (rolnika z Handzlówki - powiat łańcucki), Brunona Gruszka (rolnika ze Sokołowa - powiat jarosławski) oraz Marcina Sochę (urzędnika kolejowego z Rudnika - powiat niżański) ${ }^{15}$.

Przegranymi w okręgu rzeszowsko-jarosławskim okazały się socjaliści, miejscowa chadecja i Stronnictwo Mieszczańskie. Pozostałe ugrupowania takie jak: Związek Proletariatu Miast i Wsi czy Narodowa Partia Robotnicze jedynie zasygnalizowały swoją obecność.

Nieco inaczej przedstawiały się pierwsze wybory do senatu. W województwie lwowskim zgłoszono 13 list ubiegających się o 9 mandatów ${ }^{16}$. W wyborach do izby wyższej w Rzeszowie zwyciężyli Żydzi - lista nr 24 i Chrześcijański Związek Jedności Narodowej - lista nr 8 (odpowiednio otrzymując: 2752, 2648 głosów). Podobnie jak przy wyborach do sejmu, znacznie słabszy wynik zanotowały ugrupowania chłopskie i socjalistyczne ${ }^{17}$. Natomiast w powiecie rzeszowskim najwięcej głosów padło na listę wystawioną przez PSL „Piast” - 21911. Dobry wynik uzyskany w całym województwie lwowskim przełożył się na zdobycie przez tę partię 4 mandatów senatorskich: Andrzej Kędzior (przewodniczący Wydziału Samorządu we Lwowie), dr Julian Ignacy Nowak (profesor bakteriologii i dyrektor Instytutu Weterynarii w Krakowie), Józef Jachowicz (rolnik ze Strażowa - powiat łańcucki) oraz Stanisław Biały (członek Tymczasowego Wydziału Samorządowego we Lwowie) ${ }^{18}$. Trzy mandaty natomiast zdobyła endecja: dr Ernest Adam (dyrektor Ziemiańskiego Banku Kredytowego we Lwowie), ks. Witold Czartoryski (ziemianin zamieszkały w Pekinach - powiat jarosławski) i dr Maksymilian Thullie (profesor Politechniki Lwowskiej). Dobrze w województwie lwowskim wypadła lista żydowska - Komitet Zjednoczonych Stronnictw Narodowo-Żydowskich - wprowadzając do senatu dwóch przedstawicieli: dra Maksymiliana Bienenstocka (profesor Gimnazjum we Lwowie, publicysta) i Juliusza Artura Wurzela (adwokat i dziennikarz ze Lwowa) ${ }^{19}$.

15 T. RZEPECKI, W. RZEPECKI, Sejm i Senat Rzeczypospolitej Polskiej 1922, s. 295-297.

16 Zgodnie z ordynacją wyborczą do sejmu i senatu każde województwo stanowiło jeden okręg wyborczy, na które przypadła z góry ustalona ilość mandatów. Ilość ich zależała od liczby mieszkańców danego województwa. W województwie lwowskim mieszkało ponad 2,7 mln mieszkańców, w rezultacie czego wybierano 9 senatorów. Vide: Ordynacja wyborcza do Sejmu i Senatu z 28 lipca 1922 roku, wstępem i komentarzem opatrzył ks. dr. Kazimierz LutosŁAWSKI, Warszawa 1922, s. 52-53; Pierwszy Powszechny Spis Rzeczypospolitej Polskiej z dnia 30 września 1921 roku, s. 3.

17 PPS w Rzeszowie otrzymał 486 głosów, a PSL „Piast” - 329. Jeden głos zdobył Związek Proletariatu Miast i Wsi, natomiast 3 - Centrum Mieszczańskie. Pozostałe partie w wyborach do senatu nie otrzymały w Rzeszowie żadnego głosu. Vide: Statystyka wyborów do sejmu i senatu odbytych $w$ dniu 5 listopada, s. 115.

18 T. RZEPECKI, W. RZEPECKI, Sejm i Senat Rzeczypospolitej Polskiej 1922, s. 406-407.

19 Ibidem, s. 409. 
Wyniki przeprowadzonego głosowania do sejmu i senatu w 1922 r. świadczyły o popularności w powiecie PSL „Piast”, który miał poza miastem bardzo silną pozycję. Stanowczo poniżej swoich oczekiwań wypadła endecja. Natomiast dobry wynik w Rzeszowie zanotowali Żydzi. Redaktorzy „Ziemi Rzeszowskiej i Jarosławskiej” skomentowali to w następujący sposób: „Oto w samym Rzeszowie 4373 wyborców, prawie wyłącznie chrześcijańskich, zostało w domu i nie raczyło się potrudzić do wyborów - Oto w samym powiecie rzeszowskim było takich wygodnickich wyborców 20 tysięcy. I o to dzięki nim mamy posłem żyda, rabina, syjonistę"20. Takich utarczek słownych na łamach prasy narodowej było znacznie więcej. Publicyści krytykowali zarówno tych, którzy brali udział w wyborach, a nie głosowali na listę $\mathrm{nr} 8$, jak i tych, którzy w wyborach nie wzięli udziału.

W połowie latach dwudziestych doszło do wielu przeobrażeń i zmian organizacyjnych w najważniejszych partiach politycznych, nie tylko w skali krajowej, ale również i regionalnej. 11 maja 1924 r. na zjeździe w Rzeszowie w wyniku współpracy secesjonistów z PSL „Piast” z grupą skupioną wokół Stapińskiego z PSL „Lewicy” powstał Związek Chłopski. Prezesem partii został Andrzej Pluta, związany z powiatem rzeszowskim, zaś zastępcami Jan Stapiński i Jan Bryl ${ }^{21}$. W styczniu 1926 r. w wyniku połączenia się Związku Chłopskiego z grupą secesjonistów z PSL „Wyzwolenia”, powołano Stronnictwo Chłopskie, którego przywódcą został Jan Dąbski. Ugrupowanie w swoim programie postulowało: utworzenie jednoizbowego sejmu i rządu chłopsko-robotniczego, oddzielenie Kościoła od państwa i przekazanie majątku kościelnego na własność poszczególnych parafii. Wiele miejsca poświęcono sprawom gospodarczym. Domagano się przeprowadzenia reformy rolnej bez odszkodowania oraz zapowiadano upaństwowienie lasów, kopalń itd. ${ }^{22}$ Jednym z wiceprezesów Zarządu Głównego był A. Pluta. Na terenie powiatu rzeszowskiego partia wykazywała dużą aktywność polityczną. 28 lutego 1926 r. w Rzeszowie w sali „Sokoła” odbyło się zgromadzenie byłych delegatów Związku Chłopskiego. Sprawozdanie o sytuacji w sejmie i w rządzie złożył Władysław Wójtowicz. Głos zabrał również poseł Jan Bryl, który opowiedział zgromadzonym uczestnikom o stosunkach panujących w ZSRR. Na zakończenie uchwalono rezolucję, w której żądano natychmiastowego rozwiązania sejmu oraz przeprowadzenia nowych wyborów ${ }^{23}$. Niewątpliwie zgromadzenie to przyczyniło się $\mathrm{w}$ dużym stopniu do większej aktywizacji chłopów z powiatu rzeszowskiego, którzy zaczęli organizować gminne struktury Stronnictwa. W okolicznych wsiach (m.in. w Boguchwale czy Futomie) zakła-

20 „Ziemia Rzeszowska i Jarosławska”, nr 45: 1922, s. 3.

21 Stanisław Lato, Ruch ludowy wobec sanacji, Rzeszów 1986, s. 29-30.

22 Alicja WięziKowa, Stronnictwo Chtopskie 1926-1931, Warszawa 1963, s. 32-33; Ewelina PodgajnA, Stronnictwo Chtopskie (1926-1931). Studium z dziejów myśli politycznej, Lublin 2011, s. 64, 177-179, 204.

23 „Przyjaciel Ludu”, nr 10: 1926, s. 8; Bryl bryluje w Rzeszowie, „Ziemia Rzeszowska”, nr 10: 1926, s. 1. 
dano koła partyjne oraz wybierano ich władze (przewodniczących, zastępców, sekretarzy, skarbników) ${ }^{24}$. Partia w wyborach do sejmu i senatu w marcu $1928 \mathrm{r}$. wystawiła listę $\mathrm{nr} 10$.

Rozdrobnienie w ruchu ludowym pogłębiało się. W październiku $1927 \mathrm{r}$. działacz ruchu ludowego Jakub Bojko wystąpił z PSL „Piast” i założył organizację o prosanacyjnym charakterze - Zjednoczenie Ludu Polskiego, która w marcu 1928 r. startowała w wyborach do sejmu razem z BBWR z listy $\mathrm{nr} 1^{25}$.

27 października 1927 r. Bojko w Gręboszowie wydał manifest Do braci włościan i ludzi dobrej woli, w którym wzywał chłopów do poparcia rządów Piłsudskiego, deklarując: „Wierny programowi Polskiego Stronnictwa Ludowego, wierny aż do zgonu ideałom rzeszy chłopskiej, wierny Ojczyźnie, wyciągam swą starą spracowaną dłoń do Marszałka Piłsudskiego, wierząc głęboko, że pod Jego sztandarem chłopi polscy znajdą ochronę i pomoc w swej niedoli" ${ }^{26}$. Jednocześnie usprawiedliwiał swoje odejście z „Piasta” - z jednej strony krytykował błędną linię polityczną stronnictwa, od 1922 r. schodzącą (jego zdaniem) z drogi walki o interesy i sprawy mas chłopskich, $z$ drugiej ostro potępił politykę prowadzoną przez Wincentego Witosa, którego uważał za jedno z największych nieszczęść oraz porażek ruchu ludowego ${ }^{27}$. Głównym powodem wystąpienia Bojki z „Piasta” była próba zjednoczenia polskiego ruchu ludowego. Działacz wyrażał głębokie przekonanie do osoby Piłsudskiego, oddanego jak sądził sprawie ludowej.

Niewątpliwie odejście jednego zasłużonych działaczy ludowych wywołało duże wrażenie w kraju, a zwłaszcza w stronnictwach chłopskich ${ }^{28}$. W ślady Bojki poszedł Jan Stapiński, jeden z przywódców ruchu ludowego w Polsce. Na przełomie 1927/1928 r. został wykluczony ze Stronnictwa Chłopskiego. Powodem usunięcia była frakcyjna działalność parlamentarzysty. W styczniu 1928 r. wraz ze swoimi zwolennikami wznowił działalność Związku Chłopskiego, jako organizacji prosanacyjnej. Stapiński swe nadzieje na odegranie większej roli w życiu politycznym łączył z tym obozem i z samym Piłsudskim ${ }^{29}$. Związek Chłopski w wyborach parlamentarnych w $1928 \mathrm{r}$. startował z listy nr 14.

Warto podkreślić, że ze wszystkich partii chłopskich największe straty przed wyborami poniósł PSL „Piast”. Odejście kilku ważnych działaczy, szczególnie

24 „Przyjaciel Ludu”, nr 18: 1926, s. 6.

25 Tadeusz KowALSKI, Ruch ludowy w powiecie rzeszowskim 1895-1944, Warszawa 1973, s. 79-81.

26 Jakub Bojко, Moje stowo do Braci włościan i ludzi dobrej woli: Dnia 27 października 1927 r., Gręboszów 1927.

27 Idem, Dlaczego rzucitem Witosa? Do Braci Chłopów Jakóba Bojki, słów kilka, „Chłop Polski”, nr 1: 1927, s. 1-2.

28 Wincenty Witos krytykował wystąpienie J. Bojki pisząc na łamach prasy: „Ty jednak poszedłeś na drogę, za którą innych potępiłeś, zamiast zjednoczenia zrobiłeś krok do dalszego rozbicia, podważając u chłopów poczucie siły, jedności i honoru". Vide: Wincenty Witos, Poset Wincenty Witos w odpowiedzi na „,manifest” senatora Jakuba Bojki, „Piast”, nr 45: 1927, s. 1-2.

29 Krzysztof Dunin-Wąsowicz, Jan Stapiński, [in:] Przywódcy ruchu ludowego. Szkice biograficzne, red. A. WiĘzıKOWA, Warszawa 1968, s. 307. 
Bojki, przeniesienie starosty rzeszowskiego Tadeusza Spissa do Stanisławowa ${ }^{30}$, wewnętrze secesje oraz tworzenie konkurencyjnych partii, zwłaszcza wspomnianego Stronnictwa Chłopskiego, spowodowało zmniejszenie zaplecza politycznego ugrupowania. Dodatkowo kierownictwo „Piasta” musiało liczyć się z przychylnymi nastrojami rzesz chłopskich wobec twórcy sytemu pomajowego, z którym wiązano wielkie nadzieje ${ }^{31}$. W styczniu $1928 \mathrm{r}$. odbyły się w Rzeszowie dwa zgromadzenia PSL „Piast”. Na pierwszym 7 stycznia dokonano reorganizacji Zarządu Powiatowego i przyjęto młodych działaczy. Natomiast 13 stycznia, podczas zjazdu powiatowego, ustalono wybór kandydatów na posłów. Na zjazd przybyło ok. 500 delegatów, w tym także byli posłowie: Bruno Gruszka i Jan Pieniążek oraz senator Józef Jachowicz. Na pierwszym miejscu listy kandydatów na posłów znalazł się Andrzej Kus. Na liście byli także: Michał Szajer, Ignacy Opaliński, Jan Draus i Piotr Szczutek. Kandydatem na senatora został Stanisław Lis ${ }^{32}$. Kierownictwo partii przystąpiło do wyborów razem z Chrześcijańską Demokracją, tworząc Polski Blok Katolicki - lista nr 25.

W latach dwudziestych z rozłamami zmagał się także PSL „Wyzwolenie”. W 1924 r. część jego działaczy powołała do życia Niezależną Partię Chłopską. $\mathrm{Na}$ terenie ziemi rzeszowskiej istniały 2 koła ugrupowania w powiatach: przeworskim i rzeszowskim. W styczniu 1925 r. z inicjatywy Mieczysława Bomby oraz Józefa Kubicza powstały koła w Budziwoju i Świlczy ${ }^{33} .11$ marca $1927 \mathrm{r}$. rozporządzeniem Prezesa Rady Ministrów Niezależna Partia Chłopska została zdelegalizowana, z powodu rozbudzania na wsi nastrojów rewolucyjnych. Na początku grudnia powołano do życia Komitet Organizacyjny Lewicy Chłopskiej, którego przewodniczącym został Antoni Bomba. Z początkiem stycznia $1928 \mathrm{r}$. utworzono nową partię o programie rewolucyjnym - Zjednoczenie Lewicy Chłopskiej „Samopomoc”34. W skład zarządu tymczasowego wszedł wspomniany A. Bomba. Nowo powstała organizacja nie zyskała jednak zgody władz państwowych na wystawienie własnej listy w nadchodzących wyborach ${ }^{35}$.

30 Tadeusz Spiss pełniąc urząd starosty rzeszowskiego aktywnie działał w PSL „Piast”. Zapewniał „piastowcom” najważniejsze funkcje w organizacjach gospodarczych oraz Związku Wójtów powiatu rzeszowskiego. W 1926 r. przeniesiony został do Stanisławowa, gdzie objął urząd Inspektora Wojewódzkiego. Nowym starostą rzeszowskim został w 1927 r. dr Artur Friedrich. Vide: Ruch stużbowy, „Dziennik Urzędowy Województwa Lwowskiego”, nr 1: 1927, s. 1.

31 Janusz Socha, Stronnictwa ludowe po zamachu majowym, Warszawa 1983, s. 93-94.

32 Ze zjazdów Pow. Małopolska, „Piast”, nr 5: 1928, s. 5.

33 Benon DymeK, Niezależna Partia Chłopska, Warszawa 1972, s. 205-208.

34 Bomba Mieczysław - wspomnienia. Próba zorganizowania władzy ludowej w 1918 r. Zjednoczenie Lewicy Chłop. „Samopomoc”, lata 1928-1931, Rewolucyjne walki przeszłości Rzeszowszczyzny. Burzliwe wybory do parlamentu wiedeńskiego w Rzeszowie, APRz, KW PZPRwRz, sygn. 13392, k. 50-52.

35 Zjednoczenie Lewicy Chłopskiej „Samopomoc” zgłosiło w okręgu 47 (Rzeszów, Jarosław, Przeworsk, Łańcut, Nisko) listę pod nazwą „Niezależna Lista Stronnictwa Chłopskiego”. Została ona jednak unieważniona. Partia do wyborów w 1928 r. przystąpiła w Bloku Antyfaszystowskim, który miał polegać na współdziałaniu wszystkich ugrupowań rewolucyjnych, na czele 
Przed przewrotem majowym duże wpływy w mieście posiadała Narodowa Demokracja, która razem z chadekami zdobyła większość mandatów do Rady Miejskiej. Do czołowych działaczy endecji należeli Roman Krogulski ${ }^{36}$, Witold Czarnek, Józef Liwo i Bronisław Miara. Największe wpływy organizacja posiadała wśród urzędników, drobnomieszczaństwa, przedstawicieli wolnych zawodów np. prawników i lekarzy ${ }^{37}$. Ważną rolę w zyskiwaniu zwolenników wśród miejscowego społeczeństwa odegrała „Ziemia Rzeszowska”, organ prasowy Narodowej Demokracji. Gazeta wiele miejsca poświęcała sprawom politycznym, zwłaszcza aktualnym wydarzeniom w kraju ${ }^{38}$. Jednak po zamachu Piłsudskiego pozycja endecji osłabła. Znaczna część działaczy, w tym burmistrz Krogulski, przeszła do BBWR, wraz z kilkoma radnymi. Endecy w wyborach startowali z listy $\mathrm{nr} 24$.

Na uzyskanie głosów w wyborach liczyli także socjaliści, którzy już od 1925 r. umacniali swoją pozycję $e^{39} .24$ kwietnia 1927 r. w Rzeszowie w sali „Sokoła” Polska Partia Socjalistyczna zorganizowała uroczystość odsłonięcia sztandaru. Do miasta przybyli wówczas poseł Zygmunt Kazimierz Piotrowski, senator Dorota Kłuszyńska i jeden z delegatów Rady Krakowskiej Adam Ciołkosz ${ }^{40}$. W czerwcu 1927 r. ugrupowanie uzyskało poważny sukces w wyborach do Rady Miejskiej, wprowadzając 12 przedstawicieli. Klub Radnych PPS tworzyli m.in.: Karol Krwawicz, Wacław Buczyński, Jan Rak, Stanisław Mróz, Michał Pasierb i Czesław Wilk ${ }^{41}$. Rozwój ruchu zawodowego, głównie opanowanie przez PPS Związku Zawodowego Robotników Rolnych, spowodowały decyzję Centralnego Komitetu Wykonawczego partii o utworzeniu w Rzeszowie Okręgowego Komitetu Robotniczego, którego przewodniczącym został Karol Krwawicz, a sekreta-

z Komunistyczną Partią Polski. Listy „Samopomocy” zostały zatwierdzone w następujących okręgach: nr 8 (Ciechanów, Mława, Pułtusk, Przasnysz, Maków), nr 11( Łowicz, Kutno, Gostynin, Sochaczew), nr 20 (Kielce, Jędrzejów, Włoszczowa), nr 23 (Iłża, Kozienice, Opatów), nr 24 (Łuków, Garwolin, Puławy i nr 26 (Lublin, Chełm, Lubartów). Vide: Henryk CimeK, Zjednoczenie Lewicy Chłopskiej „,Samopomoc” 1928-1931, Lublin 1973, s. 185-187, 192.

36 Roman Krogulski (1868-1936) - adwokat, działacz społeczny oraz polityczny. W latach 19131933 pełnił obowiązki burmistrza Rzeszowa. W 1933 r. w wyniku zmiany ustawy o samorządzie został wybrany pierwszym prezydentem miasta. Po powołaniu BBWR-u stał na czele jego struktur w Rzeszowie, Vide: Jerzy GACEK, Roman Krogulski, [in:] Encyklopedia Rzeszowa, red. Zdzisław BUDZYŃSKI, Rzeszów 2004, s. 257.

37 Włodzimierz Bonusiak, Życie polityczne, [in:] Dzieje Rzeszowa, s. 511.

38 Stanisława DarŁakowa, Prasa Rzeszowa XIX $i$ XX wieku, Rzeszów 1966, s. 38.

39 W 1925 r. w Rzeszowie liczba członków PPS wynosiła ok. 300. Vide: W. Bonusiak, Życie polityczne Rzeszowa w 20-leciu międzywojennym, [in:] Z przeszłości Rzeszowa. Materiały z konferencji naukowej w 640 lecie lokacji miasta zorganizowanej przez Muzeum Okręgowe w dniach 12-13. X. 1994, red. Małgorzata JAROSIŃSKA, Rzeszów 1995, s. 179.

40 Komitet Miejscowy PPS Rzeszów. Zaproszenie na odsłonięcie sztandaru PPS w Rzeszowie, APRz, KW PZPRwRz, sygn. 14728, k. 1.

41 Wspomnienia działaczy związkowych - Związek Zawodowy Kolejarzy 1. Jan Rak, 2. Kazimierz Chabaj - od roku 1918-1945, APRz, Wojewódzka Rada Związków Zawodowych w Rzeszowie, sygn. 9, k. 25. 
rzem Jan Mirek. Pod wpływem PPS-u znajdywały się także związki zawodowe kolejarzy, robotników rolnych, metalowców, dozorców oraz transportowców. PPS w wyborach wystawił listę $\mathrm{nr} 2$.

Na terenie Rzeszowa wpływy posiadali również komuniści. Rzeszowska organizacja zaczęła się rozwijać od $1925 \mathrm{r}^{42}$ Komitet Dzielnicowy Komunistycznej Partii Polskiej Rzeszów w marcu 1928 r. liczył 7 komórek i 25 członków. KPP prowadziła agitację przede wszystkim wśród rzemieślników i drobnomieszczaństwa, ponieważ zdecydowana większość robotników była pod wpływem PPS-u. W tym celu komuniści wykorzystywali w swojej działalności organizacje takie jak: Stowarzyszenie Wolnomyślicieli Polskich czy Stowarzyszenie Esperantystów. Do aktywnych działaczy wspomnianych stowarzyszeń należeli: Mieczysław Bomba, Jakub Graber, Stanisław Jerszyna, Józef Kubicz i Szymon Wang ${ }^{43}$. KPP wywierała też znaczy wpływ na PPS „Lewicę"44. Partia powstała w Rzeszowie w lipcu 1926 r., a w grudniu 1928 r. miała liczyć ok. 900 członków. Posiadała wpływy w związkach zawodowych, głównie w Związku Zawodowym Robotników Przemysłu Chemicznego i Pokrewnych. Na czele Komitetu Miejscowego stał Stanisław Maj, sekretarzem był Stanisław Kyc, a skarbnikiem Andrzej Warzybok ${ }^{45}$. Do nadchodzących wyborów obie partie lewicowe przystąpiły z listy nr 36 PPS „Lewicy”.

W wyborach parlamentarnych udział wzięli także Żydzi. W 1921 r. w Rzeszowie mieszkało ich 11 361, a powiecie rzeszowskim $15636^{46}$. Społeczność żydowska stanowiła zróżnicowaną mozaikę polityczną. W mieście działały następujące partie polityczne: Agudas Israel, Mizrachi, Poalej Syjon oraz Żydowska Partia Socjalistyczna („Bund”). Najsilniejsze były organizacje syjonistyczne, które posiadały wpływy wśród żydowskich kupców oraz zawodowej inteligencji. Utworzyły one Żydowski Fundusz Narodowy, za pomocą którego od 1926 r. finansowano ośrodek rzeszowskiej młodzieży w Niebylcu. Przygotowywano również młodzież do pracy w Palestynie ${ }^{47}$. Żydzi w Rzeszowie i powiecie rzeszowskim zgłosili dwie listy: 17 - Zjednoczenie Narodowe Żydowskie w Małopolsce oraz 33 - Ogólnożydowski Narodowy Blok Wyborczy do Sejmu i Senatu. W 1927 r. Żydowski Komitet Współpracy z Rządem wydawał bezpartyjny tygodnik „Przegląd Rzeszowski ${ }^{48}$.

42 Mariusz KrZYSZTOFiński, Komuniści na Rzeszowszczyźnie 1918-1944/1945, Rzeszów 2010, s. 34-35.

43 H. CIMEK, Ruch robotniczy na ziemi rzeszowskiej (1918-1939), [in:] Ruch robotniczy na ziemi rzeszowskiej 1918-1975, red. Bogusław SYZDEK, Warszawa 1980, s. 48.

4413 VI 1926 r. działacze lewego skrzydła Polskiej Partii Socjalistycznej utworzyli PPS „Lewicę”. Przewodniczącym nowopowstałej partii był Andrzej Czuma (do 1929 r.). Radykalno-socjalistyczna partia istniała do lutego 1931 r. Vide: Jan Tomicki, Polska Partia Socjalistyczna 1892 1945, Warszawa 1983, s. 280.

45 Malec Franciszek - ważniejsze wspomnienia. Powstanie i działalność PPS-Lewicy w Rzeszowie, APRz, KW PZPRwRz, sygn. 13950, k. 1-5.

46 Skorowidz miejscowości, s. 39.

47 Andrzej Pотоскі, Żydzi w Podkarpackiem, Rzeszów 2004, s. 159.

48 Adrian Uluasz, Z dziejów prasy lokalnej w II Rzeczypospolitej. Żydowski „Przeglad Rzeszowski” z 1927 i 1932 roku, „Przegląd Nauk Historycznych”, R. 15/nr 1: 2016, s. 132-133. 
Porównując życie polityczne Rzeszowa i powiatu do sąsiednich terenów można odnaleźć liczne podobieństwa. Przede wszystkim w okolicznych powiatach (niskim, jarosławskim, kolbuszowskim, łańcuckim czy przeworskim) istotną rolę odgrywał PSL „Piast”, dysponując tam licznymi kołami ${ }^{49}$. Warto jednak pamiętać, że w połowie lat dwudziestych z powodu perturbacji i konfliktów wewnętrznych znaczenie partii zaczęło maleć. Ponadto w 1926 r. na arenie życia politycznego pojawiła się poważna konkurencja w postaci Stronnictwa Chłopskiego, które zaczęło odgrywać coraz ważniejszą rolę. Oczywiście dotyczyło to przede wszystkim wsi, gdyż program ugrupowań ludowych docierał do tamtejszego elektoratu.

W miastach o głosy rywalizowali endecy z socjalistami. Jak zostało wcześniej wspomniane ruch narodowy pełnił ważne miejsce w życiu politycznym Rzeszowa (do 1926). Podobnie sytuacja wyglądała w Przemyślu, gdzie dzięki aktywności lokalnych działaczy nurt ten zaczął odgrywał poważniejszą rolę. W wyborach do sejmu w 1922 r. z ramienia Chrześcijańskiego Związku Jedności Narodowej posłem został wybrany Stanisław Rymar ${ }^{50}$. W pozyskiwaniu zwolenników nieoceniony okazał się tygodnik „Ziemia Przemyska”, będący głównym forum myśli narodowej na tym terenie. Swoją pozycję umacniał w mieście Związek Ludowo-Narodowy, w skład zarządu wchodziło 45 członków. Istotne funkcje kierownicze pełnili m.in. prezes Leonard Tarnawski i jego zastępcy Jan Godek oraz Karol Janicki ${ }^{51}$. Pomimo przewrotu majowego, koło przemyskiego ZLN nadal aktywnie uczestniczyło w życiu politycznym miasta. Wpływy w regionie przemyskim posiadali również socjaliści. Począwszy od $1919 \mathrm{r}$. PPS umacniała swoją pozycję. W wyborach do sejmu w 1922 r. mandat poselski otrzymał Herman Lieberman (jeden z przywódców partii, adwokat) ${ }^{52}$. Z powodu absorbujących obowiązków parlamentarnych, wymagających stałego pobytu w Warszawie, okazjonalnie przyjeżdżał do Przemyśla. Jednak starał angażować się w życie miasta m.in. przemawiał na wiecach. 23 stycznia 1927 r. działacze przemyskiego komitetu PPS-u i przyjaciele zorganizowali Liebermanowi jubileusz z okazji 30-lecia działalności społecznej w Przemyślu oraz 20-lecia pracy parlamentarnej ${ }^{53}$. Uro-

49 W Jarosławiu działy 64 koła, w Kolbuszowie - 15, w Łańcucie - 17, w Nisku - 36. Vide: Józef Ryszard SzAFLiK, Polskie Stronnictwo Ludowe Piast 1926-1931, Warszawa 1970, s. 41.

50 Wynik wyborów w okr. Przemyśl-Dobromil-Sanok-Krosno-Brzozów, „Ziemia Przemyska” nr 46: 1922 , s. 3.

51 Janusz MAJKA, Ruch narodowy w Przemyślu w latach II Rzeczypospolitej, „Rocznik Przemyski. Zeszyt Historia", t. XLV/z. 4: 2009, s. 156.

52 Herman Lieberman z okręgu przemyskiego był również posłem do Sejmu Ustawodawczego (1919-1922). Vide: T. RzePeCKI, Sejm Rzeczypospolitej Polskiej 1919 roku, Poznań 1920, s. 209-210.

53 Uroczystość odbyła się w sali teatralnej Domu Robotniczego. Przemówienia wygłosili m.in. adwokat dr Ludwik Grossfeld, poseł Norbert Barlicki, przewodniczący Związku Parlamentarnego Polskich Socjalistów, adwokat dr Zygmunt Marek, Stanisław Posner, gen. Andrzej Galica, dowódca Okręgu Korpusu w Przemyślu i burmistrz miasta Józef Kostrzewski, który podkreślił 
czystość stanowiła dowód uznania dla jego zasług, zarówno dla miasta, jak i całego kraju. Socjaliści w Przemyślu i powiecie przemyskim mogli liczyć na poparcie głównie robotników czy przedstawicieli związków zawodowych.

Powyższe przykłady świadczą o tym, że scena polityczna w Rzeszowie w odniesieniu do sąsiednich powiatów i terenów w pewnym stopniu kształtowała się podobnie. Duży wkład w rozwój organizacyjny poszczególnych partii położyli lokalni działacze oraz wybrani z tych okręgów posłowie. Na życie polityczne Rzeszowa, powiatu lub innych miast bez wątpienia wpływ miała także aktualna sytuacja w kraju nie tylko w zakresie politycznym, ale też i społeczno-gospodarczym. Aktywność organizacyjna partii działających na terenie Rzeszowa była odbiciem polityki państwowej i jej skutków (np. przewrót majowy). $Z$ drugiej strony wszelkie wydarzenia ogólnopolskie rzutowały dosyć wyraźnie na działania lokalne partii. Co prawda nie należy zapominać, że podejmowano także akcje odnoszące się wyłączenie do warunków lokalnych, kształtujących zróżnicowanie polityczne danego regionu lub miasta.

\section{Wybory do sejmu II kadencji}

Na mocy zarządzenia prezydenta Mościckiego $O$ wyborach do Sejmu i Senatu Rzeczypospolitej z 3 grudnia 1927 r. ustalono termin wyborów parlamentarnych. Wybory do sejmu zostały wyznaczone na 4 marca 1928 r., a do senatu na 11 marca $^{54}$. Adam Próchnik, historyk i działacz PPS-u, nachodzące głosowania traktował jako test zaufania społecznego do poszczególnych ugrupowań politycznych: „Wybory te miały większe znaczenie od zwyczajnych. Winny one były być sądem opinii publicznej i nad stronnictwami, które zwyciężyły w roku 1922 i odgrywały decydującą rolę w minionej kadencji, i nad przewrotem majowym, i nad przemianami, które po przewrocie nastąpiły w obozie rządzącym"55. Wybory w ujęciu lokalnym, a więc w Rzeszowie i powiecie rzeszowskim, miały wykazać na jakie poparcie społeczne mógł liczyć nowopowstały BBWR, a z drugiej strony pozostałe partie, zwłaszcza stronnictwa chłopskie.

Rzeszów należał do okręgu nr 47, do którego wchodziły miasta: Jarosław, Przeworsk, Łańcut i Nisko. Agitacja do sejmu stanowiła niewątpliwie element mobilizujący wszystkie partie do działania oraz pozwalający na propagowanie własnych założeń ideowych i programowych. Podobnie jak w skali kraju kampa-

zasługi Liebermana dla miasta. Organizatorzy jubileuszu przygotowali dla zaproszonych gości obiad, natomiast wieczorem odbył się raut. Vide: Zenon ANDRZEJEWski, Przemyskie watki w biografii Hermana Liebermana (cz. 2), „Palestra. Pismo Adwokatury Polskiej”, nr 9-10: 2011, s. 257.

54 „Dziennik Ustaw Rzeczypospolitej Polskiej” 1927, nr 107, poz. 916.

55 Adam Próchnik, Pierwsze piętnastolecie Polski niepodległej. Zarys dziejów politycznych, Warszawa 1983, s. 218. 
nia wyborcza poszczególnych ugrupowań prowadzona była na szeroką skalę. Blok prorządowy starał się dotrzeć do potencjalnych wyborców za pośrednictwem wzmożonej agitacji, w którą zaangażowała się administracja państwowa oraz samorządowa. Wykorzystywano także prasę regionalną. Tuż przed wyborami, w lutym 1928 r. powstał organ prasowy rzeszowskiego BBWR-u „Gazeta Rzeszowska”. Tygodnik podkreślał zasługi Piłsudskiego i nawoływał do głosowania na listę $\mathrm{nr} 1:$, „1» podobna też do cepa, którym się młóci zboże, by wyłuskać ziarno i oddzielić je od wszelkiej plewy. Puszczajcie więc - w Imię Boże cepy jedynki «na te chwasty, co nam pola nasze - do dziś dnia głoszą - trzeba kochać naszą Wiarą i Polskę nie połową, ale całą duszą»! - Niech żyje Marszałek Józef Piłsudski! Niech święci się 4 i 11 marca Zwycięstwo Jego listy Nr. 1"56. W całym okręgu BBWR wystawił do sejmu 13 kandydatów. Listę z powiatu rzeszowskiego otwierali: Jakub Bojko, Jan Kolanko - nauczyciel z Niżankowic oraz Roman Krogulski - burmistrz Rzeszowa. Obóz rządowy, który szedł do wyborów pod szyldem „Zjednoczenia Ludu”, wystawiając kandydaturę znanego działacza ludowego liczył na przeciągnięcie głosów mieszkańców wsi. Pozostali kandydaci BBWR-u z okręgu nr 47 pełnili różne funkcje, byli np. dyrektorami gimnazjum czy sekretarzami Rady Powiatowej ${ }^{57}$. Nie brakowało też rolników, kupców itd. Różnił ich również wiek - najmłodszy (Jan Draus) miał 25, a najstarszy (Jakub Bojko) 70 lat - a tym samym doświadczenie polityczne ${ }^{58}$.

$\mathrm{Na}$ łamach prasy obozu sanacyjnego zamieszczano sprawozdania $\mathrm{z}$ wieców przedwyborczych organizowanych na terenie powiatu rzeszowskiego. Odbyły się one m.in. w Głogowie oraz wsiach: Trzcianie, Chmielniku, Mrowli czy Stobiernej. Na spotkaniach przedstawiciele BBWR-u prezentowali program bloku, piętnowali partyjniactwo oraz nawoływali do jedności i zgody. Na wiecach zebrani uchwalili hołd dla prezydenta Ignacego Mościckiego i marszałka Piłsudskiego oraz złożyli deklarację głosowania na listę $\mathrm{nr} 1^{59}$. Agitację na rzecz BBWR-u prowadzili starostowie, wójtowie, sołtysi oraz lokalni działacze. Aktywność wykazywał Jan Kolanko, który pod koniec 1927 r. i na początku 1928 r. odbył kilka spotkań np. w Stobiernej, Trzcianie, Mrowli i Chmielniku ${ }^{60}$. Omawiał tam sytuację polityczną przed majem 1926 r., piętnował partyjniactwo oraz nawoływał do głosowania na listę Bloku. Na spotkania przybyli chłopi z pobliskich miejscowości, którzy uchwalili rezolucję popierającą politykę obozu sanacyjnego. Zaangażowany w agitację przedwyborczą był również dr Krogulski. Burmistrz miasta odbył klika spotkań, m.in. 26 lutego 1928 r. w sali Sokoła w Rzeszowie ${ }^{61}$.

\footnotetext{
56 J. Grom, Symbol jedynki, „Gazeta Rzeszowska”, nr 1: 1928, s. 4.

57 Afisze Okręgowej Komisji Wyborczej w Rzeszowie i Lwowie 1927-1928, APRz, Okręgowa Komisja Wyborcza w Rzeszowie [dalej: OKW RZ], sygn. 16, k. 1.

58 Ibidem.

59 Sprawozdanie wiecowe BBWR z powiatu rzeszowskiego, „Gazeta Rzeszowska”, nr 1: 1928, s. 3.

60 Ibidem.

61 „Gazeta Rzeszowska”, nr 3: 1928, s. 2.
} 
Propagandę na rzecz BBWR prowadziła również prorządowa „Gazeta Lwowska”. Dziennik pozytywnie wypowiadał się na temat zmian dokonanych przez obóz sanacyjny. Popierał Piłsudskiego i chwalił jego dokonania. $Z$ drugiej strony wzywał obywateli do udziału w wyborach i spełnienia obywatelskiego obowiązku: „Kartka wyborcza będzie egzaminem każdego z nas z jego dojrzałości obywatelskiej i charakteru obywatelskiego"62.

Pod względem haseł głoszonych przez BBWR kampania wyborcza w powiecie rzeszowskim niewiele różniła się od sąsiednich powiatów i terenów. Zbliżonymi sloganami operowano np. w Przemyślu i powiecie przemyskim: „Zastanówcie się głęboko! Jeżeli kochacie Polskę, jeżeli Wasze kochacie dzieci, nie dopuście do tego, aby ludzie niegodni Wami rządzili, a w Polsce prawa stanowili. Ostrzegamy Was przed obłudnikami, którzy w swych odezwach i przemówieniach powołują się na Marszałka Piłsudskiego, a idąc przeciw Niemu i Jego Liście, wystawiając listy własne. Tu nie ma wyboru: Kto nie idzie z Nim - idzie przeciw Niemu" ${ }^{63}$. W Przemyślu, inaczej niż w Rzeszowie, aktywną kampanię na rzecz obozu sanacyjnego prowadziły kobiety, które popierały tę opcję polityczną - 12 stycznia 1928 r. z inicjatywy Heleny Stieberowej powstał tam Demokratyczny Komitet Wyborczy Kobiet Polskich ${ }^{64}$.

Agitację przedwyborczą z wykorzystaniem organów prasowych prowadziła również endecja, która przystąpiła do wyborów jako Blok Katolicko-Narodowy, w skład którego wchodziły: Związek Ludowo-Narodowy, Stronnictwo Chrześcijańsko-Narodowe, Polskie Stronnictwo Chrześcijańskiej Demokracji oraz organizacje katolickie. Na łamach tygodników związanych z obozem narodowym, „Ziemi Rzeszowskiej” oraz „Głosu Jarosławskiego”, przedstawiano programy, sprawozdania $\mathrm{z}$ wieców oraz hasła nawołujące do głosowania na listę $\mathrm{nr} 24$. Podkreślano tam silny związek z Kościołem katolickim oraz przywiązanie do jego tradycji i nauki: „Polaku i Polko Katoliczko!, Chcesz Polski Katolickiej, Chcesz aby Księdza nie usunięto ze szkoły, Chcesz aby zapanowała sprawiedliwość i praworządność, Chcesz katolickiej ochrony i obrony robotnika i bezrolnego, Chcesz ukrócenia buty rozpanoszonego żydowstwa, chcesz spolszczenia miast, Chcesz wybrać prawdziwie katolickich i narodowych posłów głosuj na nr 24"65.

62 Z Państwem czy przeciw Państwu?, „Gazeta Lwowska”, nr 53: 1928, s. 1.

63 Wybory do Sejmu i Senatu RP - odezwa Komitetu Wyborczego BBWR dla miasta Przemyśla do wyborców, nawołująca do głosowania na listę nr 1-BBWR, Archiwum Państwowe w Przemyślu, Afisze, plakaty i druki ulotne z terenu Przemyśla w zasobie Archiwum Państwowego w Przemyślu, sygn. 346, k. 1.

6416 grudnia 1927 r. w Warszawie ukonstytuował się Demokratyczny Komitet Wyborczy Kobiet Polskich. Komitet w okresie kampanii wyborczej prowadził aktywną agitację na rzecz BBWRu. Zakładał komitety powiatowe np. w Sanoku, Krośnie, Dobromilu czy tworzył też komitety obwodowe w okolicznych wsiach i miasteczkach. Vide: Regulamin Demokratycznego Komitetu Wyborczego Kobiet Polskich, Warszawa 1928, s. 1-2; Z ruchu przedwyborczego, „Tygodnik Przemyski”, nr 5: 1928, s. 2-3.

65 „Ziemia Rzeszowska”, nr 9: 1928, s. 1. 
Publicyści zamieszczali także hasła odnoszące się do kobiet i ich postawy: „Kobieto Polko! Która od dzieciństwa do grobowej deski nosisz na piersiach znamię wiary katolickiej, czy możesz inaczej głosować jak na listę nr. 24?’66. Poza tym zachęcano czytelników do wpłacania pieniędzy na fundusz wyborczy - zebrane środki miały zostać przeznaczone na agitację w terenie oraz drukowanie ulotek ${ }^{67}$.

$\mathrm{W}$ prasie katolicko-narodowej przypominano przepisy ordynacji wyborczej do sejmu oraz zasady głosowania: „Głosowanie przy wyborach sejmowych w dniu 4 marca rozpoczyna się o godzinie 9 rano i trwa bez przerwy do godziny 9 wieczorem. Wyborca zanim uda się do sali, w której urzęduje komisja wyborcza, winien zaopatrzyć się w kartkę do głosowania. Kartka do głosowania winna być koloru białego z obu stron, a na jednej stronie winien być napisany lub wydrukowany numer: $24{ }^{\prime 68}$. Z drugiej strony publicyści starali się wpływać na zachowania i postawy wyborców, sugerując kogo powinni poprzeć: „Wielu wyborców będzie w kłopocie, na którą listę oddać swój głos. Czy na socjalistów, którzy dążą do rozdziału kościoła od państwa, usunięcia religii ze szkoły, którzy szkalują nasze duchowieństwo [...] Czy oddać głosy na listę Związku Chłopskiego, na którego czele stanęli rozmaici ludzie, którzy i sami nie są chłopami i z chłopem nie mają nic wspólnego, a dążą tylko do rozbicia włościaństwa na drobne grupki w tej nadziei, że na takiem rozbiciu mogą tylko zarobić, w myśl zasady, gdzie się dwóch bije, tam trzeci korzysta [...] A może głosować na listę „Wyzwolenia”, na czele której stoją znów ludzie, którzy połączyli się z żydami, którzy do spółki z tymi wrogami polskości chcą wyzwolić handel i przemysł z rąk polskich" ${ }^{\circ 9}$. Jednocześnie przedstawiano postulaty listy katolickiej: „Czy wreszcie głosować na listę katolicko-narodową, której zwolennicy bronią polskości i pragną, by handel i rzemiosło znajdywały się w rękach Polaków, by nauka religii odbywała się jak dotychczas w naszych szkołach, by ślub małżeński był sakramentem nierozerwalnym, by kościoły i duchowieństwo było szanowane". Analizując prasę obozu narodowego należy stwierdzić, że publicyści dosyć często krytykowali działania poszczególnych partii politycznych w czasie kampanii, zwłaszcza prowadzonej przez BBWR. Atakowano kandydatów obozu rządowego, w tym głównie R. Krogulskiego. Burmistrzowi Rzeszowa zarzucano brak odpowiedzialności za losy miasta, niechlujstwo, niedbanie o interesy obywateli oraz niegospodarnośśc ${ }^{70}$.

Prasa prawicowa publikowała także listy kandydatów Bloku Katolicko-Narodowego do sejmu, przedstawiała ich krótkie życiorysy. Podkreślała zaangażowanie działaczy w życiu społeczno-gospodarczym oraz politycznym ${ }^{71}$. Na liście

66 Ibidem.

67 „Ziemia Rzeszowska”, nr 6: 1928, s. 2.

68 „Ziemia Rzeszowska”, nr 9: 1928, s. 1.

69 Na kogo głosować?, „Głos Jarosławski”, nr 3: 1928, s. 2.

70 Dr. Krogulski jako protektor żydów, jako gospodarz miasta, jako katolik, „Ziemia Rzeszowska”, nr 7: 1928, s. 2.

71 „Głos Jarosławski”, nr 6: 1928, s. 1. 
nr 24 na pierwszych trzech miejscach znaleźli się: dr Józef Liwo - adwokat z Rzeszowa i wieloletni redaktor „Ziemi Rzeszowskiej”, dr Teofil Nieć - lekarz oraz Michał Stępak - naczelnik gminy w Wiązownicy i były poseł na Sejm Krajowy $^{72}$. W całym okręgu wystawiano łącznie 14 kandydatów, pochodzących z powiatów: jarosławskiego, łańcuckiego, niżańskiego, przeworskiego i rzeszowskiego. W kampanię wyborczą zaangażowany był przede wszystkim Liwo, który brał udział w spotkaniach z wyborcami. Na jednym z nich 28 stycznia $1928 \mathrm{r}$. wygłosił przemówienie, w którym wzywał wszystkich katolików i Polaków do współpracy: „Pod hasłem jedności katolickiej, pod hasłem dobra państwa i Kościoła, nie walki z nim, iść należy do wyborów, a nie słuchać tych którzy bałamucą, obiecują za darmo rozdzielić grunta, a sami czym prędzej je kupują"73. W podobny sposób kampanię wyborczą prowadziła endecja w Przemyślu, gdzie na łamach tygodnika „Ziemi Przemyskiej” zachęcano do głosowania na listę nr 24.

W trudnej sytuacji do wyborów przystąpił PSL „Piast”. Targana problemami wewnętrznymi partia musiała odnaleźć się w nowej sytuacji politycznej. „Piastowcy" zdawali sobie sprawę, że o głosy w regionie będą musieli rywalizować z innymi poważnymi graczami na scenie politycznej, głownie z BBWR-em i Stronnictwem Chłopskim, które na terenie Rzeszowa oraz powiatu rzeszowskiego posiadało mocną pozycję. Do wyborów PSL „Piast” poszedł razem z chadecją. Policy ugrupowania wiedzieli, że trudno będzie o powtórzenie wyników z 1922 r. ${ }^{74}$ Niepokój wzbudzał również start Bojki z listy BBWR, gdyż mógł odebrać swojej byłej partii znaczną ilość głosów. W tygodniku „Piast” pisano, że: „Bojko jest tylko parawanem, wabikiem na chłopów przy wyborach”. W ten sposób przestrzegano wyborców przed oddawaniem na niego głosów. Jednocześnie podkreślano, że nie bez przyczyny kandydował w kilku miejscowościach: w Tarnowie, Jaśle, Samborze, Tarnopolu, Przemyślu i Rzeszowie. W razie osiągnięcia tam sukcesu umożliwiał wprowadzenie do sejmu innym kandydatów BBWR-u, gdyż mógł objąć mandat tylko z jednego okręgu: „Bojko w tylu okręgach posłem być nie może, więc się zrzeknie i zostanie nim następny z listy”75.

PSL „Piast” starał się prowadzić kampanię z rozmachem. Na terenie okręgu 47 przedstawiciele partii odbywali liczne wiece oraz zgromadzenia. Najbardziej zaangażowany w agitację był Jan Pieniążek, poseł sejmu I kadencji (1922-1927), otwierający listę okręgową Polskiego Bloku Katolickiego ${ }^{76}$. W czasie wieców

72 „Ziemia Rzeszowska”, nr 7: 1928, s. 1.

73 „Ziemia Rzeszowska”, nr 5: 1928, s. 2.

74 W wyborach do sejmu w 1922 r. PSL „Piast” uzyskał w skali kraju 70 mandatów, stając się tym najsilniejszą partią chłopską. Vide: T. RZEPECKI, W. RZEPECKI, Sejm i Senat Rzeczypospolitej Polskiej 1922, s. 296-297, 351.

75 G. JАкÓвCZYк, Samotrzaski p. Bojki, „Piast”, nr 7: 1928, s. 3.

76 Jan Pieniążek od 1920 r. pełnił wójta gminy Mokra Strona. Dzięki pełnieniu tej funkcji mógł zetknąć się z problemami mieszkańców wsi, jak i sprawami gminnego samorządu. Pieniążek wójtem gminy był do 1933 r. Vide: Seweryn PiENIĄŻEK, Jan Pieniążek (1881-1963), działacz ludowy i posel, Rzeszów 2010, s. 40. 
sporo uwagi poświęcał odejściu Bojki, który był jego rywalem w nachodzących wyborach. 21 grudnia 1927 r. w Przeworsku na zjeździe delegatów, mężów zaufania i wójtów z terenu powiatu wyjaśnił dlaczego Bojko wyszedł z „Piasta”. W swoich przemówieniach poruszał wiele tematów i zagadnień, np. omawiał bieżącą sytuację polityczną. Wystąpienia Pieniążka były długie. Według relacji prasowej zjazd trwał 2 godziny ${ }^{77}$. Uczestnicy spotkania podziękowali Pieniążkowi za dotychczasową pracę w sejmie oraz na terenie powiatu przeworskiego. Delegaci poparli jednogłośnie jego kandydaturę w wyborach. Były poseł wyjaśniał również różnice programowe między stronnictwami chłopskimi, wchodził w dyskusje z ich zwolennikami, np. w Medyni Głogowskiej ${ }^{78}$. Aktywnością wykazywali się także inni kandydaci, w tym Andrzej Kuś, który na zgromadzeniu przedwyborczym 2 lutego 1928 r. w Lubeni (powiat rzeszowski), stwierdził, ,że o ile nowy Sejm będzie wybrany z ludzi uczciwych, a nie dorobkiewiczów i karierowiczów, można liczyć na lepszą przyszłość"79. W zgromadzeniach oraz spotkaniach brał udział też Bruno Gruszka (poseł I kadencji), występując głównie na terenie powiatu jarosławskiego np. w Bystrowicach, Hawłowicach oraz Roźwienicy ${ }^{80}$.

O głosy mieszkańców wsi zabiegało też Stronnictwo Chłopskie. W okręgu $47 \mathrm{z}$ ramienia stronnictwa o mandat poselski ubiegali się: Andrzej Pluta - rolnik ze Szklar (powiat rzeszowski), Marcin Socha - urzędnik kolejowy z Rudnika nad Sanem (powiat niżański), Jan Sobek - rolnik z Handzlówki (powiat łańcucki), Eugeniusz Opolski - rolnik z Brzezówki (powiat rzeszowski), Stanisław Janusz - rolnik z Mokrej Strony (powiat przeworski), Tomasz Wójcik - rolnik z Rudnej Wielkiej (powiat rzeszowski), Antoni Kudła - rolnik z Pełkiń (powiat jarosławski) oraz Leon Żygadło - rolnik z Łopuszki Wielkiej (powiat przeworski) ${ }^{81}$. Warto zaznaczyć, że Pluta, Sobek i Socha byli byłymi posłami I kadencji, wówczas reprezentującymi klub „Piasta”. Niewątpliwie spośród wszystkich kandydatów wzmożoną aktywność wykazywał Pluta, który w okresie kampanii wyborczej brał udział w szeregu zgromadzeń, zarówno w powiecie rzeszowskim, jak i na terenie okręgu $\mathrm{nr} 47^{82}$. Przedstawiciele Stronnictwa Chłopskiego na zgromadzeniach i wiecach nie tylko prezentowali program wyborczy, ale również krytykowali działaczy ludowych, w tym przede wszystkim Jana Stapińskiego, przewodniczącego Związku Chłopskiego. „Przyjaciel Ludu”, organ prasowy Związku Chłopskiego, informował, że Pluta, Opolski, Socha i Janusz na zgromadzeniach w Rzeszowie, Jarosławiu, Łańcucie, Przeworsku i Rudniku nad Sanem piętnowali postawę oraz działania Stapińskiego: „Ogłosili, że Stapiński idzie

77 Relacja S. Kapusty, „Piast”, nr 3: 1928, s. 5.

78 Z ruchu wyborczego, „Piast”, nr 10: 1928, s. 3.

79 Relacja J. Pietrzyk, „Piast”, nr 8: 1928, s. 4.

80 Relacja Piastowiec z Pruchnickiego, „Piast”, nr 10: 1928, s. 3.

81 Afisze Okręgowej Komisji Wyborczej w Rzeszowie i Lwowie 1927 i 1928, APRz, OKW RZ, sygn. $16, \mathrm{k} .1$.

82 T. KOWALSKI, op. cit., s. 81. 
z obszarnikami i księżmi, czyli zdradza nas chłopów". Gazeta broniła przywódcę Związku Chłopskiego, zaś kandydatów Stronnictwa Chłopskiego nazywała zdrajcami: „Ale kłamstwo wyszło wnet na jaw, oszołomienie minęło, chłopi widzą, że Stapiński broni chłopów najlepiej, a kłamcy podcięli sami siebie w opinii chłopskiej" "3. Jak widać, w okresie agitacji przedwyborczej, kandydaci Stronnictwa Chłopskiego zmagali się z ostrą krytyką ze strony innych partii chłopskich, głównie Związku Chłopskiego. Na łamach prasy ludowej atakowano przede wszystkim jednego z liderów stronnictwa - Plutę. Obwiniano go m.in. za rozbicie ruchu ludowego czy kupowanie folwarków dla dzieci ${ }^{84}$.

Na terenie powiatu rzeszowskiego swoją obecność w okresie kampanii wyborczej zaznaczył Związek Chłopski. W wyborach do sejmu w okręgu 47 lista nr 14 wystawiła 14 kandydatów. Na pierwszym miejscu znalazł się Józef Nadzieja podchodzący z Zarzecza (powiat niżański), a mieszkający w Rzeszowie. W prasie przedstawiano jego kandydaturę i informowano o najważniejszych dokonaniach w życiu publicznym oraz społecznym: „Nadzieja Józef, nasz pierwszy kandydat, daje zupełną gwarancję, że organizacja Związku Chłopskiego w tym okręgu stanie się $\mathrm{w}$ krótkim czasie pierwszorzędną siłą polityczną. Jest to człowiek niezłomnych przekonań ludowych, nie karierowicz [...] Ukończywszy studia prawnicze, był zastępcą sekretarza Rady pow. w Rzeszowie i wówczas wprowadził biuro bezpłatnych porad prawnych. Za pracę $w$ tajnej organizacji POW otrzymał krzyż walecznych [...] Od r. 1921 do 1924 był dyrektorem Kasy chorych w Rzeszowie. Od r. 1925 jest wspólnikiem kancelarii adwokackiej, ale i na tym stanowisku nie patrzy majątku, lecz służy dobru publicznemu"85. Jednocześnie zachęcano do głosowania na listę nr 14 pod hasłem: „Pamiętajcie Bracia Chłopi!, głosujcie tylko na 14". Związek Chłopski, jako organizacja prosanacyjna, podkreślał współpracę z obozem rządowym oraz z Piłsudskim: „Nr 14 - jako jedyna w rzeszowskim okręgu lista chłopska współpracy z Rządem Marszałka Piłsudskiego!”. „Przyjaciel Ludu” w jednym z numerów zaznaczył, że kandydaci z listy chłopskiej pracowali z marszałkiem przed wojną, kiedy organizowali w Rzeszowie „Strzelca” i po wojnie, gdy pomagali organizować armię polską ${ }^{86}$. Przywołane powyżej fakty świadczą o tym, że rywalizacja między poszczególnymi stronnictwami chłopskimi była zacięta. Partie stosując różne metody i środki starały się przekonywać swoich zwolenników do głoszonych poglądów i idei.

Wybory do sejmu odbyły się 4 marca $1928 \mathrm{r}$. według ordynacji wyborczej z $1922 r{ }^{87} \mathrm{~W}$ skali kraju zgłoszono 35 list wyborczych, a w okręgu rzeszowskim -12 .

83 „Przyjaciel Ludu”, nr 4: 1928, s. 5.

84 Co zrobil Pluta chtopom-wyborcom za 9 lat postowania, a co sobie?, „Przyjaciel Ludu”, nr 2:

1928, s. 2.

85 „Przyjaciel Ludu”, nr 7: 1928, s. 5.

86 „Przyjaciel Ludu”, nr 9: 1928, s. 5.

87 „Dziennik Ustaw Rzeczypospolitej Polskiej” 1922, nr 66, poz. 590. 
Tabela 1. Listy wyborcze w powiecie rzeszowskim

\begin{tabular}{|l|}
\hline Lista nr 1 - Bezpartyjny Blok Współpracy z Rządem \\
\hline Lista nr 2 - Polska Partia Socjalistyczna \\
\hline Lista nr 3 - Polskie Stronnictwo Ludowe „Wyzwolenie” \\
\hline Lista nr 10 - Stronnictwo Chłopskie \\
\hline Lista nr 14 - Związek Chłopski \\
\hline Lista nr 17 - Zjednoczenie Narodowe Żydowskie w Małopolsce \\
\hline Lista nr 20 - Ruska \\
\hline Lista nr 24 - Blok Katolicko Narodowy \\
\hline $\begin{array}{l}\text { Lista nr } 25 \text { - Polski Blok Katolicki Polskiego Stronnictwa Ludowego „Piast” i Chrześcijańskiej } \\
\text { Demokracji }\end{array}$ \\
\hline Lista nr 30 - Katolicka Unia Ziem Zachodnich( druga lista rządowa BBWR) \\
\hline Lista nr 33 - „Ogólnożydowski Narodowy Blok Wyborczy do Sejmu i Senatu \\
\hline Lista nr 36 - PPS „Lewica” \\
\hline
\end{tabular}

Na podstawie: T. RzEPECKI, K. RzEPECKI, Sejm i Senat Rzeczypospolitej Polskiej 1928-1933, Poznań 1928, s. 13.

Mieszkańcy Rzeszowa posiadający czynne prawo wyborcze mieli możliwość sprawdzenia swoich nazwisk na listach wyborczych, wystawionych w 10 obwodowych komisjach wyborczych ${ }^{88}$. Nieprawidłowości mogli zgłaszać do 15 stycznia 1928 r. Zdarzały się przypadki, że wyborcy, którzy nie zauważyli w spisach wyborców do sejmu swoich nazwisk, zwracali się z pisemną próbą do komisji o umieszczenie ich na liście wyborczej ${ }^{89}$. W reklamacjach podawano dane personalne: imię i nazwisko, datę i miejsce urodzenia, miejsce zamieszkania oraz wykonywany zawód. W powiecie rzeszowskim działało w sumie 97 obwodowych komisji wyborczych. Najwięcej komisji w okręgu 47 było w powiecie jarosławskim - aż 113. W powiecie łańcuckim znajdywało się ich 70 , w niżańskim 63 , a w przeworskim $50^{90}$.

Nad prawidłowym przebiegiem głosowania czuwała Okręgowa Komisja Wyborcza w Rzeszowie, na czele której stał przewodniczący, sędzia Sądu Okręgowego Alojzy Bojdecki, a jego zastępcą był Franciszek Tichy. Lokal urzędowy Komisji znajdował się w gmachu Sądu Okręgowego w Rzeszowie na II piętrze. Dla osób zainteresowanych otwarty był codziennie od godziny 8 do 13 po południu. Przewodniczący, względnie jego zastępca przyjmował interesantów w sprawach wyborczych od godziny 12 do $13^{91}$.

88 Obsada personalna obwodowych komisji wyborczych, powiat Rzeszów 1927, APRz, OKW RZ, sygn. 35, k. 13-14.

89 Protokoły z posiedzeń i korespondencja obwodowych komisji wyborczych, powiat Rzeszów, ibidem, sygn. 36, k. 172.

90 Zestawienie powiatowe uprawnionych do głosowania. Dziennik podawczy 1927-1928, ibidem, sygn. 17, k. 32-50.

91 Afisze Okręgowej Komisji Wyborczej w Rzeszowie i Lwowie 1927-1928, ibidem, sygn. 16, k. 29. 
Okręgowa Komisja Wyborcza w Rzeszowie odbyła w sumie 8 posiedzeń. Pierwsze odbyło się 16 grudnia 1927 r., ostatnie 7 marca 1928 r. Na spotkaniach omawiano sprawy dotyczące wyborów: zatwierdzano zmiany członków i zastępców komisji wyborczych, składano sprawozdania z poszczególnych komisji, rozpatrzono reklamacje wyborców itd. ${ }^{92}$ Poszczególne komisje wyborcze składały się z 3 członków i 3 zastępców. Uchylenie się od pełnienia obowiązku (członków lub zastępców komisji) bez podania usprawiedliwienia skutkowało grzywną, a prawo nakładania kar przysługiwano przewodniczącemu Okręgowej Komisji Wyborczej. Przypadki takie zdarzały się również w Rzeszowie, gdzie jeden zastępców członka obwodowej komisji wyborczej nr 96 (Abraham Hofstäter) bez podania przyczyny uchylił się od wykonania obowiązku urzędowania przy wyłożeniu list wyborczych 12 stycznia 1928 r. Przewodniczący Okręgowej Komisji Wyborczej w Rzeszowie nałożył na niego 50 zł grzywny ${ }^{93}$. $Z$ analizy materiałów archiwalnych wynika, że członkowie komisji wyborczych i ich zastępcy wykonywali różne zawody: rolnik, krawiec, kupiec, murarz, fryzjer czy ślusarz. Nie brakowało też przedstawicieli klasy średniej i wyższej np. urzędników, nauczycieli, adwokatów, profesorów czy przemysłowców ${ }^{94}$. Przewodniczący Okręgowej Komisji Wyborczej w Rzeszowie Bojdecki w celu ułatwienia pracy obwodowym komisjom wyborczym opublikował pismo, w którym przypominał poszczególne przepisy ordynacji wyborczej, normujące sposób przeprowadzenia głosowania ${ }^{95}$. Według zasad głosowanie powinno odbywać się w lokalu, który oznaczono w afiszach wyborczych. W czasie głosowania obecni mieli być przynajmniej przewodniczący i dwaj członkowie komisji. Uprawnionymi do głosowania były osoby, które figurowały w spisie wyborców. Głosowanie odbywało się od godziny 9 do $21^{96}$. Karty do głosowania były koloru białego, opatrzone pieczęcią urzędową komisji okręgowej. Ważne zadanie przypadło mężom zaufania, obserwującym przebieg głosowania. Do ich praw należało zasiadanie przy stole komisyjnym, podnoszenie zarzutów przeciw tożsamości wyborców i podpisywanie protokołów oraz oświadczeń. Bojdecki zwracał także uwagę na odpowiednie przygotowywanie plakatów, informujących o wyborach do sejmu i senatu. Według zarządzenia, ogłoszenia powinny były być rozlepione we wszystkich miejscowościach, przynajmniej po jednym egzemplarzu. Natomiast $\mathrm{w}$ razie potrzeby, zastępowane do końca procedury wyborczej ${ }^{97}$.

92 Księga protokołów i protokół czynności Okręgowej Komisji Wyborczej w Rzeszowie 19271928, ibidem, sygn. 18, k. 2-14.

93 Protokoły z posiedzeń obwodowych komisji wyborczych (Rzeszów). Korespondencja Okręgowej Komisji Wyborczej w Rzeszowie z obwodowymi komisjami wyborczymi 1927-1928, ibidem, sygn. 37, k. 71.

94 Obsada personalna obwodowych komisji wyborczych, powiat Rzeszów, ibidem, sygn. 35, k. 132-134.

95 Przepisy ordynacji wyborczej 1928, ibidem, sygn. 14, k. 1-4.

96 Głosowanie przerywano jedynie w razie wybuchu pożaru czy powodzi. W takim wypadku akta i urnę opieczętowywano pieczęcią i oddawano przewodniczącemu do przechowania.

97 Afisze Okręgowej Komisji Wyborczej w Rzeszowie i Lwowie 1927-1928, APRz, OKW RZ, sygn. 16, k. 4. 
Do wyborów przygotowywały się także instytucje rządowe. Koordynatorem akcji strony rządowej był przede wszystkim Kazimierz Świtalski, dyrektor Departamentu Politycznego $\mathrm{MSW}^{98}$. Jako jeden z kierowników kampanii wyborczej BBWR brał udział $\mathrm{w}$ rozmowach $\mathrm{z}$ różnymi odłamami ugrupowań prorządowych, przedstawicielami partii opozycyjnych. Świtalski sterował także działalnością lokalnej administracji państwowej. W grudniu 1927 r. odbył kilka podroży po kraju, w celu zapoznania starostów i wojewodów z ,ogólną platformą wyborczą, którą idzie lista rządowa" ${ }^{99}$. Administracja państwowa tym sposobem została upoważniona do wspierania bloku rządowego oraz list mniejszych ugrupowań sanacyjnych. Wywierano również naciski na urzędników samorządowych i państwowych by głosowali na BBWR ${ }^{100}$. Nie stosujących się do zaleceń urzędników zwalniano z zajmowanych stanowisk. W walce wyborczej obozu rządowego istotny wpływ odegrali również nauczyciele. Za pośrednictwem odezw, druków apelowali do głosowania na listę $\mathrm{nr} 1$. Agitację na rzecz sanacji prowadził w tym przypadku np. Centralny Nauczycielski Komitet Wyborczy Współpracy z Marszałkiem Piłsudskim ${ }^{101}$. W akcję prorządową zaangażowane było również Ministerstwo Spraw Wewnętrznych. Próchnik pisał, że: „Jednym ze skutecznych środków akcji prorządowej było nakazanie okólnikiem ministra spraw wewnętrznych, aby akta wyborcze przekazywano do komisji okręgowych za pośrednictwem policji i starostw" ${ }^{102}$. W okresie przedwyborczym wydawano różne rozporządzenia, głównie o charakterze porządkowym. Wojewoda lwowski wydał zakaz sprzedaży, wyszynku i podawania napojów alkoholowych w dniach 2, 3 i 10 marca 1928 r. Starostwo w Rzeszowie w myśl tego zarządzenia, wydało ograniczenia obowiązujące: w przypadku wyborów do sejmu od 1 marca od godziny 15 po południu do 5 marca do 10 rano, natomiast w związku wyborami do senatu od 9 marca $1928 \mathrm{r}$. od godziny 15 po południu do 12 marca $1928 \mathrm{r}$. do godziny 10 rano $^{103}$. Tego rodzaju zakazy miały na celu zapewnienie porządku publicznego i spokoju w ostatnich godzinach przed wyborami, jak i w czasie samego głosowania. $\mathrm{W}$ innym piśmie zwracano uwagę, aby wszystkie lokale wyborcze na terenie powiatu były należycie opalone, oświetlone przynamniej na 10 godzin oraz zaopatrzone w niezbędne sprzęty i przybory kancelaryjne (papier, ołówek, atrament, pióro) ${ }^{104}$. Starosta rzeszowski dr Artur Friedrich polecał również Komendantom Posterunku Policji Państwowej, aby w porozumieniu z przewodniczą-

98 Waldemar KozYra, Polityka Ministerstwa Spraw Wewnętrznych wobec życia spoleczno-politycznego w Polsce w latach 1926-1928. Wybory parlamentarne z 4 i 11 marca 1928 r., „Studia z Dziejów Państwa i Prawa Polskiego", R. 20: 2017, s. 407-408.

99 Kazimierz ŚwITALSKI, Diariusz 1919-1935, Warszawa 1992, s. 295.

${ }^{100}$ Pracownicy państwowi a wybory, Warszawa 1928, s. 3-6.

${ }^{101}$ Stoimy wobec historycznych wydarzeń, wobec zmagań się idei państwowości młodego naszego państwa z brakami i wadami narodowemi, Warszawa 1928, s. 1.

102 A. PróchniK, op. cit., s. 225.

${ }^{103}$ Okólniki dotyczące wyborów 1928, APRz, OKW RZ, sygn. 15, k. 65.

${ }^{104}$ Ibidem, k. 74. 
cymi komisji wyborczych organizowali zbiórkę akt wyborczych. Poza starostwem w Rzeszowie zarządzenia związane z wyborami wydawały także inne instytucje. Dyrekcja Kolei Państwowych we Lwowie w jednym z okólników podkreślała jak ważną rolę w okresie przedwyborczym odgrywają środki łączności, w tym linie telefoniczne. Członkowie komisji i biur wyborczych mieli mieć ułatwiony dostęp do telefonów kolejowych, będących do dyspozycji pracowników kolei. Telefon mógł być użyty, gdy nie był potrzebny do porozumienia się $\mathrm{w}$ sprawie zabezpieczenia ruchów pociągów ${ }^{105}$. Ważną rolę $\mathrm{w}$ czasie trwania kampanii wyborczej pełnił też Generalny Komisarz Wyborczy, który sprawował nadzór nad czynnościami komisji wyborczych. Komisarzem, wbrew obowiązującemu prawu, został nie figurujący na liście, wiceminister sprawiedliwości Stanisław Car ${ }^{106}$. W okólnikach wyborczych przypominał przewodniczącym okręgowych komisji wyborczych, członkom oraz ich zastępcom ważniejsze zasady ordynacji wyborczej. Zwracał uwagę na kalendarz wyborczy, określający terminy dokonywania „czynności wyborczych”. Starał się on także narzucić terenowym komisjom wyborczym przyjmowanie różnych wytycznych, zgodnie którymi unieważniono listy wyborcze opozycji, głównie partii rewolucyjnych. Widać więc, że na terenie okręgu 47, a także w powiecie rzeszowskim nie tylko silna była propaganda partii politycznych, ale również ze strony instytucji rządowych oraz samorządowych. $Z$ jednej strony przypominając poszczególne ustawy i zarządzenia starano się nie tylko zapewnić spokój przed wyborami, ale także ułatwić pracę starostwom i poszczególnych komisjom wyborczym. Z drugiej strony agitacja partyjna i samorządowa, miała przyczynić się do wysokiej frekwencji.

Tabela 2. Wyniki wyborów do sejmu w 1928 r. w Rzeszowie i powiecie rzeszowskim

\begin{tabular}{|c|c|c|c|c|c|}
\hline \multirow{2}{*}{$\begin{array}{c}\text { Numer } \\
\text { listy }\end{array}$} & Nazwa listy & w Rzeszowie & $\begin{array}{c}\text { w powiecie } \\
\text { rzeszowskim }\end{array}$ & $\begin{array}{c}\text { w okręgu nr } \\
47\end{array}$ & $\begin{array}{c}\text { Liczba } \\
\text { mandatów }\end{array}$ \\
\cline { 3 - 6 } & BBWR & 2704 & 9862 & 24858 & 1 \\
\hline 1 & PPS & 1417 & 6137 & 14387 & 1 \\
\hline 3 & PSL „Wyzwolenie” & 9 & 394 & 2813 & - \\
\hline 10 & Stronnictwo Chłopskie & 9 & 25217 & 63757 & 4 \\
\hline 14 & Związek Chłopski & 41 & 2379 & 11127 & - \\
\hline 17 & $\begin{array}{c}\text { Zjednoczenie } \\
\text { Narodowe Żydowskie } \\
\text { w Małopolsce }\end{array}$ & 3019 & 4224 & 13948 & - \\
\hline
\end{tabular}

105 Ibidem, k. 54.

${ }^{106}$ Według ordynacji wyborczej z 1922 r. Generalnego Komisarza Wyborczego i jego zastępcę mianował na wniosek Prezesa Rady Ministrów prezydent. Wyboru dokonywano z pośród 3 kandydatów przedstawionych przez Zgromadzenie Prezesów Sądu Najwyższego, „Dziennik Ustaw Rzeczypospolitej Polskiej” 1922, poz. 590, nr 66. 
Tabela 2. Wyniki wyborów do sejmu w 1928 r. w Rzeszowie i powiecie rzeszowskim (cd.)

\begin{tabular}{|c|c|c|c|c|c|}
\hline \multirow{2}{*}{$\begin{array}{c}\text { Numer } \\
\text { listy }\end{array}$} & \multirow[b]{2}{*}{ Nazwa listy } & \multicolumn{3}{|c|}{ Liczba głosów } & \multirow{2}{*}{$\begin{array}{c}\text { Liczba } \\
\text { mandatów }\end{array}$} \\
\hline & & w Rzeszowie & $\begin{array}{l}\text { w powiecie } \\
\text { rzeszowskim }\end{array}$ & $\begin{array}{c}\text { w okręgu nr } \\
47\end{array}$ & \\
\hline 20 & Ruska & 2 & 2 & 3531 & - \\
\hline 24 & $\begin{array}{l}\text { Lista Katolicko- } \\
\text {-Narodowa }\end{array}$ & 1158 & 4285 & 11261 & - \\
\hline 25 & $\begin{array}{l}\text { Polski Katolicki Blok } \\
\text { PSL „Piast” } \\
\text { i Chrześcijańskiej } \\
\text { Demokracji }\end{array}$ & 49 & 2862 & 23894 & 1 \\
\hline 30 & $\begin{array}{c}\text { Katolicka Unia Ziem } \\
\text { Zachodnich }\end{array}$ & 128 & 1484 & 12821 & - \\
\hline 33 & $\begin{array}{c}\text { Ogólnożydowski } \\
\text { Narodowy Blok } \\
\text { Wyborczy do Sejmu } \\
\text { i Senatu }\end{array}$ & 342 & 431 & 2013 & - \\
\hline 36 & PPS „Lewica” & 436 & 1278 & 1336 & - \\
\hline
\end{tabular}

Na podstawie: T. RzEPECKI, K. RzEPECKI, Sejm i Senat Rzeczypospolitej Polskiej 1928, s. 98; „Gazeta Rzeszowska”, nr 4: 1928, s. 4; „Głos Jarosławski”, nr 11: 1928, s. 1; Statystyka wyborów do sejmu i senatu odbytych w dniu 4 i 11 marca 1928 roku, „Statystka Polski”, t. X, Warszawa: Nakładem Głównego Urzędu Statystycznego, 1930, s. 70-74, 138.

Frekwencja wyborcza w skali kraju była wysoka, gdyż wyniosła $78,3 \%$, na co wpływ miała nie tylko agitacja prowadzona przez poszczególne partie, a także przez administrację państwową. Zdecydowane zwycięstwo odniosło BBWR, uzyskując $21 \%$ głosów, co przekładało się na 125 mandatów ${ }^{107}$. Niewątpliwie na sukces listy nr 1 wpływ miała propaganda ze strony administracji państwowej i samorządowej. Frekwencja w Rzeszowie wyniosła 65,78\%, a w powiecie 79,30\% - natomiast w całym okręgu 47-81,58\%. W okręgu oddano 191734 ważne głosy ${ }^{108}$. BBWR w powiecie rzeszowskim wypadł gorzej niż w skali ca-

${ }^{107}$ Na wynik uzyskany przez BBWR duży wpływ miała kampania wyborcza, zwłaszcza wykorzystanie sporych nakładów finansowych. Po wyborach parlamentarnych wyszło na jaw, że Piłsudski nakazał Radzie Ministrów zwiększyć wbrew ustawie budżetowej preliminarz budżetowy z 200 tys. do $8 \mathrm{mln}$ zł. Środki miały służyć prowadzeniu agitacji wyborczej, organizowaniu wieców, najmowaniu sal, drukowaniu ulotek czy wykupywaniu pism np. lwowskiego „Słowa Polskiego". Vide: A. AJnenkiel, Polska po przewrocie majowym. Zarys dziejów politycznych Polski 1926-1939, Warszawa 1980, s. 145-147.

${ }^{108}$ W okręgu 47 unieważniono 12785 głosów. Praktyka unieważnienia głosów występowała przede wszystkim w województwach wschodnich np. w Kowle, Łucku. Przeważnie wiązało się to z poprzednim unieważnieniem poszczególnej listy ugrupowania cieszącego się dużym poparciem w danym okręgu. Vide: Tomasz SzCZEChURA, Wyniki głosowania w obwodach wiejskich na listy polskie podczas wyborów do Sejmu w latach 1919, 1922 i 1928, „Roczniki Dziejów Ruchu Ludowego", nr 10: 1968, s. 99-100. 
łego kraju, w okręgu 47 zajął drugie miejsce ${ }^{109}$. Do sejmu wprowadził Jakuba Bojkę, kandydata „Zjednoczenia Ludu”. Na uwagę zasługuje wysoki wynik jaki uzyskała PPS, która w Rzeszowie i powiecie zajęła trzecie miejsce, zdobywając jeden mandat poselski. Na Antoniego Chudego głosowało w samym powiecie rzeszowskim aż 6393 wyborców ${ }^{110}$. Należy zaznaczyć, że w okręgu 47 dominowało przede wszystkim rolnictwo, wobec czego uzyskanie przez socjalistów znacznej ilości głosów świadczyło o ich wzmożonej aktywności na scenie politycznej oraz uzyskiwaniu coraz większego poparcia. Porażkę zanotowała endecja, która pomimo dużego wsparcia przez duchownych zajęła zaledwie szóste miejsce, uzyskując w całym okręgu 11261 głosów ${ }^{111}$. W porównaniu do wyborów z $1922 \mathrm{r}$. ZLN nie wprowadził z tego terenu żadnego posła. Trzeba również podkreślić, że endecy wpływy w powiecie rzeszowskim i samym mieście stracili na rzecz BBWR-u. Spadek zanotowali także ludowcy z PSL „Piast”, którzy do wyborów przystąpili wspólnie z Chrześcijańską Demokracją, uzyskując łącznie 23894 głosy. W porównaniu do wyborów z $1922 \mathrm{r}$ był to znaczy spadek, gdyż sześć lat wcześniej partia Witosa otrzymała 76908 głosów. Tym samym z danych tych wynika, że na Polski Blok Katolicki zagłosowało mniej niż $1 / 3$ poprzednich wyborców „Piasta. Lista nr 25 najlepiej wypadła w powiecie jarosławskim, gdzie otrzymała 8000 głosów, natomiast najgorzej w powiecie niżańskim, gdzie zdobyła poparcie jedynie 266 wyborców. Ostatecznie PSL „Piast” zdobył jeden mandat poselski - partię w sejmie reprezentował Jan Pieniążek ${ }^{112}$.

Walkę o głosy i miejsce w sejmie klub „Piasta” przegrał ze Stronnictwem Chłopskim. Partia pomimo rozbicia ruchu ludowego na wiele odłamów i frakcji odniosła zdecydowane zwycięstwo w okręgu 47, uzyskując aż 63757 głosów. Lista $\mathrm{nr} 10$ ze wszystkich partii uzyskała również najlepszy wynik w powiecie rzeszowskim, gdzie głosowało na nią 25217 osób. Uzyskany wynik przełożył się na zdobycie 4 mandatów poselskich. Do sejmu Stronnictwo Chłopskie wprowadziło A. Plutę, J. Sobka, M. Sochę i E. Opolskiego. Trzej pierwsi w sejmie I kadencji byli posłami PSL „Piast”. Można dojść do wniosku, że wyborcy, którzy głosowali na te kandydatury w wyborach w 1922 r., ponownie poparli te osoby, tym razem startujące z listy Stronnictwa Chłopskiego. Ugrupowanie dobrze wypadło w obwodzie niżańskim, gdzie uzyskało 12480 głosów, natomiast słabiej w przeworskim $-8538^{113}$.

Wybory do sejmu pokazały, że program partii ludowych zupełnie nie docierał do największych miast okręgu 47. W Rzeszowie na listę Stronnictwa Chłop-

${ }^{109}$ Statystyka wyborów do sejmu i senatu odbytych w dniu 4 i 11 marca 1928 roku, „Statystka Polski”, t. X, Warszawa 1930, s. 70-74.

${ }^{110}$ Poktosie wyborcze, „Gazeta Rzeszowska”, nr 3: 1928, s. 1.

111 „Ziemia Rzeszowska”, nr 11: 1928, s. 2; Tadeusz RzePecki, Karol RzePecki, Sejm i Senat Rzeczypospolitej Polskiej 1928-1933, Poznań 1928, s. 98.

112 Statystyka wyborów do sejmu i senatu odbytych $w$ dniu 4, s. 71.

${ }^{113}$ Władysław FoŁTA, Ruch ludowy w Przeworskiem, Warszawa 1975, s. 68-69. 
skiego głosowało tylko 9 wyborców, tylu samo na PSL „Wyzwolenie”, a na PSL „Piast”- 29. Podobnie było w Jarosławiu, gdzie w sumie na trzy partię głosowało 300 wyborców ${ }^{114}$. Biorąc pod uwagę wyniki wszystkich list wyborczych w Rzeszowie, najlepiej wypadła lista nr 17 (Zjednoczenie Narodowe Żydowskie w Małopolsce), a najsłabszy wynik uzyskała PPS „Lewica”. Należy przy tym pamiętać, że administracja państwowa nie zezwoliła KPP wystawić własnej listy wyborczej, dlatego też komuniści zakonspirowali się i skupili w PPS „Lewica”.

W rezultacie z okręgu wyborczego $\mathrm{nr} 47$ posłami zostali:

1) Stronnictwo Chłopskie: Andrzej Pluta (rolnik ze Szklar, powiat rzeszowski, były poseł na Sejm Ustawodawczy 1919-1922 oraz I kadencji, prezes Stronnictwa Chłopskiego), Marcin Socha (urzędnik kolejowy z Rudnika nad Sanem, były poseł do sejmu I kadencji 1922-1927, Jan Sobek (rolnik z Handzlówki, powiat łańcucki, były poseł do sejmu I kadencji 1922-1927) oraz Eugeniusz Opolski (dzierżawca majątku Brzezówka koło Hyżnego, powiat rzeszowski);

2) Zjednoczenie Ludu: Jakub Bojko (rolnik z Gręboszowa, powiat dąbrowski, członek Rady Naczelnej PSL „Piast” w latach 1919-1927, były poseł na Sejm Ustawodawczy 1919-1922, wicemarszałek sejmu, senator w latach 19221927 i wicemarszałek senatu);

3) PSL „Piast”: Jan Pieniążek (rolnik z Mokrej Strony, powiat przeworski, działacz samorządowy, wójt gminy Mokra Strona w latach 1920-1933, były poseł sejmu I kadencji 1922-1927);

4) PPS: Antoni Chudy (nauczyciel szkoły powszechnej z Jarosławia, członek OKR PPS w Rzeszowie, były poseł na Sejm Ustawodawczy 1919-1922) ${ }^{115}$.

\section{Wybory do senatu II kadencji}

Wybory do senatu zostały rozpisane na 11 marca $1928 \mathrm{r}$. Głosowanie nie cieszyło się dużym zainteresowaniem, analogicznie jak w przypadku wyborów do I kadencji. W województwie lwowskim zgłoszono 15 list wyborczych, z których kandydaci ubiegali się o 9 mandatów. W Rzeszowie i powiecie rzeszowskim o głosy walczyło 14 ugrupowań. W zdecydowanej większości były to partie, które wystawily listy w wyborach do izby niższej. W kampanii wyborczej wykorzystywano przede wszystkim prasę i publikowane przez nią hasła oraz anonse

\footnotetext{
114 T. SZCZECHURA, op. cit., s. 99-100.

115 Piotr Majewski, Małgorzata Smogorzewska, Postowie i senatorowie Rzeczypospolitej Polskiej 1919-1939. Stownik biograficzny, t. I: $A-D$, t. IV: $M-P$; red. Andrzej Krzysztof KunERT, Grzegorz MAZUR, Warszawa 1998-2009, s. 183-184, 276, 281-282, 361-362, 388-389; Kto byt kim w Drugiej Rzeczypospolitej, red. Jacek MAJCHROWSKI, Warszawa 1994, s. 43-431; Stownik biograficzny działaczy ruchu ludowego, red. Zbigniew WINIARSKI, Warszawa 1989, s. 47, 318-319, 364-365.
} 
zachęcające do głosowania na poszczególne listy. Prorządowa „Gazeta Rzeszowska” w jednym z numerów na pierwszej stronie zamieściła slogan wzywający do oddawania głosów na listę BBWR-u: „Obywatele Wyborcy i Wyborczynie! Walka o skład polskich ciał prawodawczych dotychczas nie jest skończoną. W niedzielę dnia 11 marca odbędzie się dalsze głosowanie na członków Senatu. Prawodawcze zadania Senatu, jego wpływ na Izbę sejmową wymagają ludzi mądrych, doświadczonych, którzy powinni mieć dosyć intelektualnej siły do kontrolowania, a w razie potrzeby nawet prostowania prac Izby posłów. Zgodnie z przyjętemi przez nas obowiązkami wzywamy Was Obywatele Wyborcy i Wyborczynie do solidarnego oddania głosów na listę senacką Nr. 1"116. Do poparcia obozu rządowego w wyborach do senatu wzywała również „Gazeta Lwowska”.

Podobne hasła publikowano także na łamach prasy endeckiej, która wzywała do głosowania na listę nr 24. W jej skład weszły następujące ugrupowania: Związek Ludowy Narodowy, Stronnictwo Chrześcijańsko-Narodowe, Narodowa Partia Robotnicza (prawica) oraz inne organizacje katolicko-narodowe. „Głos Jarosławski" w okresie agitacji wyborczej opublikował listę kandydatów do senatu, a na pierwszym miejscu znalazł się ks. Witold Czartoryski. Prasa przedstawiła najważniejsze informacje na temat kandydata na senatora, jednocześnie podkreślając jego zasługi i dokonania. Endecja zaprezentowała Czartoryskiego jako dobrego gospodarza, zaangażowanego w działalność społeczną: „Kandydat nasz, to postać jasna i świetlana; to potomek wielkiego rodu, którego gorąca miłość Ojczyzny jest ogólnie znaną, a historia naszej Polski niejednokrotnie wspomina nazwisko książąt Czartoryskich, którzy zawsze pracowali dla dobra Polski, a nigdy nie łączyli się z wrogami naszej Ojczyzny. Jak sławnej pamięci Ojciec naszego kandydata śp. Jerzy, tak i nasz kandydat, Książę Witold Czartoryski, znani są z hojności dla dobra publicznego, czego najlepszym dowodem są te liczne szkoły po wioskach, te kościoły i ochronki wyposażone przez Rodzinę Książąt Czartoryskich, te liczne instytucje oświatowe i przemysłowe, których jest członkiem wspierającym"117.

Kampanię z wykorzystaniem prasy prowadził również Związek Chłopski. „Przyjaciel Ludu” nawoływał swoich zwolenników do oddawania głosów na listę nr 14. Przedstawił także kandydatów do senatu - Hipolita Śliwińskiego. Zdaniem gazety, jako osoba godna zaufana, odpowiedzialna, zaangażowana w pomoc społeczną idealnie nadawał się on do pracy w izbie wyższej ${ }^{118}$.

„Gazeta Lwowska” przebieg głosowania na terenie województwa lwowskiego oceniła jako prawidłowy, bez wystąpienia żadnych naruszeń: „Głosowanie na terenie województwa lwowskiego zakończono wszędzie punktualnie o godzinie 21. Spokój nigdzie nie został zakłócony. Udział wyborców wynosił prze-

\footnotetext{
116 „Gazeta Rzeszowska”, nr 3: 1928, s. 1.

117 „Głos Jarosławski”, nr 10: 1928, s. 1.

118 Wybory do senatu, , Przyjaciel Ludu”, nr 11: 1928, s. 1.
} 
ciętnie 50 do $60 \%$, co tłumaczyć należy - jak i gdzieindziej - fatalnymi warunkami atmosferycznymi" ${ }^{119}$.

Tabela 3. Wyniki wyborów do senatu w 1928 r. w Rzeszowie i powiecie rzeszowskim

\begin{tabular}{|c|c|c|c|c|c|}
\hline \multirow{2}{*}{$\begin{array}{l}\text { Numer } \\
\text { listy }\end{array}$} & \multirow[b]{2}{*}{ Nazwa listy } & \multicolumn{3}{|c|}{ Liczba głosów } & \multirow{2}{*}{$\begin{array}{c}\text { Liczba } \\
\text { mandatów }\end{array}$} \\
\hline & & w Rzeszowie & $\begin{array}{l}\text { w powiecie } \\
\text { rzeszowskim }\end{array}$ & $\begin{array}{l}\text { w województwie } \\
\text { lwowskim }\end{array}$ & \\
\hline 1 & BBWR & 1530 & 8832 & 197521 & 4 \\
\hline 2 & PPS & 806 & 2665 & 34255 & - \\
\hline 3 & PSL „Wyzwolenie” & 5 & 486 & 2937 & - \\
\hline 6 & $\begin{array}{l}\text { Ukraiński Związek } \\
\text { Jedności Narodowej }\end{array}$ & - & - & 62 & - \\
\hline 8 & \begin{tabular}{|c} 
Ukraińsko \\
Włościańsko- \\
-Robotnicze \\
Socjalistyczne \\
Zjednoczenie Sel-Rob
\end{tabular} & - & - & 2581 & - \\
\hline 10 & Stronnictwo Chłopskie & 5 & 12405 & 66075 & 1 \\
\hline 14 & Związek Chłopski & 5 & 98 & 19338 & - \\
\hline 17 & \begin{tabular}{|c} 
Zjednoczenie \\
Narodowe Żydowskie \\
w Małopolsce
\end{tabular} & 2217 & 2466 & 66010 & 1 \\
\hline 18 & $\begin{array}{c}\text { Blok Mniejszości } \\
\text { Narodowych }\end{array}$ & 21 & 55 & 136811 & 3 \\
\hline 20 & Ruska & 1 & 1 & 11979 & - \\
\hline 22 & $\begin{array}{l}\text { Blok Wyborczy } \\
\text { Ukraińskich } \\
\text { Socjalistycznych } \\
\text { Włościańsko } \\
\text { Robotniczych Partii }\end{array}$ & - & - & 23575 & - \\
\hline 24 & $\begin{array}{l}\text { Lista Katolicko- } \\
\text {-Narodowa }\end{array}$ & 543 & 1793 & 40448 & - \\
\hline 33 & $\begin{array}{c}\text { Ogólnożydowski } \\
\text { Narodowy Blok } \\
\text { Wyborczy do Sejmu } \\
\text { i Senatu } \\
\end{array}$ & 5 & 8 & 619 & - \\
\hline 36 & $\begin{array}{c}\text { Ukraińska Partia } \\
\text { Robotnicza }\end{array}$ & 1 & 5 & 3762 & - \\
\hline 37 & Sel-Rob-Lewica & 28 & 149 & 25929 & - \\
\hline
\end{tabular}

Na podstawie: T. RzePecki, K. RzePeCKI, Sejm i Senat Rzeczypospolitej Polskiej 1928, s. 172 174; Statystyka wyborów do sejmu i senatu, s. 138.

${ }^{119}$ Wybory do senatu, „Gazeta Lwowska”, nr 60: 1928, s. 1. 
Frekwencja w wyborach do senatu II kadencji w Rzeszowie wyniosła 54,6\%, a w powiecie rzeszowskim 58,1\%. W porównaniu do wyborów z $1922 \mathrm{r}$. liczba głosujących w Rzeszowie znacznie spadła. Należy zauważyć, że średnia frekwencja w mieście była niższa od średniej uzyskanej w powiecie, województwie lwowskim, ale także od ogólnokrajowej (odpowiednio: 58,1\%, 63\% i 63,9\%) ${ }^{120}$. W wyborach do senatu w Rzeszowie najwięcej głosów zdobyło Zjednoczenie Narodowe Żydowskie w Małopolsce $-2217^{121}$. Chociaż w powiecie zanotowało niski wynik (2466 głosów), jednak w skali całego województwa lwowskiego zyskała na tyle duże poparcie (66 010), aby w konsekwencji przełożyło się to na 1 mandat senatorski. Drugie miejsce w Rzeszowie, a także w powiecie rzeszowskim zajął BBWR (odpowiednio - 1530 i 8832 głosów), choć w skali powiatu wyraźnie przegrał ze Stronnictwem Chłopskim (12 405 głosów) ${ }^{122}$. Trzecie miejsce zarówno w mieście, jak i w powiecie odnotowało PPS (odpowiednio - 806 i 2665 głosów), jednakże w skali województwa socjaliści osiągnęli dopiero szósty wynik, a tym samym nie udało się im uzyskać mandatu senatorskiego. Porażkę zanotowała endecja, która również nie wprowadziła żadnego senatora w Rzeszowie lista nr 24 zajęła miejsce czwarte (543 głosy), a w powiecie dopiero piąte (1793). Przegranymi okazały się również listy nr 3 (PSL „Wyzwolenie”) i 14 (Związek Chłopski). Natomiast Blok Mniejszości Narodowych, który w Rzeszowie i powiecie rzeszowskim odnotował bardzo słaby wynik (odpowiednio 21 i 55 głosów), dzięki sukcesowi we wschodnich obwodach wprowadził do senatu 3 osoby.

Warto podkreślić, że analogicznie jak w przypadku wyborów do sejmu, o końcowym wyniku i podziale mandatów zadecydował większy udział oraz zaangażowanie mieszkańców wsi. Chłopi w zdecydowanej większości głosowali na kandydata, który reprezentował znane ugrupowanie, stojące $\mathrm{w}$ obronie ich praw i interesów. W rezultacie $\mathrm{z}$ województwa lwowskiego senatorami zostali wybrani:

1) BBWR: dr Stanisław Zakrzewski (profesor historii Polski na Uniwersytecie Jana Kazimierza we Lwowie, prezes Polskiego Towarzystwa Historycznego, czynny członek Polskiej Akademii Umiejętności oraz Towarzystwa Naukowego we Lwowie), dr Stanisław Dąmbski (ziemianin z Rudnej w powiecie rzeszowskim, były poseł na Sejm Krajowy we Lwowie), Antoni Nowak (rolnik i naczelnik gminy Harło w powiecie brzozowskim);

2) Chrześcijańska Demokracja (lista nr 25): dr Maksymilian Thullie (profesor Politechniki Lwowskiej, senator I kadencji 1922-1927);

3) Blok Mniejszości Narodowych (Ukraińsko-Białoruski Klub - lista nr 18): dr Kornel Trojan (adwokat z Chodorowa w powiecie bóbreckim), Helena Kisie-

${ }^{120}$ T. RzePeCKi, K. RzePeCKi, Sejm i Senat Rzeczypospolitej Polskiej 1928, s. 172-174, 241-242.

${ }^{121}$ Statystyka wyborów do sejmu i senatu odbytych w dniu 4, s. 138.

122 Tadeusz OchenduszKo, Janusz Kujawa, Kalendarium Rzeszowa 1918-1939, Rzeszów 2017, s. 95. 
lewska (redaktorka z Kołomyi) i ks. Julian Tatomyr (proboszcz z Łąki w powiecie samborskim);

4) Stronnictwo Chłopskie: dr Jerzy Miklaszewski (urzędnik z Warszawy);

5) Zjednoczenie Narodowe Żydowskie w Małopolsce (Koło Żydowskie Organizacji Syjonistycznej Małopolski Wschodniej - lista nr 17): dr Dawid Schreiber (adwokat z Lwowa, długoletni wiceprezes organizacji sjonistycznej, poseł na sejm I kadencji 1922-1927) ${ }^{123}$.

\section{Podsumowanie}

Wybory parlamentarne w powiecie rzeszowskim w 1928 r. wykazały większą postawę obywatelską mieszkańców wsi niż miast. Podobnie jak w skali kraju występowały tam znaczne różnice $\mathrm{w}$ preferencjach politycznych pomiędzy ośrodkami miejskimi a wiejskimi. Wiejski elektorat głosował przeważnie na kandydata reprezentującego znane im ugrupowanie występujące w obronie praw i interesów chłopów. We wsiach powiatu rzeszowskiego, podobnie jak w sąsiednich terenach, dominowały małe gospodarstwa nie przekraczające 2 ha, nie pozwalające na wyżywienie całej rodziny, nie wspominając już o zapewnieniu odpowiedniego dochodu. Co prawda w niektórych miejscowościach istniały małe zakłady przemysłowe, ale głównie powiązane były z miejscowym zapotrzebowaniem na podstawowe surowce (np. przemysł drzewny związany z eksploatacją lasów - tartaki). Co za tym idzie mieszkańcy wsi w przeważającej większości zmagali się z problemami dotyczącymi życia codziennego (np. głód, bieda). Nie należy też zapominać o niskim poziomie kultury i oświaty wśród chłopów, czego najlepszym przykładem był bardzo wysoki odsetek analfabetów, chociaż problem ten dotyczył nie tylko wsi, ale również miast. Co prawda występowały pewne wyjątki, ale tylko nieliczni mieszkańcy wsi wykonywali zawody pozarolnicze (np. pracowali jako nauczyciele czy urzędnicy). Czynniki te w dużej mierze spowodowały, że mieszkańcy wsi głosowali przeważnie na partie ludowe. W przypadku samego Rzeszowa struktura społeczno-zawodowa i poziom oświaty wpływały na wyrobienie polityczne i świadomość mieszkańców. Na dobry wynik mógł tam liczyć np. PPS, ponieważ znajdywało się tu więcej zakładów przemysłowych. Co prawda stały one na niskim poziomie, pod względem jakościowym i produkcyjnym, to jednak praca w nich umożliwiła zaspokojenie potrzeb. Ponieważ podstawowym elektoratem socjalistów byli głównie robotnicy, dlatego też starali się poprzez swoją kampanię wyborczą i podejmowane w niej kwestie przeciągnąć ich na swoją stronę oraz zachęcić do głosowania na swoje listy. Socjaliści w okresie kampanii wyborczej starali się też wykorzystywać miejscowe związki zawodowe czy stowarzyszenia.

123 T. RZePECKI, K. RzePeCKI, Sejm i Senat Rzeczypospolitej Polskiej 1928, s. 174-175. 
Wybory stanowiły test zaufania społecznego do poszczególnych ugrupowań. Ogólnie rzecz biorąc dla każdej opcji politycznej startującej w wyborach, stały się sprawdzianem w zakresie możliwości ich działania oraz oddziaływania na potencjalnych sympatyków. Wysoka frekwencja odnotowana w okręgu 47 świadczyła o dużej mobilizacji elektoratów, głównie poprzez działalność lokalnych liderów. Poszczególne ugrupowania prowadziły aktywną kampanię wyborczą na terenie Rzeszowa, jak i całego okręgu. Partie wystawiły na listach znanych działaczy społecznych i politycznych (np. byłych posłów), aktywnych nie tylko arenie krajowej, ale również w regionie. Poszczególni kandydaci odbywali liczne spotkania, na których przedstawiali program wyborczy i nawoływali do głosowania na określone listy. Nie wszystkie jednak partie mogły pozwolić sobie na dynamiczną kampanię, gdyż agitacja komitetów wyborczych zależała od ich możliwości finansowych i organizacyjnych. $\mathrm{Z}$ drugiej strony, występujące konflikty i spory wewnętrzne utrudniały niejednokrotnie odpowiednie przygotowanie się do wyborów.

Ważną rolę $\mathrm{w}$ kampanii odgrywała prasa, która informowała o wiecach i zgromadzeniach przedwyborczych. Jako jeden z podstawowych środków masowego przekazu oddziaływała na odbiorców, kształtowała ich myślenie oraz wyznaczała pewne trendy i postawy. Porównując pod tym względem kampanię z marca 1928 r. do poprzednich (tj. 1919 i 1922 r.) można wysunąć wniosek, że walka prasowa nabrała nowego znaczenia i rozmachu. Krytyka programu określonej partii, negacja zmian zachodzących w kraju, silna propaganda (zwłaszcza ze strony BBWR-u) oraz zatargi słowne były w tym czasie na porządku dziennym. Należy stwierdzić, że w okresie międzywojennym prawie żadne stronnictwo nie gardziło tego rodzaju bronią.

Należy jednak zauważyć, że silna agitacja na rzecz BBWR-u w okręgu 47 przełożyła się na zdobycie tylko jednego mandatu poselskiego - przez Jakuba Bojkę, kandydującego z prosanacyjnego Zjednoczenia Ludu. Wprawdzie na terenie powiatu rzeszowskiego czynna była znaczna grupa działaczy obozu sanacyjnego, to jednak ukonstytuowanie władz powiatowych nastąpiło dopiero po wyborach. Zdecydowaną porażkę odnotowała endecja, która pomimo aktywnej kampanii w Rzeszowie i w powiecie rzeszowskim, nie wprowadziła do sejmu żadnego kandydata. Wyniki wyborów na terenie powiatu rzeszowskiego wykazały także wzrost popularności PPS w ośrodkach miejskich, ale również na wsi, co niewątpliwie należy uznać za ich duży sukces. Było to efektem nasilonej agitacji. Z drugiej strony, część społeczeństwa wiejskiego nie kryła rozczarowania w stosunku do partii chłopskich i ich przywódców. Czynniki te i problemy wewnętrzne przesądziły, że poparcie stracił PSL „Piast”, który w porównaniu do wyborów w 1922 r. zanotował duży spadek. Największy sukces w wyborach osiągnęło Stronnictwo Chłopskie, a powiat rzeszowski po wyborach stał się jego „twierdzą". Stronnictwu udało się niewątpliwie przeciągnąc na swoją stronę część elektoratu „piastowców”, a także PSL „Wyzwolenia”. 
Można zgodzić się z opinią Adama Próchnika, że wybory do sejmu i senatu w marcu 1928 r. stanowiły test zaufania społecznego dla partii. Wyborcy oddając głos na BBWR pokazali, że popierają jego działania i dążenia, wyrażając przekonanie do sensu zmian dokonywanych przez obóz rządowy. Natomiast głosując na inne partie, z jednej strony pokazywali sprzeciw wobec polityki obozu sanacyjnego, a z drugiej zgadzali się z hasłami i ideami ugrupowań, którym udzielili poparcia. Tym samym społeczeństwo zaczęło wyraźnie dzielić się na zwolenników lub przeciwników sanacji.

\section{Bibliografia}

\section{Źródła archiwalne}

Archiwum Państwowe w Rzeszowie:

Komitet Wojewódzkiej Polskiej Zjednoczonej Partii Robotniczej w Rzeszowie, sygn. 13392, $13950,14728$.

Okręgowa Komisja Wyborcza w Rzeszowie, sygn. 14, 15, 16, 17, 18, 35, 36, 37.

Wojewódzka Rada Związkowych Zawodowych w Rzeszowie, sygn. 9.

Archiwum Państwowe w Przemyślu, Afisze, plakaty i druki ulotne z terenu Przemyśla w zasobie Archiwum Państwowego w Przemyślu, sygn. 346.

\section{Źródła drukowane}

BoJKo Jakub, Moje słowo do Braci włościan i ludzi dobrej woli: Dnia 27 października 1927 r., Gręboszów 1927.

„Dziennik Ustaw Rzeczypospolitej Polskiej” 1922, nr 66, poz. 590.

„Dziennik Ustaw Rzeczypospolitej Polskiej” 1922, nr 66, poz. 593.

„Dziennik Ustaw Rzeczypospolitej Polskiej” 1926, nr 78, poz. 442.

„Dziennik Ustaw Rzeczypospolitej Polskiej” 1926, nr 79, poz. 445

„Dziennik Ustaw Rzeczypospolitej Polskiej” 1927, nr 107, poz. 916.

Ordynacja wyborcza do Sejmu i Senatu z 28 lipca 1922 roku, wstępem i komentarzem opatrzył ks. dr. Kazimierz LutosŁAwsKi, Warszawa 1922.

Pierwszy Powszechny Spis Rzeczypospolitej Polskiej z dnia 30 września 1921 roku. Mieszkania, ludność, stosunki zawodowe, t. XXVII: Województwo lwowskie, Warszawa: „Nakładem Głównego Urzędu Statycznego", 1927.

Pracownicy państwowi a wybory, Warszawa 1928.

Regulamin Demokratycznego Komitetu Wyborczego Kobiet Polskich, Warszawa 1928.

Stoimy wobec historycznych wydarzeń, wobec zmagań się idei państwowości młodego naszego państwa z brakami $i$ wadami narodowemi, Warszawa 1928.

Statystyka wyborów do sejmu i senatu odbytych w dniu 5 i 12 listopada 1922 roku, „Statystyka Polski”, t. VIII, Warszawa: Nakładem Głównego Urzędu Statystycznego, 1926.

Statystyka wyborów do sejmu i senatu odbytych w dniu 4 i 11 marca 1928 roku, „Statystka Polski”, t. X, Warszawa: Nakładem Głównego Urzędu Statystycznego, 1930.

Skorowidz miejscowości Rzeczypospolitej Polskiej. Opracowany na podstawie wyników pierwszego powszechnego spisu ludności z dn. 30 września 1921 r. i innych źródet urzędowych, t. XIII: Województwo lwowskie, Warszawa: „Nakładem Głównego Urzędu Statystycznego”, 1924.

SPISs Tadeusz, Ze wspomnień c.k. urzędnika politycznego, Rzeszów: s.n., 1936

ŚwITALSKI Kazimierz, Diariusz, 1919-1935, Warszawa: Czytelnik, 1992. 


\section{Prasa}

„Chłop Polski” 1927.

„Dziennik Urzędowy Województwa Lwowskiego” 1927.

„Głos Jarosławski” 1928.

„Gazeta Lwowska” 1928.

„Gazeta Rzeszowska” 1928.

„Piast” 1926-1928.

„Polska Zbrojna” 1928.

„Przyjaciel Ludu” 1928.

„Tygodnik Przemyski” 1928.

„Ziemia Rzeszowska” 1926-1928.

„Ziemia Rzeszowska i Jarosławska” 1922.

„Ziemia Przemyska” 1922.

\section{Opracowania}

AJNENKIEl Andrzej, Parlamentaryzm II Rzeczypospolitej, Warszawa: Wiedza Powszechna, 1975.

AJNenkiel Andrzej, Polska po przewrocie majowym. Zarys dziejów politycznych Polski 19261939, Warszawa: Wiedza Powszechna, 1980.

ANDRZEJEwSKI Zenon, Przemyskie wątki w biografii Hermana Liebermana (cz. 2), „Palestra. Pismo Adwokatury Polskiej", nr 9-10: 2011, s. 247-260.

BoNUSIAK Włodzimierz, Życie polityczne Rzeszowa w 20-leciu międzywojennym, [in:] Z przeszłości Rzeszowa. Materiaty z konferencji naukowej w 640 lecie lokacji miasta zorganizowanej przez Muzeum Okręgowe w dniach 12-13. X. 1994, red. Małgorzata JAROSIŃSKA, Rzeszów: Muzeum Okręgowe w Rzeszowie, 1995, s. 173-187.

BonusiaK Włodzimierz, Życie polityczne, [in:] Dzieje Rzeszowa, t. III: Rzeszów w okresie międzywojennym i okupacji (1918-1944), red. Feliks KIRYK, Rzeszów: Urząd Miasta „Libri Ressovienses", 2001, s. 472-542.

CimeK Henryk, Zjednoczenie Lewicy Chłopskiej ,,Samopomoc” 1928-1931, Lublin: Wydawnictwo Lubelskie, 1973.

CIMEK Henryk, Ruch robotniczy na ziemi rzeszowskiej (1918-1939), [in:] Ruch robotniczy na ziemi rzeszowskiej 1918-1975, red. Bogusław SyzDEK, Warszawa: Książka i Wiedza, 1980, s. 21-136.

Chojnowski Andrzej, Pitsudczycy u władzy. Dzieje Bezpartyjnego Bloku Wspótpracy z Rządem, Wrocław: Zakład Narodowy im. Ossolińskich, 1986.

DarŁakowa Stanisława, Prasa Rzeszowa XIX i XX wieku, Rzeszów: Muzeum Okręgowe w Rzeszowie, 1966.

DesZCZYŃSKi Marek Piotr, Rzeszów na mapie gospodarczej II Rzeczypospolitej, [in:] Rzeszów Dawny $i$ Wspótczesny. Gospodarka, red. Krzysztof KASzUBA, Andrzej SzRomnik, Rzeszów: Wydawnictwo Wyższej Szkoły Zarządzania w Rzeszowie, 2005, s. 105-113.

DymeK Benon, Niezależna Partia Chłopska, Warszawa: Książka i Wiedza, 1972.

Dunin-WĄSOwicz Krzysztof, Jan Stapiński, [in:] Przywódcy ruchu ludowego. Szkice biograficzne, red. Alicja Wį̨ziKowa, Warszawa: Ludowa Spółdzielnia Wydawnicza, 1968, s. 273-307.

FoŁTA Władysław, Ruch ludowy w Przeworskiem, Warszawa: Ludowa Spółdzielnia Wydawnicza, 1975.

GACEK Jerzy, Roman Krogulski, [in:] Encyklopedia Rzeszowa, red. Zdzisław BuDZYŃsKi i in., Rzeszów: RS Druk, 2004, s. 257.

KowALSKI Tadeusz, Ruch ludowy w powiecie rzeszowskim 1895-1944, Warszawa: Ludowa Spółdzielnia Wydawnicza, 1973. 
KozYra Waldemar, Polityka Ministerstwa Spraw Wewnętrznych wobec życia społeczno-politycznego $w$ Polsce $w$ latach 1926-1928. Wybory parlamentarne z 4 i 11 marca 1928 r., „Studia z Dziejów Państwa i Prawa Polskiego", R. 20: 2017, s. 397-412.

KRZYSZTOFIŃSKi Mariusz, Komuniści na Rzeszowszczyźnie 1918-1944/1945, Rzeszów: IPN Oddział w Rzeszowie, 2010.

Kto byt kim w Drugiej Rzeczypospolitej, red. nauk. Jacek MAJCHROwSKI, Warszawa: „BGW”, 1994. LATo Stanisław, Ruch ludowy wobec sanacji, Rzeszów: Krajowa Agencja Wydawnicza, 1986.

Majewski Piotr, Smogorzewska Małgorzata., Posłowie i senatorowie Rzeczypospolitej Polskiej 1919-1939. Stownik biograficzny, t. I: $A-D$, t. IV: $M-P$, red. nauk. Andrzej Krzysztof KunERT, Grzegorz MAzUR, Warszawa: Wydawnictwo Sejmowe, 1998-2009.

MAJKA Janusz, Ruch narodowy w Przemyślu w latach II Rzeczypospolitej, „Rocznik Przemyski. Zeszyt Historia”, t. XLV/z. 4: 2009, s. 149-176.

OchenduszKo Tadeusz, Kujawa Janusz, Kalendarium Rzeszowa 1918-1939, Rzeszów: Regionalne Stowarzyszenie Pamięci Historycznej „Ślad”, 2017.

Petrus Juliusz, Stosunki Gospodarcze, [in:] Dzieje Rzeszowa, t. III: Rzeszów w okresie międzywojennym i okupacji (1918-1944), red. Feliks KIRYK, Rzeszów: Urząd Miasta „Libri Ressovienses”, 2001, s. 53-85.

PIENIĄŻEK Seweryn, Jan Pieniążek (1881-1963), działacz ludowy i poset, Rzeszów: Wydawnictwo Oświatowe Fosze, 2010.

Podgajna Ewelina, Stronnictwo Chłopskie (1926-1931). Studium z dziejów myśli politycznej, Lublin: Wydawnictwo Uniwersytetu Marii Curie-Skłodowskiej, 2011.

Ротоскі Andrzej, Żydzi w Podkarpackiem, Rzeszów: Wydawnictwo Libra, 2004.

PRÓCHNIK Adam, Pierwsze piętnastolecie Polski niepodległej. Zarys dziejów politycznych, Warszawa: Państwowe Wydawnictwo Naukowe, 1983.

RzePeCKI Tadeusz, Sejm Rzeczypospolitej Polskiej 1919 roku, Poznań: Wielkopolska Księgarnia nakładowa, 1920.

RzePeCKI Tadeusz, RzePeCKI Witold, Sejm i Senat Rzeczypospolitej Polskiej 1922-1927, Poznań: Wielkopolska Księgarnia nakładowa Karola Rzepeckiego, 1923.

RzePeCKi Tadeusz, RzePeCKi Karol, Sejm i Senat Rzeczypospolitej Polskiej 1928-1933, Poznań: Wielkopolska Księgarnia nakładowa Karola Rzepeckiego, 1928.

Stownik biograficzny działaczy ruchu ludowego, red. Zbigniew WINIARSKI, Warszawa: Ludowa Spółdzielnia Wydawnicza, 1989.

SzAFLik Józef Ryszard, Polskie Stronnictwo Ludowe Piast 1926-1931, Warszawa: Ludowa Spółdzielnia Wydawnicza, 1970.

Socha Janusz, Stronnictwa ludowe po zamachu majowym, Warszawa: Ludowa Spółdzielnia Wydawnicza, 1983.

SZCZECHURA Tomasz, Wyniki głosowania w obwodach wiejskich na listy polskie podczas wyborów do Sejmu w latach 1919, 1922 i 1928, „Roczniki Dziejów Ruchu Ludowego”, nr 10: 1968, s. $67-121$.

TOMiCKi Jan, Polska Partia Socjalistyczna 1892-1945, Warszawa: Książka i Wiedza, 1983.

UlJasz Adrian, Z dziejów prasy lokalnej w II Rzeczypospolitej. Żydowski „, Przegląd Rzeszowski” z 1927 i 1932 roku, „Przegląd Nauk Historycznych”, R. 15/ nr 1: 2016, s. 129-153.

WIĘZIKOwA Alicja, Stronnictwo Chtopskie 1926-1931, Warszawa: Ludowa Spółdzielnia Wydawnicza, 1963. 


\section{Parliamentary elections in Rzeszów and the Rzeszów poviat in 1928}

\section{Summary}

In 1926, as a result of the May coup, Józef Pilsudski comes to power. During this period, political and legal changes are taking place in the Second Polish Republic. In 1928 there were parliamentary elections, which, especially for the government camp, constituted a test of social trust. In the electoral campaign, the sanacja used various means of pressure on the administration and the press to obtain the largest number of votes.

On the other hand, the opposition parties, which criticized Pilsudski's government, accentuated their participation in the elections. It is worth devoting attention and analyzing the parliamentary elections in 1928 in the Rzeszow and poviat. The development of the article was mainly based on the regional interwar press. The individual press titles provide valuable information about the election campaign in the region.

Keywords: Rzeszow, Rzeszow poviat, parliamentary election, parliament, senate. 
Prace Naukowe Uniwersytetu Humanistyczno-Przyrodniczego im. Jana Długosza w Częstochowie

http://dx.doi.org/10.16926/zh.2019.18.08

Ryszard KRAWCZYK

https://orcid.org/0000-0001-7683-3939

Uniwersytet Jagielloński

\section{Czy Polakom potrzebne są zabytki? Kilka słów o niszczeniu zabytków nieruchomych w Polsce*}

\section{Streszczenie}

Zabytki nieruchome to kategoria prawna obiektów zabytkowych dokumentująca w najbardziej widoczny sposób poziom cywilizacyjny i kulturowy danego społeczeństwa. Artykuł podejmuje próbę odpowiedzi na pytanie, dlaczego w Polsce znajduje się ona w niemal katastrofalnej sytuacji.

Slowa kluczowe: zabytki, niszczenie, wandalizm.

Kryminalistyka to nauka zajmująca się bezpośrednim zwalczaniem przestępczości, również tej ukierunkowanej na szeroko rozumiane dziedzictwo kulturowe. Wykorzystując analizy pokrewnej kryminologii, w ramach jednej ze swoich dziedzin - strategii, kryminalistyka prognozuje rozwój przestępczości, analizuje jej przyczyny tak, aby dobrać optymalną metodykę jej zwalczania w teraźniejszości oraz przyszłości. Niniejszy artykuł podejmie próbę odpowiedzi na pytanie - co powoduje, jakie są przyczyny faktu, że w Polsce jedna z prawnych kategorii zabytków - zabytki nieruchome ${ }^{1}$, znajduje się w niemal katastrofalnej sytuacji. Kategoria ta w sposób najbardziej widoczny dokumentuje historię danego społeczeństwa i stanowi jeden z materialnych wyznaczników cywilizacji. Zabytki nieruchome reprezentują najróżniejsze formy z różnych okresów historycznych. Są to nie tylko pałace, zamki, dwory czy kościoły, ale także kamienice,

* Niniejszy artykuł powstał na bazie badań przeprowadzonych przez autora i stanowi rozwinięcie jednego z problemów podjętych, opisanych i zilustrowanych w książce pt. Niszczenie zabytków nieruchomych w Polsce. Problematyka prawna, kryminologiczna i kryminalistyczna, Kraków 2017.

1 Ilościowo w kategorii zabytków nieruchomych jest w Polsce ponad 68 tys. obiektów wpisanych do rejestrów zabytków, natomiast w ewidencjach i poza nimi posiadamy prawie 500 tys. obiektów. 
obiekty przemysłowe, kompleksy zabudowań wiejskich oraz obszary bezpośrednio z nimi powiązane, jak infrastruktura przemysłowa, kolejowa, lasy, cmentarze, parki i ogrody ${ }^{2}$. Obiekty te mają postać samodzielnych, wyodrębnionych budowli lub też tworzą ich skupiska w postaci zespołów pałacowych, ruralistycznych, industrialnych, zabytkowych centrów miast i układów dzielnic miejskich.

Tabela 1. Rodzaje zabytków nieruchomych wpisanych do rejestru zabytków

\begin{tabular}{|c|c|c|c|c|c|c|}
\hline Urbanistyka & Sakralne & Obronne & Publiczne & Zamki & Rezydencjonalne & Zieleń \\
\hline 1068 & 12655 & 1052 & 4516 & 418 & 4838 & 7272 \\
\hline Folwarczne & Gospodarcze & Mieszkalne & Przemysłowe & Cmentarze & Inne & Razem \\
\hline 5254 & 2212 & 18407 & 2328 & 4578 & 3424 & $\mathbf{6 8 0 2 2}$ \\
\hline
\end{tabular}

Na podstawie danych NID - stan na 30 VI 2014 r.

Do niedawna uważano, że w Polsce najgorszy dla zabytków nieruchomych czas miał miejsce zaraz po zakończeniu II wojny światowej oraz w czasach PRL-u. Okazuje się jednak, że było to bardzo mylne przekonanie. Zabytkowe obiekty na terenie Polski, które przetrwały obie zawieruchy wojenne, okres reformy rolnej i nacjonalizacji przemysłu w wielu przypadkach doczekały swoistej hekatomby dopiero w latach dziewięćdziesiątych ubiegłego wieku (w wyniku transformacji ustrojowej), a jej skutki trwają w zasadzie do dzisiaj ${ }^{3}$. Pomimo przemian ustrojowych, wzrostu zamożności społeczeństwa, liberalizacji i demokratyzacji życia oraz zmian w prawie, ochrona zabytków nieruchomych w naszym kraju jest ciągle słaba i niewystarczająca ${ }^{4}$.

Kryminalistyka i kryminologia poddawały wielokrotnie analizom przestępczość ukierunkowaną na zabytki. Na bieżąco sporządzane są statystki dotyczące skutków działań przestępczych i osiągnięć w ich zwalczaniu. Dogłębnym analizom poddawano obowiązujące przepisy prawne dotyczące zabytków ${ }^{5}$. Wzorem innych państw europejskich wprowadzono na naszym gruncie prawnym formalny obowiązek ochrony zabytków, skierowany do organów administracji publicznej oraz faktyczny obowiązek opieki nad zabytkami obciążający ich właścicieli i posiadaczy. W strukturach organów ścigania tworzono specjalistyczne komórki zajmujące się wyłącznie zwalczaniem przestępczości przeciwko dziedzictwu kulturowemu. Ministerstwo Kultury i Dziedzictwa Narodowego tworzy programy wytyczające działania w sferze kultury na lata do przodu. Wydaje się za-

2 Janusz SŁUGOCKI, Problemy prawne ochrony zabytkowych parków dworsko-pałacowych, [in:] Dobra chronione w prawie administracyjnym, red. Zofia DUNIEWSKA, Łódź 2014, s. 226.

3 Od 1990 r. do 2013 r. tylko na Dolnym Śląsku przestało istnieć 350 obiektów o charakterze rezydencjalnym. Vide: http://ratujemypolskiezabytki.blogspot.com/ [dostęp: wrzesień 2017].

4 Ryszard KRAWCZYK, op. cit., s. 17.

5 Między innymi, szczegółowe i dogłębne opracowania: P. Dobosza, J. KaCzMarKa, W. Kowalskiego, J. Pruszyńskiego, J. Sobczaka, W. Radeckiego, M. Trzcińskiego, K. ZALASIŃSKIEJ i K. ZEIDLERA. 
tem, że na temat znaczenia dziedzictwa kulturowego dla tożsamości każdego narodu, a także zagrożeń i ochrony zabytków powiedziano już prawie wszystko. Tymczasem niszczenie zabytków nieruchomych w Polsce stanowi ciągły, nieprzerwany proces zbliżony $\mathrm{w}$ obrazie $\mathrm{i}$ formie do zjawiska patologicznego. Ochrona zabytków w Polsce jest domeną prawa administracyjnego i sprowadza się niestety, głównie do działań o charakterze urzędniczym. Te jednak, jak się okazuje, nie zawsze rodzą pozytywne skutki. W powojennej Polsce władza państwowa nie była w stanie wypracować i wdrożyć skutecznego systemu ochrony zabytków nieruchomych. Dotyczy to nie tylko statutowo związanych z ochroną zabytków organów konserwatorskich, ale także organów prokuratury i wymiaru sprawiedliwości, które wydają się nie zauważać, że ta kategoria zabytków, bez względu na rodzaj i formę, stanowi szczególny przedmiot ochrony, wymagający bardzo specyficznego podejścia i traktowania ${ }^{6}$. Zasada zawarta w art. 5 Konstytucji $\mathrm{RP}^{7}$, zgodnie z którym strzeżenie dziedzictwa narodowego jest podstawowym obowiązkiem państwa, nie jest skutecznie realizowana. Przejawem tego jest ciągle mała ilość spraw o niszczenie zabytków nieruchomych prowadzonych przez prokuratury i wręcz incydentalna w stosunku do rozmiaru i skali zjawiska ilość spraw kierowanych w tej materii do sądów ${ }^{8}$, co zakrawa na swego rodzaju kuriozum.

Tabela 2. Ogólna liczba przestępstw przeciwko zabytkom w Polsce.

\begin{tabular}{|c|c|c|c|c|c|c|c|c|c|c|c|}
\hline Rok & $\mathbf{2 0 0 4}$ & $\mathbf{2 0 0 5}$ & $\mathbf{2 0 0 6}$ & $\mathbf{2 0 0 7}$ & $\mathbf{2 0 0 8}$ & $\mathbf{2 0 0 9}$ & $\mathbf{2 0 1 0}$ & $\mathbf{2 0 1 1}$ & $\mathbf{2 0 1 2}$ & $\mathbf{2 0 1 3}$ & $\mathbf{2 0 1 4}$ \\
\hline $\begin{array}{c}\text { Liczba } \\
\text { przestępstw }\end{array}$ & 2282 & 2368 & 1939 & 1201 & 847 & 872 & 874 & 1022 & 1058 & 1819 & 1295 \\
\hline
\end{tabular}

Źródło: opracowanie własne na podstawie danych Komendy Głównej Policji, www.policja.p1/2015.

Tabela 3. Przykład liczby prawomocnie skazanych za przestępstwo zniszczenia lub uszkodzenia zabytku w Polsce z przepisów u o. z. o. z.

\begin{tabular}{|c|c|c|c|c|c|c|c|}
\hline Rok & $\mathbf{2 0 1 0}$ & $\mathbf{2 0 1 1}$ & $\mathbf{2 0 1 2}$ & $\mathbf{2 0 1 3}$ & $\mathbf{2 0 1 4}$ & $\mathbf{2 0 1 5}$ & $\mathbf{2 0 1 6}$ \\
\hline $\begin{array}{c}\text { Liczba } \\
\text { skazanych }\end{array}$ & 19 & 21 & 44 & 38 & 43 & 22 & 30 \\
\hline
\end{tabular}

Dane z Konferencji „Zwalczanie przestępczości przeciwko dziedzictwu kulturowemu”, Wrocław, 6-7 IX 2018 r.

Zasadne zatem wydaje się postawienie pytań: dlaczego tak się dzieje? Z czego wynika taka sytuacja? Istnieją bowiem wszystkie elementy, które pozwalałyby na efektywną ochronę tej części dziedzictwa kulturowego. Posiadamy

6 R. KRAWCZYK, op. cit., s. 18.

7 Dz. U. Nr 78, poz. 483 ze zm.

8 R. KRAWCZYK, op. cit., s. 19. 
przecież stosowne akty prawne, począwszy od ustawy o ochronie zabytków i opiece nad zabytkami ${ }^{9}$, poprzez kodeks karny ${ }^{10}$, prawo budowlane ${ }^{11}$, ustawy o planowaniu i zagospodarowaniu przestrzennym ${ }^{12}$, o gospodarce nieruchomościami ${ }^{13}$ oraz wiele innych, które ilościowo i jakościowo uprawniają do stwierdzenia, iż tworzą polskie prawo ochrony zabytków, zapewniając możliwość skutecznej ochrony zabytków nieruchomych. Funkcjonują również u nas wszelkie wyspecjalizowane organy delegowane do skutecznego stosowania owego prawa. Tymczasem w realiach obraz daleki jest od ideału. Zagrożenia zabytków nieruchomych wynikają z licznych mankamentów zarówno po stronie organów ochrony zabytków, jak i obarczonych obowiązkiem opieki nad zabytkami właścicieli takich obiektów. Sygnalizowany wyżej brak zunifikowanego systemu ochrony zabytków powoduje, iż często notowana jest opieszałość, bezczynność i brak działań podejmowanych przez państwo i organy ochrony zabytków. Istnieje zbyt duża liczba przepisów prawa ochrony zabytków (,przekleństwo obfitości”), które w pewnych obszarach są po prostu martwe. W końcu, niekompletność i słaba jakość prowadzonych zestawień zabytków, nieodzwierciedlająca ich rzeczywistej liczby i stanu potęguje chaos w i tak już skomplikowanej materii ${ }^{14}$. Na uwagę w tym przypadku zasługuje również swoiste przyzwolenie społeczne na tego rodzaju sytuację. W konsekwencji prowadzi to do nagminnego poczucia bezkarności wśród sprawców niszczenia zabytków nieruchomych. Wpływa to niewątpliwie na obraz problemu i stanowi ważną, acz nie jedyną przyczynę takiego stanu rzeczy.

Należy jednak zauważyć, że aktualnie zabytki nieruchome są bardzo modne ${ }^{15}$. Posiadanie ich stanowi, $\mathrm{z}$ różnych względów, ogromną pokusę dla wielu osób. Państwo, starając się nadrobić własne, wieloletnie zaniechania i zaniedbania w tej dziedzinie, umożliwia właściwie nieskrępowany obrót zabytkowymi nieruchomościami. Wzrasta liczba obiektów nabywanych przez prywatnych inwestorów. Generalnie jest to dobry kierunek działań. Prywatyzacja zasobów zabytkowych stanowi właściwą drogę do uchronienia ich przed zniszczeniem i uratowania dla potomnych. W tym przypadku najważniejsze jest właściwe zagospodarowanie zabytku nieruchomego i użytkowanie go w odpowiedni sposób. Zwykle już sama obecność właściciela chroni obiekt zabytkowy przed niszczeniem. Niemniej ważne jest, w jaki sposób prywatyzowanie zabytków nieruchomych jest realizowane ${ }^{16}$. Modelowi powszechnej prywatyzacji towarzyszy

\footnotetext{
9 (Dz. U. Nr 162, poz. 1568 ze zm.)

10 (Dz. U. Nr 88, poz. 55 ze zm.)

1 (tekst jedn. Dz. U. z 2013 r., poz. 1409 ze zm.)

2 (tekst jedn. Dz.U. z 2012 r., poz. 647 ze zm.).

3 (tekst jedn. Dz. U. z 2004 r. nr 261, poz. 2603 ze zm.).

141500 obiektów figuruje wyłącznie w kartach ewidencyjnych rejestru, dane NiD 2017 r.

15 R. KRAWCZYK, op. cit., s. 219.

16 Ibidem, s. 221.
} 
programowe ograniczanie odpowiedzialności i roli państwa w ochronie zabytków, a to skutkuje coraz silniejszą utratą kontroli nad zabytkowym zasobem ${ }^{17}$.

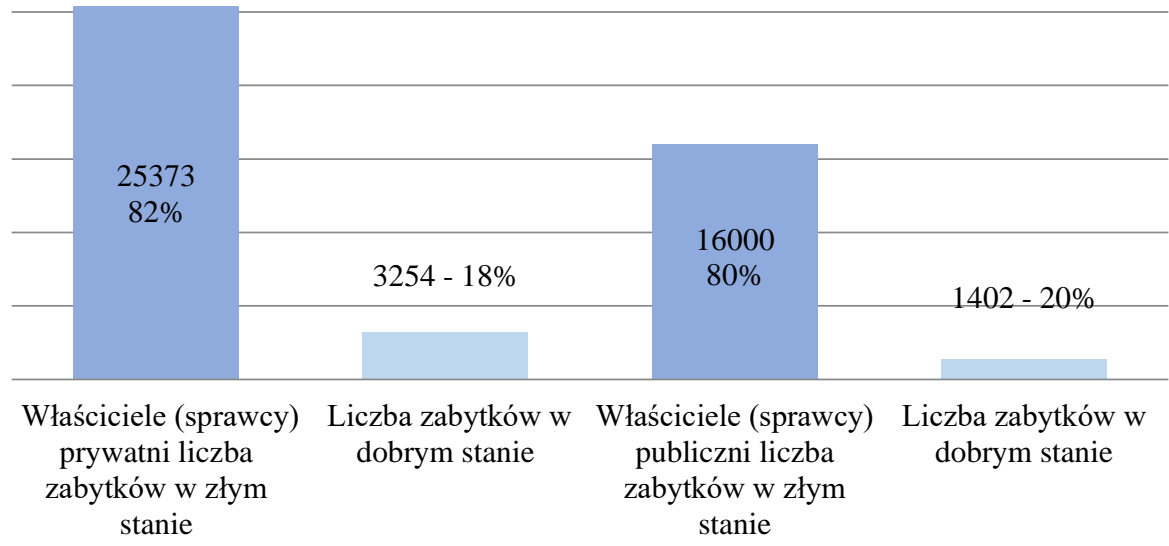

Wykres 1. Ogólna liczba zabytków nieruchomych w generalnie złym stanie w zależności od typu właściciela

Źródło: opracowanie własne autora na podstawie danych NID 2015.

Kolejny istotny element warty wspomnienia to specyfika polskiego sposobu niszczenia tej części dziedzictwa kulturowego. A w skali oraz formie jest on niespotykany i odmienny od innych tego typu przypadków w Europie. Otóż w Polsce głównymi sprawcami niszczenia zabytków nieruchomych są ich właściciele i posiadacze. Dotyczy to niestety również podmiotów publicznych, nierzadko reprezentujących państwo (sprawcy publiczni) ${ }^{18}$, podczas gdy na całym świecie (np.: brytyjski, niemiecki i francuski systemy ochrony zabytków), zasadą jest, że właściciele nie tylko dbają o techniczny stan obiektów będących ich własnością, ale co najważniejsze, poczuwają się mentalnie do sprawowania nad nim należytej opieki. W Polsce natomiast głównym modus operandi sprawców jest brak jakiegokolwiek działania - opieki nad zabytkiem nieruchomym, który najczęściej faktycznie jest porzucony wraz z „dobrodziejstwem inwentarza” czyli, zamieszkującymi je ludźmi (np. byłymi pracownikami PGR-ów) i pozostawiony, podobnie jak oni, swojemu losowi. W rezultacie skutkuje to całkowitą degradacją jego substancji. Publiczni właściciele obiektów (państwo, gminy, powiaty) często w najmniejszym nawet stopniu nie interesują się ich stanem, a nawet nie posiadają pełnego rozeznania w zasobach posiadanych obiektów zabytkowych, o czym świad-

17 Raport na temat funkcjonowania Systemu Ochrony Dziedzictwa Kulturowego w Polsce po roku 1989, oprac. Aleksander BöHM, Piotr DoBosz, Paweł JASKANIS, Jacek PuRChla, Bogusław SZMYGin, red. Jacek PuRChLA, Kraków 2008, s. 9.

18 Problem spotykanego w realiach określenia tzw. wandalizmu urzędniczego. 
czą niekompletne dane w raportach sporządzanych nawet na szczeblu ministerialnym. Dodatkowo, publiczni właściciele zabytków, poza faktem niestosowania efektywnej opieki, wykazywali i wciąż wykazują rażące niedbalstwo w gospodarowaniu podlegającymi im zabytkami nieruchomymi ${ }^{19}$.

Na porządku dziennym jest niedostateczne zabezpieczenie obiektów zabytkowych przed działaniem czynników atmosferycznych, pożarami czy rozkradaniem, co powoduje ich daleko posuniętą degradację. Publiczni właściciele, w przeważającej mierze nie podejmują żadnych działań w celu rewitalizacji zniszczonych lub niszczejących obiektów, najczęściej tłumacząc to brakiem środków finansowych. Jednocześnie nie są podejmowane jakiekolwiek starania o pozyskanie środków na te cele. Ponadto nagminnie naruszane są przepisy prawa, dotyczące realizacji zaleceń konserwatorskich, informowania o prawnym i faktycznym stanie obiektu czy uzyskiwania pozwoleń na prace przy zabytku ${ }^{20}$.

Nieliczne próby działań, inspirowane, nomen omen, nie przez przeznaczone do tego organy, a przez obywateli - miłośników zabytków, skutkują najczęściej markowaniem „pseudo działań” oraz przerzucaniem się odpowiedzialnością za ich efekty z organami ochrony zabytków. Te z kolei, również opieszale podejmują jakiekolwiek działania, zmierzające do faktycznego poprawienia stanu powierzonych im zabytków nieruchomych. Dla szerokorozumianych podmiotów publicznych, będących właścicielami obiektów zabytkowych, pojawiła się wszak nadzieja na zmianę tego niekorzystnego wizerunku. Jest nią wspomniana wyżej „moda na zabytki” i coraz większe nimi zainteresowanie prezentowane przez prywatnych inwestorów. Wpisuje się ono doskonale w ogólny trend prywatyzowania wszystkiego. Stanowi konsekwencję gwałtownych przeobrażeń zachodzących wokół nas. Wobec ogromnego wzrostu znaczenia gospodarczego turystyki narasta zapotrzebowanie na dziedzictwo w każdej formie, z zabytkami architektury i urbanistyki na czele ${ }^{21}$. Tu jednak funkcjonują nieprzemyślane i nieujednolicone procedury oraz pojawiają się dwie kolejne kategorie (sprawcy indywidualni) niszczenia zabytków nieruchomych. Są to osoby fizyczne (nabywcy i właściciele obiektów) dzielący się na dwie podkategorie.

Pierwsi, niestety w dużej liczbie, od samego początku nie są zainteresowani przejętym zabytkiem. Mentalnie nie ma dla nich żadnego znaczenia wartość historyczna, naukowa czy artystyczna reprezentowana przez obiekt, a tym bardziej nie zastanawiają się, czy zachowanie zabytku nie jest konieczne ze względu na interes ogółu społeczeństwa. Traktują go wyłącznie jako etap, a często jako przeszkodę w drodze do celu właściwego, najczęściej o charakterze merkantylnym może to być na przykład pozyskanie atrakcyjnego terenu na którym zabytek jest

19 Informacja o wynikach kontroli prawidtowości gospodarowania i nadzoru nad wybranymi zabytkami nieruchomymi $w$ latach 2004-2008, LRZ-410-09/2009, $\mathrm{Nr}$ ewid. 2/2010/P/09/ 170/LRZ, s. 8 i n., Rzeszów 2010.

20 Ibidem, s. 18 i $\mathrm{n}$.

21 Raport na temat funkcjonowania Systemu Ochrony Dziedzictwa Kulturowego, s. 12. 
posadowiony. Z uwagi na szybki rozwój techniki budowlanej, która niszczenie, jak i budowanie obiektów czyni coraz łatwiejszym, część zabytkowego zasobu jest likwidowana i zastępowana nową zabudową lub rzadziej, właściciel cierpliwe czeka, aż porzucony obiekt sam ulegnie degradacji w takim stopniu, że nawet konserwator zabytków nie jest już w stanie go ratować. Potem właściciel sprzedaje z zyskiem teren pod inwestycje.

Drugą podkategorię sprawców stanowią osoby, dla których liczy się prestiż firmowany w ich mniemaniu przez posiadany obiekt zabytkowy, np. pałac lub zamek. $\mathrm{W}$ ich wyobrażeniu, stawia ich to wyżej w stosunku do innych obywateli, podnosi znacząco ich pozycje społeczną. Generalnie tacy właściciele mają na uwadze dobro zabytku, ale ulegając modzie, nie mają kompletnie pojęcia o realiach utrzymania we właściwym stanie zabytkowego obiektu o charakterze kubaturowym - przede wszystkim chodzi tu o gigantyczne wręcz koszty i ponoszenie ogromnych nakładów finansowych. Ponadto nie są przygotowani na ogrom problemów technicznych związanych z właściwą opieką nad obiektem, jakim jest zabytek nieruchomy. Po prostu przeszacowują swoje możliwości, siły i środki. W rezultacie tego również i oni zaczynają postępować w sposób prowadzący szybko do degradacji zabytkowej substancji obiektu. Ignorują narastające problemy, unikają jakiejkolwiek formy działań ratujących zabytek, który najczęściej zostaje ostatecznie porzucony.

Takim postępowaniom sprzyja aktualny model kupna - sprzedaży zabytków nieruchomych, niestety znów firmowany przez podmioty publiczne. Wystawianie zabytków nieruchomych na przetargach nieograniczonych, w polskich realiach, przypomina polowanie na naiwnych, tylko $\mathrm{w}$ jednym celu - aby jak najszybciej pozbyć się problemu, jaki stanowi dla sprzedającego zabytek. „Zabytki nieprzydatne z punktu widzenia potrzeb i możliwości finansowych państwa przeznaczone są na prywatyzację; państwo dąży tym samym do przeniesienia odpowiedzialności za stan zachowania zabytku na prywatnego właściciela"22. Wyceny zabytków nieruchomych wystawianych na aukcjach dalekie są od ideału. Postanowienia umów najczęściej nie nakładają na nabywców konkretnych obowiązków związanych z zabytkowym charakterem obiektów. Dotychczasowi właściciele (sprawcy publiczni) nie zastrzegają możliwości kontroli sposobu gospodarowania zabytkiem po jego sprzedaży, a nader rzadko określają konsekwencje jego niestosowania. Właściciele publiczni obiektów nieużytkowanych (opuszczonych, porzuconych), podejmowali dotychczas wyłącznie starania mające na celu przekazanie własności inwestorom, którzy z kolei najczęściej, wyłącznie ustnie, deklarowali sfinansowanie rewitalizacji zabytków. Postępowania takie są nieskuteczne, bowiem nie zadawano sobie trudu, aby przed transakcją zweryfikować faktyczne możliwości finansowe nabywcy lub zastosować na przykład instytucję wpłaty kaucji na rzecz remontu obiektu ${ }^{23}$. Towarzyszy temu praktyka

22 R. KrawCZYK, op. cit., s. 223.

23 Informacja o wynikach kontroli s. 9 i nn. W latach 2008-2012 w całej Polsce przeprowadzono zaledwie 5 wywłaszczeń konserwatorskich oraz czasowych zajęć obiektu zabytkowego z po- 
organów ochrony konserwatorskiej, które wykazują się wyjątkową pobłażliwością w stosowaniu przepisów ustawy o ochronie zabytków i opiece nad zabytkami wobec właścicieli (sprawców) publicznych, zwielokrotniając swoją aktywność w przypadku nabycia obiektu przez osobę prywatną. I w tym przypadku nie prowadzi to jednak w żaden sposób do wymiernej poprawy stanu zabytków nieruchomych, z powodu ograniczenia się organów konserwatorskich niemal wyłącznie do działań o charakterze wymiany korespondencji. Faktyczne stosowanie środka nadzoru konserwatorskiego, w postaci np. wywłaszczenia związanego $\mathrm{z}$ katastrofalnym stanem zabytku, nie istnieje w praktyce, bowiem wydaje się, iż organy konserwatorskie nie chcą brać na siebie odpowiedzialności za jego zachowanie. Tworzy to rodzaj ,papierowej fikcji” działań, a tymczasem zabytki niszczone są w dalszym ciągu ${ }^{24}$.

W tym miejscu należy opisać postępowanie jeszcze jednej podkategorii indywidualnych sprawców niszczenia zabytków nieruchomych - sprawców okazjonalnych. W wyniku zaniechań właścicieli publicznych i indywidualnych do głosu dochodzą podmioty wykorzystujące cynicznie stan obiektów zabytkowych dla własnych korzyści. Jest to bodaj jedyna grupa sprawców, która wykazuje daleko idącą chęć działania. Niezabezpieczone zabytki nieruchome są dewastowane i rozkradane. Sprawcy traktują je jako bazę surowców budowlanych (cegły, złom) lub też źródło wartościowych elementów architektonicznych osiągających wysokie ceny na rynku antyków. $\mathrm{W}$ tych przypadkach niszczenie przyjmuje zdecydowanie formę zamierzonych działań, jednakże sprawcy ci w większości przypadków pozostają nieznani ${ }^{25}$.

$\mathrm{Na}$ gruncie tak (nie)zorganizowanej opieki i ochrony nad zabytkami nieruchomymi, swoistym uwieńczeniem jej nieskuteczności są tzw. pomyłki konserwatorskie, będące - ze względu na jakość - coraz większym problemem ${ }^{26}$. Rady-

wodu złego stanu technicznego. Vide: Krajowy program ochrony zabytków i opieki nad zabytkami na lata 2014-2017. Projekt, Warszawa 2014, s. 21.

24 Marek SoŚNIAK, Komentarz do Kontroli NIK w sprawie zagospodarowania prawidlowości gospodarowania i nadzoru nad wybranymi zabytkami nieruchomymi $w$ latach 2004-2008, http//biznes.onet.pl/pap.../2.1/, Press-data, [dostęp: wrzesień 2014].

25 R. KRAWCZYK, op. cit., s. 226 i n.

26 Jednym z bardziej rażących przykładów tego typu niszczenia może być „pomyłka konserwatorska” z okolic Krakowa. We wrześniu 2011 r. w Bibicach, gmina Zielonki, wpisany do gminnej ewidencji zabytków zespół baterii artyleryjskiej z 1904 r., wchodzący w skład Fortu nr 47a Węgrzce, stanowiący część pierścienia fortyfikacji Twierdzy Kraków, został zrównany z ziemią przez buldożery prywatnego przedsiębiorcy, właściciela terenu, na którym stały. O niszczeniu zabytkowych fragmentów fortu zaalarmowali media mieszkańcy Zielonek. Wójt gminy, po otrzymaniu sygnału o wyburzeniach, skierował na miejsce urzędników. Okazało się, że właściciel działki, na której znajdowały się baterie, przed przystąpieniem do rozbiórki zapytał Urząd Wojewódzkiego Konserwatora Zabytków w Krakowie, czy kaponiery są pod ochroną. Otrzymał odpowiedź, że nie [sic!]. Zgłosił więc zamiar wyburzenia w starostwie powiatowym w Zielonkach, na co, w takiej sytuacji, otrzymał zgodę. Dwie z trzech kaponier bezpowrotnie uległy zniszczeniu. Ocalała jedna bateria i okalający ją wał ziemny. Wojewódzki Konserwator Zabytków oświadczył, że doszło do pomyłki. 
kalnie rzutują one na opinię o konserwatorach, dowodząc często kompletnej niewydolności urzędu, a także, jak wynika z analizy licznych uwag zgłaszanych na forach internetowych, sugerują czasami wręcz istnienie czynów określanych mianem korupcji. Ranga tego sposobu niszczenia zabytków nieruchomych jest nie do przecenienia, głównie poprzez fakt wywoływania tragicznych dla zabytku nieruchomego skutków przez sprawcę najmniej spodziewanego - konserwatora zabytków, który jako urząd (Wojewódzki Konserwator Zabytków) uznawany jest w Polsce za najważniejszy w realizacji tej ochrony. Z racji reguł rządzących systemem administracji zespolonej w województwie, WKZ wykonuje zadania i realizuje kompetencje przysługujące wojewodzie w zakresie ochrony zabytków. Odpowiada za jej realizację i ponosi też odpowiedzialność w tym zakresie ${ }^{27}$. WKZ realizuje powyższe zadania za pomocą Wojewódzkich Urzędów Ochrony Zabytków. WUOZ-y składają się nie tylko z zespołów osób, ale również środków rzeczowych i finansowych, przy pomocy których możliwe jest realizowanie przez organ administracji publicznej zadań powierzonych mu w ustawie o ochronie zabytków i opiece nad zabytkami ${ }^{28}$. WKZ, co do zasady, posiada kompetencje do wykonywania czynności kontrolnych dotyczących zabytków nieruchomych, jako organ ochrony zabytków pierwszej instancji ${ }^{29}$. Podnoszona przez wielu specjalistów pozycja WKZ, jako obrońcy dziedzictwa narodowego, powinna stanowić rękojmię skutecznej i sumiennej ochrony zabytków. Tak jednak nie jest. Dowodem na spektrum problemów, z jakimi borykają się konserwatorzy mogą być słowa Barbary Nowak-Obelindy (WKZ we Wrocławiu) z marca 2013 r. „Niewiele mogę zrobić, nakazy remontów i zalecenia konserwatorskie są ignorowane, bo sądy nie orzekają grzywien, a prokuratury umarzają sprawy"30.

Podstawową trudnością związaną z wykonywaniem przez organy ochrony zabytków czynności kontrolnych, jest zgłaszana przez nie zbyt mała liczba osób zatrudnionych w WUOZ w stosunku do ilości zadań obciążających pracowników organów ochrony zabytków. Wynagrodzenia ich są natomiast nad wyraz niskie, co prowadzi do bardzo dużej płynności kadr, sięgającej nawet 3/4 stanu osobowego. Trudno w tych warunkach mówić o zachowaniu jakości pracy ${ }^{31}$. Okoliczność ta powoduje także opóźnienia w aktualizacji danych zawartych w rejestrze

27 Art. 2 pkt. 2 oraz art. 51-55, Ustawy z 23 stycznia 2009 r. o wojewodzie i administracji rządowej w województwie, (Dz. U. nr 31, poz. 206), oraz art. 89-96 u o. z. o. z.

28 Katarzyna ZALASIŃSKA, Wojewódzki Urząd Ochrony Zabytków, [in:] Leksykon ochrony zabytków, red. Kamil Zeidler, Warszawa 2010, s. 397. Conf. Jan Zimmermann, Prawo administracyjne, Kraków 2001, s. 146 i nn.

29 Generalny Konserwator Zabytków, działający z upoważnienia Ministra Kultury i Dziedzictwa Narodowego, może podejmować czynności kontrolne jedynie, jeżeli jest to konieczne ze względu na szczególną wagę sprawy (art. 42 u o. z. o. z.). Przykład: zburzenie przędzalni w Mysłakowicach - proces pod nadzorem GKZ.

30 Cit a: http://www.tvp.pl/hbbtv/aplikacje/teleexpress/najciekawsze/dolnoslaskie-palace-w-ruinie/10599698, [dostęp: wrzesień 2017].

31 Raport na temat funkcjonowania Systemu Ochrony Dziedzictwa Kulturowego, s. 104 i n. 
zabytków, zwłaszcza że właściciele i posiadacze zabytków nie wywiązują się najczęściej z obowiązku powiadamiania WKZ o zmianach stanu prawnego zabytku. Ponadto WUKZ cierpią ogólnie na brak środków finansowych na realizację stawianych przed nimi zadań ochronnych ${ }^{32}$. Jeśli do tego dodać, co wykazała kontrola NIK, zwykłą nierzetelność, niedbałość i niechlujstwo prowadzonych w wielu przypadkach przez WUKZ czynności, to wizerunek urzędu w żaden sposób nie stanowi gwarancji poprawy losu polskich zabytków nieruchomych ${ }^{33}$. Dodać należy, że z punktu widzenia kryminalistyki WUKZ posiadają jedną niezwykle ważną cechę. $Z$ racji podziału terytorialnego, poprzez swoje delegatury są „blisko" podlegających ich ochronie zabytków nieruchomych. Powinno to zapewnić nieustanny, efektywny nadzór nad obiektami, a w razie potrzeby spowodować natychmiastowe reakcje na sygnały o nadchodzącym zagrożeniu danego obiektu. Jednak tak w warunkach polskich nie jest. WUKZ w zatrważającym stopniu utraciły mobilność. Wydaje się, że w wielu przypadkach, pracownicy WUKZ podległe im zabytki znają wyłącznie $\mathrm{z}$ opowiadań lub wiadomości zawartych w Internecie. Nie orientują się zupełnie w powierzonej im materii ${ }^{34}$. W połączeniu z powyżej przedstawionymi „logistycznymi” problemami dotyczącymi funkcjonowania urzędów ochrony zabytków, konserwatorzy w większości przypadków stali się zwykłymi, tonącymi w papierach urzędnikami, w najbardziej pejoratywnym znaczeniu tego słowa. Nie sposób nie zauważyć, że polska ochrona zabytków, pomimo istniejącego prawa i wyspecjalizowanych organów to prawo mających stosować, faktycznie sprowadza się głównie do nieustannego powtarzania urzędowych sformułowań zawartych w setkach pism oraz wypowiedziach przedstawicieli organów ochrony zabytków dla mediów.

Ostatnim ważnym elementem, wchodzącym także częściowo w zakres modus operandi sprawców niszczenia zabytków nieruchomych jest sygnalizowany powyżej fakt znikomej ilości spraw karnych o niszczenie zabytków nieruchomych, prowadzonych przez organy prokuratury i wymiaru sprawiedliwości. Realia dowodzą, iż przypadki takie zdarzają się wręcz sporadycznie. Smutnym tego dowodem są podsumowania samego MKiDN, które w statystykach dotyczących działalności WUKZ w latach 2008-2012 nie zdecydowało się na podanie procentowych prezentacji zmienności liczby zawiadomień o popełnieniu przestępstwa „ze względu na niewielkie wartości liczbowe związane z tą formą aktywności kon-

32 Barbara Maciejewska, Rozmowa z Barbara Nowak-Obelinda, WKZ we Wrocławiu, cit. a: http://wroclaw.gazeta.pl/wroclaw/1,36743,15900650,Chca_procesu_zamiast_7_tys_za_zniszczenie_cennego.html, [dostęp: 5.05.2014]. WUKZ we Wrocławiu obejmujący swym zasięgiem najliczniejszą w kraju grupę zabytków nieruchomych otrzymuje zaledwie 700000 zł rocznie na realizację swoich statutowych zadań.

33 Informacja o wynikach kontroli, s. 72 i nn.

34 Dowodem takiego stanu są nie tylko spostrzeżenia NIK, ale też zwykłych obywateli i mediów, np. tytuły z gazet: Wyburzali zabytek, a konserwator nic nie wie - kwiecień 2014, TVN Gdańsk, lub Czworaki niekompetencji. Co konserwator ma $w$ rejestrze? Nie wie nawet on. http://m.bialystok.gazeta.pl/bialystok/51,106505,13530871.html?i=2, [dostęp: wrzesień 2017]. 
serwatorów zabytków, uznając uzyskane w ten sposób dane za niemiarodajne" ${ }^{35}$. A jest to jeden z czynników powodujących u sprawców przekonanie o bezkarności. Społecznie natomiast nie wnosi on jakiegokolwiek waloru prewencji generalnej. Społeczeństwo nie odczuwa zbytniego dyskomfortu z powodu niszczenia dziedzictwa kulturalnego, skoro w jego mniemaniu są to sporadyczne przypadki.

Jeszcze jedną cechą wskazującą przewrotnie na ułomności istniejącego systemu ochrony jest fakt, że najbardziej zainteresowane ochroną zabytków nieruchomych nie są wyznaczone do tego organy, a osoby fizyczne - miłośnicy zabytków. Działający samodzielnie lub zrzeszeni w fundacjach, stowarzyszeniach czy po prostu zorganizowani na profilach społecznościowych w Internecie. Organizują niemal corocznie akcje ratowania zabytków nieruchomych w Polsce. Robią to całkowicie bezinteresownie. Efekty działań zazwyczaj są niestety znikome, ale tym samym stanowią jeszcze jeden dowód na całkowitą niewydolność polskiego systemu ochrony zabytków nieruchomych.

Na koniec odnotować można fakt, że polscy sprawcy niszczenia zabytków posiadają jeszcze jedną charakterystyczną cechę - w większości przypadków legitymują się wyższym wykształceniem, co jak widać nie stoi w opozycji do rodzaju czynu.

Jak widać z powyższego szkicu, przyczyn katastrofalnego stanu zabytków nieruchomych w Polsce jest wiele - natury instytucjonalnej, materialnej i organizacyjnej ${ }^{36}$. Autor - kryminalistyk, prowadząc badania zmierzające do stworzenia obrazu modus operandi sprawcy niszczenia zabytku nieruchomego w Polsce, doszedł jednak do wniosku, że u podłoża takiego stanu rzeczy leży najważniejszy element - przyczyna natury mentalnej. Aby obraz modus operandi niszczenia zabytków nieruchomych był pełny, zasadne jest przeanalizowanie tła mającego wpływ na określone zachowania sprawców. Różnice w zachowaniach wynikają głównie z tego, że te same czynności wykonujemy w sposób indywidualny, tylko sobie właściwy. Wielokrotne powtarzanie tych samych czynności powoduje często powstanie przyzwyczajeń, od których człowiek rzadko odstępuje. Może ono zacząć dominować u danej osoby, a w efekcie stać się indywidualną cechą zachowania tej osoby ${ }^{37}$. Niezaprzeczalny jest jednak fakt, że wszystko to krystalizuje się w określonych, konkretnych warunkach. Szczególnie w przypadku przestępstwa niszczenia lub uszkadzania zabytków nieruchomych, znajomość realiów rzeczywistości ich dotyczącej, mającej niewątpliwy wpływ na określone postępowanie sprawców, umożliwia jego właściwą ocenę. Dopiero w kontekście tła zachowania sprawców, obraz ich modus operandi jest zupełny i w pewny sposób pozwala na odpowiedź, dlaczego postępują tak a nie inaczej ${ }^{38}$.

35 Krajowy program ochrony zabytków, s. 20.

36 R. KRAWCZYK, op. cit., s. 20.

37 Monika SĄSIADA, Modus operandi jako środek identyfikacji sprawcy przestępstwa, „Wrocławskie Studia Erazmiańskie. Zeszyty Studenckie", z. 1, red. Mirosław SAdowSKI, Piotr SzYMANIEC, Ernest BoJEK, Wrocław 2008, s. 205

38 R. KRAWCZYK, op. cit., s. 210. 
Przystępując do badania problematyki niszczenia zabytków nieruchomych w Polsce, autor uznał, że warto przekonać się z czego wynika masowość tego zjawiska. Apriorycznie założył, że duże znaczenie ma tu osobisty stosunek Polaków do badanej materii, przy czym pochodzenie, wykształcenie czy wykonywany zawód nie odgrywają w tym podstawowej roli. Interesująca była odpowiedź na pytanie, czy obywatele mają jakąkolwiek wiedzę o zabytkach, jak postrzegają sytuację zabytków, czy interesują się tą problematyką, czy mają świadomość zagrożeń na jakie narażone są obiekty zabytkowe, i w końcu, czy dysponują wewnętrzną potrzebą obcowania z czymś, co fachowo nazywa się dziedzictwem kulturowym. Badania miały stanowić między innymi krok do przodu w próbie odpowiedzi na pytanie postawione na wstępie artykułu - o przyczyny katastrofalnego stanu polskich zabytków nieruchomych.

W latach 2011-2013 autor przeprowadził badania ankietowe, dotyczące wiedzy Polaków na temat zabytków, ich zagrożeń i szerokorozumianej ochrony. Zależało mu na możliwie szerokiej reprezentacji społeczeństwa, zarówno w kontekście wieku, wykształcenia, wykonywanego zawodu, jak i miejsca zamieszkania ${ }^{39}$. Najliczniejszą, podstawową grupę respondentów stanowili studenci różnych roczników i kierunków studiów: prawa, biologii, kulturoznawstwa, dziennikarstwa, chemii, różnych wydziałów Akademii Sztuki Pięknych, filologii i psychologii. Drugą co do liczebności grupę badanych tworzyli słuchacze studiów podyplomowych, a więc ludzie już z konkretnym wykształceniem, wykonywujący określony zawód, poszerzający swoją wiedzę i umiejętności, np. nauczyciele, biznesmeni, inżynierowie, radcy prawni itp. Trzecia grupa respondentów obejmowała osoby bez wyższego wykształcenia, pracujące $\mathrm{w}$ różnorodnych zawodach - sprzedawcy, rzemieślnicy, budowlańcy, kierowcy itp. Czwartą grupę tworzyli respondenci będący z racji wykonywanego zawodu swoistymi specjalistami w omawianej problematyce - artyści, konserwatorzy zabytków, pracownicy muzeów itp. Grupa piąta, to urzędnicy różnej rangi zatrudnieni w urzędach gminnych i powiatowych. Grupę szóstą stanowili przedstawiciele zawodów prawniczych oraz organów ścigania - prokuratorzy, sędziowie, adwokaci i policjanci. Konieczne jest w przypadku tej grupy, jakże istotnej z punktu widzenia jakości ochrony zabytków, zaakcentowanie niesłychanie ważnej kwestii. Otrzymana liczba odpowiedzi (33 ze 100) świadczy jednoznacznie, że poza „grupą policyjną", przedstawiciele zawodów prawniczych wydają się nie być w ogóle zainteresowani problematyką ochrony zabytków w Polsce. W ocenie autora, potwierdza to jedną z przedstawionych ułomności i rzuca światło na praktykę ochrony zabytków w naszym kraju, zmuszając tym samym do refleksji.

W stosunku do wymienionych powyżej kategorii respondentów, grupą kontrolną byli licealiści z klas maturalnych, jako osoby bardzo młode, nie mające jeszcze wielkiego doświadczenia życiowego i zawodowego, oraz emeryci róż-

39 Ibidem, s. 211. 
nych profesji, jako osoby posiadające bogaty „bagaż doświadczeń” i umiejętności, patrzący na świat przez ich pryzmat. Istotne było, aby respondenci biorący udział w badaniach pochodzili z obszaru całego kraju. Przez ostatnie kilka lat autor przemierzył bowiem niemal całą Polskę i zetknął się z pełnym spektrum zagrożeń, na jakie narażone są zabytki nieruchome w naszym kraju. A zatem, jeśli chodzi o miejsce zamieszkania, respondenci zostali przyporządkowani do trzech ogólnych kategorii - mieszkańców miast powyżej 100000 mieszkańców, miast poniżej 100000 mieszkańców oraz wsi. Rozkład płci badanych respondentów kształtował się wg ogólnopolskiej struktury społecznej (przewaga kobiet) kobiety: 620 respondentów, mężczyźni: 431 respondentów. Łącznie przebadano 1051 osób, przy czym pełnych odpowiedzi na wszystkie postawione w ankiecie pytania udzieliło 1038 respondentów ${ }^{40}$.

Respondentom postawiono sześć (studentom siedem) pytań. Wszystkie były proste i jednoznaczne, tak aby nie nastręczały problemów odpowiadającemu. Język i pojęcia użyte w pytaniach uwzględniały różnorodność wykształcenia respondentów. Najważniejsze było uzyskanie odpowiedzi spontanicznej, dlatego poproszono o udzielanie pierwszej nasuwającej się odpowiedzi. Postawione pytania dotyczyły: zainteresowania respondenta problematyką zabytków i dzieł sztuki, problemu relatywizowania wartości zabytków ze względu na fakt, że prawo traktuje jednakowo wszystkie rodzaje zabytków, a praktyka wskazuje na częste przypadki „wartościowania obiektów zabytkowych”, autor chciał się przekonać, czy badani również stosują swoisty relatywizm, uważając, że są kategorie zabytków, którym należy się szczególna ochrona kosztem innych ich rodzajów. Przedstawiono zatem badanym katalog zabytków, prosząc o wskazanie tych, które zasługują na najlepszą ochronę. W tym przypadku pozostawiono też respondentom możliwość wskazania innego, własnego zdania (odpowiedź otwarta). W końcu postawiono pytania o najniebezpieczniejsze rodzaje zagrożeń, na jakie narażone są zabytki, a także pytania dotyczące źródeł wiedzy respondentów o zabytkach i potrzebie poszerzania wiedzy w tej tematyce.

Pod koniec 2017 r. autor powtórzył badania ankietowe na grupie 660 respondentów. Ich wyniki nie odbiegały w żaden sposób od badań przeprowadzonych cztery lata wcześniej, w pełni pokrywając się z powyżej przedstawionymi spostrzeżeniami w kwestii przyczyn stanu ochrony polskich zabytków nieruchomych ${ }^{41}$.

$\mathrm{Na}$ podstawie analizy wyników badań można stwierdzić, że świadomość i wiedza polskiego społeczeństwa w szerokorozumianej materii zabytków ich ochrony i zagrożeń pozostawiają wiele do życzenia. U Polaków generalnie nie funkcjonuje świadomość potrzeby ochrony dziedzictwa kulturalnego, a co najgorsze, również potrzeba indywidualnego obcowania z szeroko rozumianym dziedzictwem kulturowym wydaje się odbiegać od europejskich standardów.

40 Ibidem, s. 211 i nn.

41 Dokładne zobrazowanie wyników badań (wykresy, tabele, wartości procentowe) - vide: ibidem, s. $210-214$. 
Wiedza na temat ochrony zabytków praktycznie nie istnieje. Jak z tego wynika, rola państwa i jego organów w krzewieniu świadomości o dziedzictwie pokoleń jest bardzo słaba. Zabytków nie traktujemy jako części wspólnego dobra należącego do nas wszystkich, lecz raczej postrzegamy je jako indywidualne kategorie, które darzymy sympatią lub nie. Co ciekawe, taki swoisty relatywizm wykazali również respondenci zaliczani do grupy specjalistów problematyki. W ocenie autora właśnie ten relatywizm rzutuje w wielu przypadkach w zdecydowany sposób na społeczne przyzwolenie i swoistą tolerancję w stosunku do sprawców niszczenia zabytków nieruchomych, które dodatkowo postrzegane są, ze względu na ich stan, jako niczyje i bezpańskie. W wielu przypadkach takie nastawienie stanowi również legitymację do traktowania zabytku nie jako szczególnego obiektu, ale jako swoistej przeszkody (np. w bogaceniu się). Nakazy i zakazy konserwatorskie traktowane są jako ograniczenie prawa własności, uderzające we właścicieli obiektów. Bezdyskusyjna jest wśród obywateli świadomość faktu niszczenia zabytków nieruchomych. Niewielu respondentów nie spotkało się z jakimikolwiek przykładami wandalizmu obiektów zabytkowych. Skala tego zjawiska zauważana jest powszechnie i to, jak widać, przez osoby nie będące zainteresowanymi zabytkami jako takimi. Co bardzo istotne i niepokojące to nikłe zainteresowanie tematyką ochrony zabytków pośród przedstawicieli zawodów prawniczych. Świadczy o tym po pierwsze fakt zlekceważenia ankiety przez grupę sędziów i prokuratorów, od których przecież zależy w ogromnym stopniu jakość ochrony zabytków nieruchomych w Polsce, a po drugie fakt, że wszyscy ankietowani policjanci, którzy jako przedstawiciele organów ścigania mają pierwszy kontakt $\mathrm{z}$ różnymi rodzajami przestępczości ukierunkowanej na zabytki, jako podstawowe zagrożenia wskazali kradzieże obiektów zabytkowych i powiązany z nimi przemyt. Świadczyć to może o znikomej ilości przestępstw niszczenia lub uszkadzania zabytków (szczególnie nieruchomych), o jakich powiadamiane są organy ścigania. Pozytywnym wynikiem ankiety jest niemal powszechnie sygnalizowana chęć pogłębiania wiedzy o zagrożeniach zabytków. Zarówno w zaproponowanej formie szerokiej edukacji w tym zakresie, jak też doskonalenia warsztatu zawodowego przez studentów kierunków specjalistycznych ${ }^{42}$.

Podsumowując, trzeba podkreślić, że wyniki badań wpisują się doskonale w ogólne tło, które rodzi elementy modus operandi sprawców niszczenia i uszkadzania zabytków nieruchomych w naszym kraju. Działają oni przecież w określonych realiach i utrwalają przyzwyczajenia właśnie z tych realiów wynikające. Znajomość tych realiów pomaga w szczególny sposób w przypadku określenia typów sprawców niszczących zabytki. Stanowi także po części odpowiedź na pytanie o przyczyny stanu polskich zabytków nieruchomych. Dowodzi, poza innymi elementami, ogromnego znaczenia i wagi mentalności całego społeczeństwa. Szczególnie w aktualnej sytuacji, kiedy zawodzi system ogólnej oświaty.

42 Ibidem, s. 225. 
Społeczeństwo generalnie pozostaje obojętne na nieznane mu zagrożenia. Nie tylko w Polsce, ale i na całym świecie dochodzą do głosu postawy i przekonania anomiczne, nacjonalistyczne, ksenofobiczne. Budując narzędzia przeciwdziałające przestępczości przeciwko dziedzictwu kulturowemu, musimy być świadomi możliwości wzrostu działań przestępczych inspirowanych takimi właśnie cechami. Mogą one kierunkować się także na kategorię zabytków nieruchomych stanowiących w Polsce łatwy cel. W ostatnich latach coraz częściej dochodzi do działań o charakterze wandalizmu ideologicznego ${ }^{43}$, a zmieniająca się mentalność, szczególnie młodego pokolenia, może doprowadzić do ich nasilenia. A właśnie przeprowadzone badania, zjednej strony wykazujące szereg niedoskonałości mentalnych naszego społeczeństwa, jednoznacznie pokazały drogę, którą należy podążać. W tym przypadku posiadamy bardzo skuteczne narzędzie - niepozorne i zupełnie niedoceniane. Podstawowym, skutecznym środkiem zwiększającym bezpieczeństwo naszych zabytkowych zasobów, a także pozwalającym na zmianę mentalności, jest i musi być edukacja. Propagowanie tematyki, wyjaśnianie i tłumaczenie pewnych zawiłości systemu. Zdać sobie należy sprawę, że efektywność działań wyspecjalizowanych organów ochrony zabytków, podobnie jak przestępców, zależy w tej materii od świadomości ogólnospołecznej, nie zaś od nielicznych uczonych i specjalistów. Niech zatem artykuł ten stanowi małą cegiełkę $\mathrm{w}$ ramach popularyzowania niedocenianej, a trudnej i ważnej dla nas wszystkich, problematyki.

\section{Bibliografia}

\section{Dokumenty}

Informacja o wynikach kontroli prawidłowości gospodarowania i nadzoru nad wybranymi zabytkami nieruchomymi w latach 2004-2008, LRZ-410-09/2009, Nr ewid. 2/2010/P/09/170/LRZ, Rzeszów: NIK Delegatura w Rzeszowie, 2010.

Krajowy program ochrony zabytków i opieki nad zabytkami na lata 2014-2017. Projekt, Warszawa: MKiDN, 2014.

Raport na temat funkcjonowania Systemu Ochrony Dziedzictwa Kulturowego w Polsce po roku 1989, oprac. Aleksander BöHm, Piotr Dobosz, Paweł JASkAnis, Jacek PurChla, Bogusław SzMYGin, red. Jacek PuRCHLA, Kraków 2008: MKiDN, 2008.

\section{Opracowania}

BudyŃ-Kulik Magdalena, Kulik Marek, Zniszczenie lub uszkodzenie zabytku. Analiza dogmatyczna i praktyka ścigania, Warszawa: Publikacje IWS, 2014.

KRAWCZy R Ryszard, Niszczenie zabytków nieruchomych w Polsce. Problematyka prawna, kryminologiczna i kryminalistyczna, Kraków: Wydawnictwo Jak, 2017.

SĄSIADA Monika, Modus operandi jako środek identyfikacji sprawcy przestępstwa, „Wrocławskie Studia Erazmiańskie. Zeszyty Studenckie”, z. 1, red. Mirosław SAdowski, Piotr Szymaniec,

43 Przykład uszkodzenia meczetu i mizaru tatarskiego w Kruszynianach w 2013 r. 
Ernest BojeK, Wrocław: Katedra Doktryn Politycznych i Prawnych oraz Samorząd Studencki Wydziału Prawa, Administracji i Ekonomii Uniwersytetu Wrocławskiego, 2008, s. 204-222.

SŁUGOCKI Janusz, Problemy prawne ochrony zabytkowych parków dworsko-pałacowych, [in:] Dobra chronione w prawie administracyjnym, red. Zofia DUNIEWSKA, Wydawnictwo Uniwersytetu Łódzkiego 2014, s. 225-238.

SoŚNIAK Marek, Komentarz do Kontroli NIK w sprawie zagospodarowania prawidłowości gospodarowania i nadzoru nad wybranymi zabytkami nieruchomymi w latach 2004-2008, kancelaria prawna Chajec, Don-Siemion \& Żyto 2010.

ZALASIŃSKA Katarzyna, Wojewódzki Urząd Ochrony Zabytków, [in:] Leksykon ochrony zabytków, red. Kamil ZEIDLER, Warszawa 2010, s. 295-296.

\section{Netografia}

Wyburzali zabytek, a konserwator nic nie wie, www.trojmiasto.pl/TVN-Gdansk-o5165.html, [dostęp: kwiecień 2014].

Czworaki niekompetencji. Co konserwator ma w rejestrze? Nie wie nawet on. http://m.bialystok.gazeta.pl/bialystok/51,106505,13530871.html?i=2, [dostęp: wrzesień 2017].

http://www.tvp.pl/hbbtv/aplikacje/teleexpress/najciekawsze/dolnoslaskie-palace-w-ruinie/10599698, [dostęp: wrzesień 2017].

http://www.sejm.gov.pl/sejm7.nsf/InterpelacjaTresc.xsp?key=713B43BC, [dostęp: wrzesień 2017].

\section{Do Polish people need monuments? Some comments on the destruction of historical monuments in Poland}

\section{Summary}

Historical monuments vividly portray the history of the society and represent the development of civilization. The following article tries to answer the question why some historical monuments in Poland are in such a disastrous condition and what are the causes of this situation.

Keywords: monuments, destruction, vandalism. 
ŹRÓDLA 

Prace Naukowe Uniwersytetu Humanistyczno-Przyrodniczego im. Jana Długosza w Częstochowie ZESZYTY HISTORYCZNE 2019, t. XVIII, s. 171-184

http://dx.doi.org/10.16926/zh.2019.18.09

Przemysław GORZAŁKA

https://orcid.org/0000-0003-2399-7299

Częstochowa

\section{Stan twierdzy częstochowskiej w sierpniu $1807 \mathbf{r}$. w świetle raportu ppłk. Antoniego Górskiego}

\section{Streszczenie}

Zajęcie fortelem fortecy jasnogórskiej w listopadzie 1806 r. przez francuskich szaserów i polskich insurgentów miało znaczący wpływ na rozwój sytuacji militarnej na Nowym Śląsku. Pozwoliło cesarzowi Napoleonowi I na odizolowanie śląskiego teatru wojny od głównych terenów zmagań Wielkiej Armii z wojskami IV koalicji. Ponadto pozwoliło na rozprzestrzenienie się powstania w całym regionie. Forteca jasnogórska stała się ważnym punktem oparcia dla nowopowstających oddziałów polskiej jazdy, piechoty i artylerii. Artykuł ten opisuje stan twierdzy jasnogórskiej i prezentuje wiele istotnych danych dotyczących jej wyposażenia, takich jak: liczba dział, karabinów, kul czy też rozmaitych materiałów i narzędzi. Informacje te zawdzięczamy podpułkownikowi Antoniemu Górskiemu, który był komendantem twierdzy w omawianym okresie, i na rozkaz dyrektora wojny księcia Józefa Poniatowskiego sporządził szczegółowy raport na temat stanu fortecy.

Słowa kluczowe: Częstochowa, twierdza jasnogórska, Antoni Górski, Księstwo Warszawskie.

Okres napoleoński to w dziejach twierdzy jasnogórskiej niezwykle barwny i jednocześnie dramatyczny przedział czasu. Jego początek jest związany z rokiem 1806, kiedy to w okolice Częstochowy (na teren Nowego Śląska) dotarła 13 listopada 1806 r. odezwa generała Jana Henryka Dąbrowskiego i Józefa Wybickiego wzywająca do powstania zbrojnego. Dwa dni później miejscowy właściciel ziemski, Michał Pruszak, zgromadził pod swoja komendą oddział liczący około 500 ludzi, złożony z jego poddanych: oficjalistów, dzierżawców i włościan ${ }^{1}$. Odczytawszy zgromadzonym odezwę, wyruszył pod twierdzę jasnogórską obsadzoną przez pruski garnizon pod dowództwem majora Hundta, złożony $\mathrm{z}$ trzeciego batalionu muszkieterskiego 42. Regimentu generała Franza Heinricha

1 Janusz STASZEwSKI, Kaliski wysiłek zbrojny 1806-1813, Kalisz 1931, s. 9. 
Christiana von Ploetzla w sile 13 oficerów i 472 żołnierzy, oraz 2. południowopruskiej kompani weteranów liczącej niespełna 100 żołnierzy. W sumie dawało to 14 oficerów i przeszło 550 podoficerów i szeregowych ${ }^{2}$. Grupa Pruszaka otoczyła dnia 15 listopada klasztor, zajmując okoliczne wsie i odcinając Prusaków od kontaktów ze światem zewnętrznym, jednocześnie podjęte zostały rozmowy z pruskim komendantem dotyczące ewentualnej kapitulacji twierdzy. Według relacji samego Pruszaka major Hundt skłonny był kapitulować, jednakże sytuacja uległa zmianie w związku z pojawieniem się pod murami klasztoru kolejnej grupy wojska ${ }^{3} .18$ listopada do Częstochowy dotarł szwadron francuskich szaserów z 12. pułku strzelców konnych, którym dowodził szef szwadronu Jean Louis Deschamps, w sile 100 koni. Towarzyszył im oddział kawalerii powstańczej w sile 150 ludzi pod dowództwem Kaspra Miaskowskiego ${ }^{4}$ wysłany celem wsparcia Francuzów oraz organizacji władz polskich w Częstochowie. Należy zgodzić się z Achmatowiczem, iż komenda Miaskowskiego miała też bez wątpienia zabezpieczać skarbiec klasztorny przed rabunkiem ze strony francuskich sojuszników w razie jego opanowania ${ }^{5}$.

Oddziały Deschampsa, Miaskowskiego i Pruszaka nie miały żadnej szansy poważnie zagrozić twierdzy pod warunkiem, że garnizon zdecydowany by był się bronić. Jednakże komendant pruski nie myślał o oporze, co zresztą było dość powszechnym zjawiskiem podczas kampanii 1806 r. Niemniej dowodzący Francuzami Deschamps przejął inicjatywę i postanowił skłonić pruski garnizon do kapitulacji za pomocą fortelu wojennego. Chłopi, których udało się zgromadzić Pruszakowi, rozpalili w nocy mnóstwo ognisk sugerujących przybycie pod twierdzę znacznych sił francuskich. Ponadto część francuskich szaserów spieszono, doczepiając im czerwone epolety i czerwone kity do kapeluszy, co miało symulować w oczach garnizonu obecność grenadierów. W rezultacie przerażony komendant Hundt zgodził się poddać twierdzę, która skapitulowała 19 listopada 1806 r. $^{6}$

2 Dane dotyczące stanu garnizonu częstochowskiego - vide: Eduard von HöEPFNER, Der Krieg von 1806 und 1807, Berlin 1855, s. 53. Za nim powtarzają je polscy autorzy - vide: Aleksander Aснматоwicz, Epizod napoleoński w dziejach Jasnej Góry, „Studia Claramontana”, t. 8: 1987, s. 176; Dariusz ZŁotкоwsкi, Jasna Góra w czasach Księstwa Warszawskiego 1806-1813 (Analiza wybranych problemów), „Ziemia Częstochowska”, t. 23: 1996, s. 48; Dariusz NAwrot, Powstanie na Nowym Śląsku w 1806 i 1807 roku. U źródeł Zaglębia Dąbrowskiego, Czeladź: Muzeum Saturn, 2016, s. 39; Marcin BARANOwsKI, Maciej TRĄBSKI, Dwa źródta do planów modernizacji twierdzy częstochowskiej w czasach Księstwa Warszawskiego, „Studia z Dziejów Wojskowości”, t. 7: 2018, s. 360.

3 A. AChmatowicz, op. cit., s. 181.

4 D. Nawrot, Powstanie, s. 36. Marian Kukiel i Dariusz ZŁotкowski podają liczbę 120 francuskich szaserów - vide: M. KUKIEL, Dziej oręża polskiego w epoce napoleońskiej 1795-1815, Poznań 1912, s. 113; D. ZŁOTKOWSKi, op. cit., s. 49.

5 A. Achmatowicz, op. cit., s. 179.

6 Okoliczności zajęcia fortecy jasnogórskiej były już wielokrotnie opisane. Ostatnio ukazała się praca, w której znajdują się odwołania do szeregu wcześniejszych dzieł - vide: D. NAwRot, op. cit., s. 33-44. 
Zajęcie fortecy jasnogórskiej było niewątpliwie sporym sukcesem. Po pierwsze, dzięki kapitulacji garnizonu pruskiego nic nie stało już na przeszkodzie, aby powstanie przeciw Prusakom objęło całą okolicę, co też się stało. Po drugie, twierdza stała się oparciem dla nowo organizowanych oddziałów piechoty i artylerii. Jak zauważył Nawrot, jej opanowanie doprowadziło też do odizolowania obszaru śląskiego od głównego teatru działań wojennych w Prusach Wschodnich i na Mazowszu podczas kampanii $1806 / 1807^{7}$. Wreszcie nie bez znaczenia był wydźwięk propagandowy zajęcia jasnogórskiego klasztoru. Wspomniały o tym wydarzeniu 34. i 37. Biuletyny Wielkiej Armii ${ }^{8}$. Relacje dotyczące okoliczności zajęcia Jasnej Góry ukazały się też w prasie polskiej

Dowodzący III Korpusem Wielkiej Armii marszałek Louis Nicolas Davout, doceniając znaczenie strategiczne twierdzy, a jednocześnie mając świadomość grożącego jej niebezpieczeństwa ze strony wojsk pruskich stacjonujących na Śląsku, rozkazał dowódcy 12. pułku strzelców pułkownikowi Claude'owi-Raymondowi Guyonowi, aby z pozostałą częścią swego pułku ruszył do Częstochowy i objął komendę nad garnizonem ${ }^{10}$. Jednocześnie polecił, by wysłać tam dodatkowo żołnierzy ze świeżo formowanych oddziałów polskich. Do twierdzy jasnogórskiej pomaszerowały 3 kompanie z 5. pułku piechoty ppłk Józefa Gabriela Biernackiego ${ }^{11}$. Wsparcie to było niezbędne, choć w samej twierdzy od samego początku podjęto działania organizacyjne celem formowania polskiego garnizonu.

Zaraz po kapitulacji majora Hundta 60 żołnierzy zrzuciło pruskie mundury i wstąpiło na służbę polską. Dodano do nich 40 ochotników, tworząc garnizonową kompanię. Pierwszym polskim komendantem twierdzy mianowany został były kapitan strzelców polskich Stanisław Wosiński, który funkcję tę zawdzięczał decyzji Miaskowskiego. Później powierzono mu formowanie batalionu strzelców, którzy obsadzili pogranicze śląskie ${ }^{12}$. Jednocześnie na bazie zdobytych na Prusakach dział w twierdzy jasnogórskiej rozpoczęto formowanie kompanii artylerii. Zadanie to realizował początkowo przybyły pod Jasną Górę wraz z Francuzami były oficer artylerii kapitan Paschalis Grabowski, któremu udało się zebrać 75 artylerzystów pochodzących ze Starej i Nowej Częstochowy ${ }^{13}$. Zna-

7 Ibidem, s. 62.

8 Correspondance de Napoléon I-er, publiée par ordre de l'Empereur Napoléon III, t. XIII, wyd. Henri Plon, J. Dumaine, Paris 1863, s. 566; ibidem, t. XIV, Paris 1864, s. 21.

9 „Gazeta Poznańska” [dalej: „,GP”], Dodatek do nr 97 z 22 XI 1806 r.; „GP”, nr 99 z 26 XI 1806 r.; „Gazeta Korrespondenta Warszawskiego i Zagranicznego” [dalej: „GKWiZ”], nr 1 z 2 I 1807 r., s. 4; ,GW”, nr 2 z 6 I 1807 r., s. 22.

10 D. NAWROT, op. cit., s. 43.

11 Ryszard Morawski, Adam PaCzuski, Wojsko Księstwa Warszawskiego. Piechota, gwardie narodowe, weterani, t. I, Warszawa 2014, s. 22. Stan oddziału wynosił 4 oficerów i 296 żołnierzy pod komendą mjr. Więckowskiego, który objął też komendę twierdzy - vide: J. STASZEWSKI, op. cit., s. 23.

12 J. STASZEWSKI, op. cit., s. 16; D. NAWrot, op. cit., s. 41.

13 Bronisław Gembarzewski, Wojsko Polskie. Księstwo Warszawskie 1807-1814, Warszawa 1905, s. 177; R. MoRAWSKI, Andrzej NieuWAŻNy, Wojsko Księstwa Warszawskiego. Artyleria, inżynierowie, saperzy, Warszawa 2004, s. 27. 
czenie twierdzy jasnogórskiej doceniał też Miaskowski, który, pisząc do gen. Dąbrowskiego, stwierdzał: „Na komendanta do Częstochowy lub nadgranicznego według mego zdania trzeba (takiego), który umie języki. Punkt ten w teraźniejszych okolicznościach jest nader ważny. Granica tak blisko Śląska, Galicji wzgl. komunikacji, może być wielce punkt ten korzystnym [...]"14. W rozkazie dla gen. Skórzewskiego zalecano wysłanie ,najzdolniejszego oficera na komendanta Częstochowy, godnego honoru, utrzymującego karność, znającego się na poprawie fortyfikacji" ${ }^{15}$. Wreszcie 23 grudnia wystawiono rozkaz dla ppłk Górskiego ,aby natychmiast udał się do Częstochowy i objął główną komendę nad tą fortecą i znajdującym się w niej garnizonem"16. 9 stycznia 1807 r. komendę w twierdzy jasnogórskiej z rozkazu gen. J.H. Dąbrowskiego przejął podpułkownik Antoni Górski, który zastąpił na tym stanowisku majora Więckowskiego. Jednocześnie Górski miał rozpocząć w Częstochowie formację artylerii konnej, do czego ostatecznie nie doszło ${ }^{17}$.

Nowy komendant był bez wątpienia odpowiednim kandydatem na to stanowisko jako wychowanek Szkoły Artylerii Koronnej w Warszawie i kadet Korpusu Artylerii Koronnej. Uczestnik wojny polsko-rosyjskiej w 1792 r., a następnie powstania kościuszkowskiego, które ukończył w stopniu podporucznika. W Legionach Polskich we Włoszech kapitan artylerii, brał udział m.in. w zajęciu Rzymu i kampanii neapolitańskiej 1798-1799. Do służby powrócił w roku 1806, zapisując chwalebną kartę w swoim życiorysie ${ }^{18}$. Mając sobie powierzone zadanie organizacji artylerii, energicznie przystąpił do działania. Bronisław Gembarzewski podaje, iż kiedy ppłk Górski przybył do twierdzy zastał tam 40 żołnierzy (artylerzystów), a jeszcze w styczniu stan artylerzystów wynosił 160 ludzi $^{19}$.

14 Miaskowski do Dąbrowskiego, Jasna Góra 4 X 1806 r., BPAUiPAN, Teki Staszewskiego, sygn. 8745, k. 35.

15 Dąbrowski do gen. Skórzewskiego, 13 XII 1806 r., ibidem, k. 44.

16 Rozkaz A. Górskiemu ppłk art., 23 XII 1806 r., ibidem, k. 70.

17 J. Staszewski, op. cit., s. 26; D. Nawrot, op. cit., s. 100; R. Morawski, A. Nieuważny, op. cit., s. 28. W literaturze przedmiotu istnieją pewne rozbieżności dotyczące daty objęcia przez ppłk. Górskiego komendy w twierdzy jasnogórskiej. Gembarzewski podaje, iż stało się to w grudniu 1806 r. Tę datę przytaczają za nim inni autorzy - vide: B. GEMBARZEWSKI, op. cit., s. 177; D. NAWROT, op. cit., s. 100; M. BARANOWSKI, M. TRĄBSKI, op. cit., s. 361. Jednakże rozkaz dla Górskiego nosi datę 23 XII 1806 r., co wyklucza możliwość objęcia przez niego komendy w początkach tegoż miesiąca, a czyni całkiem naturalne przybycie do twierdzy 9 I 1807 r. Jeszcze 26 XII 1806 r. ppłk Więckowski jest wymieniany w raportach jako organizator 8. pp stacjonujący w Częstochowie - vide: J. STASzewski, op. cit., s. 23; R. Morawski, A. PACZUSKI, op. cit., s. 22.

18 Juliusz Willaume, Górski Antoni, [in:] PSB, t. 8, Wrocław-Kraków-Warszawa 1959-1960, s. 434; Jan PACHOŃSKI, Stownik biograficzny oficerów Legionów Polskich 1796-1807, Kraków 1998-2003, s. 81-82; Oficerowie Rzeczypospolitej Obojga Narodów 1777-1794. Spisy, t. I: Oficerowie wojska koronnego, cz. 2: Artyleria i wojska inżynierskie, oprac. Mariusz MACHYNIA, Czesław SRZEDNICKI, Kraków 1999, s. 47.

19 B. Gembarzewski, Wojsko Polskie, s. 178. 
W porównaniu z informacją, iż kapitan Grabowski sformował 75-osobowy oddział kanonierów można założyć, iż albo gdzieś wkradł się błąd w danych, albo stan kompanii artyleryjskiej na Jasnej Górze w grudniu 1806 r. uległ dość szybkiemu wykruszeniu.

Wobec uchwalenia przez tymczasowy rząd polski, zwany Komisją Rządzącą, nowego etatu Wojska Polskiego 18 stycznia 1807, każda z trzech Legii, na jakie podzielono armię polską miała mieć w składzie batalion artylerii i saperów. Jego organizacja przedstawiała się następująco: na czele batalionu artylerii i saperów stał szef batalionu, (wszyscy trzej komendanci batalionów artylerii byli w randze podpułkownika). W jego skład wchodziły trzy kompanie artylerii i jedna saperów, wszystkie w takim składzie, jak w piechocie. Oznaczało to, iż stan takiej kompanii obejmował 1 kapitana, 1 porucznika, 1 podporucznika, 1 sierżanta starszego, 1 kaprala furiera, 4 sierżantów, 8 kapralów, 2 doboszów, 1 kapelistę (muzyka) w każdej kompani parzystej, 1 cieślę w każdej kompanii nieparzystej oraz 120 żołnierzy, łącznie 140 ludzi. Ponadto batalion dysponował kompanią taborową złożoną z 1 porucznika komendanta kompanii, 1 wachmistrza starszego, 4 wachmistrzów, 1 furiera, 8 kapralów i 180 konnych. Łącznie kompania taborowa miała 195 żołnierzy i oficerów, a cały batalion artylerii liczyć powinien 756 oficerów i żołnierzy ${ }^{20}$. Każda kompania artylerii miała otrzymać 6 dział, na każdy pluton po trzy sztuki, co łącznie dawało 18 dział w batalionie ${ }^{21}$. Batalion podpułkownika Górskiego był w tej szczęśliwej sytuacji, iż miał do dyspozycji wszystkie przejęte od Prusaków działa.

Warto w tym miejscu przejść do rozważań nad rzeczywistym stanem twierdzy, zarówno jej fortyfikacji, jak i wyposażenia w działa, amunicję i pozostały sprzęt artyleryjski. To właśnie te czynniki decydowały o wartości militarnej obiektu, oczywiście obok odpowiednio silnego i zdeterminowanego garnizonu.

Pierwszy znany raport o fortyfikacjach twierdzy częstochowskiej po jej przejęciu sporządził kapitan artylerii, Mabru, zapewne przysłany w tym celu z rozkazu marszałka Davouta. Mabru po dokonaniu lustracji twierdzy, co miało miejsce pod koniec listopada 1806, sporządził następującą relację: ,Forteca składa się $\mathrm{z}$ bastionowego muru z cegieł. Powłoka muru jest bardzo dobrze zachowana. Szczyt skarpy znajduje się około dwadzieścia pięć metrów nad dnem fosy. Mamy tutaj cztery kurtyny i cztery bastiony z kazamatami [...] Jest także półksiężyc noszący nazwę rawelinu, zamykający rodzaj nadszańca, z którego możemy kryć bardzo daleko przedpole. Osłania bramę fortu, ale nie broni jej dobrze, bo nie ma między nimi drogi krytej [...] Dzieła zewnętrzne stanowi [...] dwanaście redut, redanów i fleszy. Mają one charakter ziemny i są tak zniszczone, że należy uznać

20 P. GorZaŁKA, Sprawy wojskowe w pracach Komisji Rzadzacej (1807), Praca doktorska napisana pod kierunkiem prof. dr. hab. Tadeusza Srogosza, Instytut Historii UJD, Częstochowa 2018, s. 71. Skład imienny oficerów batalionu artylerii Legii Drugiej w okresie 1806-1809 podaje B. GeMBARZEWSKI, op. cit., s. 181.

21 R. Morawski, A. NieUWAŻNY, op. cit., s. 28. 
je za ledwie istniejące. Gdyby nawet znajdowały się w lepszym stanie nie mogłyby stanowić skutecznej ochrony, gdyż większość z nich nie może wspierać się wzajemnie w walce"22.

Podpułkownik Górski również sporządził raport o stanie twierdzy ${ }^{23}$, w którym wskazywał na trudności przy ewentualnej jej obronie, w szczególności zniszczoną fosę, a także obecność dwóch wzgórz w pobliżu twierdzy (jedno w zasięgu strzału z karabinu, drugie odległości połowy strzału z działa), które sięgają wysokością poziomu wałów. Rozwiązanie tego problemu widział Górski w połączeniu obu wzgórz z twierdzą dziełami zewnętrznymi ${ }^{24}$. Pisał ponadto, iż twierdza może pomieścić co najwyżej 1000 ludzi, a 30 armat wystarczy do jej obrony. Na potencjalne magazyny wskazywał budynek klasztoru, kościoła i kazamaty pod bastionami. Podkreślał dobre zaopatrzenie apteki klasztornej oraz dobre zaopatrzenie twierdzy w wodę. Jak słusznie zauważyli M. Trąbski i M. Baranowski, to ostatnie spostrzeżenie Górskiego jest niezwykle ciekawe w kontekście okoliczności kapitulacji twierdzy jasnogórskiej przed Rosjanami w 1813 r. ${ }^{25} \mathrm{~W}$ okresie późniejszym jeszcze kilkukrotnie twierdza jasnogórska była przedmiotem analiz pod kontem zwiększenia jej możliwości obronnych, niemniej wobec konieczności inwestycji w bardziej istotne z punktu widzenia władz wojskowych Księstwa twierdz większość projektów pozostała na papierze ${ }^{26}$.

Dyskutując na temat możliwości obronnych twierdzy częstochowskiej, nie sposób nie wspomnieć o jej zaopatrzeniu w sprzęt artyleryjski, proch i amunicję. Jeśli chodzi o potencjał twierdzy w momencie jej przejęcia, to znamy przynajmniej kilka różniących się od siebie relacji. Kasper Miaskowski w swym raporcie dla generała Dąbrowskiego podaje, iż przejęto 24 armaty, 760 karabinów, 226 cetnarów prochu oraz skład mąki. Dane te przyjął J. Staszewski ${ }^{27}$. Warto nadmienić, że w nieco innej wersji raportu Miaskowskiego liczba dział wynosi $26^{28}$. Drugim istotnym dokumentem traktującym o zdobyczy w twierdzy częstochowskiej jest raport dowódcy III Korpusu Wielkiej Armii marszałka Davouta z 27

22 Raport kapitana artylerii Mabru - cyt. za: Ryszard Belosty , Fortyfikacje Księstwa Warszawskiego 1807-1813, Oświęcim 2018, s. 32.

23 Situation actuelle de la forteresse de Czenstochowa, commandée par le chef de batallion d'artillerie Antoine Górski depuis le mois de janvier 1807, [in:] B. GEMBARZEWSKI, op. cit., s. 216.

24 Ibidem.

25 M. BARANOWSKI, M. TRĄBSKI, op. cit., przypis 24, s. 365.

26 Szerzej na ten temat vide: Mariusz ŁukASIEwICZ, Armia Księcia Józefa 1813, Warszawa 1986, s. 160; R. BelostyK, op. cit., s. 32, 119-123, 253, 355-356; M. BARANOwSKI, M. TRĄBSKI, op. cit., s. 359-373.

27 Raport do JWgo Generała Dąbrowskiego, 20 XI 1806, AGAD, Teki Dąbrowskiego, t. X, p. 2, k. 45 (78); J. STASZEWSKI, op. cit., s. 10.

28 Raport ten przytacza gen. Dąbrowski w piśmie do Majora Generalnego Wielkiej Armii marszałka Aleksandra Berthiera z 21 XI 1806 r. - vide: Dat nam przyktad Bonaparte. Wspomnienia i relacje żolnierzy polskich 1796-1815, wybór, komentarze i przypisy Robert BIELECKI, oprac. tekstów Andrzej T. TyszKA, t. I, Kraków 1984, s. 142. 
listopada 1806 dla Berthiera. „Żelazny Marszałek” donosił o kapitulacji Częstochowy, wspominając o przejęciu 500 karabinów, 24 dział, 296 kwintali prochu (częściowo zepsutego), a także kilka „kiesonów”, 100 ton mąki i kilka worków owsa $^{29}$. Raport ten, dość dokładny i generalnie korespondujący z danymi zawartymi u Miaskowskiego (oprócz liczby karabinów), wydaje się wiarygodny. Niestety, pewien dysonans może wprowadzić opis zajęcia twierdzy częstochowskiej, również autorstwa marszałka Davouta, gdzie pada liczba 33 dział, 1000 karabinów i jest mowa o dużej ilości amunicji ${ }^{30}$.

37. Biuletyn Wielkiej Armii wspominał o 30 działach i przejętych magazynach, za nim powtarzają to „Gazeta Warszawska” i „Gazeta Korrespondenta Warszawskiego i Zagranicznego" ${ }^{1}$. W "Gazecie Poznańskiej” wymienia się mniejszą liczbę dział: dodatek do numeru $\mathrm{z}$ dn. 22 listopada podaje 26 armat, zaś numer z 26 listopada informuje o 25 działach $^{32}$.

Wątpliwości na temat rzeczywistej liczby przejętych w twierdzy jasnogórskiej dział pomaga rozwiać znakomity dokument źródłowy, jakim jest przechowywany w zbiorach Archiwum Głównego Akt Dawnych w Warszawie „Stan artylerii co do broni, sprzętów, narzędzi inżynierskich, tudzież rodzaj i wielość przedmiotów znajdujących się w fortecy Częstochowskiej" sygnowany przez ppłka Antoniego Górskiego ${ }^{33}$. Dokument ten, wcześniej niepublikowany, to świetny materiał do poznania nie tylko liczby i wagomiaru dział w twierdzy częstochowskiej, ale również stanu zaopatrzenia w proch, amunicję, karabiny i oraz inne sprzęty artyleryjskie i inżynierskie.

Dokładne dane zawdzięczamy pośrednio Stefanowi Vincentowi, rezydentowi napoleońskiemu przy Komisji Rządzącej. Otóż 3 sierpnia 1807 r. na sesję Dyrektorium Generalnego, zastępującego w tym czasie Komisję bawiącą w Dreźnie, dostarczono wyrażone na piśmie żądania komisarza cesarskiego, które dotyczyły m.in. stanu arsenałów, magazynów (wojskowych), map i planów należących do Księstwa Warszawskiego ${ }^{34}$. Dyrektorium sprawę skierowało do odpowiedzialnego za kwestie wojskowe dyrektora wojny ks. Józefa Poniatowskiego. Książę dyrektor odpowiedział na żądanie 6 sierpnia, pisząc: „Na zalecenie Directorium Generalnego dnia 3-go miesiąca i roku teraźniejszych wydane, względem podania stosownie do artykułu 26 traktatu w Tylży zawartego, stanu zbrojowni, skła-

29 Correspondance du Maréchal Davout prince d'Eckmühl (1801-1815), wyd. Charles de MAZADE, t. I, Paris 1885, s. 356-357.

30 Louis Nicolas Davout, Opérations $d u 3{ }^{e}$ Corps 1806-1807, Rapport du Maréchal Davout duc d'Auerstaedt, Paris 1896, s. 96.

31 Correspondance de Napoléon, s. t. XIV, s. 21; „GKWiZ”, nr 1 z 2 I 1807 r., s. 4; „GW”, nr 2 z 6 I 1807 r., s. 22.

32 „GP”, Dodatek do nr 97 z 22 XI 1806 r.; „GP”, nr 99 z 26 XI 1806 r.

33 Akta Komisji Rządzącej co do Dyrektora Wojny, AGAD, KR - AS, sygn. 55, k. 73-74.

34 Protokót czynności dyrektorium generalnego za czas od dn. 13 lipca do 12 sierpnia 1807, [in:] Marceli Handelsman, Pomiędzy Prusami a Rosją. Studia historyczne, seria 3, Warszawa 1922, s. 90 . 
dów, archiwów, dowodów, niemniej kart i planów miast obronnych, twierdz i zamków do Księstwa Warszawskiego należących ma honor odpowiedzieć: że ponieważ zbrojownie, składy, miejsca obronne, twierdze i zamki, jakie się znajdować mogą były pod zarządzeniem i pieczą generałów francuskich, których stanu Dyrektor Wojny nie miał władzy rozpoznawać ani żądać od nich rapportów, przeto nie jestem w stanie uwiadomić JW Generalnego Intendenta Wielkiego Wojska Francuskiego o tym, co pod moim nie było zawiadowaniem, przyłączając mu tylko stan rzeczy znajdujących się w Częstochowie dozorowi Wojska Polskiego Poruczony" ${ }^{35}$. Załącznikiem był sporządzony przez Górskiego prezentowany poniżej Stan artylerii.

Jak wspomniano, opisywany dokument znajduje się w zbiorach Archiwum Głównego Akt Dawnych w Warszawie, w zbiorze Komisja Rządząca pod sygnaturą 55. Rękopis zajmuje dwie strony, a całość raportu ujęta jest $\mathrm{w}$ tabeli. Na potrzeby publikacji i w trosce o odpowiednią przejrzystość materiału dokonano zmiany układu tabeli z zachowaniem wszelkich danych, nagłówków i właściwej kolejności poszczególnych pozycji wykazu. Zgodnie z adnotacją jest to kopia oryginału przesłanego przez ppłk. Górskiego, której zgodność z nim potwierdza podpisem płk Kajetan Hebdowski stojący na czele biur Dyrektoriatu Wojny (zwanych też biurami wojennymi). Dla lepszego odbioru dokumentu na końcu zamieszczony został słowniczek terminów wojskowych stosowanych na przełomie XVIII i XIX w. ${ }^{36}$

\section{Stan artylerii co do broni, sprzętów, narzędzi inżynierskich, tudzież rodzaj i wielość przedmiotów znajdujących się w fortecy Częstochowskiej}

Legion Drugi

Dywizja Kaliska

\begin{tabular}{|l|c|l|}
\hline \multicolumn{1}{|c|}{ KALIBER } & WIELOŚĆ & \multicolumn{1}{c|}{ OBJAŚNIENIA } \\
\hline \multicolumn{1}{|c|}{ Armaty polowe letkie } & & \\
\hline Armat $12 \mathrm{ft}$ z prochami i wozami & 3 & Pruskich zdatnych \\
\hline Granatnik 10 calowy z wozem i prockarą & 1 & Pruski zdatny \\
\hline Armata $6 \mathrm{ft}$ bez lawet & 1 & Polska niezdatna \\
\hline
\end{tabular}

35 Dyrektor Wojny do Directorium Generalnego zastępującego Komisję Rządzącą, Warszawa 6 VIII 1807 r., AGAD, KR - AS, sygn. 55, k. 72.

36 Oprac. na podst. Józef JAKUBOWSKI, Nauka artylerii zebrana z najróżniejszych autorów, napisana dla pożytku Korpusu Artylerii Narodowej z rozkazu i naktadem Jego Królewskiej Mci... do druku podana, t. I, Warszawa 1781; Jan KosińsKI, Zasady nauki artylleryi z rozkazu Jego Cesarzewiczowskiey Mości Wielkiego Xięcia Naczelnego Wodza, cz. I-II, Warszawa 1820; Stownik artyleryczny (wyjątki), „Przegląd Artyleryjski” R. 1: 1923, nr 5 i 6, s. 51-59; R. MORAWSKI, A. NIEUWAŻNY, Wojsko Księstwa Warszawskiego. Artyleria, inżynierowie, saperzy, Warszawa 2004. 


\begin{tabular}{|c|c|c|}
\hline KALIBER & WIELOŚĆ & OBJAŚNIENIA \\
\hline Granatników 8 calowych z prockarami & 4 & Polskich zdatnych \\
\hline Armat $3 \mathrm{ft}$ polowych z prockarami bez wozów & 7 & Polskich zdatnych \\
\hline Armat $3 \mathrm{ft}$ polowych $\mathrm{z}$ prockarami i wozem & 5 & Pruskich zdatnych \\
\hline Armat $1,5 \mathrm{ft}$ bez lawet & 2 & \\
\hline Wozów amunicyjnych rezerwowych & 6 & Pruskich zdatnych \\
\hline \multicolumn{3}{|l|}{ Strzelba } \\
\hline Śmigownic żelaznych obsadzonych & 7 & \\
\hline Szturmaków fortecznych & 70 & Polskich zdatnych \\
\hline Karabinów wcale nie użytych & 300 & \\
\hline Rur karabinowych nieobsadzonych & 200 & niezdatnych \\
\hline Janczarek tureckich różnego kalibru & 100 & niezdatnych \\
\hline \multicolumn{3}{|l|}{$\begin{array}{l}\text { Kule i kartacze } \\
\end{array}$} \\
\hline Kul $12 \mathrm{ft}$ & 588 & \\
\hline Kul $6 \mathrm{ft}$ & 3859 & \\
\hline Kul $3 \mathrm{ft}$ & 4028 & \\
\hline Kul flintowych & 36472 & \\
\hline Kul karabinowych & 12626 & \\
\hline Kartaczów $12 \mathrm{ft}$ w paczkach & 120 & \\
\hline Kartaczów $10 \mathrm{ft}$ & 394 & \\
\hline Kartaczów $8 \mathrm{ft}$ & 120 & \\
\hline Kartaczów $6 \mathrm{ft}$ & 1230 & \\
\hline Kartaczów $3 \mathrm{ft}$ & 652 & \\
\hline \multicolumn{3}{|l|}{ Granaty } \\
\hline Granatów 10 calowych & 368 & \\
\hline Granatów 8 calowych & 369 & \\
\hline Granatów ręcznych & 460 & \\
\hline \multicolumn{3}{|l|}{\begin{tabular}{|c|} 
Ladunki infanteryczne \\
\end{tabular}} \\
\hline Ładunków karabinowych & 106000 & \multirow[t]{2}{*}{ Pruskich w cetnarach 52} \\
\hline Ładunków flintowych & 145000 & \\
\hline Naczynia i machiny & Wielość & \\
\hline Horągwie polskie stare & 2 & \\
\hline Formy na kule karabinowe & 3 & \\
\hline Beczek do szlifowania kul & 4 & \\
\hline Grajcarów do wyciągania & 15 & \\
\hline Bawolich ozorów & 8 & \\
\hline Szufel do nabicia & 7 & \\
\hline Rydlów żelaznych & 32 & \\
\hline
\end{tabular}




\begin{tabular}{|c|c|c|}
\hline KALIBER & WIELOŚĆ & OBJAŚNIENIA \\
\hline Motyk i kilofów & 21 & \\
\hline Żelaznych form na kule armatnie & 2 & \\
\hline Sikawka na kołach & 1 & \\
\hline Sikawek ręcznych & 6 & \\
\hline Wiader skórzanych & 6 & \\
\hline Bosaków do ognia & 12 & \\
\hline Łopat & 2 & \\
\hline Kwadrantów mosiężnych & 8 & \\
\hline Drągów i drążków & 18 & \\
\hline Torb skórzanych na ładunki & 24 & \\
\hline Puszek do podsypywania & 24 & \\
\hline Puszek do brantek & 24 & \\
\hline Puszek do świczek & 10 & \\
\hline Świczników & 8 & \\
\hline Szelek z pozami & 30 & \\
\hline Liny & 2 & \\
\hline Łańcucha sążni? & 80 & \\
\hline Prolonzów & 8 & \\
\hline Materialy & Objaśnienia & \\
\hline Prochu ordynaryjnego cetn $32 \mathrm{ft} 83$ & w Beczkach & \\
\hline prochu dobrego $2 \mathrm{ft} 38$ & w Baryłkach & \\
\hline prochu w ładunkach cetn. $71 \mathrm{ft} 80$ & Armatnich & \\
\hline \multicolumn{3}{|l|}{ Mączki prochowej cetn. $2 \mathrm{ft} 16$} \\
\hline \multicolumn{3}{|l|}{ Ołowiu cetn 110} \\
\hline Skałek sztuk 37115 & Karabinowych & \\
\hline Skałek sztuk 10000 & Pistoletowych & \\
\hline Skałek sztuk 600 & Flintowych & \\
\hline \multicolumn{3}{|l|}{ Lontów cetn 23} \\
\hline Wieńców Pruskich 50 & Smolnych & \\
\hline \multicolumn{3}{|l|}{ Faierbali sztuk 16} \\
\hline \multicolumn{3}{|l|}{ Kartuszów 12 ft bez kul 261} \\
\hline \multicolumn{3}{|l|}{ Kartuszów $6 \mathrm{ft}$ bez kul 1448} \\
\hline Brantek sztuk 1500 & Nowych & \\
\hline \multicolumn{3}{|l|}{ Szpiglów 3 ft 553} \\
\hline \multicolumn{3}{|l|}{ Szpiglów 6 ft 2069} \\
\hline \multicolumn{3}{|l|}{ Szpiglów 12 ft 219} \\
\hline Szpagatu $6 \mathrm{ft}$ & & \\
\hline
\end{tabular}




\begin{tabular}{|l|l|l|}
\hline \multicolumn{1}{|c|}{ KALIBER } & WIELOŚĆ & OBJAŚNIENIA \\
\hline Włukna $50 \mathrm{ft}$ & & \\
\hline Sztupinów $20 \mathrm{ft}$ & do Granatów & \\
\hline Świczek paczek 24 & & \\
\hline
\end{tabular}

Podpisano Górski szef batalionu artylerii

Zgadza się z oryginałem

Dyrektor i Szef naczelny Biur Departamentu Woyny pułkownik Hebdowski

\section{Słownik terminów}

bawoli ozór - narzędzie z blachy żelaznej w kształcie ozora (języka) osadzone na rękojeści. Służyło do wydobywania kuli uwięzionej w kanale armatnim.

brandtka (przepalniczek, zapalniczek) - blaszana lub trzcinowa rurka nabita mączką prochową, przy pomocy której podpalało się nabój albo ładunek. Brandtka była wetknięta w zapał armaty, czyli mały otwór sięgający komory nabojowej. Kanonierzy trzymali je w osobnych torebkach.

faierbal (ognista piłka) - kula drelichowa wypełniona materiałami łatwopalnymi, a z wierzchu obsznurowana za pomocą węzłów: różowego, kratkowego lub siatkowego.

forma na kule (forma kulowa) - forma żelazna złożona $\mathrm{z}$ dwóch połówek w kształcie półkul, w które nalewa się żelazo. Kule ołowiane również zalewano w formach żelaznych, ale w kształcie obcęgów, składających się z dwóch szyn osadzonych na trzonku, z wydrążonymi otworami wychodzącymi na tę sama stronę i sobie odpowiadającymi. Tymi otworami wlewało się ołów.

grajcar (wykręt) - narzędzie żelazne z jednym lub dwoma wąsami, osadzone na rękojeści, służące do wykręcania rzeczy uwięzionych w kanale (przybitki i naboju).

kartusz - pojemnik zawierający ładunek prochu do broni palnej odprzodowej.

kwadrant (ćwierciokrąg) - urządzanie matematyczne i artyleryjskie służące do wyznaczenia właściwego kąta podniesienia lufy działa podczas prowadzenia ognia na duże odległości. Najprostszy kwadrant składał się z dwóch prostopadłych boków z podziałką z zaznaczonymi 90 stopniami oraz ruchomego ramienia.

lont - służył do zapalania przepalniczka, był to najczęściej lniany powróz nasączony wrzącym ługiem z popiołu z twardego drewna i niegaszonego wapna, następnie dobrze wysuszony.

mączka prochowa - łatwopalny materiał służący m.in. jako składnik przepalniczków czy świeczek.

prockara (przódkara) - używana do przewożenia armat, zbudowana była z dwóch kół z osią, dyszla i nasadu. W środku nasadu osadzony był żelazny 
sworzeń, na który przy przewożeniu działa nakładało się ogon łoża armaty dzięki wyrżniętej w jego szponie dziurze. Natomiast samo łoże (łożysko) armatnie służyło bądź do transportu armaty lub do strzelania z niej. Składano je $\mathrm{z}$ dwóch długich i mocnych drewnianych ścian połączonych czterema szponami (drewnianymi poprzeczkami) - czolną, spoczynkową, celowniczą i właśnie ogonową.

skałka - kawałek krzemienia zamocowany w szczękach kurka, stosowany w zamkach skałkowych. Podczas strzału skałka uderzała w krzesiwo, czyli metalowa płytkę przymocowana po prawej stronie broni. Powstałe po uderzeniu iskry zapalały panewkę z prochem.

śmigownica - małe działko, zwane również falkonetem.

szelki z pozami (pojazdami) - pasy, zaczepiane o wąsy osiowe lub haki ogonowe znajdujące się na armacie, służyły do przemieszczania działa jak też do zmiany jego pozycji podczas prowadzenia ognia.

szpagat - gruby sznurek wykonany z włókien Inianych lub konopnych, służył m.in. do zawiązywania na kuli woreczka wypełnionego prochem.

szpigiel (szpunt) - drewniany wałek o grubości odpowiedniej do wagomiaru (kalibru) armaty (1 do 1,5 wagomiaru), do którego z jednej strony przywiązuje się ładunek, a $\mathrm{z}$ drugiej pocisk.

sztupina (stupina) - przędzona bawełna nasycona palną zaprawą. Najczęściej do jej produkcji prócz bawełny używano saletry w proszku, mączki prochowej oraz wódki, spirytusu lub octu. W nagłej potrzebie do produkcji stupiny zalecano bawełnę zamoczyć w nafcie, a następnie posypać mączką prochową. Mogła być użyta do zaognienia brandkugli (pusty pocisk wypełniony łatwopalną zaprawą z wydrążonymi kilkoma dziurami służącymi do zapalenia zaprawy), świecących kul lub zapalników do bomb.

szturmak (petarda) - rodzaj puszki spiżowej albo drewnianej, która nabita została prochem i przymocowana do deski. Była zawieszana na bramie lub palisadzie i wypalała w nich wyłom, przez który do twierdzy wdzierali się żołnierze podczas szturmu.

szufla - łyżka miedziana w postaci półwałka, osadzona na rękojeści. Służyła do wprowadzania prochu w kanał, kiedy armata była nabijana bez ładunku.

torby skórzane - trzymano w nich ładunki, czyli naboje.

\section{Bibliografia}

\section{Źródla archiwalne}

Archiwum Główne Akt Dawnych w Warszawie, Komisja Rządząca - akta spraw, sygn. 55.

Archiwum Główne Akt Dawnych w Warszawie, Teki Dąbrowskiego, t. X, p. 2.

Biblioteka Polskiej Akademii Umiejętności i Polskiej Akademii Nauk w Krakowie, Teki Staszewskiego, sygn. 8745 . 


\section{Źródła drukowane}

BARANOWSKI Marcin, TRĄBSKI Maciej, Dwa źródła do planów modernizacji twierdzy częstochowskiej w czasach Księstwa Warszawskiego, „Studia z Dziejów Wojskowości”, t. 7: 2018, s. 359-376.

Dat nam przyktad Bonaparte. Wspomnienia i relacje żolnierzy polskich 1796-1815, t. I, wybór, komentarze i przypisy Robert BIELECKI, oprac. tekstów Andrzej T. TYSZKA, Kraków: Wydawnictwo Literackie, 1984.

Correspondance de Napoléon I-er, publiée par ordre de l'Empereur Napoléon III, t. XIII i XIV, wyd. Henri Plon, J. Dumaine, Paris 1863.

Correspondance du Maréchal Davout prince d'Eckmül (1801-1815), t. I, wyd. Charles de MAZADE, Paris 1885.

JAKUBOWSKI Józef, Nauka artylerii zebrana z najróżniejszych autorów, napisana dla pożytku Korpusu Artylerii Narodowej z rozkazu i nakładem Jego Królewskiej Mci... do druku podana, t. I, Warszawa 1781.

KosIŃSKI Jan, Zasady nauki artylleryi z rozkazu Jego Cesarzewiczowskiey Mości Wielkiego Xięcia Naczelnego Wodza, cz. I-II, Warszawa 1820.

Opérations du $3{ }^{e}$ Corps 1806-1807, Rapport du Maréchal Davout duc d'Auerstaedt, wyd. Calmann LEVY, Paris 1896.

Protokót czynności dyrektorium generalnego za czas od dn. 13 lipca do 12 sierpnia 1807, [in:] Marceli Handelsman, Pomiędzy Prusami a Rosją. Studia historyczne, seria 3, Warszawa: E. Wende i S-ka, 1922, s. 65-99.

Situation actuelle de la forteresse de Czenstochowa, commandée par le chef de batallion d'artillerie Antoine Górski depuis le mois de janvier 1807, [in:] Bronisław GemBARZEWsKi, Wojsko Polskie. Księstwo Warszawskie 1807-1814, Warszawa: Gebethner i Wolff, 1905, s. 216.

\section{Prasa}

„Gazeta Korrespondenta Warszawskiego i Zagranicznego", nr 1 z 2 I 1807 r.

„Gazeta Poznańska”, Dodatek do nr 97 z 22 XI 1806 r.; nr 99 z 26 XI 1806 r.

„Gazeta Warszawska”, nr 2 z 6 I 1807 r.

\section{Opracowania}

Achmatowicz Aleksander, Epizod napoleoński w dziejach Jasnej Góry, „Studia Claramontana” t. 8: 1987, s. 165-203.

Belosty R Ryszard, Fortyfikacje Księstwa Warszawskiego 1807-1813, Oświęcim: Wydawnictwo Napoleon V, 2018.

GorZAŁKa Przemysław, Sprawy wojskowe w pracach Komisji Rzadzacej (1807), Praca doktorska napisana pod kierunkiem prof. dr. hab. Tadeusza Srogosza, Instytut Historii UJD, Częstochowa 2018.

Gembarzewski Bronisław, Wojsko Polskie. Księstwo Warszawskie 1807-1814, Warszawa: Gebethner i Wolff, 1905.

HÖEPFNER Eduard von, Der Krieg von 1806 und 1807. Ein Beitrag zur Geschichte der Preußischen Armee, Zweiter Theil: Der Feldzug von 1807, Bd. III, Berlin: Simon Schropp \& Comp, 1855.

KuKIEL Marian, Dziej oręża polskiego w epoce napoleońskiej 1795-1815, Poznań: Zdzisław Rzepecki i Ska, 1912.

ŁuKASIEwICZ Mariusz, Armia Księcia Józefa 1813, Warszawa: Wydawnictwo Ministerstwa Obrony Narodowej, 1986.

Morawski Ryszard, NieuważNy Andrzej, Wojsko Księstwa Warszawskiego. Artyleria, inżynierowie, saperzy, Warszawa: Karabela, 2004. 
Morawski Ryszard, Paczuski Adam, Wojsko Księstwa Warszawskiego. Piechota, gwardie narodowe, weterani, t. I, Warszawa: Karabela, 2014.

Nawrot Dariusz, Powstanie na Nowym Śląsku w 1806 i 1807 roku. U źródet Zaglębia Dąbrowskiego, Czeladź: Wydawnictwo Muzeum Saturn, 2016.

Oficerowie Rzeczypospolitej Obojga Narodów 1777-1794. Spisy, t. I, Oficerowie wojska koronnego, cz. 2: Artyleria i wojska inżynierskie, oprac. Mariusz MACHYNIA, Czesław SRZEDNICKI, Kraków: Księgarnia Akademicka, 1999.

PACHOŃSKI Jan, Stownik biograficzny oficerów Legionów Polskich 1796-1807, Kraków: Księgarnia Akademicka, 1998-2003.

Stownik artyleryczny (wyjątki), „Przegląd Artyleryjski”, R. 1, nr 5 i 6: 1923, s. 51-59.

STASZEwSKI Janusz, Kaliski wysiłek zbrojny 1806-1813, Kalisz: Towarzystwo Przyjaciół Książki, 1931.

WiLlaume Juliusz, Górski Antoni, [in:] Polski Stownik Biograficzny, t. 8, Wrocław-Kraków-Warszawa 1959-1960, s. 434.

ZŁotкowski Dariusz, Jasna Góra w czasach Księstwa Warszawskiego (Analiza wybranych problemów), „Ziemia Częstochowska”, t. 23: 1996, s. 45-78.

\title{
Condition of the Jasna Góra fortress in August 1807 in the light of the lieutenant colonel Antoni Górski's report
}

\begin{abstract}
Summary
Capturing the fortress of Jasna Góra in November 1806 by the French chasseurs and Polish insurgents had a strong influence on the military situation in New Silesia. It let emperor Napoleon I separate the Silesian theatre of war from the area of main struggles between the Grande Armée and the forces of the Fourth Coalition. It also helped to spread the Polish insurrection over the region. The Jasna Góra fortress became an important support area for newly organizing Polish cavalry, infantry and artillery units. This article describes the condition of the fortress and presents lots of important data concerning its equipment such as: the number of canons, muskets, bullets or various materials and tools. We owe this information to lieutenant colonel Antoni Górski, who was a commander of the Jasna Góra stronghold in the period and was ordered to write a detailed report on the fortress by prince Józef Poniatowski, the Director of War.
\end{abstract}

Key words: Częstochowa, Jasna Góra fortress, Antoni Górski, The Duchy of Warsaw. 
Anna CZERNIECKA-HABERKO

https://orcid.org/0000-0002-4585-0127

Uniwersytet Humanistyczno-Przyrodniczy im. Jana Długosza w Częstochowie

Karolina STUDNICKA-MARIAŃCZYK

https://orcid.org/0000-0002-4116-9350

Uniwersytet Humanistyczno-Przyrodniczy im. Jana Długosza w Częstochowie

\section{Trzy odsłony Statutu Ochotniczej Straży Pożarnej w Mostach przy Jabłonkowie}

\section{Streszczenie}

Czechosłowacki system społeczny zapewnił grupom narodowym, zatem i Polakom, stosunkowo szerokie prawa narodowościowe. Prawa te Polacy wykorzystywali m.in., by organizować się w różnego typu związki społeczne. Działalność stowarzyszeń polskich na Śląsku Cieszyńskim odbywała się na wszystkich płaszczyznach życia społecznego. Funkcjonowały bowiem polskie organizacje: kulturalno-oświatowe, opiekuńcze, młodzieżowe, wyznaniowe, sportowo-turystyczne oraz gospodarcze ${ }^{1}$.

Funkcjonowanie stowarzyszeń polskich zostało przedstawione na przykładzie trzech statutów Straży Pożarnej, odnalezionych podczas kwerendy w Zemským archivie w Opawie. Pierwszy $\mathrm{z}$ nich, został zachowany w formie maszynopisu. Dwa kolejne, w formie drukowanej broszurki. Zestawienie tych trzech statutów, nie tylko pozwala ustalić sposób funkcjonowania Straży Pożarnej w Mostach oraz Straży Pożarnych w Czeskim Cieszynie, ale umożliwia również wskazanie zachodzących w ramach organizacji zmian.

Słowa kluczowe: Stowarzyszenia polskie w Czechosłowacji, statut, Straż Pożarna.

1 Anna Czerniecka-Haberko, Karolina StudnickA-MariańczkyK, Stowarzyszenia polskie $w$ Czechostowacji. 
Naród ginie, gdy znieprawia swojego ducha, naród rośnie, gdy duch jego coraz bardziej się oczyszcza i tego żadne siły zewnętrzne nie zdołają zniszczyć.

Jan Paweł II ${ }^{2}$

Stowarzyszenie to organizacja społeczna powołana do życia przez grupę ludzi mających wspólne cele lub zainteresowania. Stowarzyszenie, co oczywiste, podlega regulacjom prawnym. Należy jednak podkreślić, że prawo stowarzyszeń ma „stosunkowo” krótką historię. Pierwsze akty prawne podejmujące kwestie zrzeszania się powstały dopiero pod koniec XVIII w. Prawo zrzeszania się zostało wymienione w aktach prawnych tworzących się Stanów Zjednoczonych Ameryki Północnej oraz dokumentach Rewolucji Francuskiej. Od tego też czasu regulacje prawne dotyczące stowarzyszeń pojawiały się w konstytucjach i ustawach zwykłych innych państwach ${ }^{3}$.

W ustawodawstwie zaboru austriackiego wolność zrzeszania się zostało zapisane w postanowieniach Konstytucji 4 marca 1849 r. Zostało również wpisane do ogłoszonego dla krajów austriackich patentu z 4 marca 1849 r. o prawach politycznych poręczonych przez konstytucyjną formę państwa. Dokumenty te zostały zastąpione patentem z 31 grudnia 1851 r., by następnie - patentem z 26 listopada 1852 r. - zabronić zawiązywania stowarzyszeń, które „w jakimkolwiek zamiarze przywłaszczają sobie autorytet co do jakiejkolwiek gałęzi władzy ustawodawczej lub wykonawczej”, powstanie innych stowarzyszeń zależało od decyzji władz ${ }^{4}$.

Kolejne zmiany przyniosła ustawa zasadnicza z 21 grudnia 1867 r., która uznała prawo obywateli do tworzenia stowarzyszeń. Następne regulacje - bardziej szczegółowe - przyniosła ustawa o stowarzyszeniach z 15 listopada 1867 r. ${ }^{5}$ Wprowadziła ona system zgłoszeniowy tworzenia stowarzyszeń. Na jego mocy założyciele zostali zobowiązanie do zawiadomienia administracyjną władzę krajową (namiestnictwo) o zamiarze utworzenia stowarzyszenia, załączając projekt statutu. W przypadku gdy namiestnictwo nie wyraziło sprzeciwu, stowarzyszenie uzyskiwało wtedy od władzy administracyjnej poświadczenie istnienia. Mogło zatem rozpocząć działalność.

Działalność stowarzyszeń podlegała rozbudowanej kontroli. Nadzór prowadzono na płaszczyznach: meldunkowej (obowiązek informowania władzy admi-

2 Jan PAweŁ II, Naród, https://cytaty24.pl/cytaty/Nar\%C3\%B3d/Aforyzmy,Sentencje/k/40?pagec $=6$, [dostęp: 29.03.2019].

3 Tadeusz Szulc, Prawo do stowarzyszania się w państwach Europy Środkowo-Wschodniej w II polowie XIX w.- poczatek XX w., „Studia Prawno Ekonomiczne”, nr 68: 2003, s. 19-24; Paweł Suski, Stowarzyszenia i fundacje, Warszawa 2011, s. 17.

4 Konstanty GRzYBowski, Historia państwa i prawa Polski, t. IV, Warszawa 1982, s. 349-350.

5 Zbiór ważniejszych ustaw i rozporzadzeń administracyjnych (ogólnych i dzielnicowych) obowiazujących w Rzeczypospolitej Polskiej, oprac. Stanisław CZAPUTOwicz, Tadeusz SikORSKI, Warszawa 1925, s. 121-125; P. Suski, op. cit., s. 17. 
nistracyjnej m.in. o składzie zarządu, adresach członków), obserwacyjnej (prawo delegowania na każde zgromadzenie komisarza rządowego uprawnionego do uczestniczenia w nim, do żądania informacji o osobach wnioskodawców i mówców, do żądania spisania protokołu z przedmiotu zebrania i powziętych uchwał, prawo wglądu w protokoły powziętych uchwał) oraz represyjnej (prawo komisarza rządowego do zamknięcia zgromadzenia, prawo władzy administracyjnej do rozwiązania stowarzyszenia $\mathrm{w}$ wypadkach, gdyby podjęło ono uchwały sprzeczne z ustawą karną, albo które by co do treści lub formy zawierały przywłaszczenie sobie władzy ustawodawczej lub wykonawczej przez stowarzyszenie, gdyby przekroczyło ono określony w statucie zakres działania lub w ogóle nie odpowiadało warunkom prawnym swego istnienia) $)^{6}$.

Kolejne istotne zmiany w prawie do zrzeszania się przyniosła ustawa z 5 maja 1869 r. Zaznaczono w niej, że prawa o stowarzyszeniach może ulec zawieszeniu np. w razie wojny lub spodziewanego jej wybuchu w krótkim czasie, w razie rozruchów wewnątrz państwa oraz gdyby „pojawiły się knowania na większe rozmiary, mające na celu zdradę stanu lub gdyby knowania te naruszały konstytucję lub bezpieczeństwo osobiste"

W okresie międzywojennym podstawy prawne polskiej grupy narodowej w Czechosłowacji określały Konstytucja Republiki Czechosłowackiej i ustawy specjalne posiadające charakter prawa konstytucyjnego, ustawy zwyczajne i rozporządzenia oraz umowa polsko-czechosłowacka z 23 kwietnia $1925 \mathrm{r}$. To one regulowały różne aspekty życia Polaków mieszkających w Czechosłowacji ${ }^{8}$.

Czechosłowacki system społeczny zapewnił grupom narodowym, zatem i Polakom, stosunkowo szerokie prawa narodowościowe. Prawa te Polacy wykorzystywali m.in. aby organizować się w różnego typu związki społeczne. Działalność polskich stowarzyszeń na Śląsku Cieszyńskim odbywała się na wszystkich płaszczyznach życia społecznego. Funkcjonowały bowiem polskie organizacje: kulturalno-oświatowe, opiekuńcze, młodzieżowe, wyznaniowe, sportowo-turystyczne oraz gospodarcze ${ }^{9}$. Funkcjonowanie polskich stowarzyszeń można przedstawić na przykładzie statutów Straży Pożarnej.

Zamieszczone poniżej Statuty Ochotniczej Straży Pożarnej zostały odnalezione podczas kwerendy w Zemským archivie w Opawie, w materiałach poświęconych Ochotniczej Straży Pożarnej ${ }^{10}$. Pierwszy z nich został zachowany w formie maszynopisu, a dwa kolejne w formie drukowanych broszurek. Zestawienie

6 Tadeusz Dwernicki, O prawach obywatelskich, Kraków 1896, s. 18; P. SUSKI, op. cit., s. 17.

7 T. DWERNICKI, op. cit., s. 48-49.

8 Stanisław ZAHRADnik, Przejawy życia organizacyjnego Polaków w Czechosłowacji $w$ latach 1920-1938, „Sobótka”, t. 36/4: 1981, s. 545-546.

9 Anna Czerniecka-Haberko, Karolina Studnicka-Mariańczkyk, Stowarzyszenia polskie $w$ Czechostowacji, tekst w posiadaniu autorek.

10 Ochotnicza Straż Pożarna, ZAO, Moravskoslezský Zemský národní výbor, expozitura Ostrava, sygn. 225/327. 
tych trzech statutów, nie tylko pozwala ustalić sposób funkcjonowania Straży Pożarnej w Mostach oraz Straży Pożarnych w Czeskim Cieszynie, ale umożliwia również wskazanie zachodzących w ramach organizacji zmian.

\section{STATUT OCHOTNICZEJ STRAŻY POŻARNEJ}

\section{w Mostach przy Jabłonkowie}

I. Nazwa, siedziba i cel Towarzystwa.

1. Towarzystwo nosi nazwę: „Ochotnicza Staż Pożarna w Mostach przy Jabł."

2. Siedzibą Towarzystwa jest Mosty przy Jabłonkowie.

3. Straż Pożarna ma na celu:

1. nieść pomoc i ratunek $\mathrm{w}$ razie powstania pożaru lub innej klęski elementarnej nie tylko w miejscowej, ale i sąsiednich wioskach;

2. współdziałać w wykonywaniu posług samarytańskich;

3. wyrabiać w swych członkach ducha karności i łączności.

Do tego się przyczyniają:

a) ćwiczenia praktyczne i teoretyczne regularnie odbywana;

b) przystąpienie do Związku Polskich Straży Pożarnych w Czechosłowacji w Czeskim Cieszynie.

c) urządzanie kursów fachowych, zabaw i obchodów.

II. Członkowie, obowiązki i ich prawa.

4. Towarzystwo składa się z członków:

a) czynnych $(7,8,9,10)$;

b) wspierających (6);

c) honorowych $(5,13 \mathrm{~h}, 17 \mathrm{~h})$.

5. Członkami honorowymi mianuje Walne Zgromadzenie na [...] Wydziału osoby, zasłużone około Towarzystwa i pożarnictwa wogóle.

Członkom honorowym przysługują prawa członków czynnych (10) bez obowiązku zasilania funduszów Towarzystwa.

6. Członkami wspierającymi są wszyscy ci, którzy dobrowolnemi wkładkami rocznemi przyczyniają się do poparcia humanitarnych celów Towarzystwa. Przyjmie ich Wydział. Członkowie wspierający biorą udział w Walnych Zgromadzeniach z głosem doradczym i mogą być wybierani do Komisji rewizyjnej (23).

[7] Członkiem czynnym może być każdy mężczyzna po ukończeniu 18. roku życia, czci nieposzlakowanej, który przystępując do Towarzystwa, zobowiąże się spełnić punktualnie obowiązki, zachowywać godność strażacką wogóle poddać się przepisom organizacji [...] członków czynnych przyjmuje Wydział, który w razie nieprzyjęcia nie jest zobowiązany podawać przyczyn $(17[\ldots])$ 
Przyjętego członka przydziela Naczelnik stosownie do jego uzdolnienia i potrzeby Straży do jednego z oddziałów, uwzględniając o ile możliwie jego życzenia. $(19 \mathrm{~b}, 30)$

[8] Członkowie czynni płacą jednorazowo wpisowego 5 Kč (25) i roczną wkładkę w kwocie $10 \mathrm{Kč} \mathrm{[...]} \mathrm{(27).} \mathrm{Wysokość} \mathrm{wkładki} \mathrm{może} \mathrm{Walne}$ Zgromadzenie każdego czasu [...] zmienić, albo wogóle znieść.

Również może Walne Zgromadzenie uchwalić wkładkę na zabezpieczenie wypadku i na wypadek śmierci.

9. Każdy członek czynny powinien:

a) uczęszczać pilnie na ćwiczenia;

b) słuchać bezwarunkowo swych przełożonych tak przy pożarze, jak na placu ćwiczeń;

c) zachowywać się honorowo w służbie i poza służbą;

d) wynagrodzić wszelkie zawinione szkody, wyrządzono na majątku Straży;

e) stosować się wogóle do przepisów statutu i regulaminów Straży.

10. Członkowie czynni [...] prawo:

a) brać udział w Walnych Zgromadzeniach, prawem przemawiania, stawiania wniosków, głosowania, wyboru i wybieralności;

b) wnosić do Wydziału życzenia i zażalenia na piśmie;

c) wypożyczać bezpłatnie rysztunku za potwierdzeniem na piśmie;

d) używać mundurów i odznak w wypadkach przyzwolonych przez Wydział.

III. Zarząd Towarzystwa.

11. Sprawami Towarzystwa zarządza:

1. Walne Zgromadzenie (12, 13, 14);

2. Wydział $(15,16,17,26)$;

3. Prezes względnie naczelnik lub jego zastępca $(18,19)$;

12. Zwyczajne Walne Zgromadzenie zwołuje Wydział co rok w styczniu, a nadzwyczajne w razie potrzeby lub na pisemne wezwanie jednej piątej członków czynnych z [...] powodów. Takie nadzwyczajne Walne Zgromadzenie musi się odbyć najpóźniej w trzy tygodnie po wniesieniu żądania, jeżeli w nim nie zakreślono dłuższego terminu.

13. Do zakresu zwyczajnego Walnego Zgromadzenia należy:

a) załatwiać sprawozdania roczne $z$ czynności Wydziału i rachunku (17 f) i uchwalać preliminarz roczny;

b) rozporządzać majątkiem Straży (24);

c) uchwalać wysokość wkładek (8);

d) wybierać Wydział $(15,19)$;

e) wybierać Komisję rewizyjną (6, 17 g, 23);

f) zmieniać statuty i przepisy (14) za zgodą Zarządu Związku Polskich Straży pożarnych w Czechosłowacji, 

g) uchwalać regulamin służbowy;
h) mianować członków honorowych $(5,17 \mathrm{~h})$;
i) przyznawać członkom odznaki służbowe, pochwalne i honorowe (31);
j) rozwiązać Towarzystw $(14,34)$.

14. Do ważności uchwał na Walnom Zgromadzeniu potrzeba najmniej obecności $1 / 3$ członków czynnych; z wyjątkiem uchwał co do zmiany statutu lub rozwiązania Towarzystwa, z którymto wypadku obowiązuje przepis ostatniego ustępu tego paragrafu.

Jeżeli Walne Zgromadzenie nie ma kompletu, to następne dla tych samych przedmiotów zwołane Zgromadzenie jest bez względu na ilość przybyłych uprawnione do wiążących uchwał.

Porządek dzienny Walnego Zgromadzenia, jako też i miejsce musi być co najmniej trzy dni naprzód podane członkom do wiadomości.

Uchwały zapadają zwykłą większością głosów obecnych. W razie równości głosów rozstrzyga przewodniczący, który zresztą nie głosuje. Jedynie za uchwałą zmiany statutu, oraz rozwiązania Towarzystwa musi głosować $4 / 5$ wszystkich członków czynnych.

15. Wydział składa się z prezesa (18), naczelnika, jego zastępcy (19), sekretarza (20), skarbnika (21), rysztunkowego (magazyniera) (22), i trzech sierżantów.

Godność prezesa i naczelnika można połączyć w jednej osobie. W takim razie naczelnik wykonuje funkcje wyszczególnione w 18 i 19. Sekretarz może pełnić równocześnie obowiązki skarbnika $(20,21)$.

16. Posiedzenia Wydziału zwołuje prezes względnie naczelnik według potrzeby i kieruje obradami. Do prawomocności uchwał jest potrzebna obecność przynajmniej 5 (pięciu) członków. uchwały zapadają zwykłą większością głosów. W razie równości rozstrzyga prezes, który poza tem nie głosuje.

17. Wydział zarządza sprawami Towarzystwa, o ile nie są zastrzeżone Walnemu Zgromadzeniu. W szczególności ma prawo i obowiązek:
a) zarządzać funduszami Towarzystwa i starać sie o ich pomnożenie;
b) przyjmować i wykreślać członków czynnych i wspierających;
c) czuwać nad ładem i karnością w Towarzystwie;
d) wykonywać uchwały Walnych Zgromadzeń;
e) zwoływać Walne Zgromadzenie, przygotowywać dla nich wnioski i stanawiać porządek obrad;
f) zdawać sprawę z rachunków i czynności Walnemu Zgromadzeniu;
g) przedkładać Komisji rewizyjnej najmniej ośm dni przed Walnem Zgromadzeniem księgi kasowe i rachunki do zbadania;
h) proponować Walnemu Zgromadzeniu członków honorowych do za- mianowania.


18. Prezes względnie naczelnik zastępuje Towarzystwo na zewnątrz. W szczególności ma obowiązek:

a) zwoływania posiedzeń Wydziału;

b) przewodniczenia na posiedzeniach Wydziału i na Walnych Zgromadzeniach;

c) podpisywania wspólnie z sekretarzem wszystkich pism i ogłoszeń.

19. Naczelnik względnie jego zastępcą ma nieograniczone kierownictwo korpusem. W szczególności ma obowiązek:

a) odbierać ślubowanie od wstępujących członków czynnych (7);

b) przydzielać ich do oddziałów $(7,30)$;

c) zwoływać strażaków na ćwiczenia, czy to całego korpusu, czy też pojedyńczych oddziałów;

d) odbywać kursa teoretyczne w celu lepszego wyszkolenia strażaków;

e) stosować kary dyscyplinarne (32).

20. Sekretarz zapisuje protokoły z posiedzeń Wydziału i Walnych Zgromadzeń w księdze protokołów, prowadzi spis członków i załatwia wszelką korespondencję.

21. Skarbnik zawiaduje funduszami Straży, prowadzi księgi kasowe i jest za prawdziwe prowadzenie odpowiedzialny przez Wydziałem $(25,26,27)$.

22. Rysztunkowy (magazynier) utrzymuje w porządku sikawkę i przyrządy ku gaszeniu ognia. Jest zarazem magazynierem i jako taki stara się o utrzymanie w porządku rysztunków i mundurów.

23. Komisja rewizyjna, składa się z trzech członków, bada rachunki i obrót pieniężny Towarzystwa i stawia na Walnem Zgromadzeniu odpowiednie wnioski.

IV. Majątek Towarzystwa, rok administracyjny.

24. Na majątek Towarzystwa składa się:

a) fundusz obrotowy (27);

b) fundusze zapasowe $(25,26)$;

c) inwentarz.

25. Do funduszu zapomogowego wpływają wpisowe (8), zapisy, dary i inne przez Wydział lub Walne Zgromadzenie przeznaczone dochody.

26. Wydział udziela z funduszu zapomogowego wsparć strażakom, którzy w służbie ulegli jakiemu wypadu nieszczęśliwemu, lub bez własnej winy popadli w wielką biedę.

27. Fundusz obrotowy stanowią wkładki roczna, subwencje i inne dochody nieprzeznaczone do funduszu zapomogowego (8).

28. Rokiem administracyjnym jest rok kalendarzowy.

V. Wybory.

29. Prezesa, naczelnika, jego zastępcę, sekretarza i rysztunkowego wybiera Walne Zgromadzenie absolutną większością głosów na dwa lata. Oprócz 
tego wybiera także na przeciąg dwuletni, każdy oddział z pośród siebie jednego sierżanta, jednego zastępcę sierżanta i jednego męża zaufania.

Funkcje tych trzech ostatnich określi regulamin służbowy.

Wybory odbywają się kartkami. W razie jednomyślności można wybierać przez aklamację.

VI. Oddziały i odznaki.

Ochotnicza Straż Pożarna w Mostach p. Jabł. składa się z trzech oddziałów, a mianowicie:

1. oddział sztygarów;

2. oddział sikawkowy;

3. oddział ochronny.

Drugi i trzeci oddział mają być złączone w jeden.

31. Wszyscy członkowie otrzymują według oddziałów i czynności służbowych odznaki, które bliżej określi regulamin.

VII. Kary.

32. W stosunku do przewinień stosuje się następujące kary:

a) upomnienie (w oczy);

b) nagana;

c) wydalenie z miejsca ćwiczeń lub pożaru;

d) wykluczenie z Towarzystwa.

Kary pod a i b wymienione przysługują każdemu przełożonemu, pod c tylko naczelnikowi, pod d tylko Wydziałowi.

VIII. Załatwianie sporów.

33. Spory w służbie rozstrzyga naczelnik. Poza służbą sad polubowny, składający sie z 5 członków, z których dwóch wybiera oskarżyciel, 2 oskarżony, a ci 4 wybierają sobie piątego za przewodniczącego.

IX. Rozwiązanie Towarzystwa.

34. W razie rozwiązania Towarzystwa lub zmiany statut w tym kierunku, że przystępuje do innych organizacyj Ochotniczych Straży Pożarnych, przypada jego majątek w zupełności Związkowi Polskich Straży Pożarnych w Czechosłowacji w Czeskim Cieszynie, który bierze na siebie obowiązek majątek ten tak długo oddzielnie administrować, dopóki nie otworzy się nowe Towarzystwo Ochotniczej Straży Pożarnej w Mostach p.J. (z zastosowaniem się do 35), któremu potem majątek ten ma być oddany.

X. Urzędowanie

35. Językiem urzędowym Ochotniczej Straży Pożarnej w Mostach p.J. jest język polski. 


\section{STATUT OCHOTNICZEJ STRAŻY POZARNEJ}

\section{w Mostach przy Jabłonkowie}

[I] Nazwa, siedziba i cel Towarzystwa.

1. Towarzystwo nosi nazwę: Ochotnicza Staż Pożarna w Mostach p.J.

2. Siedzibą Towarzystwa jest (są) Mosty p.J.

3. Zadaniem straży pożarnej jest gaszenie pożarów nietylko w miejscowości, ale i w najbliższej okolicy, tudzież przedsiębranie środków zaradczych, zmierzających do zapobiegania pożarom, wreszcie niesienia pomocy przy ratowaniu życia i mienia w czasie klęsk elementarnych (żywiołowych) i współdziałanie w wykonywaniu posług samarytańskich. Do tego przyczyniają się:

a) ćwiczenia praktyczne $\mathrm{i}$ teoretyczne, odbywane regularnie;

b) urządzenie kursów fachowych, zabaw i obchodów;

c) urządzanie przedstawień teatralnych, koncertów, akademji (wykładów oświatowych) i zgromadzenie się członków wogóle.

4. Powyżej cytowana Ochotnicza Straż Pożarna jest członkiem Związku Polskich Straży Pożarnych w Czechosłowacji z siedzibą w Českém Těšíně.

Wystąpienie jej ze Związku Polskich Straży Pożarnych w Czechosłowacji może nastąpić tylko za uchwała zmiany tego statutu. Językiem urzędowym jest język polski.

II. Członkowie, obowiązki i ich prawa.

5. Towarzystwo składa się z członków:

a) czynnych $(8,9)$;

b) wspierających (7);

c) honorowych $(6,12 \mathrm{~h}, 16 \mathrm{~h})$.

6. Członkami honorowymi mianuje Walne Zgromadzenie na wniosek Wydziału straży i za zgodą Zarządu Okręgowego osoby, zasłużone około towarzystwa i pożarnictwa wogóle.

Członkom honorowym przysługują prawa członków czynnych bez obowiązku zasilania funduszów Towarzystwa.

7. Członkami wspierającymi są wszyscy ci, którzy dobrowolnemi składkami rocznemi przyczyniają się do poparcia humanitarnych celów Towarzystwa.

Przyjmuje ich Wydział. Członkowie wspierający biorą udział w Walnych Zgromadzeniach z głosem doradczym (bez prawa głosowania), a mogą być wybierani do Komisji rewizyjnej (24).

8. Członkiem czynnym może być każdy mężczyzna po ukończeniu 18 roku życia, czci nieposzlakowanej, który, przystępując do Towarzystwa, zobowiąże się spełniać punktualnie i sumiennie obowiązki, zachowywać godność strażacką, wogóle poddać się przepisom organizacji. 
Przyjętego członka przydziela naczelnik stosownie do jego uzdolnienia i potrzeby straży do jednego z oddziałów, uwzględniając, o ile możliwe, jego życzenia (18 b, 31). Przyjęty członek podpisuje deklarację i składa pisemne ślubowanie.

Pierwszych członków przyjmują proponenci.

Każdy członek czynny powinien:

a) uczęszczać pilnie na ćwiczenia;

b) słuchać bezwarunkowo swych przełożonych, tak przy pożarze, jak na polu ćwiczeń;

c) zachowywać się honorowo w służbie i poza służbą;

d) wynagrodzić wszelkie zawinione szkody, wyrządzone na majątku Straży;

e) stosować się wogóle do przepisów statutu i regulaminu Straży.

Członkowie czynni mają prawo:

a) brać udział $\mathrm{w}$ Walnych Zgromadzeniach z prawem przemawiania, stawiania wniosków, głosowania, wyboru i wybieralności;

b) wnosić do Wydziału życzenia i zażalenia na piśmie;

c) wypożyczać bezpłatnie rysztunku za potwierdzeniem na piśmie.

9. Członkowie czynni płacą jednorazowo wpisowego 2 Kč (26) i roczną składkę w kwocie 5 Kč (28). Wysokość składki może Walne Zgromadzenie każdego czasu zmienić. Również może Walne Zgromadzenie uchwalić składkę na zabezpieczenie od wypadków i na wypadek śmierci.

III. Zarząd Towarzystwa

10. Sprawami Towarzystwa O. S. P. zarządza:

1. Walne Zgromadzenie (14, 15, 16, 27),

2. Prezes względnie naczelnik lub jego zastępca $(17,18,19)$

11. Zwyczajne Walne Zgromadzenie zwołuje Wydział co roku w styczniu a nadzwyczajne w razie potrzeby na pisemne wezwanie trzeciej członków czynnych z podaniem powodów lub na wezwanie Zarządu Okręgowego. Także nadzwyczajne Walne Zgromadzenie musi się odbywać najpóźniej $\mathrm{w}$ trzy tygodnie po wniesieniu żądania, jeżeli w niem nie wyznaczonego dłuższego terminu.

12. Do zakresu zwyczajnego Walnego Zgromadzenia należy:

a) załatwiać sprawozdania roczne $\mathrm{z}$ czynności Wydziału rachunków (16 f) i uchwalać preliminarz roczny;

b) rozporządzać majątkiem straży (25); w szczególności nabywania lub sprzedawania nieruchomości;

c) uchwalać wysokość wkładek (9);

d) wybierać Wydział $(14,30)$;

e) wybierać Komisję rewizyjną (7, 16 g, 24);

f) zmieniać statuty i przepisy (13 za zgodą władz Związkowych;

g) mianować członków honorowych $(6,16 \mathrm{~h})$; 
h) rozwiązać Towarzystwo $(13,35)$

13. W Walnem Zgromadzeniu biorą udział wszyscy członkowie straży, członkowie wspierający z głosem doradczym i delegaci Zarządów Okręgowych i Rady Naczelnej.

Do ważności uchwał na Walnem Zgromadzeniu potrzeba najmniej obecności jednej trzeciej członków czynnych; do 2, 4, 35, lub rozwiązania Towarzystwa, trzeba najmniej dwie trzecie członków czynnych, w którym to wypadku obowiązuje przepis czwartego ustępu tego paragrafu. Jeżeli Walne Zgromadzenie niema kompletu, to następne dla tych samych przedmiotów zwołane Zgromadzenie jest bez względu na ilość przybyłych uprawnione do wiążących uchwał, co jednak w zaproszeniu musi być dokładnie podane.

Porządek dzienny Walnego Zgromadzenia, jako też i miejsce musi być co najmniej trzy dni naprzód podane członkom do wiadomości.

Uchwały zapadają zwykłą większością głosów obecnych. zapadają zwykłą większością głosów obecnych. W razie równości głosów rozstrzyga przewodniczący, który zresztą nie głosuje. Jedynie za uchwałą zmian 2, 4, 35 muszą głosować cztery piąte wszystkich członków czynnych.

O uchwałach władz strażackich uwiadamia się członków przy ćwiczeniach albo zgromadzeniach członków, okólnikiem lub wywieszeniem uchwały na tablicy strażackiej; tak samo podaje się do wiadomości różne ogłoszenia i zawiadomienia.

14. Wydział składa się z prezesa (17), naczelnika (18) i ich zastępców (19), sekretarza (20), skarbnika (21), skarbnika kasy pośmiertnej (22), rynsztunkowego (gospodarza) (23) i strażaków. Za naczelnika należy wybierać druhów, mających kursy strażackie.

Godność prezesa i naczelnika można połączyć w jednej osobie. W takim razie naczelnik wykonuje funkcje wyszczególnione w 17, 18.

Sekretarz pełni funkcję referenta oświatowego a może pełnić równocześnie obowiązki skarbnika $(20,21)$.

15. Posiedzenia Wydziału zwołuje prezes, względnie naczelnik według potrzeby lub na wezwanie Zarządu Okręgowego i kieruje obradami.

Do prawomocności uchwał potrzeba przynajmniej obecności 6 członków. Uchwały zapadają zwykłą większością głosów. W razie równości głosów rozstrzyga przewodniczący, który poza tem nie głosuje.

W posiedzeniach Wydziału może brać udział delegat Zarządu Okręgowego lub Rady Naczelnej z głosem doradczym.

16. Wydział zarządza sprawami Towarzystwa, o ile nie są zastrzeżone Walnemu Zgromadzeniu. W szczególności ma prawo i obowiązek:

a) zarządzać funduszami Towarzystwa i starać się o ich pomnożenie;

b) przyjmować, zwalniać wzgl. wykluczać członków czynnych i wspierających. O wykluczeniu członków donosi Radzie Naczelnej; 
c) czuwać nad ładem i karnością w Towarzystwie;

d) wykonywać uchwały Walnego Zgromadzenia;

e) zwoływać Walne Zgromadzenia, przygotowywać dla nich wnioski i ustanawiać porządek obrad;

f) zdawać sprawę z rachunków i czynności na Walnem Zgromadzeniu;

g) przedkładać Komisji rewizyjnej najmniej 8 dni przed Walnem Zgromadzeniem księgi kasowe, rachunki wraz z załącznikami i rachunki kasy pośmiertnej do zbadania;

h) proponować Walnemu Zgromadzeniu członków honorowych do zamianowania;

i) wypełniać wszelkie zarządzenia Zarządów Okręgowych i Rady Naczelnej;

k) przedkładać corocznie sprawozdania z rachunków i czynności do zatwierdzenia Radzie Naczelnej najmniej 8 dni po Walnem Zgromadzeniu.

17. Prezes zastępuje Towarzystwo na zewnątrz. W szczególności ma obowiązek:

a) zwoływanie posiedzeń Wydziału:

b) przewodniczenia na posiedzeniach Wydziału i na Walnych Zgromadzeniach;

c) podpisywania wspólnie z sekretarzem wszystkich pism i ogłoszeń;

d) zgłaszania do Zarządu Okręgowego i do Władz politycznych Walnych Zgromadzeń, jako też doniesienie obu instancjom o wyniku wyborów.

18. Naczelnik ma nieograniczone prawo kierowania korpusem. W szczególności ma obowiązek:

a) odbierać ślubowanie od wstępujących członków czynnych (8);

b) przydzielać ich do oddziałów $(8,31)$;

c) zwoływać strażaków na ćwiczenia, czy to całego korpusu, czy też pojedyńczych oddziałów;

d) odbywać kursy teoretyczne w celu lepszego wyszkolenia strażaków;

e) stosować kary dyscyplinarne (32).

19. W razie nieobecności lub choroby prezesa lub naczelnika, wchodzą we wszystkie ich prawa i obowiązki, ich zastępcy.

20. Sekretarz spisuje protokoły z posiedzeń Wydziału i Walnych Zgromadzeń w księdze protokołów, prowadzi spis członków, załatwia wszelką korespondencję i prowadzi wszelkie agendy referenta oświatowego.

21. Skarbnik zawiaduje funduszami straży według wskazówek Wydziału, prowadzi księgi kasowe i jest za prawidłowe prowadzenie odpowiedzialny przed Wydziałem $(26,27,28)$.

22. Skarbnik kasy pośmiertenej wybiera i odsyła składki do kasy pośmiertenej, proponuje przyjęcie członków do kasy pośmiertnej i jest za prawidłowe prowadzenie agend odpowiedzialny prze Wydziałem. 
Kasa pośmiertna jest sekcją Związku Polskich Straży Pożarnych w Czechosłowacji, której czynność bliżej określa regulamin kasy pośmiertnej.

23. Rynsztunkowy (gospodarz) utrzymuje w porządku remizę, sikawki i przyrządy do gaszenia ognia.

Jako gospodarz, stara się o utrzymanie w porządku rynsztunków, mundurów i wszelkiego sprzętu pożarniczego. Prowadzi spis inwentarza, a na Walnem Zgromadzeniu zdaje sprawozdanie z czynności.

24. Komisja rewizyjna, składa się z trzech członków. Bada rachunki i obrót pieniężny Towarzystwa i rachunku kasy pośmiertnej; stawia na Walnem Zgromadzeniu odpowiednie wnioski.

IV. Majątek Towarzystwa, Rok administracyjny.

[25] Na majątek Towarzystwa składają się:
a) fundusz obrotowy (28);
b) fundusze zapasowe $(26,27)$;
c) inwentarz

26. Do funduszu zapasowego wpływają: wpisowe (9) zapisy, dary i inne przez Wydział lub Walne Zgromadzenie przeznaczone dochody.

27. Wydział udziela z funduszu zapasowego wsparć strażakom którzy w służbie ulegli jakiemu nieszczęśliwemu wypadkowi lub bez własnej winy popadli w wielką biedę

28. Fundusz obrotowy stanowią składki roczne, subwencje i inne dochody nieprzeznaczone do funduszu zapasowego (9).

29. Rokiem administracyjnym jest rok kalendarzowy.

V. Wybory.

30. Prezesa, naczelnika, ich zastępców, sekretarza, skarbnika i rynsztunkowego wybiera Walne Zgromadzenie absolutną większością głosów na 2 lata. Oprócz tego wybiera także na przeciąg dwuletni każdy oddział z pośród sienie 1 sierżanta, 1 zastępcę i 1 męża zaufania. Funkcje tych trzech ostatnich określa regulamin służbowy.

Członkowie kasy pośmiertenej wybierają z pośród siebie skarbnika, który powinien być członkiem kasy pośmiertenej.

Wybory odbywają się za kartkami lub przez aklamację, o ile za tym wnioskiem oświadczy się większość zebranych członków. Członkowie ustępujący mogą być ponownie wybrani.

VI. Oddziały i Odznaki.

31. Ochotnicza Straż Pożarna w Mostach p.J., składa się z 2 do 5 oddziałów, zależnie od liczny członków.

Oddziały są:

1. toporniczy;

2. sikawkowy lub maszynowy;

3. ochronny; 
4. sanitarny;

5. wodny (w strażach liczących ponad 80 członków).

Trzeci i czwarty oddział mają być połączone.

W strażach liczących ponad 80 członków, wybiera każdy oddział oprócz wspomnianych funkcjonariuszy jeszcze po 3 sekcyjnych, których funkcje określa regulamin służbowy. W strażach takich wybiera się adjutanta.

Powyżej cytowana Straż ma prawo noszenia sztandaru, jako zeVII. Kary. wnętrznej odznaki, według urzędowego pozwolenia.

32. Za niestosowanie się do rozporządzeń, objawy niekaralności oraz za zaniedbywanie swych obowiązków względem Wydziału, stosuje się następujące kary:

a) upomnienie w cztery oczy (przysługuje sierżantowi);

b) naganę na piśmie;

c) naganę przed frontem korpusu; zapisaniem w rozkazie;

d) zawieszenie członka w czynnościach korpusu na pewien przeciąg czasu (b, c, d, przysługuje naczelnikowi);

e) usunięcie z Towarzystwa (stosuje Wydział).

VIII. Załatwienie sporów.

33. Spory w służbie rozstrzyga naczelnik. Poza służbą sąd polubowny, składający się z pięciu członków, z których 2 wybiera oskarżyciel, 2 skarżący, a ci wybierają sobie piątego za przewodniczącego. Wszyscy muszą być członkami czynnymi.

IX. Umundurowanie, uzbrojenie. Sygnalizacja.

34. Członkom czynnym i honorowym przysługuje prawo noszenia munduru i odznak, zatwierdzonych przez Władze strażackie i polityczne. Bliższe szczegóły w regulaminie.

Straży przysługuje stosowanie i używanie normalnych sygnałów.

$\mathrm{X}$. Rozwiązanie Towarzystwa.

W razie rozwiązania Towarzystwa przypada majątek Towarzystwa w zupełności Związkowi Straży Pożarnych w Czechosłowacji w Českém Těšíně, który bierze na siebie obowiązek majątek ten tak długo oddzielnie administrować, dopóki nie utworzy się nowe Towarzystwo Ochotniczej Straży Pożarnej w Mostach p.[J.] lub najbliższej okolicy (zastosowaniem się do 4), któremu potem majątek ten będzie oddany.

$\mathrm{W}$ razie likwidacji majątku towarzystwa wygasłego zgodnie z postanowieniami niniejszego statutu potrzeba uchwały Rady Naczelnej Związku Polskich Straży Pożarnych w Czechosłowacji w myśl 22, ustęp f, statutu Związku. 


\section{Statut Związku Polskich Straży Pożarnych}

\section{w Czechosłowacji w Czeskim Cieszynie}

I. Nazwa, siedziba i zadania Związku

1. Towarzystwo nosi nazwę: Związek Straży Pożarnych w Czechosłowacji w Czeskim Cieszynie. Siedzibą jego jest Český Těšin (35).

2. Związek jest naczelną organizacją polskich straży pożarnych i ma na celu:

a) Zjednoczenie na terenie swojej działalności wszystkich swoich polskich straży pożarnych w jednolita organizację;

b) organizowanie obrony od pożarów i klęsk elementarnych, jako też utrzymanie straży w stałej gotowości bojowej;

c) podniesienie, wydoskonalenie, ujednostajnienie pożarnictwa pod względem fachowym, oświatowym, samarytańskim i narodowym;

d) współprace przy wykorzystaniu rozporządzeń pożarno-policyjnych i sanitarnych;

e) tworzenie i zasilanie funduszów samopomocy: Kas pośmiertnych, zapomogowych i innych, celem przyjścia z pomocą z jednej strony strażakom, którzy w służbie ponieśli szkodę na ciele, z drugiej strony gospodarczo słabym strażom (17 k.).

3. Dla urzeczywistnienia tych celów Związek, jako zwierzchnia na swym terenie władza straży pożarnych:

a) Zespala i reguluje działalność poszczególnych Związków Okręgowych (17 c, 22 f, g, k, 29);

b) udziela rad fachowych Związkom Okręgowym i strażom, przeprowadza lustracje, urządza konferencje fachowe, organizuje kursy pożarnictwa, wykłady, wystawy, zawody, zjazdy, ćwiczenia, obchody i zabawy (17 h, 22 f, h, i, j, 29);

c) utrzymuje dla swych członków bibljoteki czytelnie, wydaje lub subwencjonuje czasopisma, broszury, podręczniki i dzieła, poświęcone sprawom pożarnictwa (28);

d) łączy się z innemi zrzeszeniami strażackiemi (17 e);

e) tworzy fundacje, udziela nagród i odznaczeń $(32,17 \mathrm{k}, 22 \mathrm{j})$;

f) wybiera składki od zorganizowanych straży za pośrednictwem Związków Okręgowych (10, 17 b, 24 a);

g) przyjmuje wsparcia, dary i dobrowolne opłaty $(24 \mathrm{a}, 32)$.

II. Członkowie

4. Członkowie Związku dzielą się na rzeczywistych $(5,9,10)$, wspierających $(6,8,10)$ i honorowych $(7,10)$.

5. Członkami rzeczywistymi są ochotnicze straże pożarne, zorganizowane w Związki Okręgowe, które przy wstąpieniu składają pisemne oświad- 
czenie, że poddają się przepisom niniejszego statutu regulaminów, instrukcyj, jako też rozkazom Związku (22 d).

6. Członkami wspierającymi mogą być:

a) Osoby prawne - gminy, miasta, instytucje i stowarzyszenia - które zgłoszą do Związku swe przystąpienie na piśmie;

b) osoby pojedyńcze, które na zasadzie zgłoszenia zostaną przez Radę Naczelną przyjęte.

7. Osoby pojedyńcze lub prawne (6), które położyły wybitne zasługi dla pożarnictwa lub Związku, mogą być obdarzone godnością członków honorowych Związku (17 i, 22 c).

8. Członkowie wspierający mogą być wykreśleni (22 d) ze Związku:

a) $\mathrm{W}$ razie niepłacenia w ciągu 2 lat składki członkowskiej;

b) osoby pojedyńcze za czyny nieetyczne.

O wykreśleniu członka decyduje Rada Naczelna (22 d); od decyzji tej przysługuje prawo odwołania się do Walnego Zgromadzenia.

9. Członkowie rzeczywiści zobowiązani są nadsyłać co roku Radzie Naczelnej nie później jak do 31. marca sprawozdanie ze swych czynności w roku sprawozdawczym, projekt budżetu i planu działalności na rok przyszły (22 f).

10. Członkowie rzeczywiści opłacaja składkę roczną do Związku P. S. P. w wysokości $50 \%$ składek, przypadających od członków związkom okręgowym, zawcze na cały rok kalendarzowy, bez względu czy w danym roku członek przystąpił lub wstąpił.

Członkowie wspierający opłacają składkę roczną w kwocie:

a) Osoby prawne Kč 50'-;

[b] osoby pojedyńcze Kč 20'-.

Wysokość składki oznacza Walne Zgromadzenie Związku (17 b). Członkowie honorowi składek nieopłacają.

10a. Każdy członek ma prawo korzystać ze wszystkich urządzeń i udogodnień, jakie daje Związek.

[10b. Członkom czynnym i honorowym O.S.O. zorganizowanych w Związku P.S.P. w Czechosłowacji przysługuje prawo noszenia munduru i oznak, zatwierdzonych przez Władze strażackie i polityczne.]

III. Władze Związku.

11. Władzami Związku są:
a) Walne Zgromadzenie (12-17);
b) Rada Naczelna (18-22)
c) Prezydjum (23-27).

12. W Walnem Zgromadzeniu biorą udział:
a) Delegaci Związków Okręgowych;
b) członkowie Rady Naczelnej;
c) członkowie honorowi; 
d) członkowie wspierający z głosem doradczy.

[e) członkowie komisji rewizyjnej.

f) członkowie Zarządów Związków Okręgowych P.S.P. w Czechosłowacji.]

Każdy Związek Okręgowy wysyła za 50 członków czynnych straży jednego delegata; resztki do 25 członków się nie liczą. Każdego delegata zaopatrzy Związek Okręgowy odpowiednią legitymacja.

13. Zwyczajne Walne Zgromadzenie zwołuje Rada Naczelna (22 b) najpóźniej w miesiącu lipcu każdego roku w miejscowości, oznaczonej przez ostatnie Walne Zgromadzenie (17 j), nadzwyczajne każdego czasu, jeżeli zachodzi potrzeba lub jeżeli tego zażądają 2 Związki Okręgowe z podaniem porządku obrad, a to do 4 tygodni od daty wniesienia podania.

Zaproszenie na Walne Zgromadzenie z podaniem czasu, miejsca, jako też porządku obrad, musi być wysłane najmniej 14 dni przed terminem odbycia Walnego Zgromadzenia.

14. Każde Walne Zgromadzenie jest bez względu na liczbę obecnych (wyjąwszy przepisy 36 i 37) prawomocne do powzięcia obowiązujących uchwał, jeżeli zostało zwołane po myśli 13 statutu.

Wybory (17 d) przeprowadza się na przeciąg 3 lat większością głosów; przy równości głosów rozstrzyga los. Ustępujący członkowie mogą być ponownie wybrani. O sposobie wybierania (aklamacją lub kartkami) rozstrzyga Walne Zgromadzenie bez dyskusji zwykłą większością głosów.

Głosowanie odbywa się przez podniesienie rąk, uchwały zapadają absolutną większością obecnych.

Obrady Walnych Zgromadzeń są publiczne dla członków straży pożarnych, należących do Związku; Walne Zgromadzenie może jednak wykluczyć publiczność od obrad.

15. Walnemu Zgromadzeniu przewodniczy prezes lub jego zastępca; w razie nieobecności tychże członek Rady Naczelnej, wybrany przez Walne Zgromadzenie.

16. Wnioski, mające wejść pod obrady Walnego Zgromadzenia, muszą być wniesione do Rady Naczelnej conajmniej 8 dni przez Walnem Zgromadzeniem. Później podane wnioski mogą być tylko po przyznaniu im nagłości przez dwie trzecie obecnych wzięte pod obrady; inaczej odkłada się je do następnego Walnego Zgromadzenia.

17. Do zakresu działania Walnego Zgromadzenia należy:

a) Zatwierdzanie sprawozdań z czynności Rady Naczelnej, Komisji Rewizyjnej i rocznych zamknięć rachunków (22 a, b, 31, 24 a);

[b] uchwalenie corocznie składki związkowej, preliminarza dochodów i wydatków planu działalności (10, 22 b, c, 24 a);

c) zmiana statutów Związku zatwierdzenie regulaminów i instrukcyj $(35,22 \mathrm{f}, \mathrm{g}, \mathrm{k}, 1)$; 
d) wybór członków Rady Naczelnej, Komisji Kontrolującej i zastępców tych $(14,18,31,32)$;

e) przystąpienie do Związku zrzeszeń strażackich w Republice Czechosłowackiej (3 d);

f) uchwalenie wniosków o likwidacji Związku P. S. (37);

g) decydowanie o kupnie i sprzedaży nieruchomości i o obciążeniu ich długami;

h) rozważanie wniosków w sprawach, mających na celu podniesienie obrony przeciwpożarowej (22 c);

i) mianowanie na wniosek Rady Naczelnej członków honorowych (7, $22 \mathrm{c})$

[j] Oznaczenie miejsca przyszłego Walnego Zgromadzenia;

k) tworzenie specjalnych funduszów i zakładanie instrukcyj samopomocy $(2$ e, 221,33$)$.

18. Rada Naczelna składa się z prezesa Związku (25), jego zastępcy, sekretarza (), skarbnika (27), instruktorów - technicznego, sanitarnego i oświatowego $(28,29,30)$, wybieranych przez Walne Zgromadzenie na przeciąg trzech lat, z naczelników okręgowych, przedstawicieli Związków Okręgowych, delegowanych przez nie po jednym z każdego na przeciąg trzech lat, skarbnika Kasy Pośmiertnej i przewodniczącego Kasy Zapomogowej (22 1).

19. Posiedzenia zwyczajne Rady Naczelnej zwołuje Prezydjum na dwa razy w roku, nadzwyczajne z własnej inicjatywy, ilekroć tego zachodzi potrzeba lub na żądanie Komisji Kontrolującej, względnie jednej trzeciej członków Rady Naczelnej.

20. Zawiadomienia o posiedzeniach Rady Naczelnej winne być przesyłane wraz z porządkiem obrad imiennie członkom na 8 dni przed posiedzeniem.

21. Na posiedzeniach Rady Naczelnej przewodniczy prezes, względnie jego zastępca. Posiedzenia są prawomocne w obecności conajmniej połowy członków Rady.

Jeżeli członek Rady Naczelnej opuści da posiedzenia Rady bez usprawiedliwienia się, może zostać wykluczony z Rady, a w jego prawa wstępuje jego zastępca (30).

Wszyscy członkowie Rady Naczelnej wykonują swe funkcje bezpłatnie. Rzeczywiste wydatki, strawne i drogowe, pokrywa Związek (22 a).

Uchwały zapadają zwykłą większością głosów obecnych. W razie równości głosów przechodzi wniosek, za którym opowiedział się przewodniczący, który również głosuje. Głosowanie odbywa się przez podniesienie rąk.

22. Do zakresu działalności Rady Naczelnej należy: 
a) Zarząd majątkiem Towarzystwa, przyznawanie wynagrodzeń, ustalanie djet, drogowego, zatwierdzanie wydatków, które nie leżą w kompetencji Prezydjum (17 b, 24 a);

b) zwoływanie Walnych Zgromadzeń (13), przedkładanie sprawozdań z czynności preliminarzy dochodów i wydatków;

c) opracowywanie i przedstawianie wniosków na Walne Zgromadzenie $(7,17 \mathrm{~h}, \mathrm{i})$;

d) przyjmowanie i wykluczanie członków $(5,6,8)$;

e) przyjmowanie i zwalnianie personelu technicznego;

f) tworzenie, względnie rozwiązywanie Zw. Okręgowych, wykonywanie kontroli nas działalnością tychże, udzielanie im dyrektyw w ramach obowiązujących regulaminów i instrukcyj, zatwierdzanie sprawozdań, preliminarzy i ich planów działalności, zatwierdzanie zmian statutów Zw. Okręgowych, jako tez straży miejscowych, wzgl. uchwał o ich likwidacji, zatwierdzanie propozycji Związków Okręgowych na mianowanie członków honorowych.

Rada Naczelna ma prawo zażądać w razie potrzeby zwołania posiedzenia zarządu lub Walnego Zgromadzenia Zw. Okręgowego i wysłać na nie swoich delegatów i może uchylić niezgodne ze statutem i obowiązującemi przepisami uchwały Zarządów lub Walnych Zgromadzeń Związków Okręgowych (3 a);

g) rozstrzyganie odwołań odnośnie do decyzyj Związków Okręgowych w ostatniej instancji;

h) organizowanie kursów pożarniczych, zawodów konkursowych, zjazdów krajowych, ćwiczeń pokazowych, wykładów, wystaw i t. p.;

i) proponowanie inspektorów pożarnych do zatwierdzania przez Wydział Krajowy na wniosek Zarządów Związków Okręgowych;

j) przyznawanie nagród i odznaczeń w myśl regulaminu;

k) ustanawianie i mianowanie specjalnych komisyj i opracowanie dla nich regulaminów czynności;

1) delegowanie przedstawicieli Związku do związkowych instytucyj samopomocy (Kasa Pośmiertna, Zapomogowa i t. p.) (2 e, 17 k).

m) wnoszenie do Władz politycznych podań o zatwierdzenie statutów i zmian statutów O.S.P., a także podań i w innych sprawach dotyczących korpusów strażackich.

23. Prezydjum składa się z 4 członków: Prezesa, zastępcy prezesa, sekretarza i skarbnika. jest organem wykonawczym uchwał Rady Naczelnej i Walnych Zgromadzeń. Schodzi się na posiedzenia na zaproszenie prezesa. Zaproszenie powinno być wysłane conajmniej 4 dni przed posiedzeniem. Posiedzenie jest prawomocne w obecności 3 członków. Przewodniczy prezes, względnie zastępca. Uchwały zapadają większością głosów obecnych. W razie równości głosów przechodzi wniosek, za którym opowie- 
dział się przewodniczący, który również głosuje. Głosowanie odbywa się przez podniesienie rąk.

24. Do zakresu działania Prezydjum należy:

a) Prowadzenie rachunkowości, układanie preliminarza, sprawozdań rocznych, statystyki związkowej, pobieranie składek członkowskich i innych wpływów i dysponowanie funduszami Związku w granicach preliminarza;

b) wykonywanie uchwał Rady Naczelnej i Walnych Zgromadzeń;

c) opracowanie i przedstawianie wniosków na Radę Naczelną;

[d] wysyłanie delegatów Związku na posiedzenia Zarządów i Walnych Zgromadzeń Związków Okręgowych;

e) wydawanie ogłoszeń, sprawozdań i pism różnego rodzaju w imieniu Związku.

25. Prezes reprezentuje Związek, prowadzi nadzór nad pracami i kasą Związku, przewodniczy na posiedzeniach Prezydjum Rady Naczelnej i Walnych Zgromadzeń.

W razie jego nieobecności wstępuje w prawa jego i obowiązki zastępca.

26. Sekretarz spisuje protokoły z posiedzeń: Prezydjum, Rady Naczelnej i Walnych Zgromadzeń, prowadzi spis członków i załatwia wszelką korespondencję i piśmienne prace. Protokoły powinne być spisane w wiązanej stronicowanej księdze, powinne podawać czas i miejsce zebrania, liczbę obecnych i uchwały w brzmieniu dosłownem, a być podpisane przez prezesa i sekretarza.

Wszystkie pisma, wychodzące ze Związku, jako też wszelkiego rodzaju umowy, ogłoszenia i akta $\mathrm{w}$ imieniu Związku podpisuje prezes z sekretarzem, dodając pieczątkę Związku.

27. Skarbnik prowadzi rachunkowość pieniężną, księgi kasowe, dokonuje wypłat na polecenie prezesa. Na każdem zebraniu Rady Naczelnej przedstawia stan kasy.

28. Instruktor oświatowy jest przewodniczącym Komisji Oświatowej i stara się o to, aby kursy, wykłady przedstawienia i t. p. urządzano w jak największej liczbie celem podniesienia moralnego i kulturalnego poziomu członków straży i wogóle obywatelstwa.. Stara się o popularyzowanie zadań i celów i prac strażactwa dla dobra bliźnich.

29. Instruktor techniczny jest przewodniczącym Komisji Technicznej i stara się, aby wyćwiczenie techniczne było ujednostajnione i na jak najwyższym poziomie. Zwołuje naczelników okręgowych (inspektorów), w razie potrzeby naczelników straży, celem zaprowadzenia jednolitości przy ćwiczeniach i ogólnej czynności straży.

30. Podobne zadanie ma inspektor sanitarny w ramach służby samarytańskiej. 
31. Zastępcy członków Rady Naczelnej wstępują w prawa członków, o ile ci nie są w stanie wykonywać swych funkcyj, o czem powinni swych zastępców na czas uwiadomić.

Gdyby w czasie trzyletniej kadencji ustąpił lub zmarł członek, delegowany przez Związek Okręgowy, wstępuje na resztę kadencji na jego miejsce zastępca. Gdyby i ten ustapił, mianuje Związek Okręgowy nowego delegata.

32. Walne Zgromadzenie Związku wybiera na przeciąg trzech lat $\mathrm{z}$ pośród członków Związku, nie będących członkami Rady Naczelnej, Komisję Kontrolującą, składającą się z 3 członków i 2 zastępców.

Do zakresu czynności Komisji Kontrolującej należy sprawdzanie ksiąg kasowych, rachunkowości, sprawozdań finansowych Rady Naczelnej, oraz zwykła lub nagła rewizja kasy. Przy rewizjach powinni być obecni 3 członkowie; o ile któryś z członków nie może przybyć, zawiadomi natychmiast zastępcę, który wstępuje w jego prawa.

Wyniki badania i wnioski przedstawia Komisja Walnemu Zgromadzeniu na piśmie, po uprzedniem zakomunikowaniu ich Radzie Naczelnej.

IV. Fundusze Związku.

33. Fundusze Związku składają się:

a) $\mathrm{Z}$ corocznych składek członków ( $3 \mathrm{f}, 10,17 \mathrm{~b}, 24 \mathrm{a})$;

b) z subwencyj władz oraz instytucji publicznych;

c) z zapisów i innych dochodów przypadkowych.

Wszystkie dochody tworzą fundusz obrotowy. Związek może jednak tworzyć specjalne fundusze rezerwowe ( $3 \mathrm{e}, 17 \mathrm{k})$.

V. Ogólne postanowienia.

34. Spory wynikające z przynależności do Związku wyrównuje z wykluczeniem drogi prawnej Sąd Honorowy, składający się z 5-u członków; każda strona mianuje po dwóch, a ci powołują po porozumieniu się piątego, na przewodniczącego, który rozstrzyga przy równości głosów.

35. Językiem urzędowym jest język polski. Pieczątka Związku musi wykazywać dokładnie firmę Towarzystwa według brzmienia statutu.

36. Wniosek o zmianie statutu musi być postawiony do porządku obrad Walnego Zgromadzenia. każdy Zarząd Okręgowy otrzyma prze Walnem Zgromadzeniem po dwie odbitki projektowanych zmian, celem przestudjowania i zajęcia stanowiska wobec zmian.

Do prawomocności uchwał przy zmianie statutu muszą być obecne na Walnem Zgromadzeniu przynajmniej dwie trzecie do głosowania uprawnionych uczestników $(13,14)$; rozstrzyga większość dwóch trzecich głosujących. Jeżeli się na oznaczony czas nie zejdzie dostateczna liczba, odbywa się drugie Walne Zgromadzenie z tym samym porządkiem obrad o godzinę później, bez względu na liczbę obecnych, co jednak 
musi być w zaproszeniu wyraźnie zaznaczone. To drugie Walne Zgromadzenie uchwala większością trzech czwartych obecnych.

37. Związek może być rozwiązany uchwałą Walnego Zgromadzenia tylko wtenczas, jeżeli odpowiedni wniosek podała Rada Naczelna członkom 28 dni naprzód do wiadomości, a uchwała zapadła w obecności dwóch trzecich wszystkich członków, większością trzech czwartych głosujących.

Pozostały majątek rozdziela się między członków rzeczywistych Związku w stosunku do ilości lat przynależności do tegoż Związku.

Statut powyższy przyjęło do wiadomości Ministerstwo Spraw Wewnętrznych reskryptem dnia 28.I.1935č.1.176/1935/2a

\section{Bibliografia}

\section{Źródła}

Zemský archivie w Opawie, Moravskoslezský Zemský národní výbor, expozitura Ostrava, Ochotnicza Straż Pożarna, sygn. 225/327.

\section{Opracowania}

Czerniecka-Haberko Anna, Studnicka-MariańCZKy Karolina, Stowarzyszenia polskie $w$ Czechostowacji, tekst w posiadaniu autorek.

Dwernicki Tadeusz, O prawach obywatelskich, Kraków: Wydawnictwo Groszowe im. Tadeusza Kościuszki, 1896.

GrZYBowski Konstanty, Historia państwa i prawa Polski, t. IV, Warszawa: Państwowe Wydawnictwo Naukowe, 1982.

JAN PAWEe II, Naród, https://cytaty24.pl/cytaty/Nar\%C3\%B3d/Aforyzmy,Sentencje/k/40?pagec=6, [dostęp: 29.03.2019].

SUSKI Paweł, Stowarzyszenia i fundacje, Warszawa: LexisNexis Polska, 2011.

Szulc Tadeusz, Prawo do stowarzyszania się w państwach Europy Środkowo-Wschodniej w II połowie XIX w.- poczatek XX w., „Studia Prawno Ekonomiczne”, nr 68: 2003, s. 19-35.

ZahradniK Stanisław, Przejawy życia organizacyjnego Polaków $w$ Czechostowacji $w$ latach 1920-1938, „Sobótka”, t. 36/4: 1981, s. 545-559.

Zbiór ważniejszych ustaw i rozporzadzeń administracyjnych (ogólnych i dzielnicowych) obowiazujacych w Rzeczypospolitej Polskiej, oprac. Stanisław CZAPUTOwICZ, Tadeusz SIKORSKI, Warszawa: Księg. F. Hoesicka, 1925. 


\title{
Three versions of the articles of associations of the Voluntary Fire Brigade in Mosty u Jablunkova
}

\begin{abstract}
Summary
The Czechoslovakian social system ensured relatively numerous national rights to various national groups, including the Polish. They used them, among others, to establish different types of social associations. The activity of Polish associations in Cieszyn Silesia covered all areas of social life. There were Polish organisations of cultural and educational, welfare, youth, religious, sportstourist and economic character.

The activity of Polish associations is presented with an example of three articles of associations for a Fire Brigade, found during the archive research in Zemský archiv in Opava. The first one has been preserved in the form of a typed text. The next two have the form of a printed brochure. The comparison of these three articles of association not only makes it possible to discover how the Fire Brigade in Mosty and the Fire Brigade in Czech Cieszyn functioned, but it also points to changes occurring within this organisation.
\end{abstract}

Keywords: Polish associations in Czechoslovakia, articles of association, Fire Brigade. 



\section{ARTYKULY RECENZYJNE I RECENZJE}



http://dx.doi.org/10.16926/zh.2019.18.11

Marek STAWSKI

https://orcid.org/0000-0002-1358-133X

Warszawa

\title{
Magiczne „ósemki” czyli nowa propozycja refleksji nad dziejami Czech
}

\author{
[rec.] Osmičky. Osudová výročí českých a československých dějin končící na \\ jednu číslici, ed. Libor JAN, Brno 2018, ss. 208
}

\section{Streszczenie}

W ubiegłym roku grupa historyków z Uniwersytetu w Brnie wydała niezwykle ciekawą pozycję zatytułowaną Osmičky (Ósemki). Autorzy próbują odpowiedzieć na pytanie dlaczego wiele z kluczowych dla historii Czech wydarzeń miało miejsce właśnie pod tą ósemkową końcówką. Autorzy zaprezentowanych w książce tekstów rozprawiają się z zagrażającemu solidnemu uprawianiu historii „fetyszyzmem” dat i mitologizowaniem przeszłości, a koncentrują się raczej na ukazaniu pewnej ciągłości historycznej. Praca pokazuje, że historia nie musi być ciekawa tylko przez narosłe wokół jej wydarzeń mity, ale przede wszystkim poprzez ukazanie dlaczego w ogóle coś miało miejsce i jakie przyniosło to później następstwa. Książka staje się tym samym swego rodzaju zwięzłym wykładem historii Czech, ale ukazanej w kontekście dziejów Europy. Natomiast dla polskiego czytelnika jest także znakomitym na lepsze poznanie i zrozumienie dziejów bratniego narodu.

Slowa kluczowe: ósemki, daty, Czechy, mity, dzieje.

W dziejach bliskich nam kulturowo i językowo Czechów, ważną rolę odgrywa liczba „,", na którą kończy się wiele ważnych dla tego narodu dat, z czego zdają sobie doskonale sprawę również i miłośnicy historii w Polsce, pamiętając np. rok 1918, 1938 czy 1968. Jak to jednak często bywa, nie tylko wśród pasjonatów, ale w ogóle we współczesnym świecie ludzie skłonni są doszukiwać się w biegu historii albo fatum, albo nie rzadko również magicznych symboli. Stało się to także udziałem czeskiej „ósemki”, która zaczęła być postrzegana w ten właśnie sposób jako liczba „prześladująca” mało szczęśliwą czeską historię. Na 
różne sposoby czeska historiografia próbowała się zmierzyć z problemem zawiłych dziejów Czech powiązanych w jakiś sposób z cyfrą „„”, a których poznanie i zrozumienie stanowi klucz do pojęcia teraźniejszości narodu ${ }^{1}$. Nie zawsze była to głębsza historyczna refleksja, a nierzadko pojawiało się nawet nie służące niczemu mitologizowanie historii ${ }^{2}$.

$\mathrm{Z}$ takim nienaukowym i magicznym postrzeganiem dziejów polemizuje grupa morawskich historyków z katedry historii Uniwersytetu im. T. Masaryka w Brnie, wydając w zeszłym roku znakomitą pozycję zatytułowaną Osmičky czyli Ósemki (Osmičky. Osudová výročí českých a československých dějin končicí na jednu čislici), pod redakcją Libora Jana ${ }^{3}$. Grupa autorów tworząca kolegium redakcyjne próbuje odpowiedzieć na pytanie dlaczego wiele z tych kluczowych dla historii Czech wydarzeń miało miejsce właśnie pod tą ósemkową końcówką. Książka zawiera więc przystępne i logiczne wyjaśnienie poszczególnych dat, w ten sposób rozprawiając się z próbami mitologizowania historii. Wszak, jak przekonuje we wstępie kierownik zespołu Libor Jan, wiele innych istotnych dla historii Czech dat wcale na liczbę „osiem” się nie kończy. Natomiast te ósemkowe to najczęściej konsekwencja pewnych długotrwałych procesów historycznych, choć czasem odgrywa tutaj rolę także zwykły przypadek. Zatem lata z cyfrą „8" na końcu oznaczają wydarzenia, które zwyczajnie i logicznie rozumując musiały się wydarzyć, bo taka była po prostu kolej rzeczy.

Zagadkową listę ,magicznych” dat otwiera rok 1158, kiedy to Władysław II otrzymał od cesarza niemieckiego koronę, a kulisy tego wydarzenia omówił Martìn Wihoda pod intrygującym tytułem Tajemnice królewskiego tytułu Władysława II. Autor przypomniał, że wyniesienie czeskiego księcia nad innych lenników cesarskich było konsekwencją jego udziału w rokowaniach cesarza Fryderyka I Barbarossy z polskim księciem Bolesławem IV Kędzierzawym pod Poznaniem latem 1157 r. ${ }^{4}$ Władysław właściwie ułożył warunki hołdu złożonego przez obóz juniorów cesarzowi, którego głównym warunkiem było wsparcie wojskowe dla Fry-

1 Na temat historii Czechów pod kątem filozofii dziejów - vide: Tomáš Garrigue MASARYK, Jan Hus: naše obrození a naše reformace, Praha 1896; Jan SLAví, Iluze a skutečnost, Praha 2000, passim. Conf: Jiří ŠTAIF, Historici, dějiny a společnost: historiografie v českých zemích od Palackého a jeho předchůdců po Gollovu školu, Praha 1997, passim; Jan PATOČKA, Kim są Czesi?, przeł. Jacek BALUCH, Kraków 1997, passim.

2 Z mitami narosłymi wokół czeskiej historii próbował zmierzyć się już Jiří RAK, Bývali Čechové - české historické mýty a stereotypy, Praha 1994, passim.

3 Osmičky. Osudová výročí českých a československých dějin končící na jednu čislici, ed. Libor JAN, Brno 2018, ss. 208.

4 Na temat problematyki polskiej w stosunkach Fryderyka I Barbarossy i Władysława II - vide: Martin WiHODA, Polská koruna českých králi̊, „Český časopis historický”, t. 102: 2004, s. 721744. Natomiast w literaturze polskiej szeroko na ten temat vide: Bronisław WŁODARSKI, Polska i Czechy w drugiej polowie XIII i poczatkach XIV wieku (1250-1306), Lwów 1931, s. 18 i n.; Antoni BARCIAK, Czechy a ziemie potudniowej Polski w XIII oraz w poczatkach XIV wieku: polityczno-ideologiczne problemy ekspansji czeskiej na ziemie poludniowej Polski, Katowice 1992, passim. 
deryka w jego wyprawie do Lombardii. Cesarz rozprawę ze zbuntowanymi miastami planował właśnie na $1158 \mathrm{r}$., a że liczył na posiłki czeskiego wojska, to 11 stycznia tego roku miała miejsce pierwsza z trzech , dziwnych” koronacji Władysława II. Martin Wihoda ciekawie przedstawia właściwie trzy odsłony tego samego aktu, z których pierwsza dokonała się w styczniu w Regensburgu, a trzecia 8 września pod upokorzonym Mediolanem. Podkreślił jednak przy tym, że cesarz faktycznie nie tytułował Władysława królem, a koronę (czy raczej diadem) czeski władca mógł używać tylko w największe uroczystości, podczas gdy prawdziwą koronę chwały nosił tylko Fryderyk ${ }^{5}$. Dość prowokacyjnie zatem Wihoda konstatuje, że czeski władca praktycznie niewiele zyskał, a za to zwiększył swoje uzależnienie od cesarstwa ${ }^{6}$.

Rok 1278 to data rycerskiej śmierci w bitwie pod Suchymi Krutami jednego z najwybitniejszych czeskich władców Przemysła Ottokara II $^{7}$, a wydarzenie to w szerszym aspekcie politycznym opisał Libor Jan. Silnej pozycji czeskiego króla, który panował nie tylko w Czechach, ale i nad większą częścią Austrii, zaczął stopniowo zagrażać Rudolf Habsburski ${ }^{8}$. Król Niemiec próbował stopniowo ograniczać władzę i wpływy polityczne Przemysła na obszarze ziem austriackiego dziedzictwa Habsburgów, wykorzystując przy tym wewnętrzną opozycję niektórych czeskich rodów. Sytuacja czeskiego władcy stawała się coraz gorsza, a wszystkie nieudane próby politycznych rokowań tylko przybliżały militarne starcie, które, jak dowodzi autor tekstu, stało się w końcu nieuchronne. Do bitwy doszło 22 sierpnia 1278 r. na tzw. Morawskim Polu w pobliżu miejscowości Dürrnkrut, a w wyniku zaciętych walk życie stracił król Czech ${ }^{9}$. Okolicznościom śmierci Przemysła Libor Jan poświęcił szczególną uwagę, przytaczając na ten temat relacje kilku niezależnych źródeł, z których jasno wynika, że na osobie czeskiego władcy dopuszczono się z pełną świadomością okrutnego morderstwa.

5 Na ten temat nieco inny pogląd prezentuje Josef Žemlička - vide: idem, Křižovatky Vladislava II. Co mohl a nemohl druhý český král? [in:] Vladislav II. Druhý král z Přemyslova rodu: $k$ 850. výročí jeho korunovace, ed. Petr SommER, Josef ŽEMLIČKA, Praha 2009, s. 17-28.

6 Martìn WiHODA, Záhady královského titulu Vladislava II., [in:] Osmičky, s. 9-21.

7 Ostatnio szeroko na temat Przemysła Otokara II - vide: J. ŽEMLIČKA, Přemysl Otakar II, Praha 2011, s. 44 i n.

8 Na ten temat - vide: Václava KofránKovÁ, Zlatý král a chudý chrabě - Přemysl Otakar II. a Rudolf Habsburský v historické tradici, Praha 2013, passim. Vide: [rec.] Marek CETwIŃSKI, Tadeusz Srogosz, Przemysta Ottokara II ,„zycie po życiu”: przyczynek do dziejów czeskiej tradycji historycznej, „Prace Naukowe Akademii im. Jana Długosza w Częstochowie. Zeszyty Historyczne", t. 15: 2016, s. 283-291. Na temat problematyki stosunków czesko-austriackich w XIII w. w literaturze polskiej: Norbert MIKA, Walka o spadek po Babenbergach 1246-1278, Racibórz 2008, passim. Conf. Česko-rakouské vztahy ve 13. století, ed. Marie BLÁHOVÁ, Ivan HLAVÁČEK, Praha 1998, passim.

9 Szerzej na temat bitwy: Andreas Kusternig, Bitva na Moravském Poli (U Suchých Krut a Jedenspeigen) 26 VIII 1278, [in:] Česko-rakouské, s. 163-188. Natomiast na temat udziału wojsk polskich: A. BARCiaK, Polacy w bitwie pod Suchymi Krutami, „Prace Naukowe Uniwersytetu Śląskiego. Prace Historyczne”, t. 4: 1975, s. 7-26. 
Na koniec autor ukazuje późniejsze echa i nawiązania do jednej z największych bitew średniowiecznej Europy, która jednocześnie dla Czechów stała się zarazem i jedną z najtragiczniejszych ${ }^{10}$.

Natomiast Tomasz Borovský w tekście zatytułowanym Rozkwit w czasie katastrof opisuje istotne znaczenie dla historii Czech roku 1348, który dla Europy pozostaje symbolem nieszczęść i śmierci. Wtedy to panujący od niedawna na czeskim tronie Karol IV na wystawionych przez siebie dokumentach zastosowal po raz pierwszy sformułowanie regnum et corona Bohemie ${ }^{11}$, co-jak podkreśla Borovský - miało istotne znaczenie dla koncepcji i kształtu ustrojowego państwa. Rok 1348 oznaczał także reformę sądownictwa i pierwsze spisane kodeksy stanowiące podstawę nowego prawnego porządku czeskiego królestwa ${ }^{12}$. Jednak przede wszystkim wówczas to Karol IV założył pierwszy w Europie środkowej Uniwersytet złożony $\mathrm{z}$ czterech wydziałów, który w znaczący sposób zapisał się w historii kultury ${ }^{13}$. Ten sam rok, co autor uważa za znaczące dla historii państwa, dał wreszcie początek szeregu ważnym fundacjom kościelnym Karola i przedsięwzięciom budowlanym ${ }^{14}$. W konsekwencji więc 1348 r. to czas, w którym Karol IV wzmacnia istotnie swoją polityczną pozycję na arenie międzynarodowej, a w Czechach wprowadza zmiany organizacji prawnej i początki nowego kształtu ustrojowego państwa ${ }^{15}$.

Libor Jan w rzędzie kolejnych kluczowych dat dla historii Czech wymienia rok 1378 i śmierć Karola IV, którego potomni nazwali „ojcem ojczyzny”. W swoim tekście skupił się przede wszystkim na ukazaniu okoliczności odejścia wielkiego władcy i ciekawym przeglądzie licznych przekazów źródłowych szczegółowo opisujących ceremoniał cesarskiego pogrzebu ${ }^{16}$. Był on, co podkreślił Libor Jan, odzwierciedleniem programu politycznego Karola IV charakteryzującego się odwołaniem do symboliki przeszłości, co stanowiło także element legitymizacji jego władzy ${ }^{17}$.

Natomiast Tomasz Borovský za przełomowy dla historii Czech uważa również rok 1458 i wybór na króla Jerzego z Podiebradów, co rozważa w tekście zatytułowanym Zjednoczyciel podzielonych ziem. Czechy skłócone i niszczone

10 L. JAN, Rytírská smrt pomazaného krále, [in:] Osmičky, s. 23-41.

11 Lenka BobkovÁ, 7. 4. 1348 - ustavení Koruny království českého: český stát Karla IV, Praha 2006, passim.

12 Jan KuKLík, Karel IV. a jeho pokusy ovlivnit podobu českého prava, [in:] Duchovní, umělecký a státnický odkaz Karla IV., ed. Lubomir HoudEK, Praha 2008, s. 9-17.

13 Martin NodL, Dekret kutnohorský, „Dějiny a současnost”, R. 36/nr 3: 2014, s. 25-27.

14 Jiří Kuthan, Praga sacra - $k$ vizi posvátné Prahy císaře Karla IV., [in:] Duchovní, umělecký, s. 17-39; Jan RoYT, Praha Karla IV, Praha 2016, passim.

15 Antonín Lojek, Jan Kober, Karel IV.: pamět', právo, reprezentace, Praha 2016, s. 30-54; Tomasz BorovsKÝ, Rozkět v čase katastrof, [in:] Osmičky, s. 43-63.

16 Szerzej na temat źródeł z epoki: Karel IV v soudobých kronikách, Praha 2016, passim. Natomiast na temat samego pogrzebu wyszedł zbiór tekstów pod wspólnym tytułem Karel IV. Pohřeb, kol., wyd: Zlín 2016, s. 7-57. Conf. A. LoJeK, J. Kober, Karel IV.: pamět', s. 78-97.

17 L. JAN, Smrt cisaře a krále Krala IV, [in:] Osmičky, s. 65-83. 
sporami religijnymi między katolikami a utrakwistami ${ }^{18}$, ogarnięte jednocześnie chaosem bezkrólewia, w momencie powołania na tron rodzimego władcy doczekały się wreszcie stabilizacji. Jerzy z Podiebradów potrafił przez swój polityczny pragmatyzm doprowadzić do pojednania zwaśnione strony i w imieniu tzw. bonum commune znaleźć kompromis pomagający ustabilizować na dłuższy czas napiętą sytuację wewnętrzną, a także zabezpieczyć byt państwa na arenie międzynarodowej. Choć z drugiej strony z tym kolorowo przedstawionym przez autora obrazem pojednanych przez króla ziem czeskiego królestwa kłóci się przykład Wrocławia, który odmówił złożenia hołdu władcy uznanemu za „,heretyka” ${ }^{19}$.

Nie ma natomiast na ogół wątpliwości co do przełomowego znaczenia, nie tylko dla dziejów czeskiego narodu, ale także dla całej ówczesnej Europy, defenestracji praskiej i początku powstania stanowego w roku $1618^{20}$. Tomasz Knoz w swoim tekście pokazuje narastający w przeciągu XVI w. konflikt wyznaniowy, który ostatecznie został uzewnętrzniony przez wyrzucenie z okien praskiego zamku cesarskich posłów. Efektem tego był wybuch powstania, które następnie przerodziło się w wielki konflikt europejski zwany wojną trzydziestoletnią. W przekonujący sposób autor wyjaśnia, jak ważny wpływ na dalszą historię Czech miały wydarzenia 1618 r., których następstwem było starcie pod Białą Górą. Klęska z 1620 r. oznaczała utratę przez Czechów niepodległego państwa oraz głębokie przemiany narodowo-społeczne, w których miał ogromne znaczenie czynnik religijny. Stał się on swego rodzaju katalizatorem utrwalającym podziały i różnice społeczne na długie lata, co niewątpliwie zdaniem autora wpłynęło na postrzeganie czeskiego narodu przez sąsiadów (np. Polaków) ${ }^{21}$. Tomasz Knoz nie zapomina jednak w swoim studium również o refleksach tych wydarzeń widocznych w architekturze, sztuce oraz w literaturze ${ }^{22}$.

Rok 1848 i dokonujące się wtedy przebudzenie społeczno-narodowe były oczywiście przełomowe dla całej Europy, jednak Jiř́i Malíŕ w swoim obszernym tekście zatytułowanym Zwycięzcami rewolucji w monarchii habsburskiej byli rolnik $i$ biurokrata podkreśla odmienny przebieg wydarzeń rewolucyjnych w Czechach i ich znaczenie dla historii tego kraju ${ }^{23}$. Silna obecność elementu

18 Petr ElBel, Správa utrakvistické církve na Moravě mezi husitksou revolucí a reformací, [in:] Náboženský život a cirkevni poměry v zemich Koruny české ve 14.-17. století, ed. L. BoBKOvÁ, J. KonviČNÁ, Praha 2009, s. 126-143.

19 T. Borovský, Sjednotitel rozdělené země, [in:] Osmičky, s. 85-101. Na ten temat: Bogusław Czechowicz, Między katedra a ratuszem. Polityczne uwarunkowania sztuki Wroctawia u schytku średniowiecza, Warszawa 2008, s. 34 i n; idem, Dvě centra v Koruně: Čechy a Slezsko na cestách integrace a rozkolu v kontextu ideologie, politiky a uméni (1348-1458), České Budějovice 2011, s. 145 i n. Conf. Martín ČAPSKÝ, K postaveni Vratislavi v českých korunnich zemich v pozdním středověku, „Český časopis historický”, t. 2: 2017, s. 346-384.

20 Dušan Uhlír, Drama Bíle hory: česká válka 1618-1620, Brno 2017, passim.

21 František KaVKa, Bíla hora a české dějiny, Praha 2003, passim.

22 Tomasz KNOZ, České povstání jako evropská krize, [in:] Osmičky, s. 103-131.

23 Stanislav KRAJNík, Bouřlivý rok 1848 očima našich krajanů, Kladno 1998, passim; Vladimír FILIP, Revoluce 1848 v Evropě, Praze a Brně, Brno 2018, passim. 
niemieckojęzycznego w życiu społecznym i kulturalnym Czech, jako tzw. białogórska konsekwencja, spowodowała, że wystąpienia postulujące zwiększenie swobód obywatelskich krzyżowały się z żądaniami o emancypację narodową i przywrócenie praw dla języka czeskiego ${ }^{24}$. W związku z tym Wiosna Ludów w Czechach miała zupełnie inny charakter niż w innych krajach europejskich, a wyrażało się to m.in. w intensywnym rozwoju piśmiennictwa w języku narodowym oraz powstawaniu licznych towarzystw będących wyrazem budzącej się aktywności społecznej na wsi i w mieście oraz idei reprezentacji w instytucjach państwowych. W konsekwencji wydarzeń marca 1848 r. w Czechach zaczynał się ruch tzw. przebudzenia narodowego i formowanie dojrzałej obywatelskiej wspólnoty, społeczeństwa świadomego potrzeby równych praw dla wszystkich jego członków i umiejętności działania samorządowego. Uwidocznił jednak również, co podkreślił Malíř, że walka o swobody obywatelskie i emancypację narodową nie zawsze szły ze sobą w parze i dla przyszłych pokoleń Czechów będzie jeszcze stanowić „trudny orzech do zgryzienia"25.

Zmierzyć się z tym przyszło Czechom już w roku 1918, kiedy to rozpad monarchii austro-węgierskiej i koniec I wojny światowej umożliwił powstanie niepodległego państwa po wielowiekowej zależności od Habsburgów. Wydarzenia przełomowego dla całej Europy 1918 r. i tworzenie się wśród szeregu przeciwności i problemów pierwszej Republiki Czechosłowackiej opisał Libor Vykoupil w artykule Powstanie niepodległego państwa czechostowackiego. W tekście autor podkreślił przede wszystkim stopniowe dojrzewanie w Czechach idei samorządności i zdolności do zbudowania niezależnej państwowości, opartej na powstałej w XIX w. idei słowiańskiej wspólnoty Czechów i Słowaków. Opisuje wreszcie szczegółowo przebieg wydarzeń, które bezpośrednio poprzedzały proklamowanie 28 października 1918 r. utworzenia dość kontrowersyjnego tworu państwowego jakim była Republika Czesko-Słowacka ${ }^{26}$. Połączenie tych dwóch narodów o odmiennej tradycji historycznej było bowiem warunkiem koniecznym, aby mogło zaistnieć nowe państwo, a Czesi mogli się cieszyć niepodległością. Zatem najważniejszym zadaniem, z którym musiało się zmierzyć nowe państwo było stworzenie pojęcia narodu czechosłowackiego, istniejącego właściwie tylko na płaszczyźnie semantycznej. Tekst kończy się odważnym stwierdzeniem, że choć było to państwo niedoskonałe, to jednak był to niepodległy organizm państwowy zasługujący na uznanie i szacunek potomnych. Samo historyczne wy-

24 Ralph Melville, Der böhmische Adel und die tschechische Nationalbewegung vor und in der Revolution von 1848, [in:] Národni obrozeni a rok 1848 v evropském kontextu (sbornik přispěvků z mezioborového vědeckého sympozia v Litomyšli ve dnech 29.-30. května 1998), ed. Milan SKŘIVÁNEK, Litomyšl 1998, s. 63-71.

25 Jiří MALíř, ,Vitězi revoluce v habsburské monarchii byli sedlák a byrokrat”, [in:] Osmičky, s. $133-178$.

26 Na temat historyczno-prawnych aspektów tych wydarzeń - vide: Ladislav VoJÁčEK, První československý zákon: pokus o opožděný komentár, Praha 2018, s. 11-39. 
darzenie zaś ma obecnych obywateli uczyć odpowiedzialności i dumy z własnego samodzielnego państwa, jakiekolwiek by ono nie było... ${ }^{27}$

Dramatyczny dla młodego państwa czechosłowackiego rok 1938 opisuje Jiř́ Němec w artykule Zatopienie demokratycznej wyspy, a swoją opowieść zaczyna od wymienienia trudności z jakimi przyszło borykać się pierwszej republice ${ }^{28}$. Jedną z największych bolączek młodego państwa był bardzo duży odsetek mniejszości narodowych, z których największą grupę stanowili Niemcy $(22,32 \%$ ludności całego kraju), co okazało się zgubnym dla samodzielności państwa. Równocześnie cały czas powracał problem Słowaków, a w konsekwencji również mniejszości węgierskiej. Nie bez znaczenia były wreszcie trudne relacje z Polakami, gdyż wydarzenia z lat 1919-1920 na Śląsku Cieszyńskim utrudniały jakiekolwiek porozumienie pomiędzy obydwoma państwami, a to w konsekwencji doprowadziło do kryzysu 38 roku i zaważyło na późniejszych wzajemnych stosun$\mathrm{kach}^{29}$. Mimo to, co podkreśla autor, udało się ówczesnym władzom republiki wypracować kompromis gwarantujący każdemu obywatelowi równe prawa i swobody. Tym samym, Czechosłowacja wobec kryzysów ustrojowych w Europie środkowej okresu międzywojennego pozostała jedynym w pełni demokratycznym i liberalnym państwem ${ }^{30}$. Jiří Němec nie omieszkał jednak dodać odważnego stwierdzenia, że ta pierwsza republika choć była liberalna, to również skorumpowana i bardzo złożona ${ }^{31}$. Autor w swoim tekście koncentruje się przede wszystkim na przyczynach, które doprowadziły do monachijskiego układu i katastrofy młodej republiki, a mniej się koncentruje na opisie przebiegu wydarzeń 1938 r. ${ }^{32}$ Nie ucieka również od trudnego tematu przyczyn, dla których Czechosłowacja nie podjęła walki zbrojnej z niemieckim agresorem. Niewątpliwie upadek państwa wywarł ogromną traumę na zbiorowej pamięci historycznej Czechów na długie dziesiątki lat, a rok 1938 w odbiorze społecznym to przede wszystkim kompromitacja dyplomacji mocarstw zachodnich, ale i jednocześnie czeskiego rządu z prezydentem na czele (oskarżanego wprost o zdradę). Jednak autor podkreśla, że prawdziwą i zapominaną tragiczną konsekwencją 1938 r. było definitywne unicestwienie tradycji pokojowego współistnienia Czechów i Niemców na jednym terytorium, kształtującego przez długie lata jego kulturę $e^{33}$.

27 Libor VyкоupIL, Vznik samostatného československého státu, [in:] Osmičky, s. 181-203.

28 Jiří NĚMEC, Potopeni demokratického strova, [in:] Osmičky, s. 205-237.

29 Conf. Michał PrZePerski, Nieznośny ciężar braterstwa. Kontakty polsko-czeskie w XX wieku, Kraków 2016, passim.

30 Vide: Československo a krize demokracie ve středni Evropě ve 30. a 40. letech XX. století: hledáni východisek, ed. Jan NĚMEČEK a kol., Praha 2010, passim. Nieco inaczej na ten temat Andrzej MaŁkiewicz, Samobójstwo demokracji: Czechosłowacja w okresie II Republiki 19381939, Zielona Góra 2013, passim.

31 J. NĚMEC, Potopení, s. 237.

32 Vide: Marek Kazimierz KAmIŃsKi, Klęska państwa czechostowackiego w 1938 roku, „Studia z dziejów Rosji i Europy Środkowo-Wschodniej”, t. 49: 2014, s. 114-125.

33 J. NĚMEC, Potopení, s. 211-236. 
Kolejną ważną cezurą czasową dla dziejów Czech był rok 1948 i całkowite przejęcie władzy przez czechosłowacką partię komunistyczną, co rozważa Tomáš Dvořák w tekście zatytułowanym Koniec wolności w powojennej Czechostowacji. Jednak, jak podkreśla autor na początku, nie ma on zamiaru opisywać i odkrywać nieznanych okoliczności, ale raczej zwrócić uwagę na kilka momentów, które mają na celu skłonić czytelnika do zastanowienia się nad przeszłością i teraźniejszością. Stawia więc na wstępie pytania czego ludzie oczekiwali w 1948 r., czego chcieli i wreszcie co otrzymali. Tym samym zwraca uwagę, że przemiany ustrojowe i przejęcie w Czechosłowacji władzy przez komunistów odbyło się przy zgodzie członków byłego rządu emigracyjnego i w konsekwencji powszechnym poparciu dużej części niejako zdezorientowanego społeczeństwa $^{34}$. Nowa władza, choć z jednej strony przyniosła ograniczenie swobód obywatelskich i wolności, to jednak z drugiej odpowiadała oczekiwaniom społeczeństwa dźwigającego się z wojennego marazmu. Natomiast Komunistyczna Partia Czechosłowacji w przeciągu 1948 r. stała się najliczniejszą partią komunistyczną na świecie, oczywiście w stosunku do liczby mieszkańców kraju ${ }^{35}$.

Nie ulega wątpliwości, że jedną z najbardziej tragicznych dat w dziejach narodu czeskiego był rok 1968 i interwencja zbrojna wojsk Układu Warszawskiego, o czym przekonują Jiří Hanuš i Denisa Nečasová w oryginalnym tekście Praska wiosna i co byto dalej.... Artykuł ten ma zupełnie inną formułę, autorzy bowiem odchodzą od tradycyjnego sposobu opisywania historii i próbują ukazać przeszłość oczami wyimaginowanej postaci Jarosława K. Para autorów tworzy zatem historię fikcyjną, ale jednak opartą na materiale źródłowym, bo wykreowana przez nich postać snuje swoje rozważania na podstawie tego co czytał i czego był świadkiem zwykły obywatel Czechosłowacji tego czasu. Rok 1968 rysuje się zatem przede wszystkim jako rok nadziei na normalizację społeczeństwa zniechęconego i zawiedzionego osiągnięciami i sposobem działania $\mathrm{KPCz}^{36}$. Poprzez postać Jaroslava K. autorzy tekstu podkreślają, że marzec 1968 r. i zmiana na stanowisku I sekretarza zaskoczyła czeskie społeczeństwo otwartą krytyką niedemokratycznej postawy poprzednich władz, ograniczania wolności oraz żądania poprawy bytu. W telewizji zaczęło się otwarcie mówić, że nastała epoka, w której wreszcie będzie można wyrażać, to co się myśli. Polityka prowadzona przez nowy gabinet Alexandra Dubčeka i proponowany przez niego „socjalizm z ludzką twarzą" paradoksalnie spowodował masowe zgłoszenia do partii komu-

34 Na temat wydarzeń 1948 r. w Czechosłowacji: 1948: únor 1948 v Československu: nástup komunistické totality a promény společnosti, wyd. Jiří Kocian, Markéta DevÁTÁ, Praha 2011, passim.

35 Tomáš DvořÁK, Konec svobody v poválečném Československu, [in:] Osmičky, s. 239-261.

36 W szerszym kontekście wydarzenia 1968 r. ukazuje zbiór studiów: 1968: Pražské jaro 1968: občanská společnost, média, prenos politických a kulturních procesü = civil society, the mass media, and the transfer of political and cultural processes in the „Prague Spring” $1968=$ der Prager Früling 1968: Zivilgesellschaft, ed. Oldřich Tuma, M. DevÁTÁ, Praha 2011, passim. 
nistycznej. Wstępowali do niej zwłaszcza ludzie młodzi ogarnięci entuzjazmem i otwartością przemian oraz błyskawicznie postępującą demokratyzacją życia społecznego w okresie od marca do sierpnia 1968 r. Nadzieje zostały szybko ostudzone, a przemiany gwałtownie zatrzymane przez interwencję wojsk Układu Warszawskiego. Czołgi z „bratnich krajów” na ulicach zmieniły społeczny entuzjazm i nadzieje w marazm, depresję i zniechęcenie do jakiegokolwiek dalszego działania. Zaufanie do władz komunistycznych zmieniło się w lęk i z konieczności tłumioną niechęć. Setki młodych ludzi wcześniej wstępujących w szeregi partii i aktywnie działających na rzecz demokratyzacji kraju udało się na emigrację, aby stamtąd prowadzić aktywną kampanię antysocjalistyczną i antykomunistyczną. Wreszcie pojawienie się na ulicach czeskich miast wojsk radzieckich skutecznie zgasiło sympatię Czechów w stosunku do Rosjan, która była widoczna w społeczeństwie od czasów XIX-wiecznego panslawizmu. Warto też zwrócić uwagę, że autorzy skupili się przede wszystkim na podkreśleniu obecności wojsk Armii Czerwonej, zaś udział pozostałych armii państw Układu Warszawskiego miało dla nich mniejsze znaczenie ${ }^{37}$. Na ponowne przebudzenie ducha narodowego Czesi musieli czekać aż do 1989 r., który przyszedł jednak o rok za późno i tym samym niestety wyłamał się z cyklu ,magicznych ósemek”, czego nie omieszkał z przekąsem skonstatować kierujący kolegium redakcyjnym Libor Jan ${ }^{38}$.

Należy podkreślić, że przygotowana przez zespół badaczy z Brna pozycja, poprzez wyjaśnienie poszczególnych dat i związanych z nimi wydarzeń, jest również znakomitym i przystępnym wykładem dziejów Czech. Autorzy zaprezentowanych w książce tekstów rozprawiają się z zagrażającemu solidnemu uprawianiu historii „fetyszyzmem” dat i mitologizowaniem przeszłości, a koncentrują się raczej na ukazaniu pewnej ciągłości historycznej. Związane z poszczególnymi datami wydarzenia zostały przedstawione w szerszym kontekście dziejów całej Europy. W ten sposób książka pokazuje Czechy nie jako niewielką i odizolowaną wyspę, ale kraj z bogatą przeszłością, w pełni uczestniczący w procesie zachodzących w Europie przemian historycznych. Warto również podkreślić, że ukazanie i opisanie przystępnym językiem poszczególnych zdarzeń przez pryzmat ich przyczyn lub długofalowych skutków wyjaśnia szerokiemu odbiorcy czym jest tzw. historyczne myślenie. Aparat naukowy w postaci przypisów zamieszczony jest zwyczajem czeskich wydawnictw na końcu pracy, po których następuje bibliografia oddzielna dla każdego tekstu z podziałem na wydawnictwa źródłowe i literaturę. Niezwykle istotnym atutem książki jest również świetna szata graficzna i bogaty materiał ilustracyjny, na który składają się m.in. reprodukcje czeskiego malarstwa narodowego otwierające poszczególne rozdziały, faksymile oryginalnych dokumentów i pieczęci, czy wreszcie zdjęcia archiwalne i fragmenty prasowe. Praca kolegów z Brna udowadnia zatem, że historia nie musi być

37 Jiří Hanuš, Denisa NeČasová, Pražské jaro a co byto dál... Př́iběh Jaroslavá K., [in:] Osmičky, s. 263-277.

38 L. JAN, Předmluva, [in:] Osmičky, s. 5-7. 
ciekawa tylko przez narosłe wokół jej wydarzeń mity, ale przede wszystkim poprzez ukazanie, dlaczego w ogóle coś miało miejsce i jakie przyniosło to później następstwa. Może być więc znakomitym sposobem popularyzowania wiedzy o przeszłości poza wąskim kręgiem jej pasjonatów.

Natomiast dla polskiego czytelnika pozycja Osmičky może być świetnym i syntetycznym ukazaniem ciekawych, a zarazem niezwykle złożonych dziejów bliskich nam Czech, o których przeciętny miłośnik historii w Polsce ma niewielkie pojęcie. Do tej pory bowiem polska historiografia doczekała się właściwie tylko jednej monografii dotyczącej czeskiej historii, a opracowanej jeszcze w latach sześćdziesiątych przez Romana Hecka i Mariana Orzechowskiego ${ }^{39}$. Historia Czech w swoim szerszym kontekście była przez długi okres czasu traktowana w naszym kraju ,po macoszemu”, co wynikało zapewne i z pewnego braku poszanowania wobec niewielkiego narodu czeskiego, ale przede wszystkim z powodu niezrozumienia jego skomplikowanych dziejów. Przemiany społeczne i polityczne następujące w Czechach powodowały, że pojęcia jedności narodu i państwa w znacznej mierze się rozmywają i nie są tak przejrzyste, jak w przypadku historii Polski. Dochodzi do tego niezwykle istotna kwestia religii i Kościoła katolickiego, który w Czech stał się raczej elementem podziału społeczeństwa i symbolem związanym z obcym suwerenem, a nie znakiem tożsamości narodowej, jak to było w Polsce. Istotną kwestią był też stosunek do Niemców, którzy przez swoją obecność w Czechach uczestniczyli w kształtowaniu oblicza kulturowego kraju, a przez Polaków byli zawsze postrzegani jako zagrożenie dla tożsamości i suwerenności. W tym miejscu dochodzimy wreszcie do istotnego dla Czechów pragmatyzmu, obecnego również w postrzeganiu dziejów, który kłóci się niezmiernie $\mathrm{z}$ tzw. polskim romantyzmem. Być może to właśnie ten polski fenomen i spoglądanie na historię przez jego pryzmat powoduje, że nawet „miłośnik" historii nie do końca rozumie i niekiedy lekceważy dzieje sąsiedniego $\mathrm{kraju}^{40}$. Niewątpliwie warto więc pokusić się o przekład na język polski znakomitej pozycji brneńskich historyków, która zdecydowanie wypełniłaby pewną istotną lukę na księgarskich półkach. Obfitują one bowiem w dzieje odległych nam krańców świata lub w monografie jednostek pancernych SS, a brakuje wśród nich przystępnego opowiedzenia historii narodu, który jest nam mimo wszystko najbliższy kulturowo i językowo.

\section{Bibliografia}

BARCIAK Antoni, Czechy a ziemie poludniowej Polski w XIII oraz w poczatkach XIV wieku: polityczno-ideologiczne problemy ekspansji czeskiej na ziemie potudniowej Polski, Katowice: Uniwersytet Śląski, 1992.

39 Roman Heck, Marian Orzechowski, Historia Czechostowacji, Warszawa 1969.

40 Conf. M. PRZEPERSKI, Nieznośny ciężar, s. 9-27. 
BarciaK Antoni, Polacy w bitwie pod Suchymi Krutami, „Prace Naukowe Uniwersytetu Śląskiego. Prace Historyczne", t. 4: 1975, s. 7-26.

BlÁHOvÁ Marie, Karel IV v soudobých kronikach, Praha: Argo, 2016.

BoBKovÁ Lenka, 7. 4. 1348 - ustavení Koruny království českého: český stát Karla IV, Praha: Havran, 2006.

ČAPSKÝ Martín, K postaveni Vratislavi v českých korunnich zemích v pozdním středověku, „Český časopis historický", t. 2: 2017, s. 346-384.

Československo a krize demokracie ve středni Evropě ve 30. a 40. letech XX. století: hledání východisek, ed. by Jan NĚMEČEK a kol. Praha: Historický ústav AV ČR, 2010.

Cetwiński Marek, Srogosz Tadeusz, Przemysta Ottokara II „życie po życiu”: przyczynek do dziejów czeskiej tradycji historycznej, „Prace Naukowe Akademii im. Jana Długosza w Częstochowie. Zeszyty Historyczne", t. 15: 2016, s. 283-291.

Czechowicz Bogusław, Dvě centra v Koruně: Čechy a Slezsko na cestách integrace a rozkolu v kontextu ideologie, politiky a umění (1348-1458), České Budějovice: Veduta, 2011.

Czechowicz Bogusław, Między katedra a ratuszem. Polityczne uwarunkowania sztuki Wrocławia u schyłku średniowiecza, Warszawa: DiG, 2008.

Elbel Petr, Správa utrakvistické církve na Moravě mezi husitksou revolucí a reformací, [in:] Náboženský život a cirkevni poměry v zemich Koruny české ve 14.-17. století, ed. L. BoBKOvÁ, J. KonviČNÁ, Praha: Filozofická fakulta Univerzity Karlovy v Praze, 2009, s. 126-143.

FiliP Vladimír, Revoluce 1848 v Evropě, Praze a Brně, Brno: Josef Filip 1938, 2018.

Heck Roman, Orzechowski Marian, Historia Czechostowacji, Warszawa: Ossolineum, 1969.

KAMIŃSKI Marek K., Klęska państwa czechosłowackiego w 1938 roku, „Studia z dziejów Rosji i Europy Środkowo-Wschodniej”, t. 49: 2014, s. 114-125.

Karel IV. Pohřeb, kol., Zlín: Academia economia, 2016.

KAVKA František, Bíla hora a české dějiny, Praha: Garamond, 2003.

KOFRÁNKOVÁ Václava, Zlatý král a chudý chrabě - Přemysl Otakar II. a Rudolf Habsburský $v$ historické tradici, Praha: Lika klub, 2013.

KRAJNíK Stanislav, Bouřlivý rok 1848 očima našich krajanů, Kladno: Okresní Muzeum Kladno, 1998.

KUKLíK Jan, Karel IV. a jeho pokusy ovlivnit podobu českého prava, [in:] Duchovni, umělecký a státnický odkaz Karla IV., ed. Lubomir HoudeK, Praha: Galén, 2008.

Kusternig Andreas, Bitva na Moravském Poli (U Suchých Krut a Jedenspeigen) 26 VIII 1278, [in:] Česko-rakouské vztahy ve 13. století, ed. Marie BlÁHovÁ, Ivan HlavÁČEK, Praha: Filozofická fakulta Univerzity Karlovy, 1998.

Kuthan Jiří, Praga sacra - $k$ vizi posvátné Prahy císaře Karla IV., [in:] Duchovní, umělecký a státnický odkaz Karla IV., ed. Lubomir HoudeK, Praha: Galén, 2008, s. 163-188.

LoJeK Antonín, Kober Jan, Karel IV.: pamèt', právo, reprezentace, Praha: Ústav státu a práva AV ČR, 2016.

MAŁKIEwICZ Andrzej, Samobójstwo demokracji: Czechostowacja w okresie II Republiki 19381939, Zielona Góra: Oficyna Wydawnicza Uniwersytetu Zielonogórskiego, 2013.

MASARYK Tomáš G., Jan Hus: naše obrozeni a naše reformace, Praha: Čas, 1896.

Melville Ralph, Der böhmische Adel und die tschechische Nationalbewegung vor und in der Revolution von 1848, [in:] Národni obrozeni a rok 1848 v evropském kontextu (sbornik př́spěvků z mezioborového védeckého sympozia v Litomyšli ve dnech 29.-30. května 1998), ed. Milan SKŘIVÁNEK, Litomyšl: Státní okresní archiv Svitavy, 1998.

MiKA Norbert, Walka o spadek po Babenbergach 1246-1278, Racibórz: Wydawnictwo i Agencja Informacyjna WAW, 2008.

NoDL Martin, Dekret kutnohorský, „Dějiny a současnost”, R. 36/nr 3: 2014, s. 63-71.

Osmičky. Osudová výročí českých a československých dějin končicí na jednu čislici, ed. Libor JAN, Brno: NLN - Nakladatelství Lidové Nowiny, 2018. 
PatoČKa Jan, Kim sq Czesi?, przeł. Jacek B ALuch, Kraków: Międzynarodowe Centrum Kultury, 1997.

PRZEPERSKI Michał, Nieznośny ciężar braterstwa. Kontakty polsko-czeskie w XX wieku, Kraków: Wydawnictwo Literackie, 2016.

RAK Jiří, Bývali Čechové - české historické mýty a stereotypy, Praha: Jinočany: H\&H, 1994.

RoYT Jan, Praha Karla IV., Praha: Karolinum, 2016.

SLAvíK Jan, Iluze a skutečnost, Praha: Academia, 2000.

ŠTAIF Jiří, Historici, dějiny a společnost: historiografie v českých zemích od Palackého a jeho edchůdců po Gollovu školu, Praha: Filozofická fakulta Univerzity Karlovy, 1997.

UhLíř Dušan, Drama Bíle hory: česká válka 1618-1620, Brno: Computer Press, 2017.

VoJÁČEK Ladislav, Prvni československý zákon: pokus o opožděný komentár̆, Praha: Wolters Kluwer, 2018.

WiHODA Martin, Polská koruna českých králi̊, „Český časopis historický”, t. 102: 2004.

WŁodARSki Bronisław, Polska i Czechy w drugiej połowie XIII i początkach XIV wieku (1250 1306), Lwów: Towarzystwo Naukowe Lwowskie, 1931.

ŽEMLIČKA Josef, Křrižovatky Vladislava II. Co mohl a nemohl druhý český král?, [in:] Vladislav II. Druhý král z Přemyslova rodu: $k$ 850. výroči jeho korunovace, ed. Petr SOMMER, Josef ŽEMLIČKA, Praha: Nakladatelství Lidové Noviny, 2009, s. 17-18.

ŽEMLIČKA Josef, Přemysl Otakar II., Praha: Nakladatelství Lidové Noviny, 2011.

1948: únor 1948 v Československu: nástup komunistické totality a proměny společnosti, ed. Jiří Kocian, Markéta DevÁtÁ, Praha: Ústav pro soudobé dějiny AV ČR, 2011.

1968: Pražské jaro 1968: občanská společnost, média, přenos politických a kulturních procesů = civil society, the mass media, and the transfer of political and cultural processes in the „Prague Spring” 1968 = der Prager Früling 1968: Zivilgesellschaft, ed. Oldřich TumA, M. DEvÁTÁ, Praha: Ústav pro soudobé dějiny AV ČR, 2011.

\title{
Magical "eighths" as the new proposition for a reflection on the Czech history
}

\author{
[rev.] Osmičky. Osudová výročí českých a československých dějin končící na \\ jednu číslici, ed. Libor JAN, Brno 2018, pp. 208
}

\begin{abstract}
Summary
Last year the group of historians from Brno University published extremely interesting piece of work titled Osmicky (Eights). Authors are trying to answer the question why so many significant events and processes important for Czech history took place exactly under that eight-ending. They are debating about the threat of a date fetishism and mythology of the past, but their main aim is to describe certain historical continuity. This dissertation proves that the essence of history itself should not be found only in myths around some event, but in the reasons and effects which particular event has brought. The book at this point becomes kind of concise historical lecture about Czech Republic in the context of Europe's history. For the Polish readers it is also a great compendium of awareness and knowledge about history and understanding of fraternal neighbor.
\end{abstract}

Keywords: eighths, Czech, dates, mits, past, historical continuity. 
Mariusz ŻYMIERSKI

https://orcid.org/0000-0003-4442-6241

Uniwersytet Humanistyczno-Przyrodniczy im. Jana Długosza w Częstochowie

\section{Współczesne nośniki kultury historycznej na przykładzie dwóch wydawnictw z powiatu lublinieckiego}

[rec.] Bogusław HRYCYK, Śladami historii - przewodnik historyczny, Lubliniec: Drukarnia Sil-Vega-Druk, 2018, ss. 61; Malgorzata GrabOLUS, Piotr Grabolus, Franciszka Ciemienga z Kanusa. Wspomnienia. Lubliniec: Wydawnictwo św. Macieja Apostoła, 2019, ss. 47

\section{Streszczenie}

Niniejsza recenzja stanowi analizę treści dwóch publikacji dotyczących powiatu lublinieckiego. Zawarte w niej materiały przedstawiają bogactwo tej ziemi. Autorzy w przystępny sposób ukazują, iż zabytki, sztuka, malarstwo, muzyka oraz ludzie i ich losy tworzą szeroko pojętą kulturę historyczną, będącą zarazem ponadwymiarowym nośnikiem nie pozwalającym zapomnieć czytelnikom o lokalnej historii, o tym skąd się wywodzą.

Słowa kluczowe: ziemia lubliniecka, kultura historyczna, Franciszka Ciemienga, Kanus.

Do współczesnych nośników kultury historycznej zaliczamy wydawnictwa popularne poświęcone różnym aspektom dziejów lokalnych, regionalnych i narodowych. Badacz tego typu przekazów, stanowiących zainteresowanie szeroko pojętej dydaktyki historii, ujawni je w najmniejszych nawet środowiskach Polski „powiatowej i gminnej”. Posłużmy się przykładem powiatu lublinieckiego. $\mathrm{W}$ jego ramie przestrzennej, w ciągu ostatnich lat informacje dotyczące wyżej wymienionego zagadnienia możemy odnaleźć w różnego typu publikacjach ukazujących się w poszczególnych gminach. 
Te stricte lokalne wydawnictwa - książki, broszurki, dzienniki, tygodniki, zajmujące się przekazywaniem wiedzy historycznej oraz wydarzeniami z regionu, o niewielkim nakładzie i zasięgu często ograniczającym się do jednej gminy, są niejednokrotnie zadziwiająco szczegółowe w relacjonowaniu miejscowych wydarzeń i zjawisk kulturowo-historycznych. Istotnym problemem jest jednak brak ich w bibliografiach jak również w zbiorach bibliotek.

Ważnym nośnikiem kultury historycznej regionu lublinieckiego jest kwartalnik społeczno-kulturalny „Ziemia Lubliniecka”, wydawany od 2007 r. z inicjatywy Starostwa Powiatowego w Lublińcu. Na stronach tej gazety bardzo często ukazują się artykuły dotyczące historii regionu oraz materiały pozwalające identyfikować kręgi inicjacji różnych form kultury historycznej Lublińca i jego okolic. Wśród ich autorów nie brakuje profesjonalnych historyków, ale najczęściej są to amatorzy historii urzeczeni niewątpliwym wdziękiem lokalnej Klio. Do tych ostatnich należy zaliczyć Bogusława Hrycyka, gorliwego propagatora różnych odmian historii, a zarazem autora jednej z dwóch recenzowanych tutaj niewielkich publikacji.

Bogusław Hrycyk, emerytowanego nauczyciel muzyki, a obecnie redaktor „Ziemi Lublinieckiej”, wielokrotnie już zamieszczał w tym piśmie artykuły dotyczące historii regionu, zaś recenzowana publikacja stanowiąca pokłosie jego pasji historycznych i krajoznawczych. Warto też podkreślić, że jest to pierwsza publikacja monograficzna w dorobku Hrycyka.

Książka Śladami historii - przewodnik historyczny ${ }^{1}$ dostarcza informacji umożliwiających podróż po dworach i pałacach powiatu lublinieckiego, ale są w niej scharakteryzowane także inne ważne miejsca dla ziemi lublinieckiej. Autor w przystępny sposób przekonuje, iż kultura, sztuka, malarstwo, muzyka oraz ludzie i ich losy tworzą szeroko pojętą cywilizację. Jego celem było, aby mieszkańcy regionu nie zapominali o lokalnej historii, o tym skąd się wywodzą. Ma ona też posłużyć jako przewodnik tym wszystkim, którzy zapragną odwiedzić ziemię lubliniecką i zagłębić się w zawiłe losy jej związków z sąsiadami. Książka jest dedykowana żonie i rodzinie autora.

Podjęta problematyka została przedstawiona na 61 stronach. Konstrukcja pracy jest klarowna i logiczna, nie budzi zastrzeżeń. Składa się ze wstępu, czterech części, tworzących główny szkielet opracowania. Po słowie wstępnym odnajdujemy mapy przedstawiające powiat lubliniecki z zaznaczonymi licznymi zabytkami kultury świeckiej, sakralnej oraz wytyczonymi szlakami turystycznymi. Jest to dobre posunięcie autora, gdyż w przejrzysty sposób zapoznaje czytelnika z pozycjami przewodnika historycznego, umiejscawiając je zarazem w przestrzeni.

W ramach części drugiej dostarczono bardzo szerokie spektrum informacji na temat historii powiatu lublinieckiego. Zawarte są w nim informacje dotyczące dworów i pałaców w poszczególnych miejscowościach - Ciasna, Patoka, Wę-

1 Bogusław HryCYK, Śladami historii-przewodnik historyczny, Lubliniec 2018, ss. 61. 
dzina, Sieraków Śląski, Kochanowice, Kochcice, Koszęcin, Gwoździany, Draliny, Czarny Las, Wieżbie. Są to jedynie krótkie notatki informacyjne, gdzie autor wykazuje się talentem popularyzatora tego obszaru. Czytelnik z każdą przeczytaną stroną przekonuje się, iż korzystając z przewodnika, w bardzo łatwy sposób może zapoznać się z historią opisywanych terenów. Bierze się to ze skrupulatnie przytaczanych przez autora opisów miejsc. Dodatkowym walorem są liczne zdjęcia opisywanych miejsc i rysunki herbów, przez co książka nabiera cech albumowych. Omawiany fragment posiada dużą wartość kulturoznawczą. Jest interesującym, syntetycznym kompendium ukazującym bogactwo kultury historycznej najbliższej okolicy.

Część trzecia przedstawia charakterystykę wybranych sanktuariów religijnych jako ważnych miejsc dla ziemi lublinieckiej oraz jej mieszkańców. Mowa tu między innymi o Górze św. Anny, Piekarach Śląskich oraz Jasnej Górze. Autor w przystępny sposób informuje o powodach, dla których odwiedzający te miejsca dawni, jak i współcześni pielgrzymi, są zachwyceni zgromadzonymi tam dziełami sztuki. Miejsca te są naturalnym łącznikiem przeszłości z teraźniejszością, o wielopłaszczyznowym przekazie, bogatym w różnego rodzaju treści kultury historycznej.

W czwartej części znajdziemy przede wszystkim dokumentację licznych zrealizowanych przedsięwzięć turystycznych autora. Wędrując do Paryża, Bawarii, Drezna, Berlina, Lwowa oraz Pragi, miejsc odległych od bliskiego mu środowiska lokalnego, starał się odczytywać szybko zmieniającą się wokół nas rzeczywistość. Historia krajów i regionów, sąsiadów bliższych i dalszych, z całą pewnością pozwala lepiej zrozumieć i poznać dzieje tworzenia się i powstawania poszczególnych narodów i państw. Pozwala także lepiej zrozumieć własną historię w odniesieniu do całej Europy. W tym fragmencie kultura historyczna ziemi lublinieckiej jest rozpatrywana jako integralna część cywilizacji europejskiej. Choć nakreślony w ten sposób obraz może wydawać się zbyt globalny to nie należy traktować tego jako mankament. Bogusław Hrycyk nie chce zamknąć świadomości swoich czytelników jedynie w obszarze najbliższego środowiska, lecz pragnie poszerzyć ją o wiedzę o jego związku z kulturą innych krajów europejskich.

Dużą zaletą recenzowanej publikacji jest zrozumiały, przejrzysty przekaz. Zastanawiające jest umiejscowienie odnośników do fotografii i grafiki w kończącej książkę bibliografii i netografii. Zastosowanie tego rozwiązania nie odrywa uwagi czytelnika od treści, lecz może sprawić pewien kłopot, gdy chce się znaleźć źródło informacji. Taki zabieg techniczny nie umniejsza jednak w żaden sposób treści książki.

Drugą recenzowaną książką jest opracowanie poświęcone Franciszce Ciemiendze z Kanusa, przygotowane przez Małgorzatę i Piotra Grabolusów ${ }^{2}$. Autorzy książki, notabene mieszkańcy Kanusa pod Lublińcem, zajmują się historią

2 Małgorzata Grabolus, Piotr Grabolus, Franciszka Ciemienga z Kanusa. Wspomnienia, Lubliniec 2019, ss. 47. 
swojej Małej Ojczyzny z zamiłowania. Ich praca zawodowa nie jest w żaden sposób powiązana z profesjonalnym uprawianiem historii. Są oni przykładem tego, iż człowiek, może nie do końca tego świadomy, zaczyna utożsamiać swój świat z miejscem, w którym mieszka. Rodzinna okolica jest nośnikiem wartości regionalnych zapisanych w obiektach dziedzictwa materialnego, obyczajach środowiska lokalnego, losach ludzi. Każdy, kto sobie to uświadomi, może stać się „strażnikiem" i popularyzatorem dziedzictwa regionalnego poprzez zaczerpnięcie i spożytkowanie tkwiących w nim wartości. Tak stało się w przypadku Małgorzaty i Piotra Grabolusów. Ich postawa czynnych regionalistów ujawniła się w wyniku zakorzenienia w rodzinnej tradycji. Nie ma bowiem przywiązania do regionu bez znajomości przeszłości tego obszaru i wielorakich związków z jego zawartością społeczną. Mówimy tu nie tylko o płaszczyźnie środowiska społecznego, położenia ekonomicznego, ale przede wszystkim uwarunkowań etnicznych, kulturowych i politycznych.

Książka Franciszka Ciemienga $z$ Kanusa jest drugą publikacją Grabolusów dotyczącą historii tego terenu³. Dotyczy jednej z najbardziej rozpoznawalnych postaci lokalnej tradycji - Francki z Kanusa, pochodzącej z okolic Lubecka. Chociaż w przekonaniu miejscowej ludności Franciszka Ciemienga zmarła w aurze świętości, to władze kościelne dotąd nie wypowiedziały się w sprawie jej dziwnych „zabrań”4. Ludność okoliczna czci ją jako pobożną charyzmatyczkę, która uczyła ludzi wytrwałej modlitwy i służyła radą w codziennych sprawach. Postać Francki z Kanusa oraz jej kult jest przejawem pewnej kultury historycznej, pewnej obyczajowości, pewnego etosu społecznego. Opisywana publikacja przeznaczona jest dla tych, którym postać Franciszki Ciemiengi nie jest obojętna. Dla osób odwiedzających jej grób, zagrodę, gdzie mieszkała, proszących o wstawiennictwo u Boga.

Zaprezentowany w pracy materiał, należy uznać za cenny, ponieważ wnosi on dużo nowych, wcześniej niepublikowanych informacji. Podjęta problematyka została zaprezentowana na 47 stronach, zawierających treści stanowiące kontynuację badań nad sanktuarium w Lubecku ${ }^{5}$. W recenzowanej pracy nie wyodrębniono rozdziałów. Po słowie wstępu napotykamy na kilkunastu stronicowy materiał dotyczący życia Franciszki Ciemiengi, przeplatany charakterystyką najbliższej okolicy. Mocną stroną pracy są wspomnienia osób, które miały styczność z bohaterką, zebrane przez Grabolusów w czasie badań archiwalnych. Odznaczają się dużą wartością naukową, gdyż w znacznej części nie były jeszcze publikowane.

Dla lepszego poznania sylwetki Franciszki Ciemiengi autorzy zamieścili kilka informacji biograficznych już we wstępie pracy. W jego dalszej części sub-

3 M. Grabolus, P. Grabolus, Żolnierze Cesarstwa Niemieckiego z ówczesnej Parafii Lubecko na frontach I wojny światowej, Kalety 2018.

4 Mianem ,zabrań” określano stany olśnienia, których doznawała Franciszka Ciemienga podczas modlitwy.

5 Andrzej Bartysiewicz, Sanktuarium Matki Boskiej Lubeckiej, Lubliniec 2005. 
telnie przenoszą czytelnika $\mathrm{w}$ atmosferę tamtych lat. Warto zwrócić uwagę, że treści te są szeroko wykorzystywane przez badaczy oraz historyków pogłębiających wiedzę analizowanego zagadnienia.

Omawiana książka posiada dużą wartość poznawczą. Podążając za myślą autorów, można stwierdzić, że publikacja powstała w związku z niesłabnącym zainteresowaniem i fascynacją życiem i działalnością Franciszki z Kanusa.

Dużą zaletą niniejszej publikacji jest zrozumiała, przejrzysta treść. Pracę wzbogacają liczne fotografie oraz wycinki z ksiąg parafialnych. Zastanawia jednak kwestia umiejscowienia wyjaśnienia nazwy przysiółka Kanus w końcowym fragmencie publikacji. Taki zapis nie umniejsza jednak w żaden sposób treści książki. Podsumowując, uznać należy, iż prezentowana praca stanowi istotny wkład w upamiętnienie postaci Francki z Kanusa. Zachęca do zapoznania się z jej życiorysem oraz do odwiedzenia miejsc z nią związanych. Konstruowanie i przekazywanie wiedzy o regionie w publikacji odbywa się w sposób wielowymiarowy, łączący pokolenia, stwarzający warunki do podejmowania dalszych badań nad życiem bohaterki.

Reasumując, można stwierdzić, iż omawiane pozycje zawierają treści umożliwiające czytelnikowi poznanie i utożsamienie się z dziedzictwem ziemi lublinieckiej. To przykład sytuacji, w której książka staje się nośnikiem wartości kulturowych, wartości, które tkwią w otoczeniu każdego z nas.

\section{Contemporary mediums of historical culture on the basis of two publishing houses from Lubliniec district}

[rev.] Bogusław HRYCYK, Śladami historii-przewodnik historyczny, Lubliniec: Drukarnia Sil-Vega-Druk, 2018, pp. 61; Malgorzata Grabolus, Piotr Grabolus, Franciszka Ciemienga $z$ Kanusa. Wspomnienia. Lubliniec: Wydawnictwo św. Macieja Apostoła, 2019, pp. 47

\section{Summary}

This review is an analysis of the content of two publications concernig Lubliniec district. The materials included present the natural wealth of this land. The authors in an accessible way show that monuments, art, painting, music and people create a broadly understood historical culture, which is also an oversized medium that does not allow readers to forget about local history and where they come from.

Keywords: Lubliniec area, historical culture, Franciszka Ciemienga, Kanus. 



\section{SPRAWOZDANIA}



Prace Naukowe Uniwersytetu Humanistyczno-Przyrodniczego im. Jana Długosza w Częstochowie ZESZYTY HISTORYCZNE 2019, t. XVIII, s. 231-238

http://dx.doi.org/10.16926/zh.2019.18.13

Anna CZERNIECKA-HABERKO

https://orcid.org/0000-0002-4585-0127

Uniwersytet Humanistyczno-Przyrodniczy im. Jana Długosza w Częstochowie

Karolina STUDNICKA-MARIAŃCZYK

https://orcid.org/0000-0002-4116-9350

Uniwersytet Humanistyczno-Przyrodniczy im. Jana Długosza w Częstochowie

\section{Sprawozdanie ze stażu naukowego w Centrum Historii Gospodarczej i Społecznej (Wydzial Filozoficzny Uniwersytet w Ostrawie)}

\section{Streszczenie}

Dr Anna Czerniecka-Haberko i dr Karolina Studnicka-Mariańczyk, w dniach 17.09.201831.12.2018 r., odbyły staż naukowy w Centrum Historii Gospodarczej i Społecznej (Instytut Historii). Centrum swoją siedzibę ma na Wydziale Filozoficznym Uniwersytetu w Ostrawie. Opiekunem stażu był prof. PhDr. , Ph.D. Aleš Zářický. W czasie stażu prowadzona była kwerenda archiwalna w archiwum w Opawie. Kwerenda archiwalna została skoncentrowana na eksploracji materiałów stanowiących pozostałość po Stowarzyszeniach polskich na Śląsku Cieszyńskim w Czechosłowacji. W zasobach w archiwum w Opawie znajduje się 1351 jednostek dotyczących Stowarzyszeń polskich ${ }^{1}$. Ich analiza pozwoliła na pogrupowanie Stowarzyszeń polskich na: oświatowo-kulturalne, opiekuńcze, religijne, sportowe oraz gospodarcze.

Słowa kluczowe: staż naukowy, kwerenda archiwalna.

Dr Anna Czerniecka-Haberko oraz dr Karolina Studnicka-Mariańczyk, w dniach 17 września-31 grudnia 2018 r., odbyły staż naukowy w Centrum Historii Gospodarczej i Społecznej (Instytut Historii), na Wydziale Filozoficznym Uniwersytetu w Ostrawie. Opiekunem stażu był prof. PhDr., Ph.D. Aleš Zářický.

1 http://digi.archives.cz/da/SearchBean.action?searchType=basic 
W czasie stażu prowadzona była kwerenda w archiwum w Opawie. Zemský archiv ma siedzibę w przepięknym gmachu dawnego kolegium jezuitów ${ }^{2}$. To archiwum szczególne, gdyż pod względem liczby zgromadzonych zbiorów jest trzecim (po praskim i brneńskim) archiwum państwowym funkcjonującym na terenie Republiki Czeskiej, chociaż ma charakter regionalny. Przechowywane tam są materiały czeskiej części dawnych księstw śląskich, Śląska Austriackiego (Rakouské Slezsko, oficjalnie Herzogtum Ober- und Niederschlesien), ziem leżących w granicach północnomorawskiego okręgu terytorialnego (Severomoravský kraj) oraz morawsko-śląskiego (Moravskoslezský kraj) i ołomunieckiego (Olomoucký kraj) regionu administracyjnego ${ }^{3}$.

Zemský archiv w Opawie posiada w swoich zbiorach dokumenty z początku XIV w., czyli z czasów, gdy Opawa była stolicą samodzielnego księstwa wydzielonego z Margrabstwa Moraw, rządzonego przez linię „levobočnou” rodu Przemyślidów. Za najcenniejszy zespół tegoż archiwum należy uznać Slezsky stavovsky archiv (SA), który obejmuje dokumenty, akta i księgi wytworzone przez urzędy ziemskie, sądy, sejm i stany księstw śląskich, przede wszystkim opawskiego, karniowskiego, cieszyńskiego i nyskiego. Zespół ten stanowi kolekcję dokumentów pochodzących z lat 1318-1884. Ma on fundamentalne znaczenie dla konstruowania prawnego, administracyjnego, gospodarczego oraz społecznego obrazu Śląska w dobie feudalizmu .

Najstarsze zbiory archiwum opawskiego obejmują również archiwalia śląskich klasztorów sekularyzowanych w okresie reform oświeceniowych przez cesarza Józefa II: dominikanów cieszyńskich i opawskich, klarysek opawskich oraz franciszkanów karniowskich i opawskich. Archiwalia te, w zdecydowanej większości, są aktami finansowymi poszczególnych klasztorów. Najczęściej sum lokowanych na dobrach ziemskich i należnych prowizji ${ }^{5}$.

Po wojnach śląskich, czyli od 1742 r., Opawa stała się centrum Śląska Austriackiego, stąd też Śląsk Austriacki stał się obszarem, z którego gromadzono zbiory archiwum. Na uwagę zasługują archiwalia stanowiące pozostałość po administracji politycznej i samorządowej Śląska po $1850 \mathrm{r}$.

2 ks. Zdzisław LeC, Kolegia jezuickie na Ślasku do 1740 r., „Perspectiva. Legnickie Studia Teologiczno-Historyczne", R. XI/nr 2 (21): 2012, s. 89-97.

3 Bohumir IndRA, 70 let Státního archivu v Opavě, [in:] idem, Sborník Státního archivu v Opavě 1968-1971, Opava 1971, s. 75-96; Karel MüLlER, 100 let Zemského archivu v Opavě. Sborník přispěvků prednesených v rámci 9. konference archivárùu ČR 23.-25. května 2001 v Opavě, Opava 2002; Marek L. WóJcik, Sprawozdanie z kwerendy $w$ Zemskym archivie $w$ Opawie w dniach 10-14 XII 2012 r., hm.kasaty.pl/wp-content/uploads/2014/hm2-560.pdf, [dostęp: 10.02.2019]; http://www.archives.cz/web/za_opava/o_archivu/ [dostęp: 10.02.2019].

4 M.L. WóJCIK, op. cit., s. 561. Vide: Stanislav DRKAL, Jaroslav DONÁT, Slezsky stavovsky archiv v Opavě 1318-1850. Inventar̆, Opava 1965; idem, Slezsky stavovsky archiv v Opavě 1318-1850. Inventař, Opava 1972.

5 M.L. WÓJCIK, op. cit., s. 560. 
W latach 50. XX w., czyli w okresie, gdy zlikwidowano odrębność archiwów rolno-leśnych, archiwum opawskie pozyskało m.in. spuścizny wielu rodzin i archiwalia przedsiębiorstw.

Zasób archiwum opawskiego stanowią również dokumenty osobowe, np. historyków i polityków. Archiwum gromadzi bowiem dokumenty podmiotów administracyjnych, sądowych, społecznych, gospodarczych oraz politycznych o charakterze regionalnym ${ }^{6}$.

Dr Anna Czerniecka-Haberko oraz dr Karolina Studnicka-Mariańczyk skoncentrowały swoją kwerendę na eksploracji materiałów stanowiących pozostałość po stowarzyszeniach polskich na Śląsku Cieszyńskim w Czechosłowacji. W zasobach w archiwum znajduje się 1351 jednostek dotyczących tego tematu ${ }^{7}$. Ich analiza pozwoliła na pogrupowanie Stowarzyszeń polskich na: oświatowo-kulturalne, opiekuńcze, religijne, sportowe oraz gospodarcze.

Kwestie oświatowe priorytetem swojej działalności uczyniła Macierz Szkolna. W 1922 r. w jej skład wchodziło 28 Kół Miejscowych z 4301 członkami, podczas gdy w 1938 r. funkcjonowały już 93 Koła z 9739 członkami, co świadczy o prężnej działalności ${ }^{8}$. Znaczenie Macierzy Szkolnej dla ludności polskiej można przedstawić na przykładzie danych z $1931 \mathrm{r}$. W tym bowiem roku Towarzystwo liczyło 90 Kół Miejscowych z 8166 członkami, 90 czytelniami czasopism, 67 bibliotekami, z 3041 czytelnikami, którzy mogli korzystać z 15030 książek. W bibliotekach tych zorganizowano 352 wykłady, 210 przedstawień teatralnych, 108 uroczystości narodowych, 269 zabaw i wieczorków. W strukturach Macierzy Szkolnej znajdowało się 75 amatorskich i 63 śpiewacze zespoły z 2330 członkami. Macierz utrzymywała również polskie gimnazjum w Orłowej z 395 uczniami, 7 szkół wydziałowych z 808 uczniami, 11 szkół podstawowych z 637 uczniami, 56 przedszkoli z 1658 dziećmi i 2 szkoły fachowe z 82 uczniami. Macierz Szkolna w Czeskim Cieszynie dysponowała księgarnią oraz i parkiem im. Adama Sikory. Park ten stał się miejscem wszystkich centralnych uroczystości organizowanych przez Polaków w Czechosłowacji ${ }^{9}$.

Praca kulturalno-oświatowa była również płaszczyzną funkcjonowania Czytelni Ludowych. Miały one na celu krzewienie oświaty wśród ludności polskiej, pielęgnowanie i rozbudzanie poczucia narodowego oraz życia towarzyskiego. Stąd też Czytelnie organizowały wykłady, przedstawienia teatralne, koncerty, zabawy oraz zebrania towarzyskie ${ }^{10}$.

6 Anna Czerniecka-Haberko, Karolina Studnicka-Mariańczkyk, Stowarzyszenia polskie $w$ Czechostowacji, tekst w posiadaniu autorek.

7 http://digi.archives.cz/da/SearchBean.action?searchType=basic

8 Stanisław Zahradnik, Przejawy życia organizacyjnego Polaków w Czechosłowacji w latach 1920-1938, „Sobótka”, R. XXXVI/4: 1981, s. 551. Vide: ZAO, Zemská vláda slezká Opava, sygn. XII-3793.

9 S. ZAHRADNIK, op. cit., 545-546.

10 ZAO, Policejní ředitestrí Moravská Ostrava, Czytelnia ludowa 1905-1910, sygn. 488/1. 
Do Stowarzyszeń o charakterze kulturalnym należy przede wszystkim zaliczyć Związek Polskich Chórów w Czechosłowacji. Związek ten istniał od $1927 \mathrm{r}$. Jego zadaniem było zespolenie polskich towarzystw śpiewaczych i muzycznych w Republice Czechosłowackiej. Nadrzędnym celem uczyniono krzewienie polskiej kultury muzycznej, a w szczególności śpiewu chórowego. Stąd też Związek czuwał nad ogólną linią działalności poszczególnych towarzystw śpiewaczych i muzycznych podlegających osobnej sekcji; urządzał zebrania, koncerty, popisy, kursy dla dyrygentów oraz zjazdy związkowe i okręgowe; ogłaszał konkursy kompozytorskie; organizował i zakładał nowe Koła, wspierał moralnie i materialnie już istniejące. Związek wydawał własny organ oraz śpiewniki i utwory muzyczne (nuty przydzielone chórom były własnością Związku), utrzymywał i prowadził skład nut i wydawnictw muzycznych oraz popierał rozwój polskiej muzyki, dążąc do uratowania jej pierwiastków miejscowych. W 1937 r. Związek zrzeszał 102 chóry z 3917 śpiewakami. W tym roku chóry przynależące do Związku odbyły 4158 prób, na których przygotowały 1636 pieśni. Chóry wystąpiły również na różnych imprezach 1135 razy $^{11}$.

Stowarzyszeniem o charakterze opiekuńczym była przede wszystkim Krajowa Rodzina Opiekuńcza. Celem tegoż stowarzyszenia było „systematyczne organizowanie i prowadzenie opieki socjalnej nad młodzieżą polską w kraju Morawskośląskim”. Dlatego też Krajowa Rodzina prowadziła ewidencję młodzieży potrzebującej wsparcia oraz ewidencję instytucji wsparcia udzielającego ${ }^{12}$.

W zasobach Archiwum w Opawie znajdują się materiały dotyczące Powiatowej Rodziny Opiekuńczej. Stowarzyszenie to miało za zadanie: „«słowem i drukiem» wzbudzać, wychowywać, pogłębiać i szerzyć zrozumienie i interes dla celów opieki socjalnej nad młodzieżą, nie tylko u czynników publicznych, lecz przede wszystkim wśród szerokich warstw ludowych; organizować pracę wszystkich jednostek ochotniczej opieki socjalnej nad młodzieżą polską w powiecie, w celu jednolitego programu; prowadzić w ewidencji wszelkie urządzenia opieki socjalnej nad młodzieżą w powiecie". Istotnym elementem działalności tegoż stowarzyszenia było podejmowanie różnorodnych form opieki nad opuszczonymi, upośledzonymi, zaniedbanymi czy wykorzystywanymi przez rodziców lub opiekunów. W tym celu ewidencjonowało rodziny, które chciały podjąć się opieki nad obcymi dziećmi ${ }^{13}$.

Stowarzyszenia miały również konotacje religijne. Stowarzyszenia religijne zakładali zarówno katolicy, jak i ewangelicy - miały one charakter wyłącznie religijny. Do Stowarzyszeń katolickich należy zaliczyć: Kongregacje Mariańskie, Zjednoczenie Polskich Związków Niewiast Katolickich czy też Związek Chrześcijan w Czechosłowacji. Stowarzyszenia ewangelickie to: Ewangelickie Stowarzyszenie Skarbca Kościelnego im. Gustawa Adolfa oraz Ewangelickie Stowa-

11 S. ZAHRADNIK, op. cit., s. 551-552.

12 Ibidem, s. 555-559.

13 ZAO, Policejní ředitestrí Moravská Ostrava, Ślązka Krajowa Rada Opiekuńcza, sygn. 1115/66. 
rzyszenie Niewiast. Wszystkie Stowarzyszenia religijne eksponowały „pracę nad odrodzeniem duchowym człowieka". Prowadziły one również działalność na płaszczyźnie kulturalnej i charytatywnej ${ }^{14}$.

Polska mniejszość narodowa zakładała również stowarzyszenia o charakterze sportowym. Do najważniejszych z nich należały: Związek Polskich Towarzystw Gimnastycznych „Sokół” w Czechosłowacji, Polskie Stowarzyszenie Robotnicze Oświatowo-Gimnastyczne „Siła” w Czechosłowacji oraz Polskie Towarzystwo Turystyczne „Beskid Śląski”.

Kluby sportowe od 1922 r. były zrzeszone w Związku Polskich Klubów Sportowych w Czechosłowacji. Związku, który w latach trzydziestych obejmował 21 klubów (m.in.: Polski Klub Sportowy „Polonia” Karwina, Klub Sportowy „Siła” Trzyniec, Klub Sportowy „Siła” Karwina oraz Polski Klub Sportowy „Gron” Bystrzyca), zrzeszających ok. 4000 członków. Celem towarzystw sportowych było rozpowszechnienie aktywności sportowej wśród ludności. Zapewne dlatego też „osiąganie wyników sportowych” było kwestią drugorzędną ${ }^{15}$.

Stowarzyszenia o charakterze gospodarczym miały przede wszystkim charakter spółdzielni kredytowych i spożywczych. Polska grupa narodowa w okresie międzywojennym była bardzo aktywna gospodarczo. Organizacje i stowarzyszenia gospodarcze były zakładane na użytek przede wszystkim: robotników, górników i rolników, co było uwarunkowane strukturą socjalną ludności polskiej. Najczęściej miały charakter spółdzielni, które były zrzeszone w Związku Spółek Zarobkowych i Gospodarczych na Śląsku Czechosłowackim, który w pierwszej połowie lat trzydziestych zmienił nazwę na Związek Spółdzielni Polskich w Czeskim Cieszynie.

Kryzys gospodarczy pierwszej połowy lat trzydziestych wpłynął niekorzystnie na działalność polskich organizacji spółdzielczych. Ponieważ zdecydowaną większość ich członków stanowili górnicy, robotnicy i drobni rolnicy, to nastąpiło osłabienie funkcjonowania stowarzyszeń o charakterze gospodarczym. Jednak mimo to spółdzielczość na Zaolziu zdołała przejść przez okres kryzysu gospodarczego bez poważniejszych strat ${ }^{16}$.

Należy podkreślić, że wszystkie stowarzyszenia miały dla polskiej grupy narodowej duże znaczenie. Pomagały utrwalać więź narodową. Pomagały utrzymywać zwartość grupy. Umożliwiały finansowanie różnych akcji narodowych. Pozwalały na zatrudnienie kilkuset członków w instytucjach polskich. Udzielały różnorodnej pomocy swoim członkom. Stąd też wszechstronność stowarzyszeń pozwala wnioskować, że zabezpieczały one - przynajmniej na papierze - egzystencję, rozwój oraz obronę swoich członków ${ }^{17}$.

14 ZAO, Severomoravský krajský národni výbor Ostrava, Polski dom katolicki, sygn. 461a; ZAO, Severomoravský krajský národni výbor Ostrava, Związek stanovczych chrzescijan, sygn. 379.

15 S. ZAHRADNIK, op. cit., s. 553-554.

16 Ibidem, s. 549-550.

17 Ibidem, s. 545-559. Vide: Paweł SuSKI, Stowarzyszenia i fundacje, Warszawa: LexisNexis Polska, 2011, s. 17. 
W wyniku kwerendy prowadzonej w ramach stażu dr Anna Czerniecka-Haberko oraz dr Karolina Studnicka-Mariańczyk pozyskały kilkadziesiąt tysięcy zdjęć wybranych jednostek archiwalnych. Pozyskane materiały, pozwalają przede wszystkim na budowanie obrazu polskich organizacji. Pozwalają również analizę funkcjonowania poszczególnych stowarzyszeń.

\section{Ilustracje}

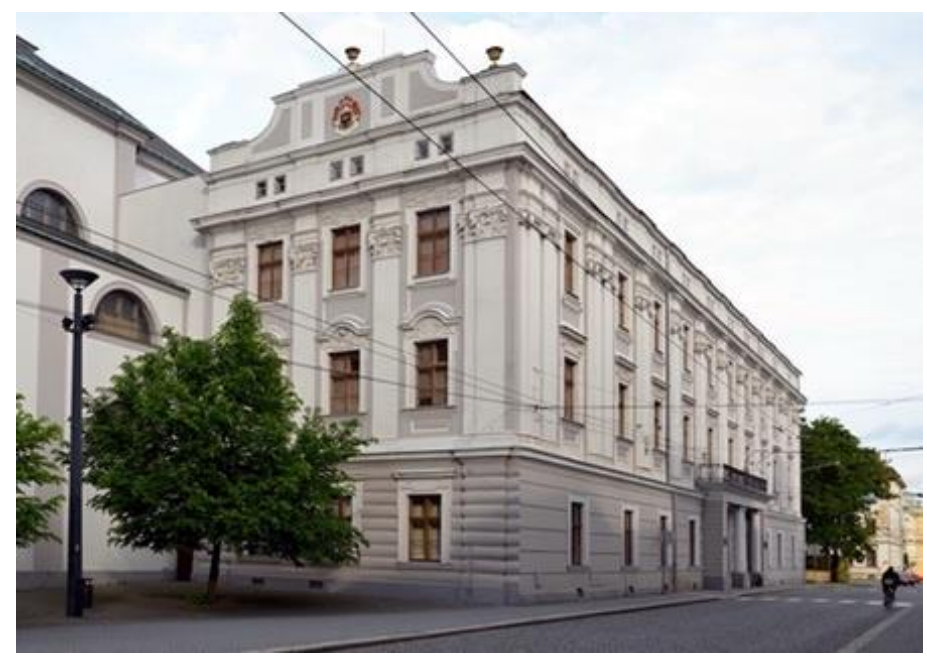

1. Zemský archiv w Opawie

Źródło: http://www.archives.cz/web/za_opava/o_archivu/

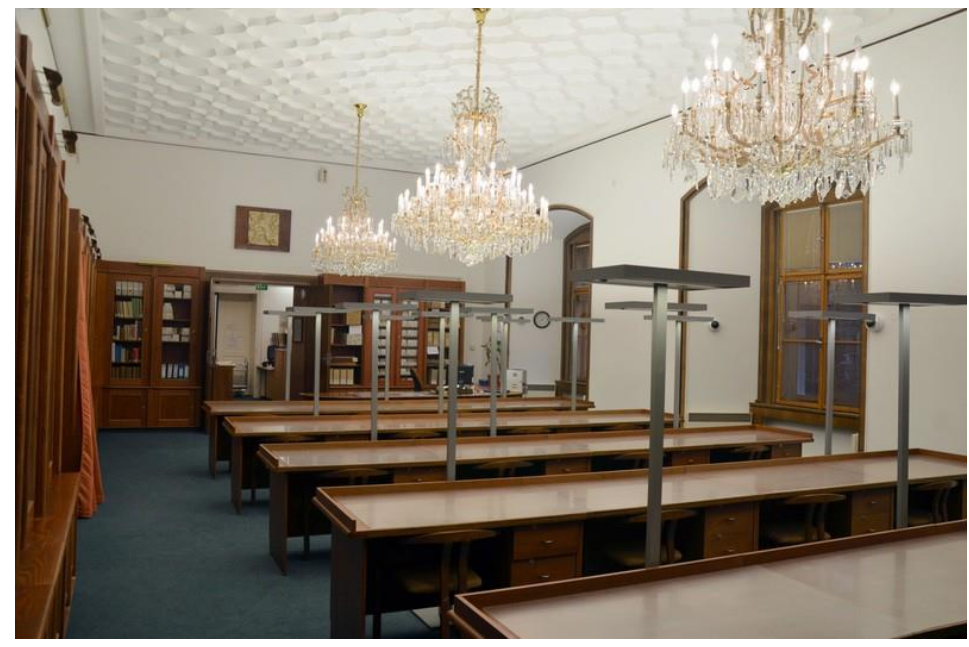

2. Pracownia naukowa

Źródło: http://www.archives.cz/web/za_opava/badatelna/ 


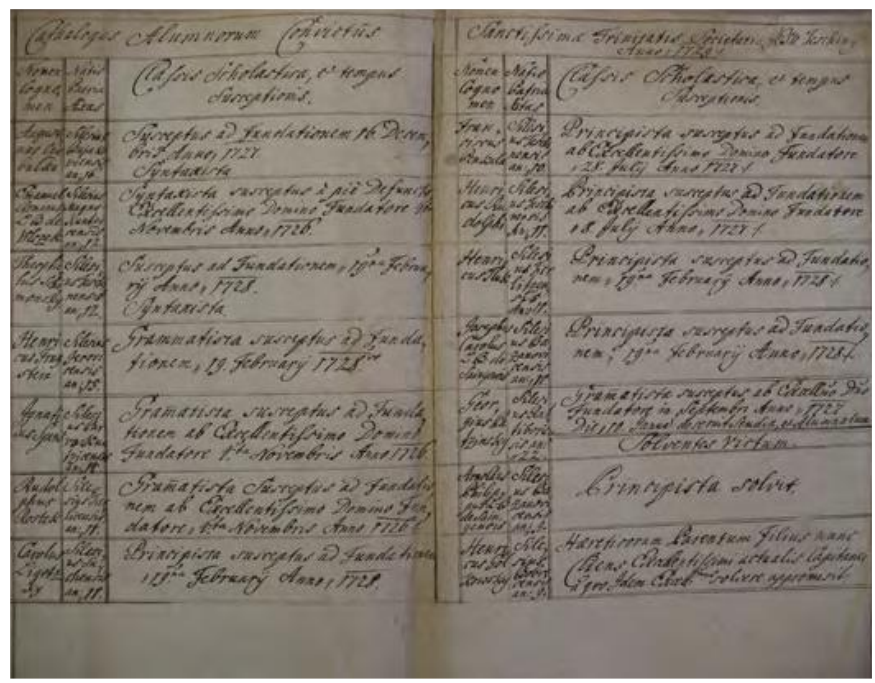

3. Spis albumów jezuickiego konwiktu Świętej Trójcy w Cieszynie z 1729 r.

Źródło: M.L. Wójcik, Sprawozdanie z kwerendy w Zemskym archivie w Opawie $w$ dniach 10-14 XII 2012 r., hm.kasaty.pl/wp-content/uploads/2014/hm2-560.pdf, [dostęp: 10.02.2019], s. 567.
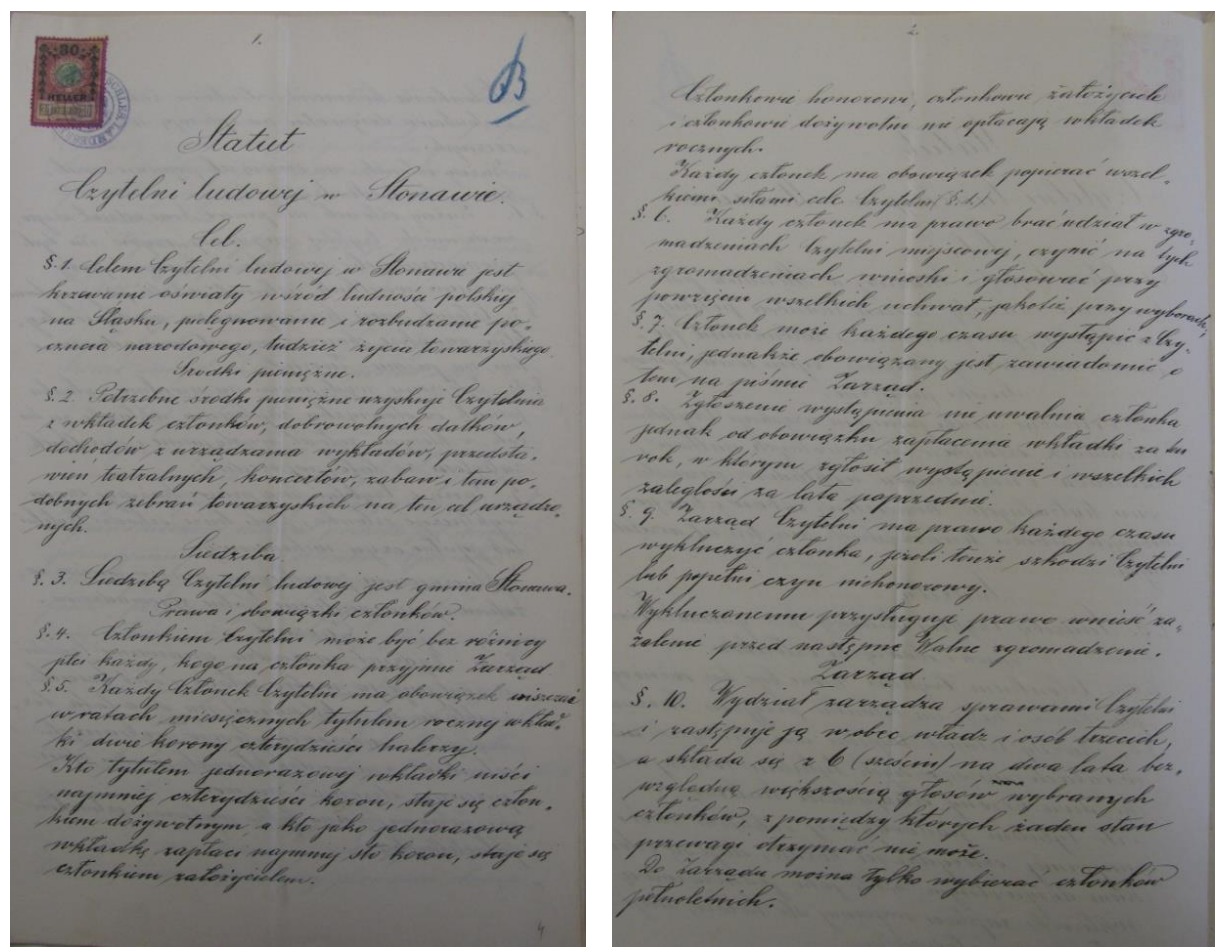

4. Statut Czytelni ludowej w Stanowie Źródło: Zemský archiv w Opawie, Policejní ředitestrí Moravská Ostrava, Czytelnia ludowa 19051910, sygn. 488/1. 


\section{Bibliografia}

\section{Źródla archiwalne}

Zemský archiv w Opawie: Policejní ředitestrí Moravská Ostrava, Czytelnia ludowa 1905-1910, sygn. 488/1; Policejní ředitestrí Moravská Ostrava, Ślązka Krajowa Rada Opiekuńcza, sygn. 1115/66; Severomoravský krajský národni výbor Ostrava, Polski dom katolicki, sygn. 461a; Severomoravský krajský národni výbor Ostrava, Związek stanovczych chrzescijan, sygn. 379; Zemská vláda slezká Opava, sygn. XII-3793.

\section{Opracowania}

Czerniecka-Haberko Anna, Studnicka-MariańCZKy Karolina, Stowarzyszenia polskie $w$ Czechosłowacji, tekst w posiadaniu autorek.

DRKAL Stanislav, DONÁT Jaroslav, Slezsky stavovsky archiv v Opavě 1318-1850. Inventar̆, Opava: Zemský archiv v Opavě, 1965.

DRKAL Stanislav, DONÁT Jaroslav, Slezsky stavovsky archiv v Opavě 1318-1850. Inventar̆, Opava: Zemský archiv v Opavě, 1972.

INDRA Bohumir, 70 let Státního archivu v Opavě, [in:] idem, Sborník Státního archivu v Opavě 1968-1971, Opava: Nákladem Státniho archivu v Opavé, 1971, s. 75-96.

ks. LeC Zdzisław, Kolegia jezuickie na Śląsku do 1740 r., „Perspectiva. Legnickie Studia Teologiczno-Historyczne", R. XI/nr 2 (21): 2012, s. 89-97.

MÜLLER Karel, 100 let Zemského archivu vOpavě. Sborník príspěvků prednesených v rámci 9. konference archivárù ČR 23.-25. května 2001 v Opavě, Opava: Opava: Zemský archiv v Opavě, 2002.

Suski Paweł, Stowarzyszenia i fundacje, Warszawa: LexisNexis Polska, 2011.

WóıCIK Marek L., Sprawozdanie z kwerendy w Zemskym archivie w Opawie w dniach 10-14 XII $2012 \quad r ., \quad$ hm.kasaty.pl/wp-content/uploads/2014/hm2-560.pdf, [dostęp: 10.02.2019]; http://www.archives.cz/web/za_opava/o_archivu/ [dostęp: 10.02.2019].

ZAHRADNIK Stanisław, Przejawy życia organizacyjnego Polaków $w$ Czechostowacji $w$ latach 1920-1938, „Sobótka”, R. XXXVI/4: 1981.

http://digi.archives.cz/da/SearchBean.action?searchType=basic [dostęp: 10.02.2019].

https://www.czso.cz/csu/2004edicniplan.nsf/t/92004043AA/\$File/13n106cd2.pdf [dostęp: 10.02.2019].

\section{Report on academic internship in the Centre for Economic and Social History (The Faculty of Philosophy, University of Ostrava)}

\section{Summary}

In 17.09.2018-31.12.2018, Anna Czerniecka-Haberko, PhD and Karolina Studnicka-Mariańczyk, $\mathrm{PhD}$, conducted their academic internship in the Centre for Economic and Social History (the Institute of History). The Centre is located at the Faculty of Philosophy at the University of Ostrava. Professor Aleš Zárický, $\mathrm{PhD}$ was the supervisor of the internship. The internship consisted in archive research in the archives in Opava. The aforesaid research focused on the analysis of materials constituting the remnants of Polish associations in Cieszyn Silesia in Czechoslovakia. The archives in Opava host 1351 items concerning Polish associations. Their analysis allowed the scholars to divide Polish associations into the following categories: educational and cultural, welfare, religious, sports and economic.

Keywords: academic internship, archive research. 


\section{Wykaz skrótów zastosowanych w przypisach}

Nazwy archiwów i bibliotek oraz przechowywanych w nich zespolów:

$\mathrm{AACz}$ - Archiwum Archidiecezji Częstochowskiej im. ks. Walentego Patykiewicza

AAN - Archiwum Akt Nowych w Warszawie

AGAD - Archiwum Główne Akt Dawnych w Warszawie

AJG - Archiwum Jasnogórskie w Częstochowie

AK - Archiwum Kameralne

AKR - Akta Komisji Rządzącej

$\mathrm{AmCz}$ - Akta miasta Częstochowy

AmP - Akta miasta Piotrkowa

ANK - Archiwum Narodowe w Krakowie

APB - Archiwum Państwowe w Bydgoszczy

$\mathrm{APCz}$ - Archiwum Państwowe w Częstochowie

APK - Archiwum Państwowe w Katowicach

APŁ - Archiwum Państwowe w Łodzi

APO - Archiwum Państwowe w Opolu

APP - Archiwum Państwowe w Poznaniu

APPT - Archiwum Państwowe w Piotrkowie Trybunalskim

APT - Archiwum Państwowe w Toruniu

APW - Archiwum Państwowe we Wrocławiu

BCzart - Biblioteka Muzeum książąt Czartoryskich w Krakowie

BJ - Biblioteka Jagiellońska w Krakowie

BN - Biblioteka Narodowa w Warszawie

BPAUiPAN - Biblioteka Polskiej Akademii Umiejętności i Polskiej Akademii

Nauk w Krakowie

BUW - Biblioteka Uniwersytetu Warszawskiego

BZNO - Biblioteka Zakładu Narodowego im. Ossolińskich we Wrocławiu

CPAHUL - Centralne Państwowe Archiwum Historyczne Ukrainy we Lwowie

KDmWiel - Kodeks dyplomatyczny miasta Wielunia

KM - Księgi Metrykalne

KRW - Komisja Rządowa Wojny

MK - Metryka Koronna 


\section{Wydawnictwa ciągle, źródłowe i czasopisma:}

AGZ - Akta grodzkie i ziemskie z czasów Rzeczpospolitej Polskiej z Archiwum tzw. Bernardyńskiego we Lwowie „AUL.FH” - „Acta Universitatis Lodziensis. Folia Historica”

CDPruss - Codex diplomaticus Prussicus. Urkundensammlungzur ältern Geschichte Preussens

CDS - Codex diplomaticus Silesiae

„GKWiZ” - „Gazeta Korrespondenta Warszawskiego i Zagranicznego”

„GP” - „Gazeta Poznańska”

"GW” - „Gazeta Warszawska”

KDM - Kodeks dyplomatyczny Małopolski

KDMaz - Kodeks dyplomatyczny księstwa mazowieckiego

KDP - Kodeks dyplomatyczny Polski

KDW - Kodeks dyplomatyczny Wielkopolski

„KH”- „Kwartalnik Historyczny”

„KHKM” - „Kwartalnik Historii Kultury Materialnej”

MPH - Monumenta Poloniae Historica

MPH SN - Monumenta Poloniae Historica Series Novae

MRPS - Matricularum Regni Poloniae Summaria, excussiscodicibus, qui in

Chartophylacio Maximo Varsoviensi asservantur

„PH” - „Przegląd Historyczny”

PSB - Polski stownik biograficzny

„RH” - „Roczniki Historyczne”

SGKP - Słownik geograficzny Królestwa Polskiego i innych krajów stowiańskich „SMHW” - „Studia i Materiały do Historii Wojskowości”

„Sobótka” - „Śląski Kwartalnik Historyczny Sobótka”

SUb - Schlesisches Urkundenbuch, wyd. H. Appelt, W. Irgang, Bd. I-V, Graz-

Köln-München 1963-1993

VL - Volumina Legum. Przedruk Zbioru Praw

„WACz” - „Wiadomości Archidiecezji Częstochowskiej”

ZDM - Zbiór dokumentów małopolskich, cz. 1-8, wyd. S. Kuraś, I. Sułkowska-

-Kurasiowa, Kraków-Wrocław 1962-1975

ZDP - Zbiór dokumentów zakonu oo. Paulinów w Polsce, z. 1, wyd. J. Fijałek, Kraków 1938

\section{Inne:}

bp - bez paginacji

cit. a: - cytowane za:

conf. - porównaj

cz. - częśś

eadem - taż 


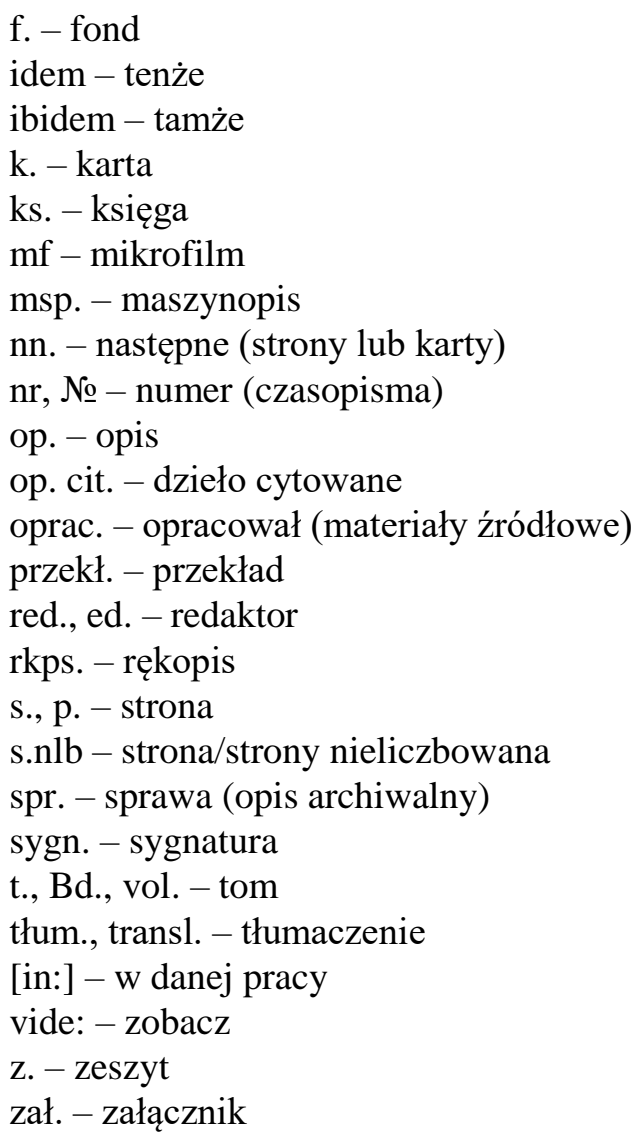





\section{Instrukcja redakcyjna}

I. Objętość przesyłanych materiałów:

1. artykuł lub tekst źródłowy - do 1,5 arkusza autorskiego (60 000 znaków);

2. artykuł recenzyjny (obszerniejsza, polemiczna recenzja) - do 1 arkusza autorskiego (40 000 znaków);

3. recenzja lub polemika - do 0,5 arkusza autorskiego (20 000 znaków),

4. sprawozdanie - 0,25 arkusza (do 10000 znaków).

II. Zalecany plik tekstowy Microsoft Word 97-2003, 2007, 2010 (.doc, .docx). Układ strony: papier A4, marginesy (górny, dolny, lewy, prawy) 2,5 cm, nagłówek i stopka $1,5 \mathrm{~cm}$. Tekst główny czcionka Time New Roman (TNR) 12 pkt., interlinia 1,5 , akapity $\mathrm{w}$ tekście głównym - wcięcie 1,25 , przypisy czcionka TNR 10 pkt., interlinia 1.

III. Układ pierwszej strony artykułu i artykułu recenzyjnego: z lewej strony u góry imię i nazwisko autora (nazwisko wersalikami), poniżej nazwa reprezentowanej instytucji (jeśli autor życzy sobie, aby tekst był afiliowany) lub miasta - wszystkie informacje czcionką TNR 12 pkt., interlinia 1. W trzeciej linijce tytuł artykułu wyśrodkowany, czcionką pogrubioną TNR 14 pkt., interlinia 1,5, poniżej tytuł artykułu w języku angielskim (jeżeli podstawowy tytuł $\mathrm{i}$ tekst artykułu jest $\mathrm{w} \mathrm{j}$. ang. wówczas $\mathrm{w} \mathrm{j}$. pol.), czcionka pogrubiona TNR 12, interlinia 1,5. Wszystkie elementy pismem tekstowym, nie wersalikami.

IV. W recenzji nad tekstem zamieszczamy nagłówek: imię i nazwisko autora recenzowanej pracy, pełny tytuł według strony tytułowej (gdy recenzja dotyczy pracy zbiorowej lub edycji źródłowej, po tytule podajemy imiona i nazwiska redaktorów lub wydawców; jeśli praca jest wielotomowa - liczbę tomów lub części cyframi arabskimi, np. t. 1-2), miejsce i rok wydania, nazwę wydawnictwa, liczbę stron, ewentualnie nazwę serii wydawniczej. W nagłówkach stosujemy skróty w języku recenzowanej pracy, np. ed., bearb. von, hrsg. von itp. Imię i nazwisko autora recenzji oraz afiliację umieszczamy pod tekstem recenzji, z prawej strony.

V. Tytuły i cytaty.

1. Tytuły dzieł i dokumentów:

a) rękopisy: oryginalne tytuły i incipity dokumentów, referatów itp. podajemy antykwą;

b) druki: tytuły dzieł i dokumentów, rozdziałów i fragmentów dzieł (dokumentów) zapisujemy kursywą, tytuły domyślne lub utarte określe- 
nia tytułowe - antykwą jak nazwy własne, np. Kronika Helmolda, Roczniki Kwedlinburskie, Geograf Bawarski.

2. Cytaty:

a) w tekście głównym i przypisach cytowane fragmenty innych prac, dokumentów bądź edycji źródłowych należy zapisywać krojem prostym, biorąc całość w cudzysłów;

b) źródła cytowane w tekście podaje się w zasadzie w thumaczeniu (wyjątkowo w oryginale); w przypisach zaś zawsze w języku oryginału; zachęcamy do podawania w przypisach oryginalnego brzemienia cytatów, które zostały podane w tekście głównym w thumaczeniu;

c) w wypadku słowiańskich alfabetów cyrylickich (białoruskiego, bułgarskiego, macedońskiego, rosyjskiego, serbsko-chorwackiego i ukraińskiego) w tekście podaje się cytat w transliteracji, w przypisach zaś w transliteracji bądź w alfabecie cyrylickim;

d) cytowanych fragmentów źródłowych nie poprzedzamy i nie kończymy wielokropkiem;

e) opuszczenia w cytowanym tekście sygnalizujemy trójkropkiem w nawiasie kwadratowym [...].

VI. W przypadku edycji źródeł wskazane jest zastosowanie istniejących instrukcji wydawania źródeł:

a) Instrukcja wydawnicza dla średniowiecznych źródel historycznych, Kraków 1925;

b) Instrukcja wydawnicza dla źródel historycznych od XVI do połowy XIX wieku, red. K. LEPSZY, Wrocław 1953;

c) A. WOLFF, Projekt instrukcji wydawniczej dla pisanych źródet historycznych do połowy XVI wieku, „Studia Źródłoznawcze”, t. 1: 1957, s. 155-181;

d) I. IHNATOWICZ, Projekt instrukcji wydawniczej dla źródet historycznych XIX i początku XX wieku, „Studia Źródłoznawcze”, t. 7: 1962, s. 99-123.

VII. Pisownia imion, nazwisk i innych wyrażeń określających osoby.

1. Stosujemy oryginalną pisownię imion i nazwisk w ojczystym języku osób wzmiankowanych, ewentualnie stosujemy transkrypcję z formą transliterowaną, w mianowniku, w nawiasie np. Szewczenko (Ševcenko). Powyższe nie dotyczy osób uznanych za powszechnie znane (np. Cyceron, Szekspir, Waszyngton, Wolter itd.), panujących i świętych. W wypadku spolonizowanych cudzoziemców można stosować formę polską.

2. Imiona osób po raz pierwszy wzmiankowanych w tekście lub narracyjnym fragmencie przypisu powinny być przytoczone w pełnym brzmieniu. $\mathrm{W}$ innych przypadkach podaje się inicjały imion i nazwisko lub - zwłaszcza w odniesieniu do postaci znanych albo często wymienianych w tekście - tylko nazwisko, np. Kościuszko, Mickiewicz. W opisach bibliograficznych i archiwalnych zawsze należy uwzględniać jedynie inicjały imion i nazwisko. 
3. Osoby wymieniane $w$ recenzjach powinny występować bez stopni oraz tytułów naukowych i zawodowych. Zasada ta nie obowiązuje w nekrologach w odniesieniu do zmarłych.

4. W recenzjach słowo „Autor” piszemy wielką literą, o ile odnosi się do autora recenzowanej pracy.

5. W nekrologach zaimki osobowe określające zmarłych piszemy wielką literą.

VIII. Skróty, daty i inne określenia czasu, liczebniki.

1. W tekstach stosujemy ogólnie przyjęte skróty: itd., m.in., etc. i inne (zob. niżej zamieszczony wykaz skrótów), a także z reguły: r. (rok) i w. (wiek).

2. Daty w tekście:

a) miesiąc słownie, np. 5 marca 1815 r.;

b) przy różnych stylach (kalendarzach): 10/20 maja 1589 r., a w nawiasach lub w przypisach: 27 II/11 III 1896 r.;

c) okresy od do: np. 1-10 maja 1914 r., 1 maja-10 czerwca 1918 r.;

d) $\mathrm{w}$ datach wtrąconych $\mathrm{w}$ nawiasie miesiąc podaje się liczbą rzymską i nie stosuje się skrótu r. na końcu, np. (1 V 1826).

3. Daty w przypisach:

a) miesiąc liczbą rzymską, np. 5 III 1914 r. (nie dotyczy cytatów i fragmentów narracyjnych);

b) $\mathrm{w}$ razie braku daty dziennej miesiąc zawsze słownie, $\mathrm{np}$. w marcu $1825 \mathrm{r}$.

4. Pisownia określeń „wiek”, „rok”:

a) przed - rozwinięte, np. w wieku XVI, w roku 1928;

b) po - skrócone, np. w XVI w., w 1928 r.

5. W określeniach typu „W drugiej połowie”, „lata osiemdziesiąte” nie używa się cyfr.

6. Liczebniki:

a) zapis cyfrowy z oddzielaniem spacją rzędów wielkości, np. 1234, 11 456, 234 567;

b) zapis cyfrowy z zastosowaniem skrótów: tys., mln, mld, np. 2 tys., $5 \mathrm{mln}, 10 \mathrm{mld}$.

7. W razie zastosowania skrótu nieznajdującego się w wykazie za pierwszym razem należy najpierw podać cały tytuł, a następnie w nawiasie kwadratowym skrót.

IX. Przypis wstawiamy przed kropką, średnikiem lub przecinkiem, za wyjątkiem skrótów kończących się kropką (w. lub r.) - wówczas po kropce. W przypisach stosuje się skróty takie jak w tekście oraz konwencjonalne skróty łacińskie: ibidem, idem, eadem, iidem, eaedem, op. cit., loc. cit., conf., a także [in:] między tytułem artykułu i tytułem tomu. Można stosować też inne, przyjęte w historycznych opracowaniach specjalistycznych, jednak z objaśnieniem przy pierwszym zastosowaniu. Przypisy bibliograficzne prac pisanych 
cyrylicą podajemy w wersji transliterowanej, a następnie w nawiasie kwadratowym $w$ oryginale.

X. Przypisy bibliograficzne.

1. Materiały źródłowe opisujemy w kolejności: tytuł dokumentu, nazwa archiwum, nazwa zespołu, numer sygnatury, numer kartu lub strony, np. Rozkaz Dzienny do Wojska Polskiego nr 45, AGAD, KRW 575, k. 50.

2. Przy pierwszym cytowaniu podajemy imię i nazwisko autora, a przy kolejnym inicjał imienia i nazwisko. Andrzej STROYNOWSKI, Wieczory sejmowe: studia nad dziejami parlamentaryzmu w epoce stanisławowskiej, Częstochowa 2013, s. 72.

3. Czasopisma: personalia autora (patrz wyżej), tytuł tekstu kursywą, tytuł czasopisma w cudzysłowie lub skrót tytułu (jeśli występuje w poniższym wykazie), rok wydania, tom, numer lub zeszyt cyframi arabskimi, strony, np.: Ewelina POLICIŃSKA, Kancelaria księcia Władysława II Opolczyka - organizacja, personel, zadania, „Częstochowskie Teki Historyczne”, t. 7: 2017, s. 11-41.

4. Serie wydawnicze: personalia autora, tytuł kursywą, miejsce i rok wydania, nazwa serii i numer tomu bez wyróżnienia (ale w tekście właściwym nazwy serii kursywą), strony na końcu. W wypadku prac zbiorowych po tytule przywoływanego tekstu następuje po przecinku [in:] tytuł opracowania zbiorowego pisany kursywą oraz imię i nazwisko redaktora, np. Andrzej WASIAK, Miasto i klasztor wobec konfederacji barskiej, [in:] Częstochowa dzieje miasta i klasztoru jasnogórskiego, t. I: Okres staropolski, red. Feliks KIRYK, Częstochowa 2002, s. 431-433.

5. Teksty zamieszczone w wydawnictwach ciągłych o charakterze wydawnictw zbiorowych traktujemy jak artykuły w czasopismach (tytuły wydawnictw w cudzysłowie), np. Jacek LABERSCHEK, Bielowie herbu Ostoja i ich zamek $w$ Btesznie na tle polityki obronnej panujacych $w$ drugiej połowie XIV wieku, [in:] idem, Częstochowa i jej okolice w średniowieczu, Kraków 2006, 134-135. Jeśli książka ukazała się jako jeden tom (zeszyt) wydawnictwa ciągłego, to stosujemy następujący opis: personalia autora, tytuł kursywą, miejsce i rok wydania, tytuł wydawnictwa ciągłego w cudzysłowie, tomy, zeszyty i podobne informacje.

6. Biogramy w Polskim Słowniku Biograficznym traktujemy jak artykuły w wydawnictwie seryjnym, np. M. ZGÓRNIAK, Haller Cezary, [in:] PSB, t. 9, Wrocław 1960-1961, s. 250.

7. Stosujemy polskie określenia skrótowe: wyd., oprac., red. (nie pod red.).

8. W wypadku korzystania z pracy thumaczonej należy podać język oryginału i datę wydania, $\mathrm{z}$ którego dokonano thumaczenia.

9. Opisy bibliograficzne wtrącone do tekstu lub wywodu w przypisie zamykamy w nawiasie okrągłym. 
10. Po incipitach prac wielokrotnie cytowanych nie umieszczamy wielokropka.

11. W opisach bibliograficznych prac opublikowanych w słowiańskich alfabetach cyrylickich najpierw podajemy je w wersji transliterowanej, a następnie w nawiasie kwadratowym w oryginale, np. Boris W. MIEGORSKIJ, «Otdat' nielzia sżecz». Ostawlenije gorodow i kriepostiej w gody Wielikoj Siewiernojwo Wojny, [in:] Wojna i orużyje. Nowyje issledowanija i matieriaty, cz. 3 [Борис В. МЕГОРСКИй, «Отдать нельзя сжечь». Оставление городов и крепостей в годы Великой Северной Войны, [в:] Война и оружие. Новые исследования и материаль, ч. III], Sankt-Pietrierburg [Санкт Петербург] 2016, s. 357.

12. Opisy archiwaliów i rękopisów modernizujemy zgodnie z zasadami określonymi w zasadach wydawnictw źródłowych.

13. Opisy bibliograficzne starodruków nie są modernizowane; modernizujemy ortografię tekstów dziewiętnasto- i dwudziestowiecznych.

XI. Bibliografia

Wraz z tekstem należy przesyłać bibliografię z podziałem na źródła archiwalne, źródła drukowane, pamiętniki i opracowania. Poniżej wzór poprawnego zapisu:

Archiwum Narodowe w Krakowie, Archiwum Młynowskie Chodkiewiczów, sygn. 1171.

[KItowicz, Jędrzej], Pamiętniki do panowania Augusta III $i$ Stanisława Augusta z rękopismu x. Andrzeja Kitowicza, wyd. A. Woy KowsKi, Poznań 1840.

ARĀJs Janis, Bitwa nad Dźwina 9 lipca 1701 roku, [in:] Wojny pótnocne w XVI-XVIII wieku. W czterechsetlecie bitwy pod Kircholmem, red. Bogusław DYBAŚ, Toruń: Towarzystwo Naukowe w Toruniu, 2007.

KowalsKa Barbara. W poszukiwaniu symboliki Dlugoszowych Roczników, Częstochowa: Wydawnictwa AJD, 2017.

Мегорский Борис В., Осады и итурмы Северной войны 1700-1721 г2., СПб: Историческая иллюстрация, 2017.

TRĄBSKI Maciej, Oblężenie i kapitulacja Twierdzy Kokenhauzen (2-7 X 1700), „Zapiski Historyczne", t. 83/3: 2018.

XII. Streszczenie i słowa kluczowe

Wraz z tekstem należy przesyłać również streszczenie $\mathrm{w}$ języku artykułu (maksymalnie 1000 znaków) i słowa kluczowe (maksymalnie 10) oraz streszczenie ze słowami kluczowymi w języku angielskim (jeżeli tekst jest przygotowany $\mathrm{w} \mathrm{j}$. ang. wówczas streszczenie w tymże języku i w j. pol.); dopuszczalny jest też abstrakt i słowa kluczowe w języku francuskim lub niemieckim jeżeli związane jest to z tematyką artykułu - czcionka TNR 12, interlinia 1,5. 